\title{
1999 Excavations at Mission Rosario
}

David L. Nickels

Follow this and additional works at: https://scholarworks.sfasu.edu/ita

Part of the American Material Culture Commons, Archaeological Anthropology Commons, Environmental Studies Commons, Other American Studies Commons, Other Arts and Humanities Commons, Other History of Art, Architecture, and Archaeology Commons, and the United States History Commons

Tell us how this article helped you.

This Article is brought to you for free and open access by the Center for Regional Heritage Research at SFA ScholarWorks. It has been accepted for inclusion in Index of Texas Archaeology: Open Access Gray Literature from the Lone Star State by an authorized editor of SFA ScholarWorks. For more information, please contact cdsscholarworks@sfasu.edu. 


\section{Excavations at Mission Rosario}

Creative Commons License

(c) (i) (8)

This work is licensed under a Creative Commons Attribution-NonCommercial 4.0 International License 


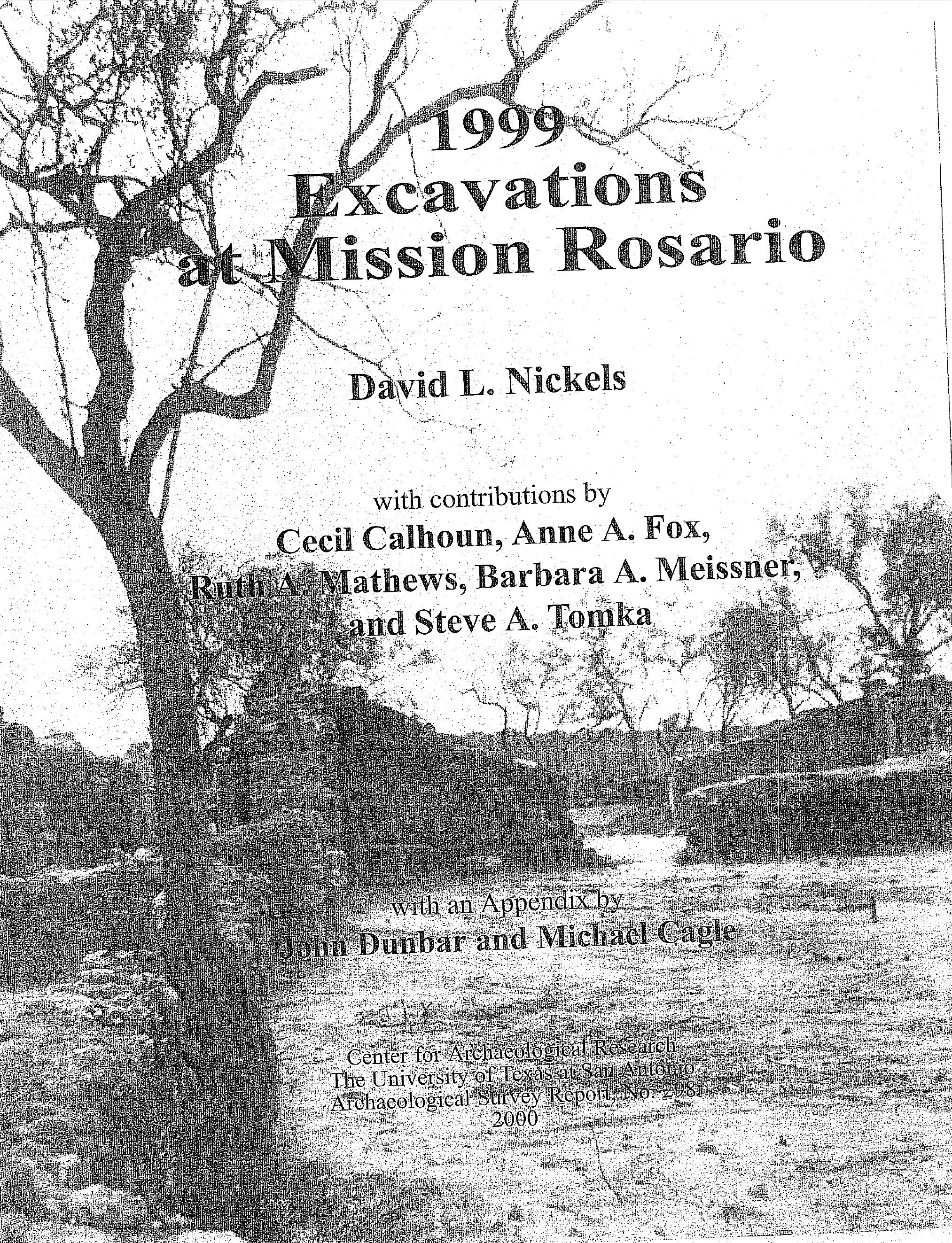





\title{
1999 \\ Excavations at Mission Rosario
}

\author{
David L. Nickels
}

\section{with Contributions by \\ Cecil Calhoun, Anne A. Fox, Ruth A. Mathews, \\ Barbara A. Meissner, and Steve A. Tomka}

\author{
and an Appendix by \\ John Dunbar and Michael Cagle
}

Robert J. Hard and C. Britt Bousman

Principall Investigators

Texas Antiquities Permit No. 2221

${ }^{\mathbb{C}}$ copyright 2000

Center for Archaeological Research

The University of Texas at San Antonio

Archaeological Survey Report, No. 298 
The following information is provided in accordance with the General Rules of Practice and Procedure, Chapter 41.11 (Investigative Reports), Texas Antiquities Committee:

1. Type of investigation: Testing

2. Project name: Mission Rosario, Goliad

3. County: Goliad

4. Principal investigators: Robert J. Hard and C. Britt Bousman

5. Name and location of sponsoring agency: Texas Parks and Wildlife Department, Austin, Texas, 78744

6. Texas Antiquities Permit No.: 2221

7. Published by the Center for Archaeological Research, The University of Texas at San Antonio, 6900 N. Loop 1604 W., San Antonio, Texas 78249-0658, 2000

A list of publications offered by the Center for Archaeological Research is available. Call (210) 458-4378; write to the Center for Archaeological Research, The University of Texas at San Antonio, 6900 N. Loop 1604 W., San Antonio, Texas 78249-0658; e-mail to car@lonestar.utsa.edu; or visit CAR's web site at http://car.utsa.edu. 


\begin{abstract}
Mission Nuestra Señora del Rosario founded in 1754, is located four miles west of modern-day Goliad, Texas. Established for the Karankawa Indians, it was finally abandoned in 1808. Archaeological investigations have been conducted at the site in the 1940s, 1970s, and 1990s. This body of work, the most recent, was conducted by the Center for Archaeological Research at The University of Texas at San Antonio (CAR) (UTSA) under the auspices of the Texas Parks and Wildlife Department (TPWD). In July through September 1999, CAR excavated 105 units, cleared some above-ground walls, and probed for buried walls or foundations. A geophysical survey complementing the archaeological investigations was conducted by Baylor University geophysicists. Archival research combined with extensive field mapping using an electronic Total Data Station has resulted in a visual synthesis of mission features and the previous investigations associated with them.
\end{abstract}




\section{Contents}

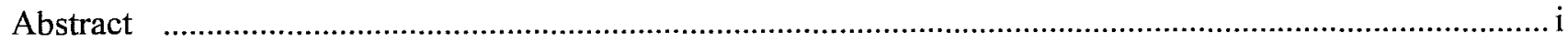

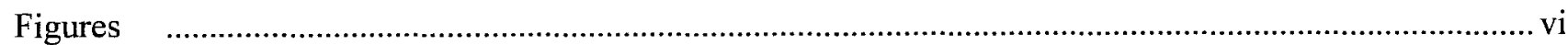

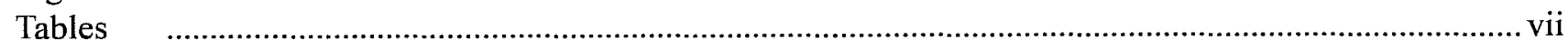

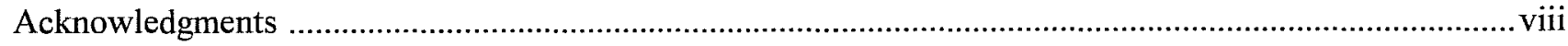

Chapter 1:

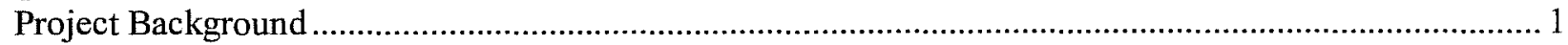

Chapter 2:

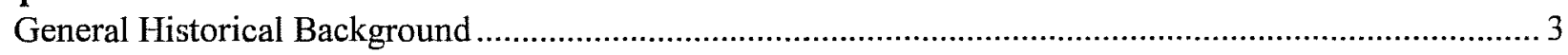

Chapter 3:

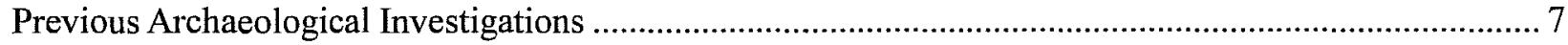

Chapter 4:

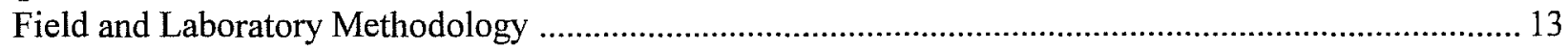

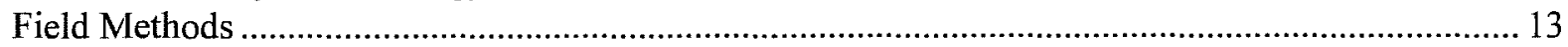

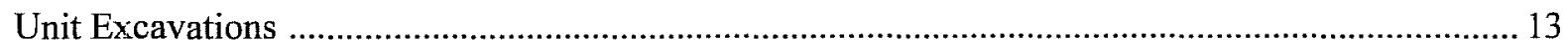

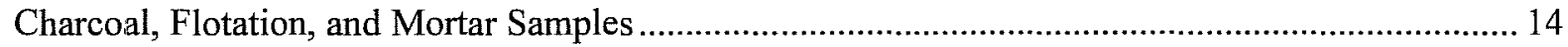

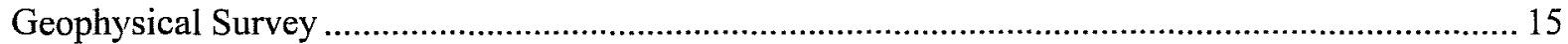

Photographic and Video Documentation .............................................................................. 15

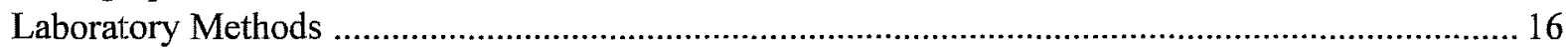

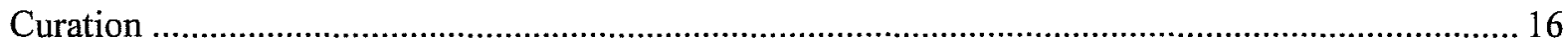

\section{Chapter 5:}

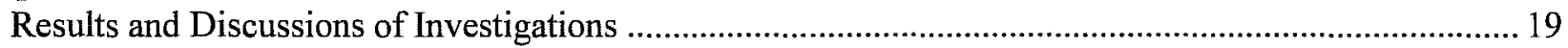

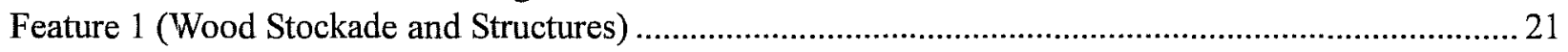

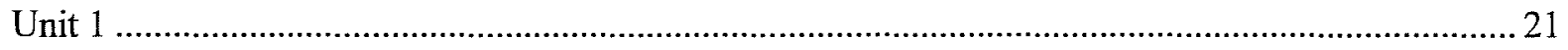

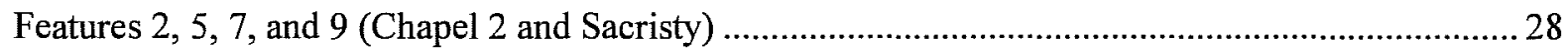

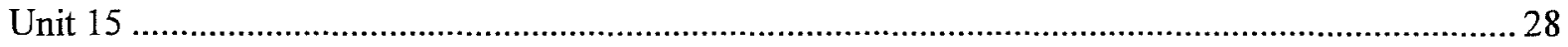

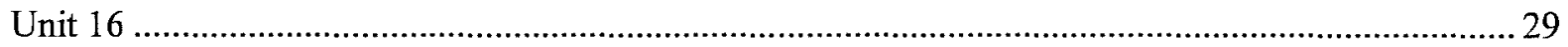

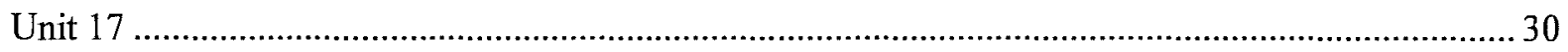

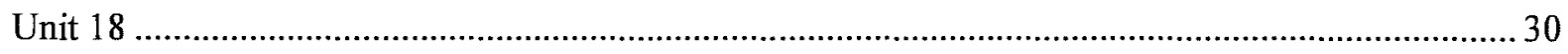

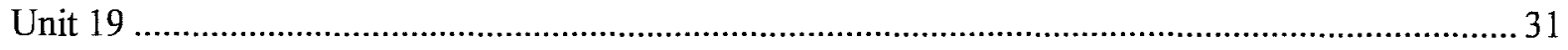

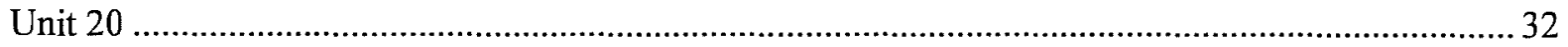

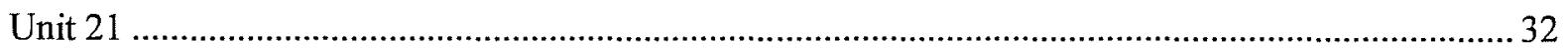

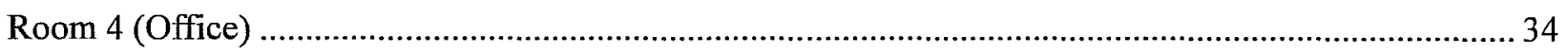

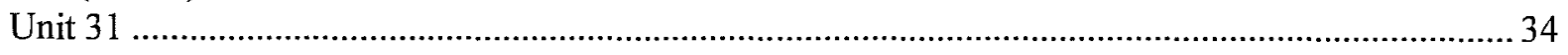

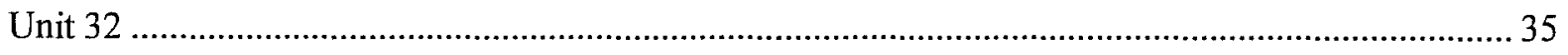

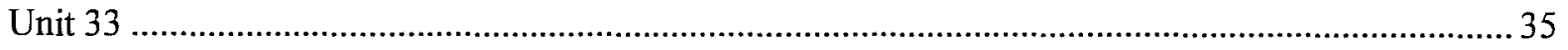

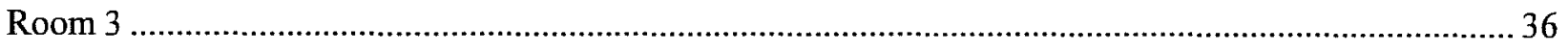

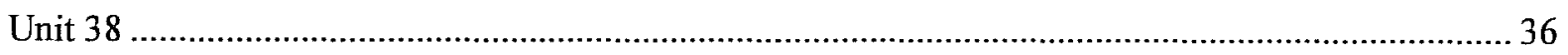

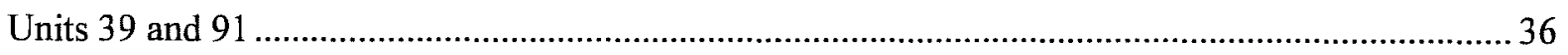

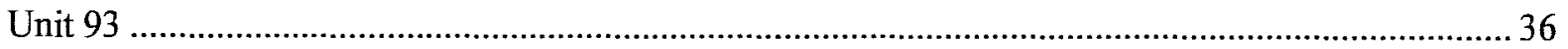

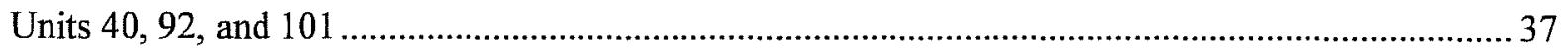

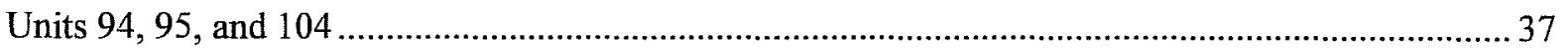

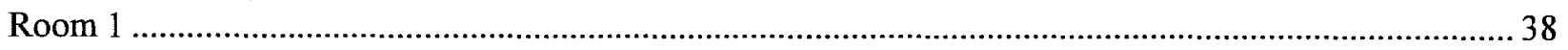

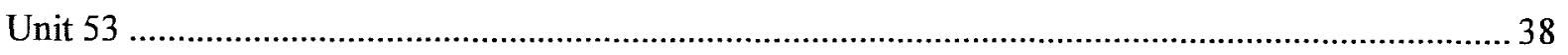

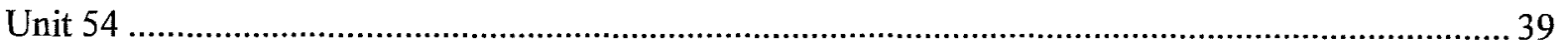

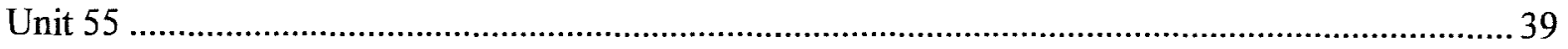

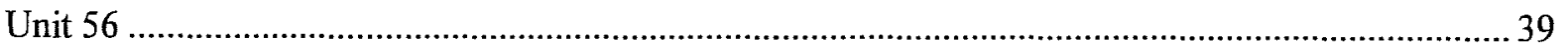




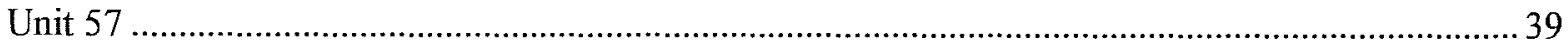

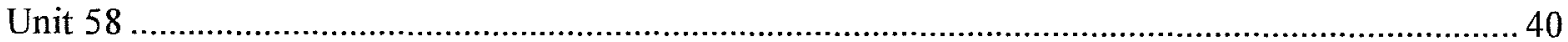

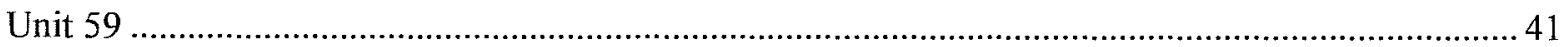

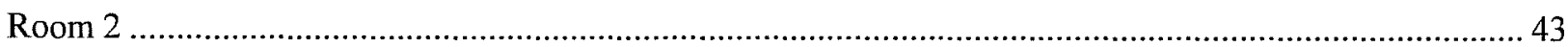

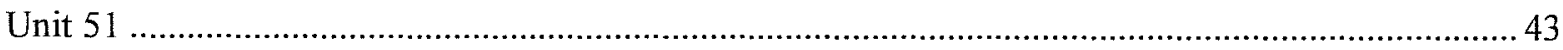

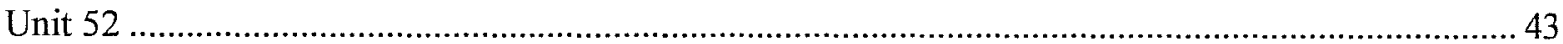

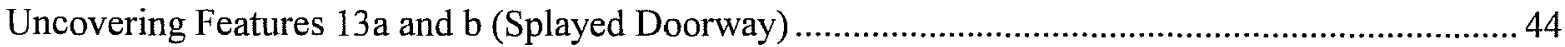

Clearing and Probes (Western Entryway) ............................................................................ 45

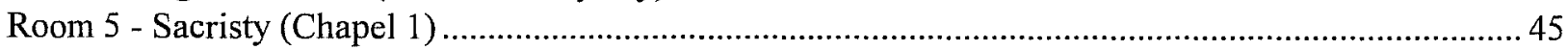

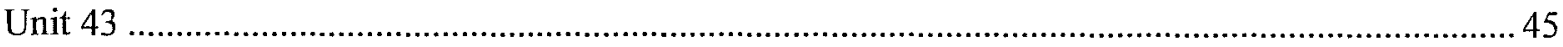

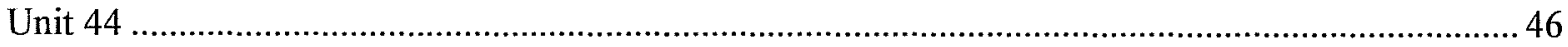

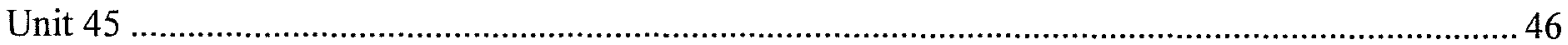

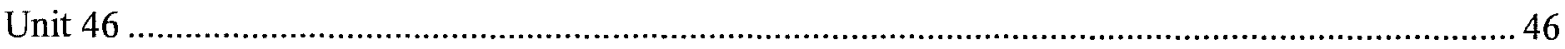

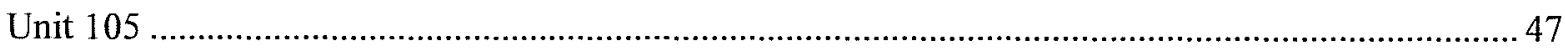

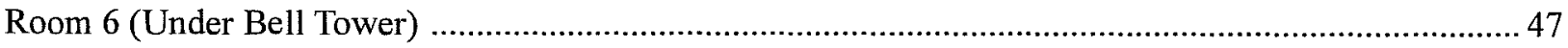

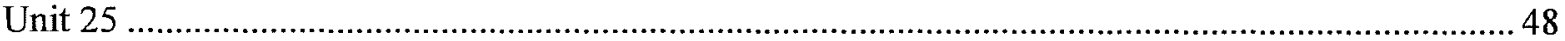

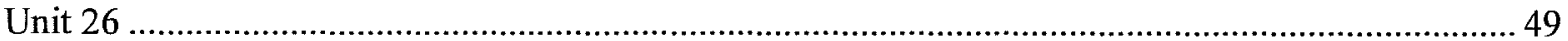

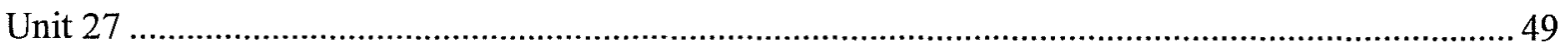

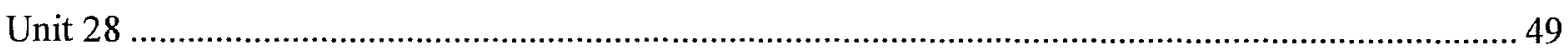

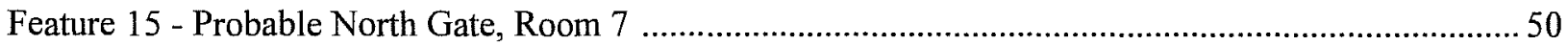

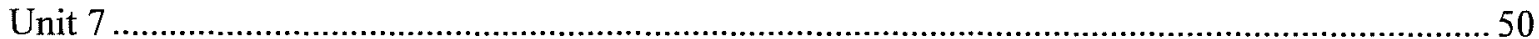

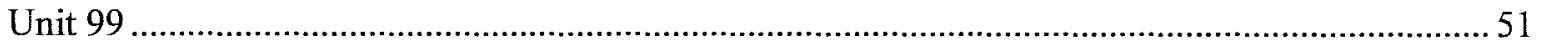

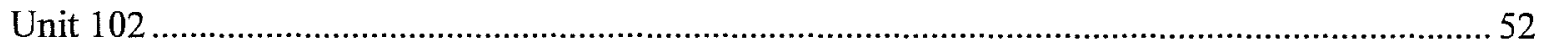

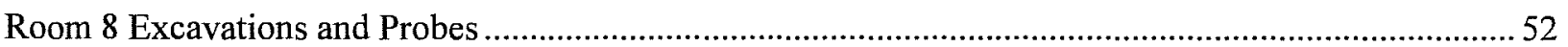

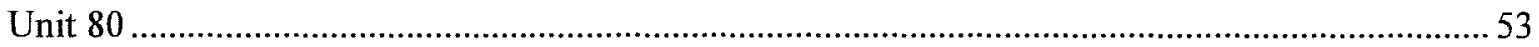

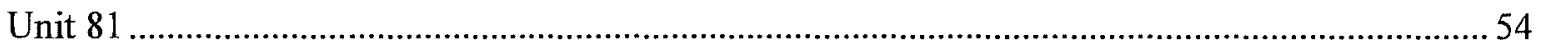

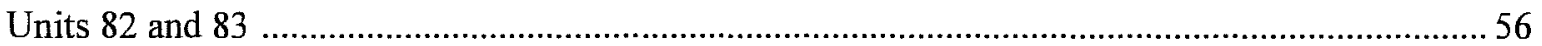

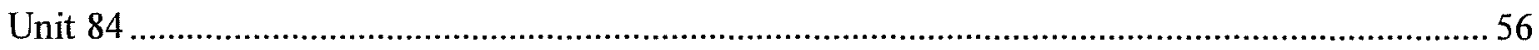

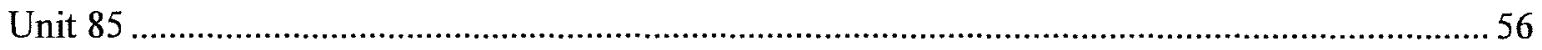

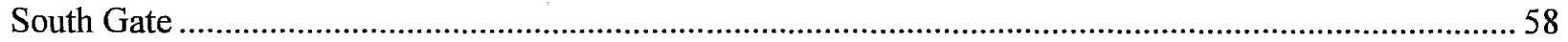

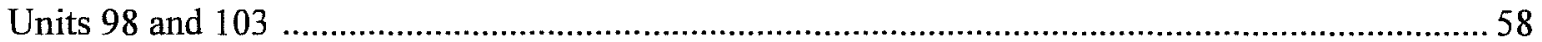

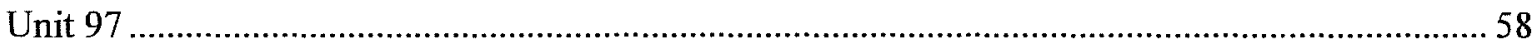

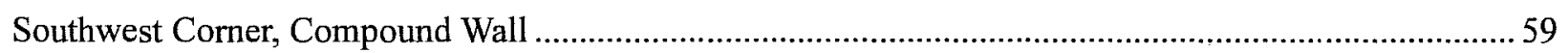

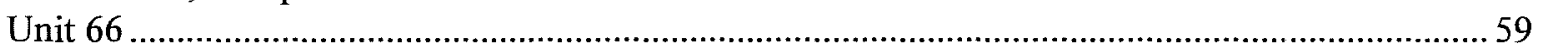

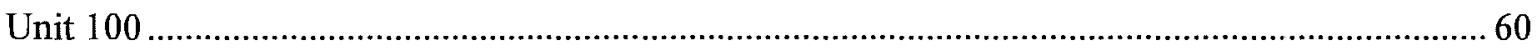

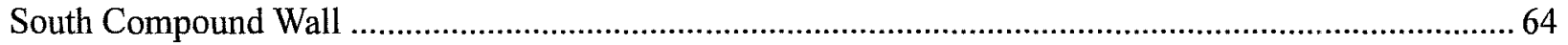

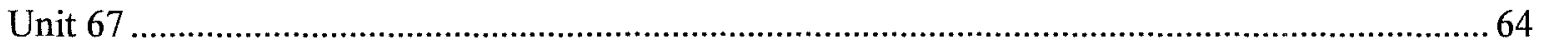

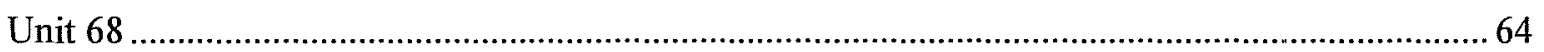

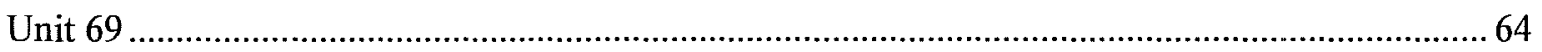

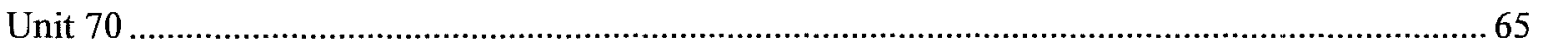

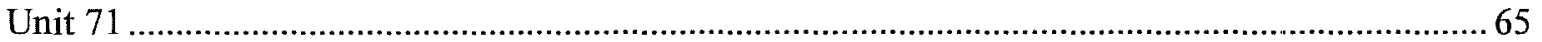

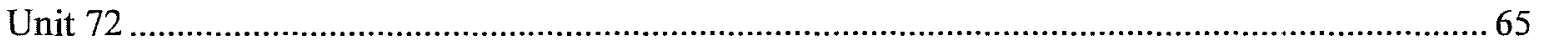

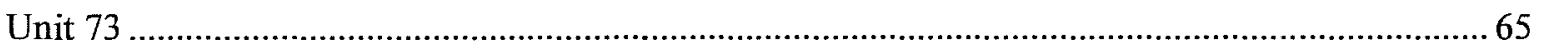

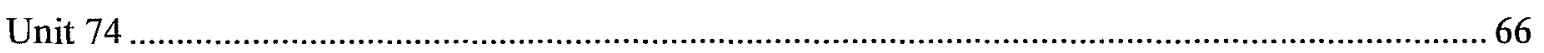

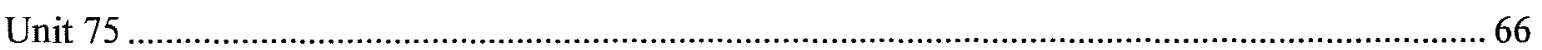

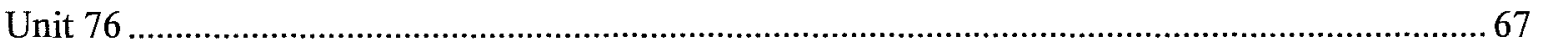

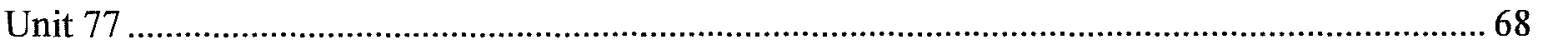

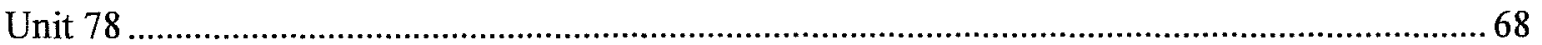




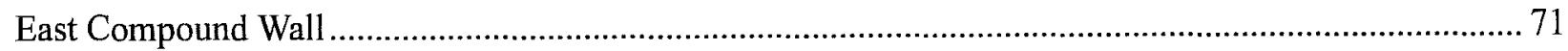

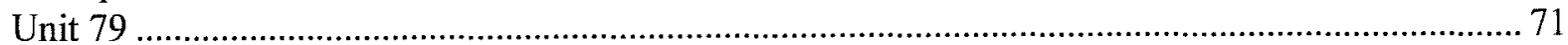

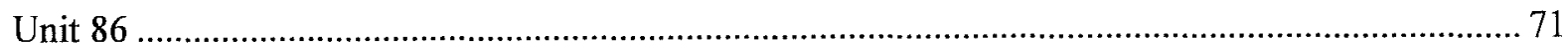

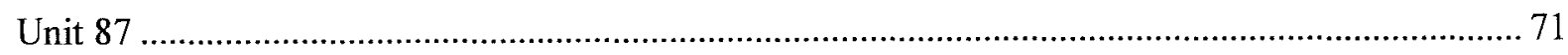

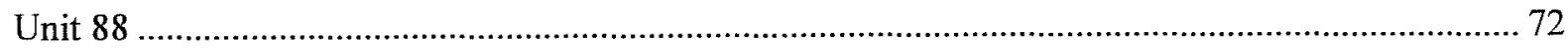

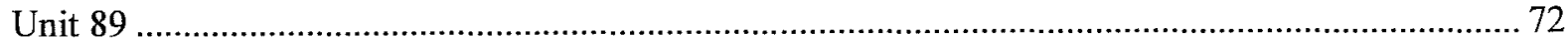

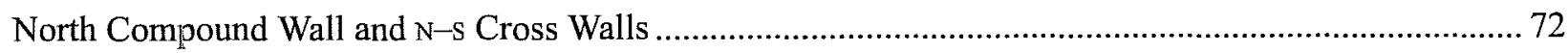

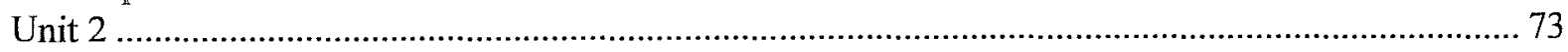

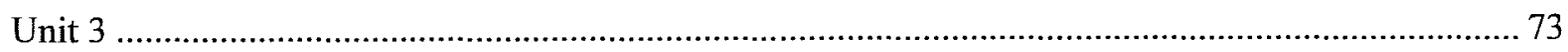

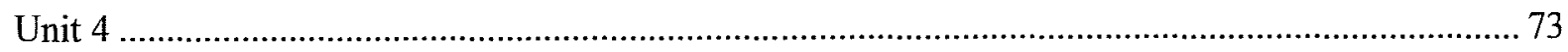

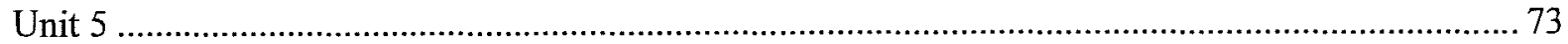

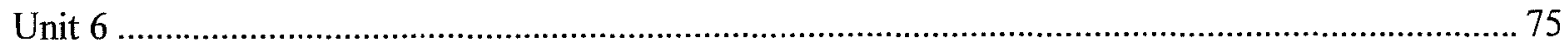

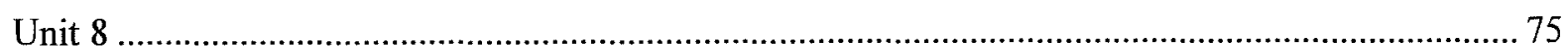

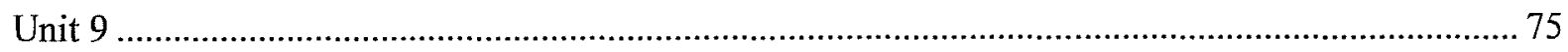

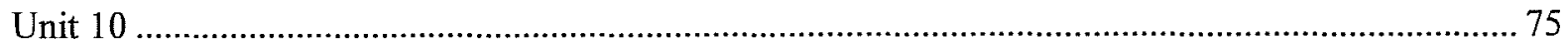

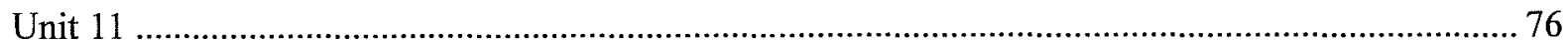

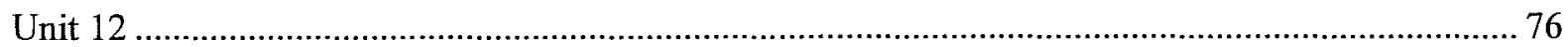

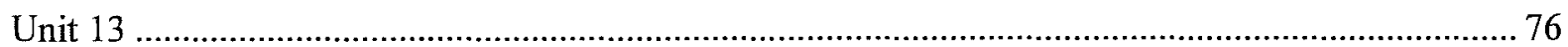

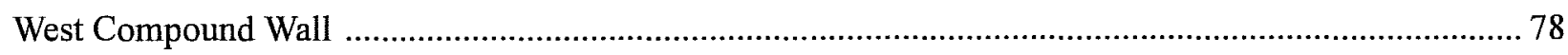

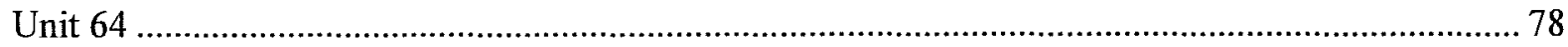

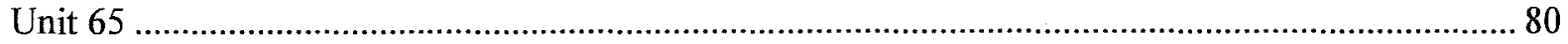

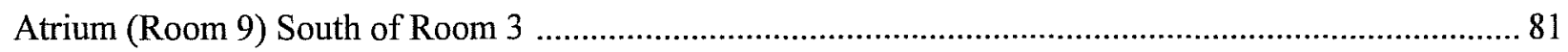

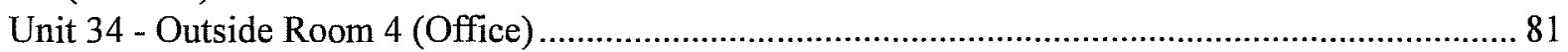

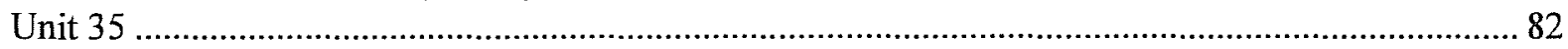

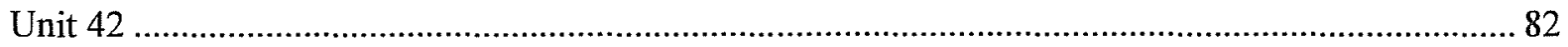

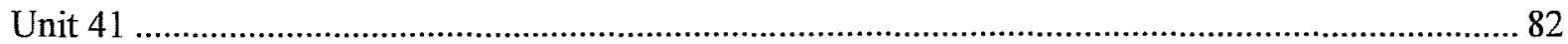

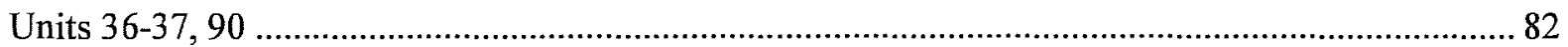

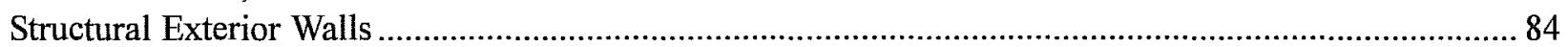

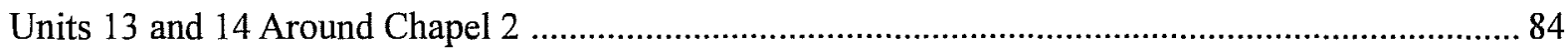

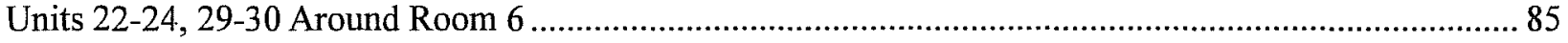

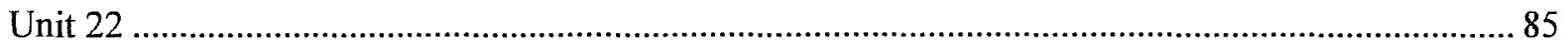

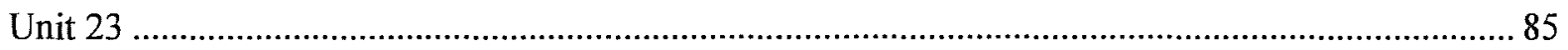

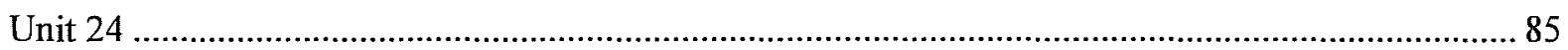

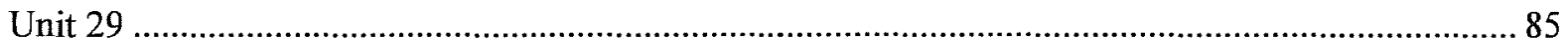

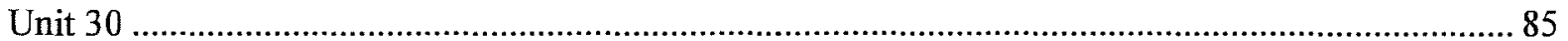

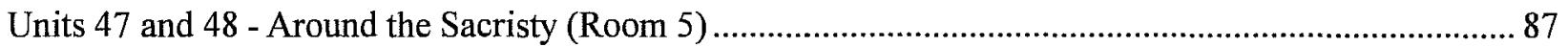

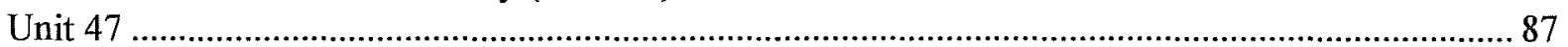

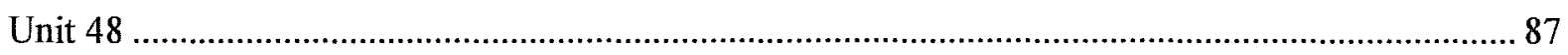

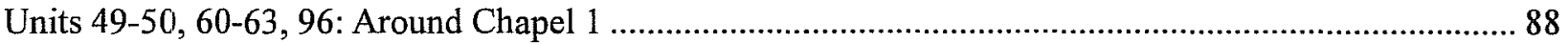

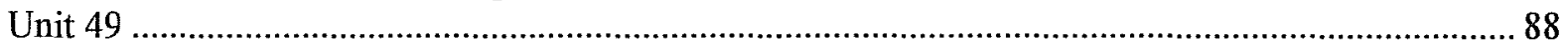

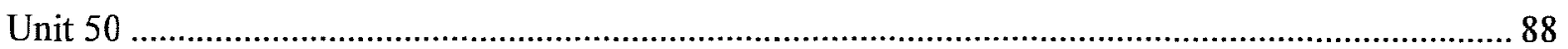

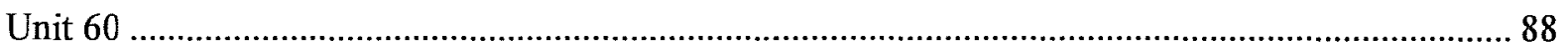

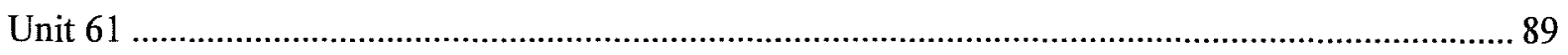

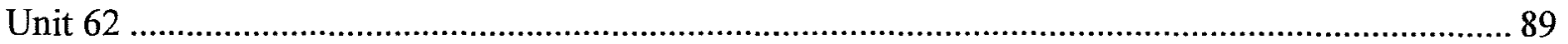

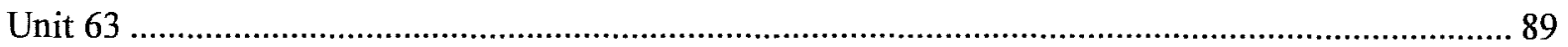

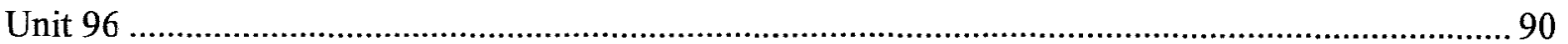

East-West Cross Wall and Semicircular Stone Alignment ............................................................. 92 


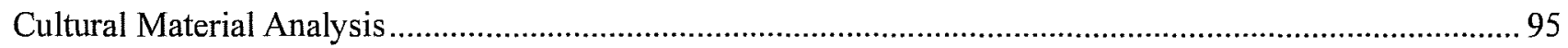

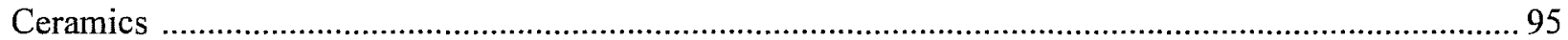

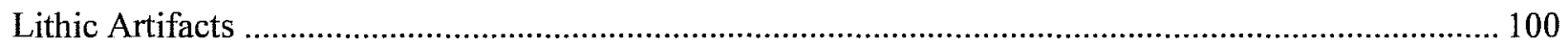

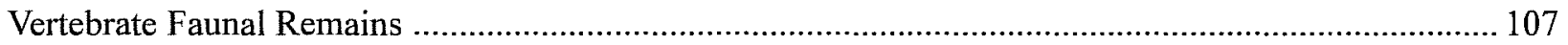

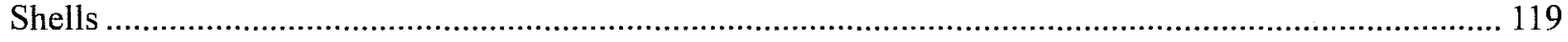

Chapter 6:

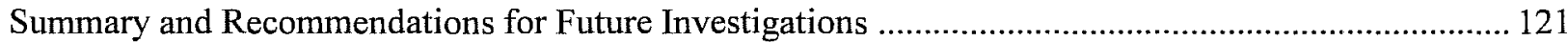

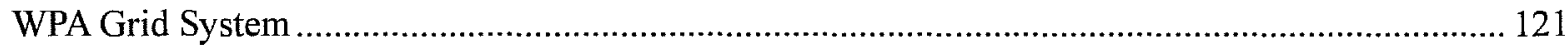

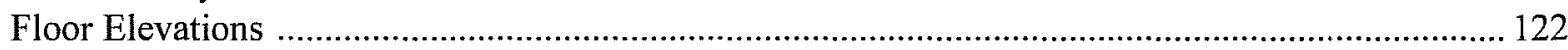

Wooden Stockade and ca. 1754-1768 Occupation ............................................................... 124

Buried Stone Walls or Foundations, ca. 1768-1780 .......................................................... 126

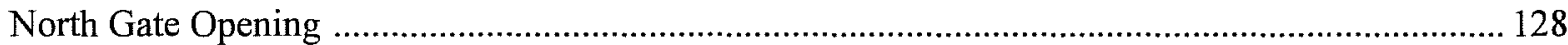

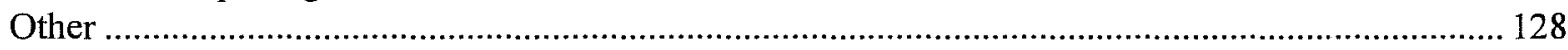

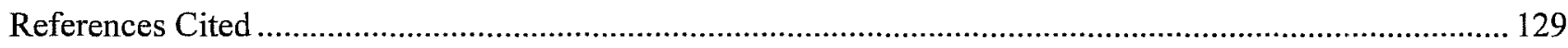

Appendix A:

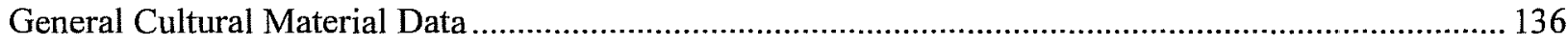

Appendix A-1

Ceramics

Appendix A-2

Glass

Appendix A-3

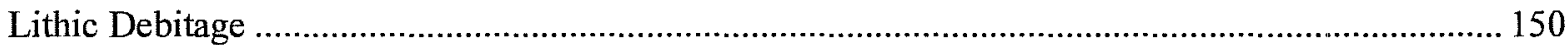

Appendix A-4

Copies of Work Projects Administration (WPA) Photographs, 1940-1941 .................................. 168

\section{Appendix B:}

Faunal Data

Appendix C:

Geophysical Survey .. 


\section{Figures}

Figure 1-1. Location of the ruins of Mission Rosario near Goliad, Texas. ................................................. 1

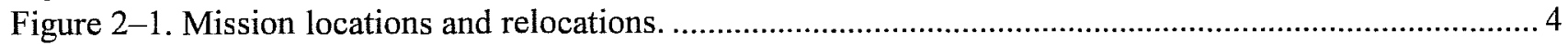

Figure 2-2. Location of Mission Rosario four miles upstream from the Presidio. ................................... 5

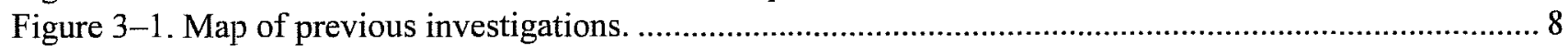

Figure 4-1. CAR staff excavating inside Room 1, Chapel 1. ............................................................ 14

Figure 4-2. John Dunbar and Michael Cagle conducting ground penetrating radar testing. ........................ 16

Figure 5-1. Map showing Features, Rooms, and Areas discussed in Chapter 5 ..................................... 18

Figure 5-2. CAR staff excavating in and around Chapel 2, Room 6 and Room 3, Chapel 1....................... 19

Figure 5-3. Photograph of trench outline and postholes $90 \mathrm{~cm}$ below the modern surface in Unit 1 ............22

Figure 5-4. East wall profile of Unit 1 in the northwest corner of the compound. ..................................23

Figure 5-5. East wall photograph of Unit 1 in the northwest corner of the compound. ...............................24

Figure 5-6. South wall photograph of Unit 1 in the northwest corner of the compound................................25

Figure 5-7. Postholes found by Gilmore and CAR in the northwest portion of the mission.........................26

Figure 5-8. West wall profile of Unit 1 in the northwest corner of the compound...................................27

Figure 5-9. North wall profile of Unit 1 in the northwest corner of the compound. ..................................27

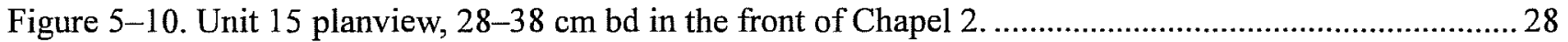

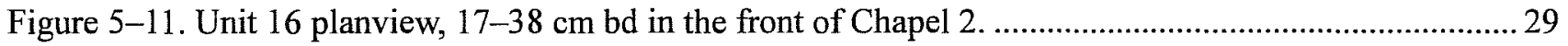

Figure 5-12. Unit 18 planview, $21-30 \mathrm{~cm}$ bd outside the west entryway to Chapel 2. ..............................3 30

Figure 5-13. Unit 19 planview, to $66 \mathrm{~cm}$ bd inside the sacristy adjoining Chapel 2 ............................... 31

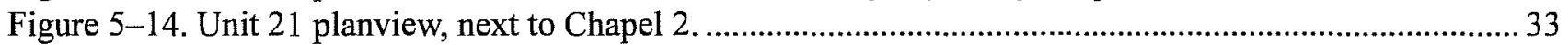

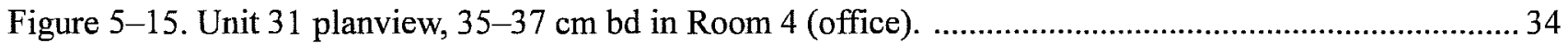

Figure 5-16. Planview of Unit 104 showing door opening in north wall of Room 3. .................................37

Figure 5-17. Planview of Unit 58 showing area of disturbance in floor in Room 1, Chapel 1. .....................40

Figure 5-18. Planview of Unit 59 showing area of disturbance in floor in Room 1, Chapel 1. .....................41

Figure 5-19. Planview of splayed doorway in east end of Room 2 (Chapel 1).........................................4 44

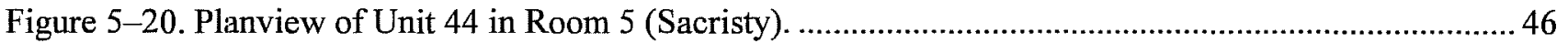

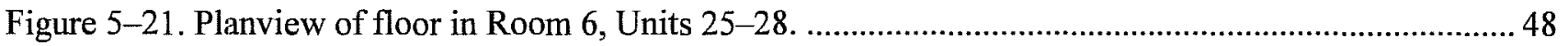

Figure 5-22. West wall profile of Unit 7 at probable north gate opening. ................................................50

Figure 5-23. Planview of Unit 7, $20 \mathrm{~cm}$ below the modern surface. .................................................... 51

Figure 5-24. Profile of north wall of Unit 80 (south wall exterior of Room 8).......................................53

Figure 5-25. Profile of east wall Unit 80 (east compound wall). ............................................................5 54

Figure 5-26. Planview of corner of Room 8 overlying buried stone wall, Unit 81 .......................................5

Figure 5-27. Photograph of corner of Room 8 overlying buried stone wall, Unit 81.................................55

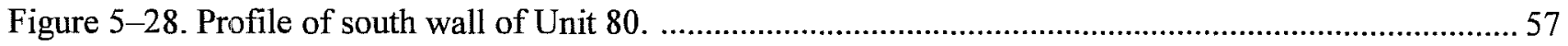

Figure 5-29. Photograph of buried wall and existing compound wall in Unit 66, facing south...................59

Figure 5-30. North wall profile of Unit 66 in the southwest corner of the compound. ..................................6 60

Figure 5-31. East wall profile of Unit 66 in the southwest corner of the compound. ...................................61

Figure 5-32. Unit 100 Planview, 54-80 cm bd, outside the southwest corner of the compound. ................. 62

Figure 5-33. Unit 100 north wall profile, outside the southwest corner of the compound wall....................63

Figure 5-34. Unit 100 west wall profile, outside the southwest corner of the compound wall. .....................6 63

Figure 5-35. Planview of east wall of Unit 75, along the south compound wall ........................................66

Figure 5-36. Profile of east wall of Unit 75, along the south compound wall........................................67

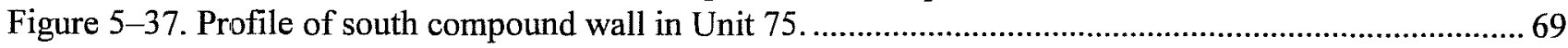

Figure 5-38. Buried wall and construction episode in Unit 4, under north compound wall. ....................... 74

Figure 5-39. Semi-circular stone alignment in Unit 5, along a cross wall and the northern compound wall. . 74

Figure 5-40. Construction and occupations in south wall profile of Unit 64 at the west compound wall. ...... 79

Figure 5-41. East view of Units 37, 90, and 36 in the Atrium (Room 9). ............................................. 83 
Figure 5-42. Unit 30 excavation exposing stone alignment underneath the south bastion of Room 6 . ..........86

Figure 5-43. Looking east into Unit 63, along the north wall of Chapel 1............................................90

Figure 5-44. Selected glass and ceramic sherds from Mission Rosario 1999 excavations. ..........................94

Figure 5-45. Selected lithic artifacts from Mission Rosario, 1999 excavations. ....................................... 102

Figure 5-46. Phalange of a goat, showing pathological tendon ossification. ......................................... 112

Figure 5-47. Bone from the south wall units compared to the rest of the collection, and to deFrance. ........ 116

Figure 6-1. Reconstructed WPA grid system laid over the site location. .............................................. 121

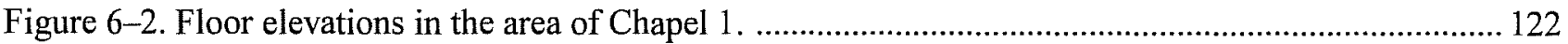

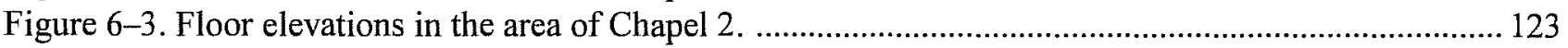

Figure 6-4. Documented postholes and possible postholes. .......................................................... 125

Figure 6-5. Buried walls or foundations and their hypothetical extensions. ........................................... 127

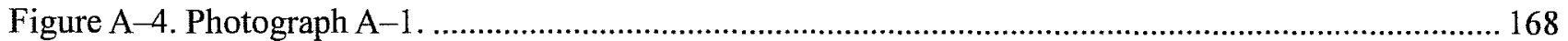

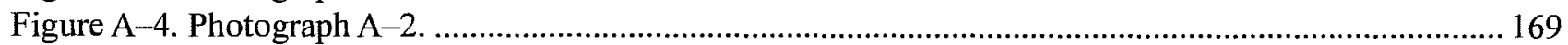

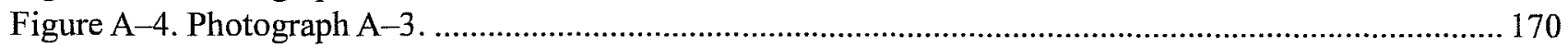

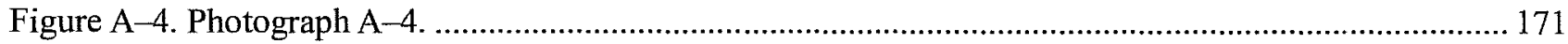

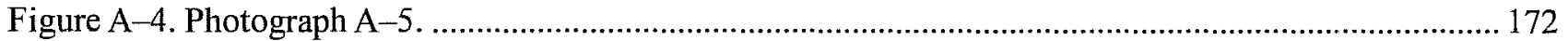

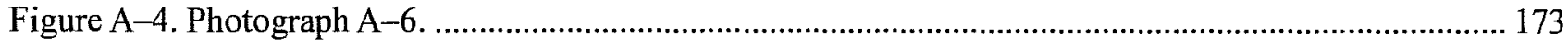

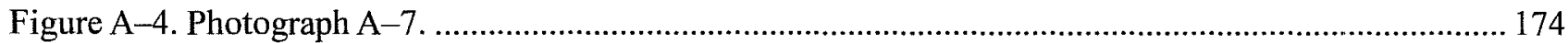

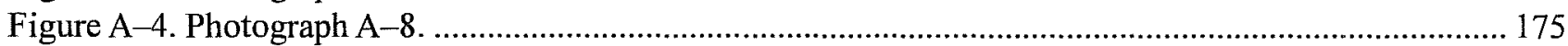

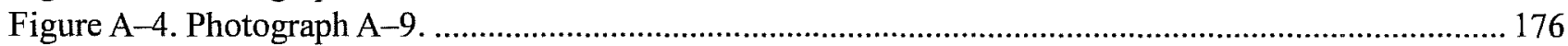

Figure C-1. Mission Rosario geophysical survey of previous excavations. .......................................... 202

Figure $\mathrm{C}-2$. Locations of ground conductivity measurements. ...................................................... 204

Figure C-3. Ground conductivity map of the Rosario site............................................................205

Figure C-4. Numbered ground conductivity anomalies described in Appendix C................................. 208

Figure C-5. Superimposed EM conductivity and Rosario site maps. .....................................................209

Figure C-6. Ground penetrating radar (GPR) profiles across Rosario. .................................................. 211

\section{Tables}

Table 5-1. Features, Rooms, and Areas shown in Figure 5-1 .........................................................20

Table 5-2. Vertical distribution of cultural material recovered from Unit 1 ...............................................2 21

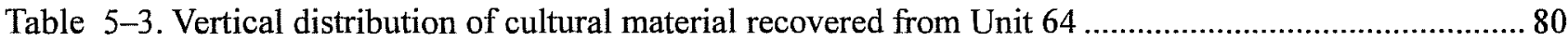

Table 5-4. Lithic tools recovered from Mission Rosario, 1999 excavations .......................................... 100

Table 5-5. Percentage of debitage by cortex category on the three most common raw material types .......... 104

Table 5-6. Percentage of debitage by size classes in the three most common raw material types ................ 104

Table 5-7. Percentage of debitage platform faceting categories in the three most common raw material ..... 105

Table 5-8. Percentage of debitage by flake type in the three most common material types ........................ 105

Table 5-9. Identified Taxa from Mission Rosario, 1999 excavations ....................................................... 108

Table 5-10. Identified Genera from Mission Rosario, 1999 excavations ............................................... 110

Table 5-11. Average bone per unit in several areas of Mission Rosario, 1999 excavations ......................... 111

Table 5-12. Comparison of Bone from Above and Below $20 \mathrm{~cm} \mathrm{bd} \mathrm{.......................................................} \mathrm{111}$

Table 5-13. Comparison of \% NISP bone weight in 8 Spanish Colonial Fauna Collections ....................... 113

Table 5-14. Percent of NISP from Wild Animal Species in 8 Recent Colonial Period excavations .............. 114

Table 5-15. A detailed comparison of the current project, Mission Rosario, 1999 with deFrance (1999) ..... 115

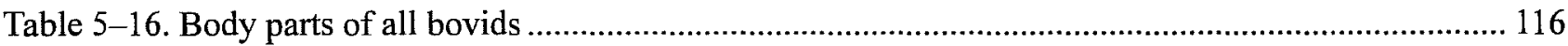




\section{Acknowledgments}

This project could not have been successful without the expertise and full cooperation shared with so many people from different organizations. An integral part of investigative archaeology is the sharing of knowledge, thoughts and ideas by professionals. We would like to thank several individuals who either visited the Mission Rosario site and/or provided insight, provocative ideas and questions: Robert Ricklis, Bill Birmingham, Smitty Schmiedlin, Cecil Calhoun, Newton Warzecha, Mike Davis, and Raymond Mauldin. Robert Ricklis was kind enough to provide an unpublished copy of his 1997 investigations at the site. Art Black and Jim Bigger of the Texas Parks and Wildlife Department (TPWD) office in Austin were extremely helpful and instrumental in the implementation and scheduling of the project, and providing many helpful comments during their visits. TPWD surveyor, Korky Kuhlman freely provided his mapping data for the mission. The TPWD field crew of Billy Flores, Johnny Light, and Leopold Kunkel professionally assisted us with clearing the site, keeping it mowed and trimmed, and coordinating additional labor for backfilling. A special thank you goes to Senior Warden Prasifka, Officer Shepherd, and the ten offenders from the McConnell Correctional Facility in Beeville, Texas for backfilling the units on a hot day. C. Britt Bousman acted as the principal investigator and Robert J. Hard assumed that role upon Britt's departure from CAR. As always, thanks are extended to the production staff at CAR, Bruce Moses and Richard Young for illustration and drafting, and to Maryanne King for editing and producing this final report. 


\section{Chapter 1:}

\section{Project Background}

\section{Introduction}

In June 1999, the Center for Archaeological Research (CAR) at The University of Texas at San Antonio (UTSA) contracted with the Texas Parks and Wildlife Department (TPWD) to conduct archaeological testing at Nuestra Señora del Rosario Mission. Mission Rosario was established in 1754 and is located on the South Texas Coastal Flood Plain. The ruins of the mission are located four miles west of the present town of Goliad atop a small knoll near the San Antonio River (Figure 1-1).
Based on the information provided the 1999 testing project was divided into three phases. The first phase of the project consisted of a detailed study of all available field notes, drawings, and photographs produced by the Work Projects Administration (WPA), Gilmore, and Ricklis. These maps show as accurately as possible, the locations of all previous excavations, buried walls, fences, and other features revealed by previous work. Phase II consisted of establishing a grid, excavating testing and test units, clearing, and probing. Phase III consisted of analysis and curation of the cultural remains, and report preparation.

Figure 1-1. Location of the ruins of Mission Rosario near Goliad, Texas.

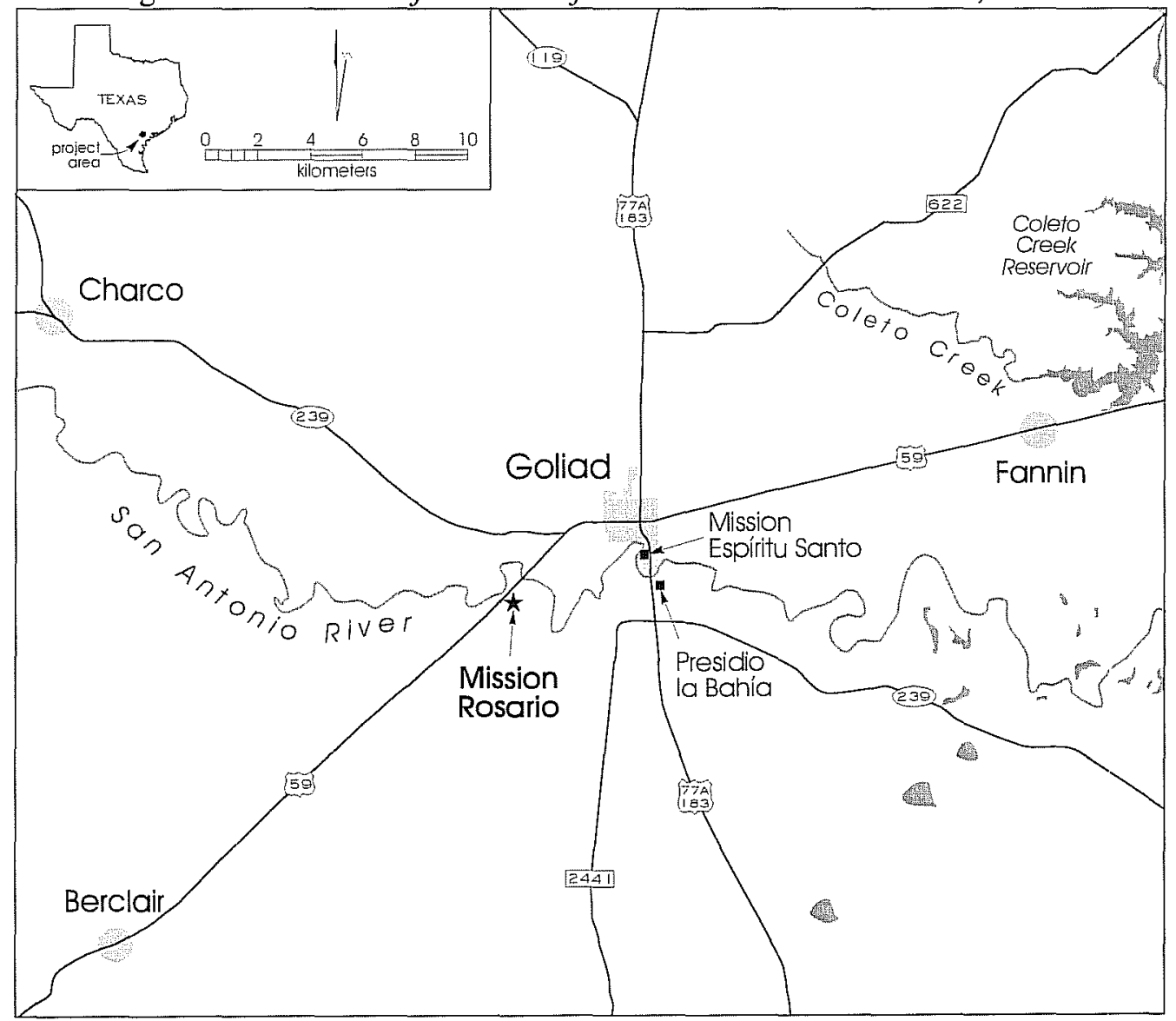


The testing was a component of a proposed TPWD stabilization project of the remaining mission walls in an effort to protect and preserve the ruins. TPWD determined to undertake the stabilization of the ruined mission walls through a combination of repointing, relaying, and minor reconstruction work. A major aspect of the stabilization required the clearing of fallen wall debris which had accumulated at the base of unstable wall sections. TPWD sponsored the archaeological investigations and testings at locations along the mission compound walls, in advance of the stabilization effort, to determine the depth to which the debris along the walls could be removed without impacting intact archaeological deposits. It was determined that a permanent archaeological metric grid should be established at the site within the entire fenced area to be used for all further testing and excavation, thus establishing the accuracy required for coordination of all future work. The grid data would then be supplied to TPWD. Research and review was required on all records available to develop a comprehensive site map for each of the previous archaeological projects conducted. This site map would delineate and illustrate the extent of all known excavation and testing locations, buried walls, fence lines, and other structural or occupational features. Maps and data would be entered into a digital format compatible with TPWD's geographic information system (GIS) format. The "testing" phase would be comprised of testing at points along selected building wall lines to determine the amount of overburden that could safely be removed without encountering or disturbing intact archaeological deposits. This testing portion was not designed to proceed further with any excavations, investigations, testing or artifact recovery once an intact archaeological deposit level was reached. The test units would be placed at each building corner, inside and outside, and one test per 20 linear feet of wall. The "test" units would be required at points along selected compound perimeter wall lines to determine the depth and type of existing foundations. Archaeological "clearing" would be limited to the removal of overburden from some subgrade walls and would terminate once the wall tops were exposed.

Texas Antiquities Committee permit number 2221 was issued for the project. All aspects of the Mission Rosario Testing Project complied with the Guidelines for Professional Performance of the council of Texas
Archaeologists. Robert J. Hard and C. Britt Bousman served as co-principal investigators, while daily field operations were directed by project archaeologists Anne Fox and David Nickels. The crew varied from two to five CAR staff members and included Richard Jones, Chris Barrett, Ricky Robinson, Ruth A. Mathews, Toni Figueroa, and Bruce Moses.

Laboratory washing, sorting and cataloging of the cultural material was performed by Anne Fox, Chris Barrett, Sharon Agold, Jessica Renaud, Shantí Morrell-Hart, Carol Leezer, B. Stillwell, and Clemente Murguia. Anne Fox, Steve Tomka, Clemente Murguia, Cecil Calhoun, and Barbara Meissner conducted analysis of the material along with David Nickels. Bruce Moses and David Nickels ran the Total Data Station, and Bruce Moses and Richard Young created the maps, plans, and profiles. The data was entered into computer databases by Barbara Meissner, David Nickels, Ruth Mathews, and Heide Casteñeda. All artifacts, field records, cultural remains, and photographs produced during this project remain the property of TPWD, and are held in trust at the curation facility located at CAR-UTSA. 


\section{Chapter 2:}

Prior to the late-seventeenth century, Spain had paid little attention to the land north of the Rio Grande. However in 1685, when rumors spread of a French colony being established by René Robert Cavalier la Sieur de La Salle, on the Texas coast (Foster 1998:4) an alarmed reaction was prompted and expeditions were hastily dispatched to search out and destroy these invaders. In 1689 , when a scouting expedition led by General Alfonso de Leon finally reached the settlement on Garcitas Creek, it was found to be deserted and in ruins.

Spurred by the threat of foreign invaders, the following year saw the establishment of Mission San Francisco de los Tejas in the piney woods of east Texas near Nacogdoches among the Hasinai Indians. Soon another mission, Santisimo Nombre de Maria, was built on the Neches (Corbin et al. 1990:9). Flood, disease, and drought combined with the disinterest of the local natives finally caused the withdrawal of the missionaries in 1693.

The next attempt by the Franciscan missionaries to reach the Texas natives came with the founding in 1700 of Mission San Juan Bautista on the Rio Grande near the Paso de Francis, a ford previously used by explorers to reach Texas (Weddle 1968:28). Two additional missions, San Francisco Solano and San Bernardo, were soon built nearby.

In 1716, an expedition led by Captain Domingo Ramón and Louis Juchereau St. Denis journeyed again to the Hasinai in east Texas. There they founded six missions in quick succession. However, in six months time it became apparent that the effort was going to be unsuccessful (Mason 1974:41). The missionaries withdrew to San Antonio, where a settlement was just beginning. Mission Solano had moved there from the Rio Grande and was renamed Mission San Antonio de Valero (Mason 1974:43). And in 1720, Mission San
José y San Miguel de Aguayo was founded in the San Antonio area about four miles down river.

In 1722, the Marques de Aguayo led an expedition to La Salle's ruined fort and began constructing Presidio La Bahía on the same site (Ramsdell 1934:1). Nearby he founded Mission Espíritu Santo to minister to the Karankawa Indians, who initially showed interest in the mission (Ricklis 1996:5). In the fall of 1923, an unfortunate quarrel between the Indians and the Spanish resulted in the murder of the presidial captain, Domingo Ramón.

As relations with the Karankawa went from bad to worse, the Spanish decided to move the mission and presidio westward to the Guadalupe River in 1726 (O'Connor 1966:15). There the local Aranama and Tamique were more tractable and receptive to the purpose of the missionaries.

A proposal by Don José de Escandón in 1747 resulted in the removal of the presidio and mission yet again. In 1749, the mission moved to its final location on the San Antonio River in an area called Santa Dorotea (O'Connor 1966:20). The purpose for choosing this particular location was to guard the trade route from San Antonio to the coast as well as the east-west La Bahía road (Roell 1988:2).

\section{History of Mission Rosario}

By the middle of the eighteenth century most of the Native peoples in the area of south Texas had come under the influence of the Spanish mission system. One large group, the Karankawa, was yet to be reached. The Karankawa consisted of five smaller bands, the Cocos, Copanos, Guapites, Cujanes, and the Karankawa proper; who were considered members of the same general group. They may have 
differed somewhat in customs and dialect, but they spoke the same basic language (Ricklis 1996:9). After the conflict with the coastal Karankawa in 1724 at the first location of Presidio La Bahía and Mission Espíritu Santo on Garcitas Creek (Figure 2-1), no concerted effort had been made to reach them again. Although, over this passage of time a few individuals from the Karankawa had joined the San Antonio missions (Bolton 1970:286).

Interest in the coastal Karankawa was rekindled in 1750 when the San Antonio missions ran short of native populations. The responsibility for all tribes along the Texas coast had been assigned by the crown to the missionaries off the college of Zacatecas (Rodnick 1974:8), but the Zacatecans had been unable to accomplish anything with the Karankawa. When the
Queréteran fathers in San Antonio began an attempt to persuade the Karankawa to come to their missions, the Zacatecans took a renewed interest. They petitioned for the creation of a new mission at Goliad, since the Karankawa refused to join with the Aranama and Tamique Indians at Mission Espíritu Santo.

The viceroy issued an order for the establishment of Mission Nuestra Señora del Rosario on April 7, 1755. However, without waiting for official approval, the mission was formally founded on a suitable site four miles upstream from the presidio (Figure 2-2) in early November 1754, with a congregation of Copanos, Guapites, and Cujanes (Ramsdell 1934:17). The following few years were difficult for the new mission, since the government was slow in providing financial support. By 1755, a "wooden" church and dwellings

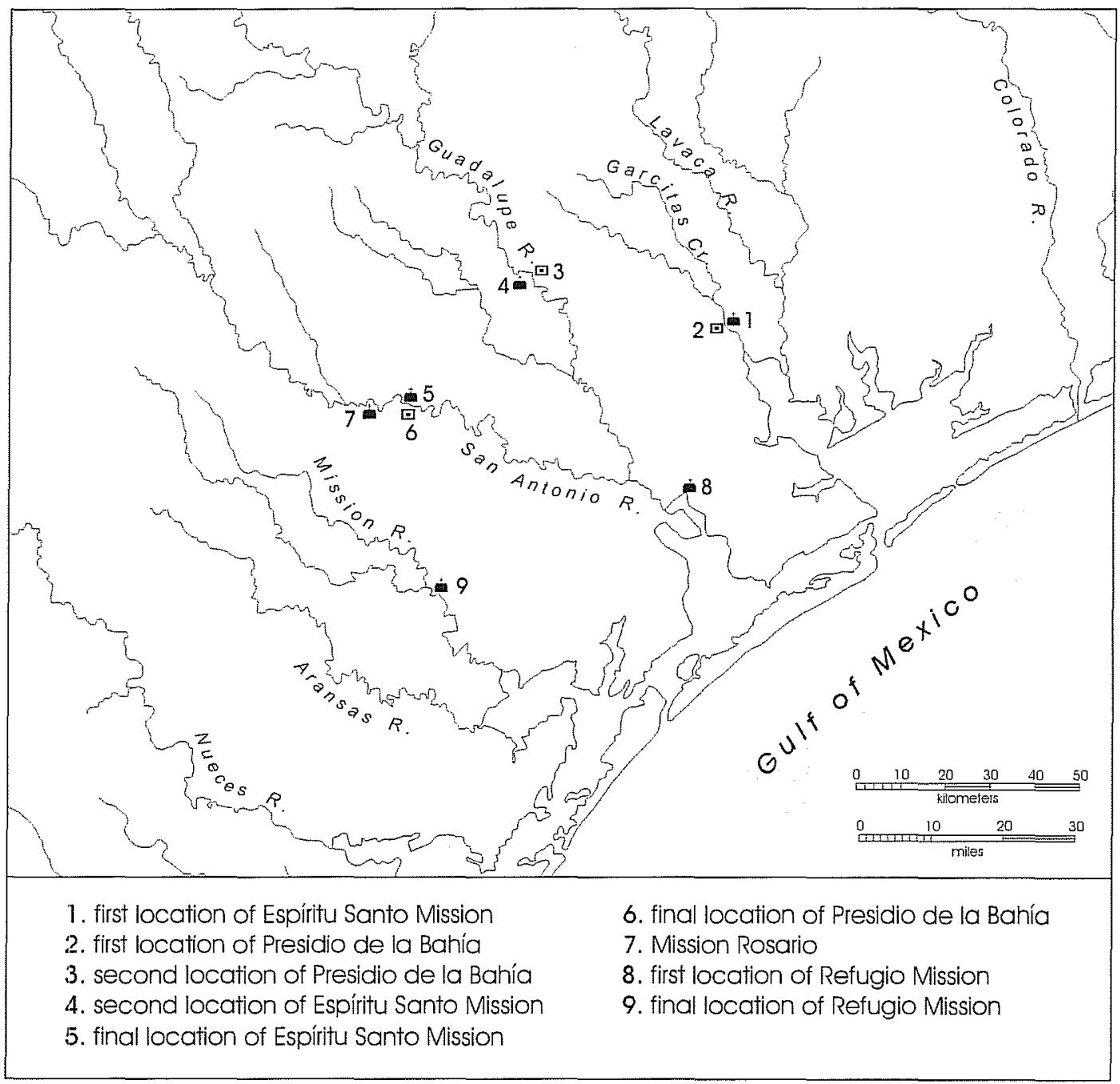

Figure 2-1. Mission locations and relocations. 
Figure 2-2. Location of Mission Rosario four miles upstream from the Presidio.

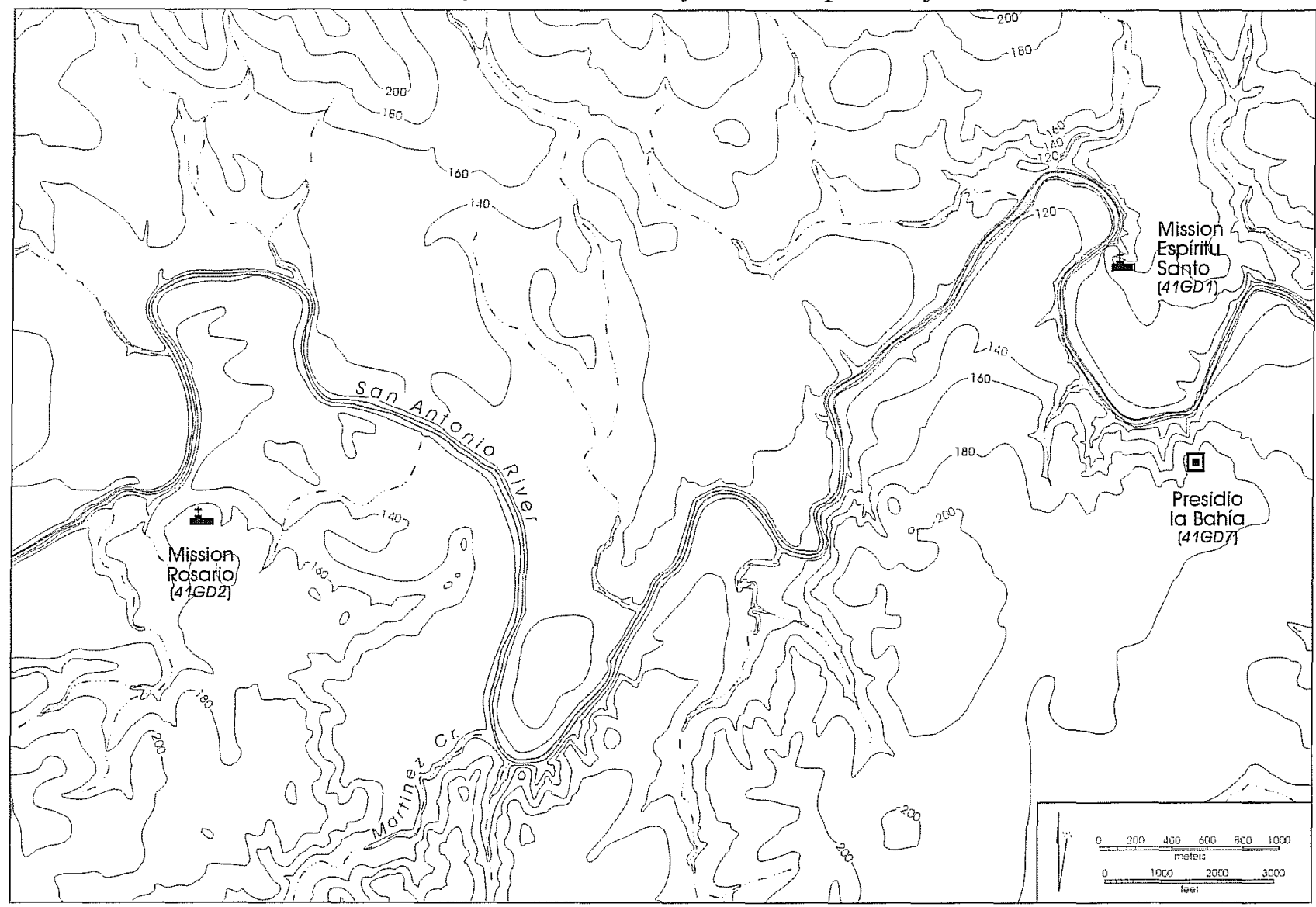

for the minister and other necessary buildings had been constructed and, soon afterward a stockade wall surrounded the mission.

In 1758, there were 400 Cujanes, Copanes, and Guapites, and numerous Karankawas at Rosario (Gilmore 1975:5), financial support had arrived, and the mission was flourishing. Ten years later, in 1768, the Indians were becoming disillusioned with mission life and began to desert the mission for their old haunts at the coast. As a result of the Franciscans' inability to keep the natives at the mission, in 1781 the mission was abandoned. The livestock and church ornaments were turned over to Mission Espíritu Santo, and by 1785 the mission was reported as being in ruins (Gilmore 1974b:19).

The Zacatecans did not completely give up, however, for in 1789 Fr. José Mariano Reyes arrived from Mexico to restore the mission. He reported that he had built a small chapel of grass and poles, since the original one had fallen, and a small hut for himself (Gilmore 1975:8). The convent, the sacristy, and two other rooms were still standing (Gilmore 1974b:19), though probably in need of repair, but the wall that surrounded the mission had deteriorated. Of the 52 Indians officially located at the mission, only 20 were present on October 8, 1790 (Gilmore 1975:9). By April 1791 , the wall had been repaired and a large hall, an office, and a sacristy had been built, and half of the church was completed. At that time, there were 85 Indians at the mission. By November, the church of stone and plaster (Rodnick 1974:12) had been finished and 114 Indians representing the same groups for which the mission had been originally founded were present.

This same year, another mission for the Karankawas, Mission Refugio, was in the process of being founded closer to the coast. After several years spent in attempts to find a proper site, in 1795 Mission Refugio was established on Medio Creek, about 15 miles inland 
from Copano Bay. By this time most of the Karankawa were expressing a preference for a mission within their own territory and were eager to join the new mission. In 1797, there were 97 Cocos and Karankawas present at Rosario, and it was decided that the Cocos would remain there while the Karankawas were sent to Refugio (Gilmore 1975:11).

On October 20 and 21, 1804, heavy rains (perhaps from a hurricane) severely damaged the Goliad area. At Rosario, a section of the church, part of a house, and several sections of the wall collapsed (Gilmore 1974:19). Two months later, Fr. President Vallejo reported that the churches at Missions Rosario and Espíritu Santo were badly deteriorated, but apparently, there were some Indians still there (Leutenegger et al. 1983:234-235).

By 1805 , the buildings at Rosario which had been reconstructed in 1791 were mostly in ruins. Although there was discussion about rebuilding, there was no money available to do so. Therefore, in 1808, Mission Rosario was formally combined with Mission Refugio and the remaining Indians were transferred there. The deserted buildings then gradually fell into complete ruins (Rodnick 1974:13).

Some years after secularization, the property on which the ruins stood was included in the Maria de Jesus de Leõn Survey. In 1853, the mission property itself was sold to the Catholic Church for $\$ 1000$ (letter to Cecil Calhoun from L. A. Searight, Assistant Director of the Texas State Historical Survey Committee, October 16, 1964). No records have yet been found which verifies interim ownership between 1853 and 1935 . However, we do know that William J. O'Connor deeded it to Goliad County in 1935 (Deed of Gift, William J. O'Connor to County of Goliad, Goliad County Court House, Goliad, July 1935). At that time the property consisted of four and seventy-seven hundredths acres (O'Connor 1966:33). In the 1930s the property was turned over to the Texas Parks and Wildlife Department. 


\section{Chapter 3:}

\section{Previous Archaeological Investigations}

\section{Introduction}

Over the years there have been other archaeological investigations carried out at Mission Rosario. The Work Projects Administration (WPA) worked at the site in the 1940s, Kathleen Gilmore in the 1970s, and Robert Ricklis in the 1990s. Figures 3-1 and 5-1 have been compiled to show the location and extent of these prior projects and the current project. The reader is also referred to a larger scale map in a packet at the end of this report.

\section{WPA Excavations}

The earliest project was carried out under the supervision of the National Park Service (NPS) and the Work Projects Administration (WPA) from July 1940 to April 1941. An archaeologist was not in charge of the excavations until March 1, 1941, when Roland Beard of Victoria joined the project. Mr. Beard, a Civil Engineer, had gained his archaeological training during work at the site of Mission Espíritu Santo at Goliad under the tutelage of National Park Service archaeologist Erik Reed. According to an anonymous "Archaeological Report" on file at the Texas Parks and Wildlife Department (TPWD), the primary purpose of the investigation was "to determine the architectural plan of the mission" and, as a secondary purpose, it was intended that the excavations gather all available information on the life and culture of the natives at the mission. Although, apparently, no archaeological screening was done during the excavations, a large collection of artifacts was recovered. The criteria for artifact collection at Mission Rosario are unknown. However, we can assume Mr. Beard used a method similar to that used at Mission Espíritu Santo. There he stated that excavations inside rooms were made by stratums and that all artifacts were recorded and collected. Excavations conducted outside of structures were accomplished in arbitrary stratigraphic levels (Mounger 1959:108-110). Whether the sediments were screened is not known; however of the available WPA photographs none depict screens or stands at Mission Rosario.

According to several sources, a grid system of $100^{\prime}$ by $100^{\prime}$ lots was laid out over the entire mission. First, all overburden, consisting of several inches of aeolian soil overlying six inches to five feet of rock fall, was removed within about four inches above the final occupation level as determined by test holes. During the second phase of the excavation which began February 1,1941 , work was concentrated on determining the possible use of certain areas and investigating the various building stages of the mission. Excavation was conducted down to the original occupation level in some areas, and trenches were excavated in order to fill out the ground plan. Throughout the work documentation was carried out by mapping and photographing, as well as with field drawings and profiles. Artifacts were recorded according to location and elevation.

Unfortunately, the project was called to a precipitous halt by the cancellation of the program due to the start of the Second World War. The entire excavation was hastily backfilled.

Of all of the records so carefully maintained, only the photographs and a few summaries of the work are known to have survived. Of these, by far the most useful have been the numerous $8 \times 10$ black and white photographs that show the extent of the excavations and the condition of the walls at that time. Nine representative photographs from this group have been included in this report and are presented in Appendix A. Later interviews conducted by Kathleen Gilmore in the 1970s with Beard and architect Raiford Stripling, who were both present during the WPA excavations 


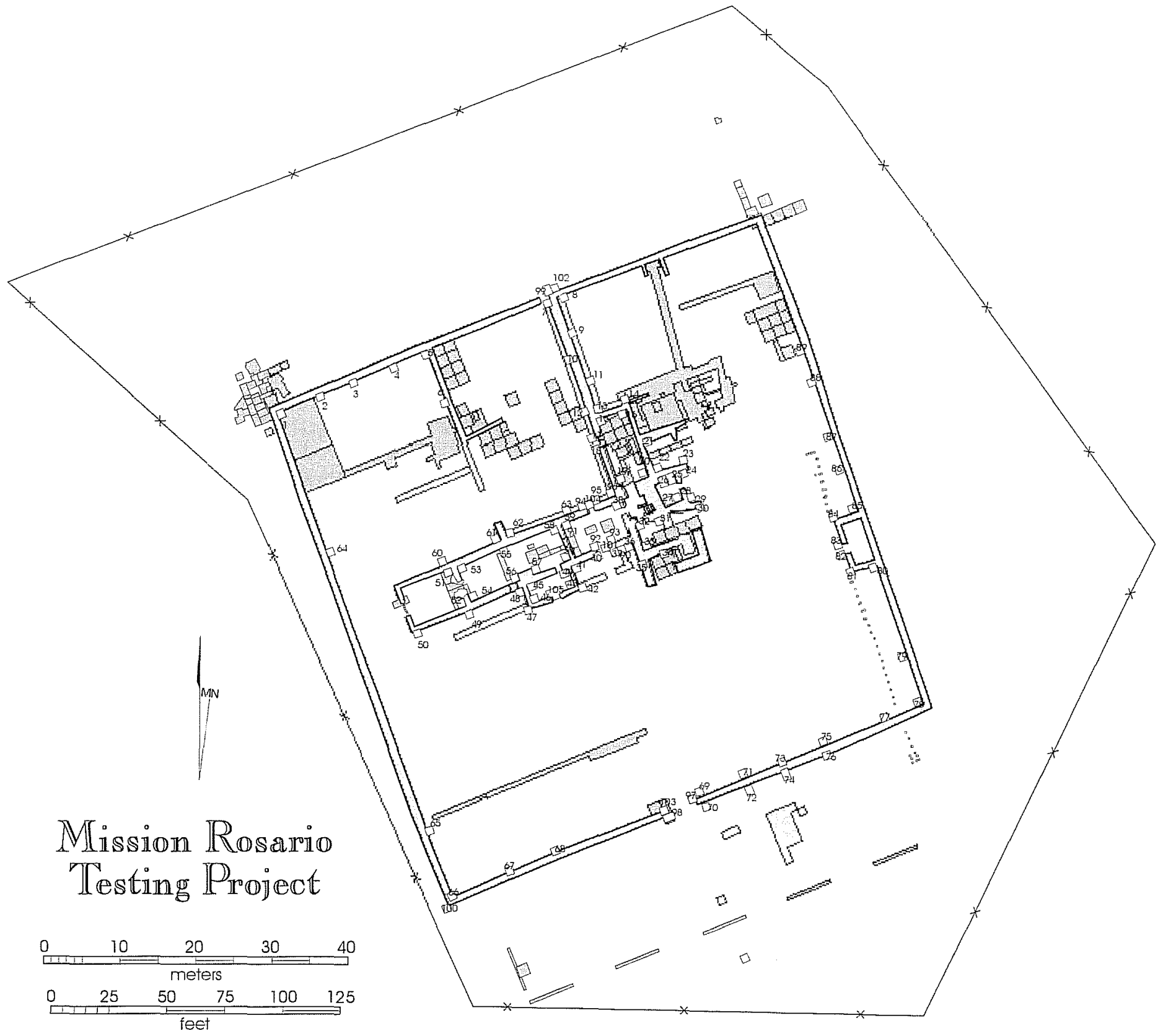

1940 and 1941 (Beard)

1973 and 1974 (Gilmore)

1997 and 1998 (Ricklis)

1999 (Fox and Nickels)

Figure 3-1. Map of previous investigations. 
have been helpful, but the only other evidence that exists of what was done during the 1940-1941 excavations is the evidence still in the ground, as recorded later by Kathleen Gilmore and confirmed and recorded during this current project. The artifacts recovered during the WPA project were stored, along with those recovered during the previous Espíritu Santo excavations. At some undetermined time later these collections seem to have been mixed, making it impossible to tell them apart (Gilmore 1974:41). The collections are currently stored at the Texas Archeological Research Laboratory in Austin.

\section{Kathleen Gilmore Excavations}

From May 7 to July 3, 1973, archaeological investigations at the mission were directed by Dr. Kathleen Gilmore for the Texas Parks and Wildlife Department (Gilmore 1974). The objectives of the work were as follows:

(1) "to determine if previous excavations could be delineated, and if the pattern of non-standing structural remains still existed;

(2) to determine the occupation periods of both Indian and Spanish;

(3) to determine the feasibility of being able to locate activity areas within the mission compound, such as craft areas, blacksmith shops, cooking and living areas." (Gilmore 1974:1)

...it was also hoped to be able to determine the various building periods of the mission.

Gilmore established a grid aligned with the north compound wall, with a zero datum point near the center of the wall. Grid coordinates were measured in feet in four directions from this central datum. In addition, walls, structures, and exploratory trenches were numbered in sequence. For the most part, screening of deposits was not done as artifacts were recorded in place. Recording elevations were tied in with Texas Highway Department elevations of the bridge spanning the San Antonio River to the east.
The excavations (see Figures 3-1 and 5-1) proceeded in trenches laid out across previously recorded features located by the WPA crews. Emphasis was placed on the location of floors and the recording of the various strata above them. Particular care was taken in Church 1 not to expose the plastered wall surfaces, since no provision had been made to preserve the plaster in place.

The area outside the northwest corner, where postholes and trenches were mapped by the 1940-1941 excavations, was re-excavated and additional postholes and trenches were recorded. No firm conclusions could be reached except that at least part of the posts appeared to be related to the stockade that once had surrounded the mission.

An area within Structure 1 in the northwest corner, where postholes and trenches were also previously recorded, was also re-excavated and more stockade postholes were identified. Indications of a Colonial dumping area outside the stockade wall (first noted outside the present northwest corner) were found to continue in this area. Traces of a building with a red clay floor and a fireplace, a burned wall or roof, and a caliche floor with rocks laid on top were recorded.

In the area of Exploratory Trenches 2 and 3 in the northwest quadrant of the compound, a number of features were recorded, including setting trenches for various walls and postholes. Scattered daub and postholes against the east wall probably indicate an early wooden structure there.

Additional work in the vicinity of Feature 3 in the northeast portion of the compound uncovered several rows of posts which represent a structure in this area. Artifacts recovered suggest that this was a living area.

Feature 6 located in the center of the compound was confirmed to be a burial area, which at one time was directly outside the front entrance of the first church. A total of twenty-eight graves had been reported by the 1940-1941 excavators in this area.

Areas A through D directly to the north were found to contain evidence of floors, postholes, and possible wall 
foundations, probably structures occupied after the abandonment of the cemetery.

A large catch basin located in the southwest quadrant of the grounds, first tested in 1940-1941, was excavated to a maximum of sixteen feet. Its purpose was not determined.

Six backhoe trenches were excavated ca. 50 -feet outside the south mission wall to gather information on the depth of artifact deposition in this area, and in an attempt to locate trash pits. Several pits were located but only one was excavated. No indications were found of structures here.

Gilmore returned to the site in the spring and again in the fall of 1974 (Gilmore 1975), in order to continue her investigations. Additional work was done in areas first tested during the previous season, including outside the northwest corner searching for more information on the original palisade wall. She also conducted further investigations within the mission's rooms where floors were found and described.

The most intensive and important work performed during the second year was the location and complete excavation of the earliest church, which had been entirely buried beneath the present surface. The church was found to be a single room $15^{\prime} \times 40^{\prime}$. By careful recording, she was able not only to locate and map twenty-six burial pits, but also to relate the burials to the floors into which they had been dug. She also was able to trace the structural history of the church, determining that it had originally extended farther west.

The reports produced from these two seasons of work provide a valuable record of the history and archaeology of the Mission Rosario site. They served as planning documents and resources for the archaeological projects that followed.

\section{Robert Ricklis Excavations}

In July and August of 1997, Dr. Robert Ricklis (1998) directed test excavations outside the south wall of the mission compound (Figures 3-1 and 5-1). Eight onemeter square units were excavated in that area. A good collection of Colonial period artifacts was recovered, along with important additional information on stratification in the area.

Based on Gilmore's reported stratigraphy in the area, plus surface reconnaissance which yielded numerous Colonial artifacts, Ricklis laid out a series of eight units parallel to and perpendicular to the south compound wall. He encountered an uppermost stratum consisting of brown silt and fine sand containing artifacts, bone, and bits of rubble. Beneath this was a layer of darker soil containing many animal bones and a higher density of artifacts. This stratum lay on a packed caliche floor. In the units farthest east Ricklis uncovered remnants of a mortared stone foundation which lay beneath the midden and bone bed layers, running east-west. The artifacts from the bone bed and the overlying midden dated these deposits to the late post- 1790 occupation of the mission.

Ricklis returned to Mission Rosario in 1998 and excavated additional units to further investigate the structure found the previous year (Figures 3-1 and 5-1). His intent was to acquire more artifactual evidence in the hope of better understanding and dating the structure. The stratigraphy revealed in these excavations made it possible to understand the comparative dates of the gate midden and the stone foundation, and how they related to each other. Floor surfaces south of the foundation were found to be constructed of caliche and adobe blocks, and to contain a row of post support basins parallel to, but approximately $2.5 \mathrm{~m}$ south of the foundation (Ricklis 1999:148). Ricklis suggests that the presence of a formal stone structure aligned with the mission compound and the location of associated floor surfaces may indicate that there was a complex of outbuildings in this area. (Ricklis 1999:165). 


\section{Other Disturbances}

Even in ruins, Mission Rosario has attracted people wishing to explore and dig around its mission walls. Travelers seeking shelter from the elements probably camped among and along the walls for protection, leaving behind artifacts and refilled potholes that can perplex the investigator. Often, evidence of these visits is revealed in later archaeological excavations. Additionally, digging by wild animals such as hogs and gophers also can add to a confused archaeological record. Since the construction of a chain link fence, which now surrounds the ruins, and increased patrols by Parks and Wildlife personnel such intrusions have been kept to a minimum. 



\section{Chapter 4:}

\section{Field and Laboratory Methodology}

\section{Introduction}

\section{Field Methods}

\section{Unit Excavations}

This chapter describes the pre-field planning, field methods, subsequent analysis of the cultural material recovered, and its preparation for curation.

A synthesis of previous archaeological investigations has resulted in the production of an overall map compiled to depict the prior and current findings (Figures 3-1 and 5-1). There should be no question that any map developed of this mission should be categorized as a model or work-in-progress designed to assist as a guide as further archival and field investigations are conducted.

\section{Pre-Field Planning}

TPWD staff archaeologist, Art Black conducted extensive archival research, locating black and white photographs (examples in Appendix A) and an area map from the 1940s WPA investigations, along with voluminous field notes from Gilmore's work in 19731974. He provided those to CAR staff, and we were thus able to minimally anticipate the results of our work in 1999. These archives supplemented the published works of Gilmore (1974a, 1974b) and Ricklis (1999). An unpublished work by Ricklis (1998) was extremely helpful in its description of soils and sediments south of the compound wall. His detailed reports describing soils and deposits outside the compound wall were synonymous with, and thus extrapolated to, deposits throughout the compound. His precise soil descriptions served as a basis for our interpretations of construction and occupation periods throughout the mission's existence.
The Gilmore and WPA excavations were conducted in feet and inches, but later excavations by Ricklis and CAR were conducted using the metric system.

A total of 105 units were excavated; 98 were "testings", a term used for those units which were meant to be excavated to a level which would provide CAR archaeologists with an assurance of the depth of sediments and soils that covered Spanish Colonial deposits. In consultation with TPWD project archaeologist, Mr. Art Black and project architect, Mr. Jim Bigger, they were strategically located throughout the compound to either examine areas not investigated by Gilmore in 1973-1974, or to complement her discoveries in other areas (Figure 3-1). Seven other "test" units were intended to be excavated below the Spanish Colonial deposits to expose the stone walls and foundations; $\operatorname{six}(1,7,64,66,75$, and 80$)$ were placed along the compound walls and one (63) was placed along the wall of Chapel 1 (Figure 4-1).

The seven test units were excavated in arbitrary 10 $\mathrm{cm}$ levels, while the 98 testings were generally excavated by strata. In all cases overburden from $1-2 \mathrm{~cm}$ to $1 \mathrm{~m}$ deep covered the Colonial soil and deposits. The overburden consisted of wall fall rubble along the structural walls and accumulated Colonial midden soil along the outer compound walls. Normally, the rubble or modern sediments sloped up against the walls and it was evident that the soils and sediments were not in situ, held no Colonial artifacts, and thus were removed with a shovel and not screened. The objective was to create a level beginning surface from which to establish a unit datum and begin standard 
excavations by strata. In a few cases, the soils were mixed and if it was unclear whether or not they held Colonial artifacts, the overburden was excavated with trowels and screened. Normally the removal of overburden during excavations would be standard and only commented on briefly, and included in this chapter. However, because the slope, sediments, and soils always varied from unit to unit, it necessitates providing details on the amount and consistency of overburden removed in the following chapter which provides the results and a discussion of each unit.

Excavated sediments and soils were screened through 1/4-inch wire mesh. Black plastic was positioned under the screens to catch the screened sediments which would be re-used as backfill at the completion of the project. All cultural material was collected and placed in paper bags labeled with the appropriate provenience, including the Mission Rosario site number (41GD2), unit, and depth below datum. Each bag was assigned a number and recorded on a field bag log form. They were then transported to the CAR laboratory every Friday afternoon.

Before completing the fieldwork, fluorescent orange, woven plastic fencing cut to size was placed in the bottom of each unit. A 10-inch datum spike was left in the corner of every unit with the expectation that future investigators with the use of a metal detector could relocate these. Datums were not always established in the same corner (e.g., sw), but they are defined within the unit descriptions in the following chapter. Ten offenders under the supervision of a corrections officer from the McConnell Corrections Facility, Beeville, Texas provided the labor to backfill all 105 units with the screened sediments. Because of the deflated state of some backfilled units, TPWD maintenance personnel provided a trailer-load of tan, river sand to bring the excavation depression cavities level with the modern surface. CAR personnel visually monitored the dumping of this river sand and observed no cultural material within it.

\section{Charcoal, Flotation, and Mortar Samples}

Ten flotation samples were collected on floors and in association with burned areas. Two charcoal samples were taken; one from a floor in Unit 1 and another from a fire cracked rock hearth feature in Unit 100. Ten mortar samples were also taken from both upper compound walls and buried walls. None of these samples were processed for this project, but were placed in acid-free boxes for future analysis.

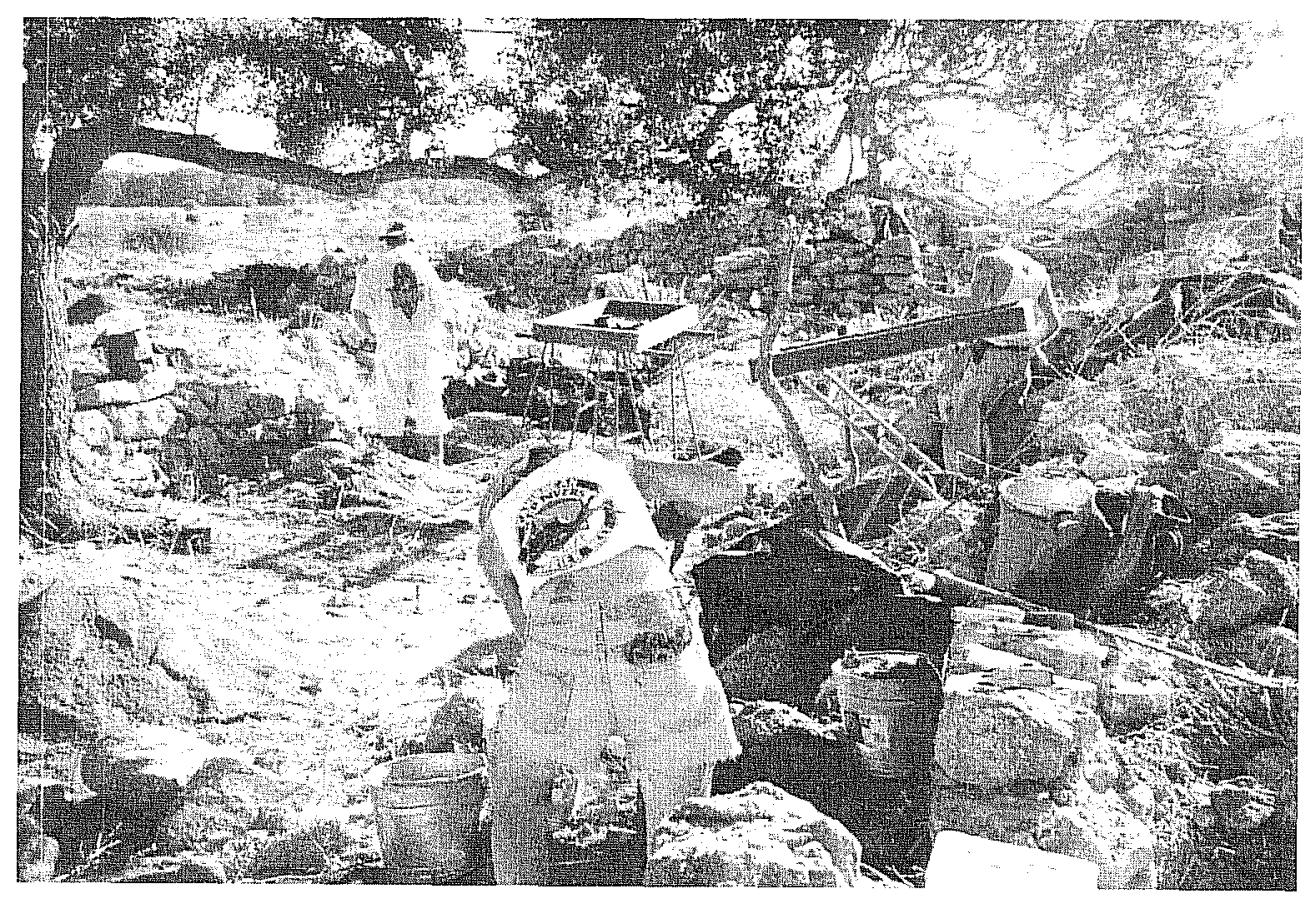

Fïgure 4-1. CAR staff excavating inside Room 1, Chapel 1. 


\section{Mapping}

Gilmore's maps were drawn based on a grid system laid out in feet and inches, and the WPA also used a feet and inches grid. TPWD surveyor Korky Kuhlman used the same system, but Ricklis and CAR based their maps on the metric system. CAR converted all data into metric for map compilations. Survey data from the site was obtained from TPWD to use as a base map. Next, 1,083 shots of south, east and elevation proveniences were recreated on a database spreadsheet from an in-depth study of Gilmore's field notes (1974a, 1974b). An iron 1/2-inch rebar driven on her last day of fieldwork in 1974 was located and was used as the site's central datum from which the mapping of our 1999 work is relevant. CAR set a Total Data Station (TDS) over that rebar, located a Gilmore 3-point provenienced nail set on the northern edge of the western opening in Room 2, and used these two points as a baseline for survey. Using the TDS, CAR shot in a Texas Department of Transportation benchmark a few meters north of the chain link fence, a TPWD benchmark within the fence along the eastern edge, the stone marker between the fence and the highway, all chain link fence corners, and a TPWD survey marker on an interior wall to insure conformity.

Gilmore also shot in the concrete monument between the mission and Highway 59 as a base. We took the same shots and correlated the data. Gilmore took a shot from an elevation marker off the Highway 59 bridge to the east over the San Antonio River. However, the bridge has been replaced since then, so data gleaned from her records relative to the bridge is obsolete. Regardless, CAR surveyor Bruce Moses was able to identify specific 3-point references within the mission complex to confidently overlay our 1999 work over Gilmore's 1973-1974 work. A total of 846 shots were recorded with TDS and combined with the 1,083 recreated Gilmore shots to make the map overlays.

Metallic unit corner markers placed by Ricklis after his 1998 excavations were located and also mapped with the TDS. A separate challenge was to distinguish with some degree where the WPA had excavated and trenched. Using photographs from the 1940s and modern survey maps, a $5^{\prime} \times 5^{\prime}$ grid was laid over the mission.
The culmination of this effort is a multi-layered, threedimensional version of buried walls, postholes, floors, and presumed living, work, and burial areas. Of course, many areas and surfaces are speculative and warrant further investigation.

Conversions from either feet or meters to the Spanish vara are stated in the following chapter when discussing compound wall or room openings. Use of the Texas vara is not appropriate, as it generally pertains to construction during the Republic of Texas period, 18361845. Mission Rosario was constructed and restructured between 1754 and 1807 under Spanish Colonial rules of architecture. Masons and builders in the colonies came mainly from Spain and depending on where they originated, would have considered a vara to be between .768 and .912 meters, with a mode ( 26 of $48 ; 54 \%$ ) of .835905 meters, or 32.909579 inches (Haggard and McLean 1941:84-87). The countries of origin for the architects and masons who built Mission Rosario are unknown, thus the rounded mode of $84 \mathrm{~cm}$, or 33 inches, per vara is used for conversion.

\section{Geophysical Survey}

A geophysical survey was conducted by John Dunbar and Michael Cagle from Baylor University in support of the archaeological investigations (Figure 4-2). A one-meter grid system was established across the site and the survey conducted using an electromagnetic conductivity meter (EM31) instrument from Geonics Limited. Over 12,000 measurements were taken and a ground conductivity map showing areas of possible walls, foundations, floors, pits and other features beneath the surface was developed. Next, a ground penetrating radar (GPR) system collecting data every 10 $\mathrm{cm}$ was used to provide a vertical cross-section along two perpendicular transect lines laid across the southern and eastern portions of the compound. At least 20 anomalies representing possible structural and nonstructural features were detected (Appendix C).

\section{Photographic and Video Documentation}

Our intimidating experience attempting to sort out what disturbances may have occurred in certain areas prior to 1999 provided the impetus to take a greater than normal number of photographs. CAR staff took 
Figure 4-2. John Dumbar and Michael Cagle conducting ground penetrating

radar testing in the southern portion of the compound.

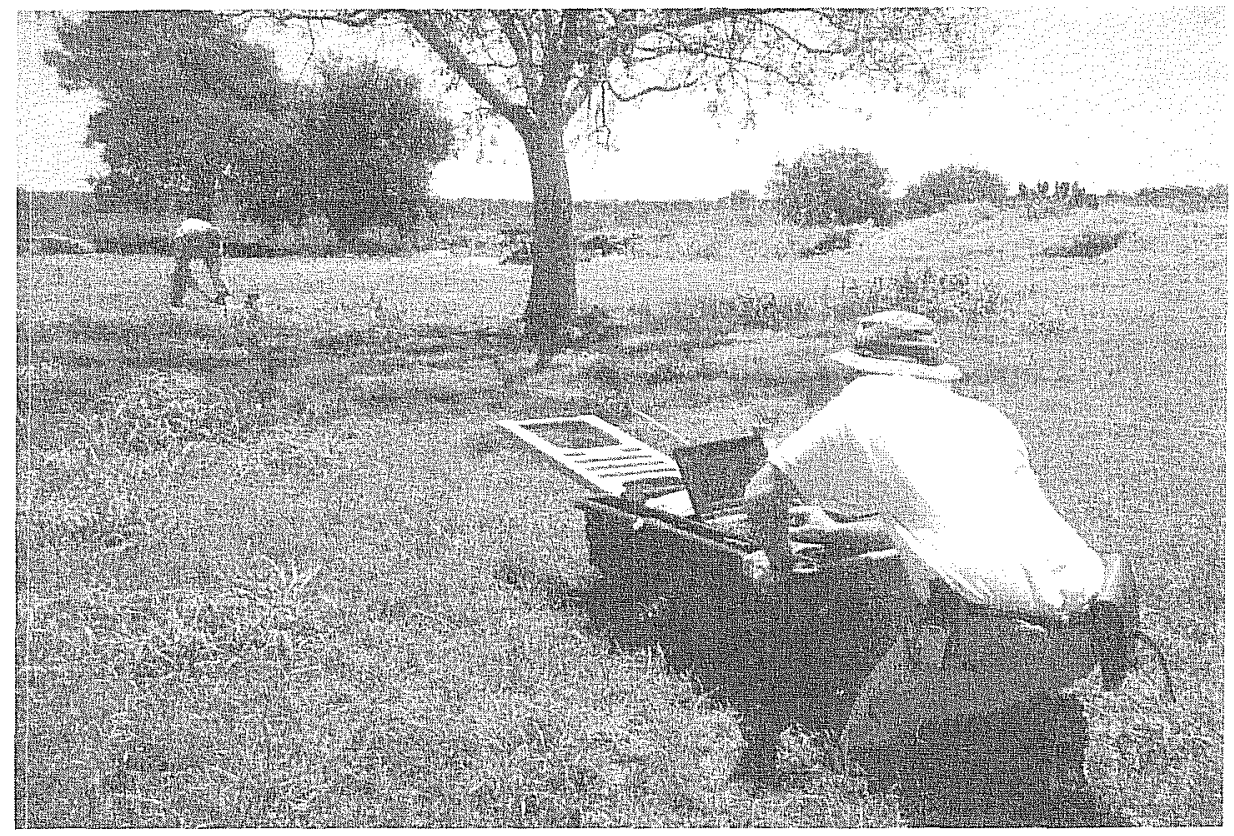

911 photographs in the field using color print and slide film with Cannon ${ }^{\circledR}$, Pentax ${ }^{\circledR}$, Polaroid ${ }^{\circledR}$, and Minolta ${ }^{\circledR}$ cameras equipped with zoom lenses. Photographs were recorded on standard CAR photo forms in the field. In addition to photographing general excavation activities, particular attention was given to features, profiles, and plan views. Midway through the project, TPWD contractor Bob Parnell arrived to take several overhead shots of the compound from a cherry picker. Attempts were also made to duplicate the vertical and horizontal angular detail of the $8 \times 10$-inch black and white photographs taken during the 1940s WPA investigations. Upon completion of the excavations and prior to backfilling, over an hour of videotape was recorded with an audio discussion highlighting significant findings throughout the project.

\section{Laboratory Methods}

Cultural materials recovered were inventoried at the CAR laboratory on the UTSA campus. Much of the laboratory processing and analyses ran concurrent with the fieldwork. Proveniences for the materials entering the CAR laboratory were double-checked through the use of a bag log number assigned to all artifact bags in the field (see field methodology). The CAR laboratory processed 920 lithic artifacts, 14,355 pieces of faunal remains, 3,091 ceramics sherds, 174 glass sherds, and a variety of metal and miscellaneous material (Appendix A). Artifacts were separated by artifact type and recovery context to facilitate analysis.

\section{Curation}

Cultural material processed in the CAR laboratory was washed, air-dried, and stored in archival-quality bags. Acid-free labels were placed in all artifact bags. Each bag was labeled with a provenience or corresponding lot number. Stone tools were labeled with permanent ink and covered by a clear coat of acrylic. Artifacts were separated by class and stored in acid-free boxes. Boxes were labeled with standard labels. Field notes, forms, photographs, and drawings were placed in labeled notebooks. Photographs, slides, and negatives were placed in archival-quality sleeves. All notebooks are stored in acid-free boxes. Documents and forms from the 1999 excavation were printed on acid-free paper. A copy of the site report and all computer disks pertaining to the 1999 investigation of Mission Rosario are stored in acid-free archival boxes and curated with the field notes and documents. Artifacts, notes, documents, and photographs from the 1999 excavations at 41GD2 are permanently housed at the Center for Archaeological Research, The University of Texas at San Antonio. 



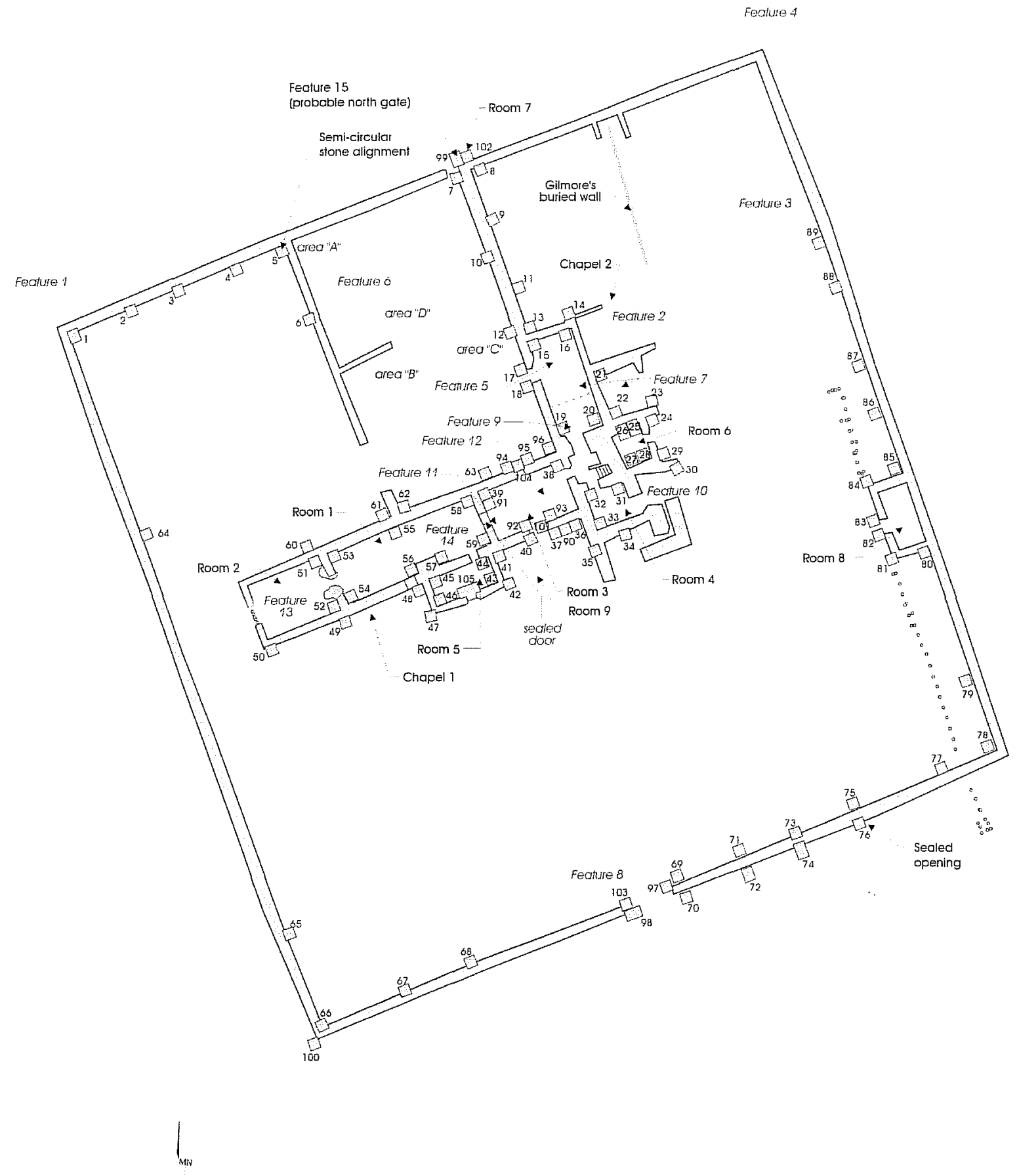

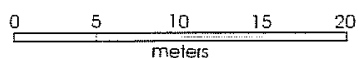

$$
\begin{aligned}
& 495 \text { CAR units } 1999 \\
& \text { previously excavaied }
\end{aligned}
$$

Figure 5-1. Map showing Features, Rooms, and Areas discussed in Chapter 5. 


\section{Chapter 5:}

\section{Results and Discussions of Investigations}

\section{Introduction}

This chapter describes the results of excavations in each of the 105 units, clearing around two stones walls, and probing for buried walls, foundations, and entryways (Figures 5-1 and 5-2). For clarity of reading the results and discussion or analysis of the results are arranged as if touring the mission, beginning with the northwest corner of the compound and hypothesizing the evidence for construction and occupation phases from the earliest period in 1754 through to the final abandonment in 1808 . From this point the reader is then invited inside the many rooms and structures that changed throughout the ca. 53 years of periodic occupation and abandonment; room-to-room inside the presumed first church and sacristy, to a probable small office with a long and narrow window just off the sacristy.
The architecture of the mission is then evaluated, particularly the floors in the three rooms of the presumed second chapel and the adjoining second sacristy. Speculations about the use of a separate room under the collapsed bell tower are made before moving on to a stone structure along the east compound wall, the function of which is unknown. Next, we return to an area adjoining the existing stone structures, which we believe to be an open-atrium with a retaining wall. Investigations continue with the exterior structural walls, structure-to-structure, postulating scenarios of construction and occupation. Finally, we travel around the compound walls and find evidence of previously undocumented buried foundations or walls, floors, and features before ending with a brief discussion of a rock wall and semicircular stone alignment in the camposanto.

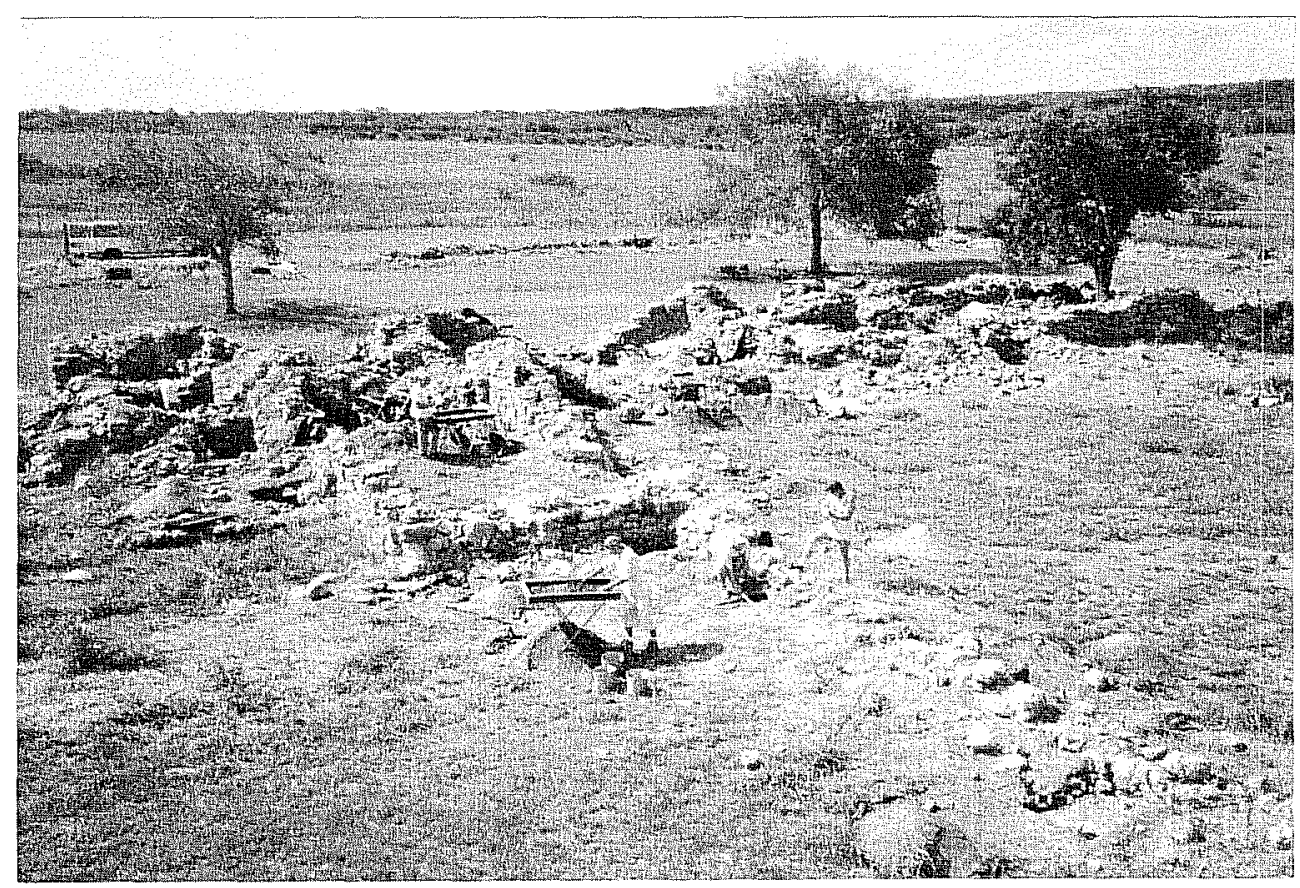

Figure 5-2. CAR staff excavating in and around Chapel 2 (forward), Room 6 (upper left) and Room 3, Chapel 1 (left center). 
Gilmore identified 14 features during her excavations. Ricklis worked in the midden area outside the south wall and exposed foundations and room floors. CAR excavated in some of those same features and areas, as well as others previously not recorded. Table 5-1 lists the features, rooms, and areas shown on Figure $5-1$ that will be discussed. For convenience, Figures 3-1 and 5-1 have been enlarged and are included in a folder at the end of this publication.

As with most technical reports, the purpose of this report is to provide great detail on the soils, cultural material, and features encountered in every aspect. Thus the results of each unit's excavation in this chapter are provided with specific metric measurements, quantities, and soil descriptions which may be laboriously intensive to comprehend without referring to the numerous drawings and photographs. Nevertheless, we knowingly have omitted an excruciating amount of detail that the archaeologists and architects who follow us will want to consume. Those numerous photographs and notes are curated at TARL.

The field methodology used during our investigations is discussed in Chapter 4 (Field and Laboratory Methodology). However, it is worth reiterating that although generally the mission compound's surface was only slightly undulating, sediments and soils up to $1 \mathrm{~m}$ deep against the stone walls were not uncommon in some areas of the compound. In many cases when it was obvious that the sloping sediments against the walls were not in situ, we removed this overburden with shovels and thus began excavation on a level surface. In a few cases our $1 \mathrm{~m}^{2}$ units did not encounter a wall or feature as planned and the units then had to be extended beyond $1 \mathrm{~m}^{2}$. Suffice it to say that all units described in this chapter should be considered $1 \mathrm{~m}^{2}$ unless stated otherwise.

Table 5-1. Features, Rooms, and Areas shown in Figure 5-1

\begin{tabular}{|c|c|c|c|c|c|}
\hline Gilmore & Ricklis & CAR & Feature & Room & Label \\
\hline $\mathrm{X}$ & & $\mathrm{X}$ & 1 & & Original Wooden Walls \\
\hline $\mathrm{X}$ & & & 2 & & First Stone Church (Chapel 2); East of N-S Cross Wall \\
\hline $\mathrm{X}$ & & & 3 & & Indian Occupation Area \\
\hline $\mathrm{X}$ & & & 4 & & Mission Dump Area \\
\hline $\mathrm{X}$ & & $\mathrm{X}$ & 5 & & First Stone Church (Chapel 2); West of N-S Cross Wall \\
\hline $\mathrm{x}$ & & $\mathrm{X}$ & $6 a$ & & Structures \\
\hline $\mathrm{X}$ & & & $6 b$ & & Possible Structures \\
\hline $\mathrm{X}$ & & & $6 c$ & & Burials in Camposanto \\
\hline $\bar{x}$ & & & $6 d$ & & E-W Cross Wall \\
\hline $\mathrm{X}$ & & $\mathrm{X}$ & 7 & & First Stone Church (Chapel 2); South Wall Area \\
\hline $\bar{X}$ & & $\mathrm{X}$ & 8 & & South Gateway \\
\hline $\mathrm{X}$ & & $\bar{x}$ & 9 & & Posthole in Sacristy off Chapel 2 \\
\hline $\mathrm{X}$ & & & 10 & & Flying Buttress \\
\hline $\bar{x}$ & & & 11 & 3 & Filled-in Doorway \\
\hline $\bar{x}$ & & & 12 & 3 & Posthole \\
\hline $\mathrm{x}$ & & $\mathrm{X}$ & 13 & 2 & Splayed Doorway \\
\hline \multirow[t]{10}{*}{$\mathrm{x}$} & & & 14 & 1 & Burial in Chapel 1 \\
\hline & & $\bar{X}$ & & 1 & Chapel 1 \\
\hline & & $\mathrm{X}$ & & 2 & Chapel 1 \\
\hline & & $\mathrm{X}$ & & 3 & Chapel 1 \\
\hline & & $\mathrm{X}$ & & 4 & Office \\
\hline & & $\mathrm{X}$ & & 5 & Chapel 1 Sacristy \\
\hline & & $\mathrm{X}$ & & 6 & Below Bell Tower \\
\hline & & $\mathrm{X}$ & & 7 & Near Opening in North Compound Wall \\
\hline & & $\mathrm{X}$ & & 8 & Structure along East Compound Wall \\
\hline & & $\mathrm{X}$ & & & Foundation, Trench, Postholes, \& Floors outside South Compound Wall \\
\hline \multirow[t]{3}{*}{$\bar{X}$} & $\mathrm{x}$ & $\mathrm{x}$ & & & Midden Outside South Compound Wall \\
\hline & & $\mathrm{X}$ & 15 & & Probable North Gate \\
\hline & & $\mathrm{X}$ & & 9 & Atrium \\
\hline
\end{tabular}




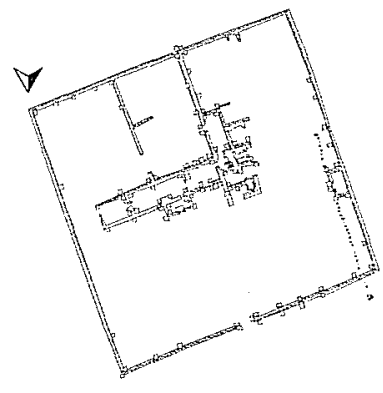

\section{Feature 1 \\ (Wood Stockade \\ and Structures)}

Gilmore (1974a, 1974b) designated the postholes, and trenches associated with the construction of the original wooden wall as Feature 1, and a floor found in the area as Structure 1 (Figures 3-1 and 5-1). Evidence of the wall and associated jacal structure(s) along the wall, presumably constructed sometime between 1754 and 1768, were found outside the northwest corner of the extant stone compound wall (Figures 3-1 and $5-1$ ). Evidence of a structure floor of presumably later, but of unknown antiquity was found on the interior of the extant stone wall near the northwest corner. CAR placed only one unit (Unit 1) in the Feature 1 area (Figures 3-1 and 5-1).

\section{Description and Results Unit 1}

Unit 1 is a $1 \times 1.25 \mathrm{~m}^{2}$ unit placed on the inside corner of the northwest corner of the compound wall
(Figures 3-1 and 5-1), and was excavated to a depth of $1.3 \mathrm{~m}$ below datum (bd). The purpose of placing a test unit here was to investigate the wall construction and integrity. Before excavation began using arbitrary $10 \mathrm{~cm}$ levels, a thin layer of sandy loam overburden approximately $2 \mathrm{~cm}$-thick along the southern portion and increasing in thickness to $15 \mathrm{~cm}$ up against the northern and northwestern stone walls was removed. Datum was then established in the southwest corner 2 $\mathrm{cm}$ below the modern surface. Disturbed, ephemeral remnants of a possible floor of intentionally laid cobbles were found between 15 and $20 \mathrm{~cm}$ below datum. Moderate amounts of bone, ceramics (18 brownware and 2 majolica sherds), and charcoal were observed in situ resting just underneath the cobbles, and were concentrated in an area which appeared to be an outline of an $\mathrm{E}-\mathrm{W}$ trench. A curved lens of charcoal was also observed in the west central portion of the unit at $20 \mathrm{~cm}$ bd. At $25 \mathrm{~cm}$ bd the matrix transitioned to a packed surface approximately $3-5 \mathrm{~cm}$ thick, and consisting of a light gray (10YR 7/2) sandy loam with yellowish plaster granule inclusions. Faunal remains were concentrated on top of the packed surface. Below the packed surface, between $30-40 \mathrm{~cm}$, the quantity of bone and Colonial sherds decreased (Table 5-2). Excavation results from between 40-50 $\mathrm{cm}$ bd produced even less bone, an absence of chipped stone debitage and Colonial ceramics, and a mass of charcoal and ash in the southwest quadrant between $43-49 \mathrm{~cm}$ bd. Excavation between $50-60 \mathrm{~cm}$ yielded the presence of chipped stone debitage, and a slight increase in faunal remains and brownware sherds (Table 5-2).

Table 5-2. Vertical distribution of cultural material recovered from Unit 1

\begin{tabular}{|c|c|c|c|c|c|c|c|c|c|c|c|c|c|c|c|c|c|c|c|c|}
\hline 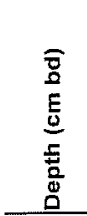 & 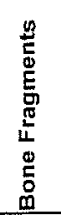 & $\begin{array}{l}\mathrm{T} \\
\stackrel{\mathrm{G}}{0} \\
\mathrm{O} \\
\end{array}$ & 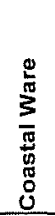 & 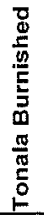 & 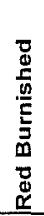 & 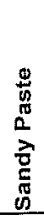 & 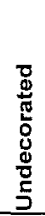 & 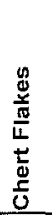 & 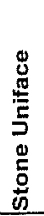 & 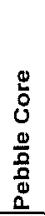 & 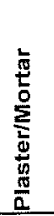 & 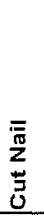 & 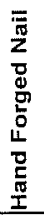 & $\begin{array}{l}\frac{0}{0} \\
\frac{0}{0} \\
0 \\
0 \\
\frac{\pi}{0} \\
\frac{0}{0} \\
0 \\
\end{array}$ & 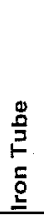 & $\begin{array}{r}\frac{9}{0} \\
0 \\
\end{array}$ & 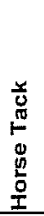 & $\stackrel{x}{\widehat{X}}$ & $\frac{\overline{\overline{\mathbf{\omega}}}}{\bar{\omega}}$ & Totals \\
\hline $0-10$ & 55 & 3 & 11 & & & & & 3 & & & 2 & & & & & & & & & 74 \\
\hline $10-14$ & 89 & & 9 & & & & & 3 & & & & & & & & & 2 & & $\mathrm{x}$ & 103 \\
\hline $14-20$ & 166 & & 20 & & & 1 & & 5 & 1 & 1 & & & 1 & & 1 & 1 & & & $x$ & 197 \\
\hline $20-30$ & 260 & & 30 & 1 & & & 2 & 4 & & & & & 1 & & & & & & $\mathrm{x}$ & 298 \\
\hline $30-40$ & 76 & 4 & 2 & & & & 1 & 1 & & & 3 & 1 & & & & & & & $x$ & 88 \\
\hline $40-50$ & 18 & & 4 & & & & & & & & 5 & & & & & & & & & 27 \\
\hline $50-60$ & 28 & & 7 & & & & & 2 & & & & & & & & & & & $\mathrm{X}$ & 37 \\
\hline $60-70$ & 59 & & 54 & & 2 & & & 6 & & & & & & 1 & & & & & $\mathrm{x}$ & 122 \\
\hline $70-80$ & 16 & & 8 & & & & & 6 & & & & & & & & & & 1 & $x$ & 31 \\
\hline $80-90$ & 5 & - & 2 & - & - & - & - & 1 & - & - & _- & - & - & - & - & - & - & - & - & 8 \\
\hline Totals & 772 & 7 & 147 & 1 & 2 & 1 & 3 & 31 & 1 & 1 & 10 & 1 & 2 & 1 & 1 & 1 & 2 & 1 & & 985 \\
\hline
\end{tabular}


An ephemeral, packed, light yellowish brown (10YR 6/4) probable floor surface was encountered $70 \mathrm{~cm}$ bd. A concentration of artifacts, shell, and faunal remains was recorded lying on, and just above the floor surface. The base of the western stone compound wall was reached at $72 \mathrm{~cm} \mathrm{bd}$, and an outline of an E-W trench filled with mottled pale brown (10YR 6/3) and dark brown (10YR 3/3) sandy loam contrasting with the consistent dark brown (10YR 3/3) sandy loam on either side became apparent between 70 and $80 \mathrm{~cm}$ bd. The few artifacts that were recovered between 70 $80 \mathrm{~cm}$ were predominately found in the trench outline. Further excavation to $90 \mathrm{~cm}$ bd clearly revealed the trench outline running east to west, and the outlines of five complete and two partial postholes approximately $14 \mathrm{~cm}$ each in diameter were now distinctly defined within the trench (Figure 5-3). The sediments on both sides of the trench had now transitioned from a dark brown, sandy loam (10YR 3/ 3 ) to a light olive brown (2.5YR 5/4). The ashy-looking-and-feeling posthole fill matrix consisted of a gray (10YR 6/1), loose, sandy loam with charcoal, bone, and calcium carbonate inclusions. The same matrix was observed in profile extending upward along the westward wall to approximately $73 \mathrm{~cm}$ bd - approximately the same depth at which the ephemeral, packed, probable floor surface was encountered. All artifacts found in the $80-90 \mathrm{~cm}$ level came from the trench area.

Excavation in the southern half of the unit was terminated to preserve the trench and posthole outlines, while the northern half of the unit was excavated to $1.3 \mathrm{~m}$ bd to examine the stone architecture of the north compound wall. No evidence of cultural material other than the cut stone wall was found below $90 \mathrm{~cm}$. Between 1-1.2 $\mathrm{m}$ bd, the soil transitioned smoothly from a light olive brown (2.5YR 5/4), sandy loam to a brownish yellow (10YR 6/6), clay loam, with few caliche granule inclusions. A gradual, smooth transition from the brownish yellow (10YR 6/6), clay loam to a very pale brown (10YR 4/7), silty clay, with caliche granule inclusions increasing with depth in quantity and size to $1 \mathrm{~cm}$ was observed at approximately 1.15 $1.2 \mathrm{~m} \mathrm{bd}$. The trench outline approximately $3-5 \mathrm{~cm}$ wide adjacent to the north compound wall base and filled with loose, dark brown (10YR 3/2) sandy loam was observed at $1.2 \mathrm{~m} \mathrm{bd}$, and the north wall base was recorded at $1.26 \mathrm{~m}$ bd.

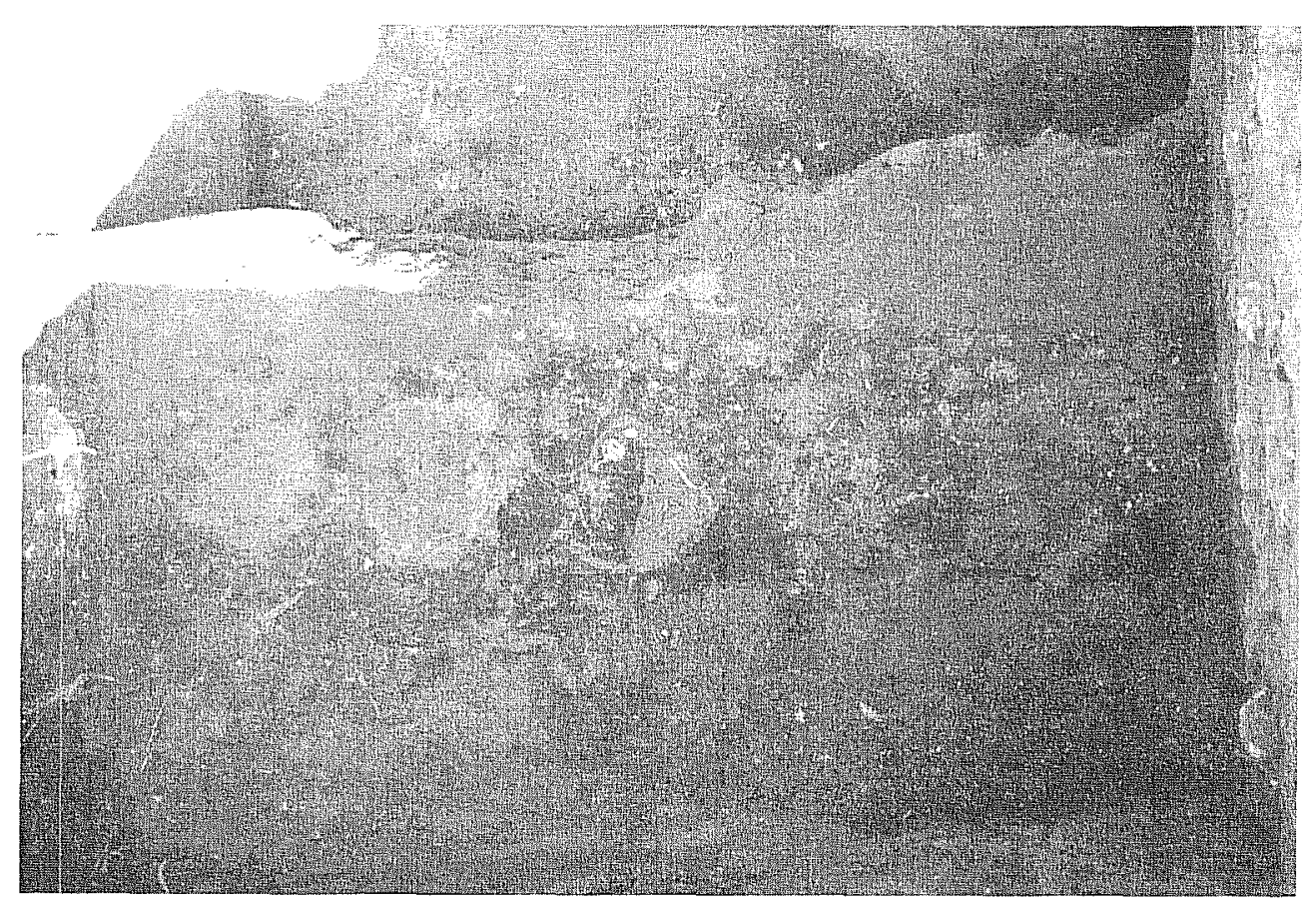

Figure 5-3. Photograph of trench outline and postholes $90 \mathrm{~cm}$ below the modern surface in Unit 1, northwest corner of the compound. 
Discussion

Prehistoric and Initial Spanish

Colonial Occupations

The presence of lithics and bone within the sandy loam, A Horizon, between 70 and $90 \mathrm{~cm}$ (with the absence of Spanish Colonial artifacts) is evidence of the prehistoric occupation at the site (Table 5-2). Evidence of the initial Spanish Colonial construction episode using wooden posts (1754-1768), and occupation at the site was found in this Unit, $20 \mathrm{~cm}$ above the deepest Prehistoric deposits, at $\mathrm{ca} .70 \mathrm{~cm}$ below the modern surface. Evidence for this construction episode was a jacal post setting trench outline found in profile in the east wall of the unit (Figure 5-4), extending downward from the $70-\mathrm{cm}$ level into the brown, sandy loam, A Horizon, but probably not as deep as the underlying Pleistocene clay.

As discussed above, the southern half of the unit was not excavated so as to preserve the trench and postholes. However, had the 1754 setting trench been dug into the underlying tan clay, there should have been mottled evidence of it in profile, overlying the A Horizon just below the grayish-white packed floor; there was none. The 1754-1768 and 1768-1780 occupation periods may be represented by approximately $40 \mathrm{~cm}$ of cultural deposits above the packed floor, or from ca. $70-30 \mathrm{~cm}$ bd (Figure 5-5).

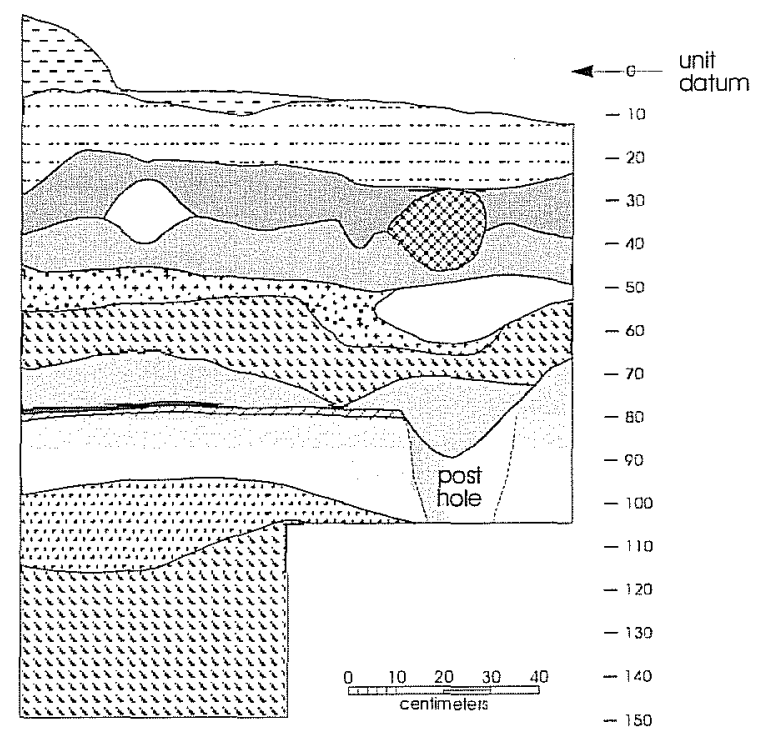

gray modern silt ( $10 Y R 5 / 1)$

sandy loam (10YR 5/2) WPA backfill

silty loam (2.5YR 6/2)

silty caliche (7.5YR 8/2)

bioturbation

construction debris with limestone fragments and mortar granules (10YR 5/2)

pale reddish brown silty clay (5YR 5/6)

dark brown sandy loam, A horizon (10YR 3/3)

gray ashy occupation lens (10YR 7/2)

yellowish brown packed caliche floor surface (10YR 6/4)

transition zone to reddish brown silty clay (7.5YR 4/4)

Figure 5-4. East wall profile of Unit 1 in the northwest corner of the compound. 
Figure 5-5. East wall photograph of Unit 1 in the northwest corner of the compound.

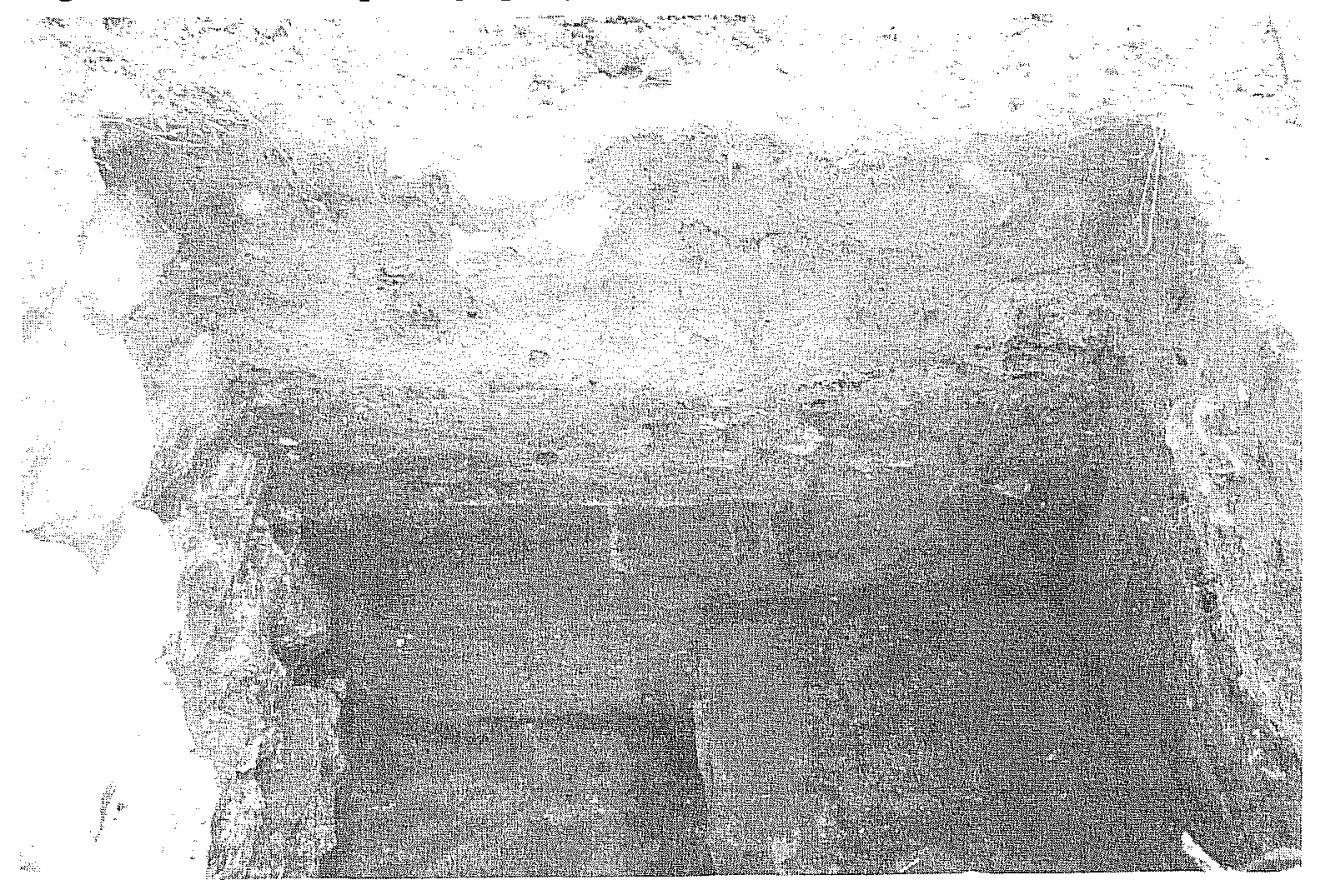

\section{Hypothesis I:}

Spanish Colonial Occupation

1789-1807

Hypothesis I assumes that the extant stone walls surrounding the compound represent the final phase of stone construction at the mission (ca. 1789-1807). It is clear that the setting trench and associated postholes discussed in the preceding paragraph predate the extant stone wall construction, as their outline continues under the western compound wall. It is further clear that the stones in the northwest corner of the two walls are interlocked; i.e., they are contemporaneous. The final period of construction at the mission (ca. 1789-1807) could be seen in the reverse stratigraphy in the unit's east and south wall profiles. The brown, sandy loam, A Horizon, and the underlying $\tan$ Pleistocene clay soil that had been brought up from beneath the hard packed 1754-1768 floor when the setting trench for the extant north stone compound wall was dug through that period's surface, was now inverted. That is, mottled remnants of the underlying Pleistocene clay now overlie remnants of the A Horizon soil, above the grayish hard packed ca. 1754 floor (Figure 5-3). In addition, a thin lens of fine limestone fragments and mortar representing the spillover from construction of the 1789-1807 extant stone wall could be seen overlying the $\tan$ Pleistocene clay remnants. Finally, the western wall base stones appeared to have been set on top of the 1754-1758 occupation cultural deposits. The cultural material from this subjected final occupation period was ca. $60 \mathrm{~cm}$ thick, extending from the modern surface to $60 \mathrm{~cm}$ below the surface.

\section{Hypothesis II:}

Spanish Colonial Abandonment and Re-Occupation

1780-1807

Still unexplained is the undulating, massive charcoal and ash lens between ca. $40-55 \mathrm{~cm}$ below the surface, that is perhaps related to the absence of metal and Colonial ceramics between $30-60 \mathrm{~cm}$ below the surface. Assuming that the inverted stratigraphy as described in Hypothesis I above, is attributed to the construction of the extant stone compound wall, then the charcoal may represent a possible structure fire between 1789-1807 (although no archival evidence of a structural fire at the mission has been found). Gilmore's (1974b:37) assessment during her 1973 investigations is that there was originally a wooden structure in this area, which may have burned. However, a second explanation is that the absence of metal and Colonial ceramics between 30-60 $\mathrm{cm}$ may represent a 
period of Spanish abandonment of the site between 1780-1789. This explanation becomes more plausible when one considers the report by Father Reyes in 1783, that soldiers stationed at the presidio had used the wood from all the buildings for firewood, as did the Apaches. The mass of charcoal found in Unit 1 (Figure 5-6) might be that of the remains of periodic occupation of the northwest corner of the site by the soldiers and Apaches between 1780 and 1789. This explanation could then lend credence to the hard packed surface above the charcoal mass, between 25$30 \mathrm{~cm}$ below the modern surface as representing the re-occupation of the site by Father Reyes in 1789. The ca. $20 \mathrm{~cm}$ of cultural deposits lying above this upper packed floor surface would then represent the 17891807 occupation period.
Embedded within this upper, final occupation deposit was what appeared to be an intentionally prepared cobble surface. Gilmore (1974b:32-33) noted remnants of the cobbled floor during her excavations in the area and opined that it represented part of a stone fireplace that remained after a structural fire, and was subsequently incorporated into a caliche floor.

Finally, the presence of a thin, gray, sandy loam, A Horizon (10YR 5/1) over the northern and western portion of the unit's surface, increasing in thickness against the extant stone compound walls is most probably the result of eolian processes following the WPA work in the 1940s. The upper level of the Colonial surface directly underlies the A Horizon, and is at the modern surface in the southeastern portion of the unit (Figure 5-6).

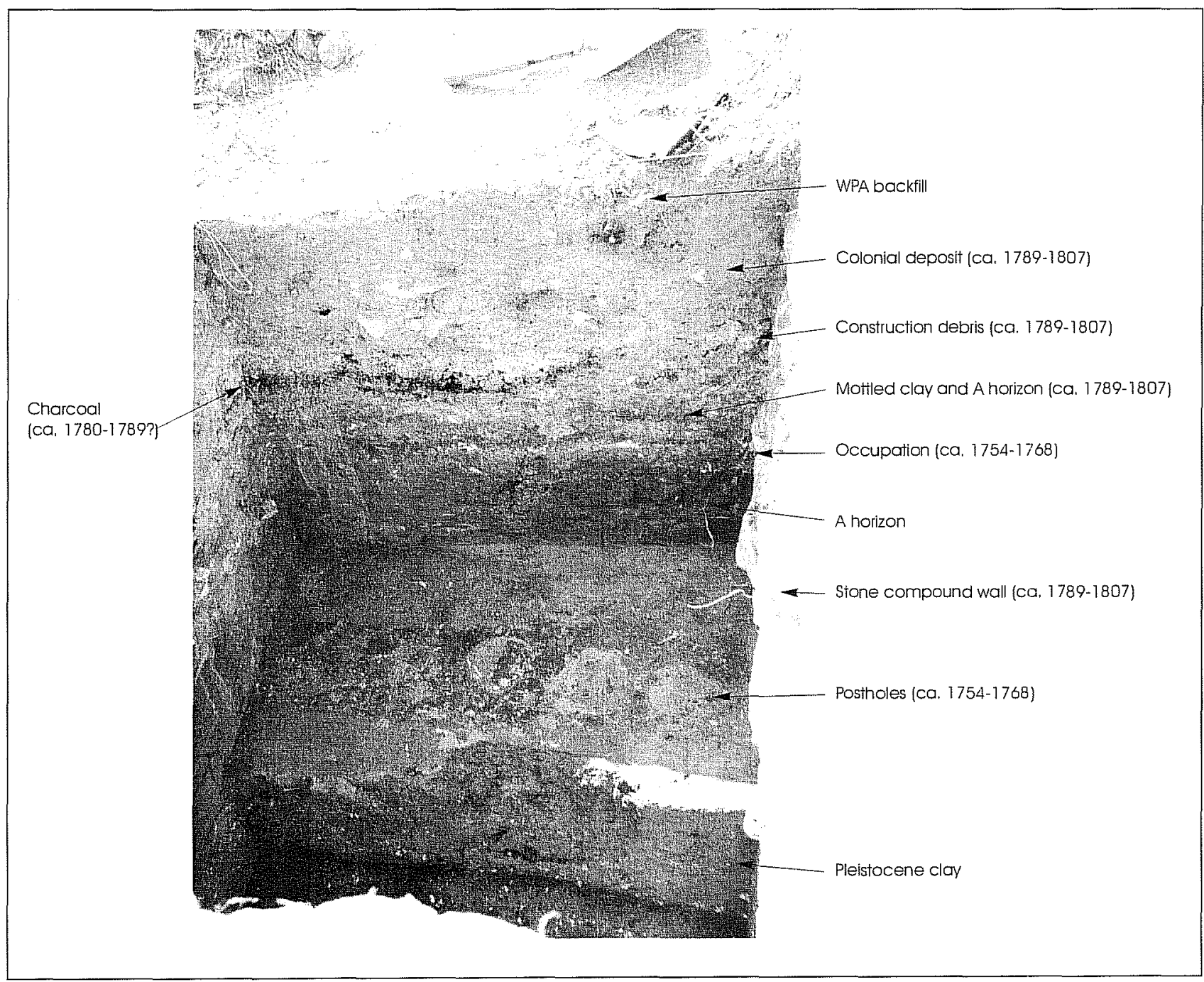

Figure 5-6. South wall photograph of Unit 1 in the northwest corner of the compound. 
In summary, evidence of the first building episode was clearly manifested in the setting trench and jacal postholes (ca. 1754-1768), and the third building episode was manifested by the inverted stratigraphy created when constructing the extant stone wall (ca. 1789-1807). The pattern of postholes discovered in this area by Gilmore (1974a, 1974b) and presumably representing the initial (1754-1768) period of construction are represented in Figure 5-7. Problematic to a final discussion of construction, occupation, and abandonment in this corner of the mission is the massive lens of charcoal with a corroborative absence of metal and Colonial ceramics sandwiched between two hard packed floors with associated Colonial material.
To construct the extant north stone compound wall a trench dug through the sandy loam, A Horizon into the Pleistocene clay. A 3-5 cm layer of sandy loam was placed on the bottom of the trench, presumably to serve as a leveler, and hewn stone was then carefully and skillfully stacked in the trench to form the wall foundation. No extended or wider footing was constructed for the north wall. The western wall's base is much shallower than that of the northern wall (see Figures 5-8 and 5-9). The western wall base stones appeared to have been set on top of the 1754-1758 occupation cultural deposits, and any evidence of a shallow trench that may have been dug for the western stone compound wall was not evident during

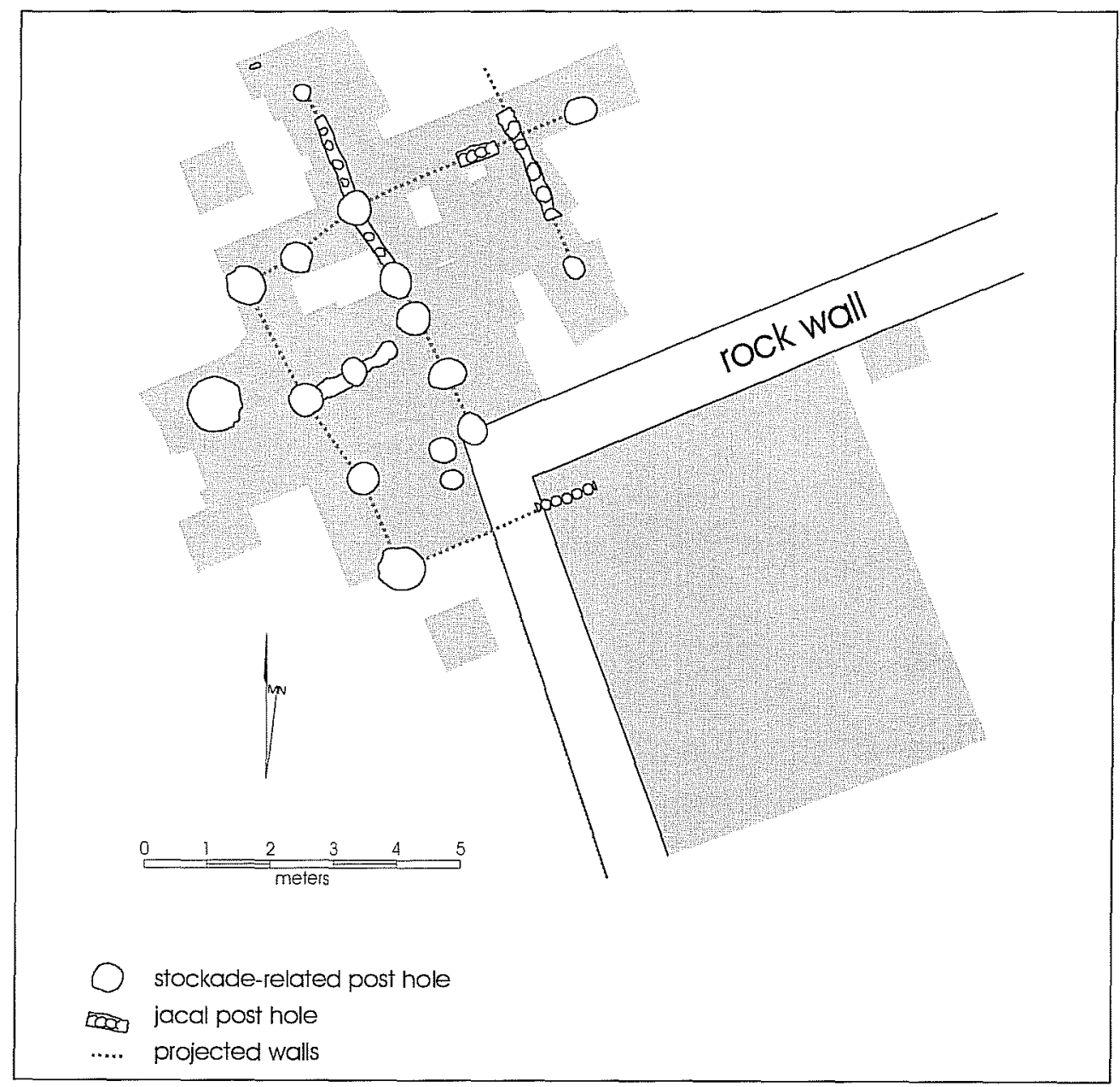

Figure 5-7. Postholes found by Gilmore and CAR in the northwest portion of the mission. 


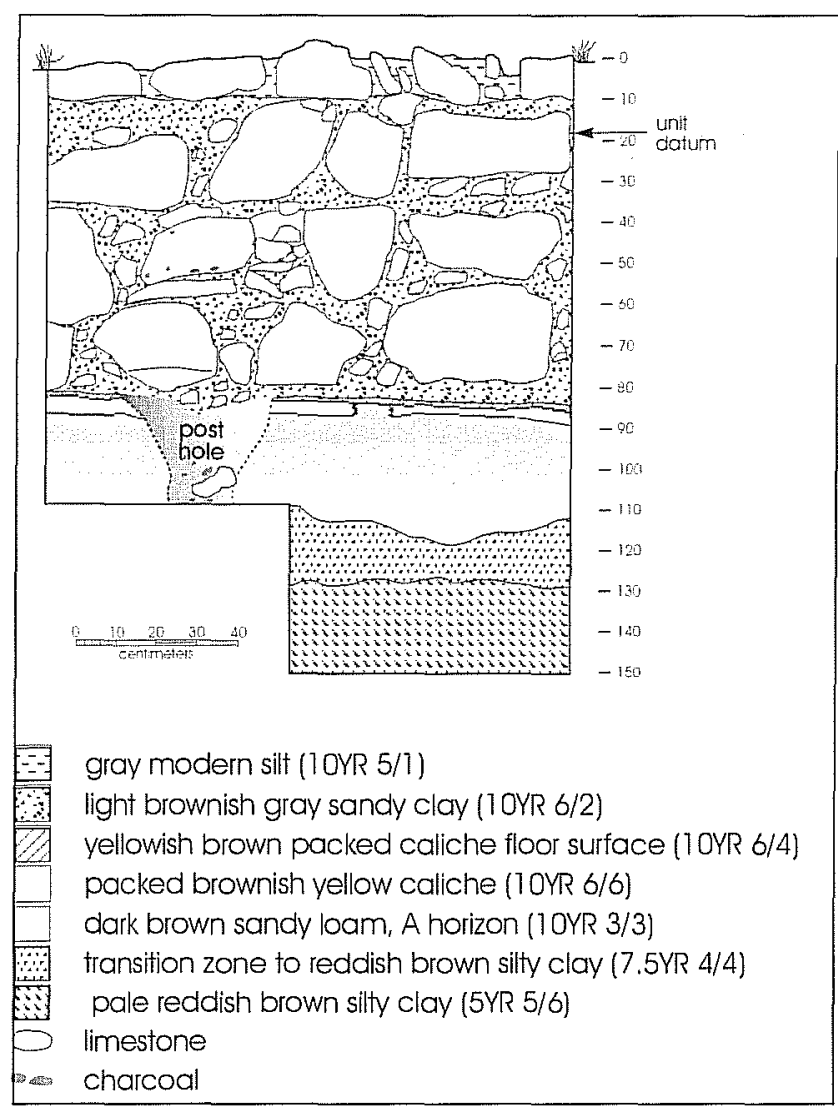

Figure 5-8. West wall profile of Unit 1 in the northwest corner of the compound.

excavation in this unit. Regardless, evidence for their contemporaneity is that the two walls are adjoined with interlocking stones at ca. $60 \mathrm{~cm}$ bd. One feasible explanation for the differences in depths of the western and northern walls is that the northern wall is implanted deeper to counteract the effects of the more pronounced slope along the outer, northern portion of the mission.

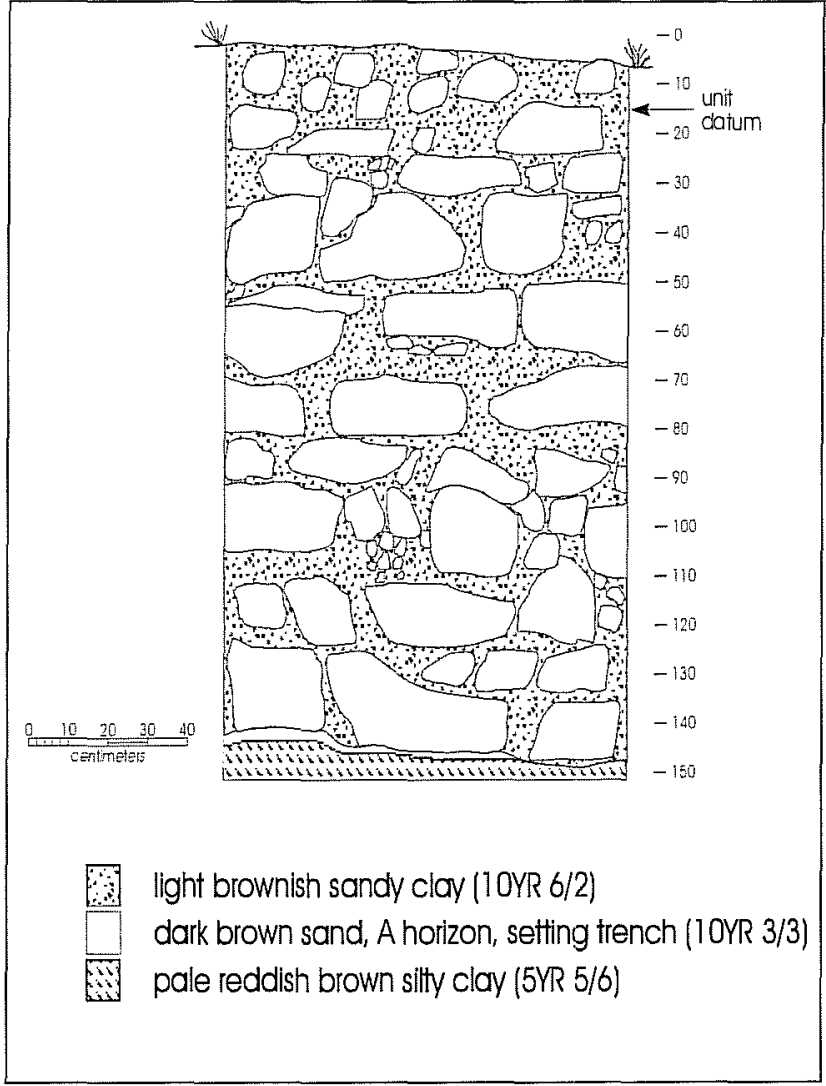

Figure 5-9. North wall profile of Unit 1 in the northwest corner of the compound. 


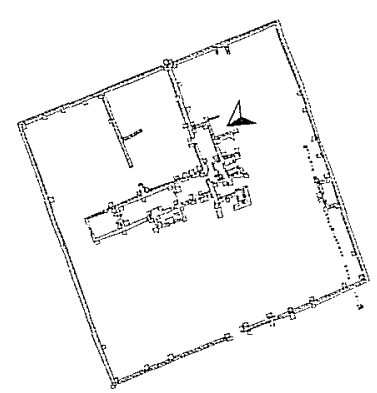

\section{Features 2, 5, 7, and 9 (Chapel 2 and Sacristy)}

Gilmore (1974a, 1974b) designated the areas inside Chapel 2 as Features 2 and 5, and a room adjoining Chapel 2 to the south that may be either the sacristy or a small chapel for the priests as Feature 9, (Figure 5-1). CAR placed seven test units in these feature-designated areas: Units 15 through 21 (see Figures $3-1$ and 5-1).

\section{Description and Results Unit 15}

the center of the unit by previous excavations (Figure $5-10)$. The floor remnants were left intact, while the center of the unit which was previously excavated by Gilmore and backfilled with tan-colored sand was reopened to $56 \mathrm{~cm}$ bd. Gilmore's field notes (1974) identified a posthole dug into red mottled clay from $50-58$ $\mathrm{cm}$. The bases of both the north and west stone walls were found at ca. $33 \mathrm{~cm}$ bd. No evidence of a setting trench was observed under either of the stone walls; they were apparently set directly on the underlying dark brown, sandy A Horizon, which was present in the unit from 33 to $50 \mathrm{~cm}$ bd. However in the northwest corner was an apparent posthole (described in Gilmore's 1974 field notes), with a series of rocks in a semicircle which may have been either a footing or support for a post. Reddish clay has been used as the "mortar" between the stone interstices in the footing stones, while gray, sandy paste mortar was used in the wall above the floor found at $28-33 \mathrm{~cm}$. Because of the backfilled material and disturbance that has occurred in this area, the upper Colonial surface is difficult to discern, but based on the floor level it is assumed to have been ca. $8 \mathrm{~cm}$ bd.
This unit was placed in an area that had previously been excavated by Gilmore in 1974 (Figures 3-1 and $5-1)$. Datum for the unit was established at the modern surface in the southeast corner. The upper 28 $\mathrm{cm}$ consisted of coarse, tan, river sand with rounded pebbles believed to be Gilmore's backfill. Artifacts recovered from this level included 5 chipped stone flakes, red flagging tape from Gilmore's excavations, mussel shell and bone fragments, brown beer bottle glass sherds, a linoleum fragment, and a single brownware sherd that was found within the stone wall matrix (Appendix A). A distinct, packed, slightly undulating, ca. $5 \mathrm{~cm}$-thick, yellowish caliche floor with gray clay mottling, probably caused by the fine-grained mortar and coarse limestone fragment inclusions, was encountered at $28 \mathrm{~cm}$ bd. The floor was not continuous across the entire unit, having been penetrated in

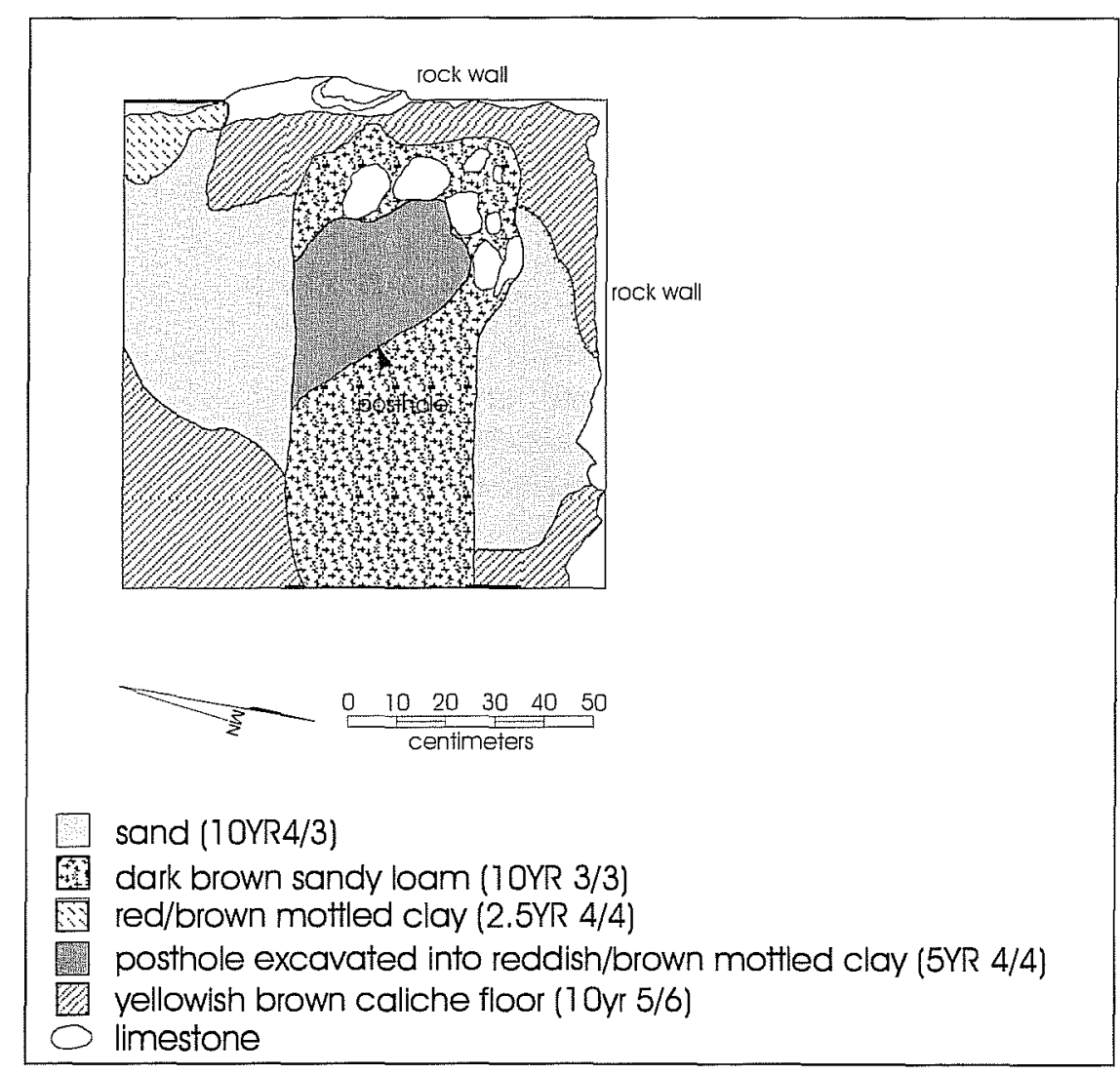

Figure 5-10. Unit 15 planview, $28-38 \mathrm{~cm}$ bd in the front of Chapel 2. 


\section{Unit 16}

This unit was placed in an area that had previously been trenched by the WPA in 1940-41, and excavated by Gilmore in 1974 (Figures 3-1 and 5-1). Datum for the unit was established at the modern surface in the southeast corner. Approximately $5 \mathrm{~cm}$ of limestone rubble and sand overburden was removed. The underlying $12 \mathrm{~cm}$ consisted of coarse, tan, river sand with rounded pebbles believed to be Gilmore's backfill. Only a few bone fragments (Appendix A) were recovered from this $0-17 \mathrm{~cm}$ level.
To expediently determine the depth of Gilmore's previous excavations, only the southeastern quad of the unit was excavated deeper (Figure 5-11). Remnants of a distinct, packed, slightly undulating, ca. 5 to 7 cm-thick, grayish caliche floor with fine-grained mortar and coarse, angular, golf ball-sized, limestone fragment inclusions, were encountered at $17 \mathrm{~cm}$ bd. The floor sloped slightly toward the northeast, and was not continuous, having been left partially intact during previous excavations (Figure 5-11). This floor is apparently the same one as described in Gilmore's (1974a) field notes as a "gray floor" overlying a yellowish caliche floor, because further excavations revealed that underlying the gray caliche floor was a layer of reddish brown, mottled sandy loam ca. $5 \mathrm{~cm}-$ thick. This was setting on remnants of a distinct, yellowish, packed, slightly undulating, ca. 5 to $7 \mathrm{~cm}$-thick, caliche floor with fine-grained mortar and coarse, angular, golf ball-sized, limestone fragment inclusions, encountered at $34 \mathrm{~cm}$ bd (obviously the same floor as found in Unit 15).

Sand backfill in the previously excavated portion of the unit was of two different consistencies; at $38 \mathrm{~cm}$, a light brown-tan fine sand with fine pebble inclusions was intermittently overlying a fine, pale brownyellowish river sand. The yellowish sand appears to have been from Gilmore, while the darker sand is apparently from WPA work. Only a single stone flake and a few bone fragments were found in the southeast quad $17-38 \mathrm{~cm}$ excavation level.

Excavations were terminated at $36 \mathrm{~cm}$ bd, and at this depth the $\mathrm{N}-\mathrm{S}$ interior chapel wall does not appear to have a footing. The base of the $\mathrm{E}-\mathrm{W}$ chapel exterior wall was not reached at this depth. As observed by Gilmore (1974), the $\mathrm{N}-\mathrm{S}$ interior chapel wall is not tied into the $\mathrm{E}-\mathrm{W}$ chapel wall, but is abutted to it. No plaster remains were found on either of the stone walls. Because of the backfilled material and disturbance that has occurred in this area, the upper Colonial surface is difficult to discern, but based on the floor levels is assumed to have been ca. $5 \mathrm{~cm}$ bd.

Figure 5-11. Unit 16 planview, $17-38 \mathrm{~cm}$ bd in the front of Chapel 2. 


\section{Unit 17}

This unit was placed in an area that had previously been trenched by the WPA in 1941, and excavated by Gilmore in 1974 (Figures 3-1 and 5-1). A thin layer (ca. $3 \mathrm{~cm}$ ) of silty overburden with grasses was removed and the datum for this unit was then established on the surface in the southwest corner. It was immediately apparent that the unit was backfilled with the darker light brown-tan fine sand with fine pebble inclusions commonly associated with the 1940-1941 WPA investigations (see Figures $3-1$ and 5-1). A semipacked, brown (7.5YR 4/2), sandy loam was reached at $29 \mathrm{~cm} \mathrm{bd}$, indicating the bottom of the WPA trench, and our excavations were terminated at that depth.

The only artifacts recovered were a few sherds, 1 thick green glass sherd, 2 patinated clear glass sherds, and 1 piece of iron scrap (Appendix A). Because of previous disturbance, the doorway opening was poorly defined as extending from $0-30 \mathrm{~cm}(\mathrm{~s}-\mathrm{N})$ in the southeast corner of the unit. There was no evidence of a threshold and apparently, previous excavations had disturbed any remnants of floors or walkways.

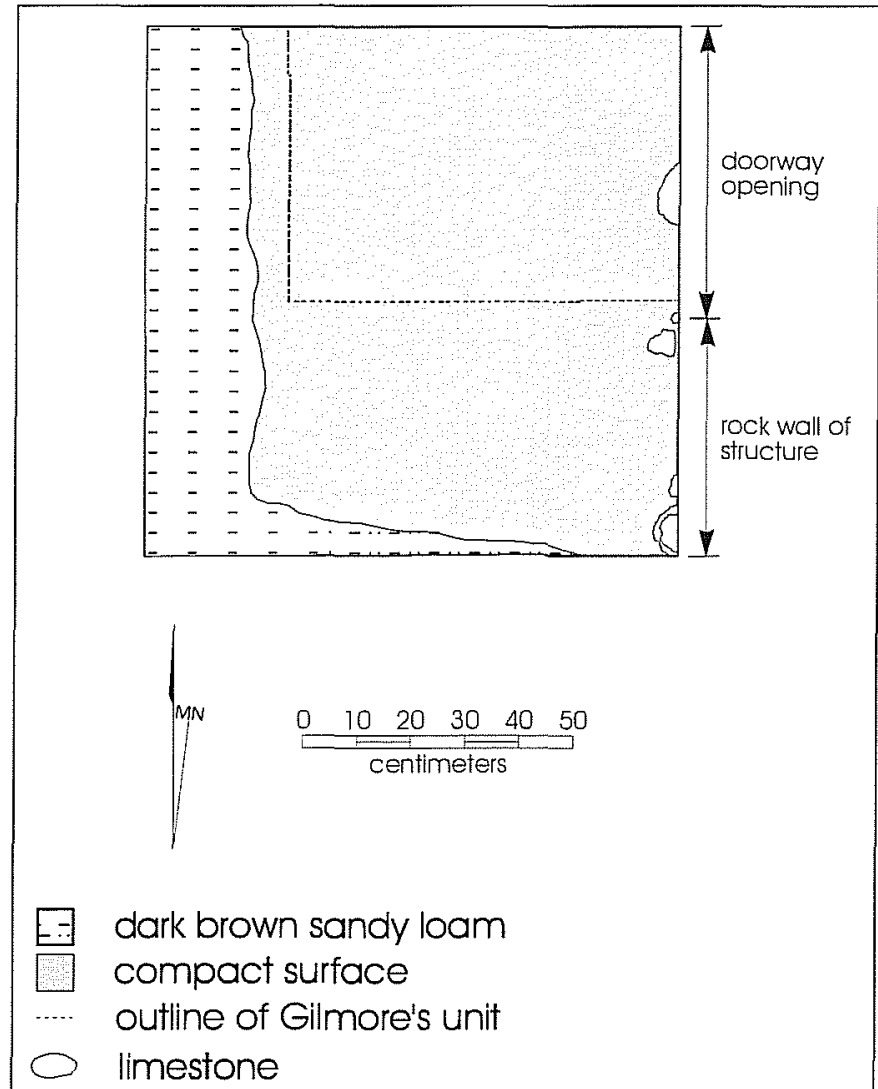

Figure 5-12. Unit 18 planview, $21-30 \mathrm{~cm}$ bd outside the west entryway to Chapel 2.
This unit was placed in an area that had previously been trenched by the WPA in 1941, and excavated by Gilmore in 1974 (Figures 3-1 and 5-1). Before excavation began, a thin layer of sandy loam overburden with grass approximately $1 \mathrm{~cm}$-thick along the western portion of the unit and increasing in thickness to 9 $\mathrm{cm}$ up against the eastern stone wall was removed. Datum was then established in the southwest corner. It was apparent that the eastern 80 percent of the unit was disturbed and had been partially backfilled with the darker light brown-tan fine sand with fine pebble inclusions commonly associated with the 1940-1941 WPA investigations, along with brown sandy loam with mortar and limestone fragment inclusions suspected to be backfill in Gilmore's 1974 unit (Figure 5-12). A compacted brown sandy loam was reached at an undulating $27-30 \mathrm{~cm}$ bd, indicating the bottom of the WPA trench, and our excavations were then terminated. Artifacts recovered were 8 chipped stone flakes, a few bone fragments, 3 unidentified pieces of metal, and 2 clear glass sherds with a slight degree of patination (Appendix A). Because of previous disturbance, the doorway opening was poorly defined as extending from $45-100 \mathrm{~cm}(\mathrm{~s}-\mathrm{N})$ in the northeast corner of the unit. As with our findings in Unit 17, there was no evidence of a threshold and apparently, previous excavations had disturbed any remnants of floors or walkways. 


\section{Unit 19}

This unit was placed in an area that had previously been trenched by the WPA in 1940-1941 and excavated by Gilmore in 1974. In the southwest corner of the room, Gilmore (1974) has opined may be either a sacristy or priests' chapel adjoining Chapel 2 to its north (Figures 3-1 and 5-1). Before excavation began, a layer of sandy loam overburden $10-15 \mathrm{~cm}$-thick along the western portion of the unit up against the eastern stone wall was removed. The unit datum was then established in the northeast corner. The upper $15 \mathrm{~cm}$ consisted of a loose layer of coarse, granular sandy loam with rounded pebbles and limestone rubble, apparently backfill because the artifacts found within it were 7 chipped stone flakes, 5 pieces of iron scrap, and 5 modern glass sherds. The remnants of a floor were uncovered in the northwest quadrant of the unit at $15 \mathrm{~cm} \mathrm{bd}$, and overlying a buried stone wall (Figure 5-13). The floor was 3-5 cmthick and consisted of a light brownish gray (10YR 6/ 2 ), caliche with small limestone cobbles and pebbles, and calcium carbonate inclusions. It was apparent that most of the floor in the unit had been removed by previous trenching, which was backfilled with a dark grayish brown (10YR 4/2), loose, granular sand commonly associated with WPA trenches from the 1940s. Further excavation within the unit defined the buried stone wall and remnants of a pale yellow (2.5YR 7/4) caliche subfloor against the wall at $40 \mathrm{~cm}$ bd. Artifacts found between $26-66 \mathrm{~cm}$ that provided evidence of WPA investigations included a metal fence staple, 3 pieces of round baling wire, and 2 pieces of aqua glass with slight patina (Appendix A). Apparent evidence of Gilmore's (1974) excavation in the area was found at the bottom of our unit as patches of pale yellow (2.5YR 8/2), loose sand with small rounded pebble inclusions (Figure 5-13), and a piece of red flagging tape was found within the pale yellow sand. Our excavations were terminated at $66 \mathrm{~cm}$ bd. Although the Spanish Colonial deposits were essentially removed by previous investigations in this unit, based on the upper floor surface remnants, it would appear the top of the Colonial deposit would have been ca. $5 \mathrm{~cm}$ bd. No plaster remnants were found on either the extant above ground, or buried stone wall.

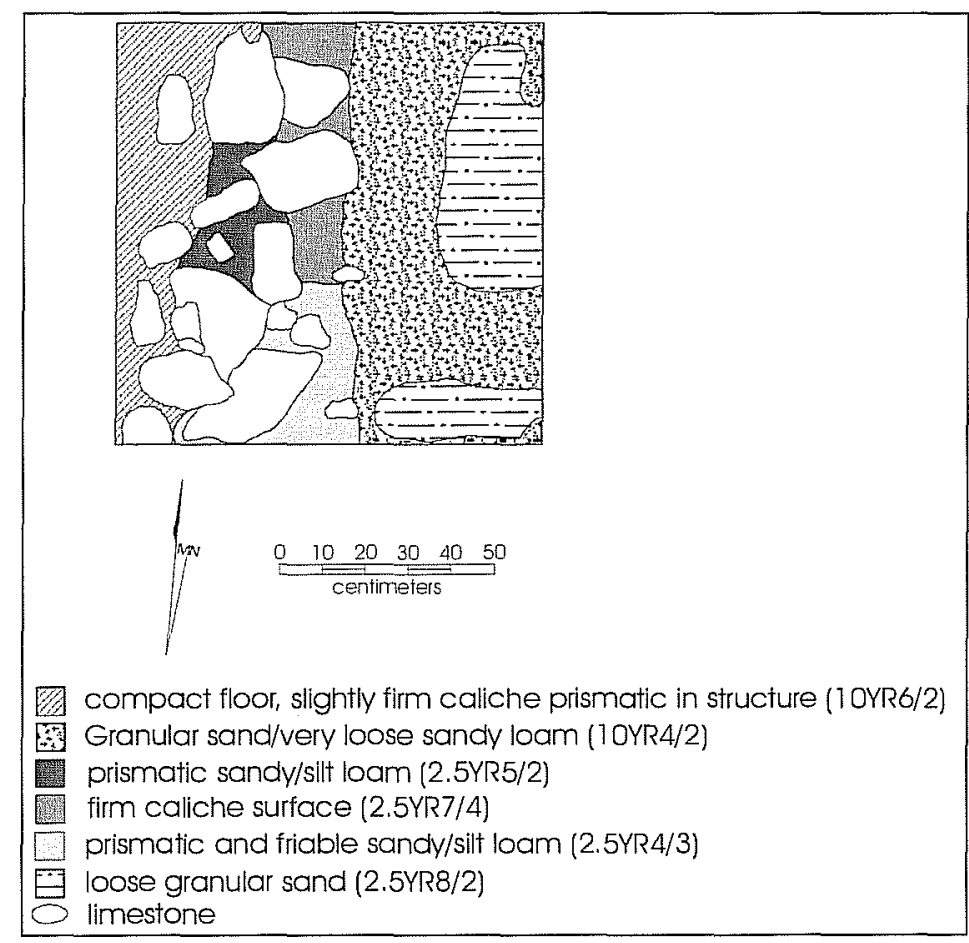

Figure 5-13. Unit 19 planview, to $66 \mathrm{~cm}$ bd inside the sacristy adjoining Chapel 2. 


\section{Unit 20}

As with Unit 19, this unit was also placed in a comer of the room Gilmore (1974) has opined may be either a sacristy or priests' chapel adjoining Chapel 2 to its north (Figures 3-1 and 5-1).

Before excavation began, a thick layer of overburden as deep as $44 \mathrm{~cm}$ in the southeast comer, consisting of compacted yellowish brown (10YR 5/4) sandy loam with large limestone chunk inclusions was removed. The unit datum was then established in the southwest corner. The overburden mentioned may have been intentionally dumped in this area in recent years to prevent looting (Anne Fox, personal communication). Excavation to $50 \mathrm{~cm}$, and then through $57 \mathrm{~cm}$ bd revealed still deeper deposits of overburden consisting of reddish brown (5YR 4/4) clay loam with brown (10YR 4/3) mottling and small limestone and plaster fragment inclusions (presumably wall fall). Although a heavily worked stone endscraper and 10 chipped stone flakes were found, the overburden was void of diagnostic Colonial artifacts, and the presence of a piece of red plastic flagging tape and aluminum foil (Appendix A) provided evidence that the deposit was out of context. Below $57 \mathrm{~cm}$ were patchy layers of brown (10YR 5/3) and yellowish brown (10YR 5/4) sandy loam with finer plaster and limestone chunks, these lying above a compacted floor, light yellowish gray in color with small pebble inclusions encountered at $67 \mathrm{~cm}$ bd. A brownware sherd, 13 chipped stone flakes, bone fragments, a mussel shell fragment, and 4 modern glass sherds were found above the floor, between $50-67 \mathrm{~cm}$. Excavations were terminated at the floor surface $(67 \mathrm{~cm}$ bd). Plaster remains (with no paint) were observed on both the eastern and southern stone walls beginning about $17 \mathrm{~cm}$ above the floor and continuing to floor level. Although the Spanish Colonial deposits were essentially removed by previous investigations in this unit, based on the caliche floor surface and the upper plaster remnants, it would appear the top of the Colonial deposit would have been ca. $50 \mathrm{~cm}$ bd.

\section{Unit 21}

This unit was placed in an area that had previously been excavated by Gilmore in 1973 (Figures 3-1 and 5-1), on the southern edge of a stone foundation (Wall 4) Gilmore has designated Feature 7, which may represent Phase 3 construction of the original church (Chapel 2) to the north, and on the eastern edge of an extant, above ground, $\mathrm{N}-\mathrm{S}$ stone wall (Figures $3-1$ and 5-1).

Before excavation began, a layer of sandy loam overburden 10-15 cm-thick along the western portion of the unit up against the eastern stone wall was removed. The unit datum was then established in the northeast corner. The underlying soil at $40 \mathrm{~cm}$ bd is the reddish brown, mottled clayey loam typical throughout the mission. The top of a buried wall was found $6 \mathrm{~cm} \mathrm{bd}$ in the north portion of the unit, and the buried southern wall of Chapel 2 was found in the western portion of the unit 5 to $12 \mathrm{~cm}$ bd (Figure 5-14). Between 30$40 \mathrm{~cm}$ it became apparent that the two walls were connected with interlocking stones. The light brown sand that Gilmore used to backfill her excavation units here was present throughout the unit to a depth of $40 \mathrm{~cm}$, which represents the base of her excavations. Overall, the plaster (without paint) is well preserved on the wall of the chapel, and appears to continue below the $40 \mathrm{~cm}$ level. The buried $\mathrm{N}-\mathrm{S}$ wall in the western portion of this unit appears to have been "mortared" with red clay, and has smaller limestone chunks set into the red clay base, but no evidence of a setting trench was observed. Although the Spanish Colonial deposits were essentially removed by previous investigations in this unit, based on the wall remnants, it would appear the top of the Colonial deposit would have been within a few $\mathrm{cm}$ of the modern surface. 
Figure 5-14. Unit 21 planview, next to Chapel 2.

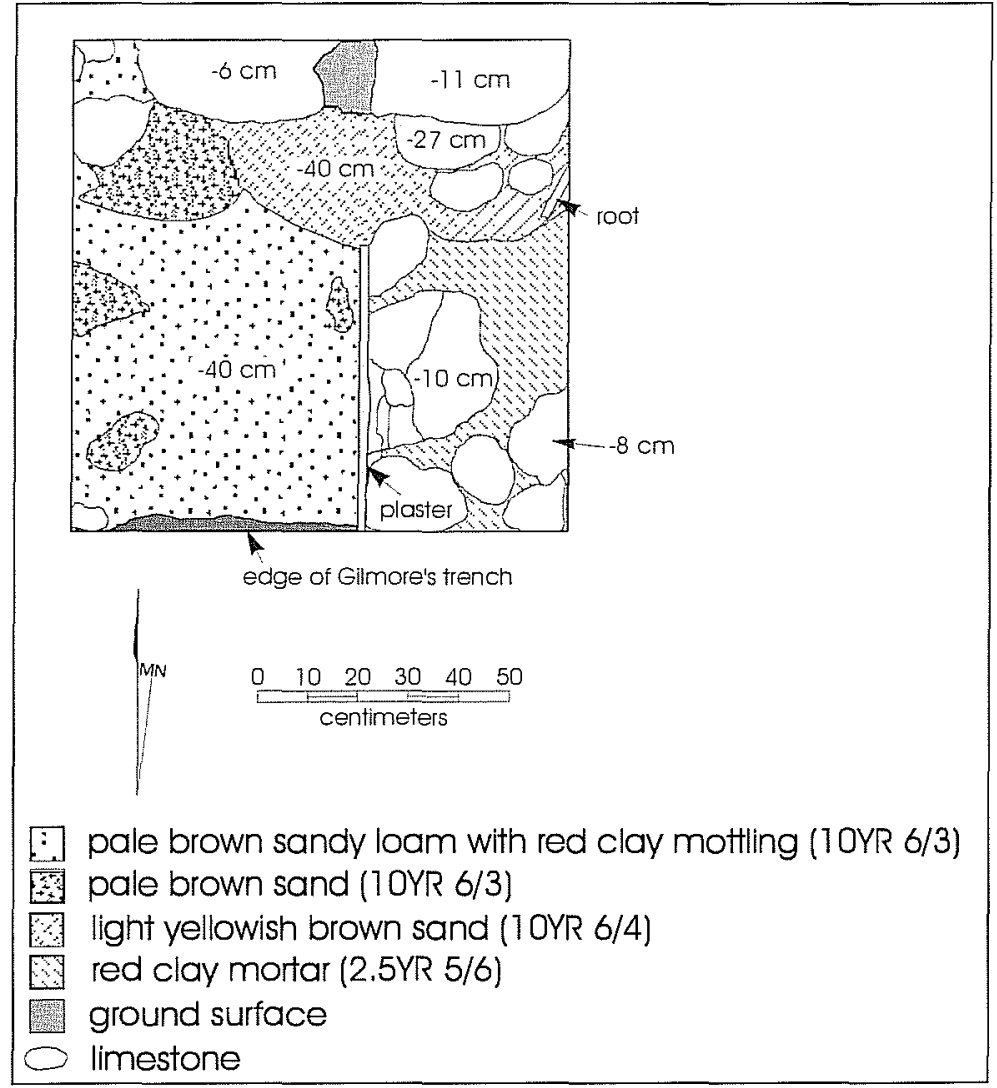

\section{Discussion}

In the western portion of Chapel 2 (Feature 5) Gilmore found two undulating floors; a gray white caliche floor, overlying a tan gray floor, and surmised that the gray floor was probably laid after the $\mathrm{N}-\mathrm{S}$ cross wall was built. She found that the floor in Feature 5 had been repaired in patches, with as many as 4 layers present. An undulating yellowish caliche floor with gray clay mottling was found in our Unit 15, but no evidence of a second floor or patching remained.

We found remnants of a grayish caliche floor with fine-grained mortar and coarse, angular, golf ball sized limestone fragments in our Unit 16. This floor is apparently the same one as described in Gilmore's (1974) field notes as a "gray floor" overlying a yellowish caliche floor, because $5 \mathrm{~cm}$ below we uncovered remnants of a distinct, yellowish, packed, slightly undulating, ca. 5 to $7 \mathrm{~cm}$-thick, caliche floor with fine-grained mortar and coarse, angular, golf ball sized, limestone fragment inclusions $34 \mathrm{~cm}$ bd (obviously the same floor as found in Unit 15).
Gilmore believed the floor in the sacristy (Feature 9) was perhaps 12 " higher than the floor in the Feature 5 area of the chapel, suggesting there was probably a step up into the sacristy. Our excavations in Units 19 and 20 in Feature 9 found an upper floor approximately $23 \mathrm{~cm}$ (9 inches) above the uppermost floor in Feature 5, thus corroborating Gilmore's suspicions that there may have been a step-up into the sacristy room from the chapel. Our Units 17 and 18 which were placed in the area around the western doorway to Chapel 2 (Figures 3-1 and 5-1) confirmed the findings of Gilmore that there was no evidence of a threshold stone or floor. Both units encountered the door opening which was determined to be $158 \mathrm{~cm}$ (62.1 inches; 1.88 Spanish varas). 


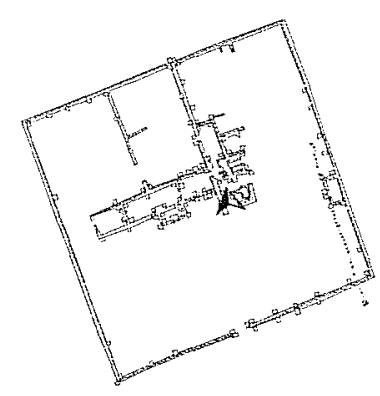

\section{Room 4 (Office)}

Gilmore (1974b:27) has suggested that the room south of the steps (Figure 5-1) may have been the office with a long and narrow window mentioned by Father Juadenes (Juadenes to Munoz, July 20, 1791). Gilmore excavated in the southeast corner and along the south wall of the room, and found a narrow window with plaster in the south wall. She also found a white, hardpacked caliche floor in the room, and commented that perhaps the upper yellowish caliche floor (which was in the sacristy above the white floor) had been removed.

CAR placed Units 31-33 within the office to investigate the wall construction and possible floor(s), and designated the room as Room 4.

\section{Description and Results Unit 31}

Unit 31 was placed in the northeast corner of the room (Figures 3-1 and 5-1). Before excavation began using arbitrary $10 \mathrm{~cm}$ levels, a thick overburden layer consisting of reddish brown sandy loam approximately $13 \mathrm{~cm}$-thick in the southwest corner and increasing in thickness to $56 \mathrm{~cm}$ in the northeast corner against the stone walls was removed. Datum was then established in the northwest corner of the unit. Here excavation continued and an additional $26 \mathrm{~cm}$ of sandy loam overburden was removed before an ephemeral floor surface was uncovered. The floor consisted of a yellowish brown (10YR 5/4) sandy loam with limestone cobbles. Limestone chunks, presumably wall fall, were lying on the floor in the southwest corner of the unit. The only artifacts recovered in the $26 \mathrm{~cm}$ above the floor were 2 chipped stone flakes and a mussel shell fragment (Appendix A). Remnants of a second floor were found $36 \mathrm{~cm}$ bd. This subfloor consisted of pale yellow (2.5YR 7/4), compacted, sandy caliche. The subfloor had been cut along the northern portion of the unit against the stone plastered wall by a trench, which was then backfilled with loose, brown (10YR 4/5) sandy loam (Figure 5-15). A modern, clear glass sherd with slight patina was found in the trench outline, suggesting it may have been a WPA trench from the 1940s. Other cultural material found between the two floors includes 3 chipped stone flakes, with bone and mussel shell fragments. The subfloor in the western $1 / 3$ of the unit had been removed, however our excavations within the unit were terminated at the 36 $\mathrm{cm}$ floor level, and the reason for the previous disturbance is unknown. The disturbed area was backfilled with dark grayish brown (10YR 4/3) sandy loam, with darker (10YR 4/2) mottling. Plaster (with no visible paint) was still adhering well to both the north and east walls of the room extending from the subfloor to $15-20 \mathrm{~cm}$ above it.

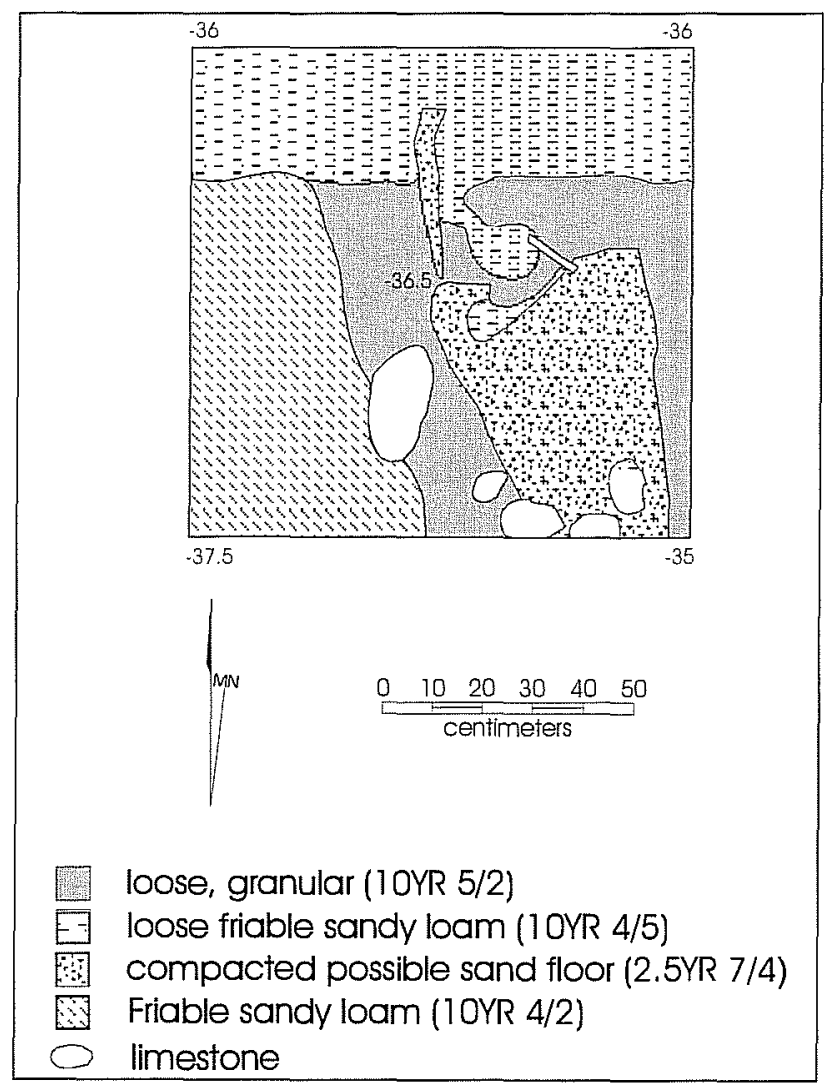

Figure 5-15. Unit 31 planview, $35-37 \mathrm{~cm}$ bd in Room 4 (office). 


\section{Unit 32}

Unit 32 was placed in the northwest corner of the room (Figures 3-1 and 5-1). A datum was established in the southeast corner of the unit, and a thick overburden layer consisting of reddish brown sandy loam, increasing in thickness to $58 \mathrm{~cm}$ in the northeast corner against the stone walls, was removed. Remnants of a compacted, grayish brown (10YR 5/2) caliche floor were uncovered at $20 \mathrm{~cm} \mathrm{bd}$, and could clearly be seen in profile $2-3 \mathrm{~cm}$-thick, extending through the doorway into the hallway to the north.

The eastern half of the unit was not excavated below this upper floor, while the western half was taken down to a subfloor found $30 \mathrm{~cm}$ bd. The recovery of baling wire, plastic flagging tape and 3 modern, clear glass sherds provides evidence for previous disturbance in the area. The subfloor consisted of compacted, brown (10YR 4/3) caliche, with few pebble inclusions.

Plaster (with no visible paint) was fairly well adhered to both walls from the subfloor upward to approximately $20 \mathrm{~cm}$ above the subfloor. The plaster was continuous in the room's northwest corner, and extended into the doorway opening.

\section{Unit 33}

Unit 33 was placed in the southwest corner of the room (Figures 3-1 and 5-1). A datum was established in the southeast corner and the unit excavated through reddish brown sandy loam with limestone rubble to a compacted yellowish brown (10YR 5/4) caliche with limestone fragments to golf ball size $20 \mathrm{~cm}$ bd. Although 2 chipped stone flakes, with bone fragments and 2 brownware sherds most probably represent the Colonial occupation at the mission, the presence of aluminum wire, plastic flagging tape, and brown beer bottle, white, and clear glass provide evidence of the disturbance that has occurred above the floor.

Painted bluish-green plaster is cracked, but otherwise fairly well adhered to the south room wall, and plaster with no paint is covering the west room wall to ca. $25 \mathrm{~cm}$ above the floor.

\section{Discussion}

Gilmore's limited excavations in the southern portion of the room provided evidence of a long, narrow window and a white, hard-packed caliche floor in the room. She did not find an upper yellowish caliche floor as was expected from her excavations (which was in the sacristy above the white floor), and commented that perhaps the yellowish floor had been removed by previous excavations.

Remnants of two floors were found in CAR's Units 31 and 32, with a single floor found in Unit 33. Based on Gilmore's and CAR's excavations, it appears the upper yellowish brown floor was at some time removed along the south wall of the room. Remnants of plaster was found on all four walls of the room, suggesting that it was a room of some prominence. We have found no evidence to suggest that the room is not the "Office" as offered by Gilmore (1974). If the occupation of the office is contemporaneous with that of the sacristy, then there may have been a step up from the sacristy into the hallway between the sacristy and the office. The floors in the office are consistently about $19 \mathrm{~cm}$ ( 8 inches) higher in the office than they are in the sacristy. The continuation of both floors from the office into the hall doorway leading to the sacristy provides further corroborating evidence. 


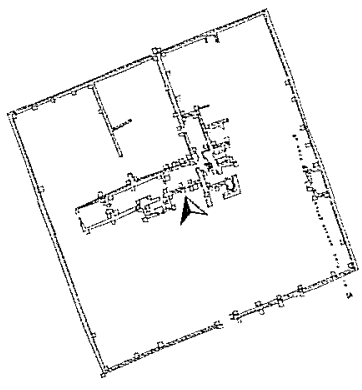

\section{Room 3}

WPA photographs (Appendix A-4:Photographs A-1 to $A-3$ ) show the room was cleared to the floor in the 1940s. Gilmore (1974) excavated in the center and around the sealed doorway of Room 3 (Figures 3-1 and 5-1), finding painted plaster on the cross wall, with a yellow tan caliche floor overlying a white gray caliche floor. CAR placed 10 test units within the room and doorways to investigate the architecture. Some of these units found evidence of Gilmore's (1974) previous excavations as well as WPA work in the 1940s.

\section{Description and Results Unit 38}

Unit 38 was placed in the northeast corner of Room 3 (Figures 3-1 and 5-1), and a datum established in the southwest corner of the unit. The upper $15 \mathrm{~cm}$ consisted of a loose, reddish brown, sandy loam with large mortar and plaster fragment inclusions. These sediments appeared to have been previously excavated backfill, with only 2 chipped stone flakes and a brownware sherd recovered (Appendix A). The unit's position was such that the eastern door opening was exposed in the southeastern corner of the unit, and what appeared to be a "possible" compacted reddish brown sandy loam floor remnant extended into the eastern doorway at $15 \mathrm{~cm}$ bd. Remnants of the same floor with plaster wall fall overlying it were also present along the western edge of the unit. Light brown sand similar to that seen in WPA trenches in Units 41, 46 , and 47 had been used as backfill where the floor was missing in the majority of the unit. A subfloor remnant consisting of compacted, yellowish caliche was encountered in the south central portion of the unit at $22 \mathrm{~cm}$ bd. Excavations were terminated at 33 $\mathrm{cm}$ bd, at what appeared to be the bottom of the WPA excavations, where the soil transitioned to the underlying brown, sandy A Horizon. Plaster (no paint or etchings discernible) was present on both stone walls, wrapped around the inside corner of their juncture.

\section{Units 39 and 91}

These units were placed in the northwest corner of Room 3 (Figures 3-1 and 5-1), and a separate datum was established for each. A yellowish, semi-compacted, undulating, caliche floor surface was encountered in both units $20-26 \mathrm{~cm}$ below the undulating surface of WPA light brown sandy loam backfill. The yellowish caliche floor is ca. 3-5 cm-thick and directly overlies a white, limey, hard packed floor with angular/crushed limestone fragments to $9 \mathrm{~cm}$ in size, exposed by excavating the yellow caliche floor from Unit 38. These floors are those described by Gilmore (1974a:69-71) when she excavated in front of the sealed doorway in this room. Both the western stone cross wall and the northern stone chapel wall were plastered down to the upper, yellowish caliche floor; however, because of deterioration, it could not be confirmed that the plaster extended to the depth of the white, limey subfloor. As is obvious above the backfill, the cross wall and chapel wall were not joined in the corner below the surface; the $\mathrm{N}-\mathrm{S}$ cross wall abuts the $\mathrm{E}-\mathrm{W}$ wall. Traces of red paint were still visible on the $\mathrm{N}-\mathrm{S}$ cross wall ca. $10-20 \mathrm{~cm}$ above the floor; no patterns in the paint or plaster could be discerned. A rotted wooden stake and yellow flagging tape provided evidence of the northern edge of Gilmore's unit that she placed along the $\mathrm{N}-\mathrm{S}$ wall straddling the filled-in door. The only artifacts recovered from these two units include 4 chipped stone flakes and a rusty round nail.

\section{Unit 93}

Unit 93 was placed in the southeast quadrant of Room 3 , east of the south doorway (Figures 3-1 and 5-1), and a unit datum established in its northeast corner on an undulating surface of WPA light brown sandy loam backfill. The yellowish, compacted caliche floor found in Units 39 and 91 was also encountered in this unit $20 \mathrm{~cm}$ bd. A cluster of limestone pebbles was impregnated within the caliche floor in the southwest quadrant of the unit, near the doorway; this could be the underlying white floor exposed in this area either by foot traffic, or from previous excavations. Plaster remnants (with no discernible paint or etching) were present near the wall base. 


\section{Units 40, 92, and 101}

These three units were placed in the doorway opening in the south wall of Room 3 (Figures 3-1 and 5-1). After excavating through light brown sandy loam with limestone wall fall rubble, the same yellowish caliche floor found elsewhere in this room was also present in all three of these units. The floor extended into the doorway and dissipated midway through the opening. Excavations were terminated at the yellowish caliche floor surface, so it can only be assumed that the white, limey subfloor is present in this area also.

The door opening was defined as $175 \mathrm{~cm}$ (ca. $5.8 \mathrm{feet}$; ca. 2.1 Spanish varas), with no evidence of a threshold stone. In Unit 40 within the doorway, the dissipating yellowish floor gave way to a hard packed, pale brown, sandy loam, undulating surface that had the appearance of being informally prepared with a layer of cobbles outside the structure.

\section{Units 94, 95, and 104}

These units were placed along the exterior of the north wall of Room 3, in front of the doorway opening (Figures 3-1 and 5-1). The southern $3 / 4$ of all three units were excavated in a WPA trench outline running parallel to the wall.

Units 94 and 95 were placed so to expose the western and eastern edges of the doorway. The upper 10 $\mathrm{cm}$ of sediments consisted of reddish brown sandy loam with large limestone wall fall rubble. The wall fall was lying on reddish clay with brown sandy loam mottling, the same WPA trench backfill as found in Unit 63 to the west (Figures 3-1 and 5-1). The base of the WPA trench, represented by contact with the underlying brown, sandy A Horizon, was encountered $19 \mathrm{~cm}$ below the modern surface in Unit 94 . As is the case in Unit 63, the WPA trench left a 5-7 $\mathrm{cm}$ buffer of A Horizon soil against the chapel stone wall, and remnants of the Colonial occupation, dark brown and ashy midden soil, could be seen in profile in the upper $8 \mathrm{~cm}$ of the north wall of the unit. Although excavations in this unit were terminated before reaching the stone wall base, there was no indication of a footing under this section.
The same stratigraphy and disturbance was observed in Unit 95. Excavations in this unit were terminated at $10 \mathrm{~cm}$ below the surface, but not before the tops of some stones jutting out were exposed; they may represent a footing under this section of the wall. Above ground, the chapel wall is obviously thicker east of the doorway.

The doorway proved to be much narrower than anticipated from the wider opening exposed above the rubble, and neither of the Units 94 or 95 defined the opening. Therefore, Unit 104 was positioned in the projected center of the doorway, and a datum was established on the modern surface in the southwest corner. As with the two adjoining units (94 and 95), there was approximately $13-15 \mathrm{~cm}$ of wall fall to be removed before reaching the apparent upper Colonial surface, a remnant of which still remained on the extreme northern portion of the unit. Inside the doorway, the compacted floor found in Room 3 extended halfway through the opening with no evidence of a threshold stone (Figure 5-16). At this level the western edge of the door opening was heavily disturbed, and thus

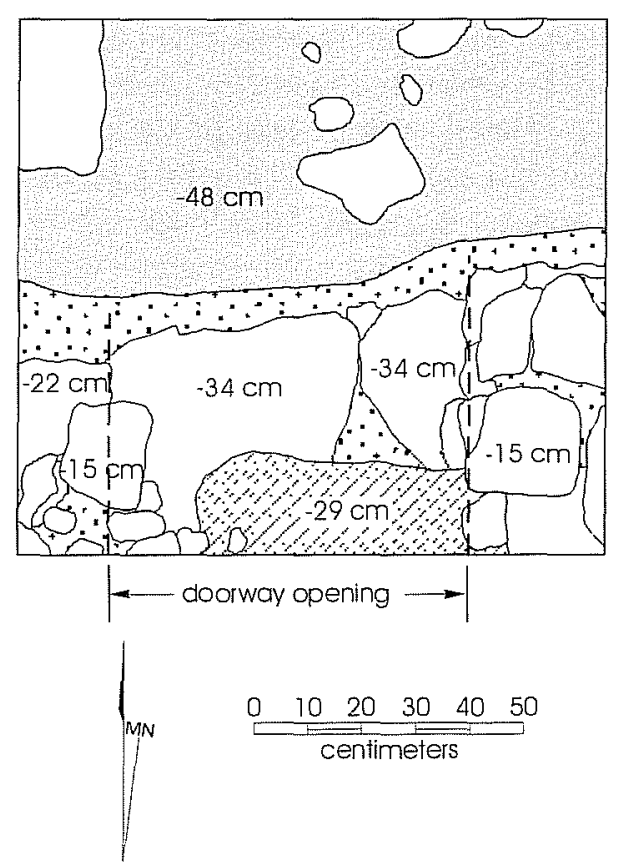

light brownish gray sandy loam (10YR 6/2)

17. very pale brown deteriorated plaster (10YR 8/2) light gray compacted floor (10YR 7/1) limestone

Figure 5-16. Planview of Unit 104 showing door opening in north wall of Room 3. 
poorly defined; therefore excavation within the backfilled WPA trench continued to $48 \mathrm{~cm}$ bd where the top of a setting trench filled with light brown sandy loam was encountered. The intact wall was found 36 $\mathrm{cm}$ bd., $7 \mathrm{~cm}$ lower than the floor inside Room 3, suggesting perhaps a threshold stone has been removed. At $36 \mathrm{~cm}$ bd the stones that are still in place indicate that the opening is narrow, measuring. ca. $67 \mathrm{~cm}$ (ca. 27 inches; ca. 0.8 Spanish vara) wide. Cultural material recovered from these three units includes 1 Goliad and 13 coastal ceramic sherds, a stone knife, 187 chipped stone flakes, 1 piece of iron scrap, 1 aluminum pop-top can lid, and a button.

\section{Discussion}

The yellowish packed caliche floor was found throughout the room and extends into the north and south extant entryways. Underlying this is a white, limey subfloor with limestone fragments. Measurements taken indicate the floor was only slightly undulating. The door opening in the south wall was defined as $175 \mathrm{~cm}$, while the opening in the north wall is only 67 $\mathrm{cm}$. Although one is much narrower than the other, this seems consistent with a photograph taken during the 1940 s excavations, which show the stones ca. $1 \mathrm{~m}$ higher than today. Based on remnants of the upper Colonial surface identified in units around the northern doorway, it appears there may have been a 7-10 $\mathrm{cm}$ step up into Room 3 from the camposanto area, while the southern doorway opened onto a hard packed, semi-prepared surface with no step in between. A possible floor of compacted, reddish brown, sandy loam found in Unit 38 is ca. $33 \mathrm{~cm}$ (13 inches) higher than the yellowish caliche floor throughout the rest of Room 3; possible remnants of the yellowish caliche floor also found in Unit 38 is still ca. $26 \mathrm{~cm}(10.5$ inches) higher than the rest of the floor. These may represent an elevated area (possibly a step) leading into the eastern doorway and adjoining hall. A photograph taken during the 1940s WPA work (Appendix A-4:Photograph A-2) indicates a higher elevated floor in the hallway than in room 3 . All four walls within the room were plastered to the top of the caliche floor, with traces of red paint still visible on the $\mathrm{N}-\mathrm{S}$ cross wall. The $\mathrm{N}-\mathrm{S}$ cross wall abutted against the $\mathrm{E}-\mathrm{W}$ chapel wall, and plaster was wrapped around the inside corner, providing proof that the two walls were plastered contemporaneously.

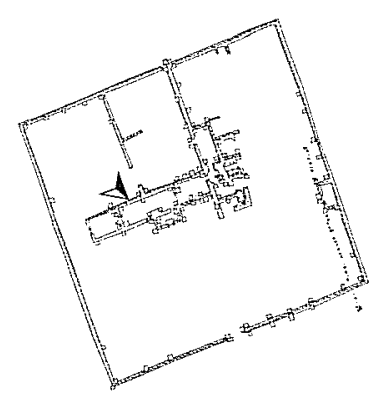

\section{Room 1}

Room 1 encompasses part of the structure that Gilmore (1974) has designated Chapel 1, and believes it is the final church. She excavated in the center of Room 1 (Figures 3-1 and 5-1), and WPA photographs show the room was cleared to the floor in the 1940s. The photos also show stacked stone "furniture" along the $\mathrm{N}-\mathrm{S}$ cross wall and the southern wall of the room (Appendix A-4:Photograph A-5). Gilmore found a yellow tan caliche floor overlying a white gray caliche floor, a single burial, and painted plaster on the stacked stone "furniture".

CAR placed 7 test units (Units 53-59) within the room to investigate the architecture. Some of these units found evidence of Gilmore's (1974) previous excavations as well as WPA work in the 1940s.

\section{Description and Results Unit 53}

Unit 53 was placed in the northwestern corner of the room (Figures 3-1 and 5-1), and a datum established in the southeast corner on the surface of dark grayish brown (10YR 4/2), loose, sandy loam. The loam was present to $22 \mathrm{~cm}$ bd, overlying a possible compacted, pale brown (10YR 6/3), sandy loam "floor", with remnants of small limestone pebbles. A large limestone and a tree penetrated the possible floor, making its clear designation as a floor problematic. Three chipped stone flakes and a ground stone fragment were recovered within the $22 \mathrm{~cm}$-thick loam deposit, believed to be WPA backfill, and 2 pieces of plastic flagging tape, with a pop-top from an aluminum can (Appendix A) provided evidence of disturbance in the area. However, a distinct, compacted, dark grayish brown (10YR 4/2) caliche floor with charcoal inclusions was encountered $30 \mathrm{~cm}$ bd, and the large limestone was 
resting on it. Artifacts found overlying the caliche floor include a chipped stone flake and brownware ceramic sherd, with mussel shell and mortar fragments (Appendix A). Excavation was terminated on the floor surface $30 \mathrm{~cm}$ bd. Plaster remnants (with no discernible paint or etching) were present in small patches on both stone walls; however, it was missing from the northwest corner where the two walls adjoined, as well as along the floor. The $\mathrm{N}-\mathrm{S}$ stone cross wall appeared to abut the $\mathrm{E}-\mathrm{W}$ stone cross wall.

\section{Unit 54}

Unit 54 was placed in the southwestern corner of the room (Figures 3-1 and 5-1), and a datum established in the southeast corner on the surface of dark grayish brown (10YR 4/2), loose, sandy loam. The $30 \mathrm{~cm}-$ thick sandy loam overburden, presumably Gilmore's backfill, contained a few bone and mortar fragments, a modern clear glass sherd, pieces of yellow flagging tape, a brownware sherd, and a small chunk of concrete (Appendix A). A gravel lens supported by very dark grayish brown (10YR 3/2), sandy loam was observed $30 \mathrm{~cm}$ bd in the northeast quadrant and could be the remnants of a possible floor; throughout the remainder of the unit was an undulating $(30-35 \mathrm{~cm}$ bd), compacted, grayish brown (10YR 5/2), sandy loam floor with limestone fragment inclusions. Excavation was terminated on the floor surface $30-35 \mathrm{~cm}$ bd. Plaster was present on both stone walls; the west wall had a salmon-colored paint ca. $26 \mathrm{~cm}$ bd, near the floor on the northern portion of the excavation unit (nearest the doorway), and the south wall contained badly deteriorated fragments with no visible paint or etchings. The plaster did extend to the floor in patches, and appeared to continue around the inside corners of the $\mathrm{E}-\mathrm{W}$ and $\mathrm{N}-\mathrm{S}$ stone walls.

\section{Unit 55}

Unit 55 was placed along the north (E-W) wall of the room (Figures 3-1 and 5-1), and a datum established in the southwest corner on the surface of dark grayish brown (10YR 4/2), loose, sandy loam. A compacted, dark grayish brown (10YR 4/2) caliche floor with pebble inclusions similar to that uncovered in Unit 53 was encountered $25 \mathrm{~cm}$ bd, and excavation in this unit was terminated after clearing the slightly undulating surface. Artifacts recovered from within the overlying overburden (presumably WPA backfill) include 2 chipped stone flakes, with a few bone and mussel shell fragments (Appendix A). The north (E-W) stone wall contained deteriorated fragments of plaster near the floor, with no visible paint or etchings. The plaster appeared to continue on the wall beneath the floor.

\section{Unit 56}

Unit 56 was placed along the south wall of the room (Figures 3-1 and 5-1), on the inside corner of what Gilmore (1974b:32-33) posits are the remnants of a $\mathrm{N}-\mathrm{S}$ cross wall that was removed. Approximately 40 $\mathrm{cm}$ of dark grayish brown (10YR 4/2), loose, sandy loam overburden was removed, and a datum was then established in the northeast corner.

Cultural material recovered from within the overlying overburden (presumably WPA backfill) included 2 chipped stone flakes and 6 ceramic sherds, with bone, mussel shell, and mortar fragments (Appendix A). A compacted, light brownish gray (10YR 6/2) caliche floor was uncovered $25 \mathrm{~cm}$ bd, and directly underlying this upper, 2-3 cm-thick floor was a grayish white (5YR 7/1) compacted caliche with lime and limestone fragments to golf ball size. Both floors were slightly undulating. Excavations were terminated at the grayish white floor surface $27 \mathrm{~cm}$ bd. Red painted plaster was adhered to the southern stone wall of the chapel, as well as the remnant stone wall (as defined by Gilmore) and appeared to continue around the inside corner of the walls. As in Unit 54 on the north wall of the chapel, although deteriorated and not totally clear, the wall plaster appeared to continue beneath the upper floor, to the lower floor.

\section{Unit 57}

Unit 57 was placed along the south wall of the room (Figures 3-1 and 5-1), on the opposite side from Unit 56 , on the inside corner of what Gilmore (1974b:3233) posits are the remains of a $\mathrm{N}-\mathrm{S}$ cross wall that was removed. Approximately $35 \mathrm{~cm}$ of dark grayish brown (10YR 4/2), loose, sandy loam overburden was removed, and a datum was then established in the southeast corner. 
Cultural material recovered from within the overlying overburden (presumably WPA backfill) included 6 chipped stone flakes and 1 ceramic sherd, with bone, mussel shell, and mortar fragments (Appendix A). A compacted, brown (7.5YR 5/2), undulating caliche floor was uncovered $34-36 \mathrm{~cm}$ bd. Red painted plaster was adhered to the southern stone wall of the chapel, as well as the remnant stone wall (as defined by Gilmore) and appeared to continue around the inside corner of the walls. Although deteriorated and not totally clear; the wall plaster appeared to continue beneath the floor. Excavation was terminated on this brown caliche floor surface, so it is not known whether the grayish white subfloor found in Unit 56 exists directly east of the stone wall remnant; however, Gilmore (1974b:32) found the grayish white subfloor in the center of Room 1, extending east to the stone altar against the $\mathrm{N}-\mathrm{S}$ cross wall between Room 1 and Room 3. Therefore, it seems likely that the grayish white subfloor extended throughout the room.

\section{Unit 58}

Unit 58 was placed in the northeast corner of the room (Figures 3-1 and 5-1) on the inside corner of an added $\mathrm{N}-\mathrm{S}$ cross wall. Approximately $25 \mathrm{~cm}$ of dark grayish brown (10YR 4/ 2), loose, sandy loam overburden was removed, and a datum was then established in the southwest corner. A compacted, possible floor surface consisting of brown (10YR 4/2) sandy loam with limestone pebble inclusions was encountered $25 \mathrm{~cm}$ bd. Several large limestones were resting on this "floor" and roots were growing horizontally across its surface.

Cultural material recovered from within the overlying overburden (presumably WPA backfill) included 1 ceramic sherd and bone fragments (Appendix A). Excavation continued to a compacted, pale brown (10YR 6/3), undulating caliche floor with charcoal and limestone pebble inclusions $40 \mathrm{~cm}$ bd. Cultural material recovered from between the two floors (25-40 $\mathrm{cm}$ bd) included 2 chipped stone flakes, 5 ceramic sherds, and a modern clear glass sherd, with few bone, mussel shell, and mortar fragments. A portion of the floor had been removed/ disturbed in the southwest quadrant of the unit (Figure 5-17), and backfilled with a matrix of brown (10YR 4/3), friable sandy loam with plaster fragments and limestone pebble inclusions. Mottling within the disturbed matrix included very dark grayish brown (10YR 3/2), very pale brown (10YR 8/4), and red (2.5YR 4/8) loam. The caliche floor sloped and dissipated into the disturbed area, and excavation was terminated $40-45 \mathrm{~cm}$ bd across the undulating surfaces. Faint remnants of red painted plaster were adhered to both stone walls, and appeared to continue around the inside corner of the walls. Although deteriorated and not totally clear, the wall plaster appeared to continue beneath the lower floor.

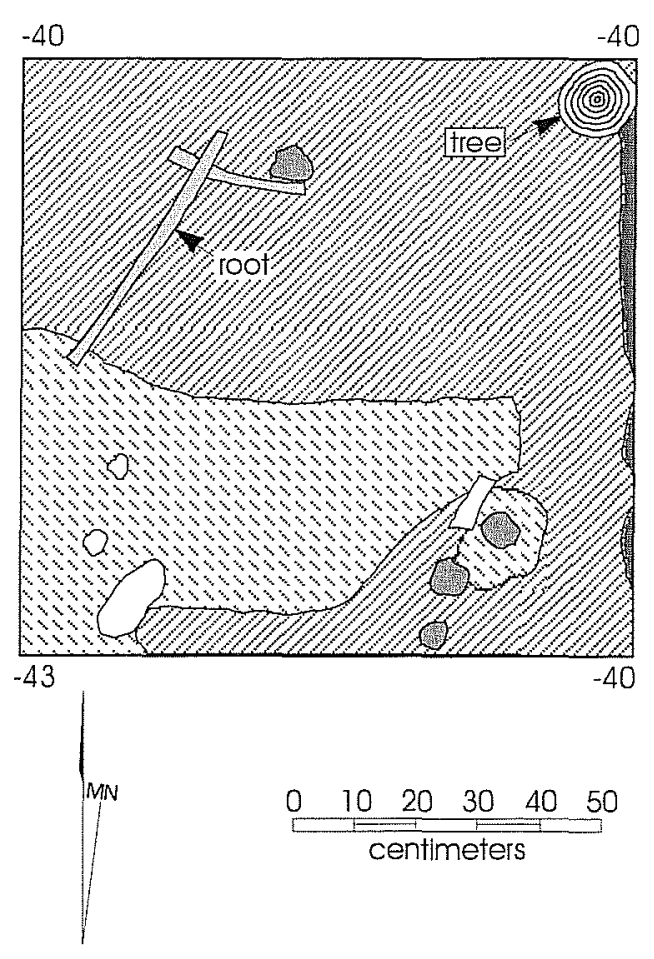

friable sand/sandy loam (10YR4/3) packed/firm caliche floor surface (10YR6/3) tuber limestone

Figure 5-17. Planview of Unit 58 showing area of disturbance in floor, $40-43 \mathrm{~cm}$ bd in Room 1, Chapel 1. 


\section{Unit 59}

Unit 59 was placed in the southeast corner of the room (Figures $3-1$ and $5-1$ ) on the inside corner of an added $\mathrm{N}-\mathrm{S}$ cross wall, and a datum was established in the southwest corner. Approximately $7 \mathrm{~cm}$ of grayish brown (10YR $5 / 2)$, loose, silty loam overlying another $20 \mathrm{~cm}$ of brown (10YR 4/3) sandy loam overburden was removed. Between $27-32 \mathrm{~cm}$ bd large limestones (presumably wall fall) were encountered in the northeastern quad within a dark brown (10YR 3/2) sandy loam mottled with light brownish gray (10YR 6/2) silty loam, while the southwestern quad was compacted sandy loam with caliche and clay mottling. Three tree roots were removed during the excavation, contributing to the soil mixture. Although a Majolica sherd was found $26 \mathrm{~cm}$ bd against the south wall of

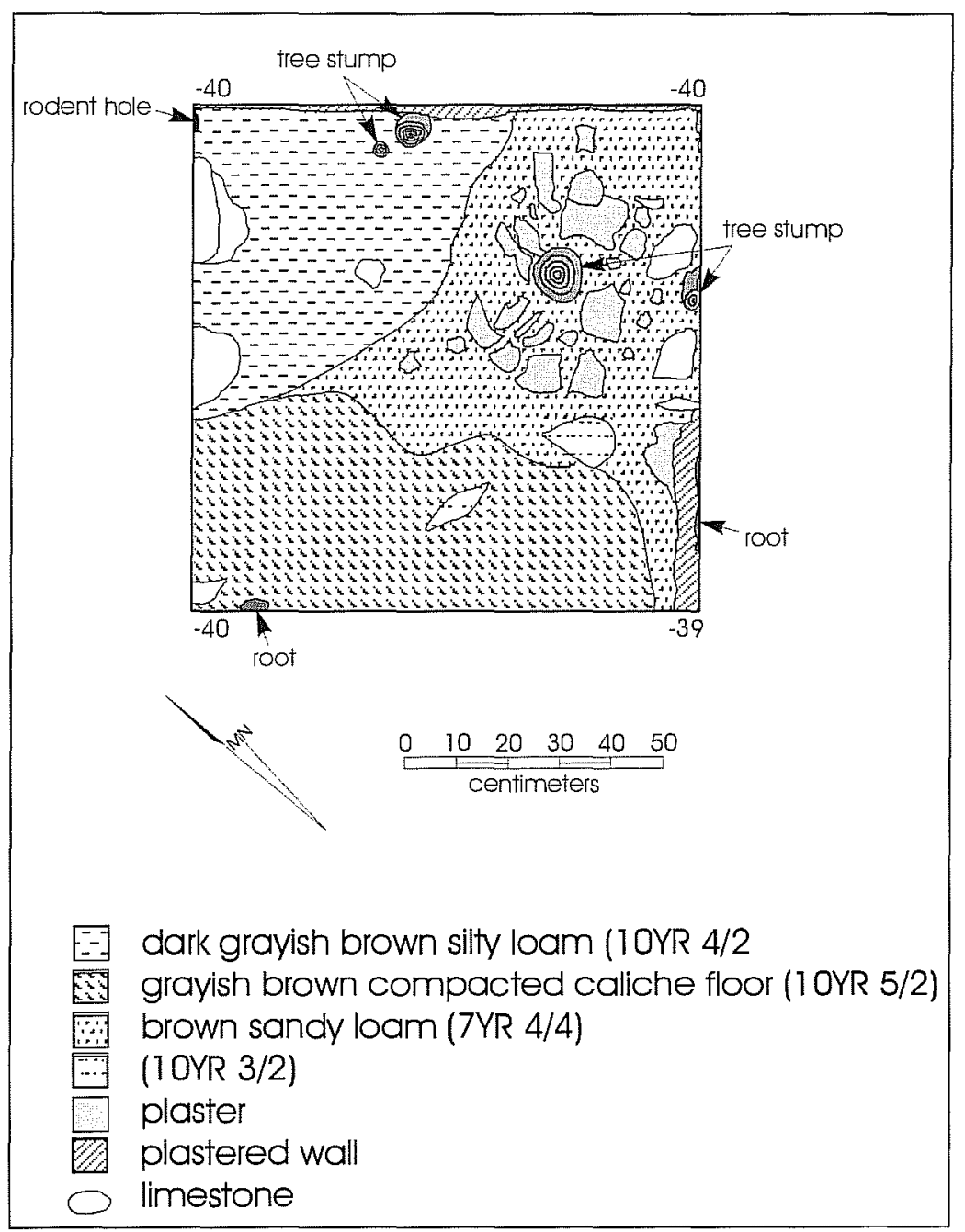

Figure 5-18. Planview of Unit 59 showing area of disturbance in floor 39-40 cm bd in Room 1, Chapel 1. the chapel, the recovery of Styrofoam cup pieces, yellow and blue plastic flagging tape, a pencil eraser, and a modern clear glass sherd to $32 \mathrm{~cm}$ bd attested to the previous excavations in this area. Remnants of a compacted floor surface consisting of grayish brown (10YR 5/2) caliche with limestone pebble inclusions was encountered $40 \mathrm{~cm}$ bd in the southern half of the unit (Figure 5-18). The floor in the northwestern portion of the unit was disturbed and had been backfilled with dark grayish brown (10YR 4/2) silty loam with no mottling, and only few pebble inclusions. The packed caliche floor in the northeastern portion of the unit had also been removed, but it had been backfilled with brown (7YR 4/4) sandy loam with large mortar and angular limestone chunks. Additional plastic flagging tape, a clear glass sherd, and a piece of Styrofoam were found along the northern $1 / 3$ of the unit, most likely from Gilmore's trench along the south side of the stone altar (just a few $\mathrm{cm}$ north of this unit). Excavation was terminated on the packed caliche floor surface. Remnants of plaster (with no visible paint or etchings) were adhered to both stone walls, and appeared to continue around the inside corner of the walls. Although deteriorated and not totally clear, the wall plaster appeared to continue beneath the grayish brown caliche floor. 


\section{Discussion}

Gilmore (1974b:33) identified three floors in the eastern half of the room (east of the wall remnant on the south chapel wall):

(1) undulating gray white caliche;

(2) tan caliche; and

(3) white caliche.

She believed that further investigations could possibly reveal a continuous floor throughout Room 1 . Our investigations uncovered a grayish brown to light brown caliche floor in all units except Unit 54. Excavation in Unit 54 was terminated on what was believed to be a compacted grayish brown sandy loam floor; however based on the information obtained on the other 6 units within the room, it may in fact be a compacted transition zone overlying the grayish brown caliche floor. This grayish brown caliche floor is most likely Gilmore's \#2, tan caliche floor. None of our units provided evidence of Gilmore's \#1, gray white caliche floor overlying it. Our excavations were generally terminated upon reaching the distinct grayish brown caliche floor, except in Unit 56 in which we uncovered a grayish white caliche floor directly underneath; this would presumably be Gilmore's \#3, white caliche.

Based on the presence of a layer of ash and charcoal between floors, Gilmore (1974b:33, Figures 17a and b) surmises that the room which previously existed west of the stone wall remnant burned. Our excavations, although, found no layer of charcoal and ash, however as discussed above our excavations generally stopped at the uppermost floor. A "possible" floor of compacted sandy loam found in Unit 59 above the grayish brown caliche floor is probably not a Colonial floor, but is more likely the unexcavated ca. 6inch berm left in the eastern portion of the room by the WPA (seen in 1940s photographs, e.g., Appendix A-4:Photograph A-5).

The nature of the disturbance in the floor of Unit 58 is undetermined; it could be a grave pit similar to one Gilmore excavated (1974:30-32) in the center of the room (Feature 14). Another possibility is that it is the end of a WPA trench from the 1940s, and the presence of a clear modern glass sherd supports this hypothesis. However, the known photographs from the WPA investigations show that the room was cleared horizontally, with no trench in this room (Appendix A-4:Photographs A-5 and A-6), and Gilmore's excavations in the eastern portion of this room revealed no evidence of a WPA trench.

The nature of the disturbance in Unit 59 is most probably the result of Gilmore's trenching around the stone altar in 1974, as well as tree roots. However, the possibility of a grave pit in the disturbed area in the northeastern portion of Unit 59 extending under the $\mathrm{N}-\mathrm{S}$ cross wall addition cannot be ruled out without further excavation.

Plaster was found on the inside of all four room corners as well as the corners adjoining the stone wall remnant and the extant southern chapel wall, and although no evidence of etching was discernible in any of the units on the deteriorated plaster, it cannot be ruled out. Besides being plastered throughout, the heightened importance of Room 1 is manifested in the remnants of painted plaster found in Units 56-58 (red), and Unit 54 (salmon-colored). Gilmore (1974b:32-33) suggests that an earlier $\mathrm{N}-\mathrm{S}$ cross wall in the center of Room 2 was removed to expand the room toward the west; later the $\mathrm{N}-\mathrm{S}$ cross wall which is now the east wall of Room 1 was added and the doorway sealed, thus finalizing the dimensions of Room 1 as we see the extant above-ground walls. Our limited excavations which found a slightly undulating, yet continuous grayish brown to pale brown caliche floor throughout the room, and a continuation of plaster in and around six corners of the room and stone wall remnant corroborate her supposition of the final order of construction in Room 1. 


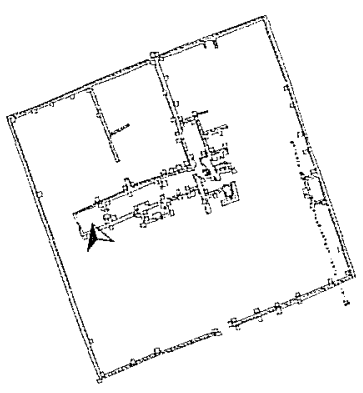

Room 2

Room 2 encompasses part of the structure that Gilmore (1974) has designated Chapel 1 , and believes it is the final church. She excavated in the eastern and western ends of Room 1 around the doorways (Figures 31 and 5-1), and WPA photographs (Appendix A-4:Photograph A-6) show the room was cleared in the 1940s (Appendix A-4). The photos show a slight rise or step into Room 1 from Room 2, and Gilmore found evidence of an apparent wooden doorsill set into a white caliche floor in Room 1. She also documented a layer of red clay and gravel west of the doorsill in Room 1. She designated both sides of an apparent splayed doorway as Features 13a and 13b. Her excavations revealed no substantial foundation to the north, south, or west walls of Room 2 and she concluded that the room must have been an "open stone fenced area." (1974b:29).

Gilmore's investigations proved there was not a distinct floor within Room 2, therefore CAR excavated two test units (Units 51 and 52) to determined the existence and depth below the modern surface of Colonial deposits. Additionally, CAR uncovered backdirt from around Features $13 a$ and $b$ to investigate the architecture (Figures 3-1 and 5-1).

\section{Description and Results Unit 51}

Unit 51 was placed in the northeast corner of Room 2, and a datum established on the modern surface in the southeast corner. What was obviously Gilmore's brown (10YR 5/3), sandy loam backdirt was removed to $30 \mathrm{~cm}$ bd. Cultural material found in the upper 30 $\mathrm{cm}$ included 2 chipped stone flakes, 1 pottery sherd, pieces of yellow flagging tape, and 2 clear modern glass sherds, with a few bone and mussel shell fragments (Appendix A). An aluminum beer can was found at $30 \mathrm{~cm} \mathrm{bd}$. The southwest quadrant of the unit was then excavated to uncover remnants of a compacted surface, consisting of a brown (10YR 4/3) sandy loam supporting a sandstone and limestone fragment clast $37-40 \mathrm{~cm}$ bd. Cultural material found in the southwest quadrant between $30-40 \mathrm{~cm}$ included 2 pottery sherds, 3 clear modern glass sherds, and pieces of yellow flagging tape, with few bone and mussel shell fragments. Yellowish caliche bricks were found under both stone walls from $18 \mathrm{~cm}$ bd to the bottom of our excavation unit, $30 \mathrm{~cm}$ bd. In order to determine where the upper Colonial surface had been in this unit, wall stratigraphy was compared to that in Unit 52 which exposed smaller footing stones resting on top of the caliche bricks. In Unit 51 a ca. $2 \mathrm{~cm}-$ thick lens of sand was lying on the brick in the north wall, and the larger stone wall sat directly on the tan sandy lens above the caliche bricks, with no smaller footing stones in between. Presumably the bottoms of these large stones represented the previously in situ upper Colonial surface. When it then became apparent that this area had been previously excavated to a depth below the upper Colonial surface, excavation was terminated. No plaster was found on either of the stone walls.

\section{Unit 52}

Unit 52 was placed in the southeast corner of Room 2 , and a datum established on the modern surface in the southeast corner of the unit. What was obviously Gilmore's brown (10YR 5/3), sandy loam backdirt was removed to $15 \mathrm{~cm}$ bd. The bottoms of the larger cut stones that comprised the southern wall of Room 2 were encountered just $2 \mathrm{~cm}$ bd. Directly underlying these larger stones was a ca. $10 \mathrm{~cm}$-thick layer of smaller "footing" stones. These smaller footing stones were resting on the tops of yellowish caliche bricks found $12 \mathrm{~cm}$ bd in the southeast corner of the unit These bricks were offset from the extant above-ground stone walls, and jutted inside the room. Specifically, they extended inward $9 \mathrm{~cm}$ from the $\mathrm{E}-\mathrm{w}$ stone wall and ran west along the wall base $39 \mathrm{~cm}$ from the southeast corner of the unit; they also extended inward 9 $\mathrm{cm}$ from the $\mathrm{N}-\mathrm{S}$ stone wall, and ran along the wall base $22 \mathrm{~cm}$ from the southeast corner of the unit. The 
soil type remained the same but became more compacted and slightly darker brown (10YR 4/3) $15 \mathrm{~cm}$ bd. Based on the positioning of the small rocks which were presumed to be wall footing, it was then apparent that this area had been previously excavated to below the upper Colonial surface. Therefore, excavation was terminated $15 \mathrm{~cm}$ bd.

Cultural material recovered included a stone graver, 2 chipped stone flakes, 1 piece of red ocher, a few bone and mussel shell fragments, along with pieces of yellow flagging tape.

\section{Uncovering Features $13 a$ and $b$ (Splayed Doorway)}

Gilmore chose to refer to Features $13 \mathrm{a}$ and $\mathrm{b}$ as the sides of a doorway, which may have held a facade. We believe the protruding sides are constructed so to provide a splayed doorway, and from henceforth we will refer to it as same. Gilmore (1974) excavated around the splayed doorway, and CAR partially uncovered her units to expose the architecture around the doorway, both interior and exterior. A datum was established in the middle of the entryway and Gilmore's backdirt, along with what was apparently WPA backdirt was removed to the compacted floor and surface levels. The south splay had been minimally displaced by tree growth, but the northern splay had been mostly destroyed, with only remnants remaining (Figure 5-19). The yellowish brown, compacted caliche floor found in our excavation units in Room 1 was encountered within the entryway also. It sloped downward toward the opening and dissipated approximately halfway into the doorway, interrupted by smaller limestone footing stones. Just in front (west) of the opening and footing stones was a prepared and compacted surface consisting of reddish chipped stone gravels imbedded within reddish sandy clay (Figure 5-19). Remnants of red painted plaster were adhering to the inside of the north splay.

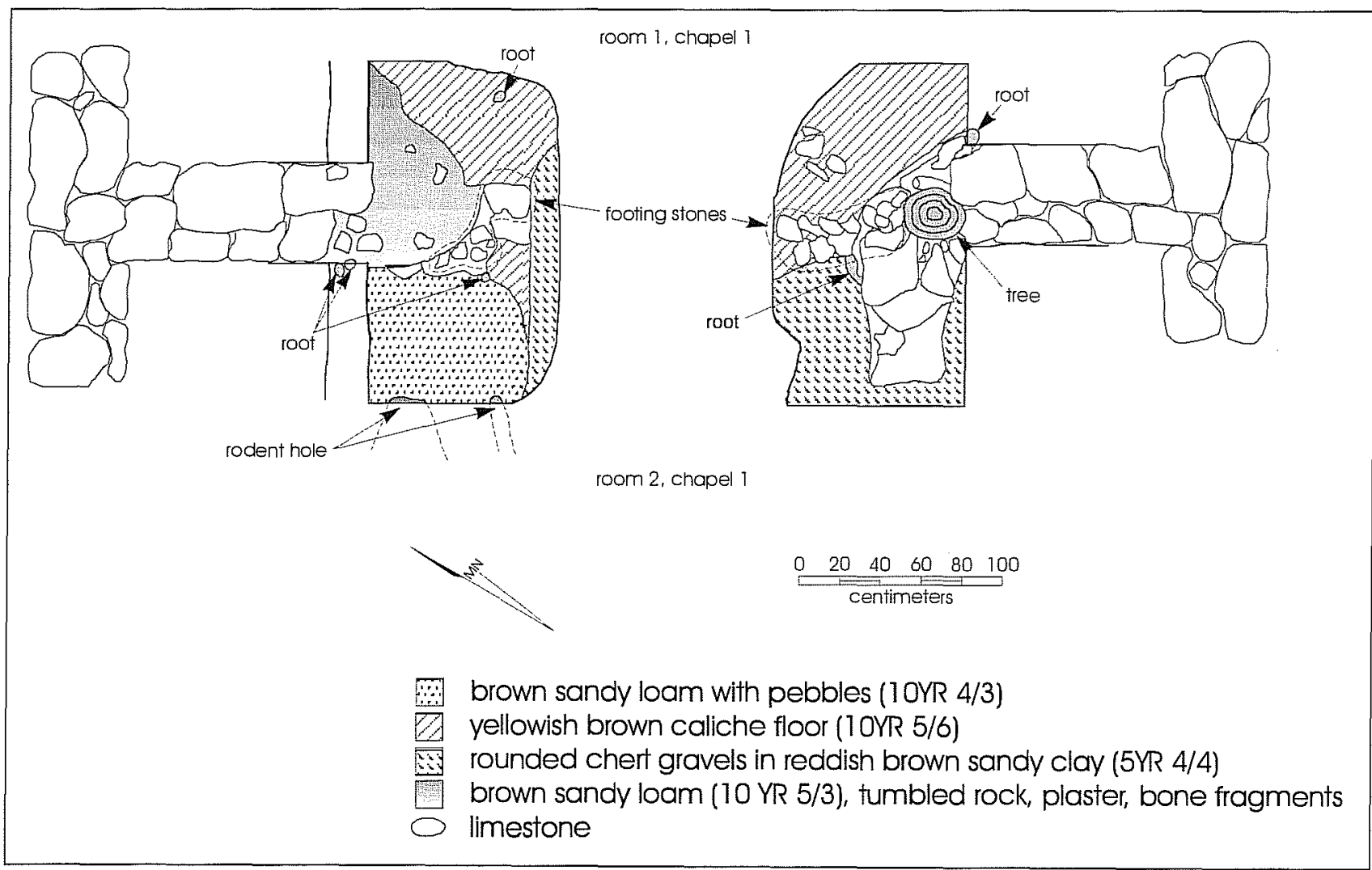

Figure 5-19. Planview of splayed doorway in east end of Room 2 (Chapel 1). 


\section{Clearing and Probes (Western Entryway)}

Gilmore excavated around the northern edge of the entryway and discovered that the stone wall was setting directly on the brown sandy loam midden soil prevalent throughout the compound, finding no evidence of footing stones or caliche bricks as a foundation. Five probes with $3 / 8$ inch rebar driven to $30 \mathrm{~cm}$ below the surface across the apparent western entryway to Room 2 (Figures 3-1 and 5-1) provided no evidence of buried stone footings, thresholds, or walls. CAR cleared the soils and sediments around the western wall stones so that they were pedestaled $5-15 \mathrm{~cm}$. Clearing provided a good outline of the in situ stones and thus we were able to define the approximate size of the opening as $165 \mathrm{~cm}$ (ca. 2 Spanish varas).

\section{Discussion}

Slightly different forms of architecture were encountered in Units 51 and 52. Although excavations uncovered yellowish caliche bricks apparently put in place as foundation material under the northern and southern walls, an additional layer of small stones presumably used as footing stones overlying the caliche bricks was found under the southern wall. Unlike Room 1 to the east, no plaster was found on the walls of Room 2, suggesting Room 2 was of lesser prominence. Conversely, the red painted plaster found on the interior of the splayed doorway suggests an entrance into a room of some prominence. Even though the northern edge of the splayed doorway was heavily disturbed, it appears that the opening would have been $84 \mathrm{~cm}$ (1 Spanish vara). Neither Gilmore's excavations or ours found evidence of a floor in Room 2 . However, the prepared and compacted surface consisting of rounded chipped stone pebbles and clay found just outside the entryway into Room 1 suggests at least a frequented walkway.

The same prepared surface was not found around the western entryway into Room 2 by Gilmore, and our limited rebar probes rebar did not detect a compacted surface. However, our clearing operation helped determine that the opening was $165 \mathrm{~cm}$ (ca. 2 Spanish varas). The only structural footings found in Room 2 were in the northeast and southeast corners, near
Room 1. Footings in those corners consisted of relatively fragile caliche bricks, small stones, and possibly sand. This suggests that perhaps the only area of Room 2 that may have been covered with light material such as poles and grass was along its eastern edge adjoining the entryway into Room 2 , and that the remainder of Room 2 may have been only stone walled and open to the air as Gilmore suggests (1974b:30).

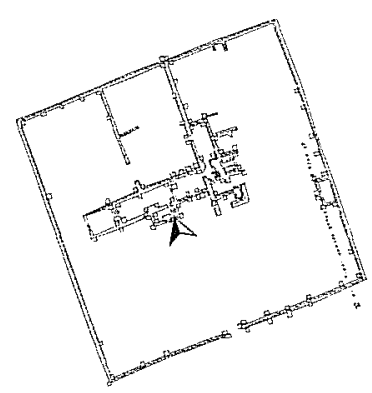

\section{Room 5 - Sacristy (Chapel 1)}

Gilmore's research (1974b:33) has suggested that the room outside the south wall of Chapel 1's Room 1 is a Sacristy. For consistency and ease of future reference, we will label it Room 5. Apparently the only excavations accomplished previously in this room were conducted by the WPA in the 1940s. Photographs show that the room had been cleared to floor level and the three doorways were clearly defined (e.g., Appendix A-4:Photograph A-3). CAR placed five excavation units (Units 43-46, 105) in the room to examine the floor and doorway openings (Figures 3-1 and 5-1).

\section{Description and Results Unit 43}

Unit 43 was placed in the southeast corner of Room 5 , and a datum established on the modern surface in the northwest corner. What was obviously WPA's pale brown (10YR 6/3), sandy loam backdirt with grass and sticks was removed to an undulating packed caliche floor between $19-21 \mathrm{~cm}$ bd. Cultural material found in the backdirt included 2 chipped stone flakes and a modern brown glass sherd (Appendix A). The undulating floor surface consisted of a compacted, light brownish gray (10YR 6/2) sandy loam with a few limestone and mortar fragments imbedded in it. Large $(\mathrm{ca} .10 \mathrm{~cm})$, smooth mortar fragments with traces of red paint were resting on the surface, and roots were 
growing horizontally across the surface. The $\mathrm{N}-\mathrm{S}$ and $\mathrm{E}-\mathrm{W}$ stone walls did not appear to be joined together in the corner; the $\mathrm{N}-\mathrm{S}$ wall abutted the $\mathrm{E}-\mathrm{W}$ wall. Plaster (with no visible paint or etchings) was still adhered to the $\mathrm{E}-\mathrm{W}$ wall, and appeared to continue eastward beyond its juncture with the $\mathrm{N}-\mathrm{S}$ wall. Excavation was terminated at floor level and because of its badly deteriorated condition, it was not clear whether the plaster extended below the floor surface.

\section{Unit 44}

Unit 44 was placed in the northeast corner of Room 5, and a datum established on the modern surface in the southwest corner. What was obviously WPA's pale brown (10YR 6/3), sandy loam backdirt with grass, sticks and wall fall limestone rubble was removed to an undulating floor between $21-23 \mathrm{~cm}$ bd.

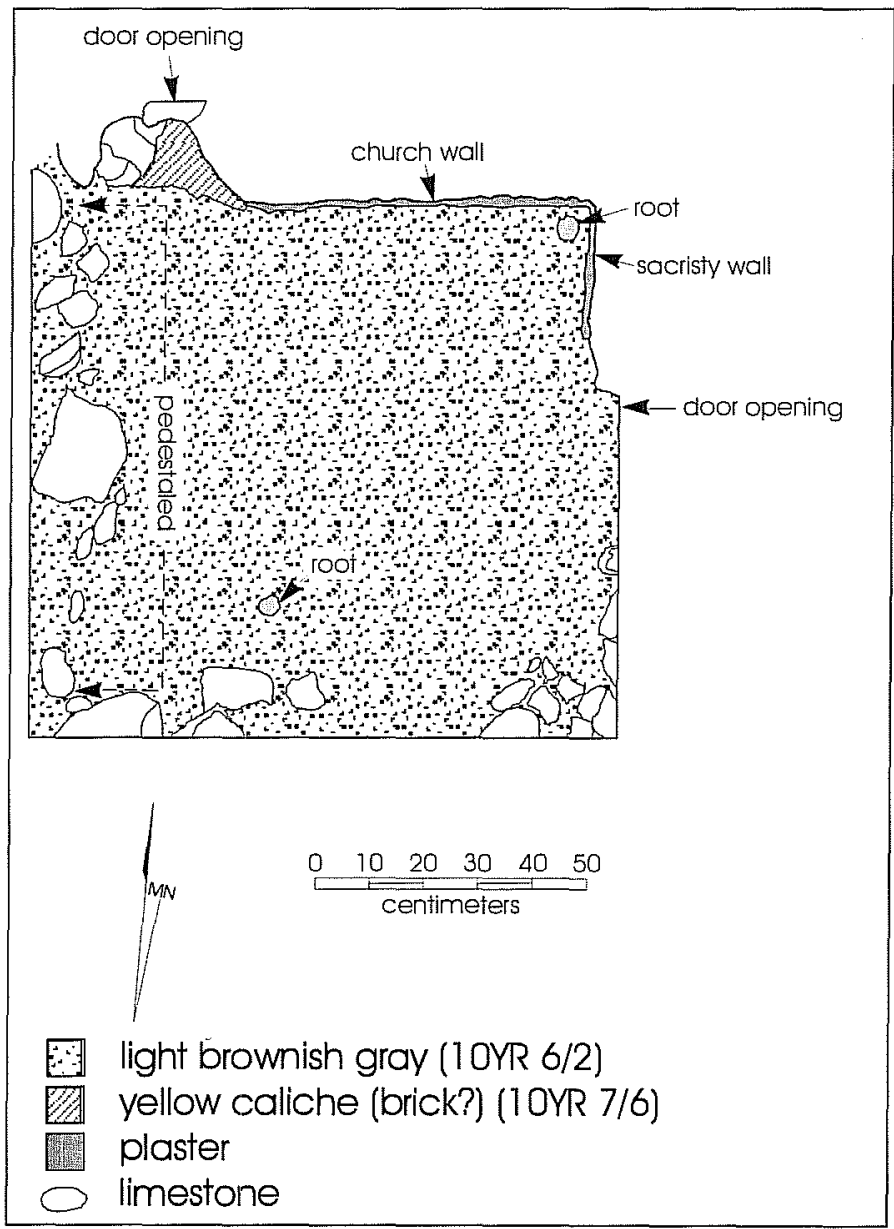

Figure 5-20. Planview of Unit 44 showing door openings and caliche brick, $19 \mathrm{~cm}$ bd in Room 5 (Sacristy).
Cultural material found in the backdirt included 2 chipped stone flakes, 2 bone fragments, and 2 modern clear glass sherds (Appendix A). The undulating floor surface consisted of a compacted, light brownish gray (10YR 6/2) sandy loam with a few small angular limestone and mortar fragments imbedded in it (Figure 520). The top of what is believed to be an adobe brick was encountered $23 \mathrm{~cm}$ bd just inside the north doorway opening on the north wall into Room 1 . The brick was the same type that Gilmore photographed (1974b:Figure 13), and we uncovered in our Units 51 and 52. Plaster (with no visible paint or etchings) still adhered to the $\mathrm{E}-\mathrm{W}$ wall and was wrapped around the inside corner with the $\mathrm{N}-\mathrm{S}$ wall. Excavation was terminated at floor level and because of the badly deteriorated condition of the plaster, it was not clear whether it extended below the floor surface.

\section{Unit 45}

Unit 45 was placed in the northwest corner of Room 5 , and a datum established on the modern surface in the southeast corner. What was obviously WPA's pale brown (10YR 6/3), sandy loam backdirt with grass, sticks and a few limestone chunks from wall fall was removed to an undulating floor between $37-38 \mathrm{~cm}$ bd. The undulating floor surface consisted of a compacted, light brownish gray (10YR 6/2) sandy loam with a few small angular limestone, mortar fragments, and caliche pebbles imbedded in it. Plaster (with no visible paint or etchings) was still adhering to the north and west stone walls, but was extremely fragile, with rotted mortar and roots pushing it away from the walls. What plaster still remained clearly wrapped around the inside northwestern corner and extended approximately $70 \mathrm{~cm}$ in each direction. Excavation was terminated at floor level, but unlike Units 43 and 44, the lower boundary of the plaster in this unit appeared to stop at floor level. No cultural material was found in this unit.

\section{Unit 46}

Unit 46 was placed in the southwest corner of Room 5 , and a datum established on the modern surface in the northwest corner. What was obviously WPA's pale brown (10YR 6/3), sandy loam backdirt with 
grass, sticks and a few limestone chunks from wall fall was removed to an undulating floor $40 \mathrm{~cm}$ bd. Cultural material found in the backdirt included 4 chipped stone flakes, bone and mussel shell fragments, a brownware ceramic sherd, and a modern clear glass sherd (Appendix A). The undulating floor surface consisted of a compacted, light brownish gray (10YR 6/2) sandy loam with a few caliche pebbles. Plaster remnants (with no visible paint or etchings) were still adhering to the west stone wall, but were badly deteriorated. Plaster was missing near the floor and unlike the northeast and northwest corners of the room (Units 44 and 45) plaster was missing in this corner. Therefore it could not be determined if the two walls were plastered contemporaneously, or if the plaster ever extended below this floor level.

\section{Unit 105}

This unit was placed along the south wall to define the floor and doorway opening, extending $80 \mathrm{~cm}$ south into the doorway. As with the rest of the room, approximately $35 \mathrm{~cm}$ of WPA's pale brown (10YR 6/ 3 ), sandy loam backdirt overlay the compacted floor. The same compacted, light brownish gray (10YR 6/ 2) sandy loam undulating floor uncovered elsewhere in the room was found extending halfway through the door opening before sloping downward ca. $6-8 \mathrm{~cm}$ and dissipating into the mixed WPA sediments. The measurement of this doorway opening is approximately $90 \mathrm{~cm}$ (ca. 1 Spanish vara).

\section{Discussion}

A compacted, pale brown, slightly undulating, sandy loam floor was found throughout the room and half way though the south doorway. In Unit 43, in the southeast corner of the room, the plaster (with no visible paint or etchings) that still adhered to the southern, E-W wall, and appeared to continue eastward beyond its juncture with the eastern, $\mathrm{N}-\mathrm{S}$ wall of the room suggests that the two walls are not contemporaneous. It may be that the eastern $\mathrm{N}-\mathrm{S}$ wall is a later addition cross wall. Further corroboration for this supposition is that the $\mathrm{N}-\mathrm{S}$ wall and $\mathrm{E}-\mathrm{W}$ walls are not joined in the southeast corner of the room; the $\mathrm{N}-\mathrm{S}$ wall abuts the $\mathrm{E}-\mathrm{W}$ wall. No evidence was found during these excavations however, to suggest that the western wall is not contemporaneous. Floor levels in the Sacristy appear consistent with those of the upper floor in the adjoining Room 1, suggesting these rooms were occupied contemporaneously. An apparent adobe brick encountered in the northern doorway of the sacristy is similar to those found under the walls in the northeastern and southeastern corners of Room 2, suggesting a different type of construction used in building the chapel that has thus far not been found elsewhere inside the extant mission compound walls; although Ricklis (1999) found an adobe brick floor south of the compound wall.

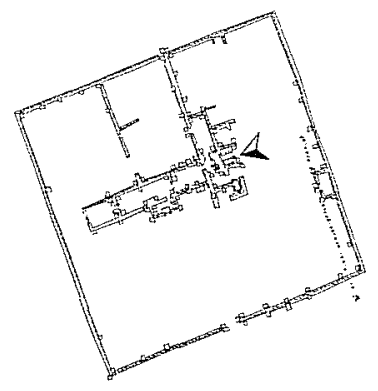

\section{Room 6 (Under Bell Tower)}

Room 6 is located on the western end of the extant stone-walled structures (Figures 3-1 and 5-1). Based on Gilmore's documentation of the collapsed corner buttress, WPA photographs from the 1940s showing second-story walls (e.g., Appendix A-4:Photographs $\mathrm{A}-1, \mathrm{~A}-2$ ), the massiveness of the existing supporting walls, and its own exterior supporting bastions, Room 6 was on the first floor of a two-story structure. Gilmore surmises the second story structure was the bell tower. Thus Room 6 was located beneath the bell tower, yet its function is unknown. Gilmore did not work in the room, and photographs available from the 1940s were taken at such angles to make it unclear whether or not the WPA excavated Room 6. However, given the extensive excavations the WPA conducted in all other existing rooms, there is little reason to doubt that Room 6 was cleared to floor level also. CAR placed four units (25-28) in Room 6 to examine the architecture, but before excavation could begin crew-members removed over a meters' depth of literally tons of reddish brown sandy clay with large limestone block wall fall and rubble by hand. 
Unit 25

Unit 25 was placed in the northeast corner of Room 6 (Figure 5-21), and a datum established in the southwest corner. Additional overburden consisting of the reddish brown clay loam with wall fall rubble was removed before encountering remnants of a floor in the northeast corner $21 \mathrm{~cm}$ bd. The 3-5 cm-thick floor consisted of a compacted, light brown (7.5YR 6/4) loam which was overlying the dark brown (10YR 4/ 2) sandy loam "midden" soil commonly found throughout the mission. Stratigraphically intact underneath the preserved floor, the dark sandy A Horizon was found underlying the midden soil at $28 \mathrm{~cm}$ bd. As shown in Figure 5-21, a large portion of the floor had been removed and then backfilled with compacted,

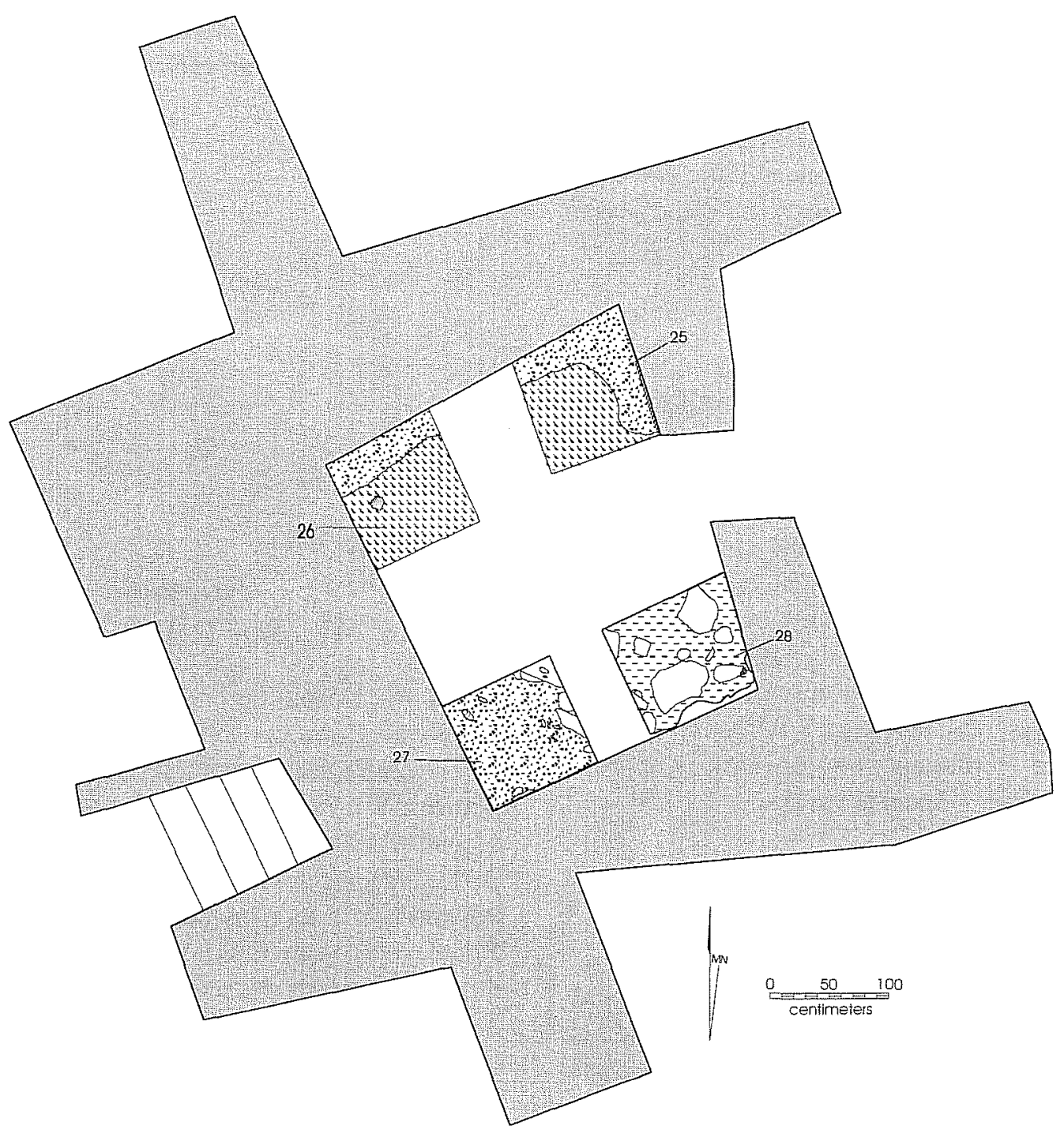

compacted, light brown sand floor (7.5YR6/4)
compacted, brown clay loam (7.5YR4/3)
brown sand (7.5YR $5 / 3$ )
rodent hole
plaster
sandy loam $5 Y R 5 / 2$
-7 intact plaster
limestone

Figure 5-21. Planview of floor in Room 6, Units 25-28. 
brown (7.5YR 4/3) clay loam containing wall fall limestone rubble and chunks of plaster. The backfill extended to the top of the A Horizon $35 \mathrm{~cm} \mathrm{bd}$, at which point excavations in this unit were terminated.

Cultural material recovered includes 4 chipped stone flakes and a few bone fragments; a tobacco tin found provides further evidence of the disturbance that has occurred in this corner of the room.

\section{Unit 26}

Unit 26 was placed in the northwest corner of Room 6 (Figure 5-21), and a datum established in the northeast corner. As with all four units in the room, additional overburden consisting of the reddish brown clay loam with wall fall rubble was removed during excavation. Spotty patches of a loose, yellowish brown (10YR 5/4) sand lens were encountered $6 \mathrm{~cm}$ bd. The 3-5 cm-thick sand patches were resting on a mottled dark brown (7.5YR 3/2) sand and brown (7.5YR 4/3) sandy loam mixture containing smaller limestone rubble fragments and chunks of plaster. A distinct, compacted floor consisting of light brown (7.5YR 6/ 4) sand with some loam was uncovered $20 \mathrm{~cm}$ bd along the north wall (Figure 5-21). The floor had previously been removed in the remainder of the unit and subsequently backfilled with the mottled dark brown sand and brown sandy loam. Excavations were terminated at the $20 \mathrm{~cm}$-floor level.

Cultural material recovered includes 3 chipped stone flakes and a few bone fragments; pieces of aluminum foil found provide further evidence of the disturbance that has occurred in this corner of the room.

\section{Unit 27}

Unit 27 was placed in the southwest corner of Room 6 (Figure 5-21), and a datum established in the northwest corner. Additional overburden consisting of the same reddish brown clay loam with wall fall rubble found in Units 25 and 26 was removed before encountering patches of a compacted, light yellowish brown (2.5YR 6/4) sand lens $10 \mathrm{~cm}$ bd. The spotty sand lens was overlying a mottled dark brown (7.5YR 3/2) sand and brown (7.5YR 4/3) sandy loam mixture containing wall fall limestone rubble and chunks of plaster with traces of faded red and salmon-colored paint. Between $25-30 \mathrm{~cm}$ bd the backfilled sediments transitioned to a brown (10YR 5/3) sandy loam with reddish brown (5YR 5/3) silty clay mottling. These sediments overlay a distinct, slightly undulating, light brown (7.5YR 6/4) compacted floor $29-30 \mathrm{~cm}$ bd, the same floor of which remnants were found in Units 25 and 26. Before excavation was terminated at floor level, chunks of red and salmon-painted plaster were observed lying face down on the floor surface. In addition to plaster fragments, other cultural material found in the overburden includes 1 chipped stone flake, and a few bone and mussel shell fragments.

\section{Unit 28}

Unit 28 was placed in the southeast corner of Room 6 (Figure 5-21), and a datum established in the southwest corner. Additional overburden consisting of the same reddish brown clay loam with wall fall rubble found throughout the room was removed before encountering remnants of a compacted, light brown floor surface $19 \mathrm{~cm}$ bd. Although our excavation in this unit was terminated at the surface of the floor remnants, this corner of the room appears to have been heavily disturbed, with large limestones imbedded deeply in reddish sandy clay below the floor remnants.

Cultural material recovered includes a Puebla Blue on White II sherd, a few bone fragments, and several chunks of red and salmon-painted plaster.

\section{Discussion}

The use of Room 6 is unknown, however with the presence of numerous chunks of red and salmon-colored painted plaster chunks that appear to have fallen on a well-compacted floor suggest that the room had held some type of prominence. The walls and floors have been heavily disturbed; no plaster was still adhering to the walls, and only remnants of the floor remained in many places. 


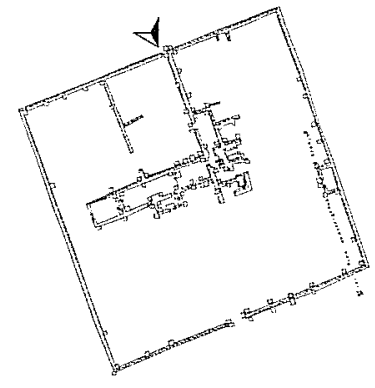

Feature 15 - Probable North Gate, Room 7

An above-ground opening in the north wall was readily apparent during this project. Whether it was an intentional Spanish Colonial design or the result of later construction was unknown. Gilmore had not conducted investigations in the area of the probable north gate; however, photographs (e.g., Appendix A-4:Photograph A-7) show that the WPA had placed a trench along the west side of the $\mathrm{N}-\mathrm{S}$ interior stone cross wall in the 1940s. CAR opened three excavation units (7, $99,102)$ in and around the opening to investigate the architecture, discovering a filled-in trench, and a room along the outer compound wall.

\section{Unit 7}

Unit 7 was placed along the north stone compound wall on the inside corner of its juncture with a $\mathrm{N}-\mathrm{S}$ stone cross wall (Figures 3-1 and 5-1) to determine their integrity and structural nature below the surface. Before excavation began using arbitrary $10 \mathrm{~cm}$ levels, a mixed overburden consisting of dark brown clay loam, yellowish gray caliche, and light brown sandy clay loam, with numerous fist-sized limestone chunks (presumably wall fall) was removed, increasing in thickness from $1 \mathrm{~cm}$ in the southwest corner of the unit to $46 \mathrm{~cm}$ up against the northern and northeastern stone walls. Datum was then established in the southwest corner $1 \mathrm{~cm}$ below the modern surface.

The upper $10 \mathrm{~cm}$ consisted of a thin layer of loose, gray (10YR 6/1) sandy loam, overlying dark grayish brown silty loam (10YR 4/2) with few fist-sized limestone cobbles (Figure 5-22). An apparently disturbed area along the eastern edge of the unit near the $\mathrm{N}-\mathrm{S}$ cross wall appeared as mottles of reddish brown sandy clay. A patch of yellow caliche encountered in the southern portion of the unit $19 \mathrm{~cm}$ bd had been cut

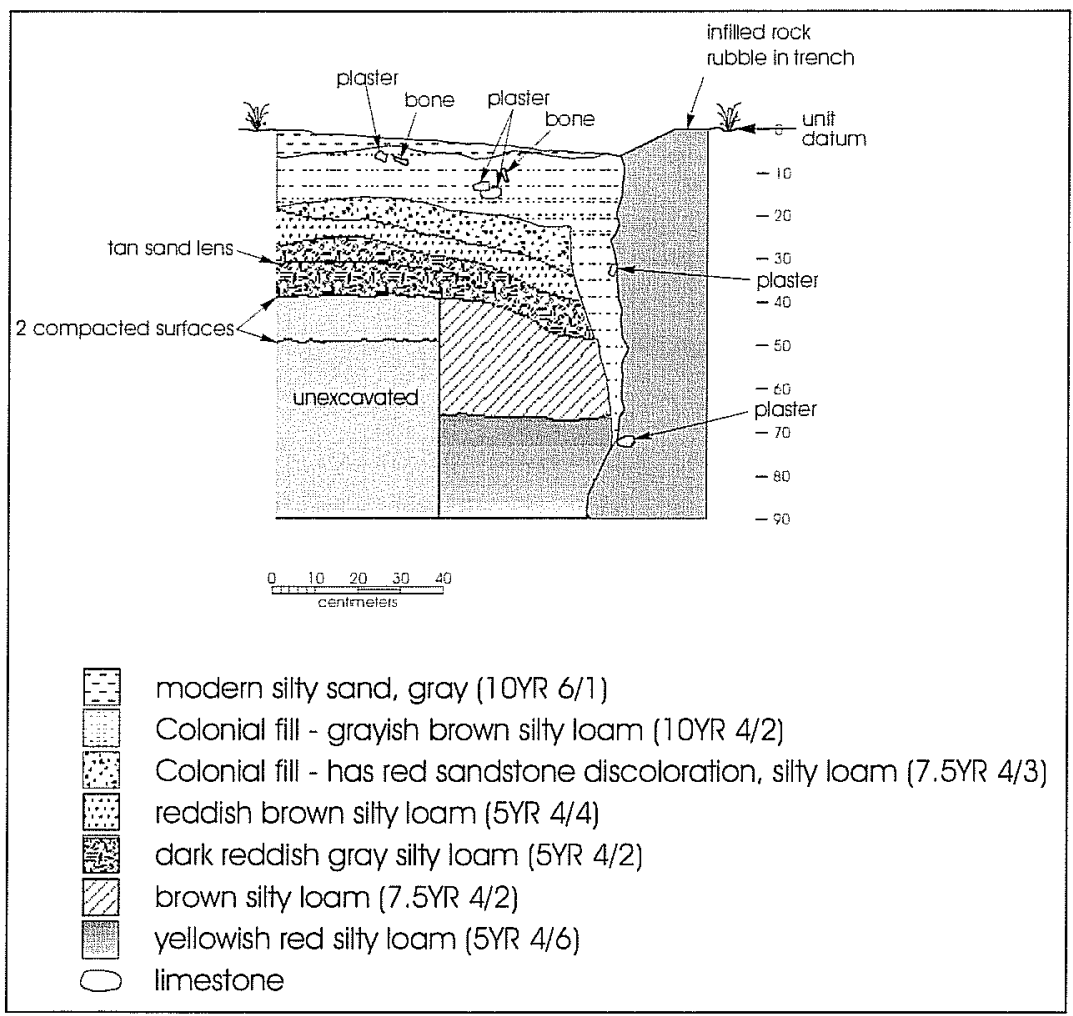

Figure 5-22. West wall profile of Unit 7 at probable north gate opening. 
through along its eastern edge; this is the disturbed area detected in the 1st level, and is apparent evidence of a WPA trench from the 1940 s, backfilled with reddish brown (10YR 4/4) clay loam. The light brownish gray (10YR 6/2) sandy loam in the western portion of the unit was apparently undisturbed at this level (Figure 5-22). A band of light yellowish brown (10YR $6 / 4$ ) rotted mortar paralleled the northern and eastern walls, ending at the WPA trench backfill (Figure 523). Because of the apparent trenching and construction activities in this area, the cultural material appears to be mixed (Appendix A).

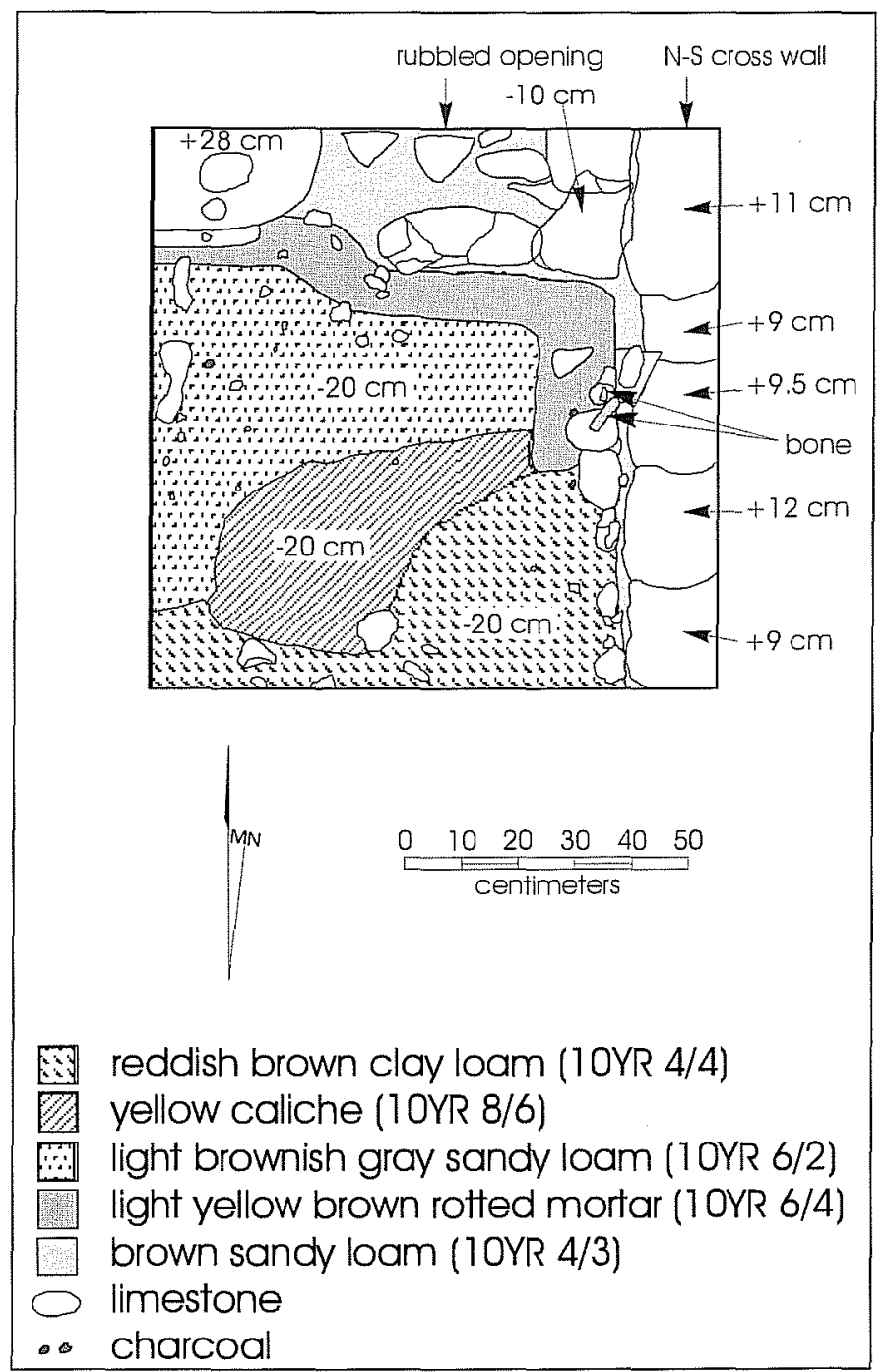

Figure 5-23. Planview of Unit 7, $20 \mathrm{~cm}$ below the modern surface.
Underlying the bottom of the reddish brown clay loam backfilled WPA trench in the southeastern portion of the unit was a brown (7.5YR 4/3) clay loam. This layer, with charcoal and red clay mottles, became evident in the west wall profile, sloping toward the north wall ca. $22 \mathrm{~cm}$ bd, (Figure 5-22). Stratigraphically below the brown clay loam, and sloping in the same direction, was a layer of reddish brown (5YR 5/4) silty clay, followed by a thin tan sand lens sandwiched over a dark reddish gray (5YR 4/2) silty loam. These upper Colonial deposits were setting over the brown (7.5YR 4/2) sandy A Horizon and yellowish red (5YR 4/6) silty clay commonly found underlying Colonial deposits throughout the mission. Unique however in this unit is that the A Horizon surface was heavily compacted between $41 \mathrm{~cm}$ bd and ca. $45 \mathrm{~cm} \mathrm{bd}$, transitioning to its typically loose, friable structure, before again becoming compacted $51 \mathrm{~cm}$ bd.

Examination of the north wall (E-W compound wall) revealed that the stones below the modern surface were not nicely dressed cut stone as appeared above the ground and in our other excavation units along northern compound walls. Rather, they were much smaller and angular, obviously thrown in the trench as filler.

\section{Unit 99}

After investigations in Unit 7 to the south determined that the $\mathrm{E}-\mathrm{W}$ stone wall in this corner was not the finely cut, intact stone found in units along the wall toward the west, Unit 99 was placed outside the compound wall in front of the probable north gate to examine the opening and to determine the nature of the $\mathrm{N}-\mathrm{S}$ stone cross wall's intersection with the compound wall. Approximately $10 \mathrm{~cm}$ of overburden consisting of wall fall rubble was removed before encountering a corner of the buried wall found in Unit 7 to the south. This buried wall cornered and extended to the west. Just outside, or north of the buried wall was a prepared surface of fist-sized and larger limestone cobbles. The prepared cobble surface sloped toward the north with the natural terrain. In addition to 72 pieces of Coastal and Goliad ware, 12 Spanish Colonial ceramic sherds were found around the buried wall and prepared cobble surface (Appendix A). 


\section{Unit 102}

Because our attempts to examine the probable north gate opening in Unit 99 were hampered by the discovery of the extended buried wall corner, we opened Unit 102 to the east (Figures 3-1 and 5-1) to investigate whether or not the upper, extant compound wall was tied into the buried wall uncovered in Units 7 and 99. After removing approximately $20 \mathrm{~cm}$ of wall fall rubble, a compacted, light brown caliche floor was uncovered. This floor was approximately at the same level as the cobbled surface found in Unit 99, but was not sloping. Plaster was adhering to both the compound wall and buried wall, and was wrapped around the inside corner juncture of the two, providing evidence that a room (Room 7) of some prominence was built outside the northern compound wall. In addition to 35 pieces of Coastal and Goliad ware, 3 Spanish Colonial ceramic sherds were found inside the room (see Appendix A).

\section{Discussion}

Excavation in Unit 7 on the interior of the compound uncovered two episodes of construction, and possibly 3 occupations. The compacted A Horizon surface at the base of the Colonial deposits (see Figure 5-22) suggests this area was heavily trodden perhaps during the initial occupation period of the mission, ca. 17541768. A buried $\mathrm{N}-\mathrm{S}$ stone wall, presumably constructed between 1768-1780, extends through the upper, E-W compound wall to a corner just north of the compound wall. It then continues to the west an undetermined distance.

Stratigraphic profiles in Unit 7 indicate that the trench for the E-W north compound wall was dug, presumably between 1789-1807, bringing up the underlying Pleistocene clay and dark brown sandy A Horizon. A thin layer of the dark sandy A Horizon found in an outline of a trench at the base of the rubble indicates that the trench was prepared to receive cut stones neatly laid in place at its base, as seen in other units along the compound walls. However, here in the gate opening the trench was then filled in with stone rubble. The trench was wide enough to allow sediments and cultural material from the upper Colonial deposits to spill, or be dumped into the trench along with the stone rubble (see Figure 5-22). The earlier-constructed, buried stone wall was incorporated into the later, presumably 1789-1807 construction of the upper compound wall, as evidenced by plaster found in Unit 102 wrapped around the corner of a room constructed outside the upper compound wall.

A prepared cobble surface, presumably a walkway in front of the north gate, sloped with the natural terrain north toward the river. The walkway abuts the north edge of the buried stone wall making its association with the 1768-1780 construction episode apparent.

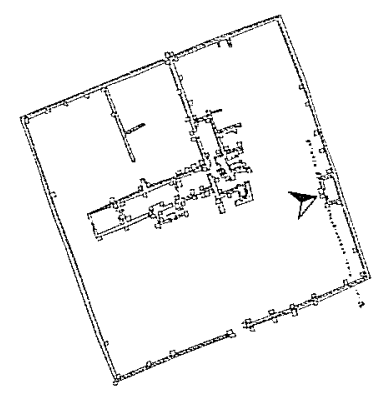

\section{Room 8 \\ Excavations and Probes}

This isolated room located on the eastern compound wall (Figures 3-1 and 5-1) was not investigated by Gilmore, however a photograph taken during the $1940 \mathrm{~s}$ WPA excavations indicates that the room was at least cleared of debris.

CAR opened four units (81-84) across the western exterior of the room and two more units ( 80 and 85 ) at the structure's juncture with the eastern compound wall. In addition to defining the doorway opening, we found evidence of an interior floor and a buried $\mathrm{N}-\mathrm{S}$ wall (Figure 5-24). A series of probes revealed that the buried stone wall continued in a southward direction for approximately $28 \mathrm{~m}$. 


\section{Unit 80}

Unit 80 was placed in the corner of the southern, $\mathrm{E}-\mathrm{W}$ wall of Room 8 and the eastern compound wall (Figures $3-1$ and 5-1) to examine the subsurface walls and footings. With about $5 \mathrm{~cm}$ of accumulated overburden removed from the northeast corner of the unit, a datum was established on the relatively level, modern surface. The upper $10 \mathrm{~cm}$ consisted of loose, dark brown (10YR 4/2) sandy loam, apparently WPA deposits, with only a few bone fragments in it. The sandy loam structure remained consistent to $30 \mathrm{~cm}$, gradually transitioning to a slightly lighter brown (7.5YR 4/4), with a Galera and 4 coastal ceramic sherds, and a heavily reworked stone end scraper. Thus it appears the upper Colonial surface in this area is approximately $10 \mathrm{~cm}$ below the modern surface. Footing stones were found 30-35 $\mathrm{cm}$ below the modern surface (Figures 5-24 and 5-25), the same depth as the top of the A Horizon shown in profile in the north wall of the unit. The footing was $50-55 \mathrm{~cm}$-thick, extending $\mathrm{ca} .12 \mathrm{~cm}$ wider than the upper walls. A thin outline of a trench was barely discernible along the base of the footing, and underlying the footing stones was a thin $(2-3 \mathrm{~cm})$ layer of dark brown (7.5YR 4/4) A Horizon soil, presumably used as a leveler in the bottom of the trench. The footings of both stone walls were exactly the same depth and height, suggesting contemporaneity, yet they did not appear to be tied together in the corner; the room wall appeared to abut the compound wall.

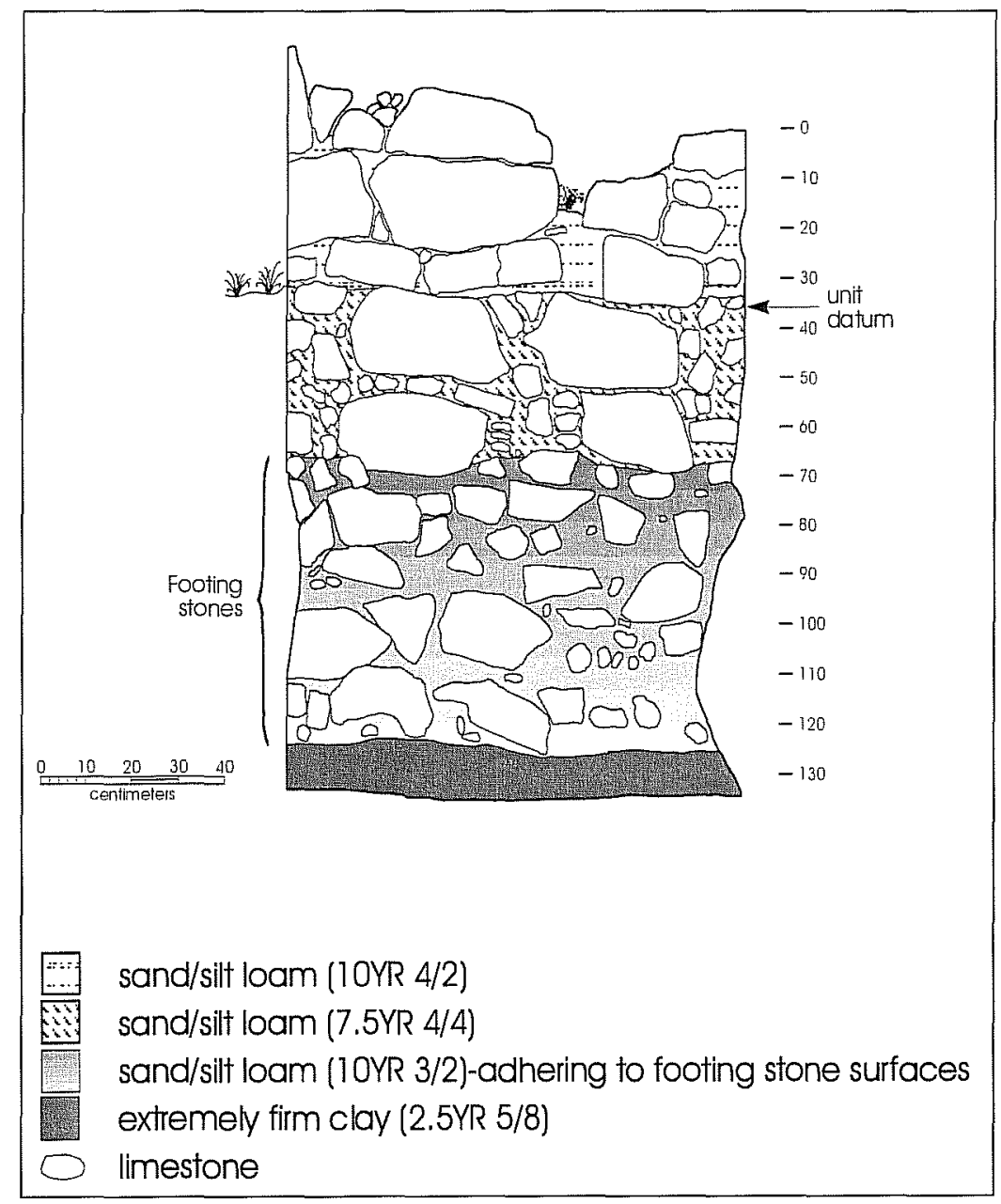

Figure 5-24. Profile of north wall of Unit 80 (south wall exterior of Room 8). 
Figure 5-25. Profile of east wall Unit 80 (east compound wall).

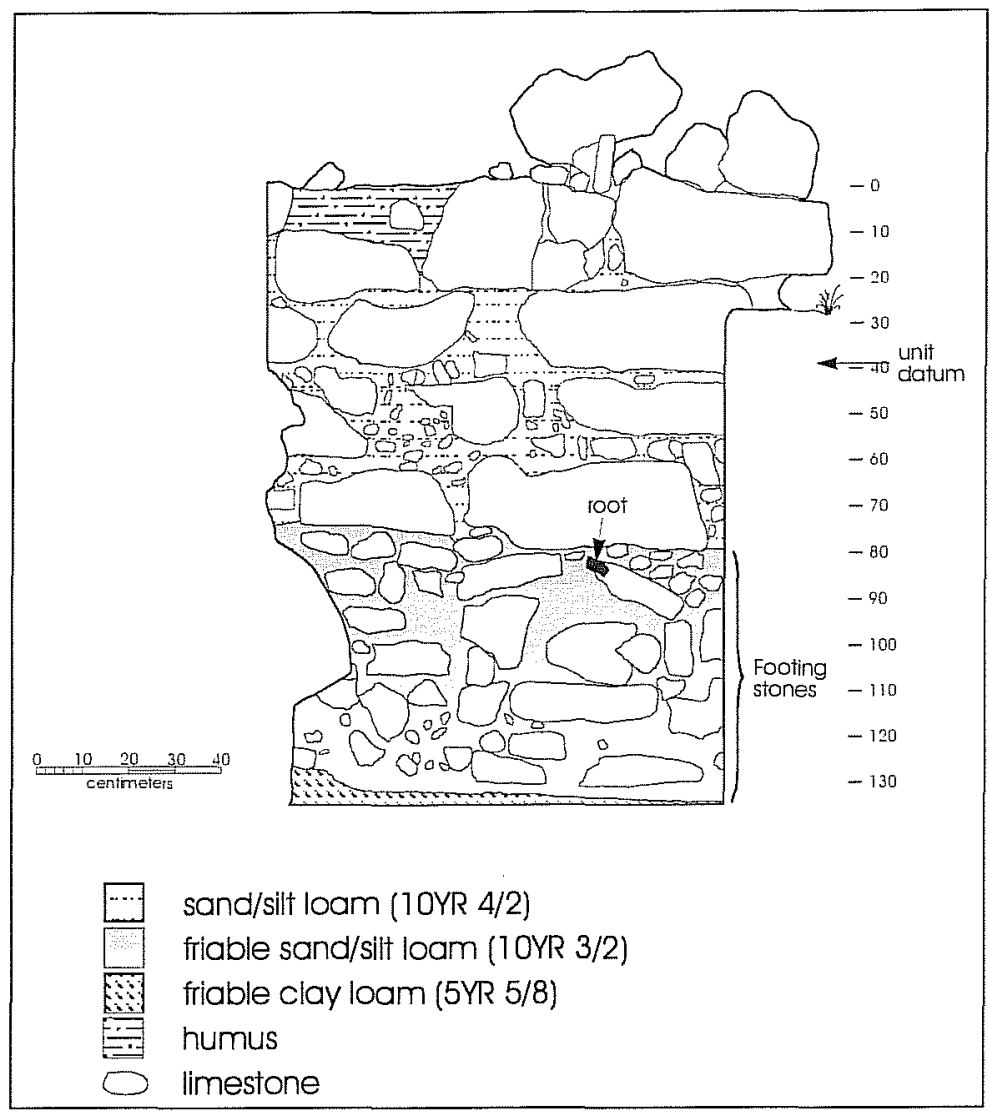

\section{Unit 81}

This unit was placed on the southwest corner of the structure to determine its integrity. Approximately 19 $\mathrm{cm}$ of overburden had accumulated against the structure and was removed before a unit datum was established and excavation in arbitrary $10 \mathrm{~cm}$ levels began. The Colonial surface appeared to be within $2-3 \mathrm{~cm}$ of the modern level ground surface in this area. A few bone and mussel shell fragments, along with a Coastal ceramic sherd were found in the upper $10 \mathrm{~cm}$ of the brown (10YR 5/3) midden soil with charcoal bit inclusions, typically found throughout the mission. No change in soil structure was noted between $10-20 \mathrm{~cm}$ bd, however the top of a limestone wall running $\mathrm{N}-\mathrm{S}$ was uncovered $11 \mathrm{~cm}$ bd. The larger cut stones were interspersed with smaller fragmented limestone and gray mortar. Cultural material found in this level includes a Coastal and Goliad sherd. A patchy layer of reddish brown clay (5YR 5/4) running along the western edge of the $\mathrm{N}-\mathrm{S}$ wall, and overlying brown
(7.5YR 4/3) sandy A Horizon, suggested that a trench had been dug into the underlying Pleistocene clay to set the wall base or footing. Cultural material recovered from $20-30 \mathrm{~cm}$ includes 3 coastal sherds and a few bone fragments. Excavation to $40 \mathrm{~cm}$ bd into the A Horizon confirmed that the $\mathrm{N}-\mathrm{S}$ wall stones continued north underneath the $\mathrm{N}-\mathrm{S}$ wall of Room 8 , and that although slightly offset, the buried wall was integrated into the construction of Room 8 as a foundation (Figure 5-26 and 5-27). A single coastal sherd and a few bone fragments were found in this level. Excavation was terminated at $40 \mathrm{~cm}$ bd.

Several probes using a length of 3/8-inch rebar were conducted $1 \mathrm{~m}$ apart on a line south of Unit 81 to determine the extent of the buried wall. The results of these probes indicate that the buried wall apparently continues southward approximately $28 \mathrm{~m}$ from Unit 81 , beyond the extant, upper, southern compound wall (Figures 3-1 and 5-1). 
Figure 5-26. Planview of corner of Room 8 overlying buried stone wall, Unit 81.
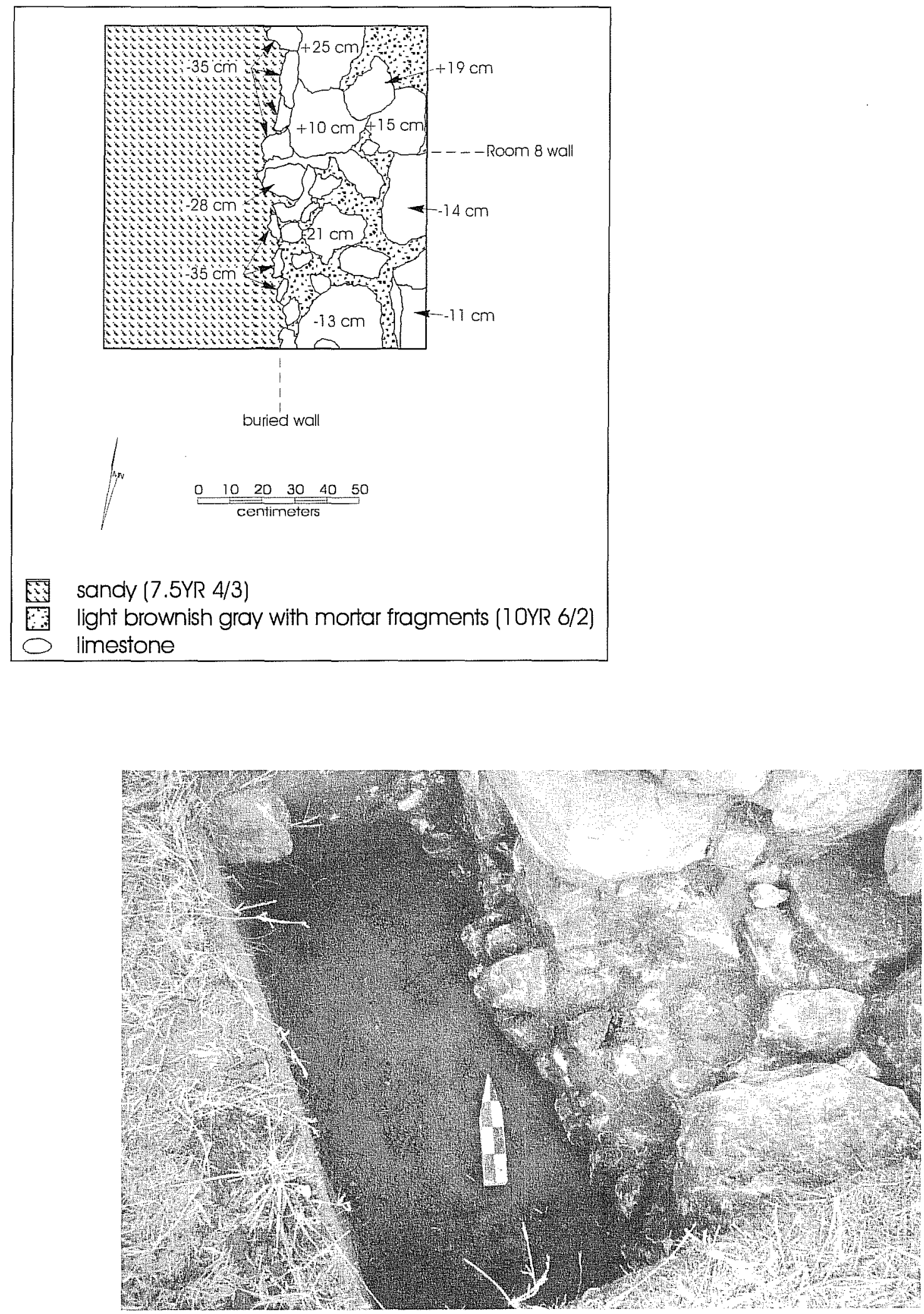

Figure 5-27. Photograph of corner of Room 8 overlying buried stone wall, Unit 81. 


\section{Units 82 and 83}

These units defined the doorway opening into Room 8. As was the case in Unit 81, approximately $20 \mathrm{~cm}$ of overburden had accumulated against the western edge of the structure and had to be removed before either datum could be set on the nearly level modern surface. Excavation began in arbitrary $10 \mathrm{~cm}$ levels; the Colonial surface appeared to be within $5-6 \mathrm{~cm}$ of the modern surface in this area. A few bone and mussel shell fragments, along with a coastal ceramic sherd were found in the upper $10 \mathrm{~cm}$ of the brown (10YR 5/ 3 ) midden soil. The slightly offset edge of the buried stone wall found in Unit 81 was uncovered in Unit 82 underneath the upper stone wall. The southern edge of the doorway was also exposed in Unit 82. The northern edge of the doorway was defined, and a possible entryway step stone was found in the doorway in Unit 83. An apparent, $3 \mathrm{~cm}$-thick brownish/yellow caliche floor with plaster granules was found overlying the step stone, however the floor was not further investigated. Before stopping excavations in each of these units at 14 and $12 \mathrm{~cm}$ respectively, 2 chipped stone flakes, 5 coastal sherds, and also a few bone fragments were found.

\section{Unit 84}

This unit was placed on the northwest corner of Room 8 to examine the integrity of the structure. As much as $24 \mathrm{~cm}$ of overburden accumulated along the stone wall was removed and a datum established on the relatively level modern ground surface. Approximately $8 \mathrm{~cm}$ of presumably WPA-deposited pale brown (10YR 6/3) sandy loam were excavated before the Colonial brown (10YR 5/3) sandy loam surface became apparent. Excavations were terminated $10 \mathrm{~cm}$ bd when we were convinced we had contacted the upper Colonial surface. At this level a 5-8 cm-wide strip of reddish sandy loam and clay was visible along both stone walls, presumably deteriorated mud mortar - although the mortar in Room 8 appears to be grayish, gritty, and limey. The Colonial soil also contained bits of mortar, and small $(<1 \mathrm{~cm})$ limestone fragments. Cultural material found in this unit includes 1 chipped stone flake, 2 coastal pottery sherds, a brown glass sherd, and a few bone fragments.

\section{Unit 85}

Unit 85 was placed in the corner of the northern $E-W$ wall of Room 8 and the eastern compound wall (Figures 3-1 and 5-1) to determine the depth of the upper Colonial surface in this area. Approximately $12 \mathrm{~cm}$ of overburden that had accumulated in the corner was removed before a datum was established on the relatively level, modern surface. The upper $10 \mathrm{~cm}$ consisted of brown (10YR 5/3) sandy loam except for a reddish strip along the room wall, similar to that found in Unit 84 on the same wall. Cultural material found in the upper $10 \mathrm{~cm}$ included a few bone fragments, an olive green glass sherd, and 10 coastal ceramic sherds, one of which has been rounded into a gaming piece. The last level (10-25 cm bd) consisted of compacted and mottled reddish, yellowish, brownish, and grayish loams. Charcoal bits were included in this hard packed layer, and more faunal remains seemed to be resting on and within it. Besides the bone fragments, other cultural material in this lower $5 \mathrm{~cm}$ included an olive green glass sherd, 5 Goliad sherds, and 2 coastal sherds. Based on the presence of artifacts and changes in the soil structure, it appears that the upper Colonial surface in this area is approximately $5 \mathrm{~cm}$ below the modern surface.

\section{Discussion}

Excavation around the exterior of Room 8 revealed that the west wall had been built over a buried, substantial stone wall. Presumably the buried wall represents the first stone episode of construction at the mission, ca. 1768-1780. Probing on a line south of Room 8 indicates the wall is approximately $30-50 \mathrm{~cm}$ below the surface, and extends for $27.72 \mathrm{~m}$ (33 Spanish varas) from the corner of Room 8 , apparently crossing under the extant, upper stone compound wall. The southern end of this buried wall may represent the eastern extent of a similar buried stone wall found by Ricklis (1999). Excavations in Units 82 and 83 defined the width of the doorway opening as $90 \mathrm{~cm}$ (ca. 1 Spanish vara) wide. A possible step stone underlying remnants of an apparent, $3 \mathrm{~cm}$-thick brownish/ yellow caliche floor with plaster granules was found, however the floor was not further investigated. 
Although the mortar in the walls of Room 8 appears to be gray and granular with lime, apparent deteriorating red mud mortar was found along the base of the room walls in Units 84 and 85, similar to the deteriorating red mud mortar found along the buried wall in Unit 81. Excavations in Units 84 and 85 were terminated at very shallow depths, and it may be that the deteriorating red mud along the walls is a manifestation of the extended buried wall lying underneath Room 8's northern wall.

One construction event and possibly three occupation layers were evident in the south wall profile of Unit 80 (Figure 5-28). The dark brown A Horizon overlay the red Pleistocene clay as it should near the bottom of the unit, however, an inverted soil stratigraphic sequence and a thin lens of gray sandy loam observed suggests the following:
(1) The original occupation period (1754-1768) at the mission is likely represented by the thin lens of gray, ashy sandy loam lying directly over the A Horizon;

(2) The second occupation period (1768-1780) is represented by the ca. $10 \mathrm{~cm}$-thick light brownish gray sandy loam deposit; and

(3) During the third occupation period (17891807) a trench was dug through the underlying dark brown A Horizon, into the red Pleistocene clay to lay the footing stones for the extant stone wall.

Backdirt from the trench and the two underlying in situ soils created the mottled reddish brown lens lying on the 1768-1780 deposits, sloping upwards, away from the stone wall. Spillover from construction of the extant stone wall can be seen lying above the trench backdirt, followed by cultural deposit within the upper, 1789-1807, midden soil.

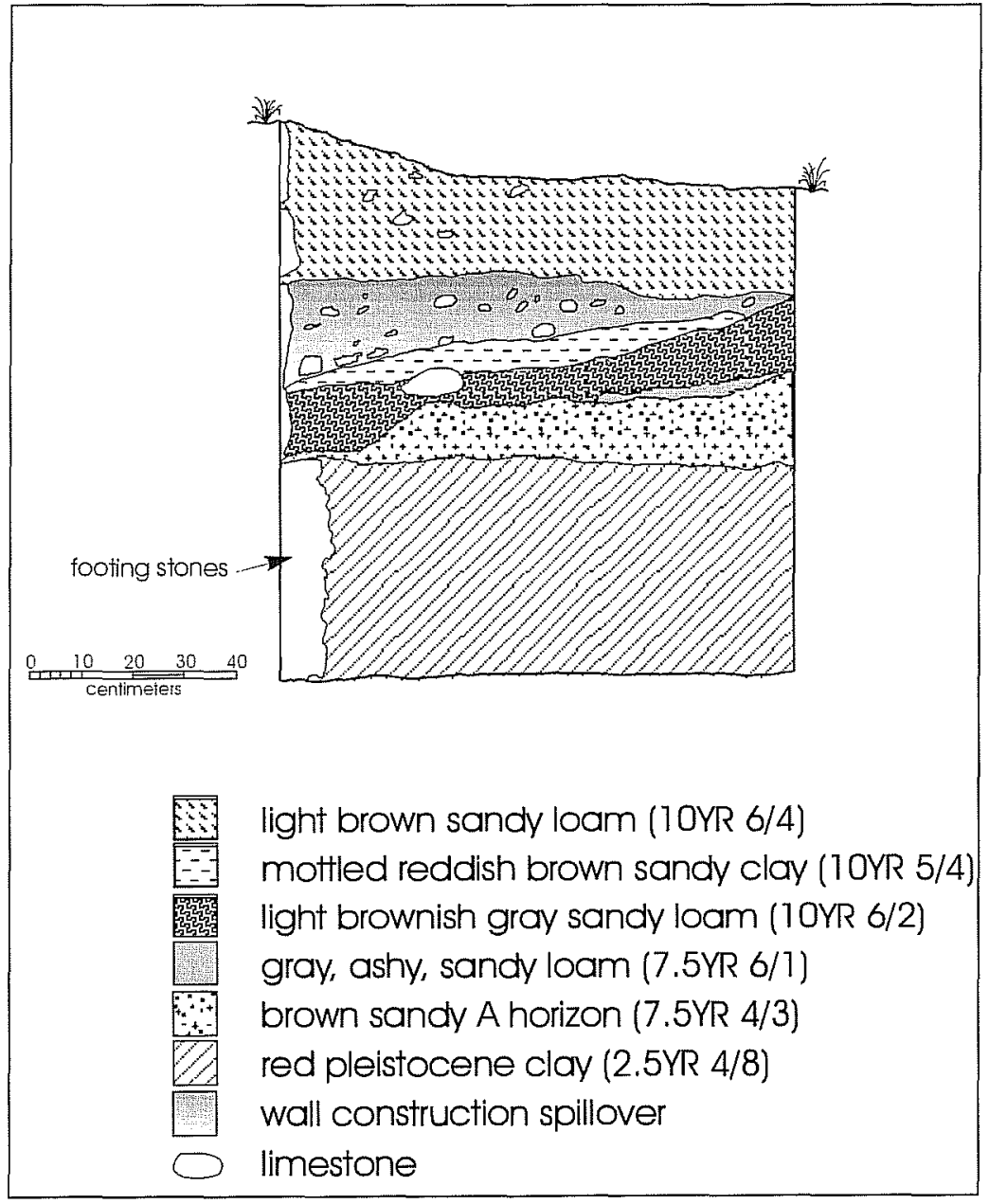

Figure 5-28. Profile of south wall of Unit 80.
The similar construction of the wall of Room 8 and the compound wall are intriguing. That the compound wall would have been built with such a massive, deep footing is not surprising if the wall was over 8 feet high (Gilmore 1974b:15). This suggests then, that the walls of Room 8 were also either the same or nearly the same height. However, although they are of similar construction, the two walls are not tied together; for the southern, EW wall of Room 8 abuts the outer, $\mathrm{N}-\mathrm{S}$ compound wall. This implies that Room 8 was an add-on, or a later addition completed after the compound wall, and a buried stone wall found in Unit 81 was used as the footing for Room 8 along its eastern wall. Units placed along the north wall of Room 8 were not excavated deep enough to examine the footings and wall juncture on that side. 


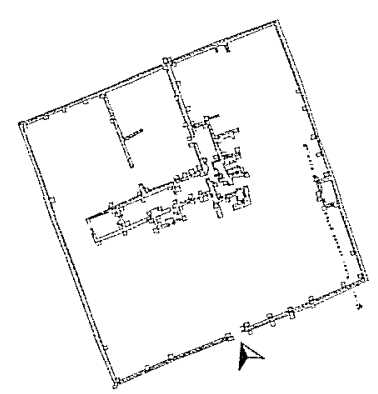

South Gate

Available photographs from the WPA(e.g., Appendix A-4:Photographs A-1, A-8) indicate that the gateway opening in the south compound wall was cleared in the 1940s. Gilmore (1974a:68) excavated around the western edge of the gateway and found that...

"The wall was set in a trench filled with stone and red clay mortar..."

She also uncovered a posthole backfilled with red clay approximately 15 inches north of the wall opening, but no evidence was apparent to suggest that the post was part of the gateway construction. CAR placed three units $(97-98,103)$ in and around the edges of the opening and defined its width.

\section{Units 98 and 103}

These units were placed on the surmised western edge of the opening (Figures 3-1 and 5-1). The end of the wall was not at all clear above the surface, and Unit 98 was extended $50 \mathrm{~cm}$ west to search for in situ stones. In situ limestone blocks were then uncovered in the northwest corner of Unit 98 and the southwest corner of Unit 103. The soil encompassing the disarticulated stones above and around the in situ stones consisted of loose, reddish brown (10YR 5/4), sandy loam with large limestone rubble wall fall. South of the in situ wall stones, outside the opening, the soil transitioned to reddish yellow (5YR 6/8) sandy loam before excavations were terminated.

\section{Unit 97}

The end of the wall was not at all clear above the surface, and Unit 97 was placed on the surmised eastern edge of the opening (Figures 3-1 and 5-1) to search for in situ stones. After removing approximately $14 \mathrm{~cm}$ of loose, reddish brown (10YR 5/4), sandy loam and limestone rubble wall fall, in situ limestone blocks were uncovered in the southeastern quadrant of the unit. Soil in the western half of the unit (inside the opening) became heavily compacted, and transitioned to brownish yellow (10YR 6/6) in the northwestern quadrant, with some charcoal and an increase in bone and ceramic quantities. The northwest quadrant of the unit was then excavated an additional $10 \mathrm{~cm}$ to examine the compacted surface in profile. The compacted surface was 5-6 cm-thick, transitioning to reddish brown (10YR 5/4) sandy loam. No evidence of a foot stone or post stone on which a gatepost would have set was found.

\section{Discussion}

Investigations in the three units placed in and around the south gate opening succeeded in defining its width as $3.96 \mathrm{~m}$ ([156 inches] [4.7 Spanish varas]). A compacted surface found inside the opening in Unit 97 was covered with a concentration of bone, native wares, and Colonial ceramics, therefore the compacted surface is presumably the result of heavy wagon, horse, and pedestrian traffic. The prolific quantities of ceramics (256), and other cultural material recovered from these three units supports Ricklis' documentation of dense midden deposits along the outside of the southern compound wall. 


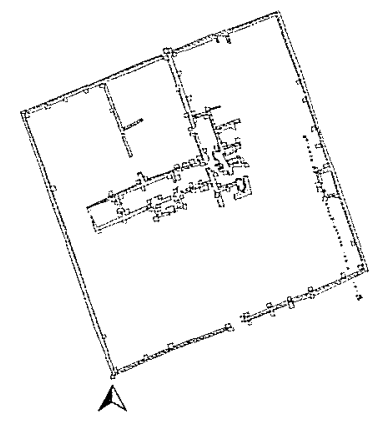

\section{Southwest Corner, Compound Wall}

Units 66 and 100 were placed on the southwestern corner of the extant stone compound wall (Figures 3 1 and 5-1) to examine the structural integrity of both walls. Available photographs from WPA work in the 1940s (e.g., Appendix A-4:Photograph A-8) indicated that the area was only minimally disturbed on the surface, and neither Gilmore (1974a, 1974b) or Ricklis imbedded in it. The matrix sandwiched between the two compacted surfaces consisted of friable sandy loam, which displayed a burned, ashy characteristic, with many of the artifacts displaying evidence of burning. A substantial increase in cultural material was recovered from $25-30 \mathrm{~cm}$ bd, concentrated on the second surface; a ground stone fragment, 2 tin glazed and 43 coastal ceramic sherds, and numerous bone fragments. Also resting on the lower surface were chunks of limestone rubble and charcoal. The compacted surface found $30 \mathrm{~cm}$ bd was left pedestaled in the eastern half of the unit. Excavation to $40 \mathrm{~cm}$ bd in the remaining $2 / 3$ of the unit revealed another compacted surface, a probable floor, consisting of firm, light brownish gray (10YR 6/2) sandy loam with roots growing horizontally across its surface. Further excavation through mottled, yellowish red clay, grayish brown and very pale brown loam revealed the top of a buried stone wall $58-60 \mathrm{~cm}$ bd (Figure 5-29). When viewed in profile (Figure 5-30) the apparent mottled soils were

(1999) worked in this corner. Both of CAR's units encountered a previously undetected stone wall underlying the upper, extant stone wall. Additionally, a posthole was found in Unit 100.

\section{Unit 66}

Unit 66 was placed on the inside of the southwest corner of the extant stone compound wall (Figures 3-1 and 5-1). Approximately $8 \mathrm{~cm}$ of pale brown silty overburden was removed prior to establishing a unit datum in the southwest corner. The next $25 \mathrm{~cm}$ consisted of very dark grayish brown (10YR 3/2) sandy loam with bits of charcoal and ash, lying over an ephemeral compacted, brown (10YR 5/ 3) sandy loam surface $25 \mathrm{~cm}$ bd, with tree roots growing horizontally across the surface. Cultural material recovered in the upper midden-like deposits include 1 chipped stone flake, a ground stone fragment, 1 San Elizario and 32 coastal ceramic sherds, with bone and mussel shell fragments. A second compacted, ephemeral surface was discerned $5 \mathrm{~cm}$ below, 30 $\mathrm{cm}$ bd. This lower surface consisted of sandy loam with small limestone cobbles

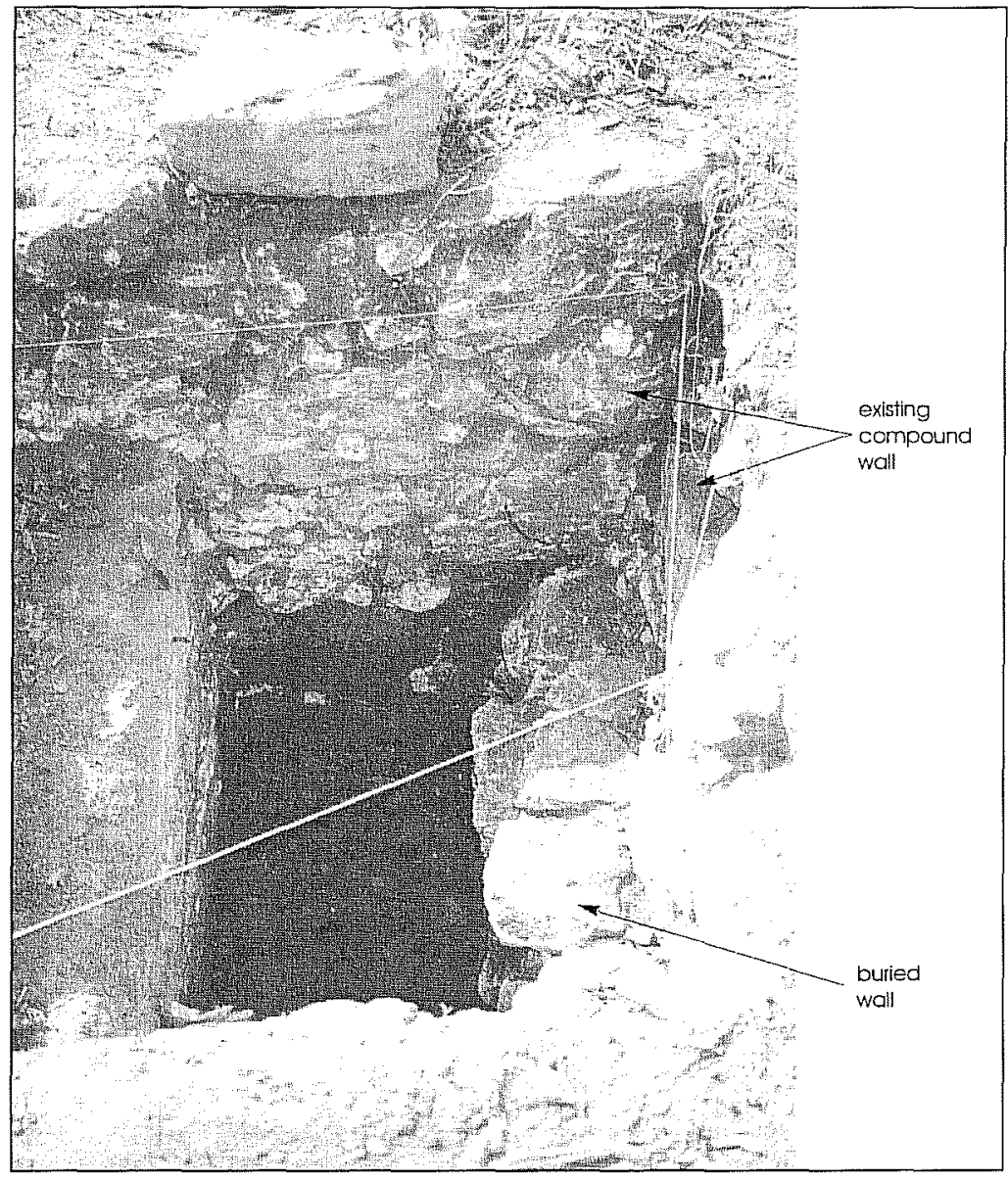

Figure 5-29. Photograph of buried wall and existing compound wall in Unit 66, facing south. 
distinguished as representing construction and occupation episodes (see the following discussion). No Spanish Colonial sherds were found below $60 \mathrm{~cm}$, the top of the stone wall. The mottled soils transitioned to a brown (10YR 4/3) sandy clay loam, with a bone bed resting underneath it $86-97 \mathrm{~cm}$ bd, within the upper few $\mathrm{cm}$ of the underlying brown (10YR 3/3), sandy A Horizon. At the bottom of this unit $(121 \mathrm{~cm} \mathrm{bd})$ the brown A Horizon began a gradual, smooth transition to the underlying yellowish red (5YR 4/6) clay.

\section{Unit 100}

After uncovering an unexpected buried stone wall in Unit 66, this unit was placed on the exterior corner of the upper, compound wall (Figure 5-31) to investigate whether or not the buried wall continued further south. Potentially, excavation in this area could have uncovered a corner linking the $\mathrm{E}-\mathrm{W}$ buried wall found by Ricklis (1999) south of the compound, with the $\mathrm{N}-$ $s$ buried wall we found in Unit 66. A unit datum was established on the modern surface in the northeast corner. Duff and pale brown (10YR 6/3) silty loam 3$7 \mathrm{~cm}$-thick covered a compacted, light brown (7.5YR $6 / 3$ ) sandy loam. The light brown sandy loam zone is an undulating $20-30 \mathrm{~cm}$-thick layer perhaps slightly lighter in this area of the mission than the Zones 1 and 2 midden soils recorded by Ricklis (1999:144145) near the south gate, nevertheless it contains the relatively large quantities of cultural material typical of the midden soils. Cultural material found in the upper $35 \mathrm{~cm}$ (midden soil) includes 1 Colonial tin glazed blue on white, a lead glazed sandy paste, 157 coastal, and 5 Goliad ceramic sherds, with numerous bone fragments. An underlying transition zone consisting of loose, friable, easy-to-dig, brown (10YR 5/ 3) silty loam was encountered between $35-45 \mathrm{~cm}$ bd. As the sediments changed with a moderate upper boundary of light brownish gray (10YR 6/2) fine silt with abundant ash and charcoal in the western half of the unit, a fire cracked rock hearth feature with an associated concentration of charcoal, ash, and bone was uncovered in the southwest quadrant, along with a concentration of bone in the northwest quadrant

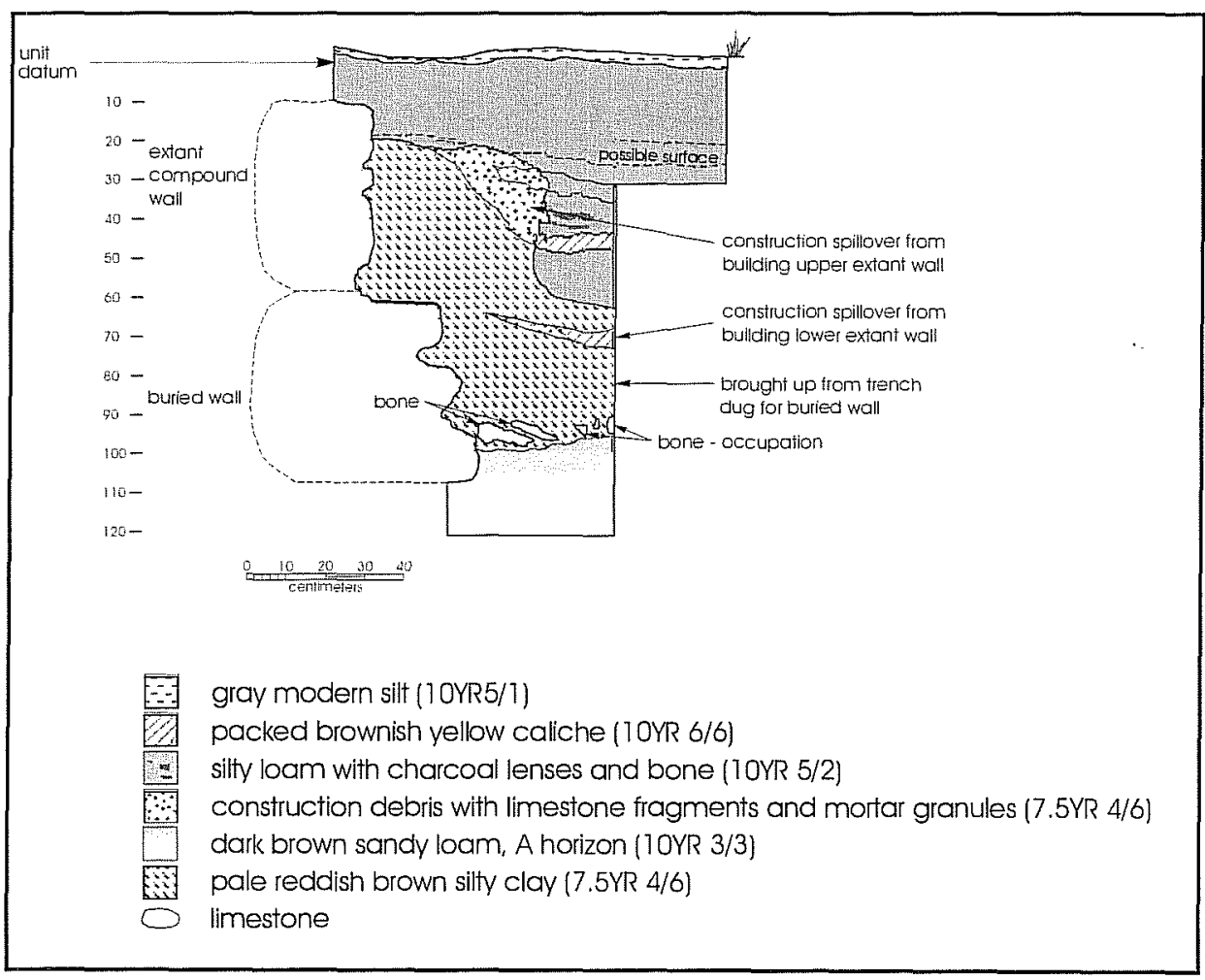

Figure 5-30. North wall profile of Unit 66 in the southwest corner of the compound. 
between $45-55 \mathrm{~cm}$ bd (Figure 5-31). However, soil and artifact quantities in the eastern half of the unit at this level contrasted sharply with those of the western half; the soil was a slightly darker, grayish brown (10YR 5/2) silty loam in the eastern half, with only specks of charcoal and ash. Notably, the eastern half was void of artifacts. Between $55-65 \mathrm{~cm}$ bd, the soil in the western half of the unit became a reddish (2.5YR 5/4) sandy clay with charcoal bits, limestone granules, bone fragments, and caliche nodules. Cultural material recovered between $55-65 \mathrm{~cm}$ includes mussel shell and bone fragments, 2 stone uniface fragments, 1 San Elizario, 1 Galera, and 70 coastal sherds. A possible floor, but more probably mortar, lime, and limestone fragments from wall construction was found underlying the bone concentration in the northwest quadrant, while the eastern half consisted of extremely fine, ashy, brown (10YR 4/3) silt with charcoal bits and small caliche granules. Excavation in the unit was terminated $80 \mathrm{~cm}$ bd at the base of a grayish, ashy strata resting on reddish, mottled, sandy clay. Cultural material recovered between $65-80 \mathrm{~cm}$ bd includes mussel shell and bone fragments, a stone uniface fragment, 15 chipped stone flakes, 3 lead glazed, 1 tin glazed, 1 Goliad, and 117 coastal ceramic sherds. The west half of the unit was more compact and harder to dig, contrasting sharply with the fine, easy-to-dig, brown (10YR 4/3) silty sand, with few artifacts and some bone. A posthole dug into the reddish brown (2.5YR 5/4) mottled, sandy clay and then subsequently filled with the grayish ash and charcoal from above was discerned beginning $65 \mathrm{~cm}$ bd. A profile of the posthole could also be discerned in the west wall profile of the unit. A second possible posthole filled with compacted red, mottled silty loam was also found in the southeastern quadrant.

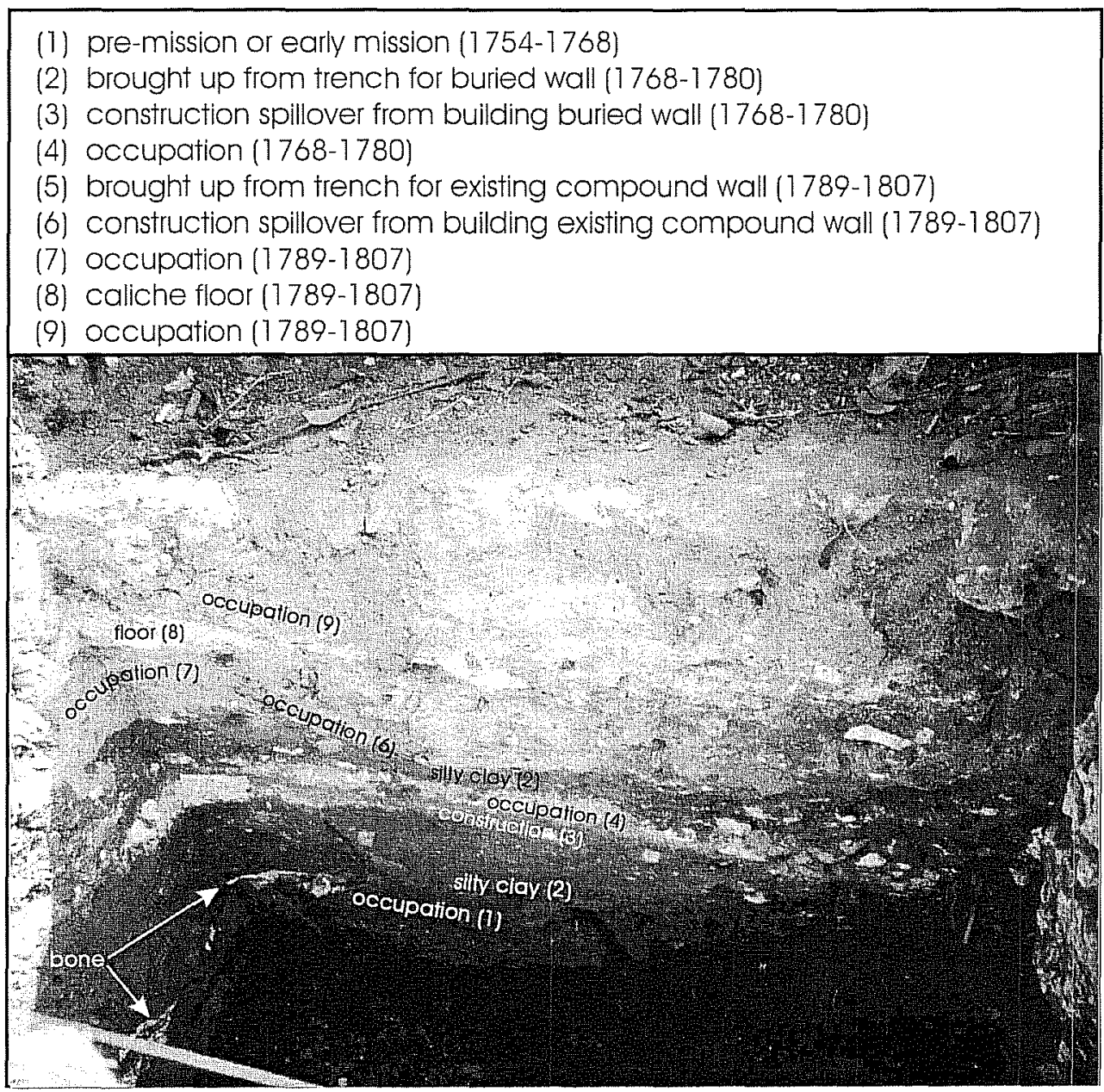

Figure 5-31. East wall profile of Unit 66 in the southwest corner of the compound. 


\section{Discussion}

Two occupation zones and possibly three episodes of construction were found in the two units combined. Inverted soil layers and compacted floors seen in profile in the north and east wall profiles of Unit 66 (Figures 5-30 and 5-31) provide evidence of possibly three periods of occupation in the southwest corner of the mission. The bone bed found on top of the underlying A Horizon suggests a period of either pre-1754, or very early mission occupation. Then a trench was dug in which to construct the now-buried stone wall, ca. 1768-1780. The trench penetrated the red Pleistocene clay beneath the A Horizon and workers spread the red clay over the bone bed. A prepared caliche surface, probably a room floor, was then laid and compacted through use, ca. 1768-1780. Apparently this corner was kept clean during this occupation period because there is no evidence of cultural debris in the profile above the packed surface; further suggesting a room rather than just an area that was kept clean. The second episode of stone construction which is the upper extant compound wall began, and construction debris spilled out onto the caliche floor, ca. 1789-1807. Sometime during this latter period of mission occupation a packed caliche floor was laid.

The buried wall found in Unit 66 (Figure 5-29) and Unit 100 (Figures 5-32 and 5-33) is oriented magnetic north, ca. 15 degrees from the upper compound wall's 345 degree orientation. Its orientation is synonymous with other buried walls and/or foundations found elsewhere in the compound, which will be synthesized, in the following chapter.

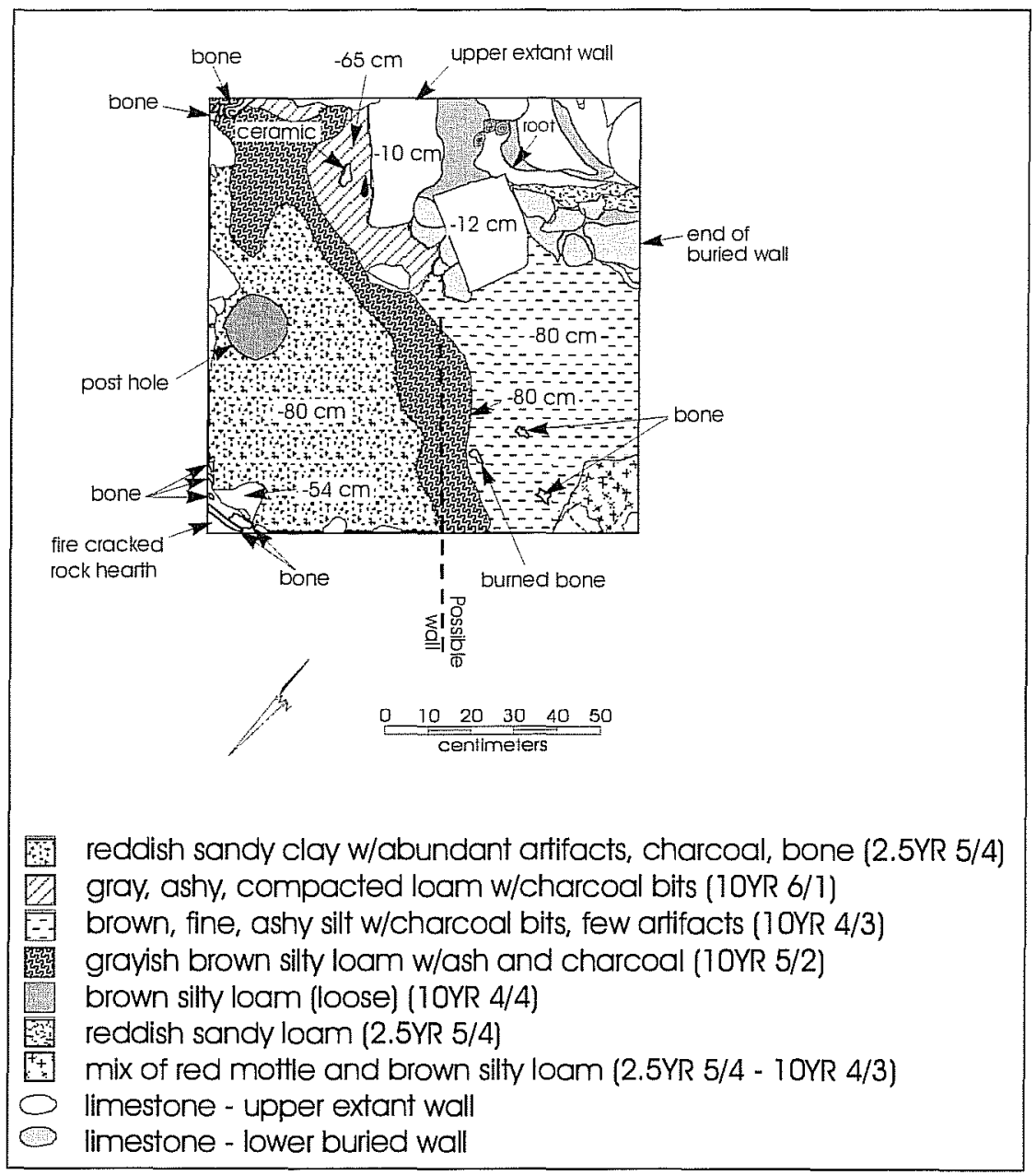

Figure 5-32. Unit 100 Planview, 54-80 $\mathrm{cm} \mathrm{bd,} \mathrm{outside} \mathrm{the} \mathrm{southwest}$ corner of the compound. 
Stratigraphy in the west, and north wall of Unit 100 (Figures 5-32 through 5-34) reveals the presence of a fire cracked rock hearth feature, a posthole, and a thick ashy layer with abundant quantities of artifacts and faunal remains. The posthole was dug into the reddish Pleistocene clay and, after removal of the post, was backfilled with the overlying ashy and charcoallaced silty loam deposits (Figure 5-32). These profiles are strikingly different from that of the east wall, which has no evidence of burning, ashy layers, or artifact concentrations. The featureless stratigraphy in the east wall and paucity of cultural material in the eastern half of the unit below ca. $30 \mathrm{~cm}$ suggests there was perhaps some sort of separation barrier existing $\mathrm{N}-\mathrm{S}$ through the approximate center of the unit, possibly a room wall (see Figure 5-32). The presence of artifacts primarily contained in an area west of a line from the corner of the buried wall directly south suggests there was a room wall supported by at least one post, extending south approximately from the corner of the buried wall. This then places the fire cracked rock hearth feature and bone concentration perhaps within the room, but outside the buried stone compound wall. The chronological context of the hearth feature is unclear, but a charcoal sample collected from within it may be processed later.

West Profile North Profile

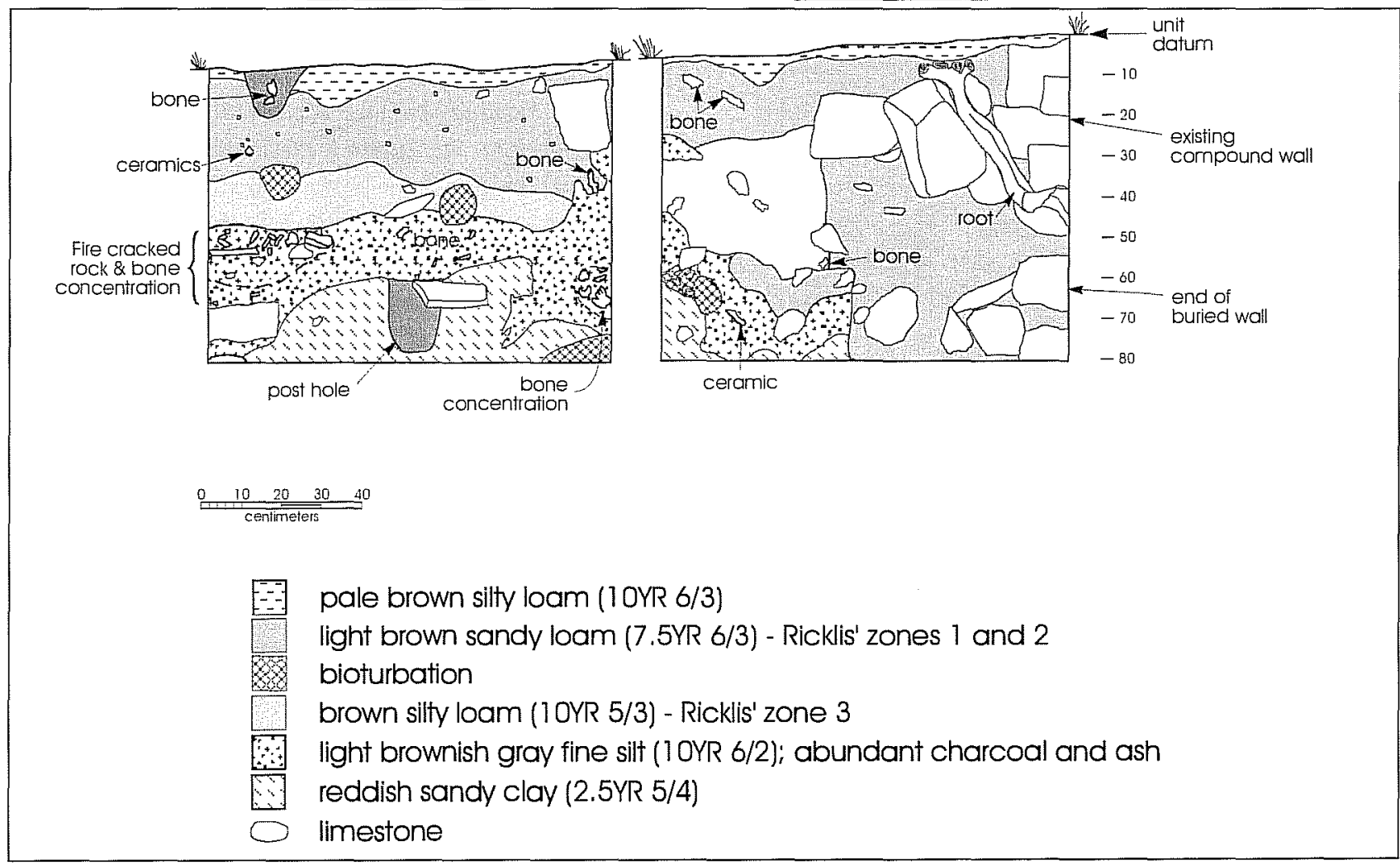

Figure 5-33. Unit 100 north wall profile, outside the southwest corner of the compound wall. Figure 5-34. Unit 100 west wall profile, outside the southwest corner of the compound wall. 


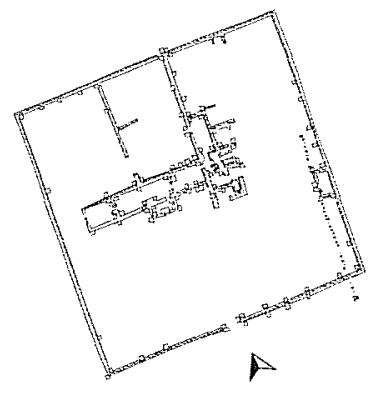

\section{South Compound Wall}

Gilmore (1974) placed six backhoe trenches and an excavation unit south of the compound wall, and Ricklis conducted single and block unit excavations south of the wall in 1997 and 1998. And as discussed previously, Gilmore had excavated around the western edge of the south gate. Although available photographs from work in the 1940s by the WPA indicate that the southern portion of the mission compound was cleared and leveled (e.g., Appendix A-4:Photographs $A-1, A-3, A-6, A-8$, and A-9) the extent to which they penetrated the Spanish Colonial level was unknown. Thus no archival information has been found to indicate that the southern compound wall and adjacent Spanish Colonial deposits had been examined along its entirety. In addition to CAR's investigations in the south gate opening, we placed 12 excavation units along the wall. Eleven of the twelve were excavated only to a depth which confirmed the upper level of the remaining Spanish Colonial deposits; the remaining unit (\#75) was to examine the integrity of the wall and possible footing by exposing a full vertical profile.

\section{Unit 67}

Unit 67 is located against the inside of the southern compound wall, east of unit 66 (Figures 3-1 and 51). A unit datum was established on the modern ground surface in the southwest corner and an accumulation of pale brown (10YR 6/3) sand and sandy loam overburden $12 \mathrm{~cm}$ deep against the stone wall was removed to create a level beginning surface. Excavation from $0-40 \mathrm{~cm}$ bd revealed an additional $33 \mathrm{~cm}$ of overburden consisting of dark grayish brown (10YR 4/2) sandy loam before contacting an apparent Colonial matrix with limestone cobble inclusions and common root disturbances. Ricklis (1999) defines this matrix as a brown silt-fine sand midden soil containing Colonial- period artifacts and faunal bone. The small quantity of artifacts collected from within the $40 \mathrm{~cm}$ of overburden includes 2 chipped stone flakes, 3 coastal ceramic sherds, with a few bone and mussel shell fragments. Excavating an additional $10 \mathrm{~cm}$ into the Colonial matrix of sandy loam with pea-size calcium carbonate, plaster, and mortar fragment inclusions revealed roots growing horizontally across a compacted surface. Cultural material recovered in the $10 \mathrm{~cm}$ above the compacted surface increased to 18 coastal ceramic sherds, with 1 chipped stone flake and a few mussel shell fragments.

\section{Unit 68}

Unit 68 is located against the southern compound wall between Unit 67 and the south gate opening (Figures 3-1 and 5-1). A unit datum was established on the modern ground surface in the southwest corner on the highest point of overburden that had accumulated against the wall. The overburden consisted of a thin layer of pale brown (10YR 6/3) sand and sandy loam, overlying dark grayish brown (10YR 4/2) sandy loam $30 \mathrm{~cm}$ deep against the stone wall was removed. Three $\mathrm{cm}$ below the modern ground surface, a slightly compacted and undulating surface was encountered not unlike the compacted surface found in Unit 67, and excavation was terminated. Deteriorated plaster and mortar fragments were laying on the compacted surface. Cultural material collected from the apparent overburden and 2-3 cm of Colonial matrix over the packed surface include 5 chipped stone flakes with a few mussel shell and bone fragments.

\section{Unit 69}

Unit 69 was placed on the southern compound wall just east of the south gate (Figures 3-1 and 5-1). A unit datum was established in the northwest corner on the modern ground surface. A few $\mathrm{cm}$ of pale brown (10YR 6/3) sandy loam overburden underlain with thicker dark grayish brown (10YR 4/2) sandy loam midden soil as deep as $27 \mathrm{~cm}$ against the stone wall was removed to create a level beginning surface. The $27 \mathrm{~cm}$-deep soils accumulated against the wall were screened with that from the first level $(0-10 \mathrm{~cm} \mathrm{bd})$. Excavation was terminated when it was evident the cultural material recovered in the first level was consistent with that found elsewhere in midden soils. In 
addition to mussel shell and bone fragments, 25 coastal, 12 Goliad, and 1 sandy paste lead glazed ceramic sherds, a stone gunflint, 4 chipped stone flakes, and a brown glass sherd were recovered. A reddish (5YR 5/6) sandy loam mixed with mortar fragment inclusions that appears to be a 8-10 cm-wide trench outline along the wall was uncovered $10 \mathrm{~cm}$ bd.

\section{Unit 70}

Unit 70 is on the outside of the southern perimeter wall, opposite unit 69 (Figures 3-1 and 5-1). An accumulation of pale brown (10YR 6/3) sand and sandy loam overburden as much as $25 \mathrm{~cm}$ deep against the stone wall was removed to create a level beginning surface. A unit datum was established in the southwest corner. Approximately $4 \mathrm{~cm}$ of modern dark grayish brown topsoil with common rootlets was then removed before encountering the brown (10YR 4/3) sandy loam midden soil described by Ricklis (1999). Limestone cobbles were present in the midden matrix, which had been partially disturbed by common roots and a large rodent hole that extended almost the entire north/south length of the unit. Excavation was terminated $6 \mathrm{~cm}$ below the upper Colonial surface $(10$ $\mathrm{cm}$ bd). Cultural material recovered from $0-10 \mathrm{~cm} \mathrm{bd}$ includes 2 stone unifaces and an arrow point blank, 12 chipped stone flakes, a tin glazed Huejotzingo, 5 lead glazed sandy paste, 7 Goliad, and 130 coastal ceramic sherds, with bone and mussel shell fragments. Two pieces of aluminum foil were also recovered, possibly from the rodent-disturbed area.

\section{Unit 71}

Unit 71 is located along the interior of the southern perimeter wall, east of unit 69. In this area the brown sandy loam midden soil described by Ricklis (1999) slopes from the modern ground surface along the north edge of the unit to $29 \mathrm{~cm}$ upward against the Colonial wall, and lies immediately atop a reddish sandy loam that is harder and packed with mortar fragment inclusions. A unit datum was established in the southeast corner on the modern ground surface, and the sloped matrix above datum was excavated before then excavating an additional $10 \mathrm{~cm}$ below datum. Other cultural material found includes a stone pebble core, 10 chipped stone flakes, a sherd of European porcelain, a tin glazed Huejotzingo, a lead glazed sandy paste, a red burnished, and 66 coastal sherds, along with bone, teeth and mussel shell fragments.

\section{Unit 72}

Unit 72 is located outside the southern perimeter wall, south of unit 71 (Figures 3-1 and 5-1). A unit datum was established in the northwest corner on the modern ground surface and an accumulation of pale brown (10YR 6/3) sand and sandy loam overburden as much as $32 \mathrm{~cm}$ deep against the stone wall was removed to create a level beginning surface. An additional 3-4 $\mathrm{cm}$ of overburden was then excavated before encountering the brown (10YR 4/3) sandy loam midden soil with limestone cobble inclusions, $6-7 \mathrm{~cm}$ below the modern surface.

The unit was then expanded $40 \mathrm{~cm}$ to the north and excavated an additional $10 \mathrm{~cm}$ bd to encounter and expose the stone wall face. Cultural material recovered from $0-20 \mathrm{~cm}$ bd includes a stone uniface fragments, tin glazed blue on blue, Huejotzingo, San Agustín, and undecorated tin glazed sherds, lead glazed Galera and sandy paste sherds, a red burnished sherd 4 Goliad, and 280 coastal sherds, with bone and mussel shell fragments, a piece of copper scrap, 19 chipped stone flakes, and a clear glass sherd.

\section{Unit 73}

Unit 73 is located east of unit 71 on the inside of the southern perimeter wall. In this area the brown (10YR 4/2) sandy loam midden soil, overlain with a thin layer of modern grayish brown topsoil, slopes from the modern ground surface along the north edge of the unit to $50 \mathrm{~cm}$ upward against the Colonial wall. A unit datum was established in the northwest corner on the modern ground surface, and the sloped matrix above datum was excavated before then excavating an additional $10 \mathrm{~cm}$ below datum. Having established the upper Colonial contact level, excavation was terminated $10 \mathrm{~cm}$ bd, and at this level the compound wall was tumbled and not intact. Cultural material recovered from this unit includes a formal stone side scraper, 12 chipped stone flakes, a piece of copper scrap, a thick green glass sherd, mussel shell and bone fragments, an undecorated tin glazed sherd, and 39 coastal ceramic sherds. 
Unit 74 is located against the south compound wall opposite Unit 73 (Figures 3-1 and 5-1). In this area the brown (10YR 4/2) sandy loam midden soil, overlain with a thin layer of modern grayish brown topsoil, slopes from the modern ground surface along the north edge of the unit to $12 \mathrm{~cm}$ upward against the Colonial wall. A unit datum was established in the southwest corner on the modern ground surface, and the sloped matrix above datum was excavated and screened with sediments and soils to $13 \mathrm{~cm}$ below datum. The unit was then expanded $25 \mathrm{~cm}$ to the north and excavated to $20 \mathrm{~cm}$ bd to encounter and expose the stone wall face. An area of extreme bioturbation was evident along the wall face, with a large, active rodent hole in the northwest corner, along with many roots of varying sizes ( $1 \mathrm{~mm}$ to $12 \mathrm{~mm}$ ) throughout the unit. Angular limestone fragments, snails, charcoal bits, and burned limestone inclusions were observed within the midden soil. The southern $1 / 3$ of the unit was slightly compacted $20 \mathrm{~cm}$ bd, and although there was no discernible color or texture change in the soil, an ash lens was exposed in the southeast quadrant. Having established the upper Colonial contact level, excavation was then terminated at $20 \mathrm{~cm}$ bd, and at this level the compound wall was tumbled and not intact.

Cultural material recovered from Unit 74 at $0-20$ $\mathrm{cm}$ bd includes numerous bone and mussel shell fragments, a brown glass sherd, a stone uniface fragment, a gunflint, 13 chipped stone flakes, tin glazed undecorated, San Augustín, and blue on white sherds, sandy paste and Galera lead glazes, and 164 coastal ceramic sherds.
Unit 75 is located inside the south compound wall and is the only unit along this portion of the wall that was intended to be excavated deep enough to examine the wall base (Figure 5-35). After removing approximately $8-10 \mathrm{~cm}$ of accumulated modern grayish/ brown topsoil overlying pale brown (10YR 6/3) sand and sandy loam overburden, the distinguishable brown (10YR 4/2) sandy loam midden soil was discernible sloping from $8 \mathrm{~cm}$ below the modern surface along the units' northern edge and rising upward $22 \mathrm{~cm}$ against the stone wall. A unit datum was established 8 $\mathrm{cm}$ below the modern surface in the northeast corner, and the sloped midden soil above datum was excavated and screened in conjunction with the first 10 $\mathrm{cm}$ below datum. Apparent grayish and light brown sandy paste mortar was leaching from the stone wall and was lying over a broader reddish sandy loam strip that may have been rotted mortar from a lower position in the wall. Cultural material recovered includes 7 chipped stone flakes, mussel shell fragments, a tin glazed undecorated, a lead glazed sandy paste, and 7 coastal ceramic sherds.

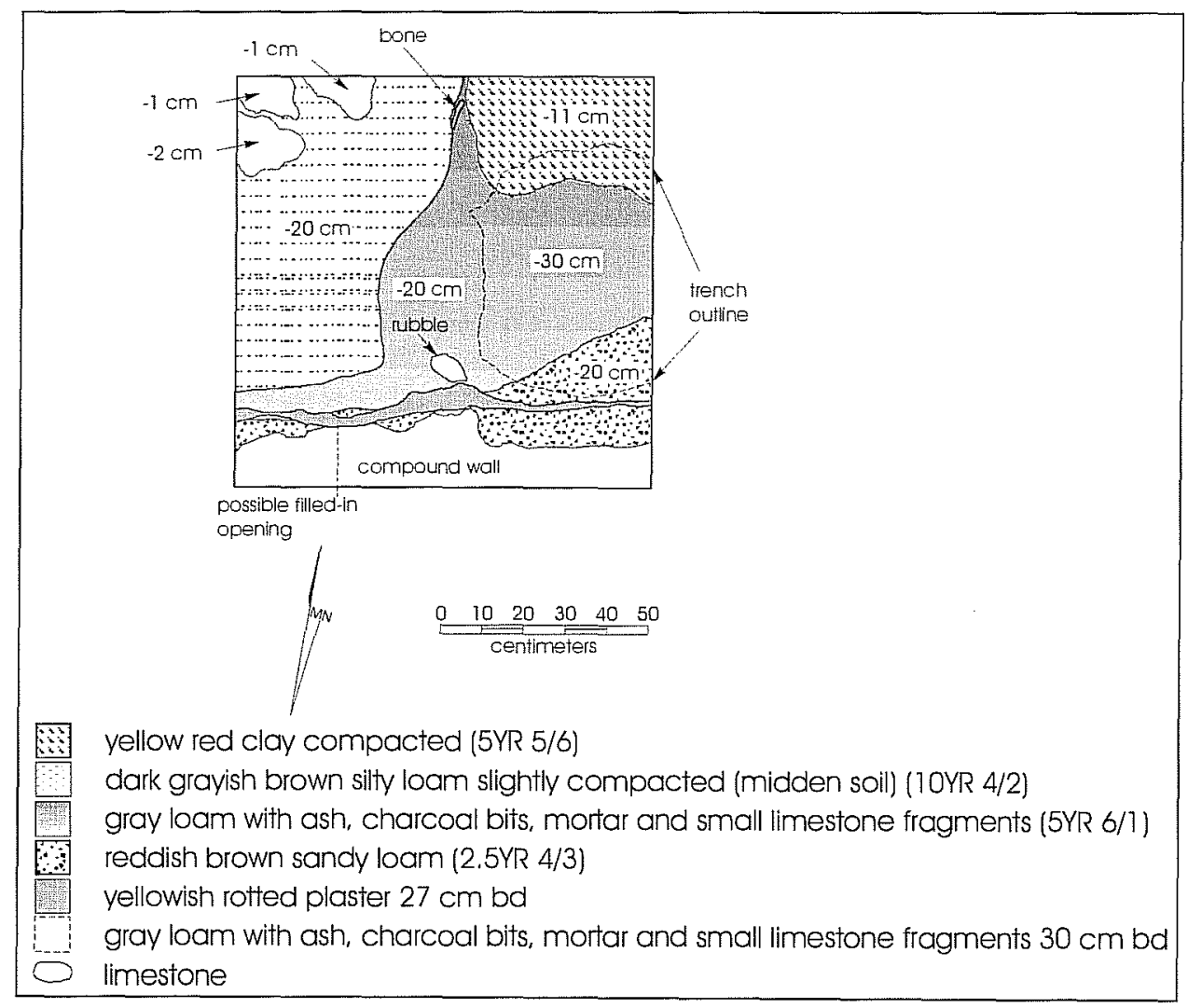

Figure 5-35. Planview of east wall of Unit 75, along the south compound wall. 
Three large $(20 \mathrm{~cm} \times 15 \mathrm{~cm})$ limestone rocks in the northwest corner of the unit extended from $8-20 \mathrm{~cm}$ bd and were resting on remnants of a compacted silty loam surface. Additionally, the top of a 7-8 cm-thick compacted red clay layer $11 \mathrm{~cm}$ bd in the northeast quadrant shared an abrupt boundary with a layer of gray loam with ash, charcoal, mortar bits, and small angular limestone inclusions (see Figures 5-35 and 5-36). Underlying the red clay and extending across the eastern portion of the unit was a layer of dark gray, slightly compacted, silty loam. Apparent reddish brown sandy loam "mortar" from the stone wall was evident also. Cultural material recovered from this level includes 1 chipped stone flake, bone and mussel shell fragments, a lead glazed Galera ceramic sherd and 12 coastal sherds.

Level 3 was excavated to a depth of $30 \mathrm{~cm}$ bd. The eastern $1 / 3$ of the unit had a grayish, mixed sediment, while the remainder of the unit was a soft, easily dug, sandy "A" horizon as defined by Ricklis (1999) and was culturally sterile. However, a ca. $55 \mathrm{~cm}$-wide trench outline became distinct and ran $10 \mathrm{~cm}$ north of, and parallel to the extant compound wall. A previously unseen strip of yellowish, apparent rotted plaster was exposed $27 \mathrm{~cm}$ bd. Cultural material collected from the eastern portion of the unit includes 3 coastal sherds and 1 chipped stone flake.

\section{Unit 76}

Unit 76 is located against the exterior south compound wall opposite unit 75 (Figures 3-1 and 5-1). In this area the brown (10YR 4/2) sandy loam midden soil, overlain with a thin layer of modern grayish brown topsoil, slopes from the modern ground surface along the north edge of the unit to $40 \mathrm{~cm}$ upward against the Colonial wall. A unit datum was established in the southwest corner on the modern ground surface. The sloped matrix above datum was excavated and screened with sediments and soils to $5 \mathrm{~cm}$ bd. The unit was then expanded $20 \mathrm{~cm}$ to the north and excavated to $20 \mathrm{~cm}$ bd to encounter and expose the stone wall face.

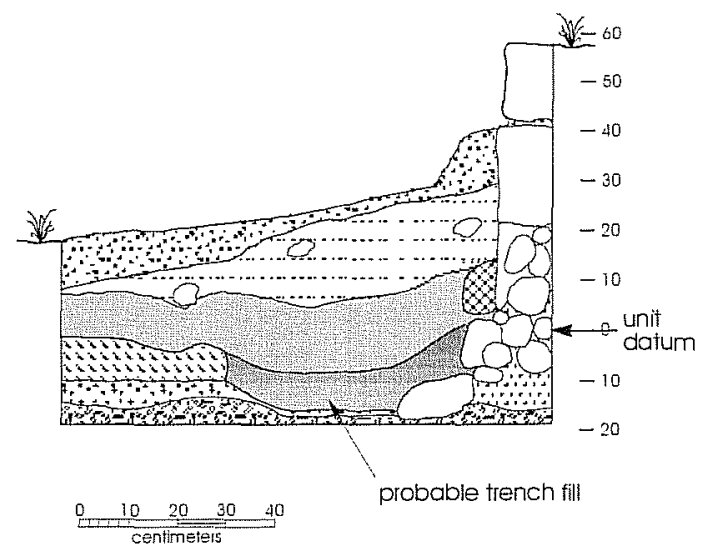

pale brown sandy loam, modern overburden (1 0VR 6/3)

dark grayish brown sandy loam (midden soll) (10YR 4/2)

brown silty loam with mortar and small limestone fragments (7.5YR 5/2)

yellowish red clay (5YR 5/6)

gray loam with ash, charcoal bits, small limestone fragments (5YR 6/1)

pale brown sity loam, compacted (10YR 3/4)

dark brown sandy A horizon (7.5YR 3/4)

reddish brown sandy loam (10YR 4/4)

bioturbation

limestone

Figure 5-36. Profile of east wall of Unit 75, along the south compound wall. 
As in most units along this wall, reddish brown sandy loam was once again associated with the Colonial wall. Three charcoal and ash lenses were observed $5 \mathrm{~cm}$ bd, two in the northwestern quad, and a third lens in the northeast corner. There was tumbled rubble throughout the unit at this level. The brown sandy loam midden soil at this level seemed more fine-grained, siltier, dryer, and more compact in the southern half of the unit. Minimal disturbances observed throughout the unit included roots and a small tree stump on the east wall.

Cultural material recovered from the sloping matrix to $5 \mathrm{~cm}$ below the modern surface includes an expedient stone side scraper, 8 chipped stone flakes, bone and mussel shell fragments, with lead glazed sandy paste and Galera, 29 coastal, and 82 Goliad sherds.

Reddish brown sandy loam associated with the stone wall continued to $20 \mathrm{~cm}$ bd, and contrasted with the brown midden soil at this depth. Limestone rubble wall fall was present throughout the unit, with an unexplained cluster of small limestone rocks located in the northeast corner. Cultural material collected includes two stone gunflints, a stone uniface, 16 chipped stone flakes, bone and mussel shell fragments, a cut nail, an olive green glass sherd, with lead and tin glazed, 159 coastal, and 5 Goliad sherds. Charcoal bits were noted throughout the unit, with a dark stain and ash lens in the northwest quadrant $20 \mathrm{~cm}$ bd. Active gopher holes had created moderate disturbance in the southern portion of the unit. Recovery of a wire nail and brown glass between $5-20 \mathrm{~cm}$ bd indicates at least some degree of disturbance has occurred in this area. However, a large quantity of Spanish Colonial sherds and native wares were also found in this level; including tin glazed blue on blue, blue on white, and undecorated, lead glazed red brown, Galera, and sandy paste, along with a burnished red, 5 Goliad and 161 coastal sherds. Additionally, a relatively high quantity of bone and mussel shell fragments was collected.

\section{Unit 77}

Unit 77 is located east of unit 75, abutting the south compound wall. In this area the brown (10YR 4/2) sandy loam midden soil, overlain with a thin layer of modern grayish brown topsoil, slopes from $5-7 \mathrm{~cm}$ below the modern ground surface along the north edge of the unit to $20 \mathrm{~cm}$ upward against the Colonial wall. A unit datum was established in the northwest corner on the modern ground surface. The sloped matrix above datum was excavated and screened with sediments and soils to $20 \mathrm{~cm}$ bd. A wall footing consisting of smaller stones was encountered $15-17 \mathrm{~cm}$ bd. It was $7-8 \mathrm{~cm}$ wider than the upper wall and was bordered by a strip of reddish sandy clay. Between 17-20 $\mathrm{cm}$ bd the soil began a gradual, smooth transition to a reddish brown, and a patch of reddish brown sandy clay loam covered the extreme northwest corner of the unit. Having established the depth of the upper Colonial surface, no excavations were conducted below $20 \mathrm{~cm}$. Four chipped stone flakes, ten coastal ceramic sherds, and mussel shell and bone fragments were collected.

\section{Unit 78}

This unit was placed on the inside, southeast corner of the compound wall (Figures 3-1 and 5-1). The walls in this corner were badly deteriorated and much lower than elsewhere. Therefore instead of an accumulation of midden and modern soils sloping up against the walls, the surface was relatively flat. A datum was established in the southwest corner and excavation revealed brown sandy loam soil to $20 \mathrm{~cm}$ bd. Excavation was terminated at that level on a compacted surface consisting of the same soil with limestone fragments. Most notably, no artifacts were found throughout the unit, suggesting this area had been previously excavated, probably by the WPA.

\section{Discussion}

\section{Walls}

Small $1-\mathrm{m}^{2}$ units and generally shallow excavation limited examination of the wall. However, it is interesting that much of the wall below the surface appears to be intact. It is generally good in Unit 67 , and slightly more deteriorated in Units $68,70,71$, and 72 . No intact wall could be discerned in Unit 73. Remnants of the Colonial wall in Unit 73 included limestone blocks, rubble, with the occasional interstice that consisted of the same reddish sandy loam with some grayish 
white mortar. No indication of a setting trench was found at the bottom of this unit. As in unit 73, the wall in Unit 74 was in very poor condition. Blocks were missing, with nothing but rubble left that spilled out across the unit floor, especially in the northwest quadrant. The soil within the interstices of the wall rubble was a reddish sandy loam. Testing in the southeast corner was limited in depth, however it did confirm that it is not intact to at least $20 \mathrm{~cm}$ below the surface. What first appeared as a probable setting trench filled with reddish (5YR 5/6) sandy loam was detected in Units $69,71,75,76$. However, this is rather interpreted as mortar between the rocks, which has leached downward and away from the walls in all units, forming a narrow strip along the wall. No definitive wall trench was found, and it appears that the southern compound wall was simply set into the brown midden soil (see Figure 5-37).

\section{Opening with Trench and Probable Floor}

Without conclusive verifications of WPA investigations in this area, it is difficult to interpret the evidence of construction and occupation episodes found in Unit 75. With its abrupt edges, it appears the compacted red clay surface found in the northeast quadrant of Unit 75 (Figures 5-35 and 5-36) is either scathed by trenching or it represents the true corner of a possible room. No evidence of postholes were found in the unit, however the abundance of midden deposits in an isolated gray loam area between the red clay and stone wall, contrasting with an area of dark grayish brown silty loam with less mortar and rubble in the western portion of the unit suggests a possible $\mathrm{N}-\mathrm{S}$ cross wall existed through the middle of the unit. The large stones found in the northwest corner of the unit lying on the silty loam, compacted surface may

\section{Wall Footings}

Although most units were not excavated deep enough to expose footings, a footing consisting of smaller stones was encountered 15-17 $\mathrm{cm}$ bd was found in Unit 77. It was $7-8 \mathrm{~cm}$ wider than the upper wall and was bordered by a strip of reddish sandy clay. Between 17$20 \mathrm{~cm}$ bd the soil began a very gradual transition to a reddish brown, and a patch of reddish brown sandy clay loam covered the extreme northwest corner of the unit. The presence of a wall footing under this portion of the wall could represent the need for additional stabilization to compensate for the steeper sloping terrain toward the east in this area of the compound, or it may somehow be associated with the buried stone wall or foundation detected with our probes just east of Unit 77 (see Figures 3-1 and 5-1). The apparent underlying reddish sandy clay loam and a clear patch of it found in the northwest corner of Unit 77, is either stratigraphically inverted or the A Horizon which generally underlies the midden soil throughout the rest of the compound is missing in this area. The latter supposition seems highly unlikely, and thus it can be speculated that the reddish sandy clay loam may be associated with trenching activities for the buried foundation or wall detected in our probes.

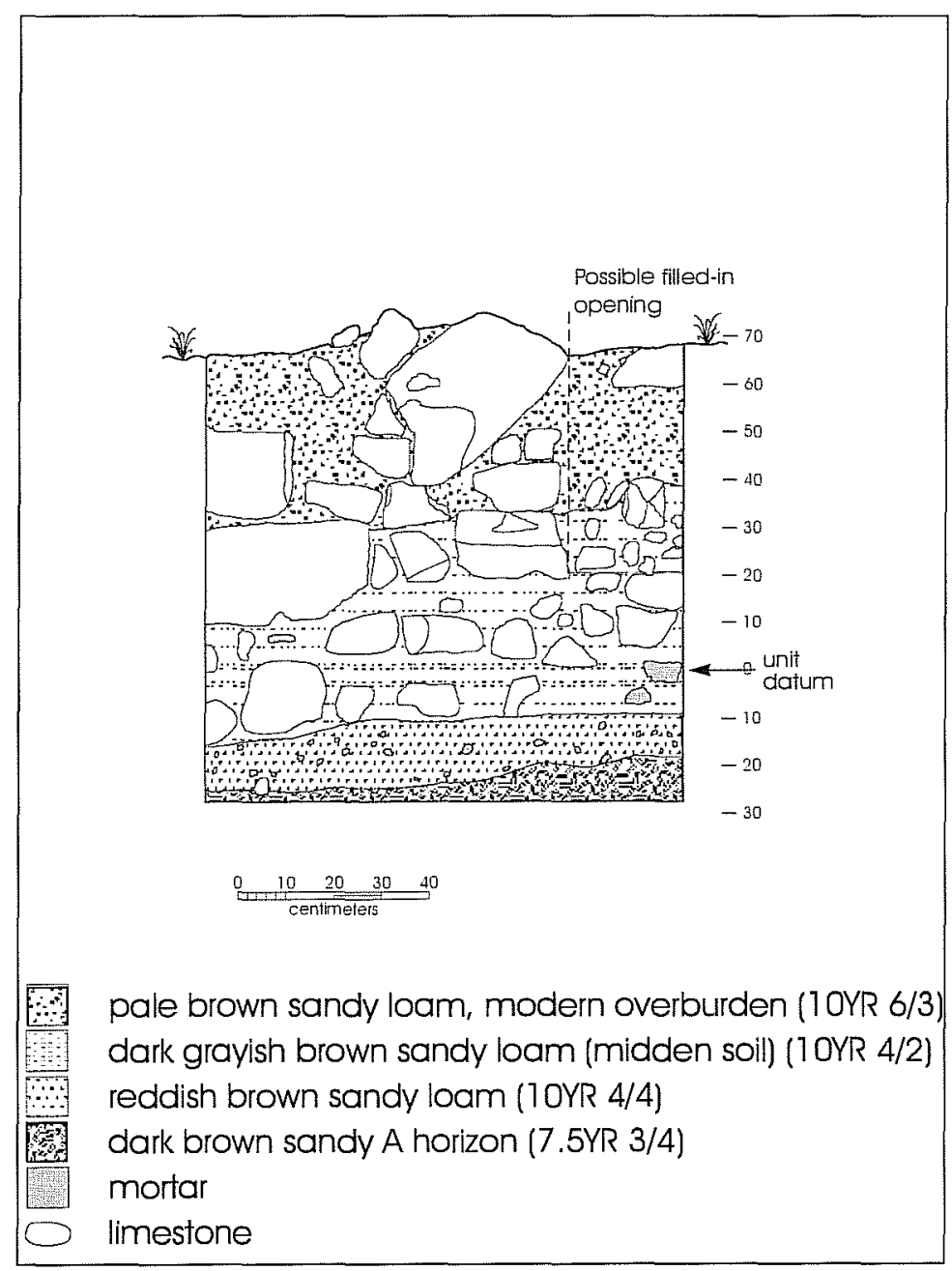

Figure 5-37. Profile of south compound wall in Unit 75. 
be associated with a possible wall, but no further evidence exists to substantiate it. Additionally, Figure 537 shows that much of the wall is intact, but the western portion of the wall appears to have a filled-in opening nearly in line with the western edge of the compacted silty loam surface (Figure 5-35). Examination of the stone wall in Unit 76 also revealed an opening in the stone wall $45 \mathrm{~cm}$ from the west edge of the unit that has filled with rubble, contiguous with the edge of the opening in Unit 75.

Finally, an apparent Colonial-period trench running perpendicular to the wall ends nearly on a line with the opening and the changes in soils (see Figure 535 ). The eastern grayish/brown mix appears to represent the near bottom of a Colonial trench that rose up so that its bottom appears in the east wall at $20 \mathrm{~cm}$ bd (see Figures 5-35 and 5-36). Ricklis (1999) encountered a similar ditch between a buried stone foundation and red clay floor laid on the A Horizon approximately $5 \mathrm{~m}$ south of the compound wall. He speculates it may have served as a drainage ditch catching runoff from the roof of the stone structure, and later the ditch was filled in when the red clay floor was laid. One difference is that the ditch documented by Ricklis was filled with red clay, while the ditch documented by CAR in Unit 75 was filled with gray loam. At first this trench was thought to be a WPA trench, but further study of the wall profiles and plan views suggests that it is clearly pre-WPA and is probably Colonial in age. That is:

(1) The trench was dug ca. 8-10 $\mathrm{cm}$ deeper than the extant wall base (Figure 5-36) truncating the underlying compacted silty loam, and is filled with ashy gray Colonial deposits; and

(2) Some of the reddish brown sandy clay rotted mortar along the wall was overlying the gray loam, ash and charcoal fill in the trench outline, which indicates that the trench was first backfilled with Colonial deposits and then rotted mortar from the extant compound wall spilled onto it.

A possible construction scenario is as follows:

(1) The compacted silty loam surface over the culturally sterile A Horizon represents an occupation surface either prehistoric or during the initial mission period before stone construction was begun, ca. 1754-1768;

(2) A red clay compacted floor was laid over the earlier surface;

(3) An E-W trench was dug for unknown purposes (possibly drainage as Ricklis speculates) which either cut through the clay floor and into the underlying earlier surface, or it was dug as a foundation trench, the clay floor was laid against it and the stones were later removed for use elsewhere; and

(4) The existing stone wall was constructed with an opening which has filled in with wall fall.

\section{Midden Soil Accumulation Against the Wall}

Limited excavations along the wall have shown that although it is covered with a thin layer of modern topsoil, the brown sandy loam midden soil with cultural material slopes upward against the wall. It is clear that compacted surfaces and a possible red clay floor (Unit 75) are generally just below the slightly undulating, yet fairly level southern portion of the compound. Although it could be presumed that the slope is the result of simple trash dumping in a convenient place during mission occupation, available photographs from the 1940s indicate that the southern area of the compound was cleared and flattened all the way to the wall; there was no slope against the wall (e.g., Appendix A-4:Photographs $\mathrm{A}-1$ and A-8). Therefore it must be assumed that the slope now present consists primarily of unscreened Colonial deposits excavated from an unknown area in the mission and then dumped along the wall by the WPA, probably to protect it. The compacted surface(s) found in some areas might represent the surface that was exposed by the WPA. 


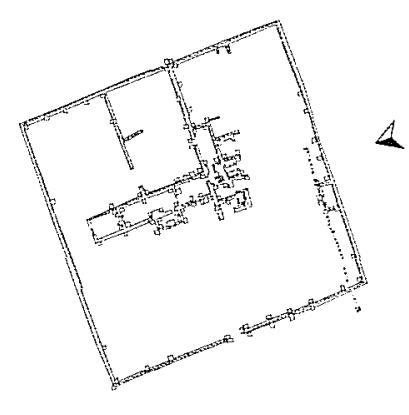

East Compound Wall

Gilmore (1974) excavated in the northeast corner of the compound wall. Based on a row of postholes and the categoric quantities of cultural remains, she posits that the area was a living area for Native Americans. Although available photographs from work in the 1940s by the WPA indicate that the eastern portion of the mission compound was cleared and leveled, the extent to which they penetrated the Spanish Colonial level was unknown. Thus no archival information has been found to indicate that the eastern compound wall and adjacent Spanish Colonial deposits had been examined along its entirety. In addition to CAR's investigations around the structure on the east wall (Room 8), we placed five excavation units $(79,86-89)$ along the interior of the wall. All were excavated only to a depth which confirmed the upper level of the remaining Spanish Colonial deposits (a full vertical profile was exposed in Unit 80, where the structure joins the wall; that unit is discussed under the section entitled "Room 8 Excavations and Probes").

\section{Unit 79}

Unlike along most of the south compound wall, the ground surface was sloping only slightly upward against the east wall in this area (Figures 3-1 and 51 ), and a datum was established on the modern surface in the southeast corner. Excavation in this unit was terminated on a compacted brown (10YR 4/4) sandy loam surface $13 \mathrm{~cm}$ bd. The brown (10YR 4/3) sandy loam, midden soil commonly found throughout the compound was overlain by a 2-3 cm-thick layer of modern, pale brown (10YR 6/3) sandy loam topsoil. Artifacts recovered from this unit include 23 coastal ceramic sherds, and 1 chipped stone flake, with bone and mussel shell fragments.

\section{Unit 86}

Unit 86 was placed along the east wall, north of the structure (Figures 3-1 and 5-1). In this area the brown (10YR 4/2) sandy loam midden soil, overlain with a thin layer of modern grayish brown topsoil, slopes from the modern ground surface along the north edge of the unit to $17 \mathrm{~cm}$ upward against the Colonial wall. A unit datum was established in the southwest corner on the modern ground surface. The sloped matrix above datum was excavated and screened with the sediments and soils to $10 \mathrm{~cm}$ bd. When a Guerrero arrow point blank, a tin glazed undecorated, 2 lead glazed Galera, 4 Goliad, and 17 coastal ceramic sherds were found within the typical brown (10YR 4/3) sandy loam midden soil, it was evident that the upper level Spanish Colonial deposits were within 2-3 cm of the sloping surface. Problematic however, with terminating excavation $10 \mathrm{~cm}$ bd were the presence of modern brown beer glass sherds also found within the same matrix. Large limestone wall fall rubble abutting the intact wall and buried at least $5 \mathrm{~cm}$ into the floor of the unit provided further impetus to continue the excavation to $15 \mathrm{~cm}$ bd. At that level a rock slab was found resting upright (on end), with its lower end on a compacted brown sandy loam midden soil surface. Additional brown beer glass sherds were found 2-3 $\mathrm{cm}$ above the compacted surface, and large bone fragments were lying on the surface. Other cultural material found in the lower $5 \mathrm{~cm}$ includes a tin glazed undecorated and 7 coastal sherds.

\section{Unit 87}

Unit 87 was placed along the east wall, north of Unit 86 (Figures 3-1 and 5-1). In this area the brown (10YR $4 / 2$ ) sandy loam midden soil, overlain with a thin layer of modern grayish brown topsoil, slopes from the modern ground surface along the north edge of the unit to $10 \mathrm{~cm}$ upward against the Colonial wall. A unit datum was established in the southwest corner on the modern ground surface. The sloped matrix above datum was excavated and combined with the sediments and soils to $10 \mathrm{~cm} \mathrm{bd}$. Excavation was terminated 10 $\mathrm{cm}$ bd on a moderately compacted surface of the same soil type. Cultural material found includes 7 chipped stone flakes, mussel shell and bone fragments, and 1 San Elizario, 1 thin brown, black and blue, 41 coastal, and 4 Goliad ceramic sherds. 


\section{Unit 88}

A unit datum was established on the modern ground surface and it became readily apparent that the immediate area around Unit 88 (Figures 3-1 and 5-1) was filled with mottled pale brown (10YR 6/3), light yellowish brown (10YR 6/4), and reddish yellow (7.5YR $6 / 8$ ) fine river sand. It is the only area in the compound where this was found during the 1999 excavations. Numerous rodent burrows filled with grayish brown (10YR 5/2) loam were prevalent throughout the unit to $50 \mathrm{~cm}$ bd. Reddish sandy clay mottling was observed along the wall beginning $18-20 \mathrm{~cm}$ bd. The upper $30 \mathrm{~cm}$ contained 4 chipped stone flakes, 1 Goliad and 7 coastal ceramic sherds, bone and mussel shell fragments, an early wrought iron hand forged nail, and a clear glass sherd. Eleven chipped stone flakes, bone fragments, a lead glazed Galera, 1 Goliad, and 18 coastal ceramic sherds, and 2 olive green glass sherds were found between $30-50 \mathrm{~cm}$ bd. The undulating dark brown (7.5YR 3/3) sandy loam midden soil was encountered $44-48 \mathrm{~cm}$ bd and excavation was then terminated $50 \mathrm{~cm}$ bd.

\section{Unit 89}

Unit 1 was the northernmost unit along the wall (Figures 3-1 and 5-1). The ground surface sloped only slightly toward the wall and a unit datum was established on the modern ground surface in the southwest corner. Excavation was conducted in a single level to $21 \mathrm{~cm}$ bd. The brown (7.5YR 4/2) sandy loam midden soil was encountered $2-3 \mathrm{~cm}$ below a layer of modern topsoil. A tin glazed, 2 lead glazed Galera, 6 Goliad and 31 coastal ceramic sherds were found in this unit, along with 15 chipped stone flakes, and mussel shell and bone fragments.

\section{Discussion}

Compared to the south wall area, relatively little midden soil and topsoil overburden had either accumulated or been dumped along the east wall. In most cases, the brown sandy loam midden soil was found within a few $\mathrm{cm}$ below the modern surface, and a moderately compacted surface was found $15 \mathrm{~cm}$ below the surface in Units 79 and 86. However, the
$44 \mathrm{~cm}$ of mottled river sand overlying the midden soil in Unit 88 is an anomaly not seen elsewhere during the CAR investigations. Available photographs from the 1940 s show sand molds pedestaled during excavations, but no discernible molds were found during the excavation in Unit $\mathbf{8 8}$. Unit 88 was the only unit that was excavated deep enough expose a substantial portion of the east wall (other than Unit 80 - see previous discussion). The wall stones in Unit 88 were intact and red sandy clay mortar was leaching from the wall.

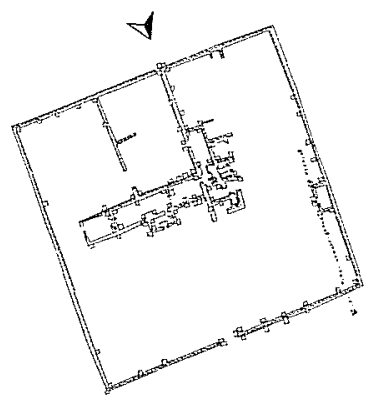

\section{North Compound Wall and N-S Cross Walls}

Available photographs from the 1940 s indicate that clearing and leveling was conducted along the interior of the north compound wall as well as the cross walls, but the depth of their investigations is unknown.

Gilmore (1974a, 1974b) conducted extensive investigations inside and outside the wall in the northwest corner; inside the wall in the camposanto area, inside the wall north of the first church, and outside the northeast corner (Figure 3-1). Among other features she pursued was a buried $\mathrm{N}-\mathrm{S}$ cross wall found in her exploratory trench 1 in the northeastern portion of the compound. In addition to a deep unit placed on the inside northwest corner (Unit 1) and three units (7, 99 and 102) around the north gate opening, CAR placed five units $(2-5,8)$ along the interior of the wall to determine the depth of the Colonial deposits, and five units $(6,9-13)$ along the two above-ground $\mathrm{N}-\mathrm{S}$ cross walls to determine the depth below surface of the Spanish Colonial occupation level (Figures 3-1 and 5-1). 


\section{Unit 2}

A unit datum was established in the southwest corner on the modern ground surface. In this area the modern ground surface over the $1 \mathrm{~m}$ length of the unit slopes from datum along the south edge of the unit to $15 \mathrm{~cm}$ upward against the Colonial wall. The sloped matrix above datum was excavated and combined with the sediments and soils to $10 \mathrm{~cm}$ bd. Reddish brown (10YR 4/3) sandy clay mottled soil in the northern 70 $\mathrm{cm}$ of the unit indicated that this area had been disturbed, probably by WPA trenching activities along the wall. Therefore the unit was excavated to $30 \mathrm{~cm}$ bd, exposing a compacted, undulating, light brownish gray (10YR 6/2) surface consisting of silty loam, with charcoal and ash inclusions. The southern $1 / 3$ of the unit was heavily bioturbated but not trenched, and consisted of brown sandy loam (10YR 4/2) midden soil to $30 \mathrm{~cm}$ bd.

Cultural material found includes 1 clear glass sherd, an expedient stone side scraper, 12 chipped stone flakes, a piece of copper scrap, bone and mussel shell fragments, tin glazed, lead glazed, and burnished ceramic sherds, along with 24 coastal and 5 Goliad wares. Although the WPA cut through much of the unit along the wall, the intact Colonial midden soil in the western portion indicates that the upper Colonial level is within $2-3 \mathrm{~cm}$ of the modern surface.

\section{Unit 3}

In this area the brown (10YR 4/2) sandy loam midden soil is overlain with a layer of apparent light brown sandy loam, with a thin layer of modern grayish brown topsoil, and slopes from the modern ground surface along the south edge of the unit to $14 \mathrm{~cm}$ upward against the Colonial wall. A unit datum was established in the southwest corner on the modern ground surface. The sloped matrix above datum was excavated and combined with the sediments and soils to $15 \mathrm{~cm}$ bd. Although sediment and soil mixing had occurred due to rodent and ant activity, the upper boundary of the darker brown midden soil with Spanish Colonial sherds and associated cultural material was otherwise distinct $10 \mathrm{~cm}$ below the surface. A clear glass sherd from the unit was found in the upper $5 \mathrm{~cm}$, within the presumably WPA fill.
The sediments sloping upwards against the wall in this area were approximately $10 \mathrm{~cm}$ higher than the more level, modern ground surface along the southern edge of the unit. As with Unit 3, a thin layer of pale brown, modern topsoil was lying over approximately $6-7 \mathrm{~cm}$ of presumably WPA fill, distinguishable in this area by a general absence of artifacts and its lighter brown color. The sloped matrix above datum was excavated and combined with the sediments and soils to $14 \mathrm{~cm}$ bd. A buried wall running underneath and parallel to the upper compound wall was uncovered ca. $15 \mathrm{~cm}$ bd (Figure 5-38). As with Unit 2 , the presence of reddish brown sandy clay in the northern portion of this unit initially suggested it had been disturbed also. However, unlike Unit 3 it appears that the intrusive soil in the unit represents inverted stratigraphy from mission construction and not from WPA trenching. A discussion of the speculated construction scenario follows and can be found at the end of this section. A moderately compacted surface consisting of undulating, light brownish gray (10YR 6/2) silty loam with charcoal and ash inclusions, similar to that found in Unit 2, was encountered $20 \mathrm{~cm}$ bd. The southern $1 / 3$ of the unit was minimally disturbed, and consisted of brown sandy loam (10YR 4/2) midden soil to $20 \mathrm{~cm}$ bd.

Cultural material found includes 4 chipped stone flakes, bone and mussel shell fragments, a piece of metal, with 3 tin glazed blue on white, a sandy paste and 3 Galera lead glazed, 2 Goliad, and 11 coastal ceramic sherds.

\section{Unit 5}

Unit 5 was placed on the inside corner of a $\mathrm{N}-\mathrm{S}$ cross wall and the north compound wall (Figures 3-1 and $5-1$ ), where the modern ground surface slopes upward approximately $10 \mathrm{~cm}$ against the northeast corner, covered by a thin $\mathrm{cm}$ layer of modern gray (10YR 5/1) topsoil. Approximately $14 \mathrm{~cm}$ of the modern topsoil and reddish yellow loam overburden was removed before a datum was established $14 \mathrm{~cm}$ below the modern surface in the southwest corner. A semi-circled stone alignment was found ca. $5 \mathrm{~cm}$ below the surface (Figure 5-39). Although moderately disturbed by 
Figure 5-38. Buried wall and construction episode in Unit 4, under north compound wall.
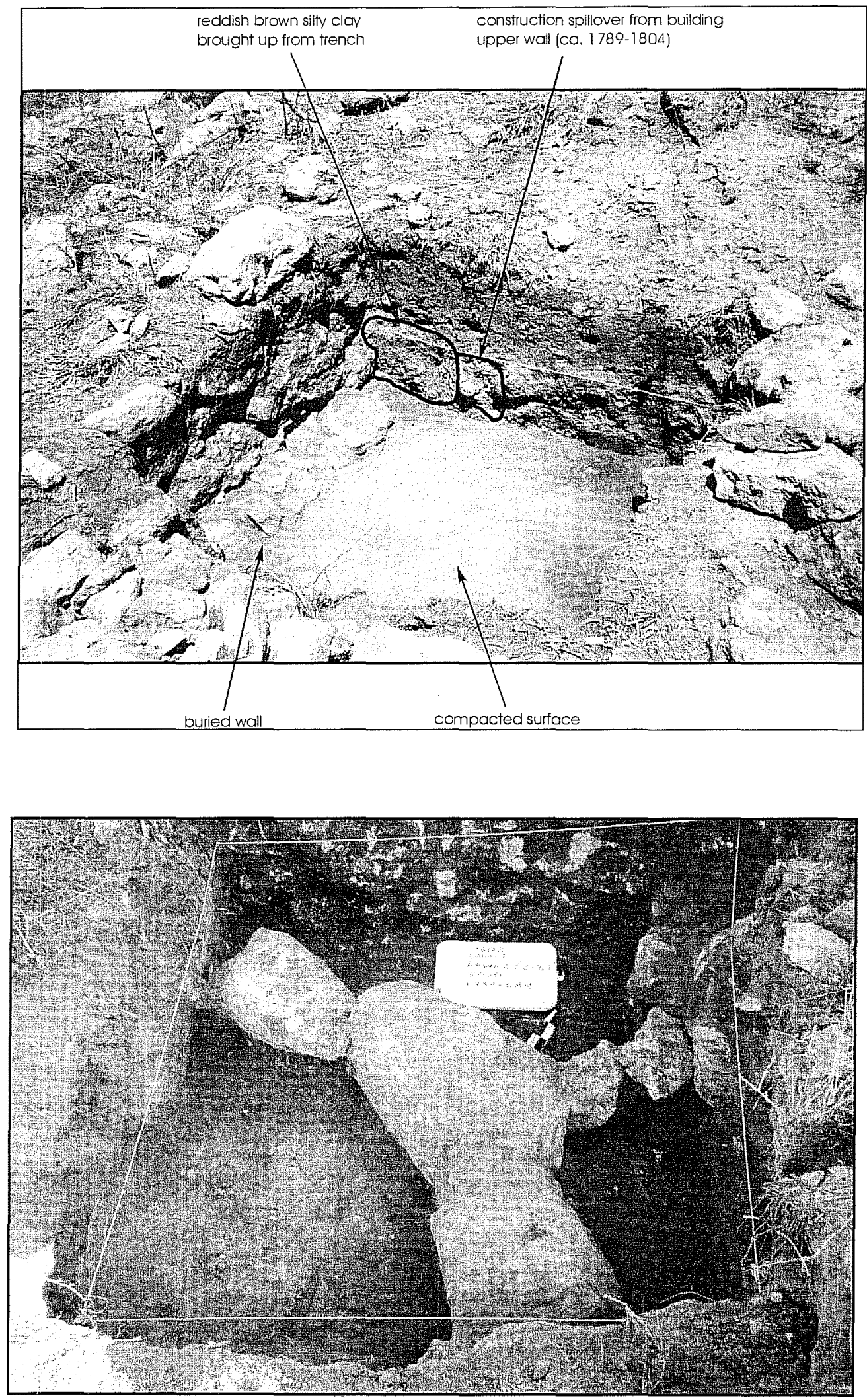

Figure 5-39. Semi-circular stone alignment in Unit 5, along a cross wall and the northern compound wall. 
rodents, the layer of reddish yellow (7.5YR 6/6) silty loam lies $3-5 \mathrm{~cm}$ below the surface, envelopes the semicircled stone alignment, and generally has an abrupt lower boundary $18-20 \mathrm{~cm}$ below the surface (ca. $2 \mathrm{~cm}$ bd). A large-scale map drawn by the WPA indicates a semicircle of stones in this area; thus it seems probable that they uncovered it and backfilled over it with the reddish yellow silty loam. Amoderately compacted surface consisting of light gray (2.5YR 7/2) silty loam lies under the reddish yellow and is believed to represent the lower level of WPA investigations. Gradual, smooth transitions in shades of grayish brown and brown (10YR 3/1-3/2-4/2) sandy loam midden soil occurred between $20-30 \mathrm{~cm}$ below the surface (4-14 $\mathrm{cm}$ bd). Although the overburden was screened, no cultural material was found within it.

Cultural material recovered in the midden soil (0-15 $\mathrm{cm}$ bd) includes a chipped stone flake, bone fragments, a plaster fragment, a tin glazed undecorated sherd, and 10 coastal sherds.

\section{Unit 6}

This unit was placed on the western-most compound wall (Figures 3-1 and 5-1) and a unit datum was established in the southwest corner on the modern surface. It appears that only a few $\mathrm{cm}$ of modern grayish brown sandy topsoil overlies the midden soil in this area. A sloping $13 \mathrm{~cm}$ of brown (10YR 3/2) sandy loam that had accumulated against the cross wall was excavated and screened with soils from $0-15 \mathrm{~cm}$ bd. Excavation was terminated at that level on an undulating, compacted, light gray (10YR 7/1) silty loam surface with lime and small $(<1 \mathrm{~cm})$ rounded pebbles. A strip of light brown sandy loam with reddish sandy loam mottling ran parallel to the wall.

Cultural material recovered from the unit includes 5 chipped stone flakes, bone and mussel shell fragments, lead and tin glazed Spanish Colonial ceramics, along with Goliad and coastal sherds.

\section{Unit 8}

As with Units 5 and 7, this unit was also placed on the inside corner of a N-S cross wall and the north compound wall (Figures 3-1 and 5-1). A unit datum was established in the southeast corner on the modern ground surface. An accumulation of a few $\mathrm{cm}$ of modern gray (10YR 5/1) topsoil underlain with dark grayish brown (10YR 4/2) sandy loam midden soil as described by Ricklis (1999) as deep as $39 \mathrm{~cm}$ against the north wall was excavated and screened with that from the first level $(0-10 \mathrm{~cm}$ bd). Excavation was then terminated on a moderately compacted, undulating, light gray (7.5YR 6/2) sandy loam floor with yellowish caliche patches, ash, charcoal and small $(<1 \mathrm{~cm})$ limestone granules. Charcoal, bone and ceramics were concentrated just above, and on the floor. The centers of two possible burned posts were found in the floor, $25 \mathrm{~cm}$ south of the compound wall, 15 and $60 \mathrm{~cm}$ east of the $\mathrm{N}-\mathrm{S}$ cross wall. They were approximately $30 \mathrm{~cm}$ in diameter.

Cultural material recovered in this corner includes 3 chipped stone flakes, a cut nail, an olive green glass sherd, along with 1 tin glazed Monterey and 1 San Elizario, 4 lead glazed Galera, and 122 coastal ceramic sherds.

\section{Unit 9}

This unit was placed on the eastern-most existing cross wall (Figures 3-1 and 5-1), and a unit datum was established in the southeast corner on the modern surface. It appears that only a few $\mathrm{cm}$ of modern grayish brown sandy topsoil overlies the midden soil in this area. A sloping $10 \mathrm{~cm}$ of brown (10YR 3/2) sandy loam that had accumulated against the cross wall was excavated and screened with soils from $0-10 \mathrm{~cm}$ bd. Excavation was terminated at that level on an undulating, moderately compacted pinkish gray (10YR 6/ 2) silty loam, with a dark reddish gray sandy loam strip along the wall. The compacted surface contained ash and bits of charcoal.

Cultural material recovered from the unit includes bone and mussel shell fragments, a tin glazed blue on white ceramic sherd, 14 coastal sherds, and 4 chipped stone flakes.

\section{Unit 10}

Unit 10 was placed on the eastern-most existing cross wall (Figures 3-1 and 5-1), and a unit datum was 
established in the northwest corner on the modern surface. It appears that only a few $\mathrm{cm}$ of modern grayish brown sandy topsoil overlies the midden soil in this area. A sloping $16 \mathrm{~cm}$ of brown (10YR 3/2) sandy loam that had accumulated against the cross wall was excavated and screened with soils from $0-19 \mathrm{~cm}$ bd. Excavation was terminated at that level on an undulating, compacted dark reddish gray (5YR 4/2) sandy loam, with a reddish yellow (5YR 6/6) sandy loam strip along the wall. The compacted surface contained ash and bits of charcoal.

Cultural material recovered from the unit includes bone and mussel shell fragments, 1 coastal and 3 Goliad ceramic sherds, 6 chipped stone flakes, and a clear glass sherd.

\section{Unit 11}

This unit was placed on the eastern-most existing cross wall (Figures 3-1 and 5-1), and a unit datum was established in the northwest corner on the modern surface. As with the Unit 9 and 10 areas, only a few $\mathrm{cm}$ of modern grayish brown sandy topsoil overlies the midden soil in this area. A sloping $13 \mathrm{~cm}$ of brown (10YR 3/2) sandy loam that had accumulated against the cross wall was excavated and screened with soils from 0-4 cm bd. Excavation was terminated at that level on an abrupt upper boundary of undulating, compacted pinkish gray (5YR 6/2) sandy loam, with small $(<1 \mathrm{~cm})$ caliche pebbles and limestone fragments. A reddish brown (5YR 5/4) sandy loam strip runs along the wall. The compacted surface contained ash and bits of charcoal.

Cultural material recovered from the unit includes bone fragments, 2 coastal ceramic sherds, and 1 chipped stone flake.

\section{Unit 12}

Unit 12 was also placed on the eastern-most existing cross wall (Figures 3-1 and 5-1), and a unit datum was established in the southwest corner on the modern surface. As with all other unit areas along this wall, only a few $\mathrm{cm}$ of modern grayish brown sandy topsoil overlies the midden soil in this area. A sloping, $9 \mathrm{~cm}$ of brown (10YR 3/2) sandy loam that had accumu- lated against the cross wall was excavated and screened with soils from $0-30 \mathrm{~cm}$ bd. The upper 20 $\mathrm{cm}$ consisted of loose, brown (10YR 4/3) sandy loam which had the consistency and color of the typical midden soil found throughout the compound, however roots and javelinas had heavily disturbed the soils in this level, and numerous pieces of modern metal and glass sherds were found. Excavation to $25 \mathrm{~cm}$ bd exposed a remnant of a compacted, dark brown (7.5YR $3 / 2$ ) sandy loam (with occasional reddish clay mottling) surface in the southwest half of the unit. The remaining northeastern portion of the unit consisted of dark brown (7.5YR 3/2) sand commonly seen in other units throughout the compound as WPA backfill. This suggests that the WPA dug a trench or pit into the underlying red clay, spilled it onto the Colonial compacted surface, and then at least partially backfilled the trench with dark brown sand. As was the case in previously excavated units along this wall, a reddish brown sandy loam strip running along the wall was found in this unit also.

Cultural material recovered from the upper $20 \mathrm{~cm}$ includes 2 coastal ceramic sherds, 9 chipped stone flakes, and bone fragments; chipped paint, modern metal can fragments, clear glass sherds, a piece of plastic, and a 1946 copper one-cent piece provide evidence that this particular area has been disturbed. Within the 20-30 $\mathrm{cm}$ level 6 pieces of unidentifiable iron scrap, a clear glass sherd, and a coastal ceramic sherd were found.

\section{Unit 13}

Unit 13 was placed in the corner of the eastern-most $\mathrm{N}-\mathrm{S}$ cross wall and the outer wall of Chapel 2 (Figures 3-1 and 5-1). A unit datum was established in the southwest corner on the modern ground surface. The upper $10 \mathrm{~cm}$ consisted of light brownish gray (10YR 6/2) sandy loam and was unusual because of its absence of artifacts, with only a few bone fragments. It was then explained when a layer of black plastic was uncovered $10 \mathrm{~cm}$ bd; although not shown on published maps, this unit was placed in an area which had most probably been excavated by Gilmore (1974). Other CAR excavations in known areas where Gilmore excavated also encountered black plastic, with yellow or red flagging tape. Apparently her unit or trench did not extend to the $\mathrm{N}-\mathrm{S}$ cross wall because a reddish 
brown strip of sandy loam was still in place along that wall. Excavating to the depth of her black plastic 33 $\mathrm{cm}$ bd, we exposed what appeared to be the end of a rock wall or foundation $22 \mathrm{~cm}$ bd in the east-central portion of the unit, $30 \mathrm{~cm}$ north of the existing Chapel 2 stone wall. Gilmore had excavated on the west end of the wall and apparently backfilled with her screened dirt, now a slightly lighter shade of dark brown (10YR 3/4). Soil on either side of the buried wall consisted of slightly darker brown (7.5YR 3/3) sandy loam, with no intact plaster, mortar or mortar stains observed at this level.

Cultural material recovered between $20-33 \mathrm{~cm}$ bd included a tin glazed, 1 coastal, and 2 Goliad ceramic sherds, a piece of brown glass (probably in Gilmore's backdirt), a chunk of unpainted plaster, and mussel shell fragments. A discussion of the buried wall found in this unit and Unit 14 can be found in the following section.

\section{Discussion}

Previous discussions of Unit 1 in this chapter detailed the deep, finely crafted cut stones that make up the north compound wall (with no footing). A separate discussion documents the disturbed area found in Unit 7, which we have labeled the north gate. The remaining units along the north wall discussed in this section generally were not excavated beyond contact with Colonial midden soils or a compacted surface with Colonial artifacts. Therefore examination of the north compound wall is limited, yet informative. In Unit 2 the wall stones are not intact, and no trench line or footing could be discerned to $30 \mathrm{~cm}$ bd. In Units 3 and 5 the wall stones were intact but again, no trench or footing could be discerned.

Excavations in Unit 4 however, yielded additional clues on construction episodes found elsewhere in the mission. A reddish brown (10YR 4/3) sandy clay mottled soil in the northern $70 \mathrm{~cm}$ of Unit 2 indicated that this area had been disturbed, probably due to WPA trenching activities. It was presumed that the same disturbance had occurred in Unit 4, and thus the unit was excavated to $20 \mathrm{~cm}$ bd. However, after exposing a buried wall $15 \mathrm{~cm}$ bd, and examining the east wall profile of the unit, it became evident that the reddish clay loam was overlain with smaller limestone fragments and mortar (Figure 5-38). Both layers were sloping away from the wall instead of toward the wall. If a WPA trench had been dug along the wall, the profile would have shown the infill sediments sloping toward the wall. In a $1 \mathrm{~m}$-long limited exposure, the stones of the buried wall are generally smaller than those in the above wall, yet they are similar to those in the buried wall in Unit 66, and are not believed to be footing stones for the upper wall. No trench outline was evident either in the bottom of the unit or in either of the unit's east or west wall profiles. Therefore, it appears that the construction scenario indicated in Unit 4 is much the same as seen for example in Unit 66 . That is, the reddish sandy clay represents the backdirt from a trench dug for setting the upper wall foundation, and the fragmented limestone chunks overlying it represent the spillover from constructing that wall. This scenario is complicated by the fact that the upper wall, though offset, generally sets on the buried wall. The fact that it is offset, however, suggests that a trench may have been dug alongside the northern edge of the buried wall. Deeper excavation in Unit 66 revealed the inverted stratigraphy and fragmented limestone spillover from constructing the buried wall, and it is likely we would find the same if Unit 4 were excavated deeper.

The $\mathrm{N}-\mathrm{s}$ cross wall sections Units 6, and 9 through 13 were not excavated deep enough to expose the base of the cross walls, however their examination in Units 5 and 8 indicate that they are setting on or within the brown sandy loam midden soil, indicating they would have held little bulk and are of later period construction (ca. 1789-1807). They may have served only as sectionals within the northern compound camposanto area. The reddish brown or brownish yellow strips of sandy loam and sandy clay found along the walls in all six units is apparently rotted mortar that has leached out of the walls. Gilmore (1974b:34-35) found a similar $\mathrm{N}-\mathrm{S}$ cross wall abutting the north compound wall in her exploratory trench 1 . It is buried beneath the modern surface in the northeastern portion of the compound, and also has no footing. It does not parallel the existing upper stone walls, but rather runs in a slightly more northeasterly-southwesterly direction. She speculated that it might have served as a screening wall, not meant for structures. 
The semicircular stone alignment uncovered in Unit 5 is an anomaly not found elsewhere along the walls, and its function is unknown. The stones were held together with grayish white, lime mortar and set on reddish brown mottled clay. This suggests that if they were structural, they were also not meant to support a large bulk. Our speculations are that they may have served as outdoor furniture, or as an outdoor altar near the camposanto.

Two possible posts that had been burned were found within a compacted floor in Unit 8 parallel to the compound wall, ca. $30 \mathrm{~cm}$ (1 foot) apart and ca. $30 \mathrm{~cm}$ (1 foot) in diameter. Gilmore (1974b:34-35) also found two postholes further east along the compound wall. They were 6 feet apart and 1 foot in diameter. She surmised that they may have been part of the original stockade wall, superstructure supports, or supports for building the existing compound wall. The postholes found by CAR in Unit 8 are of the same size, and are penetrating a floor believed to be occupied during the post-wooden stockade period of the mission, ca. 17681780. Thus we concur with her latter suppositions.

Available photographs from the 1940 s indicate that the WPA cleared the northern portion of the compound and leveled the surface evenly to the walls. As is the case with the other outer compound walls, but to a lesser degree, modern topsoil and Colonial midden soil has accumulated against the north wall. It appears that unscreened midden soil has been dumped against the wall in varying depths in an attempt to offer protection for the stones and mortar. Generally, one meter south of the wall the modern surface is relatively level with the rest of the compound's interior and the Colonial midden soil appears to be intact just a few $\mathrm{cm}$ below it. Even less soil has accumulated along the cross walls, and the Colonial midden soil is within a few $\mathrm{cm}$ there also.

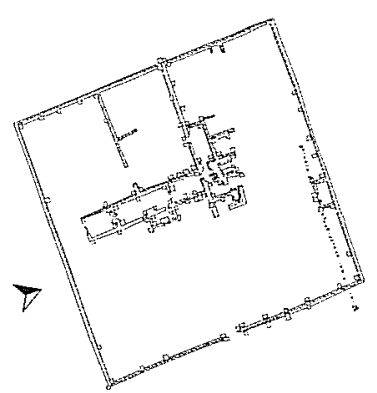

\section{West Compound Wall}

Available photographs from the 1940s indicate that clearing and leveling was also conducted along the interior of the west compound wall, but the depth of their investigations is unknown. Gilmore (1974a, 1974b) indicated that the WPA had conducted some work around the northwest corner of the compound, and she conducted extensive investigations both inside and outside the wall in the northwest corner (Figure 3-1). In addition to a deep unit placed on the inside northwest corner (Unit 1) and two units (66 and 100) around the southwest corner, CAR placed two units (64 and 65) along the interior of the wall to:

(1) Examine the architecture; and

(2) In an effort to determine the depth of the Colonial deposits.

\section{Unit 64}

Unit 64 was placed to fully expose a vertical section of the interior face of the compound wall in the northwestern portion of the mission (Figures 3-1 and 5-1). A unit datum was established in the southwest corner on the modern ground surface. Before excavation began using arbitrary $10 \mathrm{~cm}$ levels, a thin layer of gray (10YR 5/1) sandy loam overburden approximately 2 $\mathrm{cm}$-thick along the eastern portion and increasing in thickness to $17 \mathrm{~cm}$ up against the western stone wall was removed. The bottom of the wall was exposed 97 $\mathrm{cm}$ bd before terminating excavation $1-\mathrm{m}$ bd in the underlying light yellowish brown (10YR 6/4) Pleistocene clay with caliche nodules. A narrow trench outline of dark brown fine sand (A Horizon) mixed with the $\tan$ Pleistocene clay was faintly visible in profile along the stone wall (Figure 5-40), and the 2$3 \mathrm{~cm}$-thick layer of the A Horizon sand had been used 


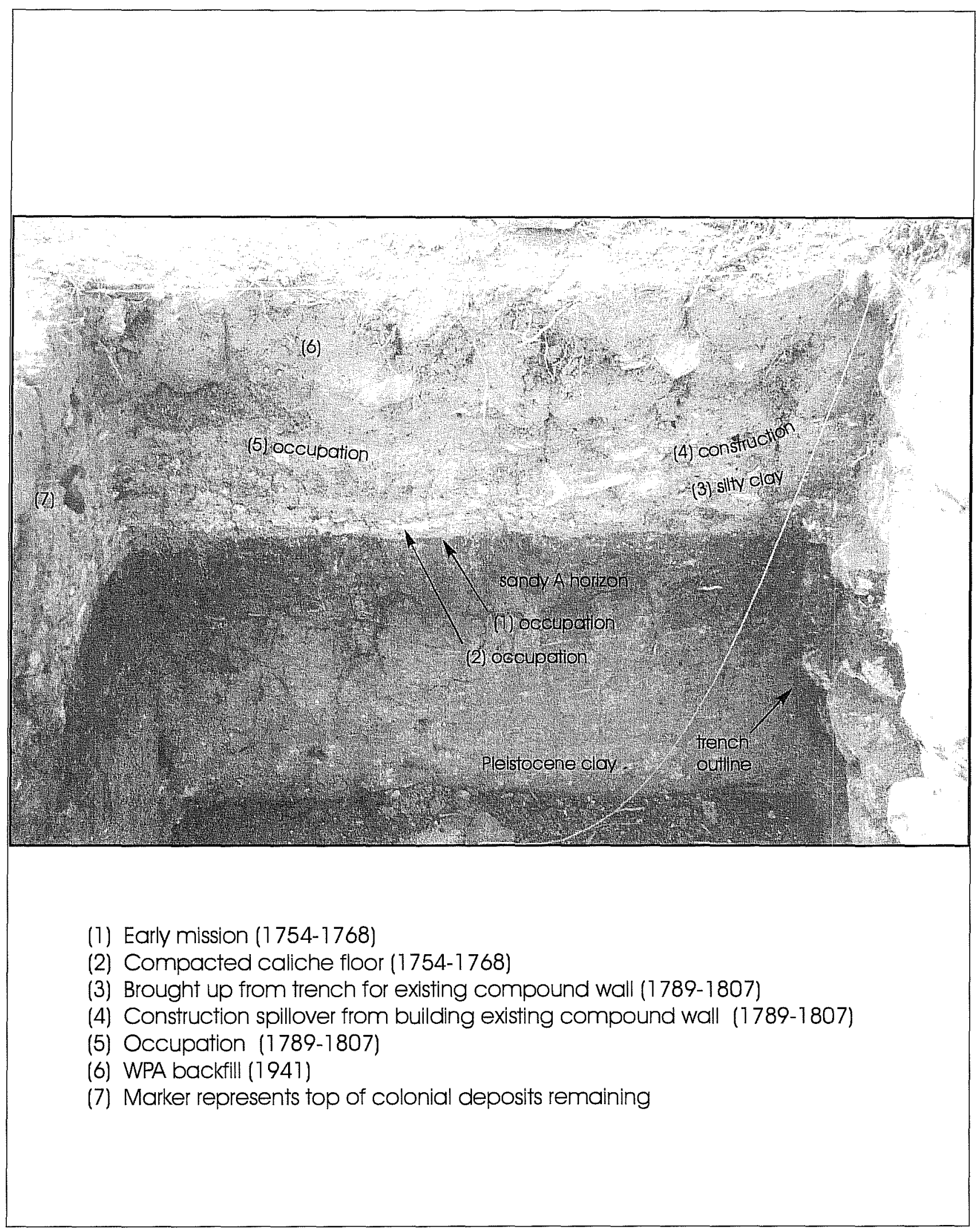

Figure 5-40. Construction and occupations in south wall profile of Unit 64 along the west compound wall. 
as leveler or settler in the base of the trench. A WPA trench had cut through the center of the unit from ca. $20 \mathrm{~cm}$ bd to $73 \mathrm{~cm}$ bd, clearly indicating the lowest level to which they reached in this area in the 1940 s. It also clearly distinguished the depth of WPA fill placed back over the surface when they departed. Because of the WPA trench and rodent disturbance the vertical distribution of cultural material is most probably mixed (see Table 5-3). fragments, lead glazed Galera, red brown, and yellow brown, 2 red paste, 2 black burnished, and 29 coastal ceramic sherds, and 4 chipped stone flakes.

Table 5-3. Vertical distribution of cultural material recovered from Unit 64

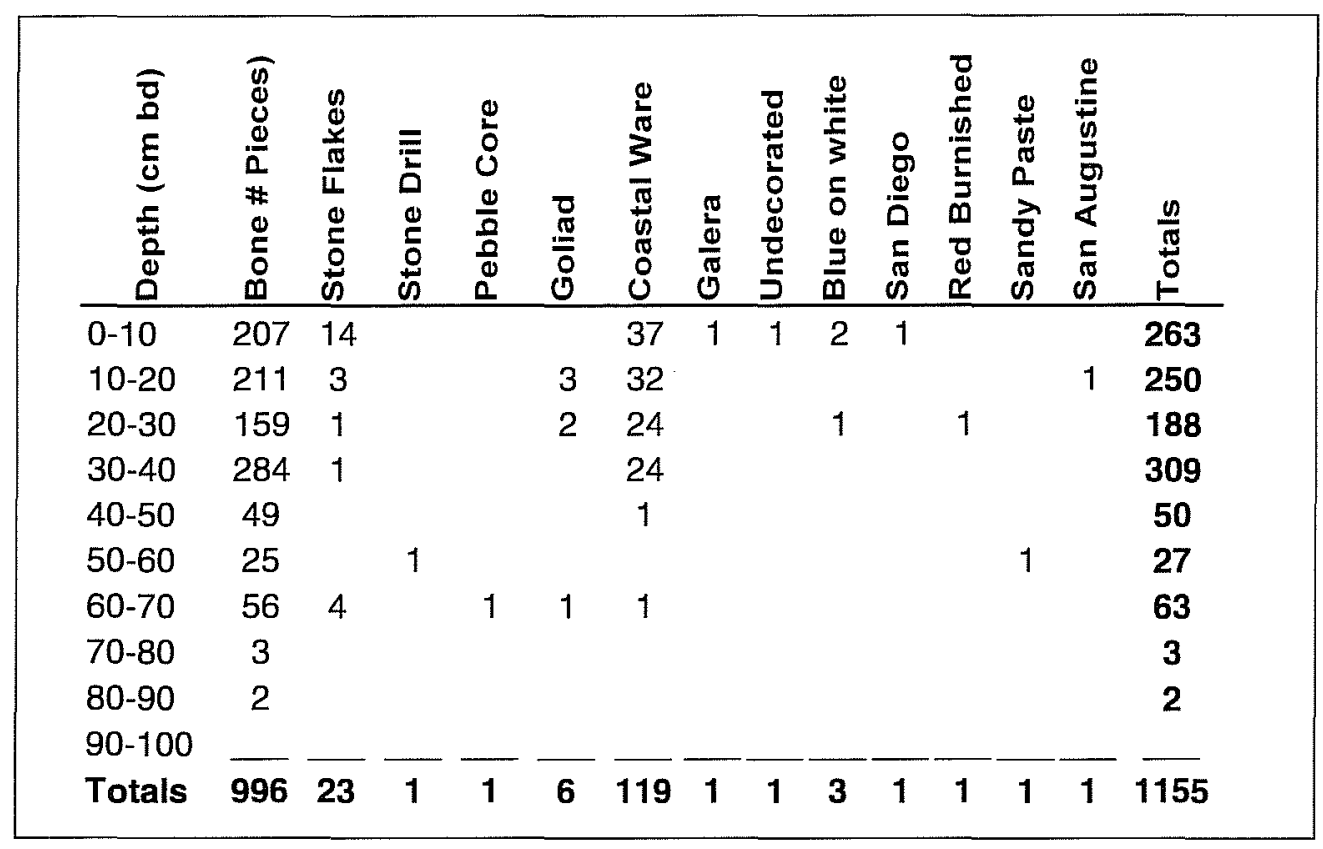

\section{Unit 65}

Unit 65 was placed along the west wall in the southern portion of the compound to determine the shallowest depth of Spanish Colonial deposits at that point (Figures 3-1 and 5-1). A unit datum was established in the southeast corner. Approximately $5 \mathrm{~cm}$ of grayish brown (10YR 5/2) silty loam overburden sloping upward against the wall was excavated and screened with sediments and soils from $0-14 \mathrm{~cm}$ bd. The soils to $14 \mathrm{~cm}$ bd consisted of brown (10YR 4/3) sandy loam, midden soil. Patches of light gray (10YR 7/2) loam with ash and small limestone fragments were present $14 \mathrm{~cm}$ bd. It appears that the upper Colonial surface is within $2-3 \mathrm{~cm}$ of the modern surface in this area. Cultural material recovered from this unit includes a stone uniface fragment, mussel shell and bone
Discussion

A scenario of a single episode of mission construction and two periods of occupation are distinguishable in the south wall of Unit 64 (Figure 5-40). A thin layer of gray (10YR 6/1) ashy, silty loam lying on top of the dark brown (10YR 3/3) sandy A Horizon with no associated evidence of stone construction suggests this is the cultural debris from the initial period of occupation, ca. 1754-1768. A compacted light gray (10YR 7/1) caliche floor then overlies the ashy lens. Although ephemerally distinct, it appears the floor and ash lens have been cut by a trench that was dug for the construction of the stone wall. This suggests that the ash lens and floor at one time may have extended westward either under, or beyond the stone wall. The underlying Pleistocene clay and A Horizon were brought 
up when the trench was dug and dumped onto the caliche floor. Overlying the backdirt is a layer of larger limestone fragments and mortar granules spilled from building the existing compound wall ca. 1789-1807. Notably absent from obvious distinction in the profile are construction and occupation zones for the second period of construction, ca. 1768-1780. The same period was also notably absent in Unit 1 profiles in the northwest corner of the compound.

The base of the western compound wall was set in a footing trench dug to $1 \mathrm{~m}$ below the modern surface after dark brown sand from the underlying A Horizon was placed in the bottom as a settling or leveling device for the hand hewn stones. The limited, $1 \mathrm{~m}$-long exposure provided by excavating Unit 64 indicates that the wall is very much intact below the modern surface at that point. Although excavation in Unit 65 exposed only the upper $19 \mathrm{~cm}$ of the wall, it appears to be intact, also.

As discussed previously in this chapter, a buried stone wall somewhat offset from the upper existing compound wall was found in Units 66 and 100 in the southwest corner of the compound. However, because the buried wall was not found in Unit 64 this is evidence that either 1) the buried wall does not extend that far north, or 2) the buried wall does not follow the same degree bearing as the upper, existing stone wall.

Unlike the south compound wall and to a lesser degree the other two walls, the western wall does not have a deep accumulation of midden soil against it. Gilmore (1974) indicates that Beard implied that the southernmost portion of the compound was leveled more so than other areas. Our limited excavations along the western wall indicates that approximately $20 \mathrm{~cm}$ of fill was placed over the Colonial deposits along the northern part of the wall near Unit 64, but extremely little or perhaps none in the areas of Units 65 and 66 (refer to Figures 3-1 and 5-1).

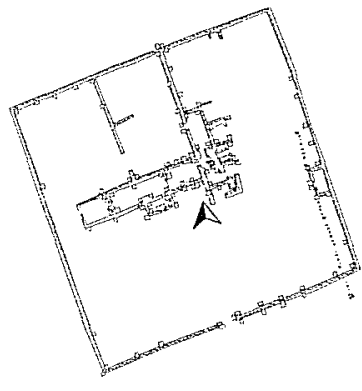

\section{Atrium (Room 9) South of Room 3}

Gilmore did not conduct investigations in this area, but available photographs from the 1940s (e.g., Appendix A-4:Photographs A-3, A-6, and A-9) show that the area between CAR's Units 35 and 42 was raised above the lower surface of the south compound. They also show large stones left in place between a deep $\mathrm{N}-\mathrm{S}$ trench near the eastern edge of the entryway to Room 3. The purpose of leaving the area pedestaled was at first unclear, but became evident after CAR excavated 7 units $(35-37,40-42,90)$ in the area. Additionally, the results of investigations in Unit 34 which was placed to the east of the atrium, but on a line with the pedestaled slope, is relative to this discussion and is thus included.

\section{Unit 34 - Outside Room 4 (Office)}

This unit was located east of the atrium to evaluate the depth of Colonial deposits in that area. Unexpectedly, a stone alignment feature most probably related to that found to the west was uncovered. Immediately after a datum was established in the southwest corner on the modern surface and excavation commenced, it was evident that this was an area disturbed by the WPA. It was also an area where they dumped their trash in with the distinctive brown sand they used as backfill in some of their trenches. This unit was excavated through the sandy backfill to the darker brown (7.5YR 4/4) sandy loam midden soil $40 \mathrm{~cm}$ bd. A loosely stacked stone alignment with no mortar, and running east-west was exposed along the north edge of the unit from 13 to $40 \mathrm{~cm}$ bd. A green tin glazed and 3 coastal ceramic sherds are the only artifacts that could be from the Colonial period. Among the many other "artifacts" found are punch-top can fragments, a tobacco tin, a kitchen salt container spout, and a Pepsodent toothpaste tube (see Chapter 6 for others). 


\section{Unit 35}

This unit was placed on the south end of an apparent buttress or wall extension from between Rooms 3 and 4 (Figures 3-1 and 5-1) to evaluate the depth of Colonial deposits. A unit datum was established in the northwest corner on the highest surface and the steep, $0-57 \mathrm{~cm}$-deep slope from south to north across the unit was excavated in one level. This exposed an intact wall end with large stones and sandy paste mortar extending south $40 \mathrm{~cm}$ into our unit. Although numerous large limestones were present in the western portion of the unit and generally running in a line from the western edge of the end of the stone wall, south through the unit, they were not neatly stacked. The tops of these sloped from north to south with the modern ground surface. The soil above and within the rocks' interstices was a reddish brown (5YR 4/3) sandy loam, versus the brown (7.5YR 4/2) sandy loam midden soil in the eastern half of the unit. Excavation was terminated within the midden soil $57 \mathrm{~cm}$ bd and yielded 4 chipped stone flakes, 1 coastal sherd and 2 Goliad ceramic sherds, bone fragments, and a wire nail.

\section{Unit 42}

This unit was placed on the outside southeast corner of Room 5 (Sacristy) to evaluate the depth of Colonial deposits in that area (Figures 3-1 and 5-1). A unit datum was established in the southwest corner and pale brown (10YR 6/3) sandy loam overburden that had accumulated against the corner was excavated, revealing a compacted surface consisting of caliche with lime and fragmented limestone in the northern portion of the unit. The compacted surface was ca. 5 cm-thick, sat on top of brown sandy loam midden soil, and covered the area northward toward the chapel (Room 3). A line of loose rocks was found at the bottom of the unit ( $35 \mathrm{~cm} \mathrm{bd}$ ) running eastward on a line from the stone corner - in the direction of Unit 35. Excavations were terminated in the midden soil and although it offered a limited exposure of the outside sacristy corner, it was evident that the corner stones were not intact to ca. $20 \mathrm{~cm}$ below the modern surface. Because the 1940s photographs (e.g., Appendix A-4:Photograph A-3) show that the area was cleared to the compacted surface level, it is not surprising that no artifacts were found in this unit.
Unit 41 was placed in the northwest corner of the atrium area against the sacristy and Room 3 exterior walls (Figures 3-1 and 5-1). A unit datum was established at the lowest corner, on the modern surface in the southwest corner. Overburden consisting of pale brown (10YR 6/3) sandy loam as deep as $22 \mathrm{~cm}$ sloping up against the corner was removed and screened with excavated sediments to $30 \mathrm{~cm}$ bd. The pale brown sandy loam was apparent WPA backfill which covered a compacted, light brownish gray (10YR 6/2) to very pale brown (10YR 8/2) caliche surface with deteriorated plaster and limestone fragments. The surface was disturbed by a $15 \mathrm{~cm}$-diameter tree trunk, which we removed with a chain saw. A narrow strip of brown sandy loam, possibly a narrow WPA trench, along the sacristy wall contrasted with the compacted surface. Badly deteriorated remnants of plaster (with no discernible paint or etchings) were still adhered to the wall of the chapel. At this level, the sacristy wall did not appear to be tied in with the chapel wall and no plaster was seen in the corner to confirm the contemporaneity of the two. Mussel shell fragments, 2 chipped stone flakes, a ground stone fragment, a coastal ceramic sherd, a modern brown glass sherd and unidentifiable metal fragments were recovered from just above the compacted surface.

\section{Units 36-37, 90}

Units 36 and 37 were placed along the exterior wall of Room 3 (Figures 3-1 and 5-1) to evaluate the depth of Colonial deposits in that area. Upon removing between 10-15 cm of pale brown (10YR 6/3) sandy loam WPA backfill typically found along the exterior walls and in the atrium area, large stones which may have been steps were uncovered in Unit 37 and a raised, prepared surface area of cobbles and lime was found in Unit 36 (Figure 5-41). Unit 90 was then placed between the two to expose what was presumed to be additional steps leading up to the prepared surface. However, no additional comparably large stones or surface were found in Unit 90. Instead a WPA trench had been cut through the unit perpendicular to, and ending at the chapel wall. The trench had been backfilled with brown sand found in other WPA disturbed areas throughout the compound. After excavation, 1940s photographs were obtained which confirmed 
Figure 5-41. Looking east at Units 37, 90, and 36 in the Atrium (Room 9) from near the doorway into Room 3.

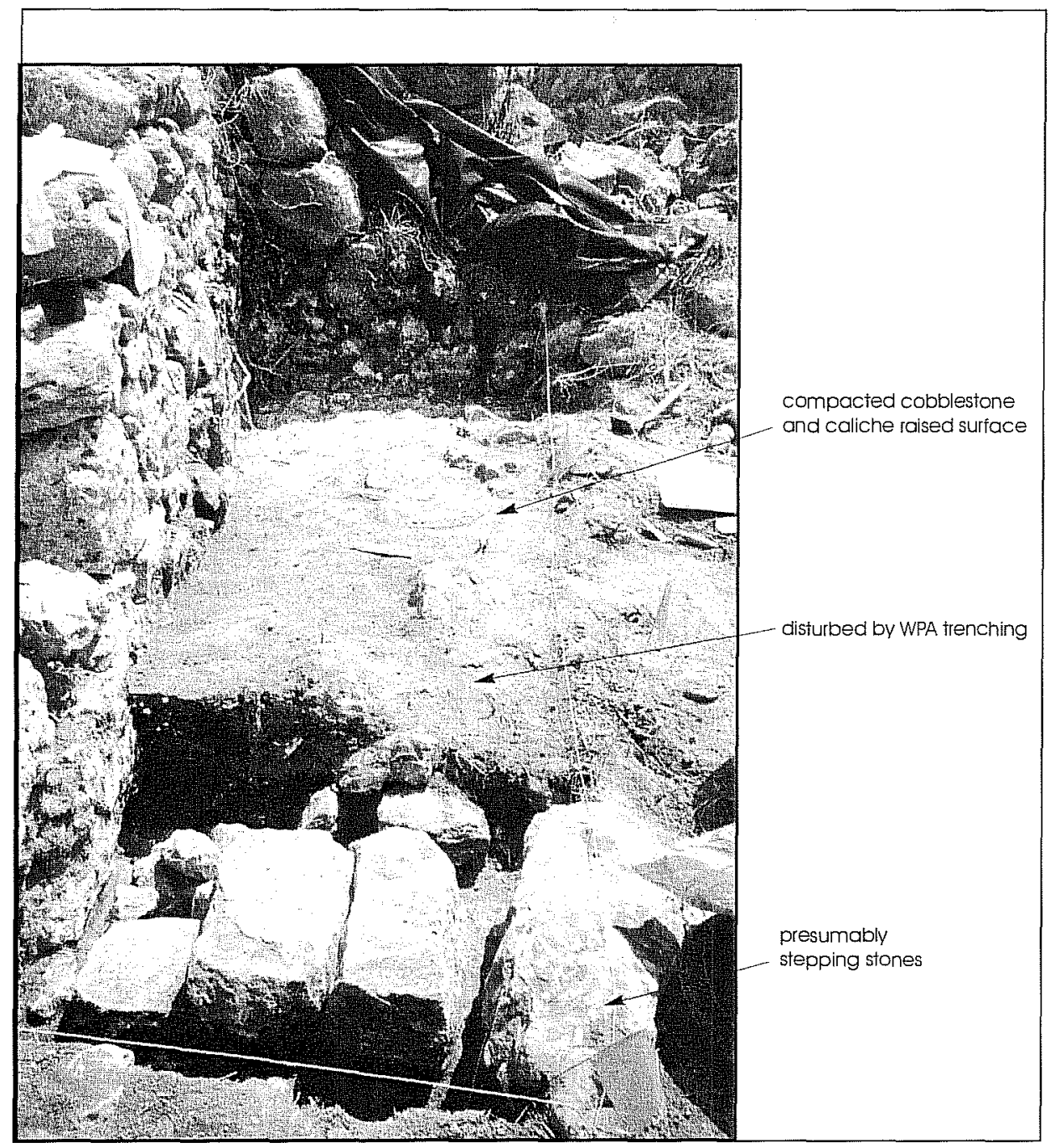

that the WPA had cut a trench through the area, had exposed the stones, and cleared the raised, prepared surface area (Appendix A-4:Photograph A-3). Cultural material recovered from this northeast corner of the atrium includes bone and mussel shell fragments, 1 Goliad and 14 coastal ceramic sherds, a stone gunflint, an expedient stone side scraper, a bifacial stone knife, a stone pebble core, and 36 chipped stone flakes.

\section{Discussion}

It is clear from excavations in Units 35 and 42 that an informally prepared stone wall was put in place, presumably to retain sediments raised above the lower southern portion of the compound. Its informal preparation suggests that if the area was covered, the stone wall was probably not meant to support a heavy roof; a roof most likely would have been lightweight, and held up with support posts. A more feasible speculation is that the area was open to the air with no roof thus we, in conjunction with Texas Parks and Wildlife Architect, Mr. Jim Bigger, have chosen to call this area an atrium, Room 9. The same informally prepared stone wall was found in Unit 34 east of the atrium and south of Room 4, suggesting a necessity to retain sediments in that area also. The prominence of this area or room is unknown, but plaster was still adhering to the walls in Units 36 and 41. An examination of the corner in Unit 41 indicates that the sacristy wall abuts the chapel wall, and thus presumably postdates the 
chapel construction. Excavation in the sacristy doorway in Unit 44 indicated that the floor extended through the doorway into the atrium area. WPA photographs (e.g., Appendix A-4:Photograph A-3) show a level surface between the two, but the color and composition of the surface is unclear. A prepared surface of caliche, fragmented limestone, and lime found in Units 41 and 42 apparently covered the western portion of the atrium area. However there appears to be a separate and distinct prepared surface around the doorway and in the northeastern corner of the atrium. As discussed previously in this chapter under the section entitled "Room 3" in Unit 40 within the doorway, the dissipating yellowish floor gave way to a hard packed, pale brown, sandy loam, undulating surface that had the appearance of being informally prepared with a layer of cobbles just inside the atrium. The raised, prepared surface uncovered in Unit 36 also was laid with cobbles and covered with brown sandy loam. The large stones may have been steps leading up to the raised surface. Because a WPA trench had cut through the area, their purpose may remain unknown.

\section{Structural Exterior Walls}

Numerous photographs from the WPA work in the 1940s show the extensive clearing and leveling that occurred around the exteriors of the standing stone structures (e.g., Appendix A-4:Photographs A-3, A-4, A-6, A-7 and A-9). Gilmore (1974a, 1974b) chose to work predominantly inside standing walls but did place some around the exterior of Chapel 2 and Room 4 (the Office). CAR placed 14 units around the walls to determine the upper extent of remaining Spanish Colonial deposits. Of these units, only Unit 63 was excavated deep enough to examine a wall base and footing.

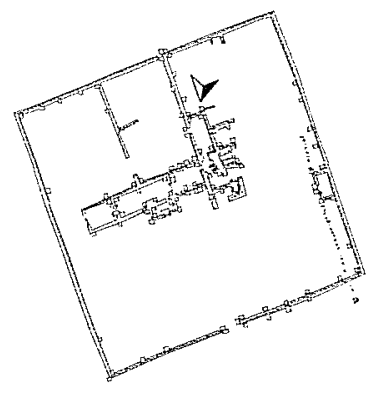

\section{Units 13 and 14 Around Chapel 2}

These two units were placed along the north wall of Chapel 2 (Figures 3-1 and 5-1). The excavation results of Unit 13 have been discussed previously in this chapter under the "North Compound Wall and $\mathrm{N}-\mathrm{S}$ cross walls" section. Suffice it to reiterate, that a buried stone wall running $30 \mathrm{~cm}$ north of, and parallel to, the northern wall of Chapel 2 was uncovered $22 \mathrm{~cm}$ bd. Unit 14 was placed west of Unit 13 along the same wall, and the buried wall found in Unit 13 rose to 8 $\mathrm{cm}$ above the surface in this area. After establishing a datum in the northeast corner on the modern surface, the unit was excavated to $25 \mathrm{~cm}$ bd. As with Unit 13, Gilmore's black plastic placed in the bottom of her trench was also found in our Unit 14 . Our $1 \times 1 \mathrm{~m}$ excavation unit exposed the western $70 \mathrm{~cm}$ of her trench as well as the E-W "buried" wall. The buried wall still runs parallel to the existing upper wall, but there is only a $5 \mathrm{~cm}$ gap between the two at this point, suggesting that perhaps the southern edge of the buried wall is disturbed in Unit 13. The buried wall continues to the east and has previously been documented by Gilmore (1974a, 1974b). Only 1 chipped stone flake was recovered from Unit 14.

\section{Discussion}

Units 13 and 14 uncovered portions of the north wall of what Gilmore had previously exposed and posits is the first stone church. Slightly offset from her excavations, CAR's two units contacted the upper Colonial surface deposits ca. $10 \mathrm{~cm}$ bd. Within these two limited exposures, we found no evidence either refuting or confirming that the buried stone wall is or is not that of the first stone church. 


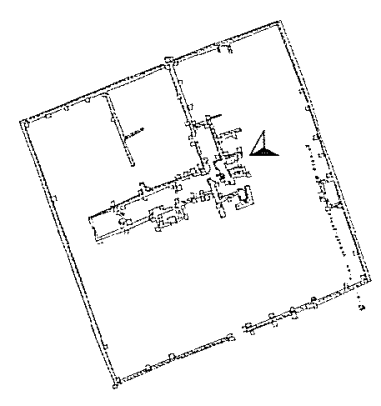

\section{Units 22-24, 29-30 Around Room 6}

\section{Unit 22}

Over $50 \mathrm{~cm}$ of rock rubble and reddish brown (5YR 4/4) sandy loam overburden was leveled in the area of Unit 22 to create a beginning excavation surface. A datum was then established in the northeast corner. The same debris was present in the upper $10 \mathrm{~cm}$ before gradually transitioning to a dark brown (7.5YR $3 / 3$ ) sandy loam with red clay mottling and common limestone from apparent wall fall. Large limestones continued to $26 \mathrm{~cm}$ bd but were resting on brown (7.5YR 4/3) sandy loam, midden soil. Excavation was terminated at that level. Although no evidence of a trench was found, limited vertical exposure of the exterior wall of Room 4 exposed smaller stones, perhaps foundation stones, beginning ca. $22 \mathrm{~cm}$ bd. Patches of reddish yellow (7.5YR 7/6) sandy loam with caliche nodules, running along the wall of Room 4 and in the middle of the unit $26 \mathrm{~cm}$ bd might be remnants of a floor which has been mostly destroyed. Historic cultural material recovered from Unit 22 includes 7 chipped stone flakes, a piece of red pigment, and bone fragments. Pieces of blue and orange flagging are evidence of the disturbance that has occurred in this area.

\section{Unit 23}

A datum for Unit 23 was established on the modern surface in the northeast corner. Approximately $28 \mathrm{~cm}$ of overburden sloping against the bastion, and consisting of limestone fragments, cobbles and chunks of mortar were leveled before excavation began, culminating $10 \mathrm{~cm}$ bd in essentially rubble-free, dark brown (7.5YR 3/3) sandy loam midden soil. Cultural material recovered from this unit includes bone fragments, a piece of iron scrap, 2 chipped stone flakes, and 2 modern glass sherds.

\section{Unit 24}

A datum for Unit 24 was established in the southeast corner on the modern surface. A sloping, $40 \mathrm{~cm}$ of wall fall rubble with brown (10YR 4/4) sandy loam was removed from the corner and screened with excavated sediments and soils to $10 \mathrm{~cm}$ bd. Remnants of a $3 \mathrm{~cm}$-thick compacted, loam with white lime surface were encountered $1 \mathrm{~cm}$ bd, overlying a reddish brown (7.5YR 4/6) sandy loam. Remnants of plaster (with no discernible paint or etching) were still adhering to the west and north stone walls in this unit. Cultural material found includes mussel shell fragments, a coastal ceramic sherd, and 9 chipped stone flakes.

\section{Unit 29}

A datum for Unit 29 was established in the northwest corner at the highest point of limestone wall fall rubble and debris accumulation against the wall of Room 6 (Figures 3-1 and 5-1). Fragmented limestone and pockets of mortar from $43-53 \mathrm{~cm}$ bd, apparently wall and bastion construction spillover, lay over a compacted surface consisting of brown (10YR 4/3) sandy loam with small $(1-2 \mathrm{~cm})$, angular limestone fragments and mortar fragments. Although no clear trench outline was found beside either of the stone walls, smaller stones seemed to make up the foundation for both. Historic cultural material recovered from this unit includes a Guerrero arrow point blank fragment, 3 chipped stone flakes, bone fragments, and 6 coastal sherds; a spent .38 caliber pistol cartridge found between $50-52 \mathrm{~cm}$ bd provides evidence of the disturbance that has occurred in this area.

\section{Unit 30}

After removing an overburden of limestone wall fall rubble within a reddish brown sandy loam matrix sloping $22 \mathrm{~cm}$ higher in the northwest corner to establish a beginning excavation surface, a datum was set in the southwest corner. A stone alignment extending from under the bastion was exposed ca. $10 \mathrm{~cm}$ bd (Figure 5-42). The alignment was offset from the bastion, 
had no mortar, was one layer thick, and was resting on, and within the brown, sandy midden soil. The alignment was left in place and the remainder of the unit excavated to a compacted, brown (10YR 3/2) sandy loam surface $36 \mathrm{~cm}$ bd.

Cultural material in this unit consisted of 10 chipped stone flakes, bone and mussel shell fragments, 2 metal can fragments, and 3 coastal ceramic sherds.

\section{Discussion}

Six shallow units around the exterior of Room 6 yielded information on areas of disturbance, depths of Colonial deposits, a previously unknown rock align- ment, and stone foundation material. After wall fall rubble and debris piled against the wall as deep as 1 $m$ in some areas was removed, and the underlying Colonial midden soil excavated, a compacted sandy loam surface was found in all units except Unit 22 which had a possible floor remnant, and Unit 24 which had a distinct, compacted loam and white lime floor. A stone alignment found in Unit 30 is offset from the above bastion, and may represent a separate building episode. Because of its one layer, non-mortared construction, it was presumably not meant to support a large, bulky structure, and may in fact be a prepared surface not meant for architectural support. Although no trench line could be discerned, apparent foundation stones much smaller than those of the upper wall of Room 6 were found in Units 22 and 30 . Generally, the walls are in fair condition.

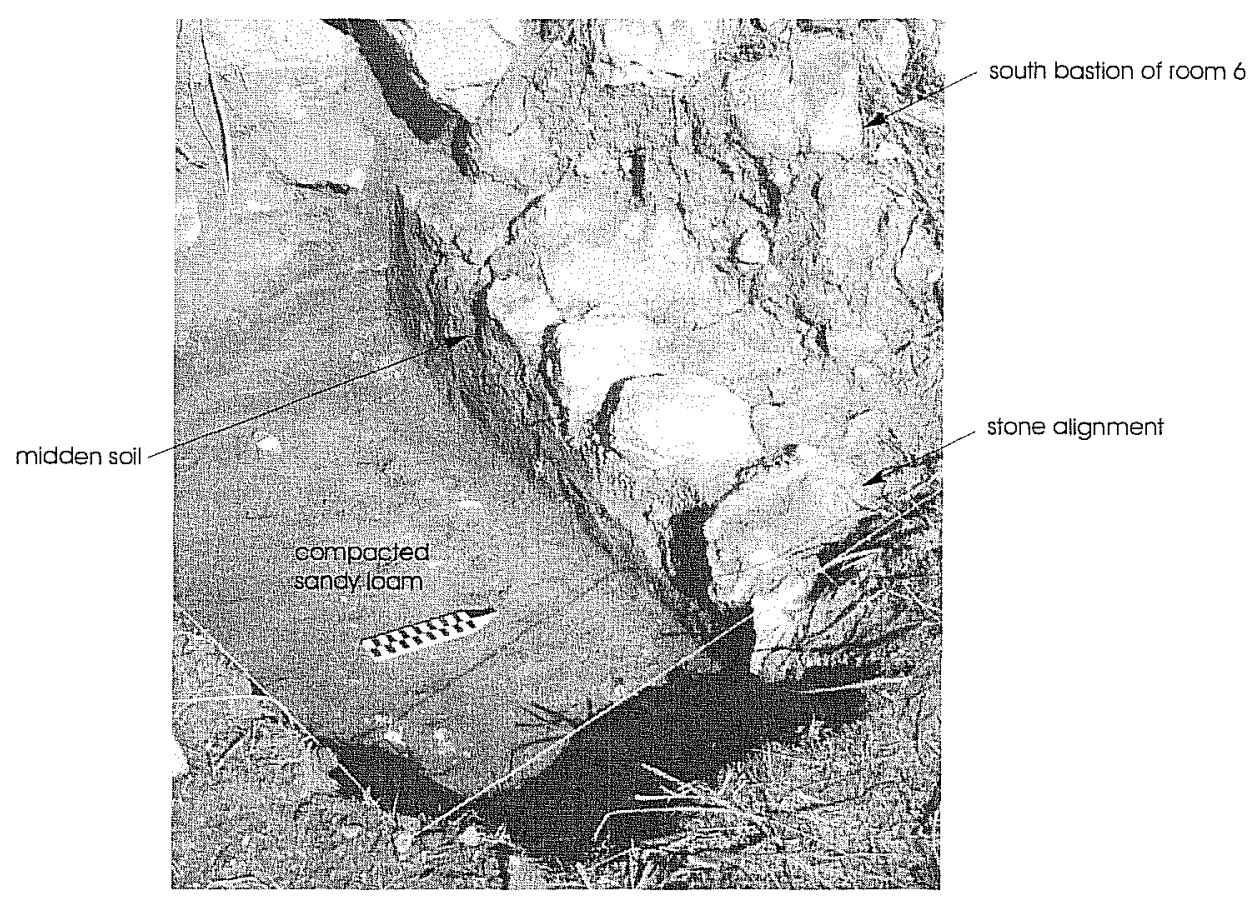

Figure 5-42. Unit 30 excavation exposing stone alignment protruding from underneath the south bastion of Room 6. 


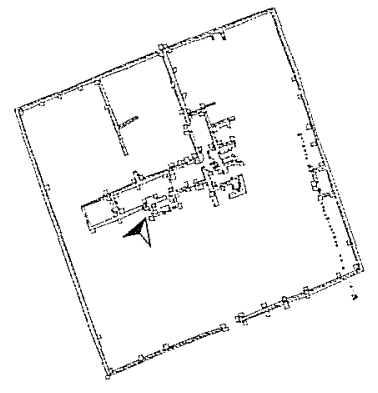

\section{Units 47 and 48 - Around the Sacristy} (Room 5)

Available photographs (e.g., Appendix A-4:Photographs A-3 and A-6) show that the WPA cleared and leveled the area around the sacristy, but in 1999, an estimated $70-90 \mathrm{~cm}$ of sediments sloped from the lower southern compound area up against the walls. Gilmore did not conduct investigations in or around the sacristy. CAR placed four units around the walls. The results of excavations in Units 41 and 42 along the east wall of the sacristy have been discussed previously in the section entitled "Atrium (Room 9) South of Room 3". A short synopsis of that discussion is that the southeast corner of the sacristy is crumbling, and its walls abut the chapel, indicating it has perhaps been added on to the chapel at a later date. Units 47 and 48 were placed on the southwest and northwest exterior corners respectively.

\section{Unit 47}

A unit datum was established in the southwest corner and $35 \mathrm{~cm}$ of brown (10YR 5/3) sandy loam overburden sloping up against the corner was removed to create a beginning excavation surface. Excavation was terminated $20 \mathrm{~cm}$ bd, penetrating the upper $2-3 \mathrm{~cm}$ of moderately compacted, darker brown (10YR 4/4) midden soil with an abrupt upper boundary. Although no mortar remains, the wall stones are still very much intact, and interlocked in this corner.

Cultural material recovered from this unit includes a stone end scraper, 6 chipped stone flakes, bone and mussel shell fragments, along with 4 Goliad, 3 coastal, and a total of 4 tin and lead glazed ceramic sherds.

\section{Unit 48}

A datum was established in the southwest corner and as much as $40 \mathrm{~cm}$ of brown (10YR 5/3) sandy loam overburden sloping up against the corner was removed to create a beginning excavation surface. A moderately compacted, surface of the same color and texture was found $45 \mathrm{~cm}$ bd in the eastern $2 / 3$ of the unit, contrasting with less compacted and darker (10YR 4/ 3 ) sandy loam midden soil in the western $1 / 3$. Bone and mussel shell fragments, 5 chipped stone flakes, a Goliad, and a coastal sherd were essentially found near $45 \mathrm{~cm}$ bd and came from within the darker midden soil. Excavation was terminated $60 \mathrm{~cm}$ on a compacted, brown (10YR 5/3) sandy loam surface with patches of plaster and caliche laying on it in the northwest and northeast corners.

Cultural material recovered from the lower $15 \mathrm{~cm}$ of this unit includes a coastal and 2 Goliad sherds, bone fragments, and 1 chipped stone flake. There was no plaster on either wall, and the walls did not appear to be tied together.

\section{Discussion}

Units 47 and 48 were excavated to compacted surfaces believed to be the lower extent of WPA clearing and leveling in the 1940s, and demonstrated that up to $1 \mathrm{~m}$ of sediments with very few artifacts were piled against the wall after the WPA excavations. The Colonial midden soil rich in artifacts was found immediately beneath the compacted surface in both units. How much was removed by the WPA is unknown, but based upon the patches of plaster and caliche found on the compacted surface in Unit 48 , it appears they may have only scratched the surface. Examination of the corner in Unit 48 indicates that the sacristy wall abuts the chapel wall, corroborating the Unit 41 findings, and the implication that the sacristy is perhaps a later addition in the third episode of construction at the mission, ca. 1789-1807. 


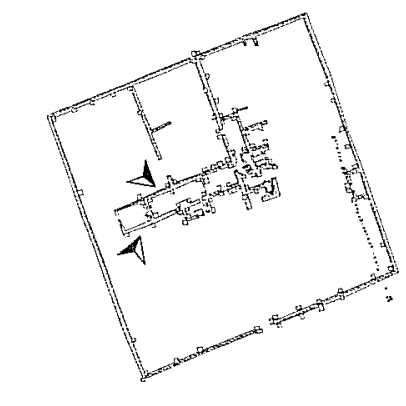

\section{Units 49-50, 60-63, 96: Around Chapel 1}

Available photographs show that the compound was cleared and leveled on both sides of Chapel 1 in the 1940s (e.g., Appendix A-4:Photographs A-4, A-6, A7 and A-9), but the depth to which the WPA excavated is not known. As previously discussed in this chapter under the section entitled "Room 2", Gilmore excavated around the northern edge of the western entryway into Room 2 and discovered that the stone wall was setting directly on the brown sandy loam midden soil prevalent throughout the compound, finding no evidence of footing stones or caliche bricks as a foundation. CAR's clearing and probing across the western entryway defined the width of the opening, but no evidence of buried stone footings, thresholds, or walls was found. Three units (94, 95, and 104) placed on Chapel 1's north wall to investigate the opening into Room 3 have also been discussed in a previous section entitled "Room 3."

\section{Unit 49}

Unit 49 was placed outside Room 1 on the south side of the chapel (Figures 3-1 and 5-1), a datum established in the southeast corner, and as much as $23 \mathrm{~cm}$ of brown (10YR 5/3) sandy loam overburden sloping up against the wall was removed to create a beginning excavation surface. A moderately compacted, sloping and undulating surface of light gray (10YR 7/ 2) caliche with plaster and mortar granules was exposed $30-36 \mathrm{~cm}$ bd in the northern $80 \mathrm{~cm}$ of the unit, contrasting with less compacted and very dark grayish brown (10YR 3/2) sandy loam midden soil in southern $20 \mathrm{~cm}$. Cultural material recovered from this unit includes 18 chipped stone flakes, bone and mussel shell fragments, a piece of iron scrap, and 12 coastal sherds. An examination of the wall indicated that the stones were setting directly on the brown sandy loam midden soil, with no foundation stones or evidence of a trench.

\section{Unit 50}

This unit was placed on the southwest corner of Room 2 (Figures 3-1 and 5-1), and a datum established in the southwest comer on a relatively flat modern surface. The upper $8 \mathrm{~cm}$ consisted of a few $\mathrm{cm}$ of pale brown (10YR 6/3) modern, loamy topsoil overlying brown (10YR 5/3) sandy loam midden soil. Having defined the top of the Colonial deposits and the midden soil, excavation was terminated $8 \mathrm{~cm}$ bd.

The cultural material which was recovered from this unit includes 6 chipped stone flakes, bone fragments, and 4 coastal sherds.

\section{Unit 60}

Unit 60 was placed on the north wall of the chapel outside Room 2 (Figures 3-1 and 5-1). A unit datum was established on the modern surface in the northwest corner. Approximately $5 \mathrm{~cm}$ of modern topsoil covered construction spillover sloping upward $28 \mathrm{~cm}$ above datum in the southeast corner where the walls of Rooms 1 and 2 abut. Excavation was terminated 9 $\mathrm{cm}$ bd at the top of the dark grayish brown (10YR 4/ 2) sandy loam, Colonial midden soil. Numerous rodent and root disturbances were present in the walls and floor. Burrowing rodents had brought dark brown midden soil and yellowish, gritty caliche from under the room wall. Gray construction spillover consisting of fragmented limestone, small pebbles, and mortar granules, sloped from the top of the midden soil upward into the corner. At this level, no evidence of a trench could be discerned under the wall. It appears that the Room 2 wall is a later addition, no trench or foundation stones were used, and the stones were set on top of the Colonial midden soil and construction debris from building the Room 1 portion of the chapel. Cultural material found in this unit includes bone fragments and a chunk of daub. 


\section{Unit 61}

Unit 61 was placed in a corner at the juncture of the northern chapel wall and the end of a $\mathrm{N}-\mathrm{S}$ cross wall (Figures 3-1 and 5-1). The modern surface sloped upward $39 \mathrm{~cm}$ from the northwest corner to the southeast corner. A unit datum was established in the northwest corner and the sloping $39 \mathrm{~cm}$ of wall fall rubble overburden was removed to create a level beginning excavation surface. After removing an additional $7 \mathrm{~cm}$ of overburden a $4 \mathrm{~cm}$-thick layer of moderately compacted, light gray (10YR 7/1) silty loam with mortar and limestone fragments, charcoal flakes, and ash was excavated to the underlying brown (10YR 4/3) sandy loam midden soil $11 \mathrm{~cm}$ bd. The light gray silty loam layer is thickest along the chapel wall, slopes away, and thins in the northern portion of the unit. Its surface was extremely undulating due to a large tree and roots, which we removed with a chain saw. An anomaly in this unit was that the dark red Pleistocene clay underlies the light gray ashy loam along both stone walls. A defined boundary between the reddish clay and brown midden soil could not be established because of the light gray ashy loam's undulating surface. Having established the depth of the Colonial deposits, excavation was terminated $11 \mathrm{~cm} \mathrm{bd}$; whether the red clay is a result of trenching activities, a prepared floor surface, or rotting mortar leached from the walls was unclear at this level. Cultural material found in this corner includes bone and mussel shell fragments, chunks of mortar, and 4 coastal sherds.

\section{Unit 62}

This unit was at the juncture of the northern chapel wall and the end of a $\mathrm{N}-\mathrm{s}$ cross wall, in a corner opposite Unit 61 (Figures 3-1 and 5-1). The modern surface sloped upward $64 \mathrm{~cm}$ from the northeast corner to the northwest corner. A unit datum was established in the northeast corner and the sloping, $64 \mathrm{~cm}$ of wall fall rubble overburden was removed to create a level beginning excavation surface. Although not mapped by Gilmore (1974a, 1974b) or noted in her field reports as having been previously excavated, pieces of black plastic (similar to that found elsewhere in her units and trenches) were found $14 \mathrm{~cm}$ into the wall fall rubble $(3 \mathrm{~cm} \mathrm{bd})$ in the northwest corner of this unit. The paucity of cultural remains found between
0-10 cm bd (a few bone fragments, 2 chipped stone flakes, and a coastal ceramic sherd) corroborates the probability that the sediments in this level had been screened. Excavation to $20 \mathrm{~cm}$ bd exposed a patch of brown (10YR 4/3) sandy loam Colonial midden soil in the extreme northeast corner of the unit farthest from the stone walls. It was also present underneath the stones in the $\mathrm{N}-\mathrm{S}$ cross wall. The remainder of the unit had been disturbed and consisted of reddish yellow (7.5YR 6/6) and brownish yellow (10YR 6/8) sandy loam with mortar and limestone fragments. It appears that excavation in this unit uncovered the southern end of one of Gilmore's units and a WPA trench running parallel to the chapel wall. The Colonial midden soil and associated material were left intact $8 \mathrm{~cm}$ bd in the northeast corner and directly underneath the base of the $\mathrm{N}-\mathrm{S}$ cross wall stones 40 $\mathrm{cm}$ north of the chapel wall. Notably, the brown midden soil under the $\mathrm{N}-\mathrm{S}$ cross wall transitioned to red clay near the chapel wall. Cultural material recovered from between $10-20 \mathrm{~cm}$ bd includes bone fragments and mortar chunks.

\section{Unit 63}

Unit 63 was placed along the north wall of Chapel 1, opposite Room 3 (Figures 3-1 and 5-1). A unit datum was established in the northeast corner and overburden consisting of limestone and mortar wall fall rubble in a reddish brown sandy clay matrix, sloping upward from $0-43 \mathrm{~cm}$ against the wall was removed with a shovel to create a level beginning excavation surface. A wall footing $12-14 \mathrm{~cm}$ wider than the wall was encountered $2 \mathrm{~cm}$ bd (Figure 5-43). A 7-8 cm-wide strip of dark brown sandy A Horizon soil ran along the footing, while the rest of the unit appeared to have been disturbed by trenching and then backfilled with mottled, dark reddish brown (5YR 3/3) silty loam with mortar chunks, plaster, and charcoal bits. The base of the $25 \mathrm{~cm}$-thick footing was found $27 \mathrm{~cm}$ bd. It had been set into a trench dug into the dark brown sandy A Horizon and backfilled with the same soil. The mottled backfill in the apparent WPA trench running though most of the unit narrowed in width, but continued deeper than the bottom of our unit at $60 \mathrm{~cm}$ bd. A remnant of brown Colonial midden sandy loam left unscathed by the WPA trench could be seen in the north wall of this unit between $10-15 \mathrm{~cm}$ below the 
Figure 5-43. Looking east into Unit 63, along the north wall of Chapel 1.

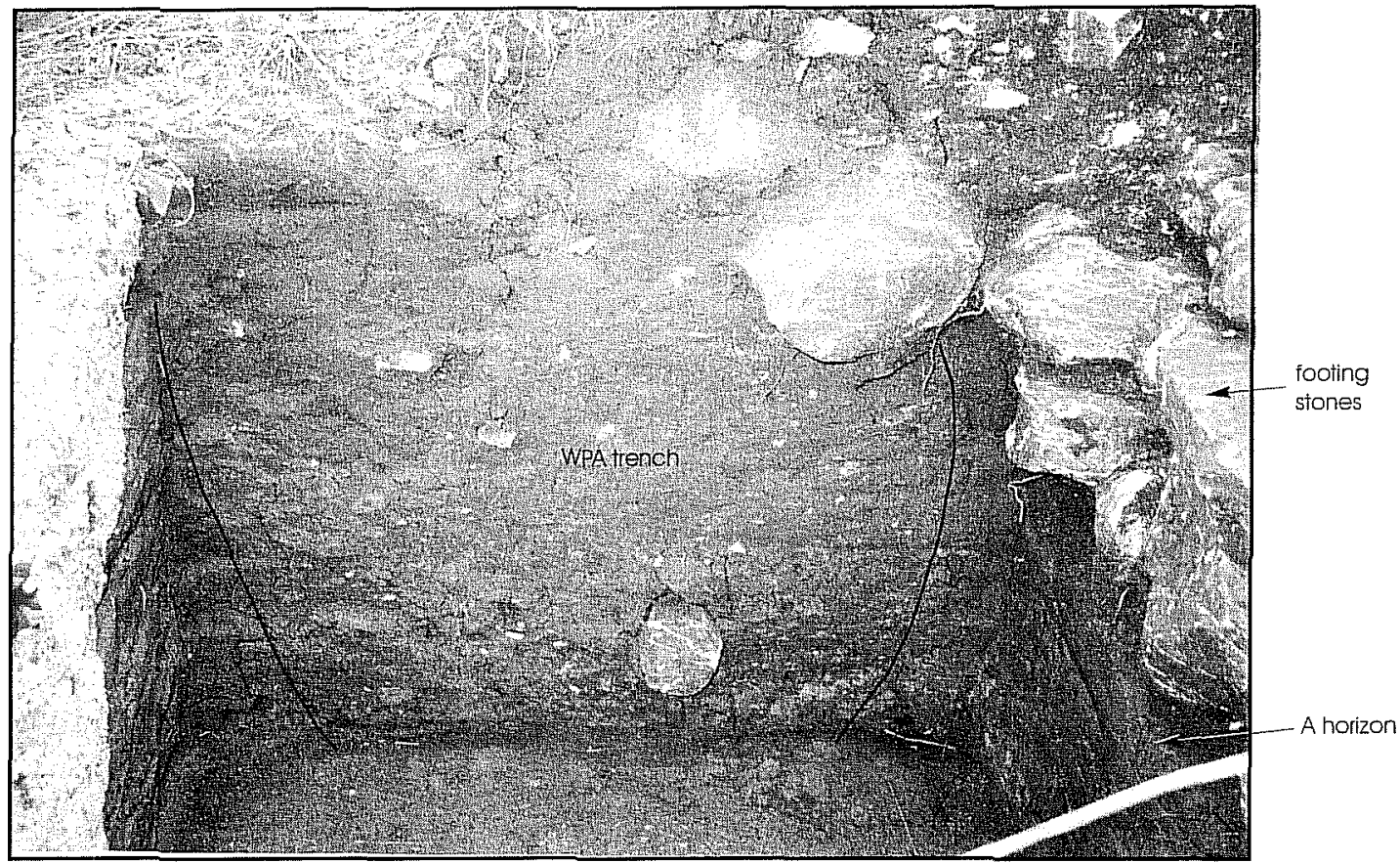

modern surface. Cultural material recovered from this unit includes stone end and side scrapers, a stone biface fragment, 17 chipped stone flakes, 2 Goliad and 1 coastal ceramic sherd, and a few bone fragments; such a relative paucity of material is indicative of the disturbance that has occurred in this area. A photograph obtained after this unit was excavated shows a WPA worker digging a trench with a shovel along this wall in the 1940s (Appendix A-4:Photograph A-4).

\section{Unit 96}

This unit was placed along the north wall, in the eastern corner (Figures 3-1 and 5-1). A unit datum was established in the southwest corner on the modern surface and overburden consisting of limestone and mortar wall fall rubble in a reddish brown sandy clay matrix, sloping upward from $0-23 \mathrm{~cm}$ against the wall was excavated as Level 1 . Only 4 chipped stone flakes and the distal fragment of a stone end scraper were found within the rubble matrix. Excavation between $23-30 \mathrm{~cm}$ bd revealed more rubble and evidence of disturbance, with a Galera ceramic sherd, 7 chipped stone flakes, and a plastic, screw-type bottle cap with a ship emblem printed on it. Excavation in this unit was terminated $40 \mathrm{~cm}$ bd, when the same mottled, dark reddish brown (5YR 3/3) silty loam with mortar chunks, plaster, and charcoal bits used to backfill the WPA trench in Unit 63 was found here. The tops of possible footing stones were also exposed at $40 \mathrm{~cm}$ bd, but having confirmed that the Colonial deposits had been removed by WPA trenching activities, no further investigations were conducted in this corner. As was the case with Unit 63, a photograph obtained after this unit was excavated shows a WPA worker digging a trench extending into this corner in the 1940s. Cultural material found between $30-40 \mathrm{~cm}$ bd includes 14 chipped stone flakes, and 2 coastal sherds.

\section{Discussion}

As discussed at the beginning of this section, available photographs show that the WPA cleared the southern portion of the compound and leveled it against the south wall of the chapel. Our excavation in Units 48 and 49 along the south wall of the chapel have revealed that the WPA then pushed or piled light brown sandy loam along the wall to $1 \mathrm{~m}$ in depth, most probably to protect it. On the extreme western end of the chapel and Room 2, only a few $\mathrm{cm}$ of modern topsoil was overlying the midden soil, indicating that probably because there were no high walls to protect here, 
the WPA did not place fill over this area. Contrasting sharply with the findings along the south wall, work in Units 60 through 63, 94 through 96, and 104 revealed that the matrix against the north wall consists of large limestones and sandy paste mortar chunks mixed with reddish brown sandy loam with some clay, likely also used as mortar. Besides the general absence of cultural material within this matrix which implicates it is wall fall, this sort of matrix is consistent with wall fall seen many places along the walls. If it was dumped along the chapel's north wall by the WPA, it could be from anywhere in the mission. The other possibility is that it is rubble that has fallen from the chapel wall since the WPA departed in 1941. A review of available photographs from the 1940s showing the wall's height compared to 1999 make this entirely feasible (Appendix A-4).

Three units were excavated deep enough to encounter footing stones, Units 63,95 , and 96 . The $25 \mathrm{~cm}$ thick, and 12-14 cm wider, footing exposed in Unit 63 was set into the sandy A Horizon, and not into the seemingly more stable, underlying red clay. The robusticity of the foundation and its shallow depth in sand suggests that the wall may have been only onestory high, but capable of supporting a heavy roof, perhaps beam and shingles or plaster. The tops of what may be footing stones were exposed in Units 95 and 96 east of the opening to Room 3, against a wall that is obviously much thicker than the rest of the wall. Further investigations are needed to evaluate the footing beneath the wall in this area.

Although as discussed previously in the section entitled "Room 2", adobe bricks were found under Room 2 walls near Room 1, excavations in Units 49, 50, 60, and 61 revealed that Room 2 walls had no footing stones, foundation or trench; the stones were simply set on midden soil. Excavation in Unit 60 revealed that the wall stones near Room 1 were setting on construction spillover that appeared to be from building Room 1, but farther west, away from Room 1, the wall stones were setting on the midden soil. A likely construction scenario then, is that Room 1 walls of the chapel were built and construction debris spilled onto the midden soil, and Room 2 walls were added later. This scenario seems plausible when the compacted surface uncovered in Unit 49 is considered: a compacted, light gray caliche surface exposed in Unit 49 stratigraphically underlies the basal wall stones of Room 2, suggests it predates the construction of Room 2, and thus may be a walkway that is associated with the occupation of Room 1. A compacted surface of light gray silty loam found in Unit 60 could also be a walkway. It has angular limestone fragments and a consistency similar to that found in Unit 49, but it slopes away from the wall, and may simply be construction spillover. Its location opposite Unit 49 and positioned in front of Room 1 however, is suggestive of a walkway.

Excavations in Unit 62 at the juncture of the $\mathrm{N}-\mathrm{S}$ cross wall and the chapel wall provided no evidence of a footing trench along the $\mathrm{N}-\mathrm{S}$ cross wall, but a layer of red clay was found under it near the chapel wall, and dissipating 60-80 $\mathrm{cm}$ north, away from the chapel. A probable construction scenario is: a trench was dug for the chapel wall, the underlying red clay was brought up and spread onto the brown midden soil; the chapel and cross wall are tied in indicating that the chapel stones were laid in a trench and once the stones reached the existing (ca. 1789-1807) Colonial surface the two walls were constructed contemporaneously, with the $\mathrm{N}-\mathrm{S}$ cross wall stones simply set on the red clay and midden soil. 


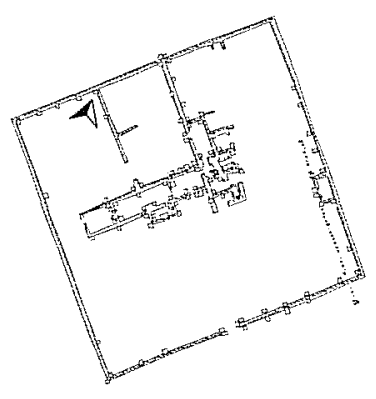

\section{East-West Cross Wall and Semicircular Stone Alignment}

According to Gilmore (1974a:48-57; 1974b:21), the WPA reportedly documented 28 burial pits in the camposanto area, of which two were excavated. Room fire pits and wall lines were also documented. Gilmore conducted extensive excavations along the rock wall and found no evidence of a foundation or setting trench for the wall in its current position. However, she did find setting trenches a few feet to the north and south of the wall, reviewed WPA photographs from the $1940 \mathrm{~s}$, and speculated that the stones may have been remnants of two walls from the two setting trenches and placed in an east-west alignment by the WPA. She investigated a portion of the semicircular rock alignment and found it was set in gray brown soil with caliche, sandstone and red clay mottling. She surmised these may have been either a walkway or WPA backfill. Finding heavy machinery marks 45$50 \mathrm{~cm}$ below the surface in the underlying Pleistocene made a sound interpretation even more problematic.

CAR cleared around the $\mathrm{E}-\mathrm{W}$ stone wall and the semicircular stone alignment, removing the brush, grass, and a few $\mathrm{cm}$ of modern topsoil. The stones appeared to have been casually set in place, with no visible mortar, and gaps in between them. Confirming Gilmore's evaluation, our examination at this shallow depth provided no evidence of either a setting trench or footing. It appears that the stones were set on, or just below the WPA backfill. However, deeper excavation around the stones is needed to confirm this. We exposed the top of the semicircular stone area, which was made up of 10-30 $\mathrm{cm}$-long rounded cobbles in a prepared, evenly spaced manner. They were from 1-5 cm below the modern topsoil and as Gilmore speculated, may have been placed there by the WPA. However, even though Gilmore conducted limited excavations on the alignment, the depth of WPA backfill in this area of the compound is unclear. We do not believe the full extent of the prepared cobble surface was uncovered and future investigations should fully expose its breadth, depth, and stratigraphic context. Nevertheless, it appears that the prepared cobbled surface is larger than a walkway and is substantially more robust. 



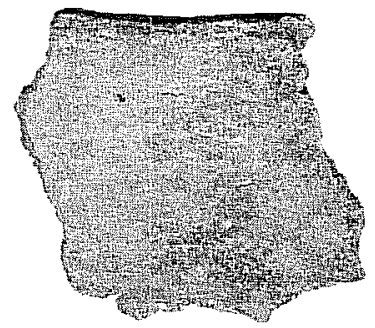

A

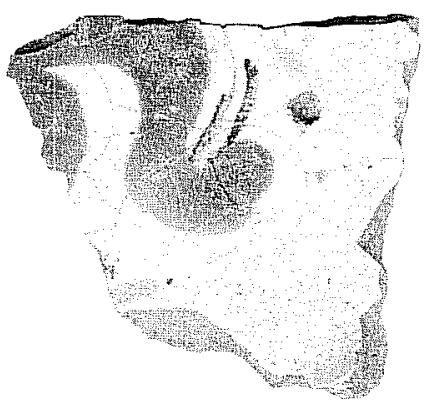

D

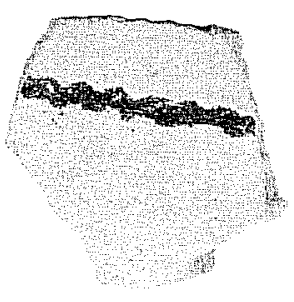

B

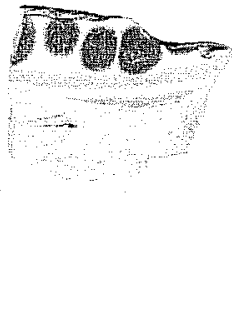

$E$

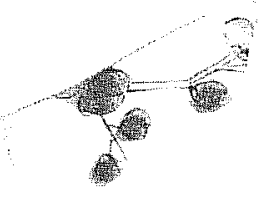

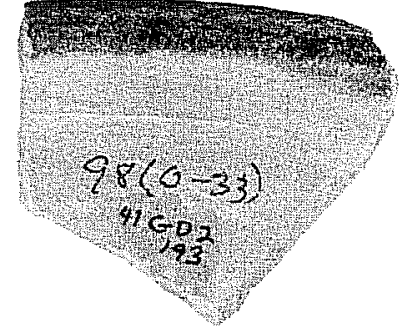

C
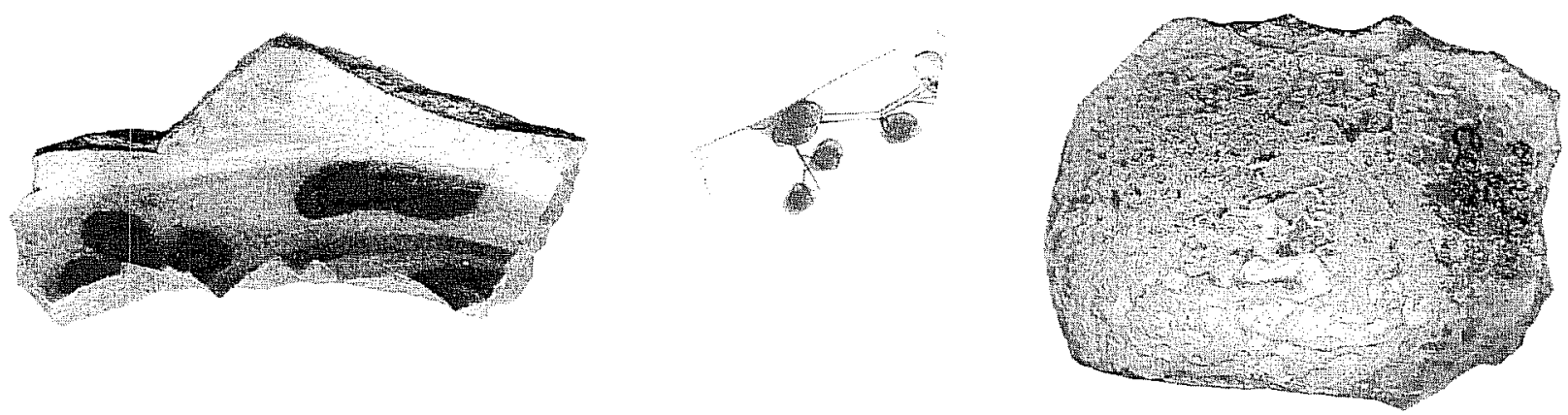

$G$

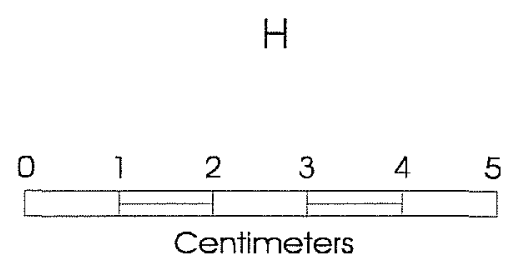

Figure 5-44. Selected glass and ceramic sherds from Mission Rosario 1999 excavations.

(a) Goliad (b) Coastal (c) burnished (d) San Agustín (e) Blue on White (f) Puebla (g) Blue on Blue (h) Chinese porcelain, and (i) olive green glass. 


\section{Cultural Material Analysis}

\section{Ceramics}

\author{
Anne A. Fox
}

Ceramics make up the largest and most useful artifact class recovered from most Spanish Colonial sites. Identification of ceramic types allows the analyst to obtain approximate dates for discrete levels or deposits within a site.

\section{Unglazed Wares}

Two types of unglazed, hand formed ceramics have been tentatively recognized in this collection as being made by local Native American groups. They were both fired over open fires which means they have a wide variety of surface and interior colors, alternating between red brown and dark gray, often on the same vessel.

From this site, the type categorized as Goliad ware (251 sherds) has numerous small white inclusions of ground bone and a rough-breaking paste somewhat resembling oatmeal in texture. Open firing has resulted in many of the sherds having a dark gray to black center. The rims are rounded and closely resemble those of Goliad ware found at the San Antonio missions (Figure 5-44a). Contrary to Goliad ware at San Antonio, many of these sherds contain sand in the paste. First named by Mounger (1959:163) when she identified it at Mission Espíritu Santo at Goliad, this type is now recognized as being present at all the San Antonio River missions as well as on other South Texas sites. It has been attributed to the Coahuiltecan groups both prehistorically and into the historic period (Fox et al. 1976:67).

The type called Coastal Ware in this collection (2651 sherds) closely resembles Rockport Ware, as described by Suhm and Jelks (1962:131-136). The paste is sandy, but not as densely sandy as samples in the CAR collections from coastal sites. These sherds also contain occasional white inclusions, but not so many as in the Goliad ware sherds. These inclusions react with dilute Hydrochloric acid, suggesting they may be shell. A large percentage of these sherds have one surface completely covered with asphaltum, and occasional ones have asphaltum decoration in the form of squiggles or lines (Figure 5-44b) as described by Suhm and Jelks 1962:131) for Rockport Black-on-Gray. The rim sherds are generally flat and often painted with asphaltum. Rockport Ware has been attributed to the Karankawa, (Gatschet 1891; Campbell 1960; Ricklis 1996) and probably represents them at this site. It is interesting to note that there is no representation of Rockport Incised Ware here. Obviously more study should be done on these Native American wares as they are represented at the Texas missions.

Two distinct types of burnished wares are commonly found on Spanish mission sites in the San Antonio River valley. Both appear to be direct descendants of pre-Columbian ceramic traditions in Mexico. A tanbodied ware with burnished red slip or burnished red, black, and yellow slip-painted designs has been identified as coming from Tonalá, Jalisco (Charlton and Katz 1979). Three sherds of this type were recovered during these excavations (Figure 5-44c).

A Red Burnished ware ( 10 sherds) also appears during every excavation on Texas mission sites. This type features matte areas, which are decorated with burnished designs. A tendency to spalling on the surface leaves many sherds with a speckled appearance. Occasional sherds of Black Burnished ware (2 sherds) are a black version of red burnished ware.

\section{Lead-Glazed Utility Wares}

These wares consist primarily of wheel-thrown bowls, jars, and pitchers. It has been supposed until recently that all of these were made in Mexico and brought to the frontier by the annual supply trains. The possibility has been raised that some of this pottery was made locally. These sherds have evenly fired paste and, for the most part, a matured lead glaze. Until evidence is found that the use of the potter's wheel and kilns for firing ceramics had reached Texas by the eighteenth century, it will be difficult to support this theory.

Bowls and jars of Sandy Paste earthenware (46 sherds) make up the largest group of lead-glazed wares. The 
glaze is very pale green or yellow, exposing the pinkto-orange color of the paste beneath (Fox 1974:56) or darker green, which often overlies a gray paste. The paste generally contains a few red brown inclusions.

Lead glazed sherds with a fine-textured, red brown paste (43 sherds) are decorated with linear and floral designs in dark brown, green, and cream on the necks of pitcher-like vessels and the outside of bean pots. These are called Galera Ware across the southwestern United States. Schuetz (1969:50) called this type West Mexico Polychrome, suggesting that it was made in Jalisco. Barnes (1980:96) states that this type of pottery appeared on the frontier after 1750 , which seems to hold true in Texas.

Sherds with a red brown glaze over a fine textured paste ( 6 sherds) are similar to a type found by Schuetz during her excavations at Mission San Juan Capistrano. She termed this type Guadalajara Ware (Schuetz 1969:51), suggesting that it came from that part of Mexico. We have discontinued the use of that name because of its possible confusion with the earlier use in Florida of Guadalajara for what we now call Tonalá Burnished Ware.

Occasional sherds with a beige colored body covered with a pale yellow glaze and decorated beneath the glaze with a brown linear design ( 1 sherd) are found on Spanish Colonial sites. Nothing is known so far about its origin, and the sherds in this collection are too small to allow speculation about the shape of the vessels it represents.

One sherd with a black luster glaze on a buff-colored paste was recovered. Schuetz (1969:52) identified this particular type as coming from Santa Fe, Michoacan.

\section{Tin Glazed Wares}

Tin-glazed earthenwares are covered with a clear lead glaze to which tin has been added in order to create a background for colored enamel decoration. The styles and colors of the decorations changed periodically which makes them useful for the dating of sites and archaeological deposits. Names have been given to the various designs with which the tin glazed vessels were decorated.

Undecorated sherds (23) can represent totally undecorated vessels. These were made throughout the whole of the eighteenth century (Lister and Lister 1974:30). They could also be undecorated portions of otherwise decorated vessels.

San Agustín ( 8 sherds) was first identified by Goggin (1968:189) and dated by him from 1700 to 1730 . Recent investigations at the San Antonio missions have suggested that there may be a later version that extends into the mid-eighteenth century or later. Goggin describes the type as bearing blue floral designs in dark and light blue, with occasional accents of black/brown, and with blue loops on the under side (Figure 5-44d). Later examples appear to be the same but do not have the loops on the back. The main problem is that so many of the sherds are too small to be able to project the entire design. At any rate, we presently continue to use the type name with a suspicion that it lasted later than first thought by Goggin, and that there may be some later changes to the design. Barnes and May (1972:31) suggest that the end date be extended to 1780 .

Blue on White (22 sherds; see Figure 5-44e) has been used here to indicate all such sherds which demonstrate evidence of blue decoration but which cannot classified further.

Huejotzingo ( 4 sherds) consists of a single band of color (in this case, blue) at and over the rim of plates and cups. This type was made throughout the whole of the eighteenth century, and therefore does not provide much assistance in dating.

San Elizario ( 3 sherds) consists of a blue pattern around the rim and in the center of tin-glazed vessels. The pattern is accented with black/brown and a blue rim band is framed on either side with brown bands. This type was identified and named by Rex Gerald (1968:45) for the site from which it came.

Thin Brown, Black, and Blue on White (2 sherds) is a descriptive term for a type first described by Schuetz 
(1969:57) at Mission San Juan Capistrano. It has since been noted at other San Antonio mission sites (see Tomka and Fox 1998:23) and previously at Mission Rosario by Gilmore (1975:48-49). The sherds are remarkably thin, decorated with delicate brown, black, and blue floral designs.

San Diego Polychrome ( 2 sherds) is the name given to a design popular on the southwestern frontier between 1770 and 1800 . It was first identified by that name in an analysis of majolicas from San Diego Presidio by Ronald May (1972:35). It consists of green, yellow, and gold/brown balls surrounded by black/ brown lines and stems alternating with half-green and half-yellow triangles. An orange rim band is outlined with thin brown lines, which identifies this as part of the general classification of Aranama Polychromes.

Monterey Polychrome ( 2 sherds) is another type identified and named by May (1972:36) for which the name has been now generally accepted. May dates this type to 1800 to 1830 in California, Barnes (1972:12) suggests it was introduced into Arizona as early as 1790. This is another sub-type of Aranama Polychrome, having a similar orange band. The design consists of green leafy sprays alternating with yellow and orange designs accented with black lines and slashes. Both of these designs are found on most San Antonio mission sites.

Tumacacori Polychrome (1 sherd) is another late-eighteenth century to early-nineteenth century type recorded by May (1972:12). It differs from other polychromes in that it has a powder blue glaze on both surfaces. It appears to be represented by plates with undulating rims bearing several different polychrome designs around the rim.

Puebla Blue on White II ( 2 sherds), which is found only on bowls and cups, is another late-eighteenth century design. It was first described by Goggin (1968:191). The decoration consists of thin blue bands on the outside of vessels accented occasionally by small blue dots (Figure 5-44f).

One unidentified type ( 1 sherd) is a very small fragment with a mottled brown surface that does not match the decoration on any presently known type. Designs that include this particular shade of brown have been observed in late-eighteenth century to early-nineteenth century majolica collections.

Another sherd with an evident green glaze is so far unidentified.

Three sherds with a blue on blue pattern (see Figure 5-44g) are similar to others found at Mission San Juan Capistrano (Schuetz 1969:56) and previously at Rosario (Fox, personal observation).

\section{Whitewares}

The presence of white-bodied wares is usually an indicator of nineteenth-century occupation on San Antonio sites. One undecorated whiteware sherd was recovered from the second level $(30-40 \mathrm{~cm})$ of Unit 34 . Since the fill in this unit has been previously determined to be WPA backfill, the presence of a late sherd is coincidental.

\section{Chinese Porcelain}

A small amount of Chinese porcelain, imported to Mexico on the Manila galleons, is present on nearly every Spanish Colonial site in Texas. It can be differentiated by very careful examination from European and American porcelain by the very slightly blue gray tint of the body, and when decorations are present, the grayish blue designs beneath the glaze or delicately painted orange floral designs over the glaze. The latter type seems to be the most frequently found in the San Antonio River Valley. In this collection, except for one sherd that has the orange decoration (Figure $5-44 \mathrm{~h}$ ) the other three sherds are so small that it is difficult to be sure of the identification as Chinese rather than European. However, in most cases identification can be reinforced by the presence in the same level of Colonial period ceramics. 


\section{Household Items}

\section{Glass containers}

Clear glass and most colored container fragments make up a large proportion of the total artifacts recovered, despite the fact the comparatively few fragments can be positively identified as being related to the Colonial occupation. This is probably a product of the mixing of Colonial and post-Colonial trash during the removal and restoration of overburden during the 1940-1941 project.

Olive green glass bottle fragments (19) are the only ones that can be tentatively identified as Spanish Colonial. Of these, only those from Units 74,88 , and 98 bear the gold patina (Figure 5-44i) that positively shows that they are eighteenth century wine bottle glass (Fox, Day, and Highley 1980:Figure 26).

Clear glass fragments (93) probably represent twentieth century containers discarded on the site. It was not until after 1930 that most glass manufacturers of lesser quality bottles took the care to produce a glass resembling crystal (Miller and Pacey 1985:45). For example, three clear molded fragments from Unit 12 $(0-20 \mathrm{~cm})$ represent a shot glass, a medicine bottle, and a heavy soda water bottle. These were accompanied by a Native American sherd, a sherd of Blue on White majolica, nine pieces of clear glass and one brown piece, a fragment of plastic tape, some fragments of dried paint, and a 1946 U.S. penny. Such an accumulation would indicate thorough mixing of the deposit, with the fragment of plastic tape representing a previous excavation.

From Unit $8(0-10 \mathrm{~cm})$ came an aqua bottle base with a pontil scar, indicating it was probably made before 1903. The color and square shape suggest the latenineteenth century (Kendrick 1967:22).

A clear glass medicine bottle base from Unit 19 (26$66 \mathrm{~cm}$ ) has an "Owens ring" on the base from a bottle making machine invented in 1903 and the makers' mark of the Illinois Glass Company -in operation from
1929 to 1966 (Toulouse 1971:403). In addition, other items recovered were one Native American sherd, three pieces of window glass, a fragment of river mussel shell, and miscellaneous bone fragments. The same level in Unit 19 yielded a sherd of red glass, which would date to the twentieth century.

Unit 34, a readily identifiable twentieth century trash deposit, yielded an extract bottle with a screw cap, sherds of clear, brown, and blue glass, several Native American sherds, and the only sherd of whiteware recovered during the excavations.

\section{Kitchen Items}

Most of the kitchen-related artifacts came from the trash deposited within Unit 34 by the 1940-41 excavators. It included a metal coffee pot lid, an aluminum pouring spout similar to ones found today on cardboard salt containers, tin cans and hundreds of small can fragments, a can opening key, and a screwtype can lid.

Other identifiable tin can fragments were recovered from the fill in Units $53(0-22 \mathrm{~cm})$, and $95(0-10 \mathrm{~cm})$.

Numerous fragments of iron scrap (62) came from various areas of the site and may represent cooking and storage items. In addition, four fragments of sheet copper were recovered. Copper fragments, usually pieces cut from worn-out copper cooking vessels, are commonly found on eighteenth century Colonial sites in the San Antonio River valley

\section{Personal Items}

Items related to clothing were limited to one domeshaped metal button with no decoration and an attached loop from level $0-23 \mathrm{~cm}$ in Unit 104, and two fragments of shoe leather from Unit 100.

A collection of small fragments of cloth came from the trash pit located in Unit 34, along with two copper pocket rivets. 
Loosely included under the term amusements could be fragments of childrens toys and a piece of writing chalk from Unit 34, a modern pencil eraser from Unit $59(0-32)$, a mouth harp from Unit $70(0-10 \mathrm{~cm})$, and a tobacco tin from Unit 34, as well as a 1946 U.S penny from Unit $12(0-20 \mathrm{~cm})$.

Ammunition recovered at the site is limited to a 20 gauge shotgun shell and a cartridge case labeled REMUMCO 38 AUTO, from Unit $21(20-30 \mathrm{~cm})$ and Unit $29(50-52 \mathrm{~cm})$. Both would have arrived on the site long after the mission was closed.

\section{Construction-Related Items}

Three types of nails were found during the excavations. Four hand-forged nails represent the Colonial period construction at the site. Two cut nails recovered date to the nineteenth century and probably came from post- 1800 repairs and reconstruction at the mission. The three wire nails, which must represent post1900 activities conducted at the site, came from Units 90,91 , and 92 .

Building materials recovered include one tar or asphaltum fragment from Unit $100(25-35 \mathrm{~cm})$, one fragment of concrete from Unit $54(0-35 \mathrm{~cm}), 91$ wall plaster fragments, many of them bearing red paint, and 89 mortar fragments from various units. Both plaster and mortar contain lime and sand in varying proportions. In addition, one fragment of burned clay daub, probably from a wooden structure, came from Unit $60(0-9 \mathrm{~cm})$.

Window glass in this collection was limited to nine fragments. Since it all measured two $\mathrm{mm}$ in thickness, and came from mixed contexts (Units 4, 19, and 34), it is extremely unlikely that it had any relation to construction at the mission.

One half of a circular white ceramic object with a hole in the center has not, as yet, been identified. It came from the first level of Unit 65, and does not appear to be related to the Colonial deposits.
Near the surface of Unit 12 was found a collection of dried oil-based paint fragments, possibly from a paint bucket. What it was doing in that location, or even on that site, is difficult to ascertain.

\section{Other Materials}

A fragment of red ocher such as would have been used in coloring the red plaster on the mission walls was found in Unit $52(10-15 \mathrm{~cm})$.

A number of pieces of modern plastic material were found in various units. Of these, the most useful were strips of plastic marking tape in red, blue, and yellow which were used by the Gilmore crew in marking their units. When these were found, it was possible to estimate where and how deep the units had been. Fragments of black plastic sheeting were also found in the bottoms of previously dug units.

Two chunks of metal slag were recovered from Unit $1,14-20 \mathrm{~cm}$ and $30-40 \mathrm{~cm}$. These may be indications of the presence of blacksmith activities somewhere in the immediate area of this unit.

One small chunk of sulfur was recovered from the trash pit in Unit $34(30-40 \mathrm{~cm})$. 


\section{Lithic Artifacts}

Steve A. Tomka

A total of 920 chipped lithic artifacts were recovered during the excavations at Mission Rosario. The majority (95\%) of the collection consists of 877 pieces of unmodified lithic debitage. The remaining specimens $(n=43,5 \%)$ are categorized into the following functional groups: four arrow points, twelve gunflints, one perforator, nine scrapers, two knives, a graver, and five cores (Table 5-4).
Tool function was determined by low-powered $(20 \mathrm{x}-$ $80 \mathrm{x}$ ) micro-wear analysis. Nine unifacially flaked artifacts are classified as indeterminate unifaces, and a single bifacially flaked specimen is classified as a miscellaneous biface fragment.

\section{Arrow Points}

Four artifacts are classified arrow points, two complete specimens are blanks and two manufacturebroken fragments are preforms (see Bradley 1975; Table 5-4). One of the complete specimens (Unit 86,

Table 5-4. Lithic tools recovered from Mission Rosario, 1999 excavations

\begin{tabular}{|c|c|c|c|c|c|c|c|}
\hline UNIT & $\begin{array}{l}\text { Depth } \\
\text { (cm bd) }\end{array}$ & Tool Type & $\begin{array}{l}\text { Max. } \\
\text { Length } \\
\text { (mm) }\end{array}$ & $\begin{array}{l}\text { Max. } \\
\text { Width } \\
\text { (mm) }\end{array}$ & $\begin{array}{c}\text { Max. } \\
\text { Thickness } \\
\text { (mm) }\end{array}$ & Blank-Type & Notes \\
\hline & & Arrow Points & & & & & \\
\hline 2 & $20-30$ & Guerrero Arrow Point Preform Prox. Frag. & & 12 & 3 & Indeterminate Flake & Broken at mid-blade; manufacture break \\
\hline 29 & $0-54$ & Guerrero Arrow Point Prefom Distal Frag. & & 12.5 & 3 & Indeterminate Flake & Proximal end broken; heavy longitudinal curvature \\
\hline 70 & $0-10$ & Complete Arrow Point Blank & 31 & 21 & 6 & Secondary Flake & May have broken distal end; difficult to establish \\
\hline \multirow[t]{2}{*}{86} & $0-10$ & Guerrero Arrow Point Blank & 20 & 15 & 3 & Tertiary Flake & Corner of blank broken in manufacture \\
\hline & & Gun Flints & & & & & \\
\hline 20 & $0-50$ & Specimen $\# 7$ & 19 & 23 & 14 & Tertiary Flake & Recycled Uniface \\
\hline 63 & $0-10$ & Specimen \# 8 & 22 & 17.5 & 9 & Tertiary Flake Frag. & Recycled Uniface \\
\hline 69 & $0-10$ & Specimen \#5 & 19 & 21 & 7 & Tertiary Blade & Broken blade mid-section; bifacial retouch; classic shape \\
\hline 70 & $0-10$ & Specimen \# 10 & & 17 & 6 & Secondary Blade Frag. & Distal blade frag., crushed and step fractured edges \\
\hline 70 & $0-10$ & Specimen \# 11 & 21 & 15 & 6.5 & Tertiary flake & Three crushed and step fractured edges \\
\hline 74 & $0-13$ & Specimen \# 1 & 26 & 21 & 4.35 & Tertiary Flake & Thin, well made, bifacially flaked \\
\hline 76 & $5-20$ & Specimen \# 3 & 25 & 22 & 5 & Tertiary Flake & Thin, hard hammer flake, bifacially flaked \\
\hline 76 & $5-20$ & Specimen \# 4 & 28 & & 4.5 & Secondary Flake & Longitudinally broken; may be manufacture break \\
\hline 76 & $5-20$ & Specimen \# 9 & 34 & 26 & 8 & Tertiary Flake & Retouch along one side \\
\hline 80 & $10-20$ & Specimen \# 6 & 30 & 26 & 14 & Secondary Flake & Recycled Uniface \\
\hline 90 & $0-10$ & Specimen \# 2 & 24 & 20.5 & 6 & Tertiary Flake & Thin, hard hammer flake, bifacially flaked \\
\hline \multirow[t]{2}{*}{98} & $33-43$ & Specimen \#12 & & 25 & 9 & Indeterminate & Use wear on break faces and bifacial edges \\
\hline & & Perforator & & & & & \\
\hline \multirow[t]{2}{*}{64} & $50-60$ & Formal Drill & 50 & 11 & 8 & Tertiary Blade & It is either a distal end or made on a distal blade fragment \\
\hline & & Serapers & & & & & \\
\hline 2 & $10-20$ & Expedient Side Scraper & 33 & 23 & 3.5 & Tertiary Flake & Made on biface manufacture flake \\
\hline 47 & $0-20$ & Minimally Retouched End Scraper & 38 & 43 & 16 & Secondary Flake & Comer of distal edge formally modified and used \\
\hline 63 & $50-60$ & Expedient Side Scraper Dist. Frag. & 28 & 21 & 6 & Secondary Flake & Made on complete hard hammerstone flake \\
\hline 73 & $0-10$ & Formal Side Scraper & 50 & 46 & 10 & Secondary Flake & Lateral edge and comer of distal edge of retouched flake blank \\
\hline 76 & $0-5$ & Expedient Side Scraper & 27 & 23 & 3 & Tertiary Flake & Lateral edge of biface thinning flake has use wear \\
\hline 90 & $0-10$ & Expedient Side Scraper & 30 & 17 & 5.5 & Secondary Flake & One working edge \\
\hline 96 & $0-23$ & Expedient End Scraper Distal Frag.. & & 20 & 8.5 & Secondary Blade & Heavy micro-flaking along distal end \\
\hline 98 & $33-43$ & Minimally Retouched End Scraper & 20 & 29 & 7 & Secondary Flake & Made on distal flake fragment \\
\hline \multirow[t]{2}{*}{103} & $25-43$ & Minimally Retouched Side Scraper & 33 & 21 & 5 & Primary Flake & Well pattemed retouch along one margin \\
\hline & & Knives & & & & & \\
\hline 90 & $0-10$ & Expedient Knife on Bifacial edge frag. & 51 & 22 & 13 & Tertiary Angular Frag. & Used break face edge as cutting edge \\
\hline \multirow[t]{2}{*}{94} & $0-10$ & Expedient Knife & 41 & 31 & 6 & Secondary Flake & Use wear on one lateral edge \\
\hline & & Graver & & & & & \\
\hline 52 & $0-15$ & Expedient Graver & 41 & 27 & 12.5 & Secondary Blade & Graver tip on sharp point of break face \\
\hline
\end{tabular}


Table $5-4$, continued....

\begin{tabular}{|c|c|c|c|c|c|c|c|}
\hline UNIT & $\begin{array}{l}\text { Depth } \\
\text { (cm-bd) }\end{array}$ & Tool Type & $\begin{array}{l}\text { Max. } \\
\text { Length } \\
(\mathrm{mm})\end{array}$ & $\begin{array}{l}\text { Max. } \\
\text { Width } \\
\text { (mm) }\end{array}$ & $\begin{array}{c}\text { Max. } \\
\text { Thickness } \\
\text { (mm) }\end{array}$ & Blank Type & Notes \\
\hline & & Indeterminate Unifaces & & & & & \\
\hline 1 & $14-20$ & Indeterminate Uniface & 64 & 53 & 15 & Secondary Flake & Large $Q$. Arenite flake with lateral and distal minimal ret. \\
\hline 100 & $55-65$ & Misc. Uniface Distal Fragment & & 29 & 6 & Tertiary Blade Frag. & Retouch on distal margin and along one side \\
\hline 100 & $55-65$ & Indeterminate Uniface Edge Frag. & & & 11 & Tertiary Agular Frag., & Minimal retouch along edge \\
\hline 65 & $0-14$ & Misc. Uniface Edge Fragment & & & 9.5 & Tertiary Agular Frag., & Difficult to discern manufacture and portion of tool \\
\hline 72 & $10-20$ & Misc. Uniface Edge Fragment & & & 7 & Tertiary Flake Frag., & Lateral edge of flake blank \\
\hline 74 & $13-20$ & Misc. Uniface Edge Fragment & & & 10 & Tertiary Angular Frag., & Difficult to discern manufacture and portion of tool \\
\hline 98 & $0-33$ & Misc. Uniface Edge Fragment & & & 8 & Secondary Indeterminate & Difficult to discern manufacture and portion of tool \\
\hline 100 & $65-80$ & Misc. Uniface Edge Fragment & & & 5.5 & Tertiary Flake Frag., & Difficult to discern manufacture and portion of tool \\
\hline \multirow[t]{2}{*}{102} & $0-7$ & Misc. Uniface Edge Fragment & & 30 & 8 & Seconadry Flake & $\begin{array}{l}\text { Has stem-like feature with unifacial retouch on opposite sides } \\
\text { appears to be like a dart point blank }\end{array}$ \\
\hline & & Indeterminate Bifaces & & & & & \\
\hline \multirow[t]{2}{*}{63} & $30-40$ & Indeterminate Biface Frag. & & & 3.5 & Indeterminate & Indeterminate biface frag., may be arrow point preform \\
\hline & & Cores & & & & & \\
\hline 1 & $14-20$ & Pebble Core & 64 & 49 & 26 & Petrified wood & Single flake scar; tested pebble \\
\hline 7 & $60-70$ & Pebble Core & 66 & 57 & 27 & Chert Pebble & Seven removal scars \\
\hline 64 & $60-70$ & Pebble Core & 80 & 62 & 35 & Chert Pebble & Eleven removal scars \\
\hline 71 & $0-10$ & Pebble Core & 76 & 63 & 42 & Chert Pebble & Three removal scars \\
\hline 90 & $10-45$ & Pebble Core & 105 & 73 & 57 & Chert Pebble & Three removal scars \\
\hline
\end{tabular}

$0-10 \mathrm{~cm} \mathrm{bd})$ is a small $(20 \times 15 \times 3 \mathrm{~mm})$, roughly triangular, tertiary flake with minimal unifacial retouch along one lateral edge. The flake removals extend only 4-5 mm from the edge and are present only along a 16 mm-long segment. The second complete arrow point blank (Unit 70, $0-10 \mathrm{~cm}$ bd) is a secondary hard hammer stone flake. Unifacial retouch is present adjacent to the bulb of percussion and is limited to one edge. The two preforms consist of a proximal and a distal fragment. The distal arrow point fragment is a heavily curved tertiary flake (Unit 29, 0-54 cm bd). Bifacial retouch is limited to the edges of the specimen. A manufacture break has removed the proximal end of the specimen. Although the fragment could have been rejuvenated into a 23-24 mm-long point, the knapper chose to discard the specimen, perhaps due to its extensive curvature. The final preform is a well-shaped proximal fragment recovered from Unit 2 (5-45a;20$30 \mathrm{~cm} \mathrm{bd}$ ). Its base and stem are bifacially flaked while the original flake ventral surface is still present on much of the remaining body. The distal and proximal arrow point fragments have proceeded sufficiently far along the manufacture trajectory and have taken on sufficient shape to allow them to be classified as Guerrero arrow point preforms. The Guerrero point type is commonly associated with mission occupations (Turner and Hester 1993:216). The specimens are characterized by triangular to lanceolate outlines and slightly to moderately concave bases.

\section{Gunflints}

Twelve gunflints made of local fine-grained chert were identified (Figures $5-45 \mathrm{~b}$ to $45 \mathrm{f}$ ). One of the specimens (Figure 5-45f; Unit 69, 0-10 cm bd) is a nearly square blade mid-section resembling the classic European-made gunflints. Use-wear, in the form of crushing and step fracturing, is present on both blade margins and on the two broken ends. Four additional gunflints have a roughly rectangular shape and are made on tertiary $(n=3)$ and secondary $(n=1)$ hard hammer stone flake blanks (Figures 5-45c and 45d). The ventral faces of these specimens are only marginally retouched with some removals intended to thin the bulb of percussion. The sixth gunflint is a roughly rectangular tertiary flake exhibiting minimal shaping. One lateral edge exhibits notable crushing and step fracturing on its ventral face. Limited use-wear is also present along the distal and proximal edges of the hard hammer stone flake. The seventh gunflint is a recycled dart point medial fragment from Unit $98(33-43 \mathrm{~cm}$ bd; Figure 5-45e). Based on the distribution of usewear, it appears that both break-faces and bifacially flaked margins of the specimen were utilized.

Three gunflints are rounded to ovate, unifacially flaked specimens that are recycled scrapers. What little remains of the specimens most resembles Late Archaic and Late Prehistoric end scrapers. However, since no 


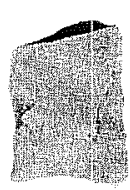

$a$

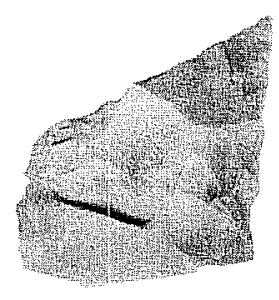

e
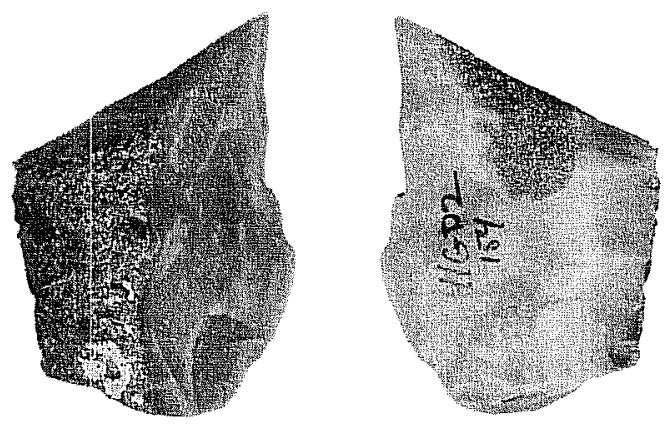

g

$\mathrm{b}$
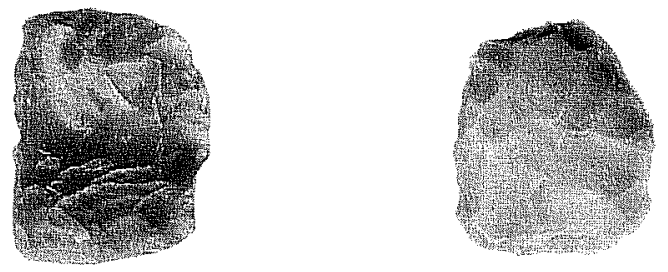

C
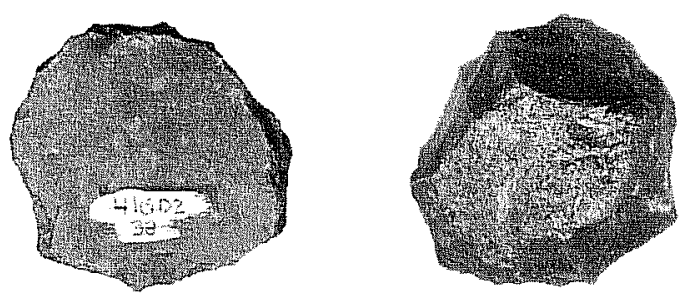

f

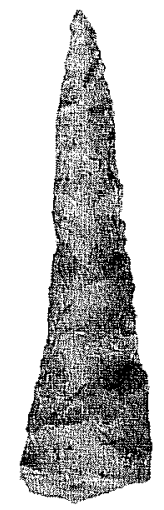

h

Figure 5-45. Selected lithic artifacts from Mission Rosario, 1999 excavations: (a) Guerrero arrow point preform (b) gunflint made on medial blade fragment (c-d) bifacially flaked gunflints made on tertiary flake blanks (e) gunflint made on recycled biface medial fragment ( $f$ ) gunflint made on recycled uniface (g) graver made on proximal blade fragment (h) drill made on distal blade fragment. 
differential patina is visible on the specimens, they lack clear indications of recycling. All specimens exhibit heavily crushed edges and step fracturing is common on their dorsal faces immediately adjacent their edges (Figure 5-45f).

\section{Scrapers}

A total of nine unifacial scrapers have been recovered from Mission Rosario excavations (Table 5-4). Based on the location of their working edges six (67\%) are classified as side scrapers, while the remaining three are end scrapers. Based on the degree of retouch on their working edges, four of the six side scrapers are expedient specimens, one is minimally retouched, and the final scraper is a formal specimen. The three end scrapers consist of two minimally retouched, and one expedient specimen (i.e., modified by use not retouch).

Although the sample sizes are small, expedient side scrapers have the shortest average working edge lengths $(13.2 \mathrm{~mm}, \mathrm{sd}=4.79)$, followed by minimally retouched $(28 \mathrm{~mm})$ and formal side scrapers $(48 \mathrm{~mm})$. Even among the three end scrapers, the two minimally retouched specimens have longer mean working edge lengths $(23.5 \mathrm{~mm}, \mathrm{sd}=2.12)$ than the single expedient end scraper $(18 \mathrm{~mm})$. This pattern suggests that at least in scraping tasks expedient side scrapers tend to be used to perform more limited tasks, at least as reflected by working edge length, than minimally retouched and formal functional equivalents.

\section{Knives}

Two items with micro-scalloped acute working edges reminiscent of serrated knife blades (see Table 5-4) are included in this group. One of the two (Unit 94, 0$10 \mathrm{~cm} \mathrm{bd}$ ) is a secondary flake with a single convex working edge. A narrow cortex-covered edge may have served as backing opposite the cutting edge of this tool. The second specimen in the collection (Unit 90, $0-27 \mathrm{~cm} \mathrm{bd}$ ) is an elongated angular piece of chert debris with one straight working edge. The shortest of the two specimens has a working edge measuring $37 \mathrm{~mm}$ in length; the working edge of the larger specimen measures $47 \mathrm{~mm}$.

\section{Graver}

A single expedient graver on a secondary proximal blade fragment is included in this category (Table 54 , Figure $5-45 \mathrm{~g}$ ). The intersection of the tangential blade break and lateral edge of the blade form a very acute point that exhibits some polish and micro flaking. At least two burin flakes have been removed along the edge of the graver in attempts to rejuvenate the working tip.

\section{Perforator}

A single drill made on a tertiary blade fragment was recovered in Unit 64 (50-60 cm bd; Table 5-4, Figure $5-45 \mathrm{~h}$ ). The $50 \mathrm{~mm}$-long specimen has a slight longitudinal curvature and the blade is $11 \mathrm{~mm}$-wide at its proximal end.

\section{Indeterminate Unifaces}

Nine unifacially retouched and/or modified flakes and flake fragments are included in this category (Table 5-4). These specimens represent items that could not be classified into functional tool categories (e.g., end or side scrapers, or knives, etc.) due to their fragmentary nature or lack of use-wear. Eight of the specimens represent unifacially retouched edge fragments. These specimens were simply too incomplete to allow meaningful measurements of dimensions. The ninth indeterminate uniface is a large secondary quartzite flake with unifacial retouch along one lateral edge and a portion of the distal end. Given the natural shine of the raw material it was not possible to determine based on polish distribution whether the tool has been used prior to discard. Therefore, it is included in this analytical category.

\section{Indeterminate Biface}

A single item is included in this category (Table 5-4). It is a small bifacially flaked edge fragment that may derive from an arrow point or some other relatively thin biface. This item is too incomplete to allow for proper identification. 


\section{Cores}

A total of five cores have been recovered during excavations (Table 5-4). One is petrified wood and four are fine-grained chert. In contrast to cores from other mission sites (D. E. Fox 1979; Tomka 1999) none of the specimens are blade/bladelet cores. Rather, they represent a combination of tested pebbles $(n=3)$, and multi-directional reduction strategies.

\section{Unmodified Debitage}

A total of 877 unmodified pieces of debitage was recovered from excavations at Mission Rosario (Appendix A, A-3). The large majority of these $(n=735$, $84 \%)$ are of fine-grained chert. Petrified wood $(n=56$, $6.4 \%)$ and quartz arenite $(n=55,6 \%$; Chandler and Lopez 1992) are the two next most common material types. Fine-grained quartzite ( $\mathrm{n}=22,2.5 \%)$ occurs in small quantities and other more coarse-grained materials (e.g., chert $[n=8]$ and quartzite $[n=1]$ ) occur in small quantities. The breakdown of cortex categories among their most common raw material types indicates that tertiary flakes constitute a higher percentage than secondary flakes in all materials (Table 5-5). Primary flakes form a small portion of the three raw material collections. Interestingly, quartz arenite contains a higher proportion of tertiary debitage than any other material type. This pattern suggests that much of the quartz arenite that arrived on site was brought in as decorticate cores or most probably decorticate blanks, preforms, and/or finished tools.
The distribution of debitage by size classes indicates that in general $11-20 \mathrm{~mm}$ specimens dominate the three most common raw material types. The $21-30$ and $31-$ $40 \mathrm{~mm}$ size class specimens occur in lower percentages (Table 5-6). The smallest size class (1-10 mm) is under-represented primarily because of the $1 / 4$ inch hardware cloth used in screening the bulk of the matrix. The percentage of specimens in the larger size classes decreases with increased size. Despite these general trends, some interesting differences emerge between the raw materials. For instance, the size of the fine-grained chert debitage suggests that the entire reduction sequence is represented in the collection. On the other hand, the high proportion of small flakes in the petrified wood debitage, and the relative lack of larger flakes suggests that they represent the reduction of relatively small raw materials such as small cores, prepared blanks or finished tools. In contrast, the high proportion of larger quartz arenite flakes in combination with the high percentage of tertiary specimens suggests that this raw material arrived on site in relatively large but partially decortified pieces such as prepared cores or large blanks or preforms.

The analysis of the debitage from the three most common raw materials indicates that the majority of the quartz arenite $(n=41,74 \%)$ and petrified wood $(n=34$, $61 \%)$ debitage consists of chips. About half $(n=375$, $51 \%$ ) of the fine-grained chert debitage retains no striking platforms. The distribution of platform facet counts on platform-bearing flakes in the three most common raw materials indicates that among the petrified wood

Table 5-5. Percentage of debitage by cortex category

on the three most common raw material types

from Mission Rosario, 1999 excavations

\begin{tabular}{lcccc|}
\hline & Primary & Secondary & Iertiary & Iotal \\
Fine-Grained Chert & 4 & 32 & 64 & 100 \\
Petrified Wood & 2 & 36 & 62 & 100 \\
Quartz Arenite & 2 & 24 & 74 & 100 \\
\hline
\end{tabular}

Table 5-6. Percentage of debitage by size classes in the three most common raw material types from Mission Rosario, 1999 excavations

\begin{tabular}{|lccccccc|}
\hline & $0-10$ & $11-20$ & $21-30$ & $31-40$ & $41-50$ & $51+$ & Totals \\
Fine-Grained Chert & 5 & 52 & 26 & 11 & 4 & 1 & 99 \\
Petrified Wood & 9 & 57 & 29 & 5 & & & 100 \\
Quartz Arenite & 2 & 43 & 33 & 9 & 13 & & 100 \\
& & & & & & & \\
\hline
\end{tabular}


and quartz arenite single faceted flakes are the most common (complete and proximal fragments, Table 57). Importantly, corticate platforms are the most common among fine-grained chert platform-bearing flakes. Platform-bearing flakes with two facets occur in nearly equal proportions among fine-grained chert and quartz arenite debitage. On the other hand, few of these platform-bearing flakes occur among the petrified wood debitage. Flakes and flake fragments with three or more platform facets are most common among the quartz arenite and petrified wood debitage. The overwhelming dominance of corticate and single faceted platform-bearing flakes among the fine-grained chert and petrified wood debitage is similar to platform faceting breakdowns in the debitage from other missions such as Concepción and San Juan Capistrano (D. E. Fox 1979:Table 5-8-5), as well as San José (Tomka 1999; Tomka and Fox 1998, Tomka et al. 1999). Raw material reduction strategies and tool manufacture was heavily skewed towards blade manufacture and the making and rejuvenation of unifacial, often expedient, tool forms. The fact that multi-faceted (two and three+) platform-bearing flakes represent one half of the quartz arenite debitage suggests that a good proportion of these specimens may be derived from the reduction of bifacial tool forms (Tomka 1989). Since about 30 percent of the finegrained chert and petrified wood debitage also consists of multi-faceted specimens, it is likely that bifacial reduction of cores and bifacial tool manufacture was also more common at Mission Rosario than at Concepción, San Juan Capistrano and San José.
The classification of the debitage from the three most common raw materials indicates that $164(22 \%)$ of the fine-grained chert specimens could not be classified into flake type categories. A total of $24(43 \%)$ of the petrified wood flakes and $18(33 \%)$ of the quartz debitage also remained unclassified. The breakdown of the remaining debitage collections in terms of flake type indicates that core/platform preparation flakes constitute the largest proportion of the fine-grained chert and petrified wood samples (Table 5-8). Given that, as mentioned before, a large proportion of the platform-bearing flakes of these raw materials are single faceted or corticate, it is likely that most of these flakes derive from the preparation of uni- or bidirectional cores rather bifacial cores (e.g., bifaces). The moderate proportion of core reduction flakes, which include blades and bladelets, among the fine-grained chert debitage seems to corroborate this observation.

Flakes identified as the products of uniface reduction (i.e., manufacture, repair, resharpening) strategies occur in small proportions among all three raw materials. The fact that nearly one-fourth of the fine-grained chert and petrified wood debitage consists of biface reduction flakes also indicates that biface manufacture was not an uncommon activity on site. The common occurrence of bifacial reduction debitage of quartz arenite indicates that a significant proportion of the lithic manufacture activities on site related to biface manufacture and/or resharpening.

Table 5-7. Percentage of debitage platform faceting categories in the three most common raw material types from Mission Rosario, 1999 excavations

\begin{tabular}{lccccc|}
\hline & Corticate & Single & Iwo & Ihreet & Totals \\
Fine-Grained Chert & 38 & 32 & 13 & 17 & 100 \\
Petrified Wood & 18 & 55 & 4 & 23 & 100 \\
Quartz Arenite & & 50 & 14 & 36 & 100 \\
\hline
\end{tabular}

Table 5-8. Percentage of debitage by flake type in the three most common material types from Mission Rosario, 1999 excavations

\begin{tabular}{lcccccc|}
\hline & $\begin{array}{c}\text { Angular } \\
\text { Debris }\end{array}$ & $\begin{array}{c}\text { Bifacial } \\
\text { Reduction }\end{array}$ & $\begin{array}{c}\text { Unifacial } \\
\text { Reduction }\end{array}$ & $\begin{array}{c}\text { Core } \\
\text { Beduction }\end{array}$ & $\begin{array}{c}\text { Core/Platform } \\
\text { Preparation }\end{array}$ & Totals \\
F-G Chert & 4 & 21 & 5 & 8 & 63 & 100 \\
Petrified Wood & 9 & 22 & 3 & 0 & 66 & 100 \\
Quartz Arenite & 5 & 43 & 5 & 5 & 41 & 100 \\
\hline
\end{tabular}


Overall, the lithic technology evident in the Rosario lithic artifacts indicates that fine-grained chert may have been obtained locally or nearby while petrified wood and quartz arenite may have been obtained at some distance from the mission, decortified or made into blanks, preforms, or finished tools before being introduced on site. The analysis of the small tool collection from the site indicates a tool kit composed primarily of expedient scrapers, and the continued manufacture of stone arrow points even though guns have already been in use judging from the large number of native-made gunflints. This assemblage composition pattern may reflect the use, availability, and long use-life of metal knives and a relative lack of raw materials for the manufacture of metal arrow points. The analysis of the gunflints indicates that some degree of artifact recycling was practiced by the inhabitants particularly when it came to the reuse of tool forms that were best suited for remanufacture into gunflints. Raw material reduction strategies are dominated by uni- or bi-directional core reduction to produce blades and flake blanks for the manufacture of gunflints and arrow points. Bifacial reduction appears to be employed in arrow point manufacture and the shaping of some gunflint blanks. In contrast to some of the other roughly contemporaneous missions in South Texas (e.g., Concepción, San José, Capistrano), bifacial reduction appears to have been more common at Rosario. Although this impression may be in part the result of mixing of pre-Colonial levels with Colonial occupation materials, relative lack of Late Prehistoric and late Archaic materials, except those recycled, in the lithic collection suggests that much of the pattern is Colonial rather than pre-Colonial in nature. The utilization of a range of raw materials and the different procurement strategies and reduction tactics they exhibit does demonstrate a degree of sophistication in lithic technology that is reminiscent of earlier time periods. 


\section{Vertebrate Faunal Remains}

\author{
Barbara A. Meissner
}

\section{Methods}

A total of 14,355 vertebrate faunal remains, with a total weight of $19,759.61 \mathrm{~g}$, was recovered during the project. The bone was identified to the most specific taxon possible using the comparative collection at CAR, as well as several reference texts (Balkwill and Cumbaa 1992; Boessneck 1970, Cohen and Serjeantson 1996; Gilbert 1990; Hildebrand 1955, Hillson 1986; Olsen 1960,1964, 1968; Schmid 1972; Sobolik and Steele 1996). Identifications were conservative; i.e., bone, which appeared to be cow-sized, was not identified as Bos taurus unless it could be differentiated from Bison and Equus species. All bone was weighed. Evidence of exposure to heat was noted on all bone. Element, portion of element, side, evidence of immaturity, and pathologies were noted on bone identified to the order taxonomic level. When bone could be identified only to class (e.g., mammal, bird, etc.) an estimate of the size of the animal was made when possible. After the analysis the bone was bagged by unit and level. Bone identified to at least the order taxonomic level was bagged separately and included in the unit-level bags.

Two measures of relative abundance were used to estimate the importance of all species to the meat diet at Rosario: Number of Identified Specimens (NISP), and bone weight. NISP is the count of specimens that have been identified to at least the genus taxonomic level. Its use as a measure of relative abundance is problematic (Grayson 1984:20-24; Reitz and Wing 1999:191192). As Reitz and Wing (1999:192) have remarked: "By using [NISP] as a measure of abundance, the analyst assumes cultural and non-cultural fragmentation is uniform, recovery rates are constant for each taxon, and all taxa have an equal opportunity to be counted." Of course, none of those assumptions should, in fact, be made. NISP cannot differentiate between 11 fragments from 11 different cows and 11 fragments of the same bone. Reliance on NISP alone will distort the estimate of relative abundance in favor of small animals and animals with parts that are more readily identifiable in fragmentary form. For instance, the anterior diaphysis of the metatarsal of the white-tailed deer (Odocoileus virginianus) is so distinctive that it can readily be identified even in very small fragments. A small fragment of the same element in other small artiodactyls, such as goat or sheep, is not so distinctive and could not be identified to genus. This will lead to the "analytical absence" (Lyman and O'Brien 1987) of fragments of artiodactyl metatarsal that are not from deer, and make the importance of deer in the collection - compared to sheep and goats- seem larger than it really was.

Minimum Number of Individuals (MNI) is a derived measure commonly used to get around some of the problems of NISP. MNI is the minimum number of animals of each species that must have been present to account for the elements identified for that species. MNI can, if properly calculated, be a useful counterpoint to NISP. However, MNI also has problems as a measure of relative abundance. Grayson (1984: 2949) has pointed out that MNI is extremely sensitive to the way in which the analyst aggregates the data. That is, MNI counts can be made to vary a great deal by changing how the analyst groups the data, for instance, by unit/level, by complete unit, by natural level, by the entire site, etc. (see Grayson 1984:34-49). In the particular case of this project, MNI does not provide useful data. Not only is MNI of questionable value in highly fragmented collections, but the way this collection was made, that is, from a series of widely dispersed units, makes calculation of MNI useless. In these circumstances, MNI becomes a count of the number of units in which a taxon was found not a measure of abundance, per se (Meissner 1998b:33). Therefore, MNI will not be used as a measure of abundance in this report.

Bone weight can also, with caution, be used as a measure of relative abundance. Bone weight is, in general, a better indicator of relative dietary importance (as opposed to relative abundance) than NISP, but this measure must not be used exclusively. In general, larger bones carry more meat, but the relationship is not linear (Reitz and Scarry 1985:18), varies among different taxa, and there is considerable variation from one part of the animal to another (e.g., lower legs of cattle are dense heavy bones but carry relatively little meat compared to other bones of the body). Bone weight also suffers from the necessary assumption that 
all taphonomic factors that affect bone weight (such as leaching, mineralization, or encrustation), have affected all bone in the collection uniformly. Bone weight tends to emphasize the importance of larger, heavier animals, and because of this, tends to counterbalance the tendency of NISP to emphasize smaller animals.

Each analytic method discussed previously is subject to a number of biases (Reitz and Wing 1999:200). Used together, however, NISP and bone weight can provide a better view of the relative importance of each species to diet than either can provide when used alone.

\section{Analysis}

Most of this collection was in a highly fragmented condition, making identification of the majority of the bone beyond the class taxonomic level impossible. The average bone weight for the entire collection was only $1.4 \mathrm{~g}$. Ninety-two percent of the bone could be identified only as mammalian. Only 404 bones ( 2.8 percent) could be identified to the genus taxonomic level. A list of identified taxa from the Mission Rosario collection is shown in Table 5-9, with counts and weights. A complete, provenienced list of all data recovered from the bone is in Appendix B.

Table 5-9. Identified Taxa from Mission Rosario, 1999 excavations

\begin{tabular}{|l|l|r|r|}
\hline \multicolumn{1}{|c|}{ Taxa } & \multicolumn{1}{|c|}{ Common Name } & Count & Weight (g) \\
\hline Mammalia & Mammals & 125 & 446.08 \\
\hline Artiodactyl & Deer, sheep, goats & 1 & 14.82 \\
\hline Bison bison & American bison & 54 & $1,602.99$ \\
\hline Bos taurus & Cattle & 125 & $1,873.44$ \\
\hline Bovinae & Cattle or bison & 6 & 14.46 \\
\hline Canis sp. & Dog, wolf, or coyote & 6 & 14.91 \\
\hline Capra hircus & Domestic goat & 2 & 1.57 \\
\hline Capra /Ovis & Goat or sheep & 3 & 0.92 \\
\hline Dasypus novemcintus & Armadillo & 7 & 19.83 \\
\hline Didelphis virginianus & Opossum & 9 & 88.57 \\
\hline Equus sp. & Horse family & 1 & 74.63 \\
\hline Equus caballos & Horse & 6 & 1.88 \\
\hline Neotoma sp. & Woodrats & 29 & 154.10 \\
\hline Odocoileus virginianus & White-tailed deer & 24 & 119.53 \\
\hline Ovis aries & Domestic sheep & 6 & 15.37 \\
\hline Pecari tajacu & Javelina, collared peccary & 1 & 0.69 \\
\hline Procyon lotor & Raccoon & 9 & 1.64 \\
\hline Rodentia & Rodents & 1 & 0.04 \\
\hline Sciurus sp. & Tree squirrels & 1 & 1.11 \\
\hline Sus scrofa & Domestic pig & & \\
\hline
\end{tabular}


Table 5-9, continued...

\begin{tabular}{|c|c|c|c|}
\hline Taxa & Common Name & Count & Weight (g) \\
\hline Sylvilagus sp. & Cottontail rabbit & 27 & 19.15 \\
\hline Ursus cf. americanus & Black bear & 1 & 1.62 \\
\hline Mammal--very small & Rat, mouse-sized & 3 & 0.24 \\
\hline Mammal--small & Rabbit-sized & 19 & 4.96 \\
\hline Mammal--medium & Dog-sized & 32 & 36.12 \\
\hline Mammal--large & Deer, sheep-sized & 118 & 308.19 \\
\hline Mammal--very large & Cattle, bison, horse-sized & 1612 & 8.447 .04 \\
\hline \multirow[t]{2}{*}{ Mammal } & Size indeterminate & 11,489 & $6,003.63$ \\
\hline & Total Mammals & $13,717.00$ & $19,267.53$ \\
\hline Aves & Birds & & \\
\hline Anas sp. & Ducks & 2 & 0.64 \\
\hline Ardeidae & Herons & 1 & 3.38 \\
\hline Branta canadensis & Canadian goose & 2 & 2.97 \\
\hline Falconiformes & Birds of prey & 1. & 7.51 \\
\hline Gallus domesticus & Chicken & 44 & 41.86 \\
\hline Meleagris gallopavo & Turkey & 18 & 47.12 \\
\hline Aves--medium & Robin-sized & 1 & 0.09 \\
\hline Aves--large & Chicken-sized & 23 & 16.99 \\
\hline Aves--very large & Turkey, hawk-sized & 25 & 25.05 \\
\hline \multirow[t]{2}{*}{ Aves } & Size indeterminate & 169 & 76.02 \\
\hline & Total Birds & 286 & 221.63 \\
\hline Reptilia & Reptiles & & \\
\hline Agkistrodon sp. & Moccasins \& copperheads & 1 & 0.12 \\
\hline Alligator mississippiensis & Alligator & 6 & 5.71 \\
\hline Chelydra serpentina & Snapping turtle & 1 & 0.32 \\
\hline Coluber constrictor & Racer & 1 & 0.15 \\
\hline Crotalus sp. & Rattlesnakes & 1 & 0.30 \\
\hline Kinosternidae & Mud and musk turtles & 4. & 5.99 \\
\hline Lampropeltis sp. & King snakes & 3 & 0.93 \\
\hline Pseudomys sp. & Pond sliders & 24 & 79.66 \\
\hline Terrepene sp. & Box turtles & 7 & 6.33 \\
\hline Thamnophis sp. & Garter snakes & 2 & 0.13 \\
\hline Trionvx sp. & Softshelled turtles & 37. & 37.34 \\
\hline \multirow[t]{2}{*}{ Testudines } & Turtles & 36 & 31.11 \\
\hline & Total Reptiles & 123 & 168.09 \\
\hline Osteichthyes & Boney Fishes & & \\
\hline Aplodinotus grunniens & Freshwater drum & 9 & 5.89 \\
\hline Ictalurus sp. & Catfish & 41 & 20.14 \\
\hline Lepisosteus sp. & Gars & 13 & 2.46 \\
\hline Micropterus sp. & Black bass & 1 & 0.47 \\
\hline Pylodictus olivaris & Bullhead catfish & 8 & 4.77 \\
\hline \multirow[t]{2}{*}{ Osteichthyes } & Unidentified fish & 82 & 23.98 \\
\hline & Total Fishes & 154 & 57.71 \\
\hline \multirow[t]{2}{*}{ Vertebrata } & Unidentified bone & 75 & 44.65 \\
\hline & Overall Totals & 14,355 & $19,759.61$ \\
\hline
\end{tabular}


There was a diverse list of identified animals in the collection. Thirty-five taxa were identified to at least the genus level in the collection, including 16 mammals, four birds, 10 reptiles (including 5 snakes,
4 turtles, and alligator), and five freshwater fish (Table 5-10). Cattle (Bos) was the most commonly identified animal, followed by chicken (Gallus), catfish (Ictalurus), soft-shelled turtle (Trionyx), deer (Odocoileus), and sheep (Ovis).

Table 5-10. Identified Genera from Mission Rosario, 1999 excavations

\begin{tabular}{|c|c|c|c|c|c|}
\hline Taxa & Common Name & Count & $\%$ & Weight (g) & $\%$ \\
\hline Mammalia & Mammals & & & & \\
\hline Bison bison & American bison & 1 & $0.2 \%$ & 14.82 & $0.62 \%$ \\
\hline Bos taurus & Catule & 54 & $13.4 \%$ & $1,602.99$ & $66.74 \%$ \\
\hline Canis sp. & Dog, wolf, or coyote & 6 & $1.5 \%$ & 14.46 & $0.60 \%$ \\
\hline Capra hircus & Domestic goat & 6 & $1.5 \%$ & 14.91 & $0.62 \%$ \\
\hline Dasypus novemcintus & Armadillo & 3. & $0.7 \%$ & 0.92 & $0.04 \%$ \\
\hline Didelphis virginianus & Opossum & 7 & $1.7 \%$ & 19.83 & $0.83 \%$ \\
\hline Equus sp. & Horse family & 9 & $2.2 \%$ & 88.57 & $3.69 \%$ \\
\hline Equus caballos & Horse & 1 & $0.2 \%$ & 74.63 & $3.11 \%$ \\
\hline Neotoma sp. & Woodrats & 6 & $1.5 \%$ & 1.88 & $0.08 \%$ \\
\hline Odocoileus virginianus & White-tailed deer & 29 & $7.2 \%$ & 154.10 & $6.42 \%$ \\
\hline Ovis aries & Domestic sheep & 24 & $5.9 \%$ & 119.53 & $4.98 \%$ \\
\hline Pecari tajacu & Javelina, collared peccary & 6 & $1.5 \%$ & 15.37 & $0.64 \%$ \\
\hline Procyon lotor & Raccoon & 1. & $0.2 \%$ & 0.69 & $0.03 \%$ \\
\hline Sciurus sp. & Tree squirrels & 1 & $0.2 \%$ & 0.04 & $<0.00 \%$ \\
\hline Sus scrofa & Domestic pig & 1. & $0.2 \%$ & 1.11 & $0.05 \%$ \\
\hline Sylvilagus sp. & Cottontail rabbit & 27 & $6.7 \%$ & 19.15 & $0.80 \%$ \\
\hline \multirow[t]{2}{*}{ Ursus cf. americanus } & Black bear & 1 & $0.2 \%$ & 1.62 & $0.07 \%$ \\
\hline & Total Mammals & 183 & $45.3 \%$ & $2,144.62$ & $89.29 \%$ \\
\hline Aves & Birds & & & & \\
\hline Anas sp. & Ducks & 2 & $0.5 \%$ & 0.64 & $0.03 \%$ \\
\hline Branta canadensis & Canadian goose & 2 & $0.5 \%$ & 2.97 & $0.12 \%$ \\
\hline Gallus domesticus & Chicken & 44 & $10.9 \%$ & 41.86 & $1.74 \%$ \\
\hline \multirow[t]{2}{*}{ Meleagris gallopavo } & Turkey & 18 & $4.5 \%$ & 47.12 & $1.96 \%$ \\
\hline & Total Birds & 66 & $16.3 \%$ & 92.59 & $3.85 \%$ \\
\hline Reptilia & Reptiles & & & & \\
\hline Agkistrdon sp. & Moccasins \& copperheads & 1 & $0.2 \%$ & 0.12 & $0.00 \%$ \\
\hline Alligator mississippiensis & Alligator & 6 & $1.5 \%$ & 5.71 & $0.24 \%$ \\
\hline Chelydra serpintina & Snapping turtle & 1 & $0.2 \%$ & 0.32 & $0.01 \%$ \\
\hline Coluber constrictor & Racer & 1 & $0.2 \%$ & 0.15 & $0.01 \%$ \\
\hline Crotalus sp. & Rattlesnakes & 1 & $0.2 \%$ & 0.30 & $0.01 \%$ \\
\hline Lampropeltis sp. & King snakes & 3 & $0.7 \%$ & 0.93 & $0.04 \%$ \\
\hline Pseudomys sp. & Pond sliders & 24 & $5.9 \%$ & 79.66 & $3.32 \%$ \\
\hline Terrepene sp. & Box turtles & 7 & $1.7 \%$ & 6.33 & $0.26 \%$ \\
\hline Thamnophis sp. & Garter snakes & 2 & $0.5 \%$ & 0.13 & $0.01 \%$ \\
\hline \multirow[t]{2}{*}{ Trionvx sp. } & Softshelled turtles & 37 & $9.2 \%$ & 37.34 & $1.55 \%$ \\
\hline & Total Reptiles & 83 & $20.5 \%$ & 130.99 & $5.45 \%$ \\
\hline Osteichthyes & Boney Fishes & & & & \\
\hline Aplodinotus grunniens & Freshwater drum & 9 & $2.2 \%$ & 5.89 & $0.25 \%$ \\
\hline Ictalurus sp. & Catfish & 41 & $10.1 \%$ & 20.14 & $0.84 \%$ \\
\hline Lepisosteus sp. & Gars & 13 & $3.2 \%$ & 2.46 & $0.10 \%$ \\
\hline Micropterus sp. & Black bass & 1 & $0.2 \%$ & 0.47 & $0.02 \%$ \\
\hline \multirow[t]{3}{*}{ Pylodictus olivaris } & Bullhead catfish & 8 & $2.0 \%$ & 4.77 & $0.20 \%$ \\
\hline & Total Fishes & 72 & $17.8 \%$ & 33.73 & $1.40 \%$ \\
\hline & Overall Totals & 404 & $100.0 \%$ & $2,401,93$ & $100.00 \%$ \\
\hline
\end{tabular}




\section{Bone Distribution}

The bone was not scattered evenly across the site. Sixty-two units had less than 100 bones each, but six units had more than 500 bones each:

$\begin{array}{ll}\text { Unit 1 } & (n=793), \\ \text { Unit 64 } & (n=996), \\ \text { Unit 66 } & (n=1958), \\ \text { Unit 72 } & (n=810), \\ \text { Unit 76 } & (n=594), \text { and } \\ \text { Unit 100 } & (n=2746),\end{array}$

In general, bone was most dense in units near the outer walls (see Table 5-11). Very little bone was recovered inside the rooms. The densest concentration of bone was at the southwest corner of the outer walls, where Units 66 and 100 were excavated (see Figures 3-1 and 5-1). Together, these two units constituted 32.8 percent $(n=4704)$ of the total bone recovered. Bone density was high all along the southern wall. These units are not far north of the units excavated by Ricklis (1998:49), which encountered large quantities of bone (deFrance 1999:171).

Table 5-11. Average bone per unit in several areas of Mission Rosario, 1999 excavations

\begin{tabular}{|c|c|c|}
\hline \multicolumn{2}{|l|}{ Unit location } & $\begin{array}{c}\text { Average } \\
\text { Count } \\
\end{array}$ \\
\hline Units inside wall & North (5 units) & 311 \\
\hline & South (7 units) & 390 \\
\hline & East (7 units) & 160 \\
\hline & West (2 units) & 562 \\
\hline Units near gates & North (4 units) & 249 \\
\hline & South (4 units) & 203 \\
\hline Units near structures & (25 units) & 20 \\
\hline Units inside structures & (27 units) & 13 \\
\hline Units outside south wall & (4 units) & 1228 \\
\hline
\end{tabular}

Excavations during this project showed that previous investigations by the WPA had disturbed about $20 \mathrm{~cm}$ of sediments over some portions of the site. In order to see if this disturbance was a major cause of the fragmentation of the bone, the collection was divided into two groups, one from levels above $20 \mathrm{~cm}$ and one from levels below $20 \mathrm{~cm}$. In some cases, the levels did not break at $20 \mathrm{~cm}$ (e.g. $0-23 \mathrm{~cm}$ below datum, or $12-22 \mathrm{~cm}$ below datum). In those cases, bone from the level was put in the category represented by the majority of the unit.

Table 5-12 shows a comparison of bone from above and below $20 \mathrm{~cm}$ bd. Three items of this comparison can be used as rough indications of relative fragmentation of the bone: the average bone weight, the percent of total bone identified to genus taxonomic level, and the percent of very large mammal bone (i.e., cow/bison/horse-sized bone) that could be identified to the genus taxonomic level. All three of these indicators show that the bone in the upper $20 \mathrm{~cm}$ of the excavations units is, if anything, slightly less fragmented than the bone below $20 \mathrm{~cm}$, however, the differences are minor. The disturbance of the upper 20 $\mathrm{cm}$ on the site does not appear to have contributed in a substantial way to the fragmentation of the bone.

Table 5-12. Comparison of Bone from

Above and Below $20 \mathrm{~cm}$ bd, Mission Rosario, 1999 excavations

\begin{tabular}{|l|r|r|}
\hline & $\begin{array}{r}\text { Levels Above } \\
20 \mathrm{~cm} \mathrm{BD}\end{array}$ & $\begin{array}{c}\text { Levels Below } \\
20 \mathrm{~cm} \mathrm{BD}\end{array}$ \\
\hline Total bone & 8206 & 6143 \\
\hline Total Weight $(g)$ & $11,546.04$ & 8276.81 \\
\hline Average Bone Weight $(\mathrm{g})$ & 1.4 & 1.3 \\
\hline Count of Genera Identified & 29 & 22 \\
\hline NISP & 252 & 151 \\
\hline$\%$ of NISP & $3.1 \%$ & $2.5 \%$ \\
\hline $\begin{array}{l}\% \text { of Identified Very Large } \\
\text { Mammal }\end{array}$ & $2.9 \%$ & \\
\hline
\end{tabular}

Other taphonomic factors certainly played a part in the fragmentation. Excavation itself will damage some bone, especially if it is already fragile. Some of the bone displayed evidence of considerable etching by acids as a result of soil $\mathrm{pH}$, biological activity, or both. Evidence of exposure to atmospheric weathering was also present on some bone. The majority of the bones were not heavily impacted by these factors.

\section{Evidence of Exposure to Heat}

Evidence of exposure to heat can indicate whether bone was routinely thrown into the fire as a disposal method. Under normal cooking conditions bone may become smoke-stained or charred, but a long period of heating at high temperatures is needed to calcine bone, circumstances normally seen only when bone is 
deliberately burned (Davis 1990:75). This collection had a relatively high percentage of bone showing heat alteration, 14.9 percent $(n=2140)$. Of these, 67.5 percent $(n=1445)$ were smoke-stained or charred, while 32.5 percent $(n=695)$ were partially calcined or calcined. This indicates that at least some of the bone was deliberately burned, probably either as fuel or as a disposal method (Lyman 1994:388).

The burned bone was not distributed evenly, however. A total of 52.1 percent (1104/2140) of all burned bone was from Unit 100. In Unit 100, 40 percent of the bone recovered had been burned. Twenty-seven percent of the bone from Unit 4 was also burned. These two units were the only ones with a total of more than 10 bones recovered that had a burned bone percentage of more than 20 percent.

\section{Pathologies}

There were very few bones exhibiting pathologies in this collection. The $2+3$ carpal of a cow showed a small amount of arthritic lipping. One first phalange of a goat (Capra hircus) showed evidence of serious inflammation of the distal end of the bone, just proximal of the epiphysis (Figure 5-46). There is excess growth and ossification of a tendon on the lateral side. This may be the result of an evulsion fracture of the tendon and subsequent incomplete healing, however, there appears to be significant involvement of the adjacent metaphysis, with some inflammatory response spreading to the epiphysis (see Figure 5-46a), which suggests a bacteriological agent is responsible.

One abnormality was noted in the canine of an opossum. The canine was normally shaped but was roughly twice the size of a normal canine. All other teeth in the maxilla were of normal size. The result of this is a "saber-tooth" appearance. Although this enlarged tooth can be considered a defect, it may or may not have interfered with normal hunting and eating.

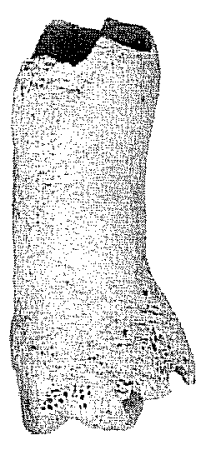

a

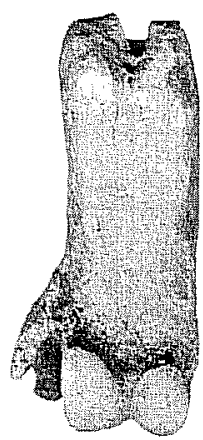

b

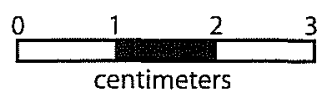

Figure 5-46. Phalange of a goat, showing pathological tendon ossification: a) anterior view, showing involvement of the metaphysis and epiphysis; b) posterior view. Actual size. 
Discussion

\section{The Meat Diet at Mission Rosario}

Table 5-10 shows that cattle are the most abundant meat resource reflected in the collection, both by NISP (13.4 percent of total NISP) and by bone weight (66.7 percent of total NISP weight). The latter is probably a closer estimate of the amount of beef in the diet than the former. The dominance of cattle can be shown by the fact that the next largest percentage of total NISP bone weight was 6.8 percent, provided by horse. However, horse may or may not have provided part of the diet. Excluding horse, deer had the next highest bone weight ( 6.4 percent), followed by sheep ( 5.0 percent), pond sliders ( 3.3 percent), turkey ( 2.0 percent), and chicken (1.7 percent).

Although the importance of cattle in the diet at Rosario is a common feature of Spanish Colonial mission sites in South Texas, comparison with seven other recent analyses from such sites (including Ricklis' 1997 excavations at Rosario [deFrance 1999] and excavations at Mission San Antonio [Meissner 1999a], Mission
San José [Meissner 1998a; Meissner 1999b; Meissner 1999c], Mission Concepción [Meissner 2000a], and Mission San Juan [Meissner 2000b] in San Antonio) shows that this collection has the lowest percentage, by weight, of cattle bone (Table 5-13). With one exception, it has the highest percentage, by weight, of deer bone, as well as more than twice the next highest percentage, by weight, of turtle. Thus, although in a general way, this collection is very similar to other Spanish Colonial sites, there is more deer and more turtle present than is usually seen in such sites.

Table 5-14 compares the NISP of wild species in the analyses listed above with the current project. The current project has the highest overall percentage, although two collections, one from San José and one from San Juan have nearly as large a percentage of wild animals (Table 5-14). There is a distinct difference, however, in which classes the wild animals are distributed. Only the current project has large percentages of both fish and reptiles (mostly turtles). In most collections, the wild animals are mostly mammals, while in the collection from the current project wild animals are almost evenly distributed between mammals, reptiles, and fish (Table 5-14).

Table 5-13. Comparison of \% of Total Number of Identified Specimens (NISP) bone weight in 8 Spanish Colonial Fauna Collections

\begin{tabular}{|l|r|r|r|r|r|r|r|r|}
\hline & \multicolumn{2}{|c|}{ Rosario } & \multicolumn{3}{|c|}{ San José } & Concepción & San Juan & San Antonio \\
\cline { 2 - 9 } & $\begin{array}{c}\text { Current } \\
\text { project }\end{array}$ & $\begin{array}{c}\text { deFrance } \\
1999 \%\end{array}$ & $\begin{array}{c}\text { Meissner } \\
1998 \mathrm{~b}\end{array}$ & $\begin{array}{c}\text { Meissner } \\
1999 \mathrm{~b}\end{array}$ & $\begin{array}{c}\text { Meissner } \\
1999 \mathrm{c}\end{array}$ & $\begin{array}{c}\text { Meissner } \\
2000 \mathrm{a}\end{array}$ & $\begin{array}{c}\text { Meissner } \\
2000 \mathrm{~b}\end{array}$ & $\begin{array}{c}\text { Meissner } \\
1999 \mathrm{a}\end{array}$ \\
\hline & \multicolumn{7}{|c|}{$\%$ of Total NISP Weight } \\
\hline Cattle & $66.7 \%$ & $93.3 \% *$ & $76.0 \%$ & $78.0 \%$ & $68.30 \%$ & $84.3 \%$ & $80.2 \%$ & $76.2 \%$ \\
\hline Sheep, goat, pig & $5.6 \%$ & $0.7 \%$ & $6.3 \%$ & $6.3 \%$ & $0.9 \%$ & $0.7 \%$ & $4.4 \%$ & $1.5 \%$ \\
\hline Birds & $3.9 \%$ & $0.6 \%$ & $1.1 \%$ & $0.4 \%$ & $1.4 \%$ & $0.4 \%$ & $1.0 \%$ & $<0.0 \%$ \\
\hline Deer & $6.4 \%$ & $4.1 \%$ & $4.5 \%$ & $5.5 \%$ & $12.8 \%$ & $2.4 \%$ & $3.4 \%$ & $1.1 \%$ \\
\hline Turtles & $5.1 \%$ & $0.4 \%$ & $1.5 \%$ & $2.4 \%$ & $0.6 \%$ & $1.3 \%$ & $1.7 \%$ & $0.2 \%$ \\
\hline Fish & $1.4 \%$ & $0.4 \%$ & $0.8 \%$ & $0.1 \%$ & $1.3 \%$ & $0.6 \%$ & $4.0 \%$ & $<0.0 \%$ \\
\hline Other wild animals & $3.3 \%$ & $2.4 \%$ & $1.8 \%$ & $6.9 \%$ & $0.3 \%$ & $5.1 \%$ & $2.2 \%$ & $19.3 \%$ \\
\hline
\end{tabular}

*Since deFrance did not differentiate between cattle and bison, all bovids are included in this NISP, and assumed to be cattle 
Table 5-14. Percent of NISP from Wild Animal Species in 8 Recent Colonial Period excavations

\begin{tabular}{|c|r|r|r|r|r|r|r|r|r|}
\hline & \multicolumn{2}{|c|}{ Rosario } & \multicolumn{3}{|c|}{ San José } & Concepción & San Juan & San Antonio & \\
\hline Wild Species & $\begin{array}{c}\text { Current } \\
\text { project }\end{array}$ & $\begin{array}{c}\text { deFrance } \\
1999 *\end{array}$ & $\begin{array}{c}\text { Meissner } \\
1998 \mathrm{~b}\end{array}$ & $\begin{array}{c}\text { Meissner } \\
1999 \mathrm{~b}\end{array}$ & $\begin{array}{c}\text { Meissner } \\
1999 \mathrm{c}\end{array}$ & $\begin{array}{c}\text { Meissner 2000a } \\
\text { Neissncr } \\
2000 \mathrm{~b}\end{array}$ & $\begin{array}{c}\text { Meissner } \\
1999 \mathrm{a}\end{array}$ & Notes \\
\hline Mammals & $18.3 \%$ & $9.2 \%$ & $24.8 \%$ & $12.0 \%$ & $25.0 \%$ & $8.0 \%$ & $29.6 \%$ & $27.4 \%$ & Does not include rats \& mice \\
\hline Birds & $5.4 \%$ & $4.0 \%$ & $1.6 \%$ & $0.4 \%$ & $2.5 \%$ & $5.9 \%$ & $5.6 \%$ & $0.6 \%$ & $\begin{array}{c}\text { Turkey is assumed to be wild. Small } \\
\text { birds (<robin-sized) not included }\end{array}$ \\
\hline Reptiles & $18.8 \%$ & $8.5 \%$ & $7.1 \%$ & $2.7 \%$ & $17.6 \%$ & $9.3 \%$ & $14.1 \%$ & $3.6 \%$ & Snakes not included \\
\hline Fish & $17.8 \%$ & $1.6 \%$ & $10.8 \%$ & $0.1 \%$ & $13.3 \%$ & $10.4 \%$ & $5.6 \%$ & $1.6 \%$ & \\
\hline Overall & $\mathbf{6 0 . 3 \%}$ & $\mathbf{2 3 . 3 \%}$ & $\mathbf{4 4 . 3 \%}$ & $\mathbf{1 5 . 2 \%}$ & $\mathbf{5 8 . 4 \%}$ & $\mathbf{3 3 . 6 \%}$ & $\mathbf{5 4 . 9 \%}$ & $\mathbf{3 3 . 2 \%}$ & \\
\hline
\end{tabular}

* deFrance did not differentiate between Bos and Bison, so all bovids are included in this NISP.

The collection has an unusually large percentage of bird bone as well, with 16.3 percent of the total NISP. Of the collections listed in Tables 5-13 and 5-14, the highest percentage of NISP from birds is 7.4 percent, from the excavations at Concepción (Meissner 2000a). Most of these birds are either chicken $(n=44)$ or turkey $(n=18)$. The large number of chicken bones is unusual in Colonial Period sites in South Texas.

\section{Comparison with deFrance 1999}

In 1997 Ricklis (1998) conducted a series of test excavations south of the south wall of the unit (see Chapter 3). The analysis of the faunal remains from these units, which were excavated only few meters south of the southern units of this project, was published by deFrance (1999). In order to compare these two analyses in detail, a few adjustments had to be made. deFrance (1999:171) did not differentiate between Bos and Bison. She also combined Capra and Ovis (goats and sheep). By using the same categories as deFrance, Table 5-15 was constructed, allowing a detailed comparison of the two analyses.

Perhaps the most striking difference in these two taxon lists is the relative richness of species in the current collection. deFrance lists only 18 different taxa (including several grouped by family instead of genus). Using the same groupings, the current project has a taxon list of 35, nearly twice as many. Bovids completely dominate the 1997 assemblage, with 71 percent of the NISP, compared to 34 percent in the current collection (Table 5-15).
The bone deFrance analyzed was from a midden area south of the south gate of the mission, while the bone from the current project came from all over the mission site. If we compare the bone from only the units along the southern wall (Units 66-78,97,98, and 100) with the bone in from the 1997 excavations, we can still see a difference (Figure 5-47). There is a higher percentage of fish and turtles in the current project and a much greater dominance of bovids in the 1997 project. However, in general, the bone from the south wall units more closely resembles the 1997 bone than the rest of the current project.

\section{Cattle Elements}

The list of elements identified for Bos taurus in this collection is in fact a list of elements that are both very resistant to breakage and readily differentiated from bison, rather than a useful list of what cattle parts were discarded at the mission. The difficulty in differentiating bison and cattle in a highly fragmented collection makes it very difficult to assess what elements were being discarded, and the degree to which the bone was being processed. The only way to achieve any sense of this is to make the assumption, at least for this part of the analysis, is that all bovid bones are cattle. We know that at least part of one bison arrived at the site (see Table 5-10), but the lack of more than a single bison element means that most of the bovid bone is probably cattle. 
Table 5-15. A detailed comparison of the current project, Mission Rosario, 1999 excavations with deFrance (1999)

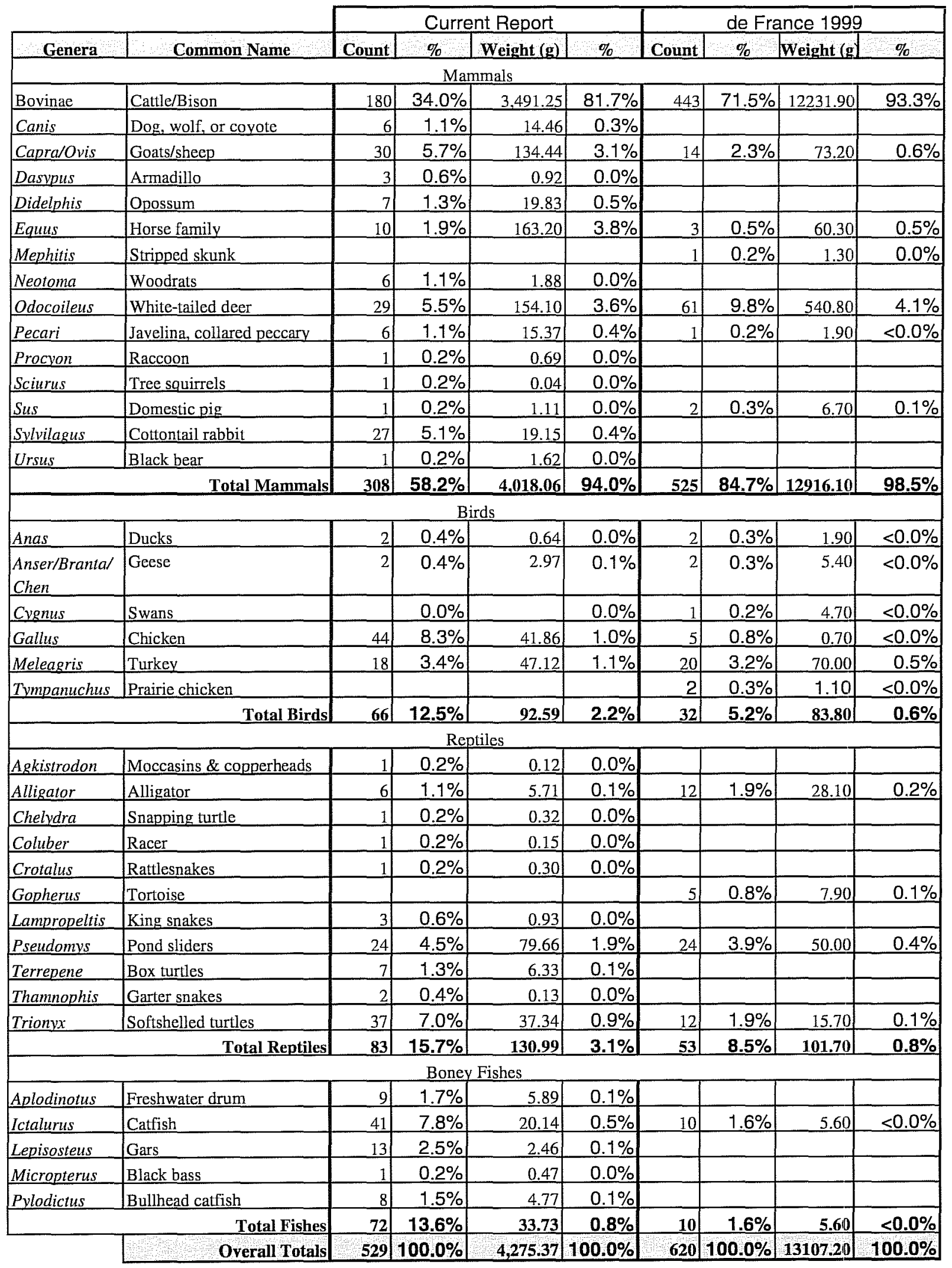


Figure 5-47. Bone from the south wall units compared to the rest of the collection, and to deFrance.

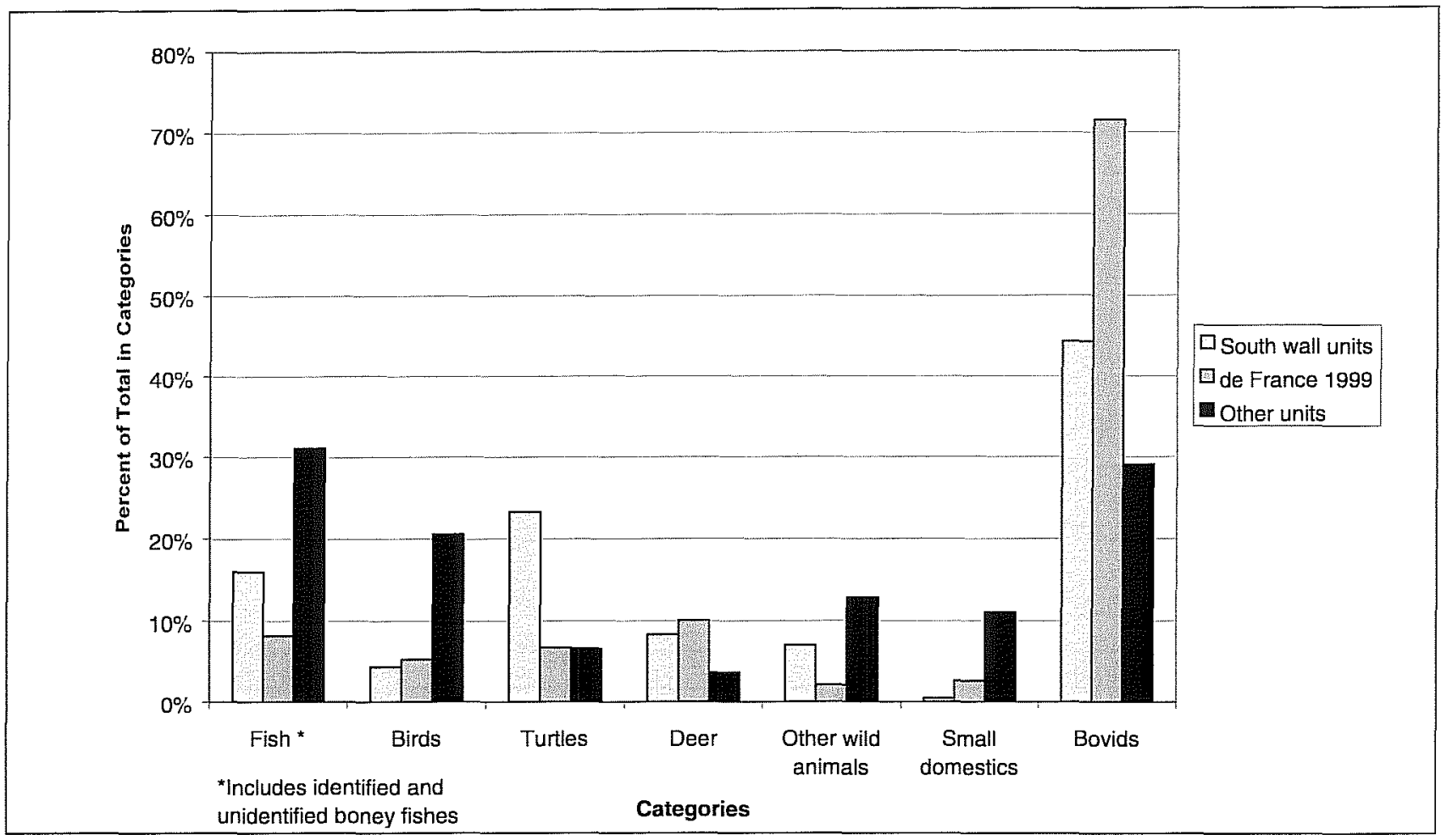

Table $5-16$ shows a list of the body parts of all bovids identified in the collection. Note, the majority are parts that have a relatively low food utility. In fact, identifiable long bones are conspicuous by their near absence. Either the inhabitants routinely disposed of the head and feet of cattle in areas tested by this project but disposed of long bones, vertebrae, etc., elsewhere, or the missing elements were processed to the point that they were no longer distinguishable. The latter possibility seems more likely. Eleven percent of the total bone $(n=1612)$ was identified only as "Very Large Mammal," that is, cow-sized animal. Eighty percent of the total collection $(\mathrm{n}=11489)$ could be identified only as mammal.

Table 5-16. Body parts of all bovids

\begin{tabular}{|c|c|c|c|c|}
\hline Head \& Tail & 32 & $21.9 \%$ & & $781 \%$ \\
\hline Lower leg & 82 & $56.2 \%$ & Low Utilty Elements & $10.1 \%$ \\
\hline Upper leg & 7 & $4.8 \%$ & \multirow{3}{*}{ High Utility Elements } & \multirow{3}{*}{$21.9 \%$} \\
\hline Body-front 1/2 & 19 & $13.0 \%$ & & \\
\hline Body-back 1/2 & 6 & $4.1 \%$ & & \\
\hline
\end{tabular}


The large number of unidentifiable fragments and the small number of long bone ends suggest a pattern that indicates most of the cattle bone was processed for bone grease (Vehik 1977). Bone grease is a concentrated food, containing protein and vitamins as well as fat, and has the added advantage of being storable (Vehik 1977:172). Although the amount of fat in an animal varies enormously according to the diet, health, season, and reproductive status, the fat in bone grease is the last to be used for energy during stress (Brink 1997:21), and is thus available to predators until the prey animal is starving.

The extraction of bone grease involves breaking bone, especially the ends of long bones, which have a high fat content, into small pieces and then boiling of the bone for an extended period. Bone fat is then periodically skimmed from the surface of the water (Brink 1997: 260; Vehik 1977:171). The extraction of all available bone grease from bone requires considerable processing time and effort, and fuel for fires to boil the bone (Vehik 1977:170). Such heavy processing of bone is common, but certainly not universal in Colonial sites in South Texas. Meissner (1999c) found this pattern in excavations at Mission San José in San Antonio. On the other hand, in the Colonial bone bed excavated in 1979 at Mission San Antonio de Valero, most of the long bones had been broken in the middle to extract marrow, but bone ends were largely intact, indicating that processing for bone grease was not carried out (Meissner 1999a:304).

\section{Summary and Conclusion}

The vertebrate faunal collection from this project consisted of 14,355 bones, most of which were in a highly fragmented condition which rendered them unidentifiable. In spite of the poor condition of most of the bone, 35 genera were identified, indicating that the people of Rosario made use of a wide variety animals in their diet. The most commonly identified animal was cattle followed by chicken, catfish, soft-shelled turtle, deer, and sheep respectively.

The bone was most dense along the walls of the mission compound, with the largest deposits excavated from Units 1,66 , and 100 . In the collection only 516 bones (3.6 percent) were recovered from inside rooms.
Although the upper $20 \mathrm{~cm}$ of sediments at the mission are known to have been disturbed by previous investigations, this does not seem to have been the major cause of bone fragmentation, as bone from below 20 $\mathrm{cm}$, in undisturbed context, appeared slightly more fragmented than bone from above $20 \mathrm{~cm}$. Non-cultural taphonomic factors such as acid etching and atmospheric weathering are probably responsible for some of the breakage as well, however the pattern of elements in identifiable condition suggests that the majority of the bone breakage was the result of processing of bone, especially cattle bone, for bone grease.

The apparent need to process bone, at no little expense of time and effort, to extract all the available nutrients, suggests that food resources were scarce. Human subsistence choices tend to maximize energy capture while maximizing stability of energy capture and minimizing costs (Jochim 1976:16-17; Kaplan and Hill 1992:168). We can assume that if the people at Rosario were processing the bones of cattle in order to extract bone grease, then they did so because it was the part of an efficient subsistence strategy, given circumstances at the time. In other words, they were going to the trouble of extracting bone grease because they felt it was necessary.

Another hint that food resources were not always abundant at Rosario is the large number of different species exploited by the inhabitants. Optimal foraging theory suggests that the presence of large numbers of readily available domestic animals would make extensive hunting and/or fishing for wild foods an inefficient use of time and energy (Kaplan and Hill 1992:169-172). In other words, if there was plenty of beef, sheep, goat, and chicken to eat, there would be no need to hunt for meat.

Some midden areas in Colonial sites reflect this situation. At Mission San Antonio, the midden excavated outside the west wall of the mission was completely dominated by beef, with very little use of wild animals (Meissner 1999a:295). In fact, the only wild animal with more than 1 percent of NISP bone weight in that collection was bison (18.9 percent). Optimal foraging models suggest that if there is generally plenty of meat, there would be little hunting even if prey was encountered in the course of other activities (Kaplan and Hill 1992:171-172). If any hunting was done, 
it would focus on large animals, such as bison, since larger animals generally provide more food for the effort of hunting them.

Optimal foraging theory also states that diet breadth, that is, the number of different species exploited, increases as the density of highly profitable prey decreases (Kaplan and Hill 1992:173). At Rosario, if domestic animals became scarce, the inhabitants would begin to hunt and fish, adding these species to their diet.

Reitz and Scarry (1985:84) have pointed out that features like trash dumps or bone beds are not necessarily representative of the complete meat diet, especially in Colonial sites. Not only might the midden in question be intended for specialized purposes, but different features or different areas in the site might represent different time periods. The analysis of the midden south of the south wall (deFrance 1999) shows a much larger dependence on cattle and much less on fish, turtles, and other wild species than is seen in the bone from the current project (see Figure 5-47). It is possible that this midden represents a different period than the majority of the bone excavated in this project, one in which there were plenty of domestic animals available for exploitation, and less need for hunting. deFrance (1999:187) points out that this midden, even though it has a large percentage of bovid bones, has more wild animals than two other South Texas midden assemblages (two locations of Mission Espíritu Santo de Zuñiga, 41GD1 and 41VT11).

In conclusion, although the vertebrate faunal material from this project was generally in very poor condition, it was possible to identify 35 different genera. This diversity of genera, and the presence of large numbers of specimens from wild species suggests more dependence on hunted foods than is commonly seen in Colonial period sites (see Table 5-14), even in other sites nearby (deFrance 1999:187). Cattle is still the dominate source of meat, but the presence of large numbers of so many other species combined with the extensive processing of the cattle bone suggests that food resources were, at least at times, scarce at Mission Rosario. 


\section{Shells}

\section{Cecil Calhoun}

By far the preponderance of shell fragments recovered $(\mathrm{n}=255$ or $86 \%)$ were from fresh water mussels. Mussels apparently were a favored food resource. Such shells are abundant on most sites occupied by inland prehistoric and historic Indian groups in south Texas.

Since there is an unusually large number of marine shells $(n=42$ or $14 \%)$ represented in the Mission Rosario collection, it was decided to identify them by genus to determine their natural habitat and, therefore, where they were likely to have been acquired by the Mission inhabitants.

The reference used for marine shell identification is Shells and Shores of Texas by Jean Andrews, published by the University of Texas Press, Austin, in 1977.

\section{Sunray Venus \\ Callista (Macrocallista) nimbosa $(n=16)$}

This genus lives in the sandy littoral zone just off shore; from about out where the breakers begin, to nearly the low tide swash zone. It is more numerous near areas influenced by water flowing from passes or inlets through the barrier islands. Reported to be $4 \frac{1}{2}$ to 5 inches in length, large examples from some coastal sites are commonly 6 inches long. The shell is porcelaneous and moderately thin, and can be knapped.

This shell is rarely found on Texas beaches today. According to the number of valves in coastal middens, and the numbers of bleached, fragmented Sunray Venus in the shell hash along and behind the beaches, they appear to have been quite plentiful in Texas at one time.

The Sunray Venus provided one of the most favored stone substitutes along the Texas Coastal Bend for some tools. An unaltered valve made an efficient digging tool. Many shells on coastal sites are unifacially chipped along the entire ventral margin (flakes are removed from the inside of the shell), to provide a sharp cutting edge, which was easily rechipped to resharpen the "knives/scrapers" as the edge wore down. Tools such as this in Texas are numerous on sites ranging from the mouth of the Guadalupe/San Antonio Rivers to the mouth of the Rio Grande; especially so from Copano Bay to Baffin Bay. On later sites from the immediate coast, small triangular arrow points were chipped from the shell. Most of them are found from Corpus Christi Bay to the Rio Grande.

\section{Giant Atlantic Cockle \\ Laevicardium (Dinocardium) robustum $(n=15)$}

Another large shell, this one is around 4 to $4 \frac{1}{2}$ inches across. The animal lives in moderately shallow water in the Gulf, about where the breakers begin (mid-littoral zone). During prolonged dry times, when some of the bays become saline enough, it will move onto sandbars within the passes and into the bays. This very common shell can be found on Texas Gulf beaches from Sabine Pass to Boca Chica and far beyond both to the north and south. In Texas, the largest ones are found only along the Gulf side of the barrier islands in inlet-influenced areas.

This shell is also common in coastal shell middens, especially from Galveston Island to the southern Coastal Bend. It is never in the majority of the species of shell, but whole, nearly whole, and fragmentary ones are almost always present. In the coastal shell middens, and on sites dating to the Spanish Colonial period the shells are larger than the ones found today, up to 6 inches or more.

Cockle shells have always been suspected of being used as a tool, for grubbing, digging, and scooping. Some broken shells were found in grave pits at the Blue Bayou Site and Huebner and Comuzzie (1992) speculated they had been used as digging tools.

One piece of cockle recovered from Unit $76(0-5 \mathrm{~cm})$ displays indications of having been utilized for a "digging" or a "scooping" type function. This piece of cockle shell has a margin which appears to be worn while the ends of the ribs along the margin exhibit signs of polishing. 


\section{Southern Quahog \\ Mercenaria campachiensis \\ $(n=3)$}

The Quahog is found on the sandy bottom offshore from the beach, about where the breakers begin, and a bit beyond. They are very common all along the coast, but are located in water a little too deep to make gathering them worthwhile. They seldom show up on beaches because they do not wash in, being too large, thick, and heavy, often reaching sizes of $6 \frac{1}{2}$ to 7 inches across. However, at Big Shell about halfway down Padre Island, where the beach is paved with shells from the shoreline to the dunes, many of them can be found. On storm-hit local beaches from Sea Rim down to Boca Chica, after a gale or hurricane long, deep windrows of this clam can be found.

These all-white shells are on some middens along the Coastal bend, but their percentage of the total shell count is always very low. It is probable that they have been incorrectly identified or perhaps overlooked in archaeological reports from the coastal area.

\section{Incongruous Ark Andara (Cunearca) brasiliana$$
(n=1)
$$

Up and down the Texas coast from just offshore beneath the breakers to the island beaches these are common. Since they are not large, only about $1 \frac{1}{2}$ to $13 / 4$ inches across, they were probably not worth collecting as a source of food. Although, their ribbed surface with serrated edge might make this shell a tool of choice for manufacturing pottery in the Rockport tradition. Scant attention is paid to these shells in sites, probably because they are so common on the beaches.

\section{Atlantic Bay Scallop Argopecten irradians amplicostatus $(n=1)$}

The Scallop is found on most any bottom except soft mud, often on and around oyster reefs, but never in large colonies. These shells measure $2 \frac{1}{2}$ to $2 \frac{3}{4}$ inches across. They are thin, yet comparatively strong with wide ribs, and a scalloped ventral margin symmetrically rounded in outline. The inside surfaces are smooth and white.

Scallop shells (probably not the fragment found in this collection) are known tools used for shaping Rockport pottery (Calhoun 1962). They may also have been strung together to be used as ornaments or rattles.

\section{Disk Dosinia \\ Dosinia discus \\ $(n=1)$}

This nearly round shell is relatively flat and measures 2 to 3 inches in diameter. Dosinia live at 2 to 12 fathoms deep, but are commonly found on all Gulf beaches. This type of shell has a thin, sharp edge and could have been employed as a cutting tool. It is present, but not numerous, on most coastal middens.

\section{Discussion}

Since each had to be carried to the site, these marine shells can be considered artifacts. While most (perhaps all) were good to eat, none of their numbers suggest that they were brought along strictly as provisions. The most commonly eaten shellfish were not present in this collection; the oyster (Crassotrea virginica and Ostrea aquestris) and the brackish water clam (Rangia). It appears that the marine shells that were brought to the site were part of an inventory of tools common to a coastal people from their traditional home environment.

All of the shells in this collection can commonly be found along the Texas Coastal Bend today, except for the Sunray Venus. However, if the Sunray Venus is included in the complete list of shells indications are that the origin of the collection is more likely to have been from Matagorda Island down to Padre Island. 


\section{Chapter 6:}

\section{Summary and Recommendations for Future Investigations}

\section{Introduction}

Chapter 6 presents a summary of the findings of CAR's 1999 investigations at Nuestra Señora del Rosario Mission, synthesizes previous investigations at Rosario, and provides a series of recommendations for any future archaeological studies conducted at the mission.

\section{WPA Grid System}

\section{Discussion}

Although much of the documentation cannot be located, photographs taken by the WPA during their work at the site in the 1940s (samples in Appendix A-4:Photographs $A-1$ to $A-9$ ) proved invaluable in reconstructing the $5 \times 5$-foot grid system which was used. Figure 6-1 shows the reconstructed WPA grid system.

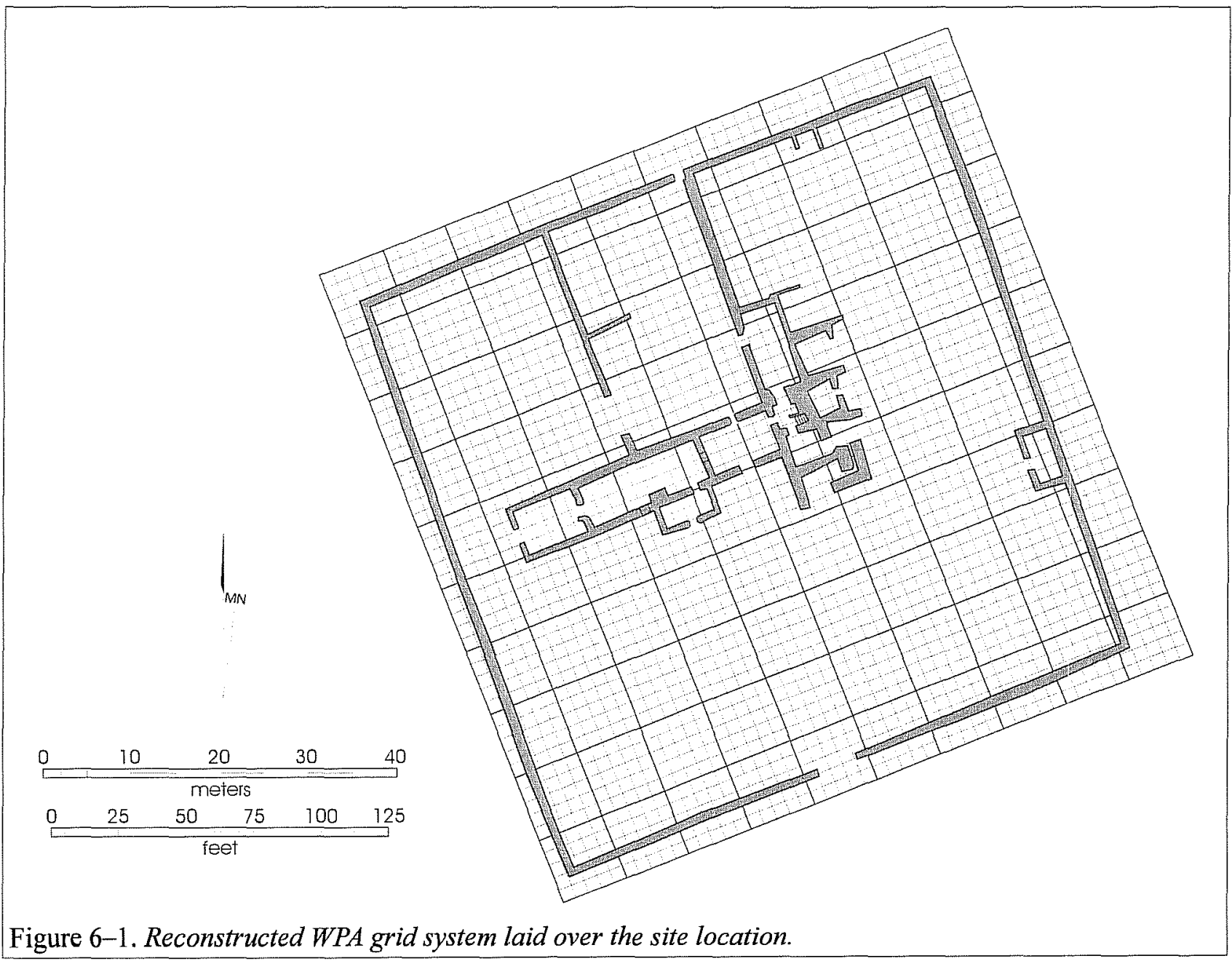




\section{Recommendations}

Additional archival research is necessary to:

(1) Locate the artifacts collected by the WPA; and

(2) Locate maps, drawings, field notes and other photographs from the WPA project.

It is clear that wooden stakes with markings denoting block numbers were driven, however the markings are not legible in the available photographs. Finding documentation of the benchmarks and central datum used is critical to establishing proveniences on the artifacts collected during their excavations.
Floor Elevations

Discussion

Floors were exposed in Rooms 1, 3-6, and the Sacristy and western end of Chapel 2 . These were shot in using the Total Data Station, and Figures 6-2 and 6-3 show their relative elevations.

Viewing the rooms from west to east (Figure 6-2), one can see that no floors were found in Room 2. The stone walls of Room 2 have no footing or foundations, and are set on the dark brown sandy loam midden soil, suggesting this room was perhaps an-open air atrium or may have been covered with light material.

Figure 6-2. Floor elevations in the area of Chapel 1.

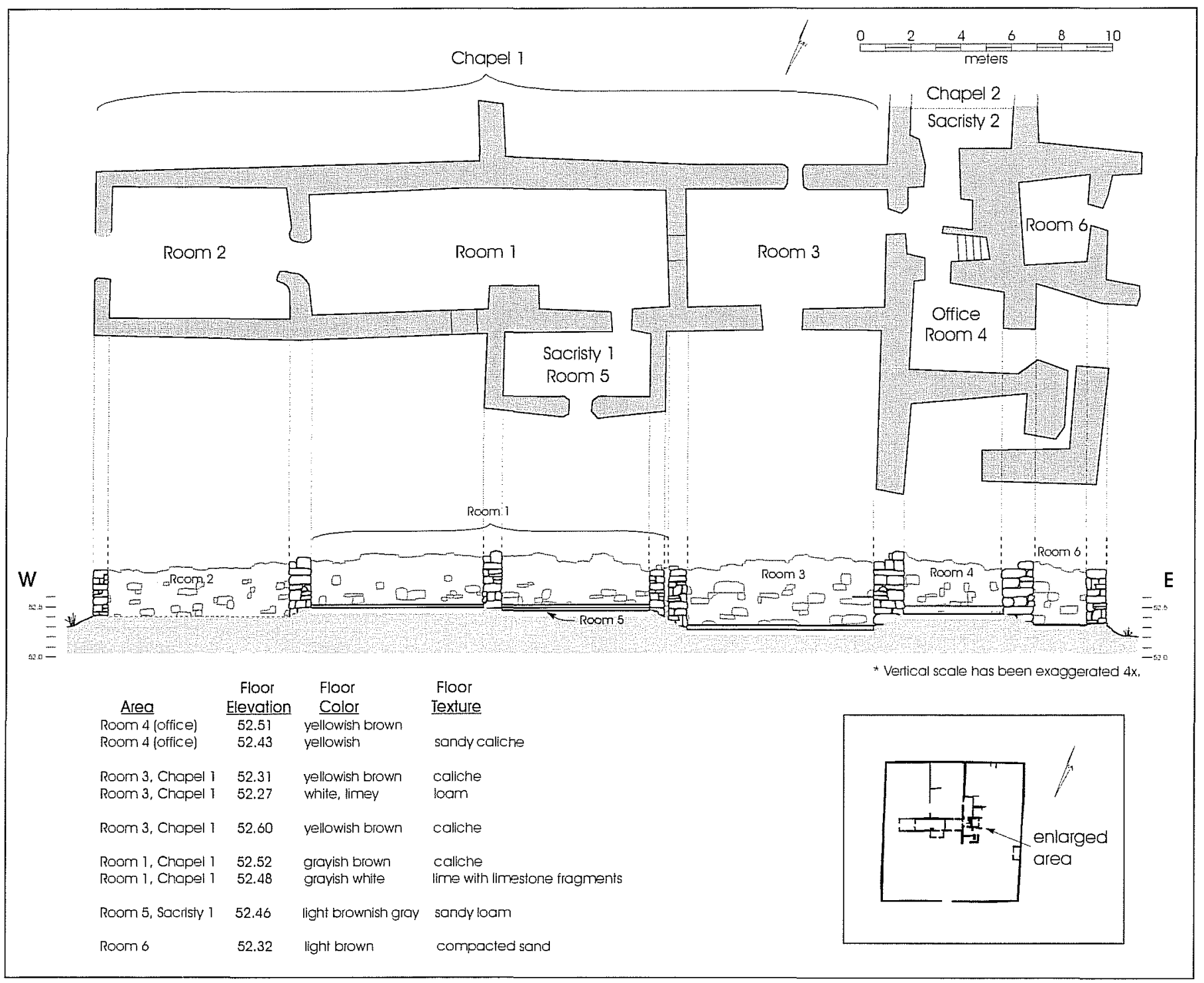


This would explain why there is no floor in Room 2 and the compacted surfaces exposed along the eastern end of the room may be walkways. Room 1, on the other hand, has two floors; a grayish brown caliche floor overlies a grayish white floor with lime and limestone fragments. A yellowish caliche floor was found in the Sacristy (Room 5) at only a slightly lower elevation. Room 3 has similar floors as Room 1, but they are clearly lower in elevation. A possible floor remnant was found in the northeast corner of Room 3, and may represent a step up into the area between the Office (Room 4) and the Sacristy off Chapel 2. Two

Figure 6-3. Floor elevations in the area of Chapel 2.

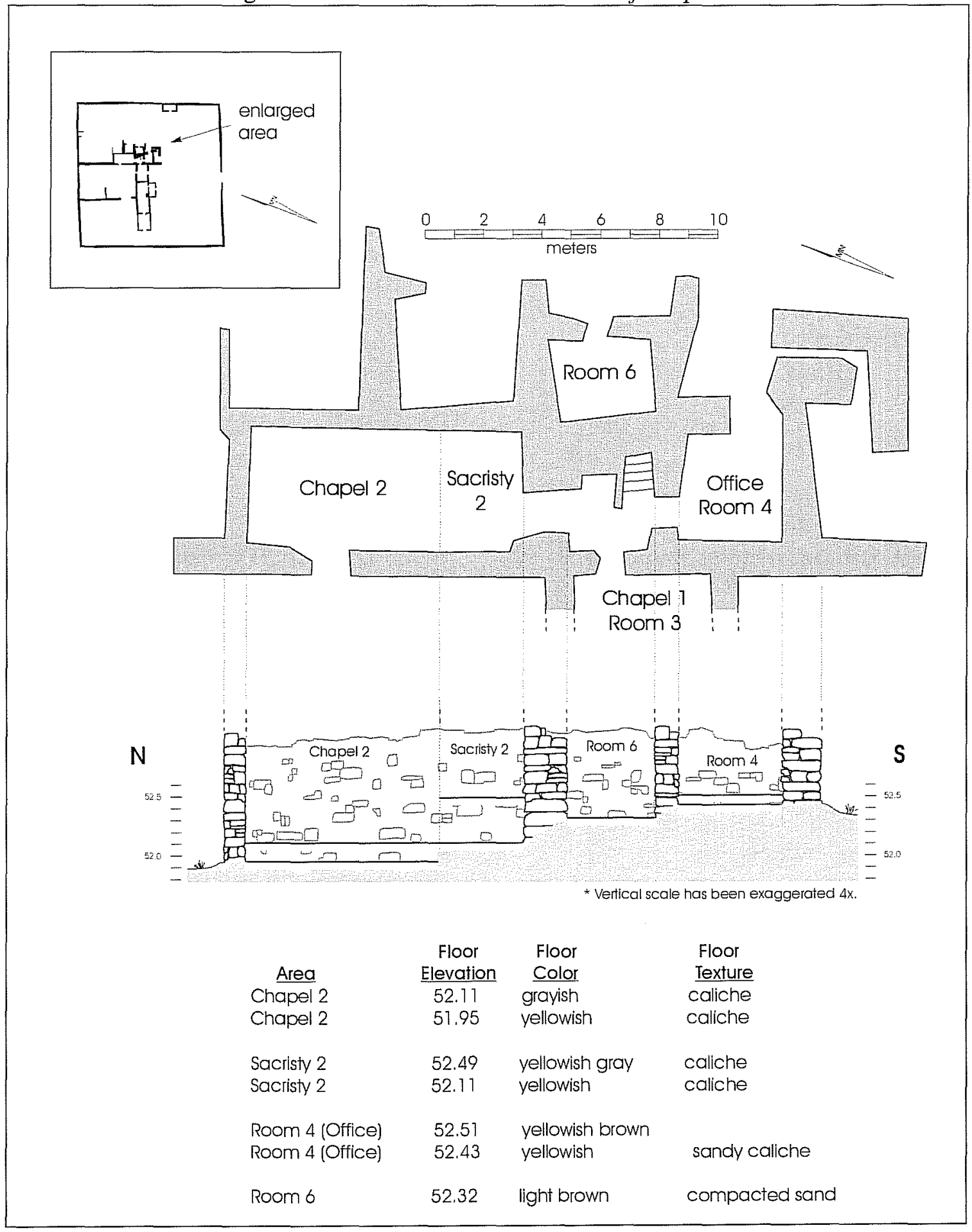


yellowish caliche floors exposed in Room 4 are clearly elevated, and relative to the upper caliche floor in the Sacristy (Figure 6-3). The floor in Room 6, under the bell tower, is of compacted sand composition, and is lower than Room 4. It is not connected with any of the other rooms, and its isolated position on the east side of the chapel may account for the difference in floor levels and composition. Our excavations revealed two floors in the Sacristy; the lower floor was a yellowish caliche which apparently extends into the west end of Chapel 2 (Figure 6-3).

Our excavations in the Sacristy found an upper floor approximately $23 \mathrm{~cm}$ ( 9 inches) above the upper-most floor in the west end of Chapel 2, but not in the Chapel, thus corroborating Gilmore's evidence of an E-W cross wall that would have separated the Sacristy from the west end of Chapel 2 (Figure 5-1), and her suspicions that there may have been a step up into the Sacristy room from the Chapel.

\section{Recommendations}

The floors in the central structures have generally been exposed sufficiently to evaluate their composition, relative elevations, and integrity. One exception may be the eastern ends of Rooms 1 and 3 in Chapel 1 . There may be a slightly elevated step or platform in each. A remnant of a possible floor was detected in Room 8 in the structure along the east wall during excavation outside the doorway, but otherwise the room has not been investigated. We recommend exposing the entire floor in Room 8 to evaluate its integrity and composition, and hopefully find some evidence that would suggest the use and period of occupation of this structure.

\section{Wooden Stockade and ca. 1754-1768 Occupation}

\section{Discussion}

Gilmore and our CAR excavations found postholes, compacted surfaces, and sediments in the northwest corner of the site, undoubtedly the area upon which nine soldiers sent by Captain Piszina from Presidio
La Bahía and a handful of Cujane Indians began the earliest period of mission occupation. Our excavations in Unit 1 found evidence of a setting trench and posts for a probable jacal structure attached to larger posts found in Gilmore's investigations that, presumably, are remains of the "fine wooden stockade" built during that time period.

Our exposure of a distinct posthole, possible posthole, and speculation of a wall held in place with posts in the southwest corner of the compound (Unit 100) outside both a buried (ca. 1768-1780) and upper, existing stone compound wall (ca. 1789-1807) may also represent that $1754-1768$ period.

In our opinion, Gilmore has done an excellent job of documenting the postholes in the area she posits is the first church (Chapel 2), and her interpretation of construction/burial scenarios are sound. Numerous other distinct postholes, and possible postholes, have been documented by Gilmore and Ricklis, and our horizontally limited $1 \mathrm{~m}^{2}$ excavation units (Figure 6-4). However, even an optimal patterning approach lends no credence, is highly theoretical, and invites immense speculation as to the outline of the mission compound during the ca. 1754-1768 period of wood construction, and contemporaneous occupation.

\section{Recommendations}

Admittedly, postholes have been commonly found throughout the site. The critical, unproven supposition is that the majority of them represent the ca. 17541768 occupation, yet that is most probably incorrect. Gilmore was able to discern the chronological differences based on the strata into which the holes penetrated around the northwest corner of the existing stone compound wall. We were essentially able to do the same in our Unit 1 in the northwest corner and Unit 100 in the southwest corner. We recommend as a beginning point, opening a block excavation exposing Gilmore's findings outside the northwest comer of the existing compound wall, and continuing eastward along the wall to at least the northeast corner of the compound, and possibly beyond. The purpose of such an undertaking is to expose the potential trench outline, postholes, and structures along the ca. 1754-1768 stockade wall. 


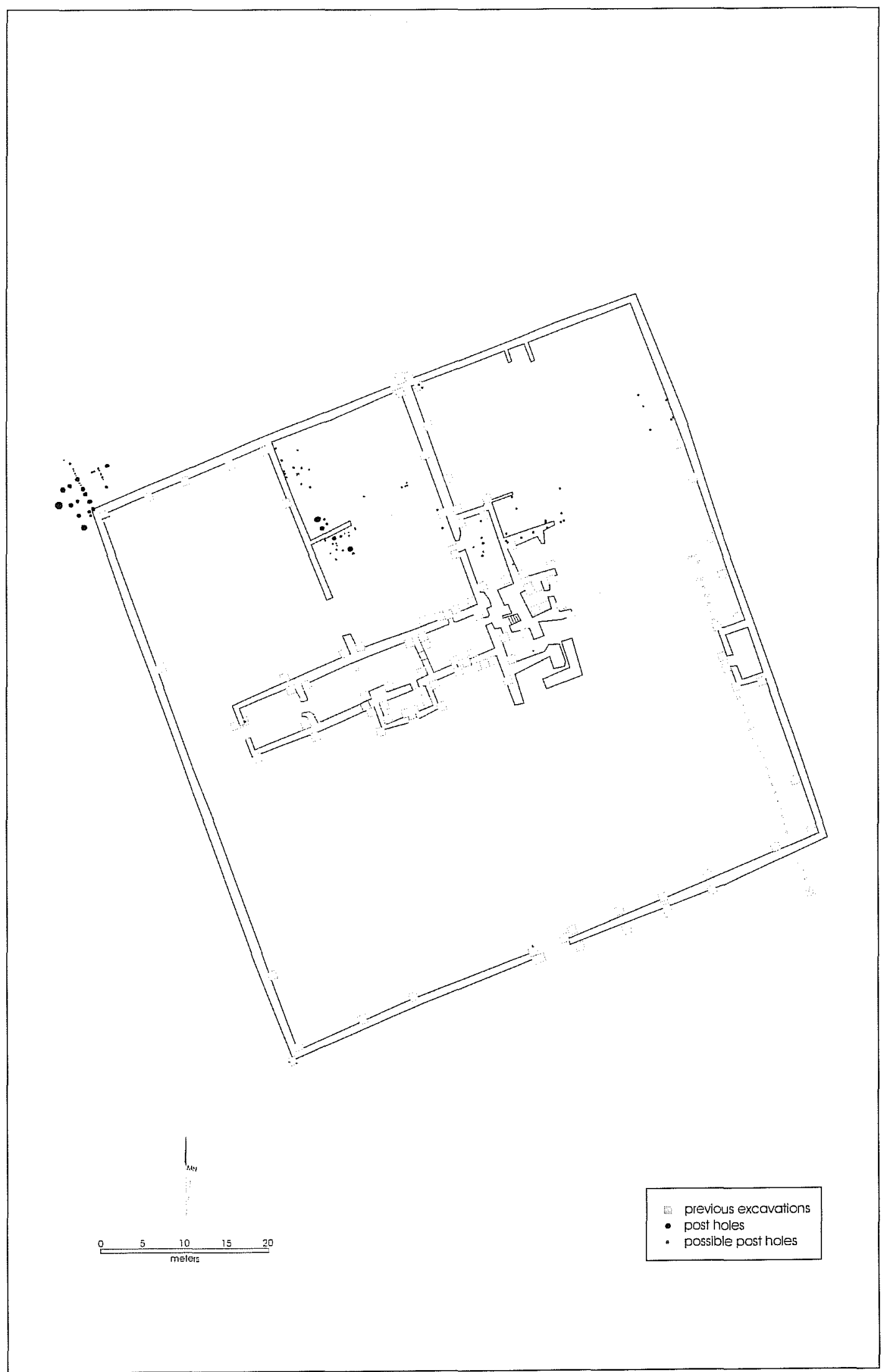

Figure 6-4. Documented postholes and possible postholes. 


\section{Buried Stone Walls \\ or Foundations, ca. 1768-1780}

\section{Discussion}

Ricklis (1999) documented a buried foundation or wall running parallel to the southern compound wall. We found a buried wall in Units 80 and 81 . Probes traced the wall south from Unit 81, presumably joining Ricklis' wall, and becoming the southeast corner of the second phase of stone construction that occurred ca. 1768-1780. We found a similar buried wall in the southwest corner of the compound in our Units 66 and 100, and under the northern compound wall in our Unit 5. Another buried stone wall was found by Gilmore in a trench in the northeastern portion of the compound.

A hypothetical extension of Ricklis' wall would join the end of the wall found in Unit 100, and the end of the wall found in our probes south of Unit 81 (Figure 6-5). In all CAR units, and in Ricklis' block excavation, the buried wall does not appear to conform to the alignment of the upper, existing compound wall, which presumably was constructed ca. 1789-1807. The buried wall alignment was shot in with a Total Data Station (TDS) in the CAR units, while maps of Gilmore's and Ricklis' walls were scanned and superpositioned over the base map using TDS aboveground reference points. As illustrated in Figure 6-5, the buried wall projection may represent the outer compound wall during the ca. 1768-1780 occupation of the mission. If this is the case, then that explains why we found evidence of the ca. 1754-1768 and ca. 1789-1807 occupations in Unit 1, but evidence of the ca. 1768-1780 stone construction and subsequent occupation is conspicuously absent. The existing compound wall and the wooden stockade wall must have been outside the western, buried, ca. 1768-1780 stone wall.

Corroborating evidence is both present and absent in Unit 64 along the existing west compound wall. A scenario of a single episode of mission construction and two periods of occupation are distinguishable in the south wall of Unit 64. A thin layer of gray ashy, silty loam lying on top of the dark brown sandy A horizon with no associated evidence of stone construction suggests this is the cultural debris from the initial period of occupation, ca. 1754-1768. A compacted light gray caliche floor then overlies the ashy lens. Although ephemerally distinct, it appears the floor and ash lens have been cut by a trench that was dug for the construction of the upper, ca. 1768-1780 stone wall. This suggests that the ash lens and floor at one time may have extended westward either under, or beyond the stone wall. Notably absent from obvious distinction in the profile are construction and occupation zones for the second period of construction, ca. 1768-1780. This same period was also notably absent in Unit 1 profiles in the northwest corner of the compound.

However, the buried wall was again uncovered under the upper ca. 1789-1807 stone compound wall in our Unit 4. Excavations in Units 2 and 3 yielded no evidence of a buried wall. Although the buried wall in Unit 4 is similar in composition and size to the previous buried wall, and the inverted soil stratigraphy seen in the unit wall profile of Unit 4 is much the same as that seen in Unit 66. Further east, our investigations in Unit 99 found the probable extended buried wall just north of the upper, existing compound wall, with an associated cobbled walkway and plastered room.

Problematic to this superimposed extension of a possible outer compound wall dating to ca. $1768-1780$ is that Gilmore did not find evidence of an eastern, $\mathrm{N}-\mathrm{S}$ stone compound wall while excavating in Feature 3 in the northeast portion of the later compound; and, our probes north along a line from Unit 84 indicated no stone wall or foundation was present. Gilmore posits that the postholes and artifacts in that area suggest it was used as Native living quarters.

\section{Recommendations}

The extent and dimensions of the buried stone walls and foundations are very much elusive and largely unknown. We concur with Ricklis' (1999) speculation that they represent the second construction episode (first stone) at the mission, ca. 1768-1780. Our very limited exposures of the buried walls indicate that they do not follow the alignment of the upper, existing compound walls visible on the surface today. We 


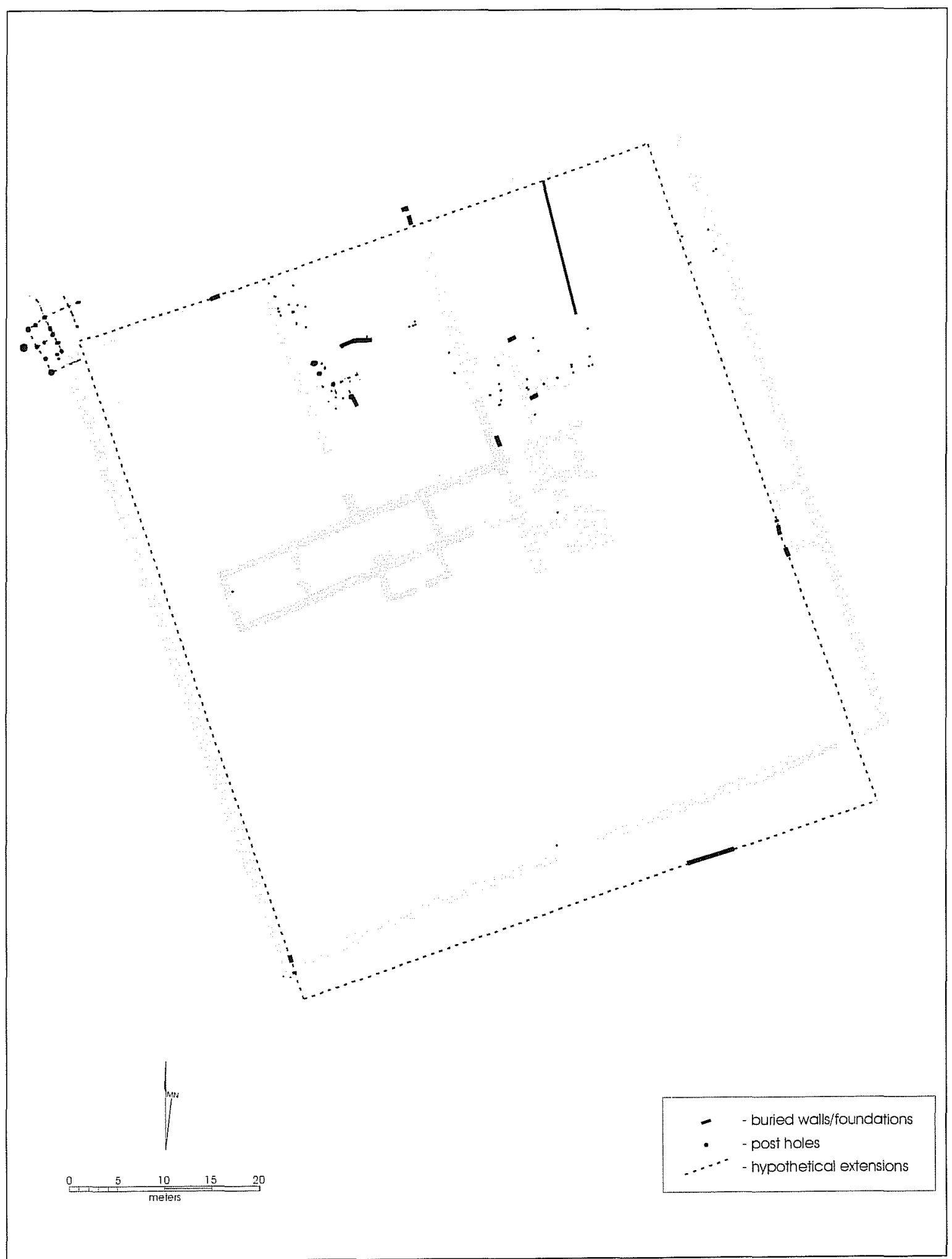

Figure 6-5. Buried walls or foundations and their hypothetical extensions. 
recommend that all buried walls be exposed throughout the compound by excavating $50 \mathrm{~cm}$ on each side, $20 \mathrm{~cm}$ below their upper-most stones. Narrow excavation units $(<1 \mathrm{~m})$ along the walls would lessen the impact of destroying living and occupation surfaces, but should be sufficient to document their presence in areas not previously disturbed by the WPA, or documented by Gilmore and Ricklis.

\section{North Gate Opening}

\section{Discussion}

Our Units 7, 99, and 102 (Figures 3-1 and 5-1) exposed a filled-in trench, buried walls, a floor, and plastered walls that created more questions than answers. It appears that a deep trench was dug to accommodate prepared and dressed footing stones for the upper, existing compound wall. For unknown, yet speculative reasons (see discussion of Unit 7, Chapter 5), the angular limestone was apparently instead tossed into the trench, but above-ground there was an opening toward the river to the north. Just outside the opening, a sloping, cobbled surface was prepared. The buried (ca. 1768-1780) wall discussed in the previous section formed a northeast corner, and accommodated an adjoining plastered room to the east along the upper (ca. 1789-1807) compound wall.

\section{Recommendations}

Further excavations are needed to expose a full vertical section of the upper, presumably ca. 1789-1807 stone wall and its opening. Investigators should be looking for evidence that would indicate the construction sequence of digging the trench, constructing the wall, and filling in the opening. The floor in the plastered room found outside and east of the opening should be exposed to determine its contemporaniety with both the buried wall and the upper compound wall. It is recommended that the buried wall should be fully followed along its length and fully exposed to confirm its construction sequence and contemporaniety with the upper wall.

\section{Other}

\section{Geophysical Survey}

At least 20 features that have not been previously investigated were identified with the use of electromagnetic sensing and ground penetrating radar (Appendix C). These anomalies should be exposed to determine what they are and if significant, placed on a masterplanning schedule for future archaeological inquiry.

\section{Mapping}

Although 1,083 points were reconstructed from Gilmore's field notes, more information can be gleaned from further study. If the WPA field maps and sketches can be found they should be added to the GIS database as overlays. Future archaeological investigations should not be mapped without the use of a Total Data Station and GIS software compatible with that used during this project. 


\section{References Cited}

Balkwill, D. M. and S. L. Cumbaa

1992 A Guide to the Identification of Postcranial Bones of Bos taurus and Bison bison. Canadian Museum of Nature, Ottawa.

Barnes, M.R.

1980 Mexican Lead Glazed Earthenwares, in Spanish Colonial Frontier Research, compiled and edited by Henry F. Dobyns. Spanish Borderlands Research 1. Center for Anthropological Studies, Albuquerque.

Barnes, M.R. and R. V. May

1972 Mexican Majolica in Northern New Spain. Pacific Coast Archaeological Society Occasional Paper, Number 2. Costa Mesa, California.

Boessneck, J.

1970 Osteological Differences Between Sheep (Ovis aries Linné) and Goats (Capra hircus Linné). In Science in Archaeology, edited by D. Brothwell and E. Higgs, pp. 331-358. Praeger, New York.

Bolton, H. E.

1970 Texas in the Middle Eighteenth Century. University of California Publications in History, Vol. 3. Original printing 1915. Reprinted by University of Texas Press, Austin.

Bradley, B. A.

1975 Lithic Reduction Sequences: A Glossary and Discussion. In Lithic Technology Making and Using Stone Tools, edited by E. Swanson, pp. 5-13. Mouton Publishers, The Hague.

Brink, J. W.

1997 Fat Content in Leg Bones of Bison bison, and Applications to Archaeology. Journal of Archaeological Science 24:259-274.

Calhoun, C. A.

1962 Scored Pottery of the Texas Coastal Bend. Bulletin of the Texas Archeological Society. Volume 32, for 1961. Austin

Campbell, T. N.

1960 Archaeology of the Central and Southern Sections of the Texas Coast. Bulletin of the Texas Archeological Society 29:145-175.

Charlton, T. H. and R. R. Katz

1979 Tonalá Bruñida Ware. Archaeology 32(1):45-53.

Chandler, C. K. , and L. Lopez

1992 A Quarry Site in Western Duval County. La Tierra 19(2):12-14.

Cohen, A. and D. Serjeantson

1996 A Manual for the Identification of Bird Bones from Archaeological Sites. Revised edition. Archetype Publications, London. 
Corbin, J. E., H. A. Brown, M. G. Canavan, and S. Toups

1990 Mission Dolores de las Ais (41SA25): San Agustine County, Texas. Archaelogical Investigation, 1984. Stephen F. Austin State University, Papers in Anthropology Number 5, Nacogdoches.

Davis, B.

1990 How Was This Bone Burnt? In Problem Solving in Taphonomy, edited by S. Solomon, I. Davidson, and D. Watson, pp. 65-79. Tempus.

deFrance, S. D.

1999 Zooarcheological Evidence of Colonial Culture Change: A Comparison of Two Locations of Mission Espíritu Santo de Zuñiga and Mission Nuestra Señora del Rosario, Texas. Bulletin of the Texas Archeological Society 70:169-195.

Foster, W. C., editor

1998 The La Salle Expedition to Texas. The Journal of Henri Joutel, 1684-1687. Texas State Historical Association, Austin.

Fox, A. A.

1974 Lead Glazed Wares. In Mission Rosario Archeological Investigations in 1973. Archeological Report 14, Part I:55-60 Texas Parks and Wildlife Department, Historic Sites and Restoration Branch, Austin.

Fox, A. A., F. A. Bass, and T. R. Hester

1976 The Archaeology and History of Alamo Plaza. Archaeological Survey Report 16. Center for Archaeological Research, The University of Texas at San Antonio,

Fox, A. A., D. W. Day, and L. Highley

1980 Archaeological and Historical Investigations at Wallisville Lake, Chambers and Liberty Counties, Texas. Archaeological Survey Report 90. Center for Archaeological Research, The University of Texas at San Antonio.

Fox, D. E.

1979 The Lithic Artifacts of Indians at the Spanish Colonial Missions, San Antonio, Texas. Special Report No. 8. The Center for Archaeological Research, The University of Texas at San Antonio.

Gatschet, A. S.

1891 The Karankawa Indians, The Coast People of Texas. Archaeological and Ethnological Papers of the Peabody Museum, Harvard University 1(2), Cambridge.

Gerald, Rex E.

1968 Spanish Presidios of the Late Eighteenth Century in Northern New Spain. Museum of New Mexico Research Records No. 7, Museum of New Mexico Press, Santa Fe.

Gilbert, B. M.

1990 Mammalian Osteology. Missouri Archaeological Society, Columbia. 
Gilmore, K.

1974a Field notes, maps, and sketches created during the 1974 field excavations. Copies on file, Center for Archaeological Research, The University of Texas at San Antonio.

1974b Mission Rosario, Archeological Investigations 1973. Archeological Report 14, Part 1. Texas Parks and Wildlife Department, Historic Sites and Restoration Branch, Austin.

1975 Mission Rosario, Archeological Investigations 1974. Archeological Report 14, Part 2. Texas Parks and Wildlife Department, Historic Sites and Restoration Branch, Austin

Goggin, J. M.

1968 Spanish Majolica in the New World. Yale University Publications in Anthropology 72, New Haven.

Grayson, D. K.

1984 Quantitative Zooarchaeology. Academic Press, New York.

Haggard, J. V., and M. D. McLean

1941 Handbook for Translators of Spanish Historical Documents. Semco Color Press, Oklahoma City.

Hildebrand, $\mathrm{M}$.

1955 Skeletal Differences Between Deer, Sheep, and Goats. California Fish and Game 41:327-346.

Hillson, S.

1986 Teeth. Cambridge University Press, Cambridge.

Huebner, J. A., and A. G. Comuzzie

1992 The Archeology and Bioarcheology of Blue Bayou: A Late Archaic and Late Prehistoric Mortuary Locality in Victoria County, Texas. Studies in Archeology 9. Texas Archeological Research Laboratory, The University of Texas at Austin.

Jochim, M. A.

1976 Hunter-Gatherer Subsistence and Settlement: A Predictive Model. Academic Press, New York.

Juadenes, Fray José Francisco

1791 To Munoz, July 20. Bexar County Archives, 021:0554. San Antonio, Texas.

Kaplan, H., and K. Hill

1992 The Evolutionary Ecology of Food Acquisition. In Evolutionary Ecology and Human Behavior, edited by E. A. Smith and B. Winterhalder, pp. 167-201. Aldine de Gruyter, New York.

Kendrick, G.

1967 Bottle Fragments Betray Age of Historial Sites. El Palacio 74(2):19-24.

Leutenegger, Fr. B., Fr. M. Habig, and M. Carmen Casso

1983 The San José Papers, Part II:August 1791-June 1809. Old Spanish Missions Research Library at San José Mission, San Antonio.

Lister, F. C., and R. H. Lister

1974 Majolica in Colonial Spanish America. Historical Archaeology 8:17-52. 
Lyman, R. L.

1994 Vertebrate Taphonomy. Cambridge University Press, Cambridge.

Lyman, R. L., and M. J. O’Brien

1987 Plow-Zone Zooarchaeology: fragmentation and identifiability. Journal of Archaeological Science $16: 2,93-317$.

Mason, H. M., Jr.

1974 Southern Living. The Missions of Texas. Oxmoor House, Inc. Birmingham, Alabama.

Meissner, B. A.

1998a Vertebrate Faunal Remains. In Mission San José Indian Quarters Foundation Project, Bexar County, Texas: With Appendixes on the Monitoring of the San Jose Bus Drive and Granary Parking Lot, and on the Monitoring and Shovel Testing of the San José Service Drive, by S. A. Tomka and A. A. Fox. Archaeological Survey Report, No. 278. Center for Archaeological Research, The University of Texas at San Antonio.

1998b Analysis of Vertebrate Faunal Remains from a Spanish Colonial Mission, San Antonio de Valero (the Alamo). Unpublished Masters' Thesis, College of Social and Behavioral Sciences, the University of Texas at San Antonio.

1999a Analysis of Vertebrate Faunal Remains from a Spanish Colonial Deposit at Mission San Antonio de Valero (the Alamo). Bulletin of the Texas Archeological Society 70:281-313.

1999b Vertebrate Faunal Remains. In Archaeological Investigation of Rainwater Catchment Basins Along the South Wall of Mission San José, San Antonio, Texas, by S. A. Tomka and A. A. Fox, pp. 39-46. Archaeological Survey Report No. 287, Center for Archaeological Research, the University of Texas at San Antonio.

1999c Vertebrate Faunal Remains. In Mission San José Repointing and Underpinning Project, San Antonio, Texas, by S. A. Tomka, A. A. Fox, and B. A. Meissner, pp. 35-41. Archaeological Survey Report No. 294, Center for Archaeological Research, the University of Texas at San Antonio.

2000a Excavations at Mission Concepción. In Archaeological Investigations at Four San Antonio Missions: The Mission Trails Underground Conversion Project, edited by C. Tennis. Archaeological Survey Report No. 297, Center for Archaeological Research, the University of Texas at San Antonio. In preparation.

2000b Vertebrate Faunal Remains from Mission San Juan. In Archaeological Investigations at Four San Antonio Missions: The Mission Trails Underground Conversion Project, edited by C. Tennis. Archaeological Survey Report No. 297, Center for Archaeological Research, the University of Texas at San Antonio. In preparation.

Miller, G. L., and A. Pacey

1985 Impact of Mechanization in the Glass Container Industry: The Dominion Glass Company of Montreal, a Case Study. Historical Archaeology 19(1):38-50.

Mounger, M. A.

1959 Mission Espíritu Santo of Coastal Texas: An Example of Historic Site Archeology. M. A. Thesis, The University of Texas, Austin. 
Olsen, Stanley J.

1960 Post-Cranial Skeletal Characters of Bison and Bos. Peabody Museum, Cambridge, MA.

1964 Mammal Remains from Archaeological Sites Part I; Southeastern and Southwestern United States. Peabody Museum, Cambridge.

1968 Fish, Amphibian, and Reptile Remains from Archaeological Sites Part I: Southeastern and Southwestern United States. Peabody Museum, Cambridge.

O'Connor, Kathryn S.

1966 The Presidio la Bahía del Espíritu de Zuniga, 1721-1846. Van Boeckmann-Jones Co., Austin.

Ramsdell, C.

1934 Spanish Goliad. Manuscript on file, The Center for American History, University of Texas, Austin.

Reitz, E. J., and C. M. Scarry

1985 Reconstructing Historic Subsistence with an Example from Sixteenth-Century Spanish Florida. Special Publications No. 3. Society for Historical Archaeology, Ann Arbor, MI.

Reitz, E. J., and E. S. Wing

1999 Zooarchaeology. Cambridge University Press, Cambridge.

Ricklis, R. A.

1996 The Karankawa Indians of Texas. University of Texas Press, Austin.

1998 Archaeological Investigations at the Spanish Colonial Mission Sites of Espiritu Santo and Nuestra Señora del Rosario, Goliad County, Texas. Interim Report on the 1997 Testing. Coastal Archaeological Studies, Inc. Corpus Christi, TX.

1999 The Spanish Colonial Missions of Espíritu Santo (41GD1) and Nuestra Señora del Rosario (41GD2), Goliad, Texas: Exploring Patterns of Ethnicity, Interaction, and Acculturation. Bulletin of the Texas Archeological Society 70:133-168.

Rodnick, D.

1974 History of the Goliad Missions and Their Indians. In Mission Rosario Archeological Investigations 1973, Archeological Report 14, Part 1, pp. 7-18 by Kathleen Gilmore, Texas Parks and Wildlife Department, Parks Division, Historic Sites and Restoration Branch, Austin.

Roell, C. H.

1988 Presidio La Bahia and the Presidio System in Texas: A Report on the State of Scholarship. Resource Paper prepared for interpretive master planning process for Goliad, Texas. Texas Parks \& Wildlife, Austin.

Schmid, E.

1972 Atlas of Animal Bones for Prehistorians, Archaeologists, and Quaternary Geologists (Knochenatlas Für Prähistoriker, Archäologen und Quartärgeologen). Elsevier Publishing, Amsterdam.

Schuetz, M. K.

1969 The History and Archeology of Mission San Juan Capistrano, San Antonio, Texas. Volume II. State Building Commission Archeological Program, Report 11, Austin. 
Sobolik, K. D., and D. G. Steele

1996 A Turtle Atlas to Facilitate Archaeological Identifications. Mammoth Site of Hot Springs, SD, Inc., Rapid City, SD.

Suhm, D. A., and E. B. Jelks

1962 Handbook of Texas Archeology: Type Descriptions. Texas Archeological Society Special Publication Number One, Texas Memorial Museum Bulletin Number Four, Austin.

Tomka, S. A.

1989 Differentiating Lithic Reduction Techniques: An Experimental Approach. In Experiments in Lithic Technology, edited by Daniel S. Amick and Raymond P. Mauldin. BAR International Series 528, pp. 137-161.

1999 Historic Period Lithic Technology at Mission San José y San Miguel de Aguayo. Bulletin of the Texas Archeological Society 70:241-263.

Tomka, S. A., and A. A. Fox

1998 Mission San José Indian Quarters Wall Base Project, Bexar County, Texas. Archaeological Survey Report No. 278. Center for Archaeological Research, The University of Texas at San Antonio.

1999 Archaeological Investigations of Rainwater Catchment Basins along the South Wall of Mission San José, San Antonio, Texas. Archaeological Survey Report No. 287. Center for Archaeological Research, The University of Texas at San Antonio.

Tomka, S. A., A. A. Fox, and B. A. Meissner

1999 Mission San José Repointing and Underpinning Project, San Antonio, Texas, by S. A. Tomka, A. A. Fox, and B. A. Meissner, pp. 35-41. Archaeological Survey Report No. 294, Center for Archaeological Research, the University of Texas at San Antonio.

Toulouse, J. H.

1971 Bottle Makers and Their Marks. Thomas Nelson, Inc., New York.

Turner, E. S., and T. R. Hester

1993 A Field Guide to Stone Artifacts of Texas Indians. Second Edition. Texas Monthly Field Guide Series, Gulf, Houston.

Vehik, S. C.

1977 Bone Fragments and Bone Grease Manufacturing: A Review of Their Archaeological Use and Potential. Plains Anthropologist 22:169-182.

Weddle, R. S.

1968 San Juan Bautista, Gateway to Spanish Texas. University of Texas Press, Austin. 
Appendix A

General Cultural Material Data 


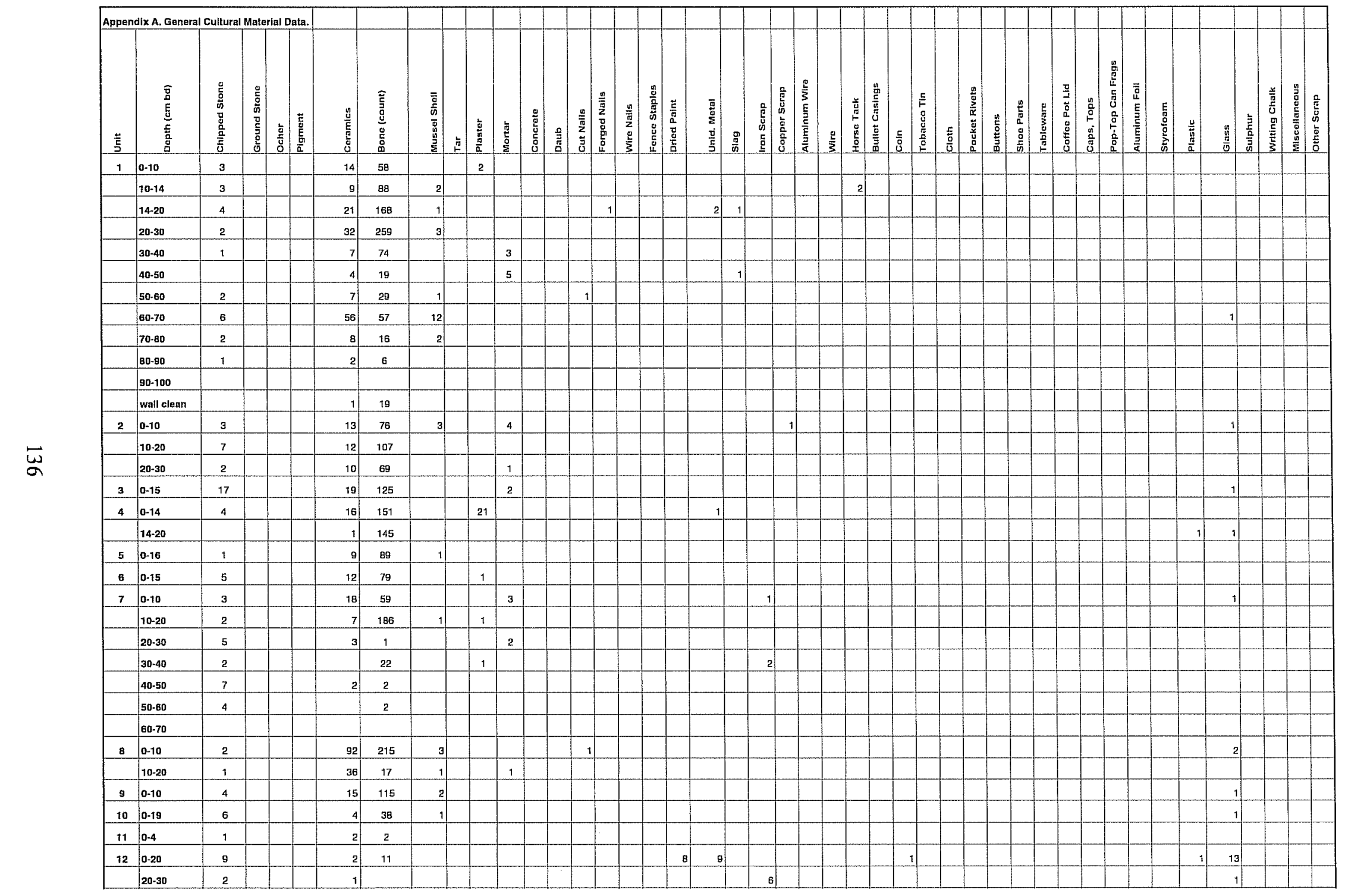




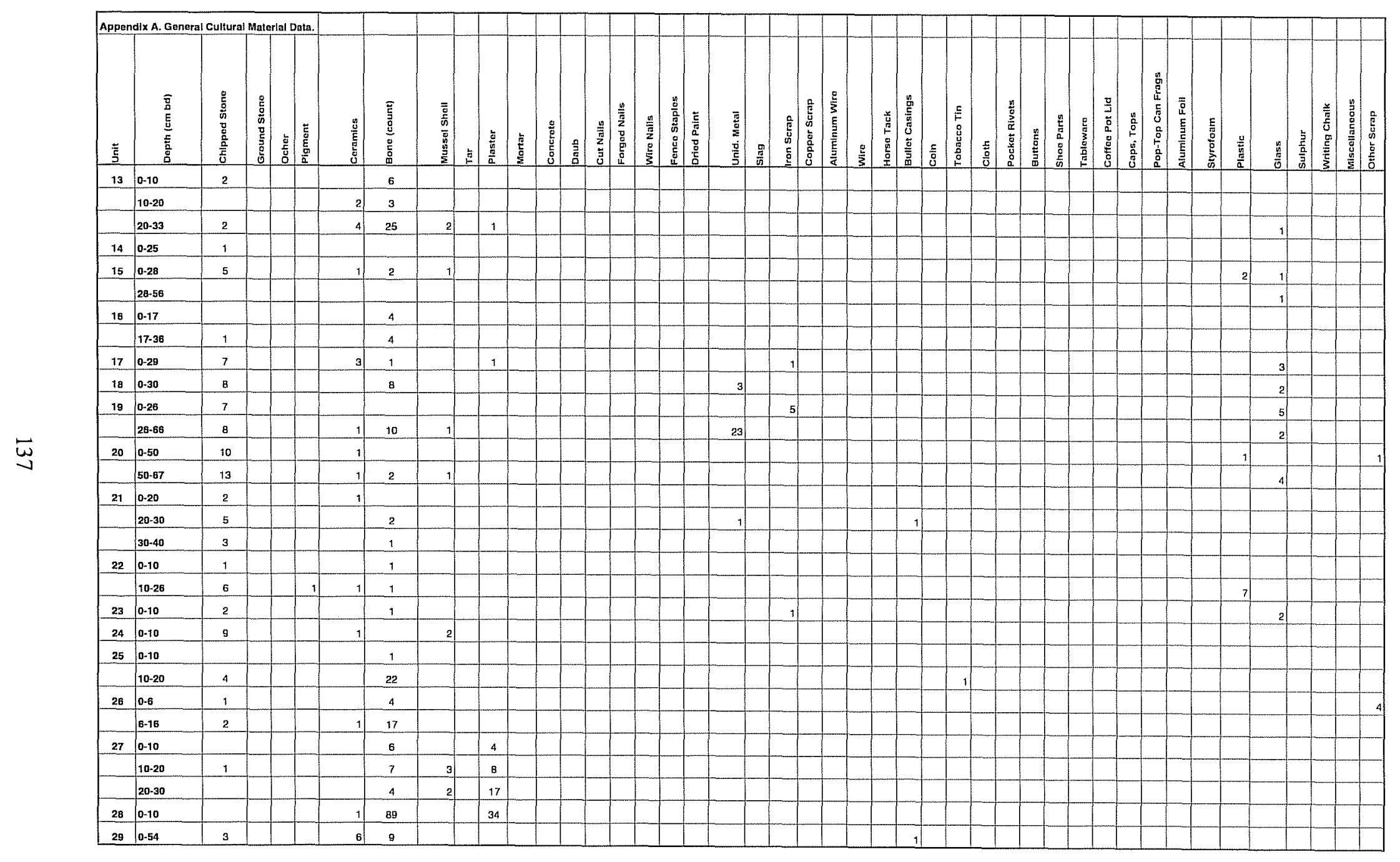



Appendix A-1

Ceramics 


\begin{tabular}{|c|c|c|c|c|c|c|c|c|c|c|c|c|c|c|c|c|c|c|c|c|c|c|c|}
\hline & & $\frac{0}{\frac{\pi}{0}}$ & & a) & $\overleftarrow{N}$ & लै & N & $\nabla$ & $N i$ & 员. & $\infty$ & $N$ & $\stackrel{m}{-2}$ & 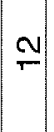 & 우 & $\stackrel{9}{-}$ & $\stackrel{\varphi}{=}$ & $\sigma$ & $\cong$ & $\stackrel{\infty}{\tau} r$ & $N$ & $\infty$ & $\sigma$ \\
\hline & $\begin{array}{l}\mathbf{g} \\
\frac{\mathbf{a}}{3}\end{array}$ & & & & & & & & & & & & & & & & & & & & & & \\
\hline & \pm & әsəu!ฺว ‘u!ejəojod & & & & & & & & & & & & & & & & & & & & & \\
\hline & $\sum$ & pәџелоэәрun & & & & & & & & & & & & & & & & & & & & & \\
\hline & & (әn|q uo әn|q) Јәчұo & & & & & & & & & & & & & & & & & & & & & \\
\hline & & 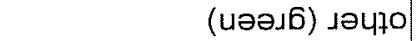 & & & & & & & & & & & & & & & & & & & & & \\
\hline & & 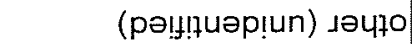 & & & & & & & & & & & & & & & & & & & & & \\
\hline & & 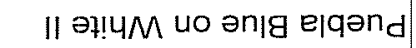 & & & & & & & & & & & & & & $T$ & & & & & & & \\
\hline & & !_ojejeun $\perp$ & & & & & & & & & & & & & & & & & & & & & \\
\hline & & КөנәฺนоW & & & & & & & & & & & & & & - & & & & & & & $\tau$ \\
\hline & & obə!a ues & & & & & & & & & & & & & & & & & & & & & \\
\hline & & 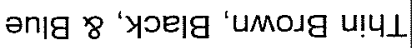 & & & & & & & & & & & & & & & & & & & & & \\
\hline & & O!ıez!Iヨ ues & & & & & & & & & & & & & & & & & & & & & \\
\hline & & obu!zıo[ənH] & & & & & & & & & & & & & & & & & & & & & \\
\hline & g్ & әฺ!ЧM Uo әn।g & & & & & & & & & & & & & & & & & & & & & \\
\hline & $\frac{\pi}{0}$ & u!nsn6n $\forall$ ues & & & & & & & & & & & & & & & & & & & & & \\
\hline & 듭 & pәјелоэәрun & & & & $N$ & $\tau$ & & & & & & & & & & & & & & & & \\
\hline & & 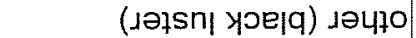 & & & & & & & & & & & & & & & & & & & & & \\
\hline & 通 & uMOנq/M MO||әК & & & & & & & & & & & & & & & & & & & & & \\
\hline & $\bar{U}$ & uMO」q pəد & & & & & & & & & & & & & & & & & & & & & \\
\hline & 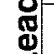 & Eл키 & & & & & & & & & & & $T$ & & & $\pi$ & $m$ & & & $\tau$ & & & $\theta$ \\
\hline & & 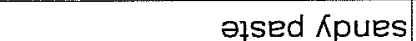 & & & $T$ & & & & & & & & $\tau$ & 5 & $\tau$ & $\Gamma$ & $\Gamma$ & & 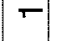 & & & & \\
\hline & & pəus!uınq pəد| & & & & & & & & $N$ & & & & & - & & & & & & & & \\
\hline & & pəus!uunq yәе|q & & & & & & & & & & & & & & & & & & & & & \\
\hline & 傿 & pəus!uung ejeuo & & & & - & & & & & & & & $\tau$ & & & & & & & & & \\
\hline 을 & $\frac{\pi}{5}$ & |Ejseoo & $\mp$ & का & 이 & S & $\mathbf{N}$ & 寸 & $N i$ & Lิ & $\infty 7$ & $\mathrm{~T}$ & $\infty$ & $\infty$ & $\infty$ & & 익 & $\sigma$ & 7 & $\mp 1$ & $N m$ & $2 N$ & $\widehat{\infty}$ \\
\hline 0 & & pel|OS & $m$ & & & & $\theta$ & & & & & & m & $N$ & & 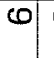 & N & & 우 & $\infty$ & & & \\
\hline$\frac{\dot{x}}{\mathrm{x}}$ & & $\mid \nabla \wedge ә\rceil \mid$ & 이 & 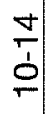 & $\begin{array}{l}\stackrel{O}{2} \\
\text { yे } \\
\end{array}$ & 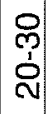 & 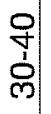 & $\begin{array}{l}0 \\
1 \\
0 \\
+\end{array}$ & $\begin{array}{l}8 \\
0 \\
0 \\
0 \\
\end{array}$ & \begin{tabular}{l}
0 \\
\multirow{1}{1}{} \\
0 \\
0
\end{tabular} & \begin{tabular}{ll}
8 & \multicolumn{1}{c}{} \\
0 \\
0
\end{tabular} & & $=\frac{0}{\frac{1}{0}}$ & 잉 & $\begin{array}{l}\text { Pे } \\
\text { ô }\end{array}$ & & $\frac{\nabla}{0}$ & 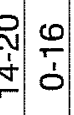 & 占 & 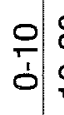 & & \begin{tabular}{|l|l} 
\\
0
\end{tabular} & 잉 \\
\hline 인 & & f!un & - & & & & & & & & & & N & & & & 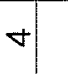 & L) & $\omega$ & N & & & $\infty$ \\
\hline
\end{tabular}




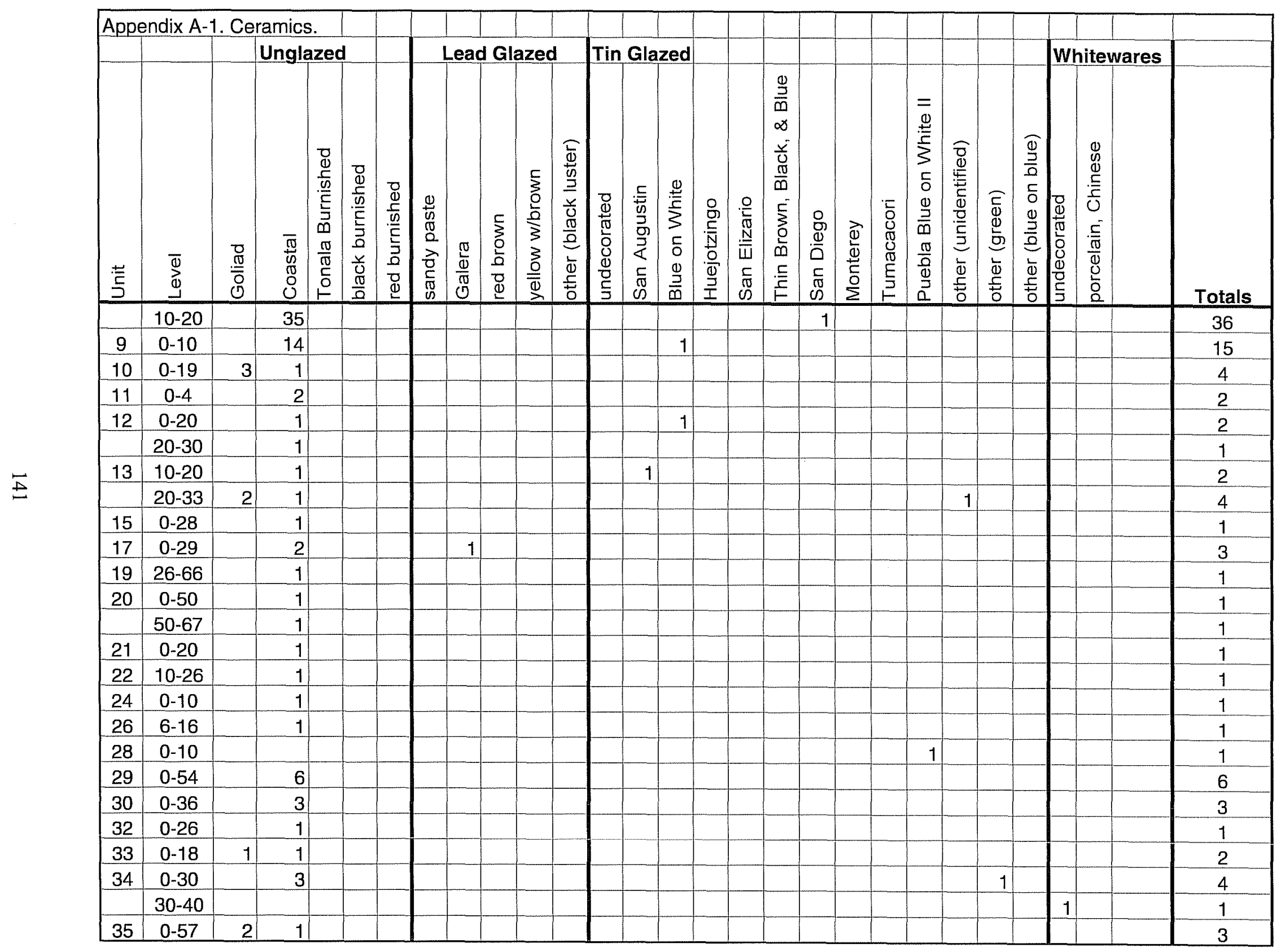




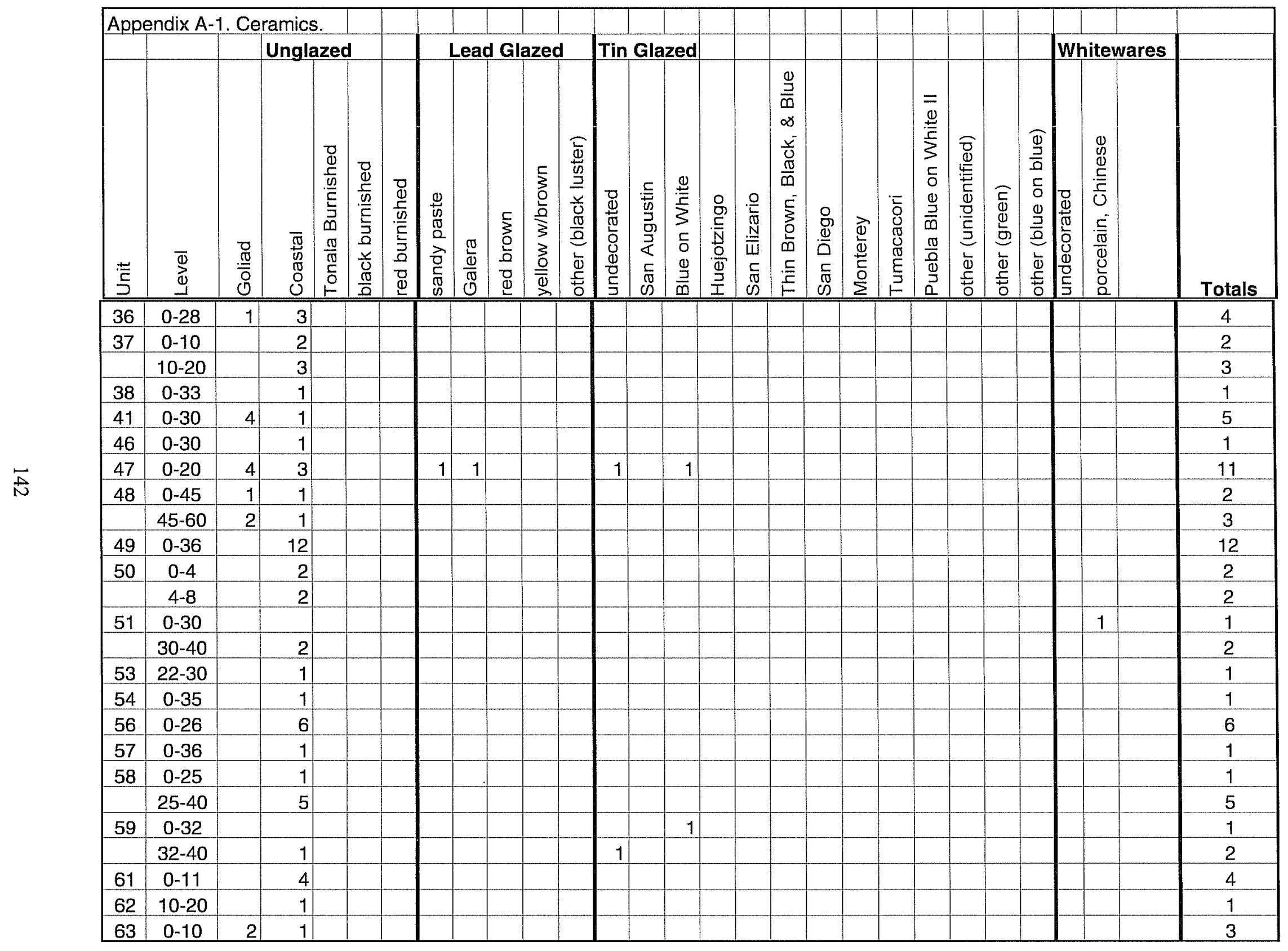




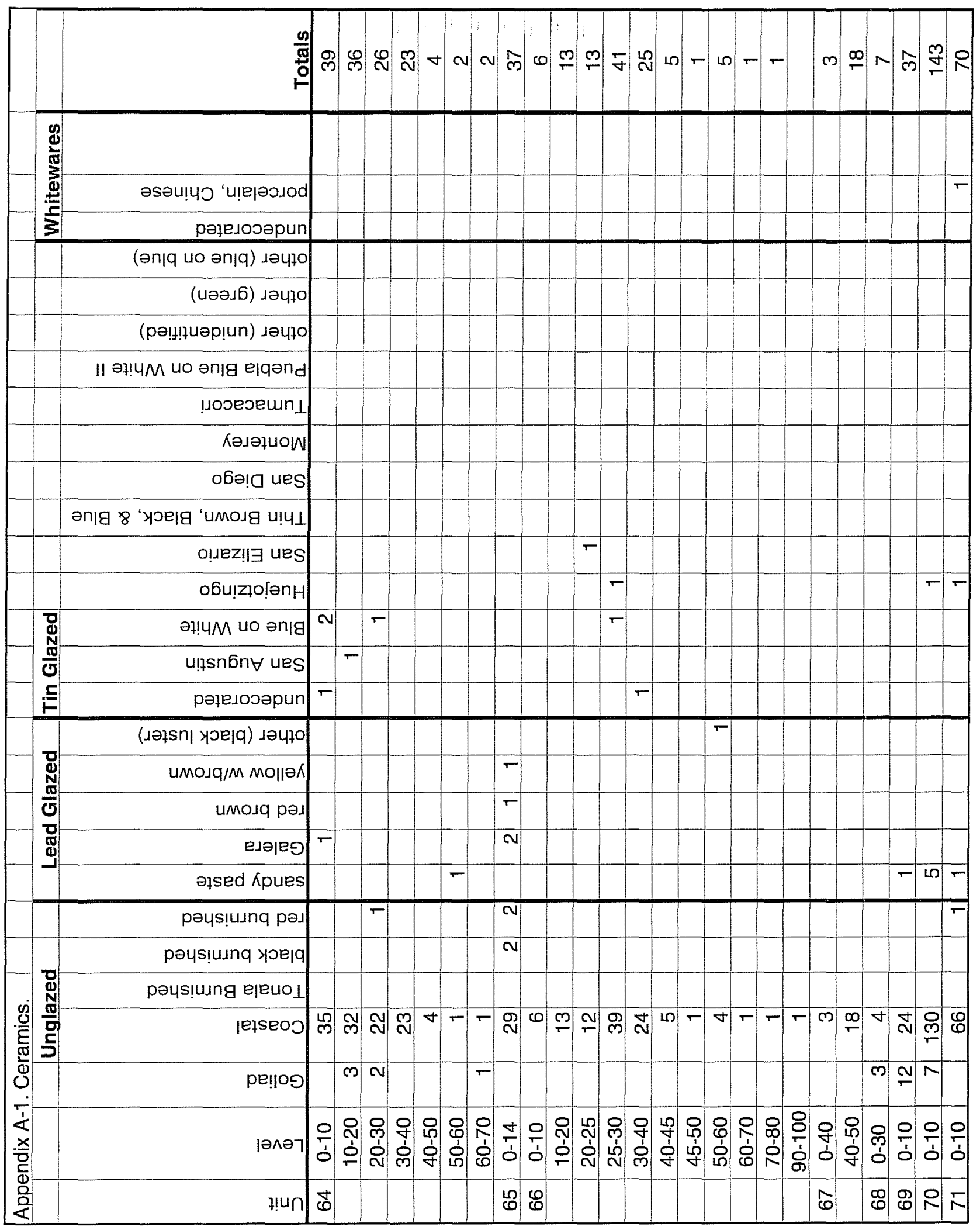




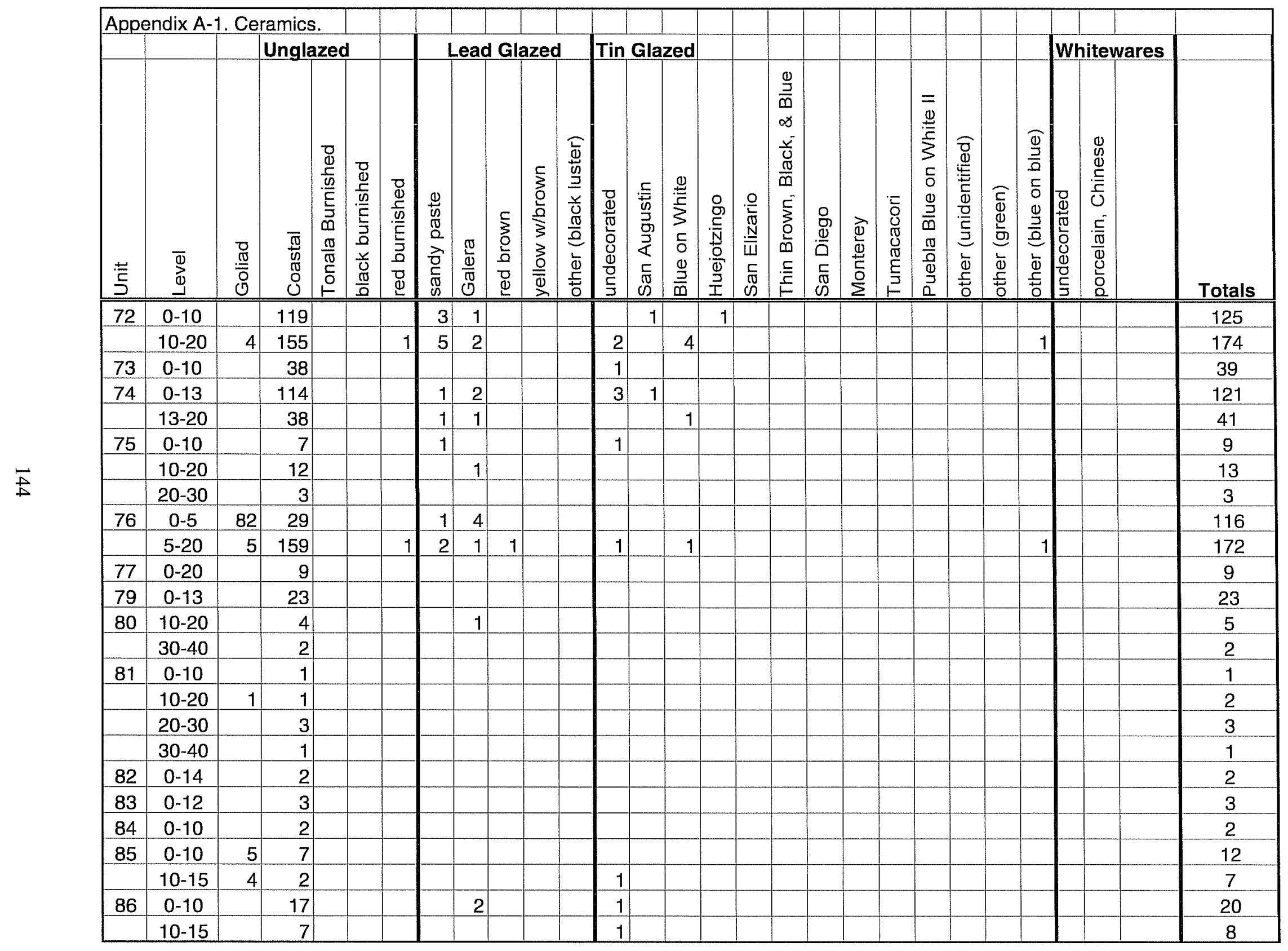




\begin{tabular}{|c|c|c|c|c|c|c|c|c|c|c|c|c|c|c|c|c|c|c|c|c|c|c|c|c|}
\hline & & 욤요 & & - & 寸 & $\infty$ & $\stackrel{N}{\sim}$ & & ஓ & 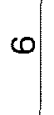 & - & - & 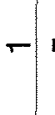 & 100 & $N$ & - & N & $\stackrel{\varphi}{2}$ & $\bar{N}-$ & $\frac{m}{7}$ & $\mathscr{0}$ & $\overline{6} N$ & 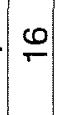 & $\stackrel{m}{q}$ \\
\hline & $\frac{9}{0}$ & & & & & & & & & & & & & & & & & & & & & & & \\
\hline & $\stackrel{\Phi}{\Xi}$ & 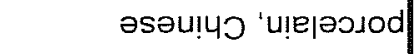 & & & & & & & & & & & & & & & & & & & & & & \\
\hline & $\sum$ & рәرелоoәрun & & & & & & & & & & & & & & & & & & & & & & \\
\hline & & (әnıq uo әn।q) дәцाо & & & & & & & & & & & & & & & & & & & & & & \\
\hline & & (บәәเ6) มәчนо & & & & & & & & & & & & & & & & & & & & & & \\
\hline & & 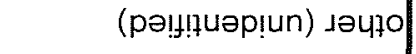 & & & & & & & & & & & & & & & & & & & & & & \\
\hline & & II әा!Ч $M$ uo әnןg elqənd & & & & & & & & & & & & & & & & & & & & & & \\
\hline & & ! Joэeวeun $\perp$ & & & & & & & & & & & & & & & & & & & & & & \\
\hline & & Kəدə]นоW & & & & & & & & & & & & & & & & & & & & & & \\
\hline & & obə!c ues & & & & & & & & & & & & & & & & & & & & 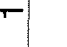 & & \\
\hline & & 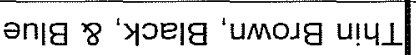 & $T$ & & & & & & & & & & & & & & & & & $T$ & & & & \\
\hline & & o!sez!l & - & & & & & & & & & & & & & & & $\tau$ & & & & & & \\
\hline & & o6u!zıо!ənH & & & & & & & & & & & & & & & & & & & & & & \\
\hline & ]్ & әฺ! & & & & & & & & & & & & & & & & & & $T$ & $\tau T$ & 7 & 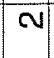 & \\
\hline & $\frac{10}{0}$ & u!nsn6n $\forall$ ues & & & & & & & & & & & & & & & & & $T$ & & & & & \\
\hline & $=$ & рәэелоэәрип & & & $T$ & & & & & & & & & & & & & & & & $T T$ & $T$ & $\tau$ & \\
\hline & & (ләІsn| уәе|q) дәцұО & & & & & & & & & & & & & & & & & & & & & & \\
\hline & d & uMOJq/M MO||әК & & & & & & & & & & & & & & & & & & & & & & \\
\hline & $\overline{\mathbf{\omega}}$ & uмо.q pән & & & & & & & & & & & & & & & & & $N$ & $N$ & & & & \\
\hline & . & esә|еэ| & & & & & $\tau$ & & $N$ & & & & & & & $T$ & & & & & & $m$ - & & \\
\hline & & əfsed Kpues & & & & & & & & & & & & & & & & N & & $\mathrm{N}$ & $\theta /$ & - & & \\
\hline & & pəus!uınq pəد| & & & & & & & & & & & & & & & & & & & & - & & \\
\hline & & pəus!uınq Yoe|q| & & & & & & & & & & & & & & & & & & & & & & \\
\hline & 岕 & pous!uung ejeuol & & & & & & & & & & & & & & & & & & $\tau$ & & & & \\
\hline 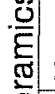 & 흠 & |elseoj & $\overline{7}$ & $T$ & ल) & $N$ & $\mp$ & N & $\bar{m}$ & 6 & $\tau$ & $T$ & $T h$ & $5=$ & $T$ & & N & का? & \begin{tabular}{l|l}
$\infty$ & - \\
& -1
\end{tabular} & \begin{tabular}{|l|}
8 \\
\end{tabular} & กิ & 0 & 10 & ম্లি \\
\hline 0 & & pe!nog & 8 & & & $\tau$ & & $\tau$ & $\varpi$ & & & & & $r$ & & & & & & & & $\mathbb{N}$ & $\infty$ & (8) \\
\hline 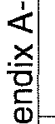 & & |ә^әา| & 웅 & $\frac{n}{b}$ & 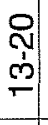 & 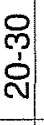 & 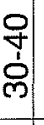 & $\begin{array}{l}0 \\
\text { Ln } \\
0 \\
q \\
\end{array}$ & $\begin{array}{l}\bar{N} \\
0 \\
0\end{array}$ & 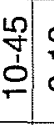 & $\begin{array}{l}0 \\
\frac{1}{0}\end{array}$ & 웅. & \begin{tabular}{l} 
స్̣ \\
$\vdots$ \\
\hdashline
\end{tabular} & $\frac{0}{0} \frac{9}{0}$ & : & $\begin{array}{c}\text { ô } \\
\text { ஸे } \\
\text { ஸे } \\
\end{array}$ & 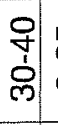 & 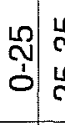 & 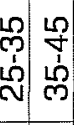 & $\begin{array}{l}m \\
0 \\
0 \\
0\end{array}$ & $\begin{array}{l}9 \\
\dot{y} \\
m \\
m\end{array}$ & $\begin{array}{lll}0 \\
\\
\end{array}$ & 只 & $\frac{n}{0}$ \\
\hline 인 & & १!un & $\infty$ & 岕 & & & & & \$ & 요 & ऽ) & హ) & & ठ & \% & வ & & के & & 8 & 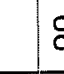 & (3) & & 요 웅 \\
\hline
\end{tabular}




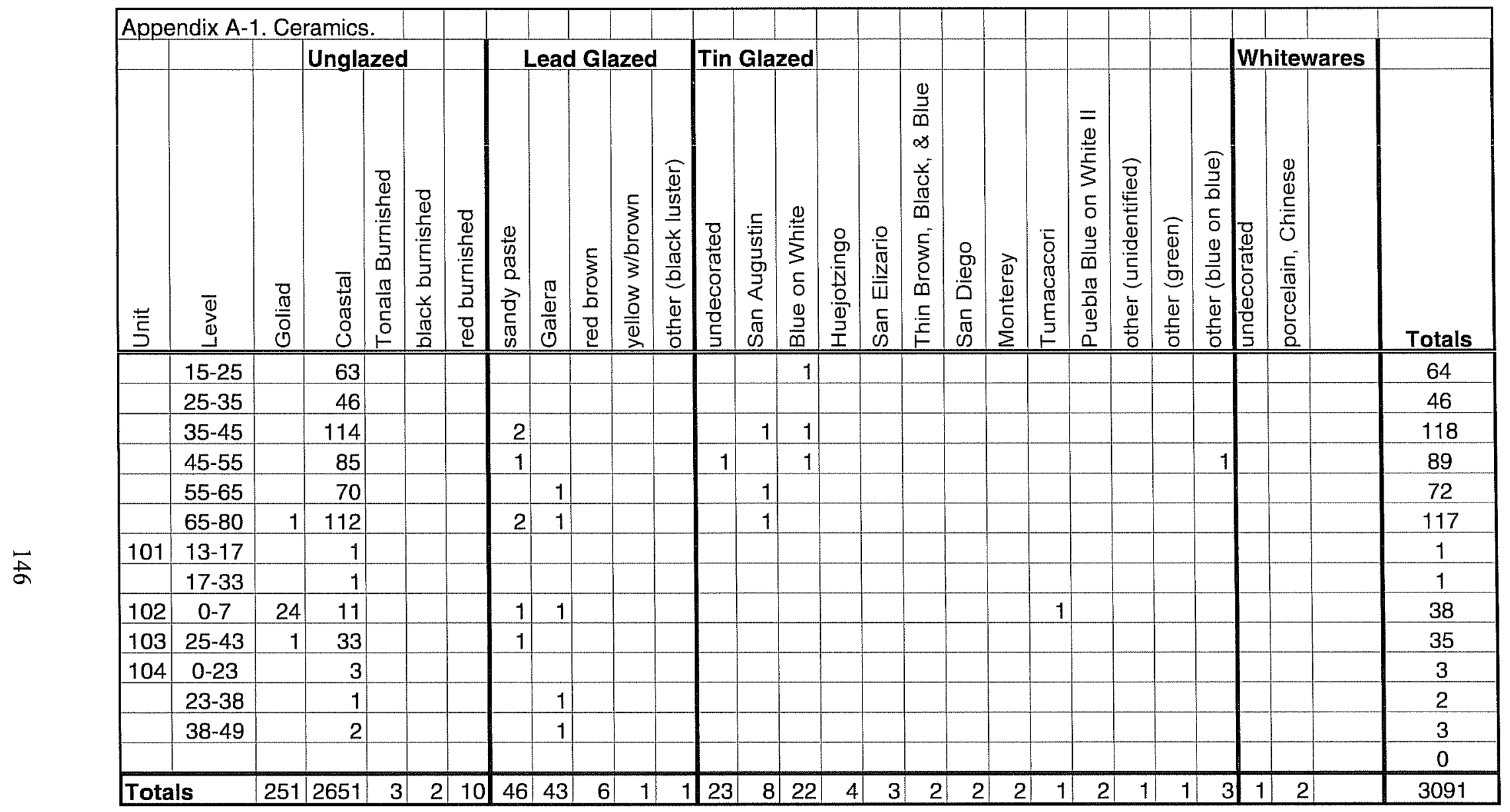


Appendix A-2

Glass 


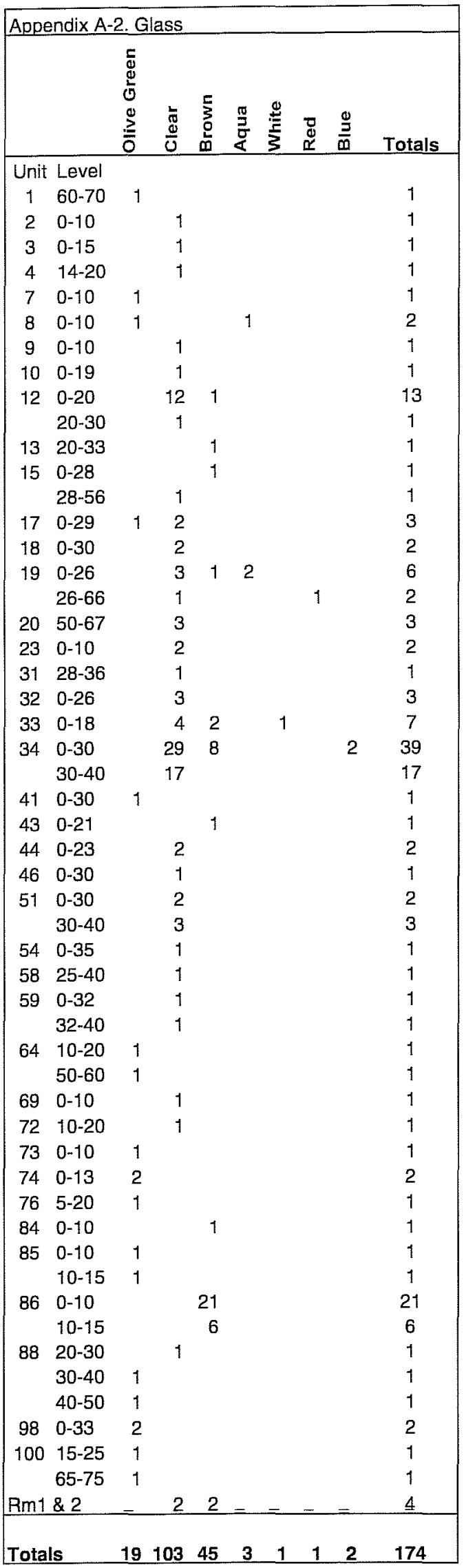


Appendix A-3
Lithic Debitage 


\begin{tabular}{|c|c|c|c|c|c|c|c|c|c|}
\hline 葛 & 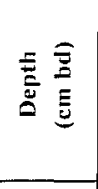 & 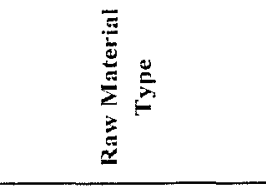 & 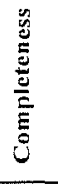 & 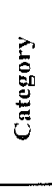 & 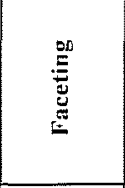 & 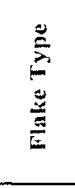 & 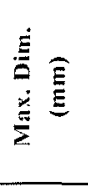 & 菢 & $\begin{array}{l}\text { \# } \\
\stackrel{a}{9}\end{array}$ \\
\hline 1 & $0-10$ & Fine-Grained Chert & $M$ & $S$ & $\mathrm{NA}$ & $\mathrm{BL}$ & 28 & & 1 \\
\hline 1 & $0-10$ & Fine-Grained Chert & $\mathrm{M}$ & $\mathrm{T}$ & $\mathrm{NA}$ & IN & 19 & & 1 \\
\hline 1 & $0-10$ & Fine-Grained Chert & $\mathrm{P}$ & $s$ & Two & $\mathrm{PP}$ & 14 & & 1 \\
\hline 1 & $10-14$ & Petrified Wood & $P$ & $s$ & Two & $\mathrm{BL}$ & 35 & & 2 \\
\hline 1 & $10-14$ & Petrified Wood & C & $s$ & Single & IN & 26 & & 2 \\
\hline 1 & $10-14$ & Fine-Grained Chert & $\mathrm{P}$ & $T$ & Single & IN & 15 & & 2 \\
\hline 1 & $14-20$ & Fine-Grained Chert & $\mathrm{M}$ & $T$ & $\mathrm{NA}$ & IN & 14 & & 106 \\
\hline 1 & $14-20$ & Fine-Grained Chert & $\mathrm{M}$ & $\mathrm{T}$ & NA & IN & 12 & & 106 \\
\hline 1 & $14-20$ & Fine-Grained Chert & $\mathrm{C}$ & $s$ & Single & IN & 40 & & 106 \\
\hline 1 & $14-20$ & Fine-Grained Chert & $\mathrm{C}$ & $\mathrm{T}$ & Single & $\mathrm{PP}$ & 15 & & 106 \\
\hline 1 & $20-30$ & Fine-Grained Chert & C & $s$ & Single & BL & 42 & & 14 \\
\hline 1 & $20-30$ & Fine-Grained Chert & C & $S$ & Two & PP & 33 & & 14 \\
\hline 1 & $30-40$ & Fine-Grained Chert & C & $s$ & Single & $B L$ & 45 & & 16 \\
\hline 1 & $50-60$ & Quartz Arenite & $P$ & $T$ & Two & BM & 35 & Light Tan Color & 20 \\
\hline 1 & $50-60$ & Quartzite & $\mathrm{M}$ & $\mathrm{T}$ & $\mathrm{NA}$ & BT & 15 & & 20 \\
\hline 1 & $60-70$ & Fine-Grained Chert & $\mathrm{P}$ & $S$ & Single & $\mathrm{CR}$ & 18 & & 25 \\
\hline 1 & $60-70$ & Fine-Grained Chert & $\mathrm{P}$ & $T$ & Single & $\mathrm{CR}$ & 30 & & 25 \\
\hline 1 & $60-70$ & Fine-Grained Chert & D & $\mathrm{T}$ & NA & IN & 16 & & 25 \\
\hline 1 & $60-70$ & Quartz Arenite & $\mathrm{M}$ & $\mathrm{T}$ & NA & $\mathbb{I N}$ & 18 & & 25 \\
\hline 1 & $60-70$ & Fine-Grained Chert & $\mathrm{P}$ & $\mathrm{T}$ & Single & $\mathbb{I N}$ & 21 & & 25 \\
\hline 1 & $60-70$ & Petrified Wood & C & $\mathrm{T}$ & Single & PP & 19 & & 25 \\
\hline 1 & $70-80$ & Fine-Grained Chert & $\mathrm{C}$ & $\mathrm{T}$ & Single & $\mathbb{I N}$ & 16 & & 29 \\
\hline 1 & $70-80$ & Fine-Grained Chert & C & $\mathrm{T}$ & Single & $\mathrm{PP}$ & 17 & & 223 \\
\hline 1 & $80-90$ & Petrified Wood & $\mathrm{D}$ & $\mathrm{S}$ & $\mathrm{NA}$ & $\mathbb{I N}$ & 25 & & 31 \\
\hline 2 & $0-10$ & Petrified Wood & $\mathrm{D}$ & $\mathrm{T}$ & NA & $\mathbb{N}$ & 17 & & 112 \\
\hline 2 & $0-10$ & Petrified Wood & C & $\mathrm{s}$ & Corticate & PP & 20 & & 112 \\
\hline 2 & $0-10$ & Fine-Grained Chert & C & $s$ & Single & PP & 16 & & 112 \\
\hline 2 & $10-20$ & Fine-Grained Chert & $\mathrm{D}$ & $\mathrm{S}$ & NA & $\mathrm{BL}$ & 33 & & 113 \\
\hline 2 & $10-20$ & Fine-Grained Chert & $\mathrm{P}$ & $\mathrm{T}$ & Two & $\mathrm{BL}$ & 30 & & 113 \\
\hline 2 & $10-20$ & Fine-Grained Chert & $\mathrm{D}$ & $\mathrm{T}$ & NA & BT & 26 & & 113 \\
\hline 2 & $10-20$ & Fine-Grained Chert & D & $s$ & NA & IN & 34 & & 113 \\
\hline 2 & $10-20$ & Fine-Grained Chert & M & $T$ & NA & $\mathrm{IN}$ & 11 & & 113 \\
\hline 2 & $10-20$ & Quartz Arenite & $\mathrm{D}$ & $s$ & NA & $\mathrm{PP}$ & 14 & & 113 \\
\hline 2 & $10-20$ & Fine-Grained Chert & $\mathrm{C}$ & $\mathrm{T}$ & Single & PP & 15 & & 113 \\
\hline 2 & $20-30$ & Fine-Grained Chert & $\mathrm{D}$ & $T$ & NA & $\mathrm{IN}$ & 15 & & 114 \\
\hline 2 & $20-30$ & Quartz Arenite & $\mathrm{D}$ & $\mathrm{T}$ & NA & PP & 21 & Not Transluscent; White & 114 \\
\hline 3 & $0-15$ & Coarse-Grained Chert & $\mathrm{C}$ & $\mathrm{T}$ & Corticate & $B L$ & 33 & & 110 \\
\hline 3 & $0-15$ & Coarse-Grained Chert & C & $T$ & Corticate & $\mathrm{BL}$ & 33 & & 110 \\
\hline 3 & $0-15$ & Fine-Grained Chert & $\mathrm{D}$ & $\mathrm{T}$ & NA & $\mathrm{BM}$ & 19 & & 110 \\
\hline 3 & $0-15$ & Fine-Grained Chert & D & $\mathrm{T}$ & NA & BM & 19 & & 110 \\
\hline 3 & $0-15$ & Fine-Grained Chert & $P$ & $s$ & Corticate & $\mathrm{CR}$ & 36 & Heat Spalled & 110 \\
\hline 3 & $0-15$ & Fine-Grained Chert & $\mathrm{P}$ & $S$ & Corticale & $\mathrm{CR}$ & 36 & Heat Spalled & 110 \\
\hline 3 & $0-15$ & Fine-Grained Chert & $P$ & $\mathrm{~T}$ & Corticate & $\mathrm{pp}$ & 16 & & 110 \\
\hline 3 & $0-15$ & Fine-Grained Chert & $\mathrm{P}$ & $\mathrm{T}$ & Corticate & PP & 16 & & 110 \\
\hline 3 & $0-15$ & Fine-Grained Chert & $\mathrm{M}$ & $s$ & NA & PP & 15 & & 110 \\
\hline 3 & $0-15$ & Fine-Grained Chert & M & $s$ & $\mathrm{NA}$ & PP & 15 & & 110 \\
\hline 3 & $0-15$ & Fine-Grained Chert & $\mathrm{D}$ & $\mathrm{T}$ & $\mathrm{NA}$ & PP & 21 & & 110 \\
\hline 3 & $0-15$ & Fine-Grained Chert & $M$ & $\mathrm{~T}$ & NA & $\mathrm{PP}$ & 10 & & 110 \\
\hline 3 & $0-15$ & Fine-Grained Chert & $\mathrm{M}$ & $\mathrm{T}$ & $\mathrm{NA}$ & $\mathrm{pP}$ & 10 & & 110 \\
\hline 3 & $0-15$ & Fine-Grained Chert & $\mathrm{D}$ & $S$ & NA & UM & 27 & Heat Spalled & 110 \\
\hline 3 & $0-15$ & Fine-Grained Chert & $\mathrm{D}$ & $s$ & NA & UM & 27 & Heat Spalled & 110 \\
\hline 3 & $0-15$ & Fine-Grained Chert & $\mathrm{P}$ & $\mathrm{T}$ & Two & US & 10 & & 110 \\
\hline 3 & $0-15$ & Fine-Grained Chert & $\mathbf{P}$ & $\mathrm{T}$ & Two & US & 10 & & 110 \\
\hline 4 & $0-14$ & Fine-Grained Chert & C & $s$ & Single & $\mathrm{CR}$ & 53 & & 63 \\
\hline 4 & $0-14$ & Fine-Grained Chert & $\mathrm{C}$ & $\mathrm{s}$ & Single & $\mathrm{CR}$ & 53 & & 63 \\
\hline 4 & $0-14$ & Fine-Grained Chert & D & $T$ & NA & PP & 17 & & 63 \\
\hline
\end{tabular}




\begin{tabular}{|c|c|c|c|c|c|c|c|c|c|}
\hline$\stackrel{\equiv}{\underline{\Xi}}$ & 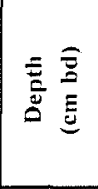 & 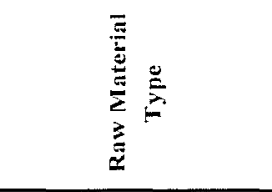 & 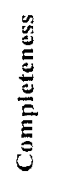 & 咅 & : & 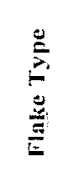 & $\begin{array}{l}\dot{\vec{E}} \\
\dot{E} \\
\dot{E}\end{array}$ & 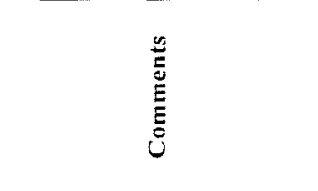 & $\stackrel{\#}{\stackrel{\#}{\Xi}}$ \\
\hline 4 & $0-14$ & Fine-Grained Chert & D & $\mathrm{T}$ & NA & $\mathrm{PP}$ & 17 & & 63 \\
\hline 5 & $0-16$ & Fine-Grained Chert & $\mathrm{P}$ & $T$ & Single & $\mathrm{CR}$ & 39 & & 115 \\
\hline 6 & $0-15$ & Fine-Grained Chert & $P$ & $\mathrm{~T}$ & Two & BT & 20 & & 68 \\
\hline 6 & $0-15$ & Fine-Grained Chert & $P$ & $s$ & Single & $\mathrm{CR}$ & 37 & & 68 \\
\hline 6 & $0-15$ & Fine-Grained Cherl & D & $\mathrm{s}$ & $\mathrm{NA}$ & IN & 19 & & 68 \\
\hline 6 & $0-15$ & Fine-Grained Chert & $\mathrm{D}$ & $\mathrm{T}$ & NA & PP & 11 & & 68 \\
\hline 6 & $0-15$ & Fine-Grained Chert & C & $T$ & Single & US & 20 & & 68 \\
\hline 7 & $0-10$ & Fine-Grained Chert & $\mathrm{D}$ & $s$ & $\mathrm{NA}$ & BM & 25 & & 12 \\
\hline 7 & $0-10$ & Fine-Grained Chert & $\mathrm{D}$ & $\mathrm{T}$ & $\mathrm{NA}$ & IN & 27 & & 12 \\
\hline 7 & $0-10$ & Fine-Grained Chert & $\mathrm{D}$ & $T$ & $\mathrm{NA}$ & $\mathrm{pP}$ & 13 & Heat Treated & 12 \\
\hline 7 & $10-20$ & Fine-Grained Chent & $\mathrm{M}$ & $\mathrm{T}$ & $\mathrm{NA}$ & IN & 9 & & 13 \\
\hline 7 & $10-20$ & Fine-Grained Chert & $C$ & $\mathrm{~T}$ & Two & US & 14 & & 13 \\
\hline 7 & $20-30$ & Fine-Grained Chert & C & $s$ & Two & $\mathrm{BL}$ & 40 & & 24 \\
\hline 7 & $20-30$ & Fine-Grained Chert & $\mathrm{M}$ & $\mathrm{T}$ & NA & IN & 15 & & 24 \\
\hline 7 & $20-30$ & Fine-Grained Chert & D & $Y$ & NA & IN & 31 & & 24 \\
\hline 7 & $20-30$ & Fine-Grained Chert & $\mathrm{M}$ & $\mathrm{T}$ & NA & PP & 11 & & 24 \\
\hline 7 & $20-30$ & Fine-Grained Chert & $\mathrm{C}$ & $\mathrm{D}$ & Three+ + & PP & 22 & & 24 \\
\hline 7 & $30-40$ & Quartz Arenite & $\mathrm{D}$ & $T$ & NA & IN & 18 & & 22 \\
\hline 7 & $30-40$ & Quartz Arenite & D & $T$ & NA & UM & 25 & & 22 \\
\hline 7 & $40-50$ & Fine-Grained Chert & D & $\mathrm{T}$ & $\mathrm{NA}$ & IN & 26 & & 23 \\
\hline 7 & $40-50$ & Fine-Grained Chert & $\mathrm{D}$ & $\mathrm{T}$ & NA & IN & 18 & & 23 \\
\hline 7 & $40-50$ & Fine-Grained Chert & $\mathrm{M}$ & $\mathrm{T}$ & NA & IN & 15 & & 23 \\
\hline 7 & $40-50$ & Fine-Grained Chert & $\mathrm{P}$ & $\mathrm{T}$ & Single & IN & 15 & & 23 \\
\hline 7 & $40-50$ & Fine-Grained Chert & $\mathrm{P}$ & $s$ & Single & $\mathrm{PP}$ & 12 & & 23 \\
\hline 7 & $40-50$ & Fine-Grained Chert & C & $\mathrm{T}$ & Single & UM & 22 & & 23 \\
\hline 7 & $40-50$ & Fine-Grained Chert & C & $T$ & Single & UR & 10 & & 23 \\
\hline 7 & $50-60$ & Fine-Grained Chert & $\mathrm{P}$ & $T$ & Corticate & IN & 16 & & 27 \\
\hline 7 & $50-60$ & Fine-Grained Chert & $\mathrm{D}$ & $\mathrm{T}$ & NA & IN & 11 & & 27 \\
\hline 7 & $50-60$ & Petrified Wood & $\mathrm{P}$ & $\mathrm{T}$ & Single & IN & 20 & & 27 \\
\hline 7 & $50-60$ & Quartzite & $\mathrm{P}$ & $\mathrm{T}$ & Threet & $\mathrm{PP}$ & 13 & & 27 \\
\hline 8 & $0-10$ & Fine-Grained Chert & C & $\mathrm{s}$ & Corticate & $\mathrm{BL}$ & 43 & & 54 \\
\hline 8 & $0-10$ & Quartz Arenite & $\mathrm{M}$ & $\mathrm{T}$ & NA & $\mathbb{I N}$ & 21 & & 54 \\
\hline 8 & $10-20$ & Coarse-Grained Chert & $\mathrm{FC}$ & $\mathrm{s}$ & NA & FCR & 46 & & 62 \\
\hline 9 & $10-20$ & Fine-Grained Chert & $\mathrm{AD}$ & $\mathrm{T}$ & NA & $\mathrm{AD}$ & 16 & & 85 \\
\hline 9 & $10-20$ & Fine-Grained Chert & $\mathrm{C}$ & $\mathrm{s}$ & Two & $\mathrm{BL}$ & 38 & & 85 \\
\hline 9 & $10-20$ & Fine-Grained Quartzite & $\mathrm{D}$ & $\mathrm{P}$ & $\mathrm{NA}$ & $\mathrm{PP}$ & 17 & & 85 \\
\hline 9 & $10-20$ & Fine-Grained Chert & $P$ & $S$ & Two & PP & 13 & & 85 \\
\hline 10 & $0-19$ & Fine-Grained Chert & $\mathrm{D}$ & $\mathrm{T}$ & NA & BT & 24 & & 83 \\
\hline 10 & $0-19$ & Fine-Grained Chert & $\mathrm{M}$ & $\mathrm{T}$ & $\mathrm{NA}$ & BT & 16 & & 83 \\
\hline 10 & $0-19$ & Fine-Grained Chert & $M$ & $\mathrm{P}$ & $\mathrm{NA}$ & IN & 36 & & 83 \\
\hline 10 & $0-19$ & Quartz Arenite & $\mathrm{D}$ & $s$ & $\mathrm{NA}$ & IN & 21 & Yellowish-Brown & 83 \\
\hline 10 & $0-19$ & Fine-Grained Chert & C & $s$ & Corticate & PP & 20 & & 83 \\
\hline 10 & $0-19$ & Fine-Grained Chert & M & $\mathrm{T}$ & $\mathrm{NA}$ & $\mathrm{PP}$ & 23 & & 83 \\
\hline 11 & $0-4$ & Fine-Grained Chert & $\mathrm{D}$ & $T$ & $\mathrm{NA}$ & $\mathrm{BM}$ & 26 & Post-depositional Retouch & 90 \\
\hline 12 & $0-20$ & Fine-Grained Chert & $\mathrm{AD}$ & $s$ & NA & $A D$ & 29 & & 106 \\
\hline 12 & $0-20$ & Fine-Grained Chert & $M$ & $\mathrm{~T}$ & $\mathrm{NA}$ & $\mathrm{BL}$ & 20 & & 106 \\
\hline 12 & $0-20$ & Fine-Grained Chert & C & $\mathrm{T}$ & Threet & $\mathrm{BM}$ & 35 & & 106 \\
\hline 12 & $0-20$ & Quartz Arenite & $\mathrm{P}$ & $\mathrm{T}$ & Threet & BT & 12 & & 106 \\
\hline 12 & $0-20$ & Fine-Grained Chert & $\mathrm{D}$ & $\mathrm{T}$ & $\mathrm{NA}$ & IN & 17 & & 106 \\
\hline 12 & $0-20$ & Fine-Grained Chert & $\mathrm{M}$ & $T$ & $\mathrm{NA}$ & IN & 20 & & 106 \\
\hline 12 & $0-20$ & Fine-Grained Chert & $\mathrm{P}$ & $s$ & Single & IN & 18 & & 106 \\
\hline 12 & $0-20$ & Fine-Grained Chert & $\mathrm{P}$ & $\mathrm{T}$ & Two & PP & 15 & & 106 \\
\hline 12 & $0-20$ & Fine-Grained Chert & $\mathrm{C}$ & $T$ & Single & UM & 11 & & 106 \\
\hline 12 & $20-30$ & Fine-Grained Chert & $M$ & $s$ & $\mathrm{NA}$ & IN & 19 & & 108 \\
\hline 12 & $20-30$ & Fine-Grained Chert & D & $s$ & $\mathrm{NA}$ & PP & 31 & & 108 \\
\hline 13 & $0-10$ & Fine-Grained Chert & $\mathrm{C}$ & $\mathrm{T}$ & Three+ & PP & 22 & & 143 \\
\hline
\end{tabular}




\begin{tabular}{|c|c|c|c|c|c|c|c|c|c|}
\hline $\bar{E}$ & 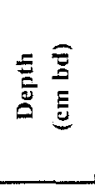 & 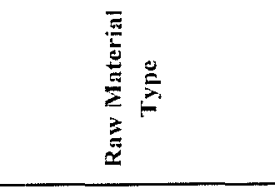 & 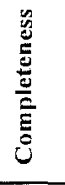 & 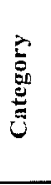 & 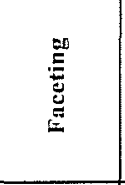 & 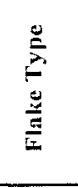 & $\begin{array}{l}\stackrel{\dot{E}}{\hat{\theta}} \widehat{\bar{E}} \\
\dot{\tilde{E}} \\
\frac{\dot{E}}{E}\end{array}$ & 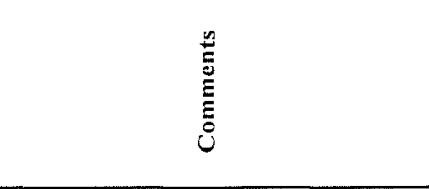 & $\begin{array}{l}\text { Z } \\
\stackrel{\Xi}{\Xi}\end{array}$ \\
\hline 13 & $0-10$ & Fine-Grained Chert & $\mathrm{M}$ & $T$ & $\mathrm{NA}$ & UM & 13 & & 97 \\
\hline 13 & $20-33$ & Fine-Grained Chert & $\mathrm{D}$ & 5 & $\mathrm{NA}$ & $\mathrm{BL}$ & 29 & & 99 \\
\hline 13 & $20-33$ & Fine-Grained Chert & $\mathrm{M}$ & $\mathrm{T}$ & NA & $\mathrm{PP}$ & 18 & & 99 \\
\hline 14 & $0-25$ & Fine-Grained Chert & C & $\mathrm{T}$ & Two & $\mathrm{PP}$ & 35 & & 150 \\
\hline 15 & $0-28$ & Fine-Grained Chert & $\mathrm{C}$ & $\mathrm{T}$ & Single & $\mathrm{BL}$ & 24 & & 173 \\
\hline 15 & $0-28$ & Quartz Arenite & $\mathrm{D}$ & $\mathrm{T}$ & NA & $\mathrm{BM}$ & 22 & & 173 \\
\hline 15 & $0-28$ & Fine-Grained Chert & C & $\mathrm{P}$ & Corticate & IN & 30 & Yellowish-Black Chert & 173 \\
\hline 15 & $0-28$ & Fine-Grained Chert & $\mathrm{P}$ & $\mathrm{T}$ & Single & IN & 12 & & 173 \\
\hline 15 & $0-28$ & Fine-Grained Chert & $\mathrm{C}$ & $\mathrm{T}$ & Two & IN & 23 & & 173 \\
\hline 16 & $17-36$ & Fine-Grained Chert & $\mathrm{C}$ & $\mathrm{T}$ & Three+ & $\mathrm{BL}$ & 24 & Pinkish Chert with Burgundy Specks & 181 \\
\hline 17 & $0-29$ & Petrified Wood & $\mathrm{AD}$ & $\mathrm{T}$ & NA & $A D$ & 10 & & 116 \\
\hline 17 & $0-29$ & Fine-Grained Chert & C & $\mathrm{s}$ & Single & $B L$ & 30 & & 116 \\
\hline 17 & $0-29$ & Fine-Grained Chert & $\mathrm{C}$ & $T$ & Threet & BM & 36 & & 116 \\
\hline 17 & $0-29$ & Fine-Grained Chert & $\mathrm{D}$ & $\mathrm{T}$ & $\mathrm{NA}$ & IN & 17 & & 116 \\
\hline 17 & $0-29$ & Fine-Grained Chert & D & $T$ & NA & IN & 22 & & 116 \\
\hline 17 & $0-29$ & Petrified Wood & M & $\mathrm{s}$ & $\mathrm{NA}$ & $\mathrm{pP}$ & 10 & & 116 \\
\hline 17 & $0-29$ & Fine-Grained Chert & $\mathrm{P}$ & $T$ & Threet & PP & 11 & & 116 \\
\hline 18 & $0-30$ & Fine-Grained Quartzite & C & $s$ & Single & $\mathrm{BL}$ & 31 & & 119 \\
\hline 18 & $0-30$ & Quartz Arenite & $\mathrm{M}$ & $\mathrm{T}$ & $\mathrm{NA}$ & $\mathrm{BT}$ & 14 & & 119 \\
\hline 18 & $0-30$ & Fine-Grained Chert & $\mathrm{D}$ & $\mathrm{P}$ & NA & $\mathrm{IN}$ & 43 & & 119 \\
\hline 18 & $0-30$ & Fine-Grained Chert & $\mathrm{D}$ & $\mathrm{T}$ & NA & IN & 18 & Heat Spalled & 119 \\
\hline 18 & $0-30$ & Fine-Grained Chert & $\mathrm{D}$ & $T$ & $\mathrm{NA}$ & IN & 25 & & 119 \\
\hline 18 & $0-30$ & Fine-Grained Chert & $\mathrm{C}$ & $S$ & Single & PP & 19 & & 119 \\
\hline 18 & $0-30$ & Fine-Grained Chert & D & $T$ & $\mathrm{NA}$ & UM & 22 & & 119 \\
\hline 18 & $0-30$ & Fine-Grained Chert & $\mathrm{C}$ & $T$ & Single & UR & 16 & & 119 \\
\hline 19 & $0-26$ & Fine-Grained Chert & $\mathrm{M}$ & $\underline{s}$ & NA & BL & 20 & & 189 \\
\hline 19 & $0-26$ & Fine-Grained Chert & $\mathrm{M}$ & $\mathrm{T}$ & $\mathrm{NA}$ & $\mathrm{BL}$ & 24 & & 189 \\
\hline 19 & $0-26$ & Fine-Grained Chert & $C$ & $S$ & Single & $\mathrm{BL}$ & 32 & & 189 \\
\hline 19 & $0-26$ & Fine-Grained Chert & $\mathrm{C}$ & $\mathrm{T}$ & Single & $\mathrm{BL}$ & 32 & Blade-like & 189 \\
\hline 19 & $0-26$ & Quartz Arenite & $\mathrm{D}$ & $T$ & NA & BM & 47 & & 189 \\
\hline 19 & $0-26$ & Quartz Arenite & $M$ & $\mathrm{~T}$ & NA & IN & 27 & & 189 \\
\hline 19 & $0-26$ & Quartz Arenite & $\mathrm{D}$ & $T$ & $\mathrm{NA}$ & $\mathrm{PP}$ & 16 & & 189 \\
\hline 19 & $26-66$ & Fine-Grained Chert & $\mathrm{AD}$ & $\mathrm{T}$ & NA & $A D$ & 13 & & 191 \\
\hline 19 & $26-66$ & Fine-Grained Chert & C & $\mathrm{P}$ & Corticate & $\mathrm{BL}$ & 51 & & 191 \\
\hline 19 & $26-66$ & Fine-Grained Chert & C & $\mathrm{S}$ & Single & $\mathrm{BL}$ & 37 & & 191 \\
\hline 19 & $26-66$ & Petrified Wood & $\mathrm{D}$ & $\mathrm{T}$ & NA & BM & 30 & & 191 \\
\hline 19 & $26-66$ & Petrified Wood & $\mathrm{C}$ & $\mathrm{P}$ & Corticate & IN & 16 & & 191 \\
\hline 19 & $26-66$ & Fine-Grained Chert & $\mathrm{D}$ & $S$ & NA & IN & 14 & & 191 \\
\hline 19 & $26-66$ & Petrified Wood & $\mathrm{M}$ & $T$ & $\mathrm{NA}$ & $\mathbb{I N}$ & 28 & & 191 \\
\hline 19 & $26-66$ & Fine-Grained Chert & D & $\mathrm{T}$ & NA & PP & 23 & & 191 \\
\hline 20 & $0-50$ & Fine-Grained Chert & $\mathrm{P}$ & $S$ & Two & $\mathrm{BL}$ & 32 & & 176 \\
\hline 20 & $0-50$ & Fine-Grained Chert & $\mathrm{C}$ & $s$ & Threet & $\mathrm{BL}$ & 28 & & 176 \\
\hline 20 & $0-50$ & Fine-Grained Chert & C & $\mathrm{T}$ & Threet & BM & 28 & & 176 \\
\hline 20 & $0-50$ & Petrified Wood & $\mathrm{P}$ & $T$ & Threet & BM & 16 & & 176 \\
\hline 20 & $0-50$ & Fine-Grained Chert & D & $\mathrm{T}$ & NA & BT & 19 & & 176 \\
\hline 20 & $0-50$ & Petrified Wood & D & $s$ & NA & IN & 11 & & 176 \\
\hline 20 & $0-50$ & Quartz Arenite & $P$ & $s$ & Single & IN & 43 & & 176 \\
\hline 20 & $0-50$ & Fine-Grained Chert & $\mathrm{p}$ & $\mathrm{T}$ & Two & IN & 28 & & 176 \\
\hline 20 & $0-50$ & Fine-Grained Chert & C & $T$ & Single & PP & 17 & & 176 \\
\hline 20 & $0-50$ & Fine-Grained Chert & $P$ & $T$ & Single & PP & 20 & & 176 \\
\hline 20 & $50-67$ & Fine-Grained Chert & $\mathrm{C}$ & $T$ & Corticate & BL & 34 & & 185 \\
\hline 20 & $50-67$ & Fine-Grained Chert & C & $\mathrm{s}$ & Threet & $\mathrm{BL}$ & 31 & & 185 \\
\hline 20 & $50-67$ & Fine-Grained Chert & C & $T$ & Corticate & BM & 45 & & 185 \\
\hline 20 & $50-67$ & Fine-Grained Chert & $\mathrm{M}$ & $\mathrm{s}$ & NA & $\mathrm{BM}$ & 32 & & 185 \\
\hline 20 & $50-67$ & Fine-Grained Chert & $\mathrm{M}$ & $S$ & $\mathrm{NA}$ & BM & 39 & & 185 \\
\hline 20 & $50-67$ & Quartz Arenite & D & $\mathrm{T}$ & NA & $\mathrm{CR}$ & 50 & & 185 \\
\hline
\end{tabular}




\begin{tabular}{|c|c|c|c|c|c|c|c|c|c|}
\hline 音 & 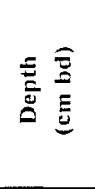 & 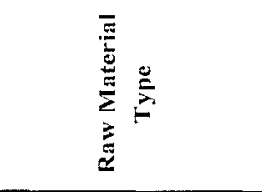 & 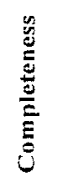 & : & : & 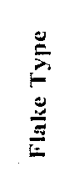 & $\begin{array}{l}\stackrel{\dot{E}}{\hat{\theta}} \widehat{\bar{E}} \\
\dot{e} \\
\dot{E}\end{array}$ & 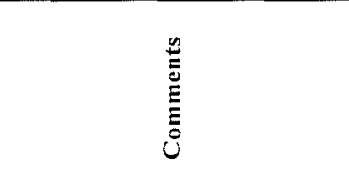 & $\begin{array}{l} \pm \\
\stackrel{ \pm}{\Xi}\end{array}$ \\
\hline 20 & 50-67 & Fine-Grained Chert & $\mathrm{D}$ & $S$ & NA & IN & 18 & & 185 \\
\hline 20 & $50-67$ & Fine-Grained Chert & M & $s$ & $\mathrm{NA}$ & IN & 32 & & 185 \\
\hline 20 & $50-67$ & Quartz Arenite & $M$ & $\mathrm{~T}$ & $\mathrm{NA}$ & IN & 42 & & 185 \\
\hline 20 & $50-67$ & Quartz Arenite & $\mathrm{C}$ & $\mathrm{T}$ & Single & IN & 31 & & 185 \\
\hline 20 & $50-67$ & Fine-Grained Chert & C & $s$ & Corticate & $\mathrm{PP}$ & 35 & & 185 \\
\hline 20 & $50-67$ & Fine-Grained Chert & $\mathrm{D}$ & $\mathrm{T}$ & NA & PP & 13 & & 185 \\
\hline 20 & $50-67$ & Fine-Grained Chert & $\mathrm{M}$ & $T$ & $\mathrm{NA}$ & $\mathrm{PP}$ & 12 & & 185 \\
\hline 21 & $0-20$ & Quartz Arenite & $\mathrm{M}$ & $T$ & NA & BT & 14 & & 133 \\
\hline 21 & $0-20$ & Coarse-Grained Chert & $\mathrm{P}$ & $T$ & Corticate & IN & 38 & & 133 \\
\hline 21 & $20-30$ & Fine-Grained Chert & $\mathrm{C}$ & $\mathrm{s}$ & Single & BL & 28 & & 134 \\
\hline 21 & $20-30$ & Fine-Grained Chert & C & $T$ & Corticate & IN & 35 & & 134 \\
\hline 21 & $20-30$ & Fine-Grained Chert & $\mathrm{P}$ & $\mathrm{s}$ & Corticate & PP & 12 & & 134 \\
\hline 21 & $20-30$ & Fine-Grained Chert & $\mathrm{D}$ & $\mathrm{T}$ & NA & $\mathrm{PP}$ & 17 & & 134 \\
\hline 21 & $20-30$ & Quartz Arenite & $\mathrm{C}$ & $\mathrm{T}$ & Single & $\mathrm{PP}$ & 18 & Yellowish-Brown & 134 \\
\hline 21 & $30-40$ & Fine-Grained Chert & C & $\mathrm{s}$ & Two & $\mathrm{BL}$ & 45 & & 140 \\
\hline 21 & $30-40$ & Fine-Grained Chert & $\mathrm{M}$ & $\mathrm{T}$ & NA & IN & 18 & & 140 \\
\hline 21 & $30-40$ & Fine-Grained Chert & C & $\mathrm{T}$ & Two & $\mathrm{PP}$ & 21 & & 140 \\
\hline 22 & $0-10$ & Fine-Grained Chert & $\mathrm{P}$ & $s$ & Threet & $\mathrm{CR}$ & 36 & & 144 \\
\hline 22 & $10-26$ & Quartzite & $\mathrm{D}$ & $T$ & $\mathrm{NA}$ & BM & 40 & Large Bifacial Manufacturing & 152 \\
\hline 22 & $10-26$ & Fine-Grained Chert & $\mathrm{P}$ & $\mathrm{s}$ & Two & BM & 30 & & 152 \\
\hline 22 & $10-26$ & Quartzite & $\mathrm{M}$ & $\mathrm{T}$ & NA & IN & 18 & & 152 \\
\hline 22 & $10-26$ & Fine-Grained Chert & $\mathrm{P}$ & $S$ & Single & IN & 24 & & 152 \\
\hline 22 & $10-26$ & Fine-Grained Chert & $P$ & $\mathrm{~T}$ & Single & US & 16 & May be Off Gauge? & 152 \\
\hline 22 & $10-26$ & Fine-Grained Chert & $\mathrm{C}$ & $\mathrm{T}$ & Single & US & 18 & Resharpening & 152 \\
\hline 23 & $0-10$ & Fine-Grained Chert & $\mathrm{M}$ & $\mathrm{s}$ & $\mathrm{NA}$ & IN & 18 & & 157 \\
\hline 23 & $0-10$ & Quartzite & $\mathrm{M}$ & $\mathrm{T}$ & NA & IN & 20 & & 157 \\
\hline 24 & $0-10$ & Fine-Grained Chert & $\mathrm{P}$ & $\mathrm{T}$ & Corticate & BL & 17 & & 139 \\
\hline 24 & $0-10$ & Fine-Grained Chert & C & $\mathrm{P}$ & Single & $\mathrm{BL}$ & 16 & & 139 \\
\hline 24 & $0-10$ & Fine-Grained Chert & $\mathrm{P}$ & $\mathrm{T}$ & Single & $\mathrm{BL}$ & 23 & & 139 \\
\hline 24 & $0-10$ & Fine-Grained Chert & $\mathrm{D}$ & $T$ & NA & BM & 26 & & 139 \\
\hline 24 & $0-10$ & Fine-Grained Chert & $\mathrm{C}$ & $\mathrm{T}$ & Single & $\mathrm{BM}$ & 37 & & 139 \\
\hline 24 & $0-10$ & Fine-Grained Chert & $\mathrm{M}$ & $\mathrm{T}$ & $\mathrm{NA}$ & PP & 13 & & 139 \\
\hline 24 & $0-10$ & Fine-Grained Chert & $\mathrm{M}$ & $\mathrm{T}$ & NA & $\mathrm{PP}$ & 13 & & 139 \\
\hline 24 & $0-10$ & Fine-Grained Chert & $\mathrm{M}$ & $T$ & $\mathrm{NA}$ & $\mathrm{PP}$ & 17 & & 139 \\
\hline 24 & $0-10$ & Fine-Grained Chert & $\mathrm{P}$ & $\mathrm{T}$ & Single & Pp & 13 & & 139 \\
\hline 25 & $10-20$ & Fine-Grained Quartz & $\mathrm{P}$ & $\underline{s}$ & Single & $\mathrm{BL}$ & 21 & & 189 \\
\hline 25 & $10-20$ & Fine-Grained Chert & $\mathrm{P}$ & $\mathrm{s}$ & Two & BL & 34 & & 189 \\
\hline 25 & $10-20$ & Fine-Grained Chert & D & $T$ & $\mathrm{NA}$ & BM & 18 & & 189 \\
\hline 25 & $10-20$ & Fine-Grained Chert & $\mathrm{P}$ & $\mathrm{T}$ & Corticate & PP & 16 & & 189 \\
\hline 26 & $0-6$ & Fine-Grained Chert & C & $T$ & Single & BM & 24 & & 183 \\
\hline 26 & $6-16$ & Petrified Wood & C & $\mathrm{T}$ & Threet & IN & 17 & & 190 \\
\hline 26 & $6-16$ & Fine-Grained Chert & $\mathrm{C}$ & $\mathrm{s}$ & Three+ & PP & 20 & & 190 \\
\hline 27 & $10-20$ & Fine-Grained Chert & $\mathrm{M}$ & $\mathrm{s}$ & NA & IN & 23 & & 161 \\
\hline 29 & $0-54$ & Fine-Grained Chert & $\mathrm{D}$ & $T$ & NA & BM & 28 & & 135 \\
\hline 29 & $0-54$ & Petrified Wood & $\mathrm{M}$ & $T$ & $\mathrm{NA}$ & IN & 19 & & 135 \\
\hline 29 & $0-54$ & Quartz Arenite & $\mathrm{p}$ & $T$ & Three+ & IN & 14 & & 135 \\
\hline 30 & $0-36$ & Fine-Grained Chert & $\mathrm{P}$ & $\mathrm{s}$ & Corticate & $\mathrm{BL}$ & 53 & & 137 \\
\hline 30 & $0-36$ & Fine-Grained Chert & $\mathrm{M}$ & $\mathrm{s}$ & $\mathrm{NA}$ & BL & 23 & & 137 \\
\hline 30 & $0-36$ & Fine-Grained Chert & C & $\mathrm{T}$ & Two & $\mathrm{BL}$ & 34 & & 137 \\
\hline 30 & $0-36$ & Fine-Grained Chert & $\mathrm{M}$ & $\mathrm{s}$ & $\mathrm{NA}$ & BM & 27 & & 137 \\
\hline 30 & $0-36$ & Fine-Grained Chert & C & $T$ & Single & BM & 43 & & 137 \\
\hline 30 & $0-36$ & Fine-Grained Chert & $\mathrm{D}$ & $T$ & NA & $\mathrm{BT}$ & 26 & & 137 \\
\hline 30 & $0-36$ & Fine-Grained Chert & $P$ & $T$ & Two & IN & 20 & & 137 \\
\hline 30 & $0-36$ & Fine-Grained Chert & $\mathrm{D}$ & $s$ & $\mathrm{NA}$ & $\mathrm{PP}$ & 21 & & 137 \\
\hline 30 & $0-36$ & Fine-Grained Chert & $\mathrm{M}$ & $\mathrm{s}$ & NA & $\mathrm{PP}$ & 14 & & 137 \\
\hline 30 & $0-36$ & Petrified Wood & $M$ & $T$ & NA & $\mathrm{PP}$ & 12 & & 137 \\
\hline
\end{tabular}




\begin{tabular}{|c|c|c|c|c|c|c|c|c|c|}
\hline$\vec{E}$ & 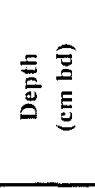 & 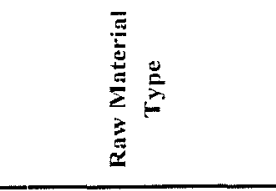 & 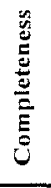 & 窝 & 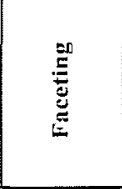 & 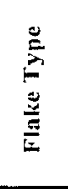 & 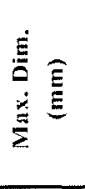 & 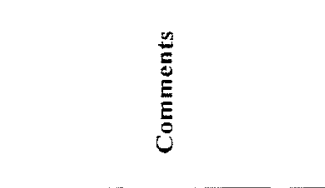 & $\begin{array}{l}\# \\
\stackrel{\#}{\lrcorner}\end{array}$ \\
\hline 31 & $0-26$ & Fine-Grained Chert & $\mathrm{C}$ & $\mathrm{p}$ & Corticate & PP & 17 & & 172 \\
\hline 31 & $0-26$ & Fine-Grained Quartzite & $\mathrm{C}$ & $\mathrm{S}$ & Corticate & $\mathrm{PP}$ & 16 & & 172 \\
\hline 31 & $26-36$ & Fine-Grained Chert & $\mathrm{D}$ & $s$ & NA & $\mathrm{BL}$ & 29 & & 175 \\
\hline 31 & $26-36$ & Fine-Grained Chert & C & $\mathrm{T}$ & Three + & $\mathrm{CR}$ & 31 & & 175 \\
\hline 31 & $26-36$ & Petrified Wood & D & $\mathrm{s}$ & NA & IN & 24 & & 175 \\
\hline 32 & $0-36$ & Fine-Grained Chert & $\mathrm{D}$ & $\mathrm{T}$ & $\mathrm{NA}$ & $\mathrm{BM}$ & 33 & Stage Heat Treatment & 126 \\
\hline 32 & $0-36$ & Fine-Grained Chert & $\mathrm{D}$ & $\mathrm{T}$ & NA & BM & 29 & & 126 \\
\hline 32 & $0-36$ & Fine-Grained Chert & $\mathrm{D}$ & $\mathrm{T}$ & NA & $\mathrm{BM}$ & 18 & & 126 \\
\hline 32 & $0-36$ & Fine-Grained Chert & $\mathrm{D}$ & $\mathrm{T}$ & NA & BM & 20 & & 126 \\
\hline 32 & $0-36$ & Fine-Grained Chert & $\mathrm{P}$ & $T$ & Threet & BM & 17 & Heat Spalled & 126 \\
\hline 32 & $0-36$ & Petrified Wood & $\mathrm{D}$ & $\mathrm{T}$ & NA & IN & 15 & & 126 \\
\hline 32 & $0-36$ & Fine-Grained Chert & $\mathrm{M}$ & $\mathrm{T}$ & $\mathrm{NA}$ & IN & 14 & & 126 \\
\hline 32 & $0-36$ & Quartz Arenite & M & $\mathrm{T}$ & $\mathrm{NA}$ & $\mathbb{I N}$ & 17 & & 126 \\
\hline 32 & $0-36$ & Fine-Grained Chert & $\mathrm{P}$ & $\mathrm{T}$ & Single & IN & 34 & & 126 \\
\hline 32 & $0-36$ & Fine-Grained Chert & $\mathrm{P}$ & $\mathrm{T}$ & Two & IN & 14 & & 126 \\
\hline 32 & $0-36$ & Fine-Grained Chert & $\mathrm{C}$ & $\mathrm{T}$ & Single & PP & 22 & & 126 \\
\hline 32 & $0-36$ & Fine-Grained Chert & $P$ & $\mathrm{~T}$ & Single & $\mathrm{PP}$ & 24 & & 126 \\
\hline 33 & $0-18$ & Fine-Grained Chert & $\mathrm{M}$ & $\mathrm{T}$ & $\mathrm{NA}$ & $\mathrm{BT}$ & 20 & & 118 \\
\hline 33 & $0-18$ & Quartz Arenite & $\mathrm{D}$ & $T$ & $\mathrm{NA}$ & IN & 28 & & 118 \\
\hline 34 & $0-30$ & Fine-Grained Chert & $C$ & $S$ & Single & $\mathrm{BL}$ & 42 & & 131 \\
\hline 34 & $0-30$ & Fine-Grained Chert & $\mathrm{D}$ & $\mathrm{T}$ & NA & $\mathrm{BM}$ & 27 & & 131 \\
\hline 34 & $0-30$ & Fine-Grained Chert & D & $\mathrm{T}$ & $\mathrm{NA}$ & BT & 18 & & 131 \\
\hline 34 & $0-30$ & Fine-Grained Chert & $\mathrm{M}$ & $\mathrm{T}$ & $\mathrm{NA}$ & IN & 11 & & 131 \\
\hline 34 & $0-30$ & Fine-Grained Chert & $\mathrm{P}$ & $\mathrm{T}$ & Single & IN & 18 & & 131 \\
\hline 34 & $0-30$ & Fine-Grained Chert & C & $\mathrm{T}$ & Single & UM & 17 & & 131 \\
\hline 35 & 0.57 & Finc-Grained Chert & $\mathrm{M}$ & $\mathrm{s}$ & NA & IN & 22 & Bumed & 127 \\
\hline 35 & $0-57$ & Fine-Grained Chert & $\mathrm{P}$ & $\mathrm{P}$ & Single & IN & 14 & & 127 \\
\hline 35 & $0-57$ & Fine-Grained Chert & $\mathrm{P}$ & $\mathrm{T}$ & Single & IN & 13 & & 127 \\
\hline 35 & $0-57$ & Fine-Grained Chert & C & $\mathrm{T}$ & Single & $\mathrm{PP}$ & 25 & & 127 \\
\hline 36 & $0-28$ & Fine-Grained Chert & C & $\mathrm{T}$ & Corticate & $\mathrm{BL}$ & 35 & & 125 \\
\hline 36 & $0-28$ & Fine-Grained Chert & C & $s$ & Single & BL & 48 & & 125 \\
\hline 36 & $0-28$ & Fine-Grained Chert & $\mathrm{P}$ & $\mathrm{P}$ & Single & $\mathrm{BL}$ & 27 & & 125 \\
\hline 36 & $0-28$ & Fine-Grained Chert & M & $T$ & NA & BM & 22 & & 125 \\
\hline 36 & $0-28$ & Fine-Grained Chert & $C$ & $s$ & Single & $\mathrm{CR}$ & 58 & & 125 \\
\hline 36 & $0-28$ & Fine-Grained Chert & $\mathrm{M}$ & $\mathrm{S}$ & NA & PP & 13 & & 125 \\
\hline 36 & $0-28$ & Fine-Grained Chert & D & $T$ & NA & PP & 11 & & 125 \\
\hline 37 & $0-10$ & Fine-Grained Chert & M & $s$ & NA & BL & 28 & Blade-like & 122 \\
\hline 37 & $0-10$ & Chert Fragment & $\mathrm{M}$ & $\mathrm{T}$ & NA & $\mathrm{BL}$ & 15 & & 122 \\
\hline 37 & $0-10$ & Fine-Grained Chert & $\mathrm{C}$ & $S$ & Single & $\mathrm{BL}$ & 35 & Blade-like & 122 \\
\hline 37 & $0-10$ & Fine-Grained Chert & $\mathrm{P}$ & $s$ & Single & BL & 20 & Blade-like & 122 \\
\hline 37 & $0-10$ & Fine-Grained Chert & $\mathrm{C}$ & $\mathrm{T}$ & Single & BM & 25 & & 122 \\
\hline 37 & $0-10$ & Quartz Arenite & $\mathrm{P}$ & $\mathrm{T}$ & Two & $\mathrm{BM}$ & 27 & Transluscent, Milky White & 122 \\
\hline 37 & $0-10$ & Fine-Grained Chert & $\mathrm{C}$ & $\mathrm{T}$ & Three+ & BT & 22 & & 122 \\
\hline 37 & $0-10$ & Fine-Grained Chert & $\mathrm{D}$ & $\mathrm{T}$ & NA & $\mathbb{I N}$ & 19 & & 122 \\
\hline 37 & $0-10$ & Fine-Grained Chert & $\mathrm{D}$ & $\mathrm{T}$ & NA & $\underline{I N}$ & 11 & & 122 \\
\hline 37 & $0-10$ & Petrified Wood & $\mathrm{D}$ & $\mathrm{T}$ & $\mathrm{NA}$ & $\mathbb{I N}$ & 15 & & 122 \\
\hline 37 & $0-10$ & Fine-Grained Chert & $M$ & $\mathrm{~T}$ & $\mathrm{NA}$ & $\mathrm{IN}$ & 11 & & 122 \\
\hline 37 & $10-20$ & Fine-Grained Chert & M & $S$ & $\mathrm{NA}$ & $\mathrm{BL}$ & 22 & & 124 \\
\hline 37 & $10-20$ & Fine-Grained Chert & $\mathrm{C}$ & $T$ & Single & $\mathrm{BL}$ & 30 & & 124 \\
\hline 37 & $10-20$ & Fine-Grained Chert & M & $T$ & $\mathrm{NA}$ & PP & 14 & & 124 \\
\hline 38 & $0-33$ & Fine-Grained Chert & C & $T$ & Single & BL & 34 & & 151 \\
\hline 38 & $0-33$ & Fine-Grained Chert & $M$ & $T$ & NA & $\mathrm{BM}$ & 37 & & 151 \\
\hline 41 & $0-30$ & Fine-Grained Chert & C & $s$ & Corticate & PP & 16 & & 120 \\
\hline 41 & $0-30$ & Fine-Grained Chert & $\mathrm{C}$ & $s$ & Corticate & PP & 16 & & 120 \\
\hline 43 & $0-21$ & Fine-Grained Chert & $\mathrm{D}$ & $\mathrm{T}$ & NA & $\mathrm{PP}$ & 20 & & 165 \\
\hline 43 & $0-21$ & Fine-Grained Chert & C & $\mathrm{T}$ & Single & $\mathrm{PP}$ & 12 & & 165 \\
\hline
\end{tabular}




\begin{tabular}{|c|c|c|c|c|c|c|c|c|c|}
\hline 音 & 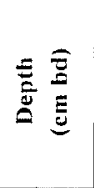 & 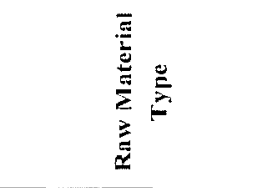 & & 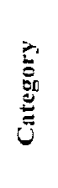 & 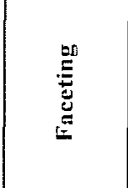 & 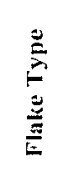 & 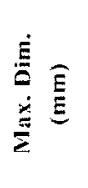 & $\begin{array}{l}\frac{n}{E} \\
\stackrel{E}{E} \\
\dot{E}\end{array}$ & $\frac{\text { 㖣 }}{5}$ \\
\hline 44 & $0-23$ & Fine-Grained Chert & $\mathrm{M}$ & $s$ & $\mathrm{NA}$ & IN & 16 & & 166 \\
\hline 44 & $0-23$ & Fine-Grained Chert & $\underline{P}$ & $\mathrm{~T}$ & Single & IN & 18 & & 166 \\
\hline 46 & $30-40$ & Fine-Grained Chert & $\mathrm{AD}$ & $s$ & NA & $\mathrm{AD}$ & 14 & & 179 \\
\hline 46 & $30-40$ & Fine-Grained Chert & $\mathrm{M}$ & $\mathrm{T}$ & NA & IN & 15 & & 179 \\
\hline 46 & $30-40$ & Fine-Grained Chert & $\mathrm{P}$ & $s$ & Single & PP & 17 & & 179 \\
\hline 46 & $30-40$ & Finc-Grained Chert & C & $\mathrm{T}$ & Two & PP & 12 & & 179 \\
\hline 47 & $0-20$ & Fine-Grained Chert & C & $\mathrm{T}$ & Single & $\mathrm{BT}$ & 18 & & 121 \\
\hline 47 & $0-20$ & Fine-Grained Chert & $\mathrm{M}$ & $s$ & NA & IN & 26 & Probable Bifacial Manufacturing Flake & 121 \\
\hline 47 & $0-20$ & Fine-Grained Cherl & M & $\mathrm{T}$ & $\mathrm{NA}$ & $\mathrm{IN}$ & 20 & & 121 \\
\hline 47 & $0-20$ & Fine-Grained Chert & $\mathrm{C}$ & $\mathrm{T}$ & Threet & IN & 11 & & 121 \\
\hline 47 & $0-20$ & Fine-Grained Chert & $\mathrm{D}$ & $\mathrm{T}$ & NA & $\mathrm{PP}$ & 13 & & 121 \\
\hline 47 & $0-20$ & Fine-Grained Chert & C & $\mathrm{T}$ & Single & PP & 14 & & 121 \\
\hline 48 & $0-45$ & Fine-Grained Chert & C & $\mathrm{T}$ & Single & $\mathrm{BL}$ & 22 & & 105 \\
\hline 48 & $0-45$ & Fine-Grained Chert & C & $T$ & Threet & $\mathrm{BT}$ & 33 & & 105 \\
\hline 48 & $0-45$ & Fine-Grained Chert & C & $T$ & Two & $\mathrm{BT}$ & 23 & & 105 \\
\hline 48 & $0-45$ & Fine-Grained Chert & $\mathrm{P}$ & $\mathrm{T}$ & Two & IN & 16 & & 105 \\
\hline 48 & $0-45$ & Fine-Grained Chert & C & $s$ & Corticate & PP & 22 & & 105 \\
\hline 48 & $45-60$ & Fine-Grained Chert & C & $\mathrm{s}$ & Threet & $\mathrm{BD}$ & 56 & Classic Blade & 107 \\
\hline 49 & $0-36$ & Petrified Wood & D & $\mathrm{s}$ & NA & $\mathrm{BL}$ & 21 & & 98 \\
\hline 49 & $0-36$ & Fine-Grained Chert & D & $T$ & NA & $\mathrm{BL}$ & 23 & & 98 \\
\hline 49 & $0-36$ & Fine-Grained Chert & $\mathrm{D}$ & $T$ & NA & BT & 20 & & 98 \\
\hline 49 & $0-36$ & Fine-Grained Chert & D & $T$ & NA & $\mathrm{BT}$ & 14 & & 98 \\
\hline 49 & $0-36$ & Fine-Grained Chert & D & $T$ & NA & BT & 13 & & 98 \\
\hline 49 & $0-36$ & Fine-Grained Chert & C & $T$ & Threet & $\mathrm{BT}$ & 16 & & 98 \\
\hline 49 & $0-36$ & Fine-Grained Chert & D & $S$ & $\mathrm{NA}$ & $\mathrm{CR}$ & 25 & & 98 \\
\hline 49 & $0-36$ & Fine-Grained Chert & M & $S$ & $\mathrm{NA}$ & $\mathrm{CR}$ & 37 & & 98 \\
\hline 49 & $0-36$ & Fine-Grained Chert & $C$ & $s$ & Two & $\mathrm{CR}$ & 35 & & 98 \\
\hline 49 & $0-36$ & Fine-Grained Chert & D & $\mathrm{T}$ & NA & IN & 18 & & 98 \\
\hline 49 & $0-36$ & Fine-Grained Chert & M & $T$ & $\mathrm{NA}$ & IN & 13 & & 98 \\
\hline 49 & $0-36$ & Fine-Grained Quartzite & $\mathrm{C}$ & $\mathrm{s}$ & Corticate & $\mathrm{PP}$ & 29 & & 98 \\
\hline 49 & $0-36$ & Fine-Grained Chert & D & $\mathrm{P}$ & $\mathrm{NA}$ & PP & 15 & & 98 \\
\hline 49 & $0-36$ & Petrified Wood & $\mathrm{D}$ & $s$ & $\mathrm{NA}$ & $\mathrm{PP}$ & 20 & & 98 \\
\hline 49 & $0-36$ & Fine-Grained Chert & $\mathrm{P}$ & $\mathrm{T}$ & Single & $\mathrm{PP}$ & 13 & & 98 \\
\hline 49 & $0-36$ & Fine-Grained Chert & C & $\mathrm{T}$ & Threet & $\mathrm{PP}$ & 24 & & 98 \\
\hline 49 & $0-36$ & Fine-Grained Chert & C & $T$ & Two & PP & 21 & & 98 \\
\hline 49 & $0-36$ & Fine-Grained Chert & $\mathrm{P}$ & $\mathrm{T}$ & Single & US & 14 & & 98 \\
\hline 50 & $0-4$ & Fine-Grained Chert & $\mathrm{AD}$ & $T$ & $\mathrm{NA}$ & $\mathrm{AD}$ & 28 & & 94 \\
\hline 50 & $0-4$ & Fine-Grained Chert & $\mathrm{M}$ & $\mathrm{s}$ & NA & IN & 18 & & 94 \\
\hline 50 & $4-8$ & Coarse-Grained Chert & $\mathrm{AD}$ & $\mathrm{P}$ & NA & $\mathrm{AD}$ & 16 & & 95 \\
\hline 50 & $4-8$ & Coarse-Grained Chert & $\mathrm{AD}$ & $\mathrm{P}$ & $\mathrm{NA}$ & $\mathrm{AD}$ & 16 & & 95 \\
\hline 50 & $4-8$ & Fine-Grained Chert & M & $\mathrm{s}$ & NA & IN & 20 & & 95 \\
\hline 50 & $4-8$ & Petrified Wood & $\mathrm{M}$ & $\mathrm{T}$ & NA & $\mathrm{PP}$ & 10 & & 95 \\
\hline 51 & $0-30$ & Fine-Grained Chert & D & $T$ & NA & BT & 29 & & 142 \\
\hline 51 & $0-30$ & Fine-Grained Chert & $\mathrm{C}$ & $\mathrm{T}$ & Single & $\mathrm{CR}$ & 34 & & 142 \\
\hline 52 & $0-15$ & Petrified Wood & C & $\mathrm{s}$ & Single & BL & 27 & & 154 \\
\hline 52 & $0-15$ & Petrified Wood & C & $T$ & Threet & IN & 18 & & 154 \\
\hline 53 & $0-22$ & Fine-Grained Chert & $\mathbf{P}$ & $T$ & Two & $\mathrm{BL}$ & 23 & & 155 \\
\hline 53 & $0-22$ & Fine-Grained Chert & $\mathrm{P}$ & $\mathrm{T}$ & Threet & $\mathrm{BT}$ & 14 & & 155 \\
\hline 53 & $0-22$ & Fine-Grained Chert & D & $T$ & $\mathrm{NA}$ & IN & 11 & & 155 \\
\hline 53 & $22-30$ & Fine-Grained Chert & $\mathrm{D}$ & $\mathrm{T}$ & $\mathrm{NA}$ & IN & 28 & & 158 \\
\hline 55 & $0-26$ & Fine-Grained Chert & M & $\mathrm{s}$ & $\mathrm{NA}$ & $\mathrm{CR}$ & 27 & & 159 \\
\hline 55 & $0-26$ & Fine-Grained Chert & D & $T$ & NA & $\mathrm{PP}$ & 11 & & 159 \\
\hline 56 & $0-26$ & Fine-Grained Chert & $\mathrm{P}$ & $T$ & Threet & BM & 24 & & 97 \\
\hline 56 & $0-26$ & Fine-Grained Chert & D & $\mathrm{T}$ & NA & IN & 12 & & 163 \\
\hline 57 & $0-36$ & Fine-Grained Chert & $\mathrm{D}$ & $s$ & $\mathrm{NA}$ & IN & 14 & & 162 \\
\hline 57 & $0-36$ & Fine-Grained Chert & C & $\mathrm{T}$ & Corticate & PP & 22 & & 162 \\
\hline
\end{tabular}




\begin{tabular}{|c|c|c|c|c|c|c|c|c|c|}
\hline 䇂 & 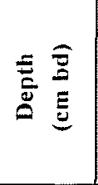 & 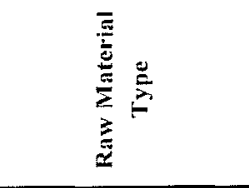 & 竞 & 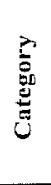 & 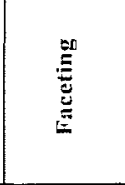 & $\begin{array}{l}\stackrel{\mathscr{E}}{E} \\
\stackrel{\underline{E}}{\underline{E}} \\
\frac{E}{E}\end{array}$ & 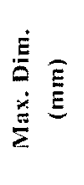 & 总 & $\begin{array}{l}\# \\
\dot{\Xi}\end{array}$ \\
\hline 57 & $0-36$ & Fine-Grained Chert & $\mathrm{D}$ & $s$ & NA & $\mathrm{PP}$ & 11 & & 162 \\
\hline 57 & $0-36$ & Fine-Grained Chert & $\mathrm{D}$ & $\mathrm{T}$ & NA & $\mathrm{PP}$ & 15 & & 162 \\
\hline 57 & $0-36$ & Fine-Grained Chert & M & $\mathrm{T}$ & NA & $\mathrm{PP}$ & 11 & & 162 \\
\hline 57 & $0-36$ & Fine-Grained Chert & M & $\mathrm{T}$ & NA & PP & 10 & & 162 \\
\hline 58 & $25-40$ & Fine-Grained Chert & $\mathrm{D}$ & $T$ & NA & BL & 45 & Removal of Angular Edge & 171 \\
\hline 58 & $25-40$ & Quartz Arenite & $\mathrm{M}$ & $\mathrm{T}$ & NA & $\mathrm{BM}$ & 20 & & 171 \\
\hline 59 & $0-32$ & Fine-Grained Chert & $\mathrm{C}$ & $S$ & Single & BL & 30 & & 164 \\
\hline 59 & $0-32$ & Fine-Grained Chert & $\mathrm{D}$ & $S$ & $\mathrm{NA}$ & BM & 45 & & 164 \\
\hline 59 & $0-32$ & Petrified Wood & $\mathrm{D}$ & $\mathrm{s}$ & NA & $\mathrm{BM}$ & 17 & & 164 \\
\hline 59 & $0-32$ & Fine-Grained Chert & $\mathrm{P}$ & $T$ & Threet & BT & 12 & & 164 \\
\hline 59 & $0-32$ & Fine-Grained Chert & M & $\mathrm{s}$ & NA & IN & 14 & & 164 \\
\hline 59 & $0-32$ & Fine-Grained Chert & $\mathrm{M}$ & $\mathrm{s}$ & $\mathrm{NA}$ & $\mathrm{PP}$ & 15 & & 164 \\
\hline 59 & $32-40$ & Fine-Grained Chert & $\mathrm{D}$ & $T$ & NA & BM & 38 & & 170 \\
\hline 59 & $32-40$ & Fine-Grained Chert & $\mathrm{D}$ & $\mathrm{T}$ & $\mathrm{NA}$ & BT & 18 & & 170 \\
\hline 59 & $32-40$ & Quartz Arenite & $\mathrm{D}$ & $\mathrm{T}$ & NA & BT & 29 & & 170 \\
\hline 59 & $32-40$ & Fine-Grained Chert & $\mathrm{P}$ & $\mathrm{s}$ & Single & $\mathrm{PP}$ & 15 & & 170 \\
\hline 59 & $32-40$ & Fine-Grained Chert & $\mathrm{C}$ & $\mathrm{T}$ & Single & $\mathrm{PP}$ & 17 & & 170 \\
\hline 62 & $0-10$ & Fine-Grained Chert & $\mathrm{P}$ & $s$ & Single & $\mathrm{BL}$ & 24 & & 130 \\
\hline 62 & $0-10$ & Fine-Grained Chert & C & $\mathrm{T}$ & $\mathrm{NA}$ & $\mathrm{BT}$ & 22 & & 130 \\
\hline 63 & $0-10$ & Fine-Grained Chert & $\mathrm{D}$ & $\mathrm{T}$ & $\mathrm{NA}$ & BT & 14 & & 7 \\
\hline 63 & $0-10$ & Fine-Grained Chert & $\mathrm{P}$ & $s$ & Threet & IN & 21 & & 7 \\
\hline 63 & $10-20$ & Fine-Grained Chert & $\mathrm{C}$ & $\mathrm{T}$ & Corticate & $\mathrm{BL}$ & 36 & & 8 \\
\hline 63 & $20-30$ & Quartzite & M & $\mathrm{T}$ & NA & $\mathrm{BL}$ & 19 & May be Heat Treated & 9 \\
\hline 63 & $20-30$ & Petrified Wood & $\mathrm{C}$ & $\mathrm{T}$ & Three+ & BM & 24 & & 9 \\
\hline 63 & $20-30$ & Fine-Grained Chert & $\mathrm{P}$ & $\mathrm{T}$ & Two & $\mathrm{BM}$ & 11 & & 9 \\
\hline 63 & $20-30$ & Fine-Grained Chert & $\mathrm{M}$ & $\mathrm{T}$ & $\mathrm{NA}$ & BT & 10 & & 9 \\
\hline 63 & $20-30$ & Fine-Grained Chert & $\mathrm{D}$ & $\mathrm{T}$ & NA & IN & 9 & May be Resharpening Flake & 9 \\
\hline 63 & $20-30$ & Fine-Grained Chert & $\mathrm{D}$ & $\mathrm{T}$ & NA & $\mathbb{N}$ & 18 & & 9 \\
\hline 63 & $20-30$ & Fine-Grained Chert & D & $\mathrm{T}$ & $\mathrm{NA}$ & IN & 9 & & 9 \\
\hline 63 & $20-30$ & Fine-Grained Chert & $\mathrm{C}$ & $\mathrm{T}$ & Single & IN & 33 & Specimen \#9 & 9 \\
\hline 63 & $20-30$ & Fine-Grained Chert & $\mathrm{P}$ & $\mathrm{T}$ & Single & $\mathbb{I N}$ & 12 & & 9 \\
\hline 63 & $20-30$ & Fine-Grained Chert & $\mathrm{D}$ & $s$ & NA & PP & 7 & & 9 \\
\hline 63 & $20-30$ & Fine-Grained Chert & $\mathrm{D}$ & $\mathrm{T}$ & NA & $\mathrm{PP}$ & 13 & & 9 \\
\hline 63 & $20-30$ & Fine-Grained Chert & $\mathrm{M}$ & $\mathrm{T}$ & NA & $\mathrm{PP}$ & 11 & & 9 \\
\hline 63 & $20-30$ & Fine-Grained Chert & $\mathrm{C}$ & $\mathrm{T}$ & Two & PP & 13 & & 9 \\
\hline 63 & $30-40$ & Fine-Grained Chert & D & $\mathrm{T}$ & NA & BT & 27 & & 10 \\
\hline 63 & $30-40$ & Quartz Arenite & $\mathrm{P}$ & $\mathrm{T}$ & Threet & IN & 19 & & 10 \\
\hline 63 & $30-40$ & Fine-Grained Chert & M & $\mathrm{T}$ & NA & PP & 19 & & 10 \\
\hline 63 & $30-40$ & Fine-Grained Chert & $\mathrm{C}$ & $s$ & Single & $\mathrm{PP}$ & 27 & & 10 \\
\hline 63 & $30-40$ & Fine-Grained Chert & $\mathrm{C}$ & $\mathrm{S}$ & Threet & PP & 26 & & 10 \\
\hline 63 & $40-50$ & Fine-Grained Chert & $\mathrm{P}$ & $\mathrm{T}$ & NA & BJ & 12 & Same Wide-lipped Platform With Wear as \#39 & 39 \\
\hline 63 & $40-50$ & Fine-Grained Chert & $\mathrm{P}$ & $\mathrm{T}$ & Threet & $\mathrm{BJ}$ & 20 & Wide-lipped Flake with Use-wear Platform as \#39 & 39 \\
\hline 63 & $40-50$ & Fine-Grained Chert & $\mathrm{D}$ & $\mathrm{T}$ & NA & BT & 20 & & 39 \\
\hline 63 & $40-50$ & Fine-Grained Chert & $\mathrm{D}$ & $T$ & NA & IN & 17 & & 39 \\
\hline 63 & $40-50$ & Fine-Grained Chert & $\mathrm{P}$ & $S$ & Two & IN & 17 & & 39 \\
\hline 63 & $50-60$ & Fine-Grained Chert & $\mathrm{C}$ & $\mathrm{T}$ & Threet & $\underline{I N}$ & 21 & & 34 \\
\hline 64 & $0-10$ & Fine-Grained Chert & $\mathrm{D}$ & $\mathrm{T}$ & $\mathrm{NA}$ & $\mathrm{BD}$ & 25 & $15 \mathrm{~mm}$ Wide & 11 \\
\hline 64 & $0-10$ & Fine-Grained Chert & $\mathrm{C}$ & $\mathrm{T}$ & Two & BD & 29 & $14 \mathrm{~mm}$ Wide & 11 \\
\hline 64 & $0-10$ & Fine-Grained Chert & $\mathrm{C}$ & $s$ & Corticate & BL & 34 & & 11 \\
\hline 64 & $0-10$ & Fine-Grained Chert & C & $\mathrm{T}$ & Single & $\mathrm{BL}$ & 29 & & 11 \\
\hline 64 & $0-10$ & Fine-Grained Chert & C & $s$ & Two & $\mathrm{BL}$ & 26 & & 11 \\
\hline 64 & $0-10$ & Fine-Grained Chert & $\mathrm{D}$ & $T$ & NA & $\mathrm{BM}$ & 28 & & 11 \\
\hline 64 & $0-10$ & Fine-Grained Chert & $\mathrm{C}$ & $\mathrm{S}$ & Single & $\mathrm{CR}$ & 48 & Flake from Core Face & 11 \\
\hline 64 & $0-10$ & Fine-Grained Chert & $\mathrm{P}$ & $\mathrm{T}$ & Corticate & PP & 15 & & 11 \\
\hline 64 & $0-10$ & Fine-Grained Chert & $\mathrm{D}$ & $\mathrm{T}$ & NA & $\mathrm{PP}$ & 17 & & 11 \\
\hline 64 & $0-10$ & Fine-Grained Chert & $\mathrm{C}$ & $S$ & Single & $\mathrm{PP}$ & 19 & & 11 \\
\hline
\end{tabular}




\begin{tabular}{|c|c|c|c|c|c|c|c|c|c|}
\hline$\overline{\bar{E}}$ & $\begin{array}{l}\text { 言言 } \\
\text { 音 }\end{array}$ & 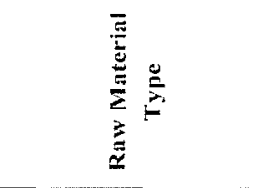 & & 莺 & 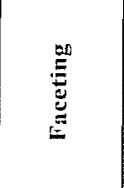 & 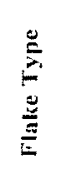 & 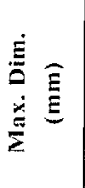 & 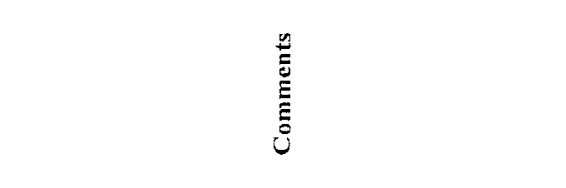 & 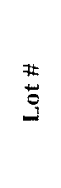 \\
\hline 64 & $0-10$ & Fine-Grained Chert & C & $T$ & Single & PP & 24 & Bumed & 11 \\
\hline 64 & $0-10$ & Fine-Grained Chert & C & $\mathrm{T}$ & Single & PP & 16 & & 11 \\
\hline 64 & $0-10$ & Fine-Grained Chert & C & $\mathrm{T}$ & Two & $\mathrm{PP}$ & 14 & & 11 \\
\hline 64 & $0-10$ & Fine-Grained Chert & C & $T$ & Single & UJ & 28 & & 11 \\
\hline 64 & $10-20$ & Fine-Grained Chert & $\mathrm{AD}$ & $\mathrm{T}$ & NA & $\mathrm{AD}$ & 20 & & 17 \\
\hline 64 & $10-20$ & Fine-Grained Chert & D & $s$ & NA & $\mathrm{CR}$ & 46 & & 17 \\
\hline 64 & $10-20$ & Fine-Grained Chert & D & $T$ & $\mathrm{NA}$ & $\mathrm{PP}$ & 14 & & 17 \\
\hline 64 & $20-30$ & Fine-Grained Chert & D & $T$ & $\mathrm{NA}$ & BM & 25 & & 21 \\
\hline 64 & $30-40$ & Fine-Grained Chert & C & $\mathrm{s}$ & Corticate & PP & 19 & Heat Spalled & 28 \\
\hline 64 & $60-70$ & Fine-Grained Chert & C & $T$ & Single & $\mathrm{BD}$ & 49 & $17 \mathrm{~mm}$ Maximum Length & 41 \\
\hline 64 & $60-70$ & Fine-Grained Chert & C & $\mathrm{T}$ & Single & $B D$ & 49 & $17 \mathrm{~mm}$ Maxium Width & 41 \\
\hline 64 & $60-70$ & Fine-Grained Chert & C & $\mathrm{T}$ & Single & BL & 46 & Heavy Patina & 41 \\
\hline 64 & $60-70$ & Fine-Grained Chert & C & $\mathrm{T}$ & Single & BL & 46 & Heavy Patina & 41 \\
\hline 65 & $0-14$ & Fine-Grained Chert & M & $T$ & NA & BM & 19 & & 117 \\
\hline 65 & $0-14$ & Fine-Grained Chert & M & $\mathrm{T}$ & NA & BM & 19 & & 117 \\
\hline 66 & $20-25$ & Fine-Grained Chert & D & $\mathrm{T}$ & $\mathrm{NA}$ & $\mathrm{PP}$ & 13 & & 44 \\
\hline 66 & $80-90$ & Fine-Grained Chert & M & $\mathrm{T}$ & NA & $\mathrm{PP}$ & 14 & & 59 \\
\hline 67 & $0-40$ & Fine-Grained Chert & $\mathrm{C}$ & $S$ & Two & $\mathrm{BL}$ & 31 & & 66 \\
\hline 67 & $0-40$ & Fine-Grained Chert & $\mathrm{P}$ & $s$ & Single & IN & 24 & & 66 \\
\hline 67 & $40-50$ & Fine-Grained Chert & c & $\mathrm{T}$ & Single & UM & 11 & & 67 \\
\hline 68 & $0-10$ & Fine-Grained Chert & C & $s$ & Corticate & $\mathrm{BL}$ & 34 & & 69 \\
\hline 68 & $0-10$ & Fine-Grained Chert & $\mathrm{C}$ & $\mathrm{T}$ & Corticate & $\mathrm{BL}$ & 34 & & 69 \\
\hline 68 & $0-10$ & Fine-Grained Chert & C & $\mathrm{s}$ & Two & BM & 39 & & 69 \\
\hline 68 & $0-10$ & Fine-Grained Chert & C & $\mathrm{T}$ & Single & $\mathrm{CR}$ & 41 & & 69 \\
\hline 68 & $0-10$ & Fine-Grained Chert & $\mathrm{M}$ & $S$ & $\mathrm{NA}$ & IN & 20 & & 69 \\
\hline 69 & $0-10$ & Fine-Grained Chert & D & $s$ & NA & $\mathbb{I N}$ & 14 & & 92 \\
\hline 69 & $0-10$ & Fine-Grained Chert & $\mathrm{M}$ & $T$ & $\mathrm{NA}$ & IN & 20 & & 92 \\
\hline 69 & $0-10$ & Fine-Grained Chert & $\mathrm{P}$ & $\mathrm{P}$ & Corticate & PP & 12 & & 92 \\
\hline 69 & $0-10$ & Fine-Grained Chert & D & $T$ & NA & UM & 14 & Missing Platform, but Correct Morphology & 92 \\
\hline 70 & $0-10$ & Quartz Arenite & $\mathrm{AD}$ & $\mathrm{P}$ & NA & $\mathrm{AD}$ & 19 & & 84 \\
\hline 70 & $0-10$ & Fine-Grained Chert & D & $\mathrm{s}$ & NA & $\mathrm{BD}$ & 27 & & 84 \\
\hline 70 & $0-10$ & Fine-Grained Chert & D & $\mathrm{s}$ & NA & $\mathrm{PP}$ & 12 & & 84 \\
\hline 70 & $0-10$ & Fine-Grained Chert & D & $s$ & $\mathrm{NA}$ & PP & 21 & & 84 \\
\hline 70 & $0-10$ & Quartz Arenite & C & $\mathrm{s}$ & Single & $\mathrm{PP}$ & 24 & & 84 \\
\hline 70 & $0-10$ & Fine-Grained Chert & $\mathrm{C}$ & $\mathrm{T}$ & Single & $\mathrm{PP}$ & 22 & & 84 \\
\hline 71 & $0-10$ & Fine-Grained Chert & $\mathrm{AD}$ & $s$ & NA & $A D$ & 16 & & 101 \\
\hline 71 & $0-10$ & Fine-Grained Chert & $\mathrm{AD}$ & $\mathrm{T}$ & NA & $\mathrm{AD}$ & 60 & & 101 \\
\hline 71 & $0-10$ & Quartz Arenite & $\mathrm{D}$ & $\mathrm{T}$ & $\mathrm{NA}$ & IN & 18 & & 101 \\
\hline 71 & $0-10$ & Fine-Grained Chert & $\mathrm{M}$ & $\mathrm{T}$ & NA & IN & 25 & & 101 \\
\hline 71 & $0-10$ & Fine-Grained Chert & M & $s$ & NA & PP & 18 & & 101 \\
\hline 71 & $0-10$ & Quartz Arenite & $\mathrm{D}$ & $T$ & NA & $\mathrm{PP}$ & 21 & & 101 \\
\hline 72 & $0-10$ & Fine-Grained Chert & $\mathrm{AD}$ & $\mathrm{s}$ & $\mathrm{NA}$ & $A D$ & 19 & & 86 \\
\hline 72 & $0-10$ & Fine-Grained Chert & $\mathrm{P}$ & $\mathrm{s}$ & Threet & BL & 26 & $10 \mathrm{~mm}$ Wide & 86 \\
\hline 72 & $0-10$ & Fine-Grained Quartzite & $P$ & $\mathrm{~T}$ & Single & $\mathrm{BL}$ & 19 & Dark Grey with Yellow Mottles & 86 \\
\hline 72 & $0-10$ & Fine-Grained Chert & C & $\mathrm{T}$ & Single & $\mathrm{BL}$ & 31 & & 86 \\
\hline 72 & $0-10$ & Fine-Grained Chert & $\underline{P}$ & $\mathrm{~T}$ & Single & IN & 15 & & 86 \\
\hline 72 & $0-10$ & Fine-Grained Chert & $\mathbf{P}$ & $\mathrm{s}$ & Two & IN & 22 & & 86 \\
\hline 72 & $0-10$ & Fine-Grained Chert & $\mathrm{C}$ & $T$ & Single & $\mathrm{PP}$ & 15 & Burned & 86 \\
\hline 72 & $0-10$ & Fine-Grained Chert & $\mathrm{C}$ & $\mathrm{T}$ & Single & PP & 15 & & 86 \\
\hline 72 & $0-10$ & Fine-Grained Chert & C & $\mathrm{T}$ & Two & $\mathrm{PP}$ & 18 & & 86 \\
\hline 72 & $0-10$ & Fine-Grained Chert & $\mathrm{C}$ & $\mathrm{T}$ & Threet & UJ & 17 & Uniface Central Face is Dorsal Face of Flake \#86 & 86 \\
\hline 72 & $10-20$ & Fine-Grained Chert & $\mathrm{C}$ & $\mathrm{T}$ & Threet & BL & 21 & & 93 \\
\hline 72 & $10-20$ & Fine-Grained Chert & $\mathrm{D}$ & $\mathrm{T}$ & NA & IN & 12 & & 93 \\
\hline 72 & $10-20$ & Fine-Grained Chert & $\mathrm{M}$ & $T$ & $\mathrm{NA}$ & IN & 12 & & 93 \\
\hline 72 & $10-20$ & Quartz Arenite & $\mathrm{M}$ & $\mathrm{T}$ & NA & IN & 19 & & 93 \\
\hline 72 & $10-20$ & Fine-Grained Chert & $\mathrm{C}$ & $\mathrm{T}$ & Single & $\mathbb{I N}$ & 17 & Possible Uniface Resharpening Flake & 93 \\
\hline
\end{tabular}




\begin{tabular}{|c|c|c|c|c|c|c|c|c|c|}
\hline E & 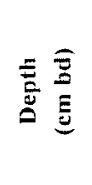 & 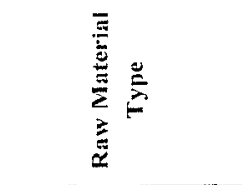 & 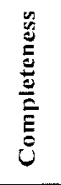 & 离 & 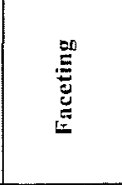 & 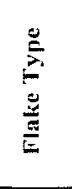 & 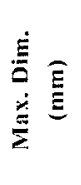 & 苞 & $\begin{array}{l}\text { \# } \\
\stackrel{ \pm}{\Xi}\end{array}$ \\
\hline 72 & $10-20$ & Fine-Grained Cherl & $\mathrm{P}$ & $T$ & Corticate & $\mathrm{PP}$ & 13 & & 93 \\
\hline 72 & $10-20$ & Fine-Grained Chert & D & $s$ & NA & $\mathrm{PP}$ & 21 & & 93 \\
\hline 72 & $10-20$ & Fine-Grained Chert & C & $s$ & Single & $\mathrm{PP}$ & 20 & & 93 \\
\hline 72 & $10-20$ & Fine-Grained Chert & $\mathrm{P}$ & $\mathrm{T}$ & Single & PP & 17 & & 93 \\
\hline 73 & $0-10$ & Fine-Grained Chert & $\mathrm{D}$ & $T$ & NA & BM & 31 & & 100 \\
\hline 73 & $0-10$ & Fine-Grained Chert & C & $s$ & Single & $\mathrm{CR}$ & 56 & & 100 \\
\hline 73 & $0-10$ & Petrified Wood & D & $\mathrm{T}$ & NA & IN & 27 & & 100 \\
\hline 73 & $0-10$ & Petrified Wood & $\mathrm{D}$ & $\mathrm{T}$ & NA & IN & 11 & & 100 \\
\hline 73 & $0-10$ & Fine-Grained Chent & $\mathrm{M}$ & $\mathrm{T}$ & NA & IN & 14 & & 100 \\
\hline 73 & $0-10$ & Fine-Grained Chert & $\mathrm{P}$ & $\mathrm{T}$ & Threet & IN & 16 & & 100 \\
\hline 73 & $0-10$ & Fine-Grained Chert & $P$ & $\mathrm{~T}$ & Corlicate & $\mathrm{PP}$ & 14 & & 100 \\
\hline 73 & $0-10$ & Fine-Grained Chert & D & $s$ & NA & $\mathrm{PP}$ & 23 & & 100 \\
\hline 73 & $0-10$ & Fine-Grained Chert & C & $\mathrm{T}$ & Single & $\mathrm{PP}$ & 27 & & 100 \\
\hline 73 & $0-10$ & Fine-Grained Chert & C & $\mathrm{T}$ & Single & $\mathrm{PP}$ & 19 & & 100 \\
\hline 73 & $0-10$ & Fine-Grained Chert & $\mathrm{P}$ & $S$ & Threet & $\mathrm{PP}$ & 12 & & 100 \\
\hline 73 & $0-10$ & Fine-Grained Chert & $\mathrm{C}$ & $\mathrm{T}$ & Two & PP & 10 & & 100 \\
\hline 74 & $0-13$ & Fine-Grained Chert & M & $s$ & $\mathrm{NA}$ & BL & 28 & & 103 \\
\hline 74 & $0-13$ & Fine-Grained Chert & $\mathrm{M}$ & $\mathrm{T}$ & NA & BM & 23 & & 103 \\
\hline 74 & $0-13$ & Fine-Grained Chert & $M$ & $S$ & NA & $\mathrm{CR}$ & 24 & & 103 \\
\hline 74 & $0-13$ & Fine-Grained Chert & $\mathrm{D}$ & $T$ & NA & IN & 16 & & 103 \\
\hline 74 & $0-13$ & Fine-Grained Chert & M & $\mathrm{T}$ & NA & IN & 16 & & 103 \\
\hline 74 & $0-13$ & Fine-Grained Chert & $\mathrm{M}$ & $s$ & $\mathrm{NA}$ & $\mathrm{PP}$ & 16 & & 103 \\
\hline 74 & $0-13$ & Fine-Grained Chert & $M$ & $T$ & $\mathrm{NA}$ & PP & 18 & & 103 \\
\hline 74 & $0-13$ & Fine-Grained Chert & C & $\mathrm{s}$ & Single & $\mathrm{PP}$ & 17 & & 103 \\
\hline 74 & $0-13$ & Fine-Grained Chert & $\mathrm{C}$ & $\mathrm{T}$ & Single & PP & 16 & & 103 \\
\hline 74 & $0-13$ & Fine-Grained Chert & $\mathrm{D}$ & $\mathrm{T}$ & NA & UM & 14 & & 103 \\
\hline 74 & $0-13$ & Fine-Grained Chert & $M$ & $\mathrm{~T}$ & $\mathrm{NA}$ & UM & 11 & & 103 \\
\hline 74 & $13-20$ & Fine-Grained Chert & $\mathrm{C}$ & $\mathrm{T}$ & Corticate & $B L$ & 29 & & 102 \\
\hline 74 & $13-20$ & Fine-Grained Chert & $\mathrm{P}$ & $\mathrm{P}$ & Single & PP & 21 & & 102 \\
\hline 75 & $0-10$ & Fine-Grained Chert & C & $s$ & Single & $\mathrm{CR}$ & 72 & & 35 \\
\hline 75 & $0-10$ & Fine-Grained Chert & $\mathrm{C}$ & $s$ & Single & $\mathrm{CR}$ & 72 & & 35 \\
\hline 75 & $0-10$ & Fine-Grained Chert & D & $s$ & NA & IN & 21 & Heat Spalled & 35 \\
\hline 75 & $0-10$ & Fine-Grained Chert & D & $s$ & NA & IN & 21 & Heat Spalled & 35 \\
\hline 75 & $0-10$ & Fine-Grained Chert & $\mathrm{D}$ & $\mathrm{T}$ & NA & PP & 19 & & 35 \\
\hline 75 & $0-10$ & Fine-Grained Chert & $\mathrm{D}$ & $\mathrm{T}$ & NA & $\mathrm{PP}$ & 19 & & 35 \\
\hline 75 & $0-10$ & Fine-Grained Chert & $\mathrm{P}$ & $T$ & Single & PP & 12 & & 35 \\
\hline 75 & $0-10$ & Fine-Grained Chert & $\mathrm{P}$ & $\mathrm{T}$ & Single & PP & 12 & & 35 \\
\hline 75 & $10-20$ & Fine-Grained Chert & $\mathrm{C}$ & $\mathrm{T}$ & Corticate & PP & 29 & & 36 \\
\hline 75 & $20-30$ & Petrified Wood & $\mathrm{P}$ & $S$ & Single & $\mathrm{PP}$ & 13 & & 37 \\
\hline 76 & $0-5$ & Fine-Grained Chert & $\mathrm{C}$ & $\mathrm{T}$ & Corticate & BL & 44 & & 109 \\
\hline 76 & $0-5$ & Quartz Arenite & M & $\mathrm{T}$ & NA & IN & 24 & & 109 \\
\hline 76 & $0-5$ & Fine-Grained Chet & C & $s$ & Single & IN & 17 & & 109 \\
\hline 76 & $0-5$ & Fine-Grained Chert & $C$ & $\mathrm{~T}$ & Three+ & IN & 10 & & 109 \\
\hline 76 & $0-5$ & Fine-Grained Chert & $\mathrm{C}$ & $\mathrm{T}$ & Corticate & $\mathrm{PP}$ & 15 & & 109 \\
\hline 76 & $0-5$ & Fine-Grained Chert & $\mathrm{D}$ & $\mathrm{P}$ & NA & PP & 20 & & 109 \\
\hline 76 & $0-5$ & Fine-Grained Chert & C & $\mathrm{P}$ & Single & PP & 17 & & 109 \\
\hline 76 & $0-5$ & Fine-Grained Chert & $\mathrm{C}$ & $\mathrm{s}$ & Two & PP & 13 & & 109 \\
\hline 76 & $5-20$ & Fine-Grained Chert & $A D$ & $s$ & NA & $\mathrm{AD}$ & 19 & & 111 \\
\hline 76 & $5-20$ & Fine-Grained Chert & $\mathrm{AD}$ & $\mathrm{T}$ & NA & $\mathrm{AD}$ & 32 & & 111 \\
\hline 76 & $5-20$ & Quartz Arenite & $\mathrm{AD}$ & $\mathrm{T}$ & NA & $\mathrm{AD}$ & 23 & & 111 \\
\hline 76 & $5-20$ & Fine-Grained Chert & $\mathbf{P}$ & $\mathrm{T}$ & Corticate & $\mathrm{BL}$ & 26 & & 111 \\
\hline 76 & $5-20$ & Fine-Grained Chert & $P$ & $\mathrm{~s}$ & Threet & $B M$ & 29 & & 111 \\
\hline 76 & $5-20$ & Fine-Grained Chert & $\mathrm{D}$ & $\mathrm{s}$ & NA & $\mathrm{CR}$ & 27 & Burned & 111 \\
\hline 76 & $5-20$ & Quartz Arenite & $\mathrm{C}$ & $\mathrm{s}$ & Single & $\mathrm{CR}$ & 42 & & 111 \\
\hline 76 & $5-20$ & Petrified Wood & $P$ & $\mathrm{~T}$ & Single & IN & 20 & May be Jasper & 111 \\
\hline 76 & $5-20$ & Fine-Grained Chert & C & $\mathrm{T}$ & Corticate & $\mathrm{PP}$ & 10 & & 111 \\
\hline
\end{tabular}




\begin{tabular}{|c|c|c|c|c|c|c|c|c|c|}
\hline$\vec{E}$ & 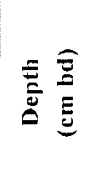 & 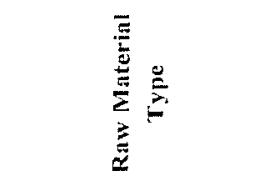 & 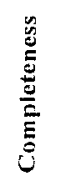 & 密 & : & 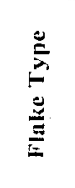 & 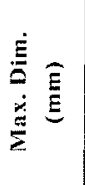 & 蒡 & 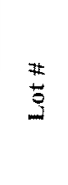 \\
\hline 76 & 5-20 & Fine-Grained Chert & $\mathrm{D}$ & $\mathrm{P}$ & $\mathrm{NA}$ & $\mathrm{PP}$ & 18 & & 111 \\
\hline 76 & $5-20$ & Fine-Grained Chert & $\mathrm{D}$ & $T$ & NA & $\mathrm{PP}$ & 12 & & 111 \\
\hline 76 & $5-20$ & Fine-Grained Chert & D & $\mathrm{T}$ & NA & PP & 11 & & 111 \\
\hline 76 & $5-20$ & Fine-Grained Chert & C & $s$ & Single & $\mathrm{PP}$ & 15 & & 111 \\
\hline 76 & $5-20$ & Fine-Grained Chert & C & $s$ & Single & $\mathrm{PP}$ & 11 & & 111 \\
\hline 76 & $5-20$ & Fine-Grained Chert & $\mathrm{C}$ & $\mathrm{T}$ & Two & $\mathrm{PP}$ & 10 & & 111 \\
\hline 76 & $5-20$ & Fine-Grained Chert & C & $\mathrm{T}$ & Single & UM & 21 & & 111 \\
\hline 77 & $0-20$ & Fine-Grained Chert & $\mathrm{AD}$ & $P$ & $\mathrm{NA}$ & $\mathrm{AD}$ & 29 & & 104 \\
\hline 77 & $0-20$ & Fine-Grained Chert & D & $s$ & NA & $\mathrm{BL}$ & 27 & & 104 \\
\hline 77 & $0-20$ & Petrified Wood & D & $T$ & NA & PP & 23 & & 104 \\
\hline 77 & $0-20$ & Fine-Grained Chert & M & $T$ & NA & PP & 19 & & 104 \\
\hline 79 & $0-13$ & Fine-Grained Chert & C & $\mathrm{T}$ & Three+ & PP & 22 & & 225 \\
\hline 80 & $20-30$ & Fine-Grained Chert & $\mathrm{P}$ & $\mathrm{T}$ & Threet & $\mathrm{BM}$ & 29 & & 80 \\
\hline 80 & $40-50$ & Fine-Grained Chert & C & $s$ & Single & PP & 12 & & 72 \\
\hline 80 & $50-60$ & Fine-Grained Chert & D & $\mathrm{T}$ & NA & $\mathrm{BM}$ & 27 & & 76 \\
\hline 83 & $0-12$ & Fine-Grained Chert & $\mathrm{D}$ & $T$ & $\mathrm{NA}$ & PP & 11 & & 76 \\
\hline 83 & $0-12$ & Fine-Grained Chert & D & $T$ & NA & PP & 11 & & 76 \\
\hline 84 & $0-10$ & Fine-Grained Chert & $\mathrm{P}$ & $s$ & Single & IN & 40 & & 74 \\
\hline 86 & $0-10$ & Fine-Grained Chert & C & $\mathrm{s}$ & Corlicate & $\mathrm{BL}$ & 28 & & 88 \\
\hline 86 & $0-10$ & Fine-Grained Chert & $\mathrm{D}$ & $\mathrm{T}$ & NA & $\mathrm{BM}$ & 38 & & 88 \\
\hline 86 & $0-10$ & Fine-Grained Chert & $\mathrm{M}$ & $\mathrm{T}$ & NA & IN & 13 & & 88 \\
\hline 86 & $0-10$ & Fine-Grained Chert & $\mathrm{C}$ & $T$ & Three+ & PP & 20 & & 88 \\
\hline 87 & $0-10$ & Fine-Grained Chert & $\mathrm{D}$ & $\mathrm{p}$ & NA & $\mathrm{BL}$ & 22 & & 223 \\
\hline 87 & $0-10$ & Fine-Grained Chert & C & $S$ & Corticate & IN & 27 & & 223 \\
\hline 87 & $0-10$ & Fine-Grained Chert & D & $\mathrm{T}$ & $\mathrm{NA}$ & $\mathbb{I N}$ & 21 & & 223 \\
\hline 87 & $0-10$ & Fine-Grained Chert & C & $\mathrm{T}$ & Threet & IN & 13 & & 223 \\
\hline 87 & $0-10$ & Fine-Grained Chert & $\mathrm{M}$ & $s$ & $\mathrm{NA}$ & PP & 20 & & 223 \\
\hline 87 & $0-10$ & Fine-Grained Chert & $\mathrm{C}$ & $\mathrm{s}$ & Single & PP & 25 & & 223 \\
\hline 87 & $0-10$ & Fine-Grained Chert & C & $\mathrm{T}$ & Two & PP & 23 & & 223 \\
\hline 88 & $13-20$ & Fine-Grained Chert & D & $\mathrm{T}$ & $\mathrm{NA}$ & $\mathrm{BT}$ & 17 & & 220 \\
\hline 88 & $20-30$ & Fine-Grained Chert & C & $T$ & Single & BS & 13 & & 221 \\
\hline 88 & $20-30$ & Fine-Grained Chert & C & $\mathrm{T}$ & Single & IN & 17 & Possible Uniface Rejuvination Flake & 221 \\
\hline 88 & $20-30$ & Fine-Grained Chert & $\mathrm{M}$ & $\mathrm{T}$ & NA & $\mathrm{PP}$ & 15 & & 221 \\
\hline 88 & $30-40$ & Fine-Grained Chert & $\mathrm{P}$ & $\mathrm{P}$ & Corticate & $\mathrm{BL}$ & 46 & & 222 \\
\hline 88 & $30-40$ & Fine-Grained Chert & D & $P$ & NA & $\mathrm{BL}$ & 33 & & 222 \\
\hline 88 & $30-40$ & Fine-Grained Chert & C & $\mathrm{T}$ & Single & BM & 30 & & 222 \\
\hline 88 & $30-40$ & Fine-Grained Chert & $\mathrm{P}$ & $T$ & Threet & $\mathrm{BM}$ & 33 & & 222 \\
\hline 88 & $30-40$ & Fine-Grained Chert & C & $\mathrm{T}$ & Two & BM & 27 & Burgundy Color & 222 \\
\hline 88 & $30-40$ & Fine-Grained Chert & $\mathrm{P}$ & $s$ & Single & $\mathrm{CR}$ & 35 & & 222 \\
\hline 88 & $30-40$ & Fine-Grained Chert & D & $s$ & $\mathrm{NA}$ & IN & 31 & & 222 \\
\hline 88 & $30-40$ & Fine-Grained Chert & M & $T$ & NA & PP & 14 & & 222 \\
\hline 88 & $30-40$ & Fine-Grained Chert & $\mathrm{C}$ & $T$ & Single & $\mathrm{PP}$ & 25 & & 222 \\
\hline 88 & $40-50$ & Fine-Grained Chert & $\mathrm{P}$ & $\mathrm{T}$ & Threet & $\mathrm{BM}$ & 21 & & 224 \\
\hline 88 & $40-50$ & Fine-Grained Chert & $\mathrm{D}$ & $S$ & NA & IN & 15 & & 36 \\
\hline 89 & $0-21$ & Fine-Grained Chert & $\mathbf{P}$ & $s$ & Single & $\mathrm{BL}$ & 31 & & 87 \\
\hline 89 & $0-21$ & Fine-Grained Chert & C & $\mathrm{T}$ & Single & $\mathrm{BL}$ & 29 & & 87 \\
\hline 89 & $0-21$ & Fine-Grained Chert & $\mathrm{D}$ & $\mathrm{T}$ & $\mathrm{NA}$ & BM & 20 & & 87 \\
\hline 89 & $0-21$ & Fine-Grained Chert & $\mathrm{p}$ & $\mathrm{s}$ & Threet & BM & 39 & & 87 \\
\hline 89 & $0-21$ & Fine-Grained Chert & $\mathrm{C}$ & $\mathrm{T}$ & Threet & BM & 26 & & 87 \\
\hline 89 & $0-21$ & Fine-Grained Quartzite & $\mathrm{C}$ & $\mathrm{T}$ & Threet & BM & 31 & & 87 \\
\hline 89 & $0-21$ & Fine-Grained Chert & $\mathrm{D}$ & $T$ & NA & BT & 17 & & 87 \\
\hline 89 & $0-21$ & Fine-Grained Chert & $\mathrm{M}$ & $T$ & NA & $\mathrm{BT}$ & 19 & & 87 \\
\hline 89 & $0-21$ & Fine-Grained Chert & $\mathrm{M}$ & $\mathrm{T}$ & NA & IN & 9 & & 87 \\
\hline 89 & $0-21$ & Fine-Grained Chert & $\mathrm{P}$ & $\mathrm{T}$ & Two & IN & 34 & & 87 \\
\hline 89 & $0-21$ & Fine-Grained Chert & D & $s$ & NA & PP & 15 & & 87 \\
\hline 89 & $0-21$ & Fine-Grained Chert & $\mathrm{D}$ & $s$ & $\mathrm{NA}$ & PP & 13 & & 87 \\
\hline
\end{tabular}




\begin{tabular}{|c|c|c|c|c|c|c|c|c|c|}
\hline$\ddot{E}$ & 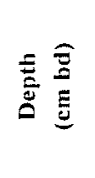 & 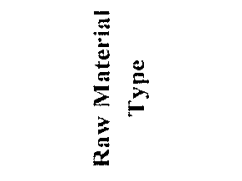 & 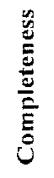 & 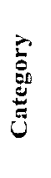 & 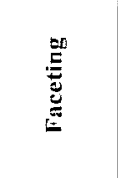 & 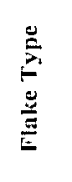 & 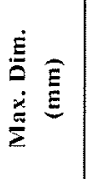 & 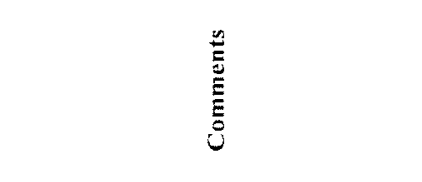 & $\begin{array}{l}\text { \# } \\
\stackrel{9}{9}\end{array}$ \\
\hline 89 & $0-21$ & Fine-Grained Chert & C & $\mathrm{T}$ & Single & PP & 26 & Bladelet & 87 \\
\hline 89 & $0-21$ & Fine-Grained Chert & $\mathrm{C}$ & $\mathrm{T}$ & Single & PP & 20 & & 87 \\
\hline 89 & $0-21$ & Petrified Wood & $\mathrm{C}$ & $\mathrm{T}$ & Single & PP & 13 & & 87 \\
\hline 90 & $0-10$ & Fine-Grained Chert & $\mathrm{M}$ & $\mathrm{T}$ & NA & BM & 19 & Post-Depositional Flaking & 184 \\
\hline 90 & $0-10$ & Fine-Grained Chert & $\mathrm{D}$ & $\mathrm{T}$ & $\mathrm{NA}$ & BT & 21 & & 184 \\
\hline 90 & $0-10$ & Fine-Grained Chert & $\mathrm{D}$ & $s$ & $\mathrm{NA}$ & $\mathrm{PP}$ & 12 & & 184 \\
\hline 90 & $0-10$ & Fine-Grained Chert & $\mathrm{D}$ & $s$ & $\mathrm{NA}$ & PP & 13 & & 184 \\
\hline 90 & $0-10$ & Fine-Grained Chert & $\mathrm{D}$ & $s$ & NA & $\mathrm{PP}$ & 17 & & 184 \\
\hline 90 & $0-10$ & Petrified Wood & D & $\mathrm{s}$ & NA & $\mathrm{PP}$ & 22 & & 184 \\
\hline 90 & $0-10$ & Fine-Grained Chert & $\mathrm{D}$ & $\mathrm{T}$ & NA & $\mathrm{PP}$ & 21 & & 184 \\
\hline 90 & $0-10$ & Fine-Grained Chert & $\mathrm{P}$ & $s$ & Three+ & $\mathrm{PP}$ & 21 & & 184 \\
\hline 90 & $10-45$ & Fine-Grained Chert & $\mathrm{D}$ & $\mathrm{T}$ & NA & BL & 42 & & 187 \\
\hline 90 & $10-45$ & Quartz Arenite & D & $\mathrm{T}$ & NA & BM & 27 & & 187 \\
\hline 90 & $10-45$ & Quartz Arenite & $\mathrm{M}$ & $\mathrm{T}$ & $\mathrm{NA}$ & BT & 20 & & 187 \\
\hline 90 & $10-45$ & Fine-Grained Chert & $\mathrm{M}$ & $\mathrm{T}$ & $\mathrm{NA}$ & IN & 12 & & 187 \\
\hline 90 & $10-45$ & Fine-Grained Chert & D & $\mathrm{T}$ & $\mathrm{NA}$ & $\mathrm{PP}$ & 24 & & 187 \\
\hline 90 & $10-45$ & Fine-Grained Chert & $\mathrm{D}$ & $\mathrm{T}$ & NA & $\mathrm{PP}$ & 15 & & 187 \\
\hline 90 & $10-45$ & Quartz Arenite & $\mathrm{M}$ & $\mathrm{T}$ & NA & PP & 10 & & 187 \\
\hline 90 & $10-45$ & Fine-Grained Chert & C & $T$ & Single & $\mathrm{PP}$ & 23 & & 187 \\
\hline 90 & $10-45$ & Fine-Grained Chert & $\mathrm{C}$ & $T$ & Single & $\mathrm{PP}$ & 15 & & 187 \\
\hline 90 & $10-45$ & Fine-Grained Chert & $\mathrm{P}$ & $\mathrm{T}$ & Single & PP & 23 & & 187 \\
\hline 90 & $10-45$ & Fine-Grained Chert & $\mathrm{P}$ & $s$ & Two & PP & 15 & & 187 \\
\hline 91 & $21-26$ & Fine-Grained Chert & $\mathrm{C}$ & $\mathrm{T}$ & Two & BT & 28 & & 149 \\
\hline 91 & $21-26$ & Petrified Wood & M & $\mathrm{T}$ & NA & IN & 16 & & 149 \\
\hline 92 & $0-10$ & Fine-Grained Chert & C & $s$ & Single & $\mathrm{BM}$ & 51 & & 143 \\
\hline 92 & $0-10$ & Fine-Grained Chert & D & $\mathrm{T}$ & $\mathrm{NA}$ & BT & 25 & & 143 \\
\hline 92 & $0-10$ & Fine-Grained Chert & $\mathrm{D}$ & $T$ & $\mathrm{NA}$ & BT & 30 & & 143 \\
\hline 92 & $0-10$ & Fine-Grained Chert & $\mathrm{C}$ & $T$ & Corticate & $\mathrm{PP}$ & 19 & & 143 \\
\hline 92 & $10-16$ & Fine-Grained Chert & $\mathrm{C}$ & $\mathrm{s}$ & Single & $\mathrm{PP}$ & 19 & & 147 \\
\hline 93 & $0-10$ & Fine-Grained Chert & $\mathrm{D}$ & $T$ & Single & $\mathrm{BL}$ & 31 & Step Fracture Correction & 138 \\
\hline 93 & $0-10$ & Petrified Wood & $\mathrm{C}$ & $s$ & NA & BM & 20 & & 138 \\
\hline 93 & $0-10$ & Fine-Grained Chert & C & $\mathbf{P}$ & Single & $\mathrm{PP}$ & 20 & & 138 \\
\hline 93 & $10-20$ & Fine-Grained Chert & $\mathrm{D}$ & $\mathrm{T}$ & $\mathrm{NA}$ & $\mathrm{BL}$ & 26 & $9 \mathrm{~mm}$ Wide & 141 \\
\hline 93 & $10-20$ & Petrified Wood & $\mathrm{D}$ & $\mathrm{T}$ & NA & BM & 31 & & 141 \\
\hline 93 & $10-20$ & Fine-Grained Chert & $\mathrm{D}$ & $\mathrm{T}$ & $\mathrm{NA}$ & $\mathrm{PP}$ & 18 & & 141 \\
\hline 93. & $10-20$ & Fine-Grained Chert & $\mathrm{C}$ & $S$ & Single & $\mathrm{PP}$ & 22 & & 141 \\
\hline 93 & $10-20$ & Fine-Grained Chert & $\mathrm{D}$ & $\mathrm{T}$ & NA & UM & 21 & Has All Features & 141 \\
\hline 94 & $0-10$ & Fine-Grained Chert & $\mathrm{M}$ & $s$ & NA & $\mathrm{BD}$ & 26 & $15 \mathrm{~mm}$ Wide & 186 \\
\hline 94 & $0-10$ & Fine-Grained Chert & $\mathrm{D}$ & $\mathrm{T}$ & $\mathrm{NA}$ & BL & 32 & $13 \mathrm{~mm}$ Wide & 186 \\
\hline 94 & $0-10$ & Fine-Grained Chert & $\mathrm{P}$ & $S$ & Single & $\mathrm{BL}$ & 22 & $10 \mathrm{~mm}$ Wide & 186 \\
\hline 94 & $0-10$ & Fine-Grained Chert & C & $\mathrm{T}$ & Two & BL & 26 & $9 \mathrm{~mm}$ Wide & 186 \\
\hline 94 & $0-10$ & Fine-Grained Chert & D & $s$ & NA & $\mathrm{BL}$ & 22 & Burned & 186 \\
\hline 94 & $0-10$ & Fine-Grained Chert & M & $s$ & $\mathrm{NA}$ & BL & 27 & & 186 \\
\hline 94 & $0-10$ & Fine-Grained Chert & $\mathrm{C}$ & $\mathrm{s}$ & Single & $\mathrm{BL}$ & 35 & & 186 \\
\hline 94 & $0-10$ & Fine-Grained Chert & $\mathrm{D}$ & $\mathrm{T}$ & NA & BM & 30 & & 186 \\
\hline 94 & $0-10$ & Quartz Arenite & M & $\mathrm{T}$ & NA & BM & 29 & & 186 \\
\hline 94 & $0-10$ & Fine-Grained Chert & $\mathrm{P}$ & $\mathrm{T}$ & Three+ & BM & 15 & & 186 \\
\hline 94 & $0-10$ & Fine-Grained Chert & $\mathrm{D}$ & $T$ & $\mathrm{NA}$ & BT & 14 & & 186 \\
\hline 94 & $0-10$ & Fine-Grained Chert & $\mathrm{D}$ & $\mathrm{T}$ & $\mathrm{NA}$ & BT & 13 & & 186 \\
\hline 94 & $0-10$ & Quartz Arenite & $\mathrm{D}$ & $T$ & NA & BT & 16 & & 186 \\
\hline 94 & $0-10$ & Fine-Grained Chert & $\mathrm{M}$ & $\mathrm{T}$ & NA & BT & 10 & & 186 \\
\hline 94 & $0-10$ & Fine-Grained Chert & $\mathrm{M}$ & $\mathrm{T}$ & $\mathrm{NA}$ & BT & 15 & & 186 \\
\hline 94 & $0-10$ & Fine-Grained Chert & $\mathrm{C}$ & $\mathrm{s}$ & Single & $\mathrm{CR}$ & 46 & & 186 \\
\hline 94 & $0-10$ & Fine-Grained Chert & $\mathrm{M}$ & $\mathrm{P}$ & NA & IN & 11 & & 186 \\
\hline 94 & $0-10$ & Fine-Grained Chert & $\mathrm{D}$ & $s$ & $\mathrm{NA}$ & IN & 21 & & 186 \\
\hline 94 & $0-10$ & Fine-Grained Chert & $\mathrm{P}$ & $\mathrm{T}$ & NA & IN & 9 & ble Bifacial Resharpenir & 186 \\
\hline
\end{tabular}




\begin{tabular}{|c|c|c|c|c|c|c|c|c|c|}
\hline 䓂 & 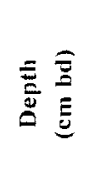 & 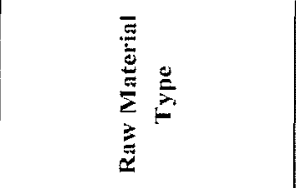 & 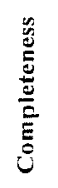 & 窝 & 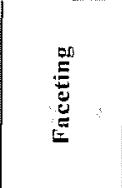 & 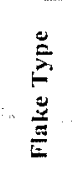 & $\begin{array}{l}\dot{\dot{E}} \\
\stackrel{\bar{E}}{\dot{E}} \\
\dot{\vec{E}}\end{array}$ & 章 & $\begin{array}{l}\# \\
\stackrel{\Xi}{د}\end{array}$ \\
\hline 94 & $0-10$ & Fine-Grained Chert & $\mathrm{D}$ & $T$ & $\mathrm{NA}$ & IN & 11 & & 186 \\
\hline 94 & $0-10$ & Fine-Grained Chert & $\mathrm{D}$ & $\mathrm{T}$ & NA & IN & 18 & & 186 \\
\hline 94 & $0-10$ & Fine-Grained Chert & $\mathrm{M}$ & $\mathrm{T}$ & NA & IN & 13 & & 186 \\
\hline 94 & $0-10$ & Fine-Grained Cherl & $\mathrm{M}$ & $\mathrm{T}$ & $\mathrm{NA}$ & IN & 14 & & 186 \\
\hline 94 & $0-10$ & Fine-Grained Chert & $\mathrm{M}$ & $\mathrm{T}$ & $\mathrm{NA}$ & IN & 19 & & 186 \\
\hline 94 & $0-10$ & Quartz Arenite & $\mathrm{M}$ & $\mathrm{T}$ & $\mathrm{NA}$ & IN & 15 & & 186 \\
\hline 94 & $0-10$ & Fine-Grained Chert & $\mathrm{P}$ & $\mathrm{T}$ & Single & IN & 20 & Heavily Patinated & 186 \\
\hline 94 & $0-10$ & Fine-Grained Chert & $\mathrm{C}$ & $\mathrm{T}$ & Single & $\mathrm{IN}$ & 11 & Possible Biface Resharpening Flake & 186 \\
\hline 94 & $0-10$ & Fine-Grained Chert & $\mathrm{P}$ & $s$ & Three+ & IN & 14 & & 186 \\
\hline 94 & $0-10$ & Fine-Grained Chert & $\mathrm{P}$ & $s$ & Two & IN & 19 & & 186 \\
\hline 94 & $0-10$ & Fine-Grained Chert & C & $\mathrm{T}$ & Single & NO & 11 & Second in Sequence & 186 \\
\hline 94 & $0-10$ & Coarse-Grained Quartzite & $\mathrm{D}$ & $s$ & NA & $\mathrm{PP}$ & 17 & & 186 \\
\hline 94 & $0-10$ & Quartz Arenite & D & $s$ & NA & $\mathrm{pp}$ & 12 & & 186 \\
\hline 94 & $0-10$ & Quartz Arenite & $\mathrm{M}$ & $\mathrm{S}$ & NA & $\mathrm{PP}$ & 19 & & -186 \\
\hline 94 & $0-10$ & Fine-Grained Chert & $\mathrm{D}$ & $\mathrm{T}$ & NA & $\mathrm{PP}$ & 14 & & 186 \\
\hline 94 & $0-10$ & Fine-Grained Chert & $\mathrm{D}$ & $\mathrm{T}$ & NA & $\mathrm{PP}$ & 16 & & 186 \\
\hline 94 & $0-10$ & Quarlz Arenite & $\mathrm{D}$ & $\mathrm{T}$ & $\mathrm{NA}$ & $\mathrm{PP}$ & 15 & & 186 \\
\hline 94 & $0-10$ & Fine-Grained Chert & $\mathrm{M}$ & $\mathrm{T}$ & $\mathrm{NA}$ & PP & 18 & & 186 \\
\hline 94 & $0-10$ & Quartz Arenite & $\mathrm{M}$ & $\mathrm{T}$ & $\mathrm{NA}$ & $\mathrm{PP}$ & 11 & & 186 \\
\hline 94 & $0-10$ & Fine-Grained Chert & C & $\mathrm{T}$ & Single & PP & 24 & & 186 \\
\hline 94 & $0-10$ & Fine-Grained Chert & $\mathrm{P}$ & $\mathrm{T}$ & Single & $\mathrm{PP}$ & 9 & & 186 \\
\hline 94 & $0-10$ & Fine-Grained Chert & $\mathrm{P}$ & $S$ & Two & PP & 12 & & 186 \\
\hline 94 & $0-10$ & Fine-Grained Chert & C & $T$ & Two & PP & 11 & & 186 \\
\hline 94 & $10-20$ & Fine-Grained Chert & C & $s$ & Corticate & $\mathrm{BL}$ & 26 & & 188 \\
\hline 94 & $10-20$ & Fine-Grained Chert & $C$ & $\mathrm{~s}$ & Single & $\mathrm{BL}$ & 45 & & 188 \\
\hline 94 & $10-20$ & Fine-Grained Chert & $\mathrm{D}$ & $\mathrm{T}$ & $\mathrm{NA}$ & BS & 11 & & 188 \\
\hline 94 & $10-20$ & Fine-Grained Chert & $\mathrm{D}$ & $\mathrm{T}$ & $\mathrm{NA}$ & $\mathrm{BT}$ & 16 & & 188 \\
\hline 94 & $10-20$ & Fine-Grained Chert & $\mathrm{D}$ & $s$ & $\mathrm{NA}$ & $\mathrm{PP}$ & 15 & & 188 \\
\hline 94 & $10-20$ & Petrified Wood & D & $\underline{s}$ & NA & PP & 16 & & 188 \\
\hline 94 & $10-20$ & Fine-Grained Chert & $M$ & $s$ & NA & PP & 10 & & 188 \\
\hline 94 & $10-20$ & Fine-Grained Chert & D & $\mathrm{T}$ & NA & PP & 16 & & 188 \\
\hline 94 & $10-20$ & Fine-Grained Chert & D & $\mathrm{T}$ & NA & $\mathrm{PP}$ & 15 & & 188 \\
\hline 94 & $10-20$ & Petrified Wood & C & $s$ & Single & PP & 25 & & 188 \\
\hline 94 & $10-20$ & Quartz Arenite & C & $s$ & Single & UM & 19 & & 188 \\
\hline 95 & $0-10$ & Fine-Grained Chert & D & $\mathrm{T}$ & NA & $\mathrm{BM}$ & 22 & & 216 \\
\hline 95 & $0-10$ & Fine-Grained Chert & $\mathrm{C}$ & $\mathrm{s}$ & Single & $\mathrm{BM}$ & 29 & & 216 \\
\hline 95 & $0-10$ & Fine-Grained Chert & $\mathrm{M}$ & $s$ & NA & IN & 13 & & 216 \\
\hline 95 & $0-10$ & Fine-Grained Chert & $\mathrm{C}$ & $\mathrm{T}$ & NA & IN & 10 & & 216 \\
\hline 95 & $0-10$ & Fine-Grained Chert & D & $\mathrm{T}$ & NA & IN & 22 & & 216 \\
\hline 95 & $0-10$ & Fine-Grained Chert & D & $\mathrm{T}$ & NA & IN & 15 & & 216 \\
\hline 95 & $0-10$ & Fine-Grained Chert & $\mathrm{D}$ & $\mathrm{T}$ & NA & IN & 13 & & 216 \\
\hline 95 & $0-10$ & Fine-Grained Chert & $\mathrm{C}$ & $\mathrm{T}$ & Single & $\mathrm{PP}$ & 15 & & 216 \\
\hline 95 & $0-10$ & Fine-Grained Chert & $\mathrm{P}$ & $\mathrm{T}$ & Single & $\mathrm{PP}$ & 14 & & 216 \\
\hline 96 & $0-23$ & Quartz Arenite & D & $s$ & $\mathrm{NA}$ & BL & 36 & & 125 \\
\hline 96 & $0-23$ & Fine-Grained Chert & C & $s$ & Single & BL & 31 & & 125 \\
\hline 96 & $0-23$ & Fine-Grained Chert & C & $s$ & Single & BL & 46 & & 125 \\
\hline 96 & $0-23$ & Fine-Grained Quartzite & M & D & $\mathrm{NA}$ & $\mathrm{PP}$ & 26 & & 125 \\
\hline 96 & $23-30$ & Fine-Grained Chert & $\mathrm{D}$ & $\mathrm{T}$ & NA & BM & 33 & & 136 \\
\hline 96 & $23-30$ & Fine-Grained Chert & $P$ & $\mathrm{~T}$ & Threet & BT & 11 & & 136 \\
\hline 96 & 23-30 & Fine-Grained Chert & $\mathrm{D}$ & $s$ & NA & $\mathrm{CR}$ & 31 & & 136 \\
\hline 96 & 23-30 & Fine-Grained Chert & C & $\mathrm{T}$ & Threet & IN & 24 & & 136 \\
\hline 96 & $23-30$ & Fine-Grained Chert & $\mathrm{C}$ & $\mathrm{S}$ & Corticate & $\mathrm{PP}$ & 25 & & 136 \\
\hline 96 & $23-30$ & Fine-Grained Chert & M & $s$ & NA & $\mathrm{PP}$ & 10 & & 136 \\
\hline 96 & $23-30$ & Fine-Grained Chert & $\mathrm{C}$ & $\mathrm{T}$ & Threet & PP & 19 & & 136 \\
\hline 96 & $30-40$ & Petrified Wood & $\mathrm{C}$ & $\mathrm{s}$ & Single & $\mathrm{BL}$ & 30 & Mottled Orangish-Brown & 132 \\
\hline 96 & $30-40$ & Quartz Arenite & $\mathrm{P}$ & $s$ & Threet & BL & 30 & Burned & 132 \\
\hline
\end{tabular}




\begin{tabular}{|c|c|c|c|c|c|c|c|c|c|}
\hline 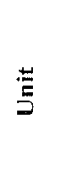 & 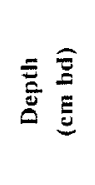 & 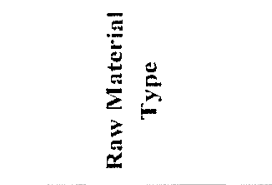 & 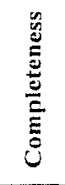 & 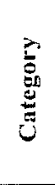 & 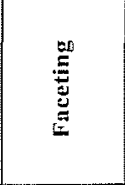 & & 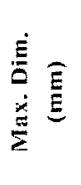 & & $\stackrel{\#}{\stackrel{\#}{د}}$ \\
\hline 96 & $30-40$ & Quartz Arenite & $\mathrm{D}$ & $\mathrm{T}$ & $\mathrm{NA}$ & $\mathrm{BM}$ & 44 & Heavily Curved, Brown & 132 \\
\hline 96 & $30-40$ & Quartz Arenite & M & $\mathrm{T}$ & NA & BM & 33 & Orangish-Brown & 132 \\
\hline 96 & $30-40$ & Fine-Grained Chert & $\mathrm{C}$ & $\mathrm{T}$ & Three+ & BM & 19 & & 132 \\
\hline 96 & $30-40$ & Fine-Grained Chert & C & $\mathrm{T}$ & Two & $\mathrm{BM}$ & 33 & & 132 \\
\hline 96 & $30-40$ & Fine-Grained Chert & $\mathrm{D}$ & $\mathrm{T}$ & NA & BT & 17 & & 132 \\
\hline 96 & $30-40$ & Fine-Grained Chert & $M$ & $T$ & NA & IN & 17 & Burned & 132 \\
\hline 96 & $30-40$ & Fine-Grained Chert & M & $T$ & NA & IN & 17 & & 132 \\
\hline 96 & $30-40$ & Fine-Grained Chert & $\mathrm{D}$ & $\mathrm{T}$ & NA & $\mathrm{PP}$ & 12 & & 132 \\
\hline 96 & $30-40$ & Fine-Grained Chert & $\mathrm{D}$ & $\mathrm{T}$ & NA & PP & 11 & & 132 \\
\hline 96 & $30-40$ & Quartz Arenite & C & $s$ & Threet & PP & 26 & Brown & 132 \\
\hline 96 & $30-40$ & Fine-Grained Chert & C & $\mathrm{T}$ & Threet & PP & 9 & & 132 \\
\hline 96 & $30-40$ & Fine-Grained Chert & $\mathrm{C}$ & $T$ & Threet & $\mathrm{PP}$ & 23 & & 132 \\
\hline 97 & $0-25$ & Fine-Grained Chert & M & $\mathrm{T}$ & $\mathrm{NA}$ & BM & 27 & & 192 \\
\hline 97 & $0-25$ & Fine-Grained Chent & C & $\mathrm{s}$ & Single & $\mathrm{CR}$ & 47 & & 192 \\
\hline 97 & $0-25$ & Fine-Grained Chert & $\mathrm{C}$ & $\mathrm{P}$ & Corticate & PP & 16 & & 192 \\
\hline 97 & $0-25$ & Fine-Grained Chert & $\mathrm{D}$ & $T$ & NA & $\mathrm{PP}$ & 15 & & 192 \\
\hline 97 & $0-25$ & Fine-Grained Chert & C & $\mathrm{T}$ & Single & PP & 13 & & 192 \\
\hline 97 & $25-35$ & Fine-Grained Chert & D & $\mathrm{S}$ & $\mathrm{NA}$ & $\mathrm{BL}$ & 27 & & 195 \\
\hline 97 & $25-35$ & Fine-Grained Chert & $\mathrm{P}$ & $\mathrm{T}$ & Corticate & PP & 16 & & 195 \\
\hline 97 & $25-35$ & Fine-Grained Chert & D & $\mathrm{T}$ & $\mathrm{NA}$ & PP & 13 & & 195 \\
\hline 97 & $25-35$ & Fine-Grained Chert & M & $T$ & NA & $\mathrm{PP}$ & 13 & & 195 \\
\hline 97 & $25-35$ & Fine-Grained Chert & D & $T$ & NA & UM & 19 & & 195 \\
\hline 98 & $0-33$ & Fine-Grained Chert & $\mathrm{AD}$ & $\mathrm{T}$ & NA & $\mathrm{AD}$ & 15 & & 193 \\
\hline 98 & $0-33$ & Fine-Grained Chert & $\mathrm{P}$ & $\mathrm{T}$ & Corticate & $B L$ & 42 & Blade-like & 193 \\
\hline 98 & $0-33$ & Fine-Grained Chert & $\mathrm{C}$ & $\mathrm{T}$ & Corticate & IN & 33 & & 193 \\
\hline 98 & $0-33$ & Fine-Grained Chert & $M$ & $\mathrm{~T}$ & NA & IN & 13 & & 193 \\
\hline 98 & $0-33$ & Fine-Grained Chert & C & $T$ & Corticate & PP & 24 & & 193 \\
\hline 98 & $0-33$ & Fine-Grained Chert & $\mathrm{P}$ & $\mathrm{T}$ & Single & $\mathrm{PP}$ & 12 & & 193 \\
\hline 98 & $33-43$ & Fine-Grained Chert & D & $\mathrm{s}$ & NA & $\mathrm{BL}$ & 38 & & 194 \\
\hline 98 & $33-43$ & Fine-Grained Chert & C & $s$ & Single & $\mathrm{BL}$ & 29 & & 194 \\
\hline 98 & $33-43$ & Fine-Grained Chert & D & $\mathrm{T}$ & NA & $\mathrm{BT}$ & 27 & & 194 \\
\hline 98 & $33-43$ & Fine-Grained Quartz & $\mathrm{M}$ & $\mathrm{P}$ & NA & IN & 17 & & 194 \\
\hline 98 & $33-43$ & Fine-Grained Chert & M & $\mathrm{T}$ & NA & IN & 15 & & 194 \\
\hline 98 & $33-43$ & Fine-Grained Chert & $\mathrm{P}$ & $\mathrm{T}$ & Single & IN & 12 & & 194 \\
\hline 98 & $33-43$ & Fine-Grained Chert & C & $\mathrm{T}$ & Threet & IN & 26 & & 194 \\
\hline 98 & $33-43$ & Petrified Wood & $\mathrm{C}$ & $\mathrm{T}$ & Corticate & $\mathrm{PP}$ & 19 & & 194 \\
\hline 98 & $33-43$ & Fine-Grained Chert & $\mathrm{D}$ & $\mathrm{S}$ & NA & PP & 17 & & 194 \\
\hline 98 & $33-43$ & Fine-Grained Chert & $\mathrm{D}$ & $s$ & NA & PP & 13 & & 194 \\
\hline 98 & $33-43$ & Fine-Grained Chert & $\mathrm{p}$ & $s$ & $\mathrm{NA}$ & $\mathrm{PP}$ & 15 & & 194 \\
\hline 98 & $33-43$ & Fine-Grained Chert & $\mathrm{C}$ & $\mathrm{s}$ & Single & PP & 22 & & 194 \\
\hline 98 & $33-43$ & Fine-Grained Chert & $\mathrm{C}$ & $T$ & Single & PP & 25 & & 194 \\
\hline 98 & $33-43$ & Fine-Grained Chert & C & $s$ & Two & PP & 20 & & 194 \\
\hline 99 & $0-10$ & Fine-Grained Chert & $\mathrm{AD}$ & $\mathrm{T}$ & NA & $\mathrm{AD}$ & 23 & & 197 \\
\hline 99 & $0-10$ & Fine-Grained Chert & $\mathrm{AD}$ & $\mathrm{T}$ & $\mathrm{NA}$ & $\mathrm{AD}$ & 13 & & 197 \\
\hline 99 & $0-10$ & Fine-Grained Chert & C & $\mathrm{s}$ & Single & $\mathrm{BL}$ & 32 & & 197 \\
\hline 99 & $0-10$ & Fine-Grained Chert & $\mathrm{D}$ & $\mathrm{T}$ & NA & $\mathrm{BT}$ & 16 & & 197 \\
\hline 99 & $10-20$ & Fine-Grained Chert & $\mathrm{AD}$ & $T$ & $\mathrm{NA}$ & $\mathrm{AD}$ & 16 & & 207 \\
\hline 99 & $20-30$ & Fine-Grained Chert & $\mathrm{D}$ & $\mathrm{T}$ & NA & IN & 14 & & 204 \\
\hline 99 & $20-30$ & Petrified Wood & $\mathrm{M}$ & $\mathrm{T}$ & $\mathrm{NA}$ & IN & 16 & & 204 \\
\hline 99 & $20-30$ & Fine-Grained Chert & $\mathrm{C}$ & $\mathrm{P}$ & Corticate & PP & 10 & & 204 \\
\hline 99 & $20-30$ & Fine-Grained Chert & $\mathrm{C}$ & $\mathrm{T}$ & Single & PP & 22 & Heavy Patina & 204 \\
\hline 99 & $20-30$ & Fine-Grained Quartzite & $\mathrm{P}$ & $s$ & Three+ & PP & 16 & & 204 \\
\hline 99 & 20-30 & Petrified Wood & M & $\mathrm{T}$ & $\mathrm{NA}$ & IN & 16 & Heavy Patina & 204 \\
\hline 99 & $20-30$ & Fine-Grained Chert & $D$ & $\mathrm{~T}$ & $\mathrm{NA}$ & IN & 14 & & 204 \\
\hline 99 & $20-30$ & Fine-Grained Chert & $\mathrm{C}$ & $\mathrm{P}$ & Corticate & PP & 10 & & 204 \\
\hline 99 & $20-30$ & Fine-Grained Chert & $\mathrm{C}$ & $\mathrm{T}$ & Single & $\mathrm{PP}$ & 22 & & 204 \\
\hline
\end{tabular}




\begin{tabular}{|c|c|c|c|c|c|c|c|c|c|}
\hline$\ddot{E}$ & 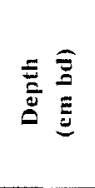 & 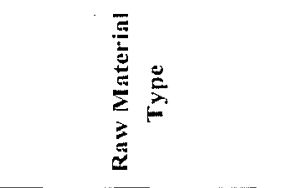 & 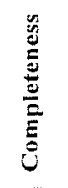 & 竟 & : & 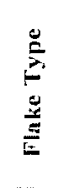 & 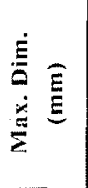 & 泀 & $\begin{array}{l}\text { F } \\
\text { 苛 }\end{array}$ \\
\hline 99 & $20-30$ & Fine-Grained Quartzite & $\mathrm{P}$ & $s$ & Threet & $\mathrm{PP}$ & 16 & & 204 \\
\hline 100 & $0-15$ & Coarse-Grained Chert & $\mathrm{P}$ & $T$ & Single & $\mathrm{BL}$ & 27 & & 196 \\
\hline 100 & $0-15$ & Fine-Grained Chert & $\mathrm{M}$ & $\mathrm{s}$ & $\mathrm{NA}$ & $\mathrm{CR}$ & 42 & & 196 \\
\hline 100 & $0-15$ & Fine-Grained Chert & $\mathrm{D}$ & $\mathrm{T}$ & $\mathrm{NA}$ & $\mathrm{PP}$ & 23 & & 196 \\
\hline 100 & $0-15$ & Fine-Grained Chert & C & $\mathrm{s}$ & Single & PP & 23 & & 196 \\
\hline 100 & $15-25$ & Petrified Wood & $\mathrm{AD}$ & $s$ & NA & $A D$ & 36 & & 208 \\
\hline 100 & $15-25$ & Fine-Grained Chert & $\mathrm{AD}$ & $\mathrm{T}$ & $\mathrm{NA}$ & $A D$ & 21 & & 208 \\
\hline 100 & $15-25$ & Fine-Grained Chert & C & $\mathrm{T}$ & Corticate & PP & 17 & & 208 \\
\hline 100 & $15-25$ & Finc-Grained Chert & $\mathrm{D}$ & $s$ & NA & $\mathrm{PP}$ & 20 & & 208 \\
\hline 100 & $15-25$ & Fine-Grained Chert & D & $s$ & $\mathrm{NA}$ & PP & 14 & & 208 \\
\hline 100 & $15-25$ & Fine-Grained Chert & D & $\mathrm{T}$ & NA & PP & 24 & & 208 \\
\hline 100 & $25-35$ & Fine-Grained Chert & $\mathrm{p}$ & $s$ & Corticate & IN & 35 & & 209 \\
\hline 100 & $25-35$ & Fine-Grained Chert & C & $\mathrm{s}$ & Corticate & $\mathrm{PP}$ & 16 & & 209 \\
\hline 100 & $35-45$ & Fine-Grained Chert & $\mathrm{AD}$ & $s$ & NA & $\mathrm{AD}$ & 14 & & 210 \\
\hline 100 & $35-45$ & Fine-Grained Chert & $\mathrm{AD}$ & $\mathrm{T}$ & NA & $\mathrm{AD}$ & 14 & & 210 \\
\hline 100 & $35-45$ & Fine-Grained Chert & D & $s$ & $\mathrm{NA}$ & $\mathrm{BL}$ & 38 & & 210 \\
\hline 100 & $35-45$ & Fine-Grained Chert & C & $\mathrm{T}$ & Single & $\mathrm{BL}$ & 40 & & 210 \\
\hline 100 & $35-45$ & Fine-Grained Chert & M & $\mathrm{T}$ & NA & $\mathrm{BT}$ & 11 & & 210 \\
\hline 100 & $35-45$ & Fine-Grained Chert & $\mathrm{C}$ & $\mathrm{T}$ & Two & $\mathrm{PP}$ & 23 & & 210 \\
\hline 100 & $45-55$ & Fine-Grained Chert & $\mathrm{P}$ & $T$ & Threet & $\mathrm{BM}$ & 16 & & 211 \\
\hline 100 & $45-55$ & Fine-Grained Chert & C & $T$ & Two & IN & 15 & & 211 \\
\hline 100 & $45-55$ & Fine-Grained Chert & D & $s$ & NA & $\mathrm{PP}$ & 17 & & 211 \\
\hline 100 & $45-55$ & Fine-Grained Chert & $\mathrm{D}$ & $\mathrm{T}$ & NA & $\mathrm{PP}$ & 15 & & 211 \\
\hline 100 & $55-65$ & Fine-Grained Chert & $\mathrm{AD}$ & $S$ & NA & $\mathrm{AD}$ & 12 & & 212 \\
\hline 100 & $55-65$ & Fine-Grained Quartzite & $\mathrm{D}$ & $s$ & $\mathrm{NA}$ & $\mathrm{CR}$ & 36 & & 212 \\
\hline 100 & $55-65$ & Fine-Grained Chert & D & $s$ & $\mathrm{NA}$ & IN & 20 & & 212 \\
\hline 100 & $55-65$ & Quartz Arenite & $\mathrm{M}$ & $\mathrm{T}$ & $\mathrm{NA}$ & IN & 18 & & 212 \\
\hline 100 & $55-65$ & Fine-Grained Chert & D & $T$ & $\mathrm{NA}$ & $\mathrm{PP}$ & 24 & & 212 \\
\hline 100 & $65-75$ & Fine-Grained Chert & $\mathrm{D}$ & $S$ & $\mathrm{NA}$ & $\mathrm{BD}$ & 27 & & 213 \\
\hline 100 & $65-75$ & Fine-Grained Chent & $D$ & $T$ & NA & $\mathrm{BD}$ & 28 & & 213 \\
\hline 100 & $65-75$ & Fine-Grained Chert & $\mathrm{C}$ & $\underline{s}$ & Corticate & BL & 43 & Blade Core Preparation & 213 \\
\hline 100 & $65-75$ & Fine-Grained Chert & C & $s$ & Corticate & $B L_{2}$ & 44 & Blade Core Preparation & 213 \\
\hline 100 & $65-75$ & Quartz Arenite & $\mathrm{C}$ & $S$ & Single & $\mathrm{BL}$ & 41 & & 213 \\
\hline 100 & $65-75$ & Fine-Grained Chert & $\mathrm{M}$ & $T$ & $\mathrm{NA}$ & $\mathrm{BM}$ & 30 & & 213 \\
\hline-100 & $65-75$ & Fine-Grained Chert & $\mathrm{M}$ & $T$ & NA & IN & 14 & & 213 \\
\hline 100 & $65-75$ & Fine-Grained Chert & C & $\mathrm{s}$ & Corticate & $\mathrm{PP}$ & 17 & & 213 \\
\hline 100 & $65-75$ & Fine-Grained Chert & $\mathrm{D}$ & $\mathrm{T}$ & NA & PP & 12 & & 213 \\
\hline 100 & $65-75$ & Fine-Grained Chert & C & $\mathrm{P}$ & Single & PP & 14 & & 213 \\
\hline 100 & $65-75$ & Fine-Grained Chert & $\mathrm{C}$ & $\mathrm{s}$ & Single & $\mathrm{PP}$ & 26 & & 213 \\
\hline 101 & $0-13$ & Petrified Wood & $\mathrm{M}$ & $\mathrm{T}$ & $\mathrm{NA}$ & IN & 11 & & 200 \\
\hline 101 & $0-13$ & Fine-Grained Chert & C & $\mathrm{T}$ & Single & IN & 19 & & 200 \\
\hline 101 & $0-13$ & Fine-Grained Chert & C & $\mathrm{T}$ & Threet & IN & 24 & & 200 \\
\hline 101 & $0-13$ & Fine-Grained Chert & D & $\mathrm{P}$ & NA & $\mathrm{PP}$ & 11 & & 200 \\
\hline 101 & $0-13$ & Fine-Grained Chert & $\mathrm{D}$ & $T$ & NA & PP & 13 & & 200 \\
\hline 101 & $0-13$ & Fine-Grained Chert & $\mathrm{D}$ & $\mathrm{T}$ & $\mathrm{NA}$ & PP & 17 & & 200 \\
\hline 101 & $0-13$ & Fine-Grained Chert & $\mathrm{D}$ & $\mathrm{T}$ & $\mathrm{NA}$ & PP & 10 & & 200 \\
\hline 101 & $0-13$ & Fine-Grained Chert & $\mathrm{D}$ & $\mathrm{T}$ & $\mathrm{NA}$ & $\mathrm{PP}$ & 8 & & 200 \\
\hline 101 & $0-13$ & Fine-Grained Chert & $\mathrm{M}$ & $\mathrm{T}$ & NA & PP & 14 & & 200 \\
\hline 101 & $0-13$ & Fine-Grained Chert & M & $\mathrm{T}$ & $\mathrm{NA}$ & $\mathrm{PP}$ & 10 & & 200 \\
\hline 101 & $0-13$ & Petrified Wood & $\mathrm{M}$ & $\mathrm{T}$ & $\mathrm{NA}$ & $\mathrm{PP}$ & 8 & & 200 \\
\hline 101 & $0-13$ & Fine-Grained Chert & $\mathrm{C}$ & $s$ & Single & $\mathrm{PP}$ & 14 & & 200 \\
\hline 101 & $13-17$ & Fine-Grained Chert & $\mathrm{P}$ & $T$ & Three+ & $\mathrm{BT}$ & 12 & & 201 \\
\hline 101 & $13-17$ & Fine-Grained Chert & $\mathrm{D}$ & $\mathrm{T}$ & NA & IN & 15 & & 201 \\
\hline 101 & $13-17$ & Fine-Grained Chert & D & $\mathrm{s}$ & $\mathrm{NA}$ & $\mathrm{PP}$ & 16 & & 201 \\
\hline 101 & $13-17$ & Fine-Grained Chert & $\mathrm{C}$ & $\mathrm{T}$ & Single & PP & 9 & & 201 \\
\hline 101 & $13-17$ & Fine-Grained Chert & $C$ & $T$ & Single & $\mathrm{PP}$ & 15 & & 201 \\
\hline
\end{tabular}




\begin{tabular}{|c|c|c|c|c|c|c|c|c|c|}
\hline 莑 & $\begin{array}{l}\overline{\bar{E}} \\
\bar{E} \\
\bar{E} \\
\bar{E}\end{array}$ & 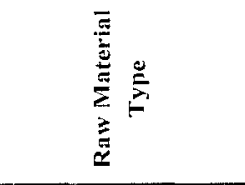 & 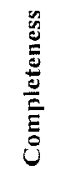 & 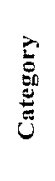 & 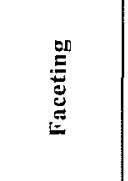 & 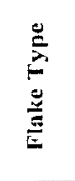 & 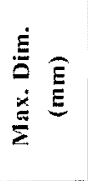 & 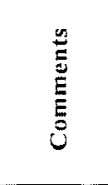 & $\begin{array}{l}\# \\
\vdots \\
\Xi\end{array}$ \\
\hline 101 & $17-33$ & Quartz Arenite & $M$ & $T$ & $\mathrm{NA}$ & $\mathrm{BT}$ & 35 & & 203 \\
\hline 101 & $17-33$ & Fine-Grained Chert & D & $s$ & NA & $\mathrm{CR}$ & 40 & & 203 \\
\hline 101 & $17-33$ & Fine-Grained Chert & $\mathrm{M}$ & $\mathrm{s}$ & $\mathrm{NA}$ & IN & 43 & & 203 \\
\hline 101 & $17-33$ & Fine-Grained Chert & $\mathrm{D}$ & $\mathrm{T}$ & $\mathrm{NA}$ & IN & 7 & & 203 \\
\hline 101 & $17-33$ & Fine-Grained Chert & $\mathrm{M}$ & $\mathrm{T}$ & $\mathrm{NA}$ & IN & 14 & & 203 \\
\hline 101 & $17-33$ & Fine-Grained Chert & $\mathrm{P}$ & $\mathrm{T}$ & Single & IN & 12 & & 203 \\
\hline 101 & $17-33$ & Petrified Wood & $\mathrm{C}$ & $\mathrm{T}$ & Corticate & $\mathrm{PP}$ & 22 & & 203 \\
\hline 101 & $17-33$ & Fine-Grained Chert & D & $S$ & NA & $\mathrm{PP}$ & 20 & & 203 \\
\hline 101 & $17-33$ & Fine-Grained Chert & $C$ & $\mathrm{~T}$ & Single & PP & 11 & & 203 \\
\hline 101 & $17-33$ & Fine-Grained Chert & C & $\mathrm{T}$ & Single & $\mathrm{PP}$ & 14 & & 203 \\
\hline 101 & $17-33$ & Fine-Grained Chert & $\mathrm{P}$ & $T$ & Single & $\mathrm{PP}$ & 12 & & 203 \\
\hline 101 & $17-33$ & Fine-Grained Chert & C & $\mathrm{T}$ & Single & UM & 13 & & 203 \\
\hline 101 & $17-33$ & Fine-Grained Chert & $\mathrm{C}$ & $\mathrm{T}$ & Single & UM & 14 & & 203 \\
\hline 102 & $0-7$ & Petrified Wood & $\mathrm{M}$ & $\mathrm{s}$ & NA & IN & 15 & & 199 \\
\hline 102 & $0-7$ & Fine-Grained Chert & $\mathrm{D}$ & $\mathrm{T}$ & NA & IN & 11 & & 199 \\
\hline 102 & $0-7$ & Fine-Grained Chert & $\mathrm{D}$ & $\mathrm{s}$ & NA & PP & 15 & & 199 \\
\hline 102 & $0-7$ & Fine-Grained Chert & $\mathrm{D}$ & $T$ & NA & PP & 12 & & 199 \\
\hline 102 & $0-7$ & Fine-Grained Chert & $\mathrm{M}$ & $\mathrm{T}$ & $\mathrm{NA}$ & PP & 15 & & 199 \\
\hline 102 & $0-7$ & Fine-Grained Chert & $\mathrm{M}$ & $\mathrm{T}$ & NA & $\mathrm{PP}$ & 18 & & 199 \\
\hline 102 & $0-7$ & Fine-Grained Chert & $\mathrm{C}$ & $\mathrm{T}$ & Single & PP & 9 & & 199 \\
\hline 103 & $25-43$ & Fine-Grained Chert & $\mathrm{D}$ & $\mathrm{T}$ & NA & IN & 27 & & 202 \\
\hline 104 & $0-23$ & Petrified Wood & $\mathrm{AD}$ & $T$ & NA & $\mathrm{AD}$ & 17 & & 206 \\
\hline 104 & $0-23$ & Fine-Grained Chert & D & $s$ & NA & BL & 23 & & 206 \\
\hline 104 & $0-23$ & Fine-Grained Chert & $\mathrm{M}$ & $\mathrm{s}$ & $\mathrm{NA}$ & $\mathrm{BL}$ & 23 & & 206 \\
\hline 104 & $0-23$ & Fine-Grained Chert & $\mathrm{P}$ & $S$ & $\mathrm{NA}$ & $\mathrm{BL}$ & 26 & & 206 \\
\hline 104 & $0-23$ & Fine-Grained Chert & M & $T$ & NA & $\mathrm{BM}$ & 28 & Burned & 206 \\
\hline 104 & $0-23$ & Fine-Grained Chert & $\mathrm{M}$ & $\mathrm{T}$ & NA & $\mathrm{BT}$ & 14 & & 206 \\
\hline 104 & $0-23$ & Fine-Grained Chert & $\mathrm{P}$ & $\mathrm{T}$ & Single & $\mathrm{CR}$ & 29 & & 206 \\
\hline 104 & $0-23$ & Quartz Arenite & $\mathrm{D}$ & $s$ & NA & IN & 28 & & 206 \\
\hline 104 & $0-23$ & Fine-Grained Chert & $M$ & $s$ & NA & IN & 21 & & 206 \\
\hline 104 & $0-23$ & Fine-Grained Chert & $\mathrm{D}$ & $\mathrm{T}$ & $\mathrm{NA}$ & IN & 20 & & 206 \\
\hline 104 & $0-23$ & Fine-Grained Chert & $\mathrm{M}$ & $\mathrm{T}$ & $\mathrm{NA}$ & IN & 14 & & 206 \\
\hline 104 & $0-23$ & Petrified Wood & $\mathrm{M}$ & $\mathrm{T}$ & NA & $\mathrm{IN}$ & 18 & & 206 \\
\hline 104 & $0-23$ & Fine-Grained Chert & $\mathrm{C}$ & $s$ & Single & IN & 33 & & 206 \\
\hline 104 & $0-23$ & Petrified Wood & $\mathrm{C}$ & $\mathrm{T}$ & Single & IN & 23 & & 206 \\
\hline 104 & $0-23$ & Fine-Grained Chert & $P$ & $\mathrm{~T}$ & Threet & IN & 14 & & 206 \\
\hline 104 & $0-23$ & Fine-Grained Chert & $\mathrm{C}$ & $\mathrm{s}$ & Corticate & $\mathrm{PP}$ & 28 & & 206 \\
\hline 104 & $0-23$ & Fine-Grained Chert & $\mathrm{D}$ & $S$ & NA & $\mathrm{PP}$ & 15 & & 206 \\
\hline 104 & $0-23$ & Fine-Grained Chert & $\mathrm{D}$ & $\mathrm{T}$ & NA & PP & 12 & & 206 \\
\hline 104 & $0-23$ & Fine-Grained Chert & $\mathrm{D}$ & $\mathrm{T}$ & NA & $\mathrm{PP}$ & 10 & & 206 \\
\hline 104 & $0-23$ & Fine-Grained Chert & $\mathrm{D}$ & $\mathrm{T}$ & $\mathrm{NA}$ & $\mathrm{PP}$ & 10 & & 206 \\
\hline 104 & $0-23$ & Petrified Wood & $\mathrm{D}$ & $\mathrm{T}$ & NA & PP & 10 & & 206 \\
\hline 104 & $0-23$ & Fine-Grained Chert & M & $T$ & NA & PP & 14 & & 206 \\
\hline 104 & $0-23$ & Fine-Grained Chert & M & $\mathrm{T}$ & NA & PP & 15 & & 206 \\
\hline 104 & $0-23$ & Fine-Grained Chert & $\mathrm{M}$ & $\mathrm{T}$ & NA & $\mathrm{PP}$ & 8 & & 206 \\
\hline 104 & $0-23$ & Petrified Wood & $\mathrm{M}$ & $\mathrm{T}$ & NA & PP & 14 & & 206 \\
\hline 104 & $0-23$ & Fine-Grained Chert & $\mathbf{P}$ & $s$ & Single & PP & 20 & & 206 \\
\hline 104 & $0-23$ & Fine-Grained Chert & $\mathrm{P}$ & $S$ & Single & PP & 11 & & 206 \\
\hline 104 & $0-23$ & Fine-Grained Chert & $P$ & $\mathrm{~s}$ & Single & $\mathrm{PP}$ & 15 & & 206 \\
\hline 104 & $0-23$ & Fine-Grained Chert & $\mathrm{p}$ & $\mathrm{T}$ & Threet & $\mathrm{PP}$ & 10 & & 206 \\
\hline 104 & $23-38$ & Fine-Grained Chert & $\mathrm{C}$ & $s$ & Corticate & $\mathrm{BL}$ & 37 & & 214 \\
\hline 104 & $23-38$ & Fine-Grained Chert & $\mathrm{M}$ & $s$ & NA & BL & 19 & & 214 \\
\hline 104 & $23-38$ & Fine-Grained Chert & $\mathbf{P}$ & $\mathrm{T}$ & Threet & $\mathrm{BL}$ & 14 & & 214 \\
\hline 104 & $23-38$ & Fine-Grained Chert & M & $\mathrm{T}$ & $\mathrm{NA}$ & $\mathrm{BM}$ & 32 & & 214 \\
\hline 104 & $23-38$ & Fine-Grained Chert & $\mathrm{D}$ & $\mathrm{s}$ & NA & BT & 16 & & 214 \\
\hline 104 & $23-38$ & Petrified Wood & $\mathrm{C}$ & $T$ & Three+ & $\mathrm{BT}$ & 15 & & 214 \\
\hline
\end{tabular}




\begin{tabular}{|c|c|c|c|c|c|c|c|c|c|}
\hline $\begin{array}{l}\text { 昔 } \\
\end{array}$ & 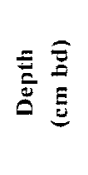 & 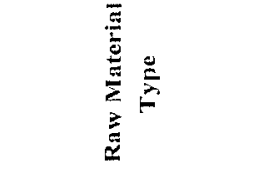 & 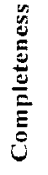 & 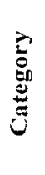 & 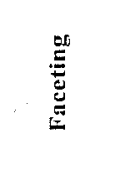 & 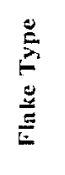 & 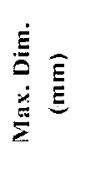 & 䓂 & $\begin{array}{l}\# \\
\stackrel{3}{3}\end{array}$ \\
\hline 104 & $23-38$ & Fine-Grained Chert & D & $T$ & $\mathrm{NA}$ & IN & 18 & & 214 \\
\hline 104 & $23-38$ & Fine-Grained Chert & D & $\mathrm{T}$ & NA & IN & 11 & & 214 \\
\hline 104 & $23-38$ & Fine-Grained Chert & M & $T$ & NA & $\mathrm{IN}$ & 14 & & 214 \\
\hline 104 & $23-38$ & Fine-Grained Chert & $\mathrm{M}$ & $T$ & NA & IN & 12 & & 214 \\
\hline 104 & $23-38$ & Fine-Grained Chert & $\mathrm{C}$ & $\mathrm{T}$ & Threet & IN & 25 & & 214 \\
\hline 104 & $23-38$ & Fine-Grained Chert & $\mathrm{P}$ & $\mathrm{T}$ & Threet & IN & 11 & & 214 \\
\hline 104 & $23-38$ & Quartzite & C & $\mathrm{T}$ & Two & IN & 22 & & 214 \\
\hline 104 & 23-38 & Fine-Grained Chert & D & $T$ & NA & PP & 13 & & 214 \\
\hline 104 & $23-38$ & Fine-Grained Cherl & $\mathrm{C}$ & $T$ & Single & PP & 17 & & 214 \\
\hline 104 & $23-38$ & Fine-Grained Chert & $P$ & $\mathrm{~T}$ & Single & PP & 15 & & 214 \\
\hline 104 & $23-38$ & Fine-Grained Chert & $\mathrm{p}$ & $\mathrm{s}$ & Threet & PP & 16 & & 214 \\
\hline 104 & $23-38$ & Fine-Grained Chert & C & $T$ & Threet & PP & 12 & & 214 \\
\hline 104 & $23-38$ & Fine-Grained Chert & C & $\mathrm{s}$ & Two & $\mathrm{PP}$ & 29 & & 214 \\
\hline 104 & $23-38$ & Fine-Grained Chert & C & $\mathrm{T}$ & Two & PP & 8 & & 214 \\
\hline 104 & $23-38$ & Petrified Wood & C & $\underline{S}$ & Single & UM & 14 & Uniface Manufacturing & 214 \\
\hline 104 & $38-49$ & Fine-Grained Chert & C & $s$ & Corticate & $\mathrm{BM}$ & 50 & & 215 \\
\hline 104 & $38-49$ & Fine-Grained Chert & D & $T$ & $\mathrm{NA}$ & BM & 27 & & 215 \\
\hline 104 & $38-49$ & Fine-Grained Chert & $\mathrm{D}$ & $\mathrm{T}$ & NA & BM & 24 & & 215 \\
\hline 104 & $38-49$ & Fine-Grained Chert & C & $T$ & Threet & BS & 16 & & 215 \\
\hline 104 & $38-49$ & Fine-Grained Chert & D & $\mathrm{T}$ & NA & $\mathrm{BT}$ & 13 & & 215 \\
\hline 104 & $38-49$ & Fine-Grained Chert & D & $\mathrm{T}$ & $\mathrm{NA}$ & $\mathrm{BT}$ & 11 & & 215 \\
\hline 104 & $38-49$ & Fine-Grained Chert & $\mathrm{M}$ & $\mathrm{P}$ & NA & IN & 16 & & 215 \\
\hline 104 & $38-49$ & Fine-Grained Chert & D & $\mathrm{T}$ & NA & IN & 9 & May be Resharpening Flake & 215 \\
\hline 104 & $38-49$ & Quartzite & $\mathrm{M}$ & $T$ & NA & IN & 24 & Quartz Arenite & 215 \\
\hline 104 & $38-49$ & Quartzite & D & $\mathrm{T}$ & NA & IN & 10 & & 215 \\
\hline 104 & $38-49$ & Fine-Grained Chert & M & $\mathrm{T}$ & NA & IN & 16 & & 215 \\
\hline 104 & $38-49$ & Petrified Wood & $\mathrm{C}$ & $\mathrm{T}$ & Single & IN & 21 & & 215 \\
\hline 104 & $38-49$ & Fine-Grained Chert & $\mathrm{P}$ & $s$ & Corticate & PP & 14 & & 215 \\
\hline 104 & $38-49$ & Fine-Grained Chert & D & $\mathrm{P}$ & NA & PP & 11 & & 215 \\
\hline 104 & $38-49$ & Coarse-Grained Chert & M & $s$ & $\mathrm{NA}$ & $\mathrm{PP}$ & 22 & & 215 \\
\hline 104 & $38-49$ & Fine-Grained Chert & $\mathrm{D}$ & $\mathrm{T}$ & NA & $\mathrm{PP}$ & 19 & & 215 \\
\hline 104 & $38-49$ & Fine-Grained Chert & $\mathrm{D}$ & $T$ & NA & PP & 11 & & 215 \\
\hline 104 & $38-49$ & Fine-Grained Chert & D & $\mathrm{T}$ & NA & $\mathrm{PP}$ & 12 & & 215 \\
\hline 104 & $38-49$ & Quartzite & D & $T$ & $\mathrm{NA}$ & $\mathrm{PP}$ & 14 & & 215 \\
\hline 104 & $38-49$ & Fine-Grained Chert & C & $\mathrm{P}$ & Single & $\mathrm{PP}$ & 22 & & 215 \\
\hline 104 & $38-49$ & Fine-Grained Chert & C & $S$ & Single & $\mathrm{PP}$ & 33 & & 215 \\
\hline 104 & $38-49$ & Fine-Grained Chert & C & $\underline{S}$ & Single & $\mathrm{PP}$ & 17 & & 215 \\
\hline
\end{tabular}

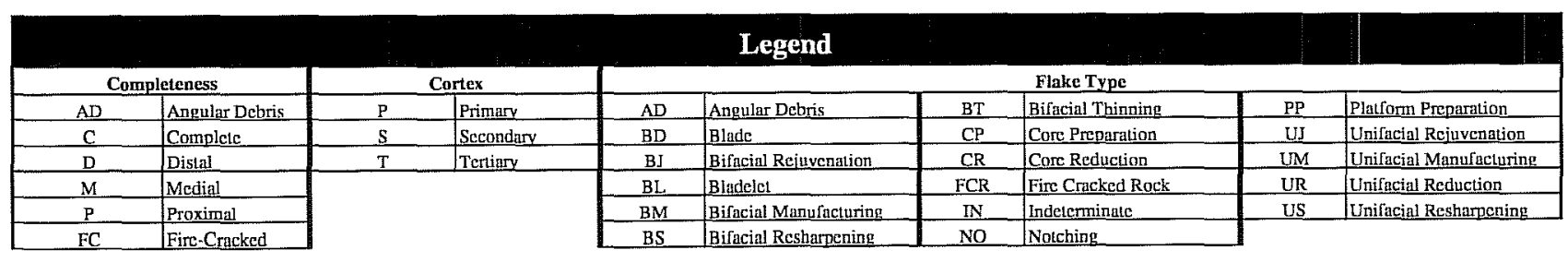





\section{Appendix A-4 \\ Copies of Work Projects Administration (WPA) \\ Photographs, 1940-1941}


Figure A-4. Photograph A-1.

Looking south through Room 3, Chapel 1.

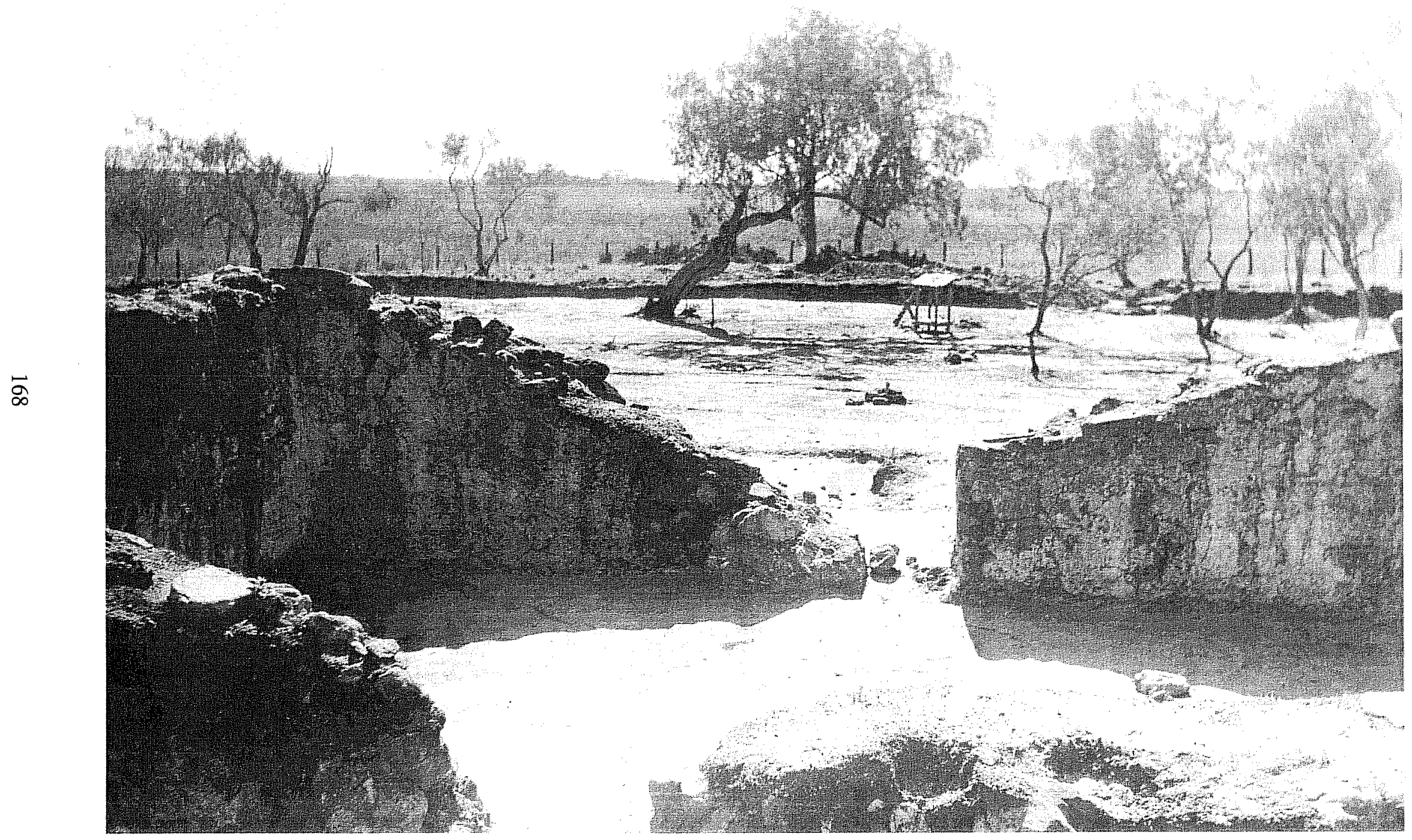

(Photograph in the WPA Mission Rosario Records collection, Cultural Resource Program, Archeology Laboratory, Texas Parks and Wildlife Department, Austin, Texas. Used with permission.) 
Figure A-4. Photograph A-2.

Looking northeast from Room 3, Chapel 1 into stairway area. Note the slight rise or step-up into the stairway area.

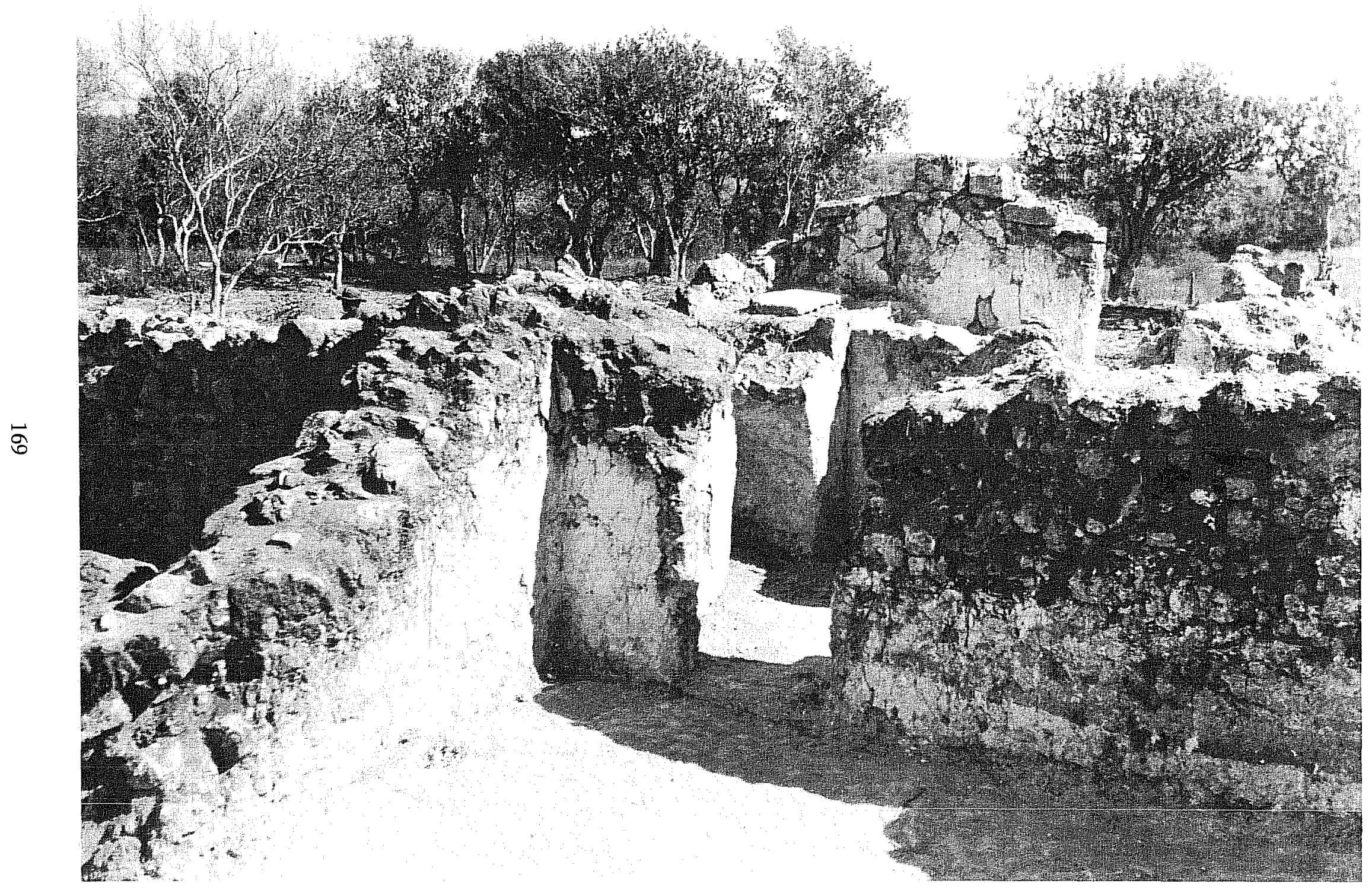

(Photograph in the WPA Mission Rosario Records collection, Cultural Resource Program, Archeology Laboratory, Texas Parks and Wildlife Department, Austin, Texas. Used with permission.) 
Figure A-4. Photograph A-3.

Looking west-northwest at the south side of the central structure, or back of the long side of the "L"; Room 3 on right, Room 5 on left.

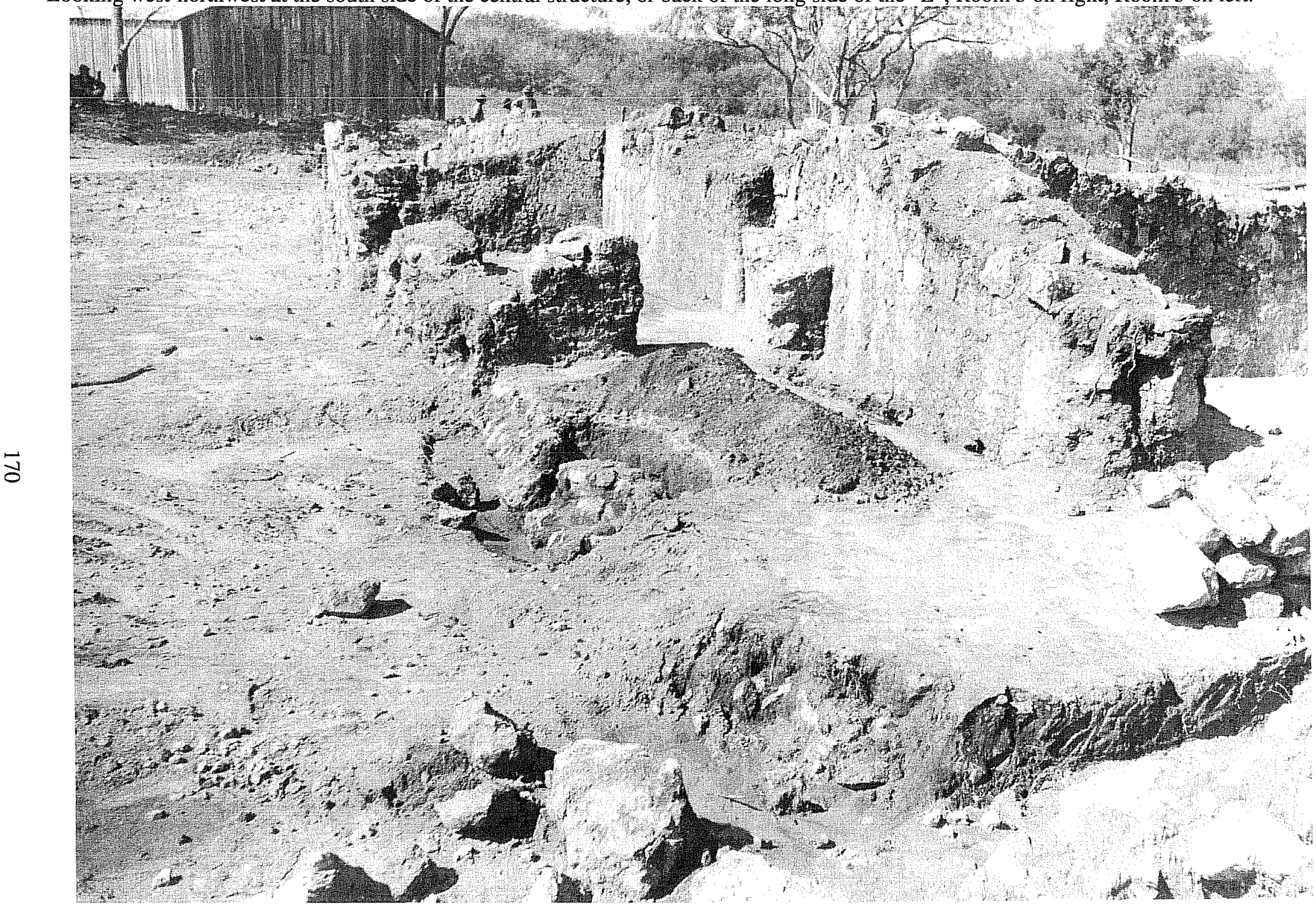

(Photograph in the WPA Mission Rosario Records collection, Cultural Resource Program, Archeology Laboratory, Texas Parks and Wildlife Department, Austin, Texas. Used with permission.) 
Figure A-4. Photograph A-4.

Looking east-southeast along the second chapel wall, bell tower steps in background. This photograph was taken twenty feet north of the west end of the Chapel 2 ruins.

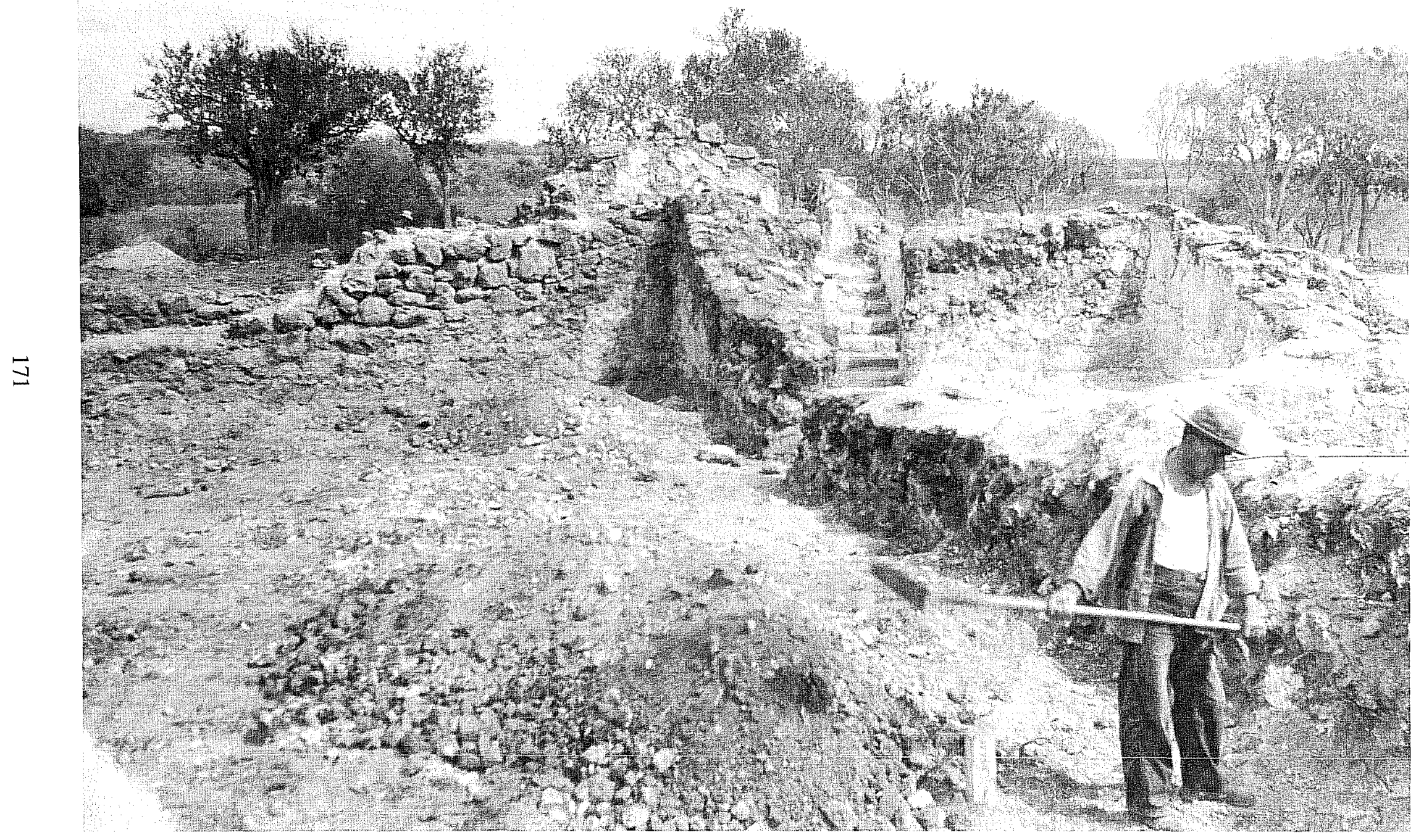

(Photograph in the WPA Mission Rosario Records collection, Cultural Resource Program, Archeology Laboratory, Texas Parks and Wildlife Department, Austin, Texas. Used with permission.) 
Figure A-4. Photograph A-5.

Looking east at the end wall in Room 1, Chapel 1.

This photograph shows the amount of plaster present on the walls, the berm or raised platform areas left in place, and the stone "altar" or furniture abutting the wall.

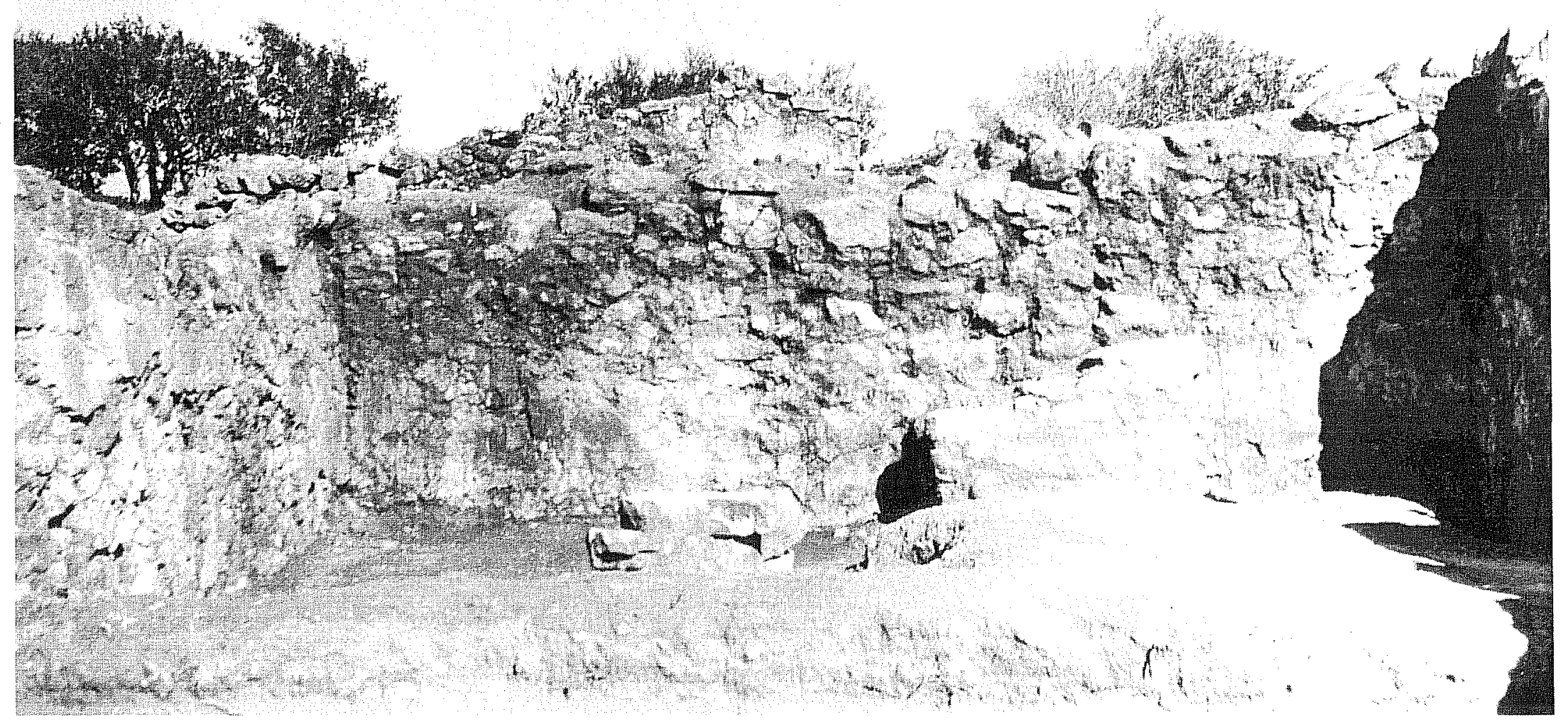

(Photograph in the WPA Mission Rosario Records collection, Cultural Resource Program, Archeology Laboratory, Texas Parks and Wildlife Department, Austin, Texas. Used with permission.) 


\section{Figure A-4. Photograph A-6.}

Looking east-northeast along the south wall of the chapel. Note the trench and level of the compound.

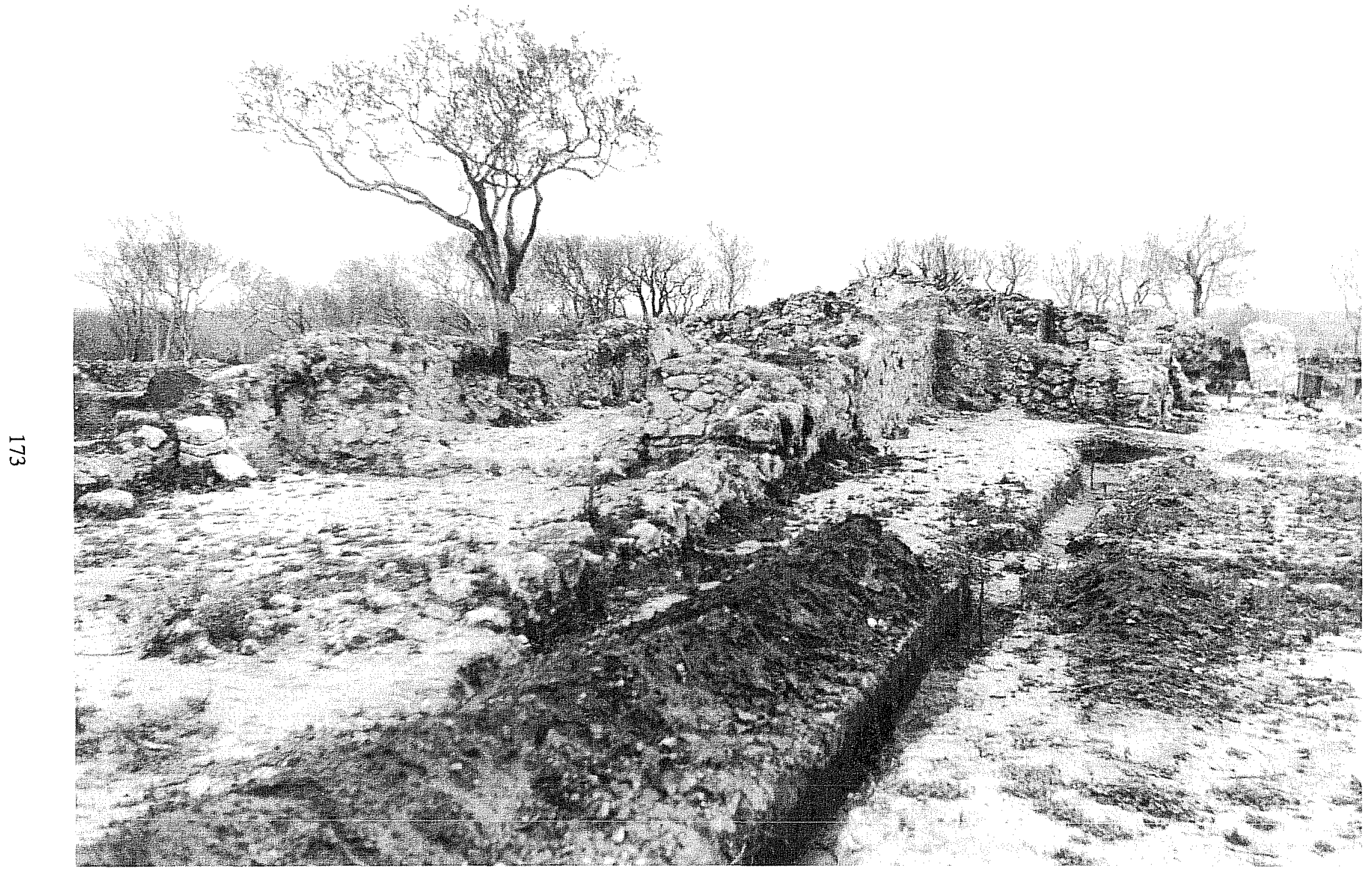

(Photograph in the WPA Mission Rosario Records collection, Cultural Resource Program, Archeology Laboratory, Texas Parks and Wildlife Department, Austin, Texas. Used with permission.) 
Figure A-4. Photograph A-7.

Looking north to south; first church is on the left. Taken after about two feet of overburden had been removed from the entire compound, following trenching operations along the walls. This photograph was taken north of photograph \#3 because the tree is still in the picture. The large circular stone in the east-west wall in the left portion of the photograph was still intact in 1999, eighteen inches above the modern surface. Note the apparent twenty-five foot grid stakes.

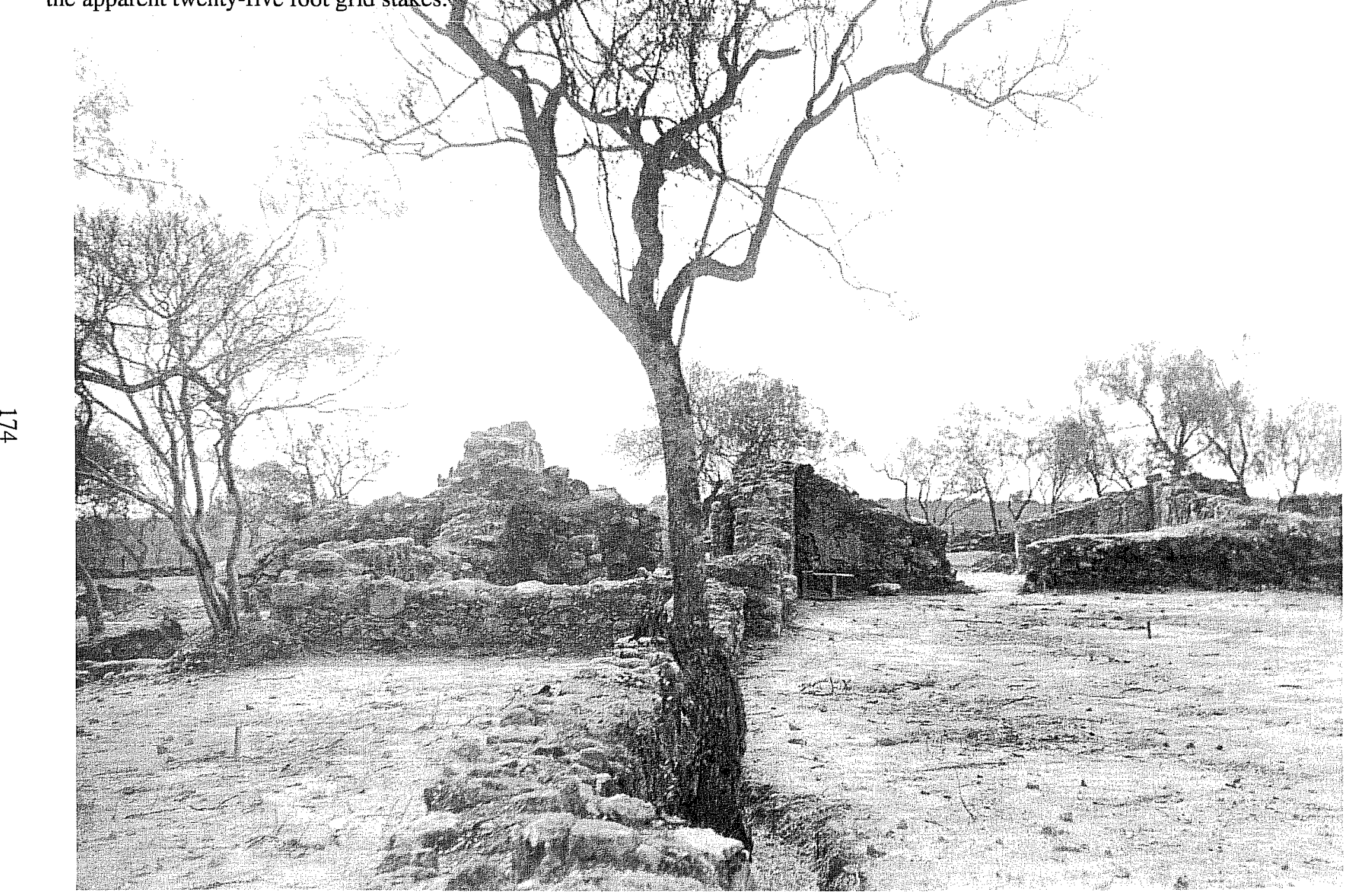

(Photograph in the WPA Mission Rosario Records collection, Cultural Resource Program, Archeology Laboratory, Texas Parks and Wildlife Department, Austin, Texas. Used with permission.) 


\section{Figure A-4. Photograph A-8.}

Looking south at the north and south walls of Room 1, Chapel 1.

The backdirt piled outside the gate in the south compound wall can be seen in the background.

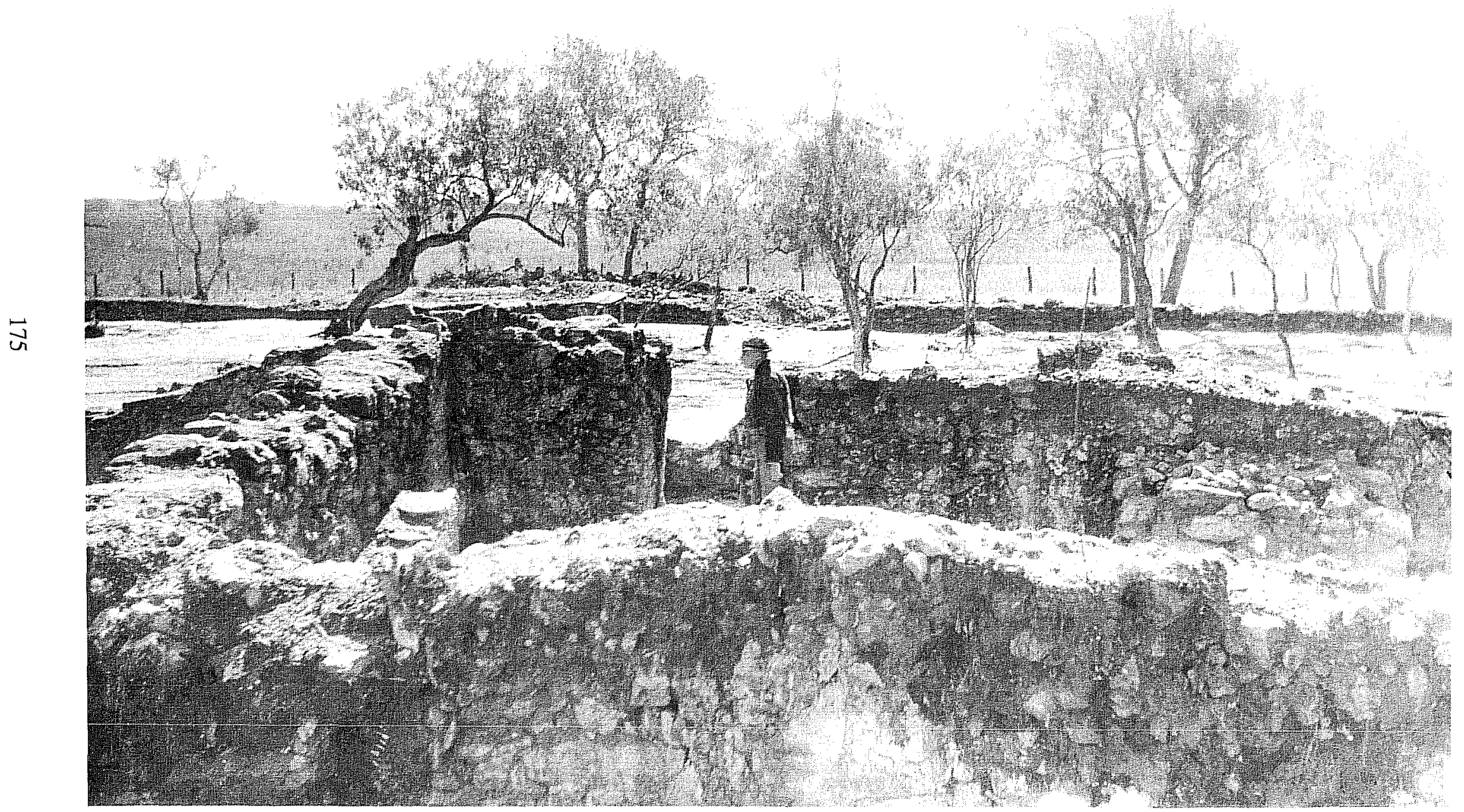

(Photograph in the WPA Mission Rosario Records collection, Cultural Resource Program, Archeology Laboratory, Texas Parks and Wildlife Department, Austin, Texas. Used with permission.) 


\section{Figure A-4. Photograph A-9.}

Looking west-northwest at the south side of the central structure (Chapel 1).

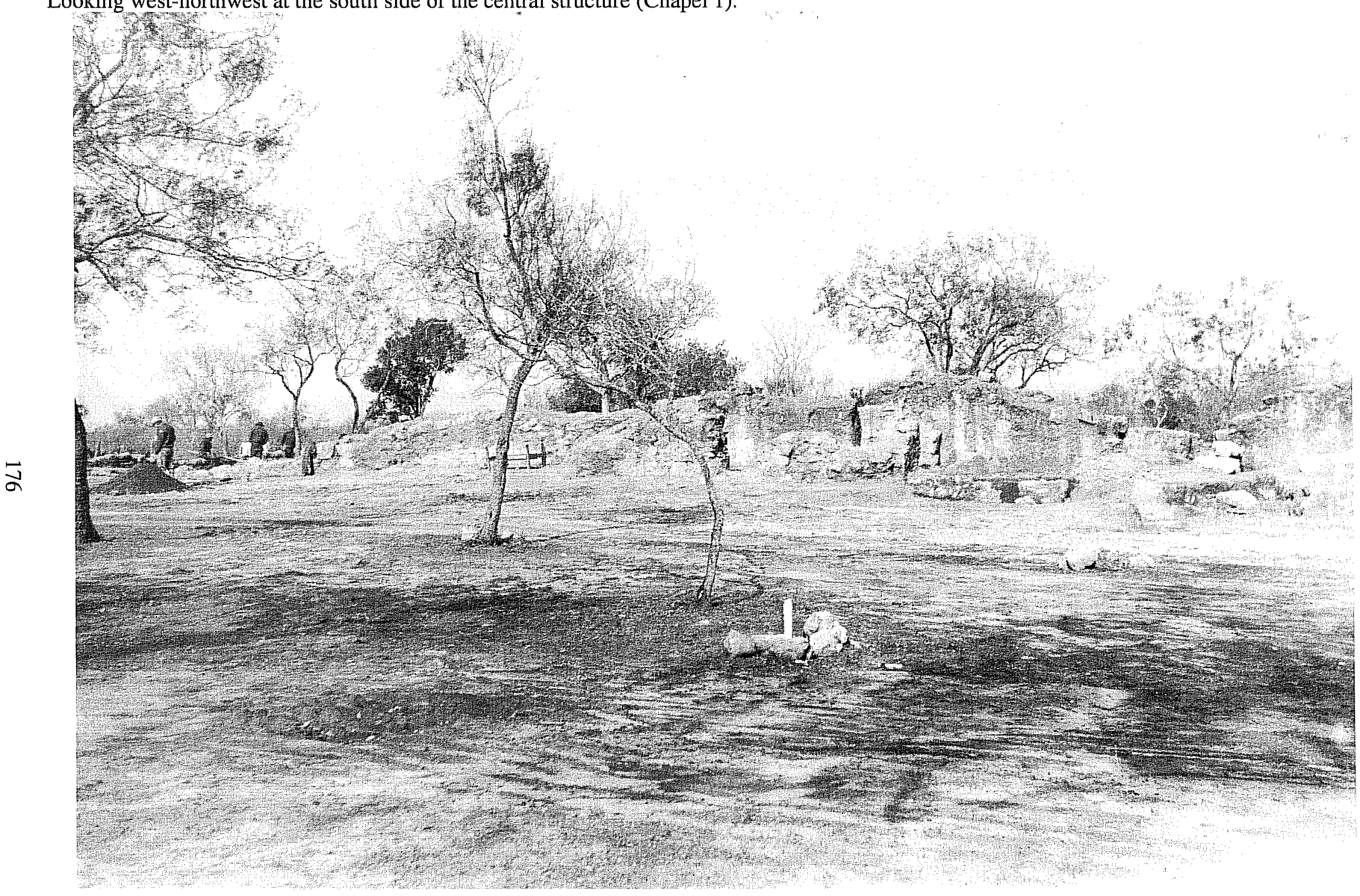

(Photograph in the WPA Mission Rosario Records collection, Cultural Resource Program, Archeology Laboratory, Texas Parks and Wildlife Department, Austin, Texas. Used with permission.) 
Appendix B
Faunal Data 


\begin{tabular}{|c|c|c|c|c|c|c|c|c|c|c|c|c|}
\hline Uni1 & $\begin{array}{c}\text { Depth } \\
(\mathrm{cm} \text { BD })\end{array}$ & Taxn日 & $\mathrm{C}$ & Wot (a) & Element & Portinn & $\frac{2}{5}$ & 芦 & 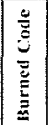 & Butcher & Marks & Notes \\
\hline 1 & $0-10$ & Alligator mississippiensis & 1 & 0.39 & Scuic & Fragnent & & & 0 & & & \\
\hline 1 & $0-10$ & Artiodactyl & 11 & 1.13 & Rib & Frapment & & & 0 & & & \\
\hline 1. & $0-10$ & Aniodactyl & 1 & 2.31 & 1st phalange & All but proximal epiphysis & & $\gamma$ & 0 & & & Unscaled \\
\hline 1 & $0-10$ & Artiodactyl & 1 & 0.71 & Carapace & Complete & & & 0 & & & \\
\hline 1 & $0-10$ & Artiodnciyl & 1 & 3.7 & Astrilapus & Fragmen! & & & 0 & & & \\
\hline 1 & $0-10$ & Aves & 2 & 0.6 & & & & & 0 & & & \\
\hline 1 & $0-10$ & Bos tamerus & 1 & 31.24 & lst phalange & Completc & & & 0 & & & \\
\hline 1 & $0-10$ & Ictalurtus sp. & 1 & 0.31 & Veriebra & Cenurum & & & 0 & & & \\
\hline 1 & $0-10$ & Ictalurtes sp. & 1 & 0.88 & Cranium & Fragment & & & 0 & & & \\
\hline 1 & $0-10$ & Ictalurus sp. & 1 & 0.42 & Cranium & Fragment & & & 0 & & & \\
\hline 1 & $0-10$ & letalurus sp. & 1 & 0.24 & Cranium & Fragmen & & & 0 & & & \\
\hline 1 & $0-10$ & Mammal & 36 & 12.59 & & & & & 0 & & & \\
\hline 1 & $0-10$ & Mammal-very large & 9 & 19.21 & & & & & 0 & & & \\
\hline 1 & $0-10$ & Ostcichihyes & 1 & 0.07 & & & & & 0 & & & \\
\hline 1 & $10-14$ & Artiodactyl & 1 & 10.79 & Radius & Distal 2/3 & & $Y$ & 0 & & & Distal cnd is unsealed, texlure suggests very young \\
\hline 1 & $10-14$ & Avcs & 3 & 0.86 & & & & & 0 & & & \\
\hline 1. & $10-14$ & Bovinae & 1 & 5.45 & Rib & Fragment & & & 1. & 3 & 1 & \\
\hline 1 & $10-14$ & Mammal & 67 & 20.12 & & & & & 0 & & & \\
\hline 1 & $10-14$ & Manmal & 6 & 0.97 & & & & & 2 & & & \\
\hline 1 & $10-14$ & Mammal & 1 & 0.23 & & & & & 0 & & & \\
\hline 1 & $10-14$ & Mammal--large & 1 & 1,17 & & & & & 0 & & & \\
\hline 1 & 10-14 & Mammil--very large & 7 & 15.39 & & & & & 0 & & & \\
\hline 1 & $10-14$ & Ostcichlbyes & 1 & 0.65 & & & & & 0 & & & \\
\hline 1 & $14-20$ & Aplodinotus grumiens. & 1 & 1.45 & Veriebra & Cenirum & & & 0 & & & \\
\hline 1. & $14-20$ & Aplodinotus gnunniens & 1 & 0.43 & Venebra & Frupmeni & & & 0 & & & \\
\hline 1 & $14-20$ & Artiodactyl & 1 & 2.47 & Mandiblc & $\begin{array}{l}\text { Fragment of ascending } \\
\text { ramus and condyle }\end{array}$ & & & 0 & & & \\
\hline 1 & $14-20$ & Artiodaciyl & 1 & 8.13 & Fernur & Dissul end of diaphysis & & $\mathrm{Y}$ & 0 & & & Unsealed epiphysis \\
\hline 1) & $14-20$ & Aves & 12 & 3 & & & & & 0 & & & \\
\hline 1 & $14-20$ & Bos talnas & 1 & 7.57 & Lumbar vertebra & Fragment & & & 0 & & & \\
\hline 1 & $14-20$ & Capra hircus & 1 & 1.3 & 2nd phalange & Completc & & & 0 & & & \\
\hline 1 & $14-20$ & Chelydra sementina & 1 & 0.32 & Humerus & Almost complete & L & & 0 & & & \\
\hline 1 & $14-20$ & Gallus domesticus & 1 & 0.6 & Carapace & All but 3rd metacarp & & & 0 & & & \\
\hline 1 & $14-20$ & Gallus domesticus & 1 & 0.21 & $\begin{array}{l}\text { 1st phalangc } \\
(\text { foot })\end{array}$ & Completc & & & 0 & & & \\
\hline 1 & 1420 & Gallus domesticus & 1 & 0.13 & $\begin{array}{l}\text { 3rd pbalange } \\
\text { (wing) }\end{array}$ & Complete & & & 0 & & & \\
\hline 1 & $14-20$ & Mammal & 104 & 30.79 & & & & & 0 & & & \\
\hline 1 & $14-20$ & Maminal & 3 & 0.31 & & & & & 1 & & & \\
\hline 1 & $14-20$ & Mammal & 4 & 2.49 & & & & & 2 & & & \\
\hline 1 & $14-20$ & Munmal & 9 & 2.45 & & & & & 3 & & & \\
\hline 1 & $14-20$ & Mammal & 3 & 0.83 & & & & & 4 & & & \\
\hline 1 & 14-20 & Mammal-1arge & 2 & 3.39 & & & & & 0 & & & \\
\hline 1 & $14-20$ & Maminal--very large & 6 & 50.28 & & & & & 0 & & & \\
\hline 1 & $14-20$ & Mammal-very large & 2 & 3.37 & & & & & 2 & & & \\
\hline 1 & $14-20$ & Mammal--very large & 1 & 0.68 & & & & & 3 & & & \\
\hline 1 & $14-20$ & Ostcichthyes & 4 & 0.46 & & & & & 0 & & & \\
\hline 1 & $14-20$ & Pylodichus olivaris & 1 & 0.75 & Cleithrum & Anterior $2 / 3$ & & & 0 & & & \\
\hline 1 & $14-20$ & Pylodictus olivaris & 1 & 0.21 & Dentary & Fragment & & & 0 & & & \\
\hline 1 & 1420 & Rodentin & 1) & 0.05 & Scale & Fragment & & & 0 & & & \\
\hline 1 & $14-20$ & Testudines & 3 & 2.51 & & & & & 0 & & & \\
\hline 1 & $14-20$ & Vertebrata & 2 & 1.2 & & & & & 0 & & & \\
\hline 1 & $20-30$ & Aplodinotus grumiens & 1 & 0.37 & Vertebra & Centrum & & & 2 & & & \\
\hline 1 & $20-30$ & Aplodinous granniens & 1 & 0.35 & Caudal fin & Fragment & & & 0 & & & \\
\hline 1 & $20-30$ & Artiodactyl & 1 & 17.95 & Humenus & All but epiphyses & $\mathrm{R}$ & $Y$ & 0 & & & All unsealed \\
\hline 1 & $20-30$ & Artiodnctyl & 1 & 4.49 & Humerus & Part of proximal cpiphysis & $R$ & $Y$ & 0 & & & Unsealed-very young \\
\hline 1 & $20-30$ & Artiodactyl & 1) & 1.73 & Humens & Hend & $\mathrm{R}$ & $Y$ & 0 & & & Unscaled \\
\hline 1 & $20-30$ & Artiodactyl & 1 & 2 & Humerus & Latcral tuberousity & L & $Y$ & 0 & & & Unscaled \\
\hline 1 & $20-30$ & Artiodnelyl & 1 & 1.49 & Femur & Part or head & & $\mathrm{Y}$ & 0 & & & Unsealed \\
\hline 1 & $20-30$ & Artiodaclyl & 1 & 0.34 & Femly & $\begin{array}{l}\text { epiphysis of grealer } \\
\text { trocthanter }\end{array}$ & & $\mathrm{Y}$ & 0 & & & Unscaled \\
\hline 1 & $20-30$ & Artiodactyl & 1 & 1.59 & 1st phalange & All but proximal epiphysis & L & & 0 & & & Unsealed \\
\hline 1 & $20-30$ & Artiodsctyl & 3 & 7.74 & Lumbar vertebra & Ceninum and neural areb & & $\mathrm{Y}$ & 0 & & & Centrum epiphysis present but unsealed \\
\hline 1 & $20-30$ & Artiodactyl & 1 & 3.94 & Innominate & Part of acctabulum & & $\mathrm{Y}$ & 0 & & & Unsealed to other parts of acetabulum \\
\hline 1 & $20-30$ & Artiodaclyl & 1 & 0.82 & Rib & Fragment & & & 0 & & & \\
\hline 1 & $20-30$ & Artiodactyl & 1 & 1.28 & Lumbar vertebru & Fragment & & & 0 & & & \\
\hline 1 & $20-30$ & Artiodactyl & 1 & 1.1 & Caudal vertebra & Almost completc & & & 0 & & & \\
\hline
\end{tabular}




\begin{tabular}{|c|c|c|c|c|c|c|c|c|c|c|c|c|}
\hline \multirow[b]{2}{*}{ Unit. } & \multirow{2}{*}{$\begin{array}{c}\text { Depth } \\
\text { (cm BD) }\end{array}$} & \multirow[b]{2}{*}{ Tuxun } & \multirow[b]{2}{*}{$\mathrm{Cl}$} & \multirow[b]{2}{*}{ Wur. $(u)$} & \multirow[b]{2}{*}{ Elament: } & \multirow[b]{2}{*}{$\therefore$ Portion } & \multirow{2}{*}{ 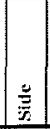 } & \multirow[t]{2}{*}{ 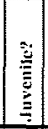 } & $\begin{array}{l}\frac{0}{E} \\
\bar{s} \\
\bar{E} \\
\bar{E}\end{array}$ & Butcher & Marks & \\
\hline & & & & & & & & & & Trne & Cotunt & Nintes \\
\hline 1. & $20-30$ & Artiodacly & 1 & 0.6 & Caudal vericbra & & $\mathrm{L}$ & & 0 & & & \\
\hline 1 & $20-30$ & Aves & 2 & 0.42 & & & & & 0 & & & \\
\hline 1 & $20-30$ & Aves--large & 13 & 5.71 & & & & & 0 & & & \\
\hline 1 & $20-30$ & Aves--very larpe & 1 & 0.59 & & & & & 2 & & & \\
\hline 1 & $20-30$ & Aves--very larpe & 1 & 0.35 & & & & & 1 & & & \\
\hline 1 & $20-30$ & Bovinac & 1 & 14.44 & Patclla & Complete & & $Y$ & 0 & & & Very small and undeveloged \\
\hline 1) & $20-30$ & Bovinue & 1 & 0.89 & 2nd phalange & Proximal cpiphysis & & $\mathrm{Y}$ & 0 & & & Unscaled \\
\hline 1 & $20-30$ & Bovinac & 1 & 59.11 & Scapula & Fragment of glendid fassa & & & 0 & 3 & 1 & \\
\hline 1$]$ & $20-30$ & Bovinac & 1 & 30.11 & Thoracic vertebra & Spineous process & & & 0 & 3 & 2 & \\
\hline 1 & $20-30$ & Bovinac & 1 & 16.95 & Rib & Fragmenı & & & 0 & 3 & 1 & \\
\hline 1 & $20-30$ & Bovinac & 1 & 15.76 & Rib & Fragment & & & 0 & & & \\
\hline 1 & $20-30$ & Gallus domesticus & 1 & 0.49 & Carpometacarpus & All but 3td metacarpal & & & 0 & & & \\
\hline 1. & $20 \cdot 30$ & Gallus domesticus & 2 & 3.6 & Tibiolarius & Almost complete & L & & 0 & & & \\
\hline 1 & $20-30$ & Gallis domesticus & 1 & 1.38 & Tibiotarsus & Distill $1 / 3$ & $R$ & & 0 & & & \\
\hline 1 & $20-30$ & Gallus domesticus & 1 & 1.14 & Radius & Proximal $2 / 3$ & $L$ & & 0 & & & \\
\hline 1 & $20-30$ & Gallus domesticus & 1 & 0.19 & Radius & Distal 1/4 & $\mathrm{L}$ & & 0 & & & \\
\hline 1 & $20-30$ & Gallus domesticus & 1 & 0.38 & Radius & Distal $1 / 4$ & & & 0 & & & \\
\hline 1 & $20-30$ & Gallus domesticus & 1 & 0.39 & Corocoid & Fragment & & & 0 & & & \\
\hline 1 & $20-30$ & Gallis domesticus & 1 & 0.12 & $\begin{array}{l}\text { Ist phalange } \\
\text { (foo:) }\end{array}$ & Complete & & & 0 & & & \\
\hline 1 & $20-30$ & Gallus domesticus & 1 & 0.18 & Cervical vertebra & Almost complete & & & 0 & & & \\
\hline 1 & $20-30$ & Gallus domesticus & 1 & 0.15 & Cervical vertebra & Almost completc & & & 0 & & & \\
\hline 1 & $20-30$ & Gallus domesticus & 1. & 0.95 & Humerus & Complete & & $\mathrm{Y}$ & 0 & & & Smal, undeveloped \\
\hline 1 & $20-30$ & Gallus domesticus & 1 & 1.18 & Tibiolursus & Complete & & $\mathrm{Y}$ & 0 & & & Small undeveloped, distal epiphysis unsealed \\
\hline 1 & $20-30$ & Gallus domestictus & 1 & 0.23 & Tibiotarsus & Distal $1 / 4$ & & $\mathrm{Y}$ & 0 & & & Small, undeveloped, distal cpiphysis unsealed \\
\hline 1 & $20-30$ & Ictalirrus sp. & 1 & 0.89 & Dorsal spine & Frapment & & & 0 & & & \\
\hline 1. & $20-30$ & Mammal & 145 & 80.35 & & & & & 0 & & & \\
\hline 1 & $20-30$ & Mammin & 4. & 1.43 & & & & & 2 & & & \\
\hline 1 & $20-30$ & Mammal & 3 & 1.05 & & & & & 4 & & & \\
\hline 1 & $20-30$ & Mammal--larpe & 11 & 31.47 & & & & & 0 & & & \\
\hline 1 & $20-30$ & Marnmal--medium & 6 & 2.89 & & & & & 0 & & & \\
\hline 1 & $20-30$ & Mammal--very large & 18 & 120.1 & & & & & 0 & & & \\
\hline 1 & $20-30$ & Mammal-very large & 1) & 2.43 & & & & & 3 & & & \\
\hline 1. & $20-30$ & Oslcichthyes & 8 & 1.62 & & & & & 0 & & & \\
\hline 1. & $20-30$ & Ovis aries & 1 & 25.83 & Radius & Dislat $1 / 2$ & & & 0 & 3 & 2 & \\
\hline 1 & $20-30$ & Ovis aries & 1 & 0.9 & 3rd phalange & Complese & & & 0 & & & \\
\hline 1. & $20-30$ & Vcrtebratal & 6 & 1,05 & & & & & 0 & & & \\
\hline 1 & $30-40$ & Artiodactyl & 1 & 1.271 & Molar & Fragmen! & & & 0 & & & \\
\hline 1 & $30-40$ & Artiodaciyl & 1 & 0.84 & Mandible & & & $\mathrm{Y}$ & 0 & & & very young \\
\hline 1. & $30-40$ & Artiodactyl & 1 & 2.5 & $\mathrm{Rib}$ & Fragment & & & 0 & & & \\
\hline 1 & $30-40$ & Aves & 5 & 1.6 & & & & & 0 & & & \\
\hline 1 & $30-40$ & Aves-very large & 1 & 0.55 & & & & & 0 & & & \\
\hline 1 & $30-40$ & Gallus domesticus & 2 & 2.411 & Femur & Almost compleis & $\mathrm{R}$ & & 0 & & & \\
\hline 1 & $30-40$ & Gallus domesticus & 2 & $2.4 \mathrm{~T}$ & Tibiolarsus & Almost complele & $\mathrm{L}$ & & 0 & & & \\
\hline 1 & $30-40$ & Gallus domesticus & 1. & 3.05 & Tibiotarsus & Proximal 2/3 & $\mathrm{R}$ & & 0 & & & \\
\hline 1 & $30-40$ & Mammal & 49 & 17.54 & & & & & 0 & & & \\
\hline 1 & $30-40$ & Mammal--very large & 3 & 25.47 & & & & & 0 & & & \\
\hline 1 & $30-40$ & Meleagris gallopavo & 1 & $16.93 \mathrm{~F}$ & Humenus & Almost completc & & & 0 & & & \\
\hline 1 & $30-40$ & Odocoileus virginianus & 6 & 7.18 & Mandible & Fragment & & $\mathrm{Y}$ & 0 & & & w/ deciduous tecth. 2 molar uncrupled \\
\hline 1 & $30-40$ & Osteichthyes & 1 & 0.21 & & & & & 0 & & & \\
\hline 1 & $40-50$ & Aves & 1 & 0.05 & & & & & 0 & & & \\
\hline 1 & $40-50$ & Bovinae & 1 & 16.52 & Molar & Fragment & & & 0 & & & \\
\hline 1 & 40.50 & Mammul & 15 & 12.02 & & & & & 0 & & & \\
\hline 1 & $40-50$ & Mammal & 2 & 0.76 & & & & & 2 & & & \\
\hline 1. & $50-60$ & Bos falurzLs & 2 & 11.23 & 2nd phalange & Complete & & $\mathrm{Y}$ & 0 & & & Proximal and is unsented \\
\hline 1 & $50-60$ & Bovinae & 1 & 2.5 & $\begin{array}{l}\text { Deciduous } \\
\text { premolar }\end{array}$ & Complete & & $\mathrm{Y}$ & 0 & & & Did not crupt \\
\hline 1 & $50-60$ & Mammal & 23 & 16.12 & & & & & 0 & & & \\
\hline 1 & $50-60$ & Manmal-very large & 3 & 22.57 & & & & & 0 & & & \\
\hline 1 & $60-70$ & Artiodactyl & 1 & 3.82 & Thoracic vertebra & Ceninum and neural arch & & $\mathrm{Y}$ & 0 & 3 & $1 \mathrm{t}$ & Unsealed cenirum \\
\hline 1 & $60-70$ & Artiodactyl & 1 & 1,16 & Rib & Eragment & & & 0 & & & \\
\hline 1 & $60-70$ & Aves & 3 & 0.6 & & & & & 0 & & & \\
\hline 1 & $60-70$ & Bos valuns & 1 & 24.89 & 3rd phalange & Almost complete & & & 0 & & & \\
\hline 1 & $60-70$ & Bos taurus & 1 & 14.39 & 4th carpal & Complele & $\mathrm{R}$ & & 0 & & & \\
\hline 1 & 60.70 & Bovinac & 2 & 3.691 & Incisar & Almosi complese & & & 0 & & & Very little wear \\
\hline 1 & $60-70$ & Bovinae & 1 & 2.61 & Distal scsmoid & Complelc & & & 0 & & & \\
\hline 1 & $60-70$ & Ictalurtes sp. & 1 & 0.96 & Pectoral spine & Fragment of proximnl end & & & 0 & & & \\
\hline
\end{tabular}




\begin{tabular}{|c|c|c|c|c|c|c|c|c|c|c|c|c|}
\hline \multirow[b]{2}{*}{ Unit } & \multirow{2}{*}{$\begin{array}{c}\text { Depth } \\
(\mathrm{cm} B D)\end{array}$} & \multirow[b]{2}{*}{ Taxan. } & \multirow[b]{2}{*}{$\mathrm{Cl}$} & \multirow[b]{2}{*}{ Wat. (n) } & \multirow[b]{2}{*}{ Element } & \multirow[b]{2}{*}{ Partion } & \multirow{2}{*}{ 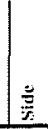 } & 吾 & 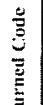 & Butcher & Marks & \\
\hline & & & & & & & & & & Tyne & Count & Nates \\
\hline 1 & $60-70$ & Ictalurus sp. & 1 & 0.49 & Rib & Almost complese & & & 0 & & & \\
\hline 1 & $60-70$ & Ictalurus sp. & 1 & 0.63 & Rib & Almost complete & & & 0 & & & \\
\hline 1 & $60-70$ & Marnmal & 30 & 10.19 & & & & & 0 & & & \\
\hline 1 & $60-70$ & Mannnal-medium & 1 & 0.57 & & & & & 0 & & & \\
\hline 1 & $60-70$ & Mammal--very large & 9 & 51.49 & & & & & 0 & & & \\
\hline 1. & $60-70$ & Ostcichuthyes & 3. & 0.21 & & & & & 0 & & & \\
\hline 1 & $60-70$ & Testudines & 1 & 0.76 & & & & & 0 & & & \\
\hline 1 & $70-80$ & Manmual & 10 & 6.54 & & & & & 0 & & & \\
\hline 1 & $70-80$ & Mammal & 1 & 0.22 & & & & & 3 & & & \\
\hline 1 & $70-80$ & Mammal-very large & 5 & 80.49 & & & & & 0 & & & \\
\hline 1 & $80-90$ & Anas sp. & 1 & 0.35 & Carpometncarpus & Proximal $1 / 2$ & & & 0 & & & \\
\hline 1 & $80-90$ & Anas sp. & 1 & 0.29 & Ula & Distal $1 / 2$ & & & 0 & & & \\
\hline 1 & $80-90$ & Aves & 3 & 0.19 & & & & & 0 & & & \\
\hline 1 & $80-90$ & Aves--large & 1 & 1.34 & & & & & 0 & & & \\
\hline 1 & & Capro hircus & 2 & 4,16 & Ulna & Proxingal 1/2 & $\mathrm{L}$ & & 0 & & & \\
\hline 1 & & Mamnnal & 13 & 2.79 & & & & & 0 & & & \\
\hline 1 & & Mummal & 1 & 0.39 & & & & & 2 & & & \\
\hline 1 & & Mammal--very large & 1 & 5.42 & & & & & 0 & & & \\
\hline 1 & & Osteichthyes & 2 & 0.38 & & & & & 0 & & & \\
\hline 2 & $0-10$ & Aves & 1 & 0.63 & & & & & 0 & & & \\
\hline 2 & $0-10$ & Bovinae & 1 & 24.53 & Metapodial & Fragment of diaphysis & & & 0 & & & \\
\hline 2 & $0-10$ & Gallus domesticus & 1 & 0.28 & Tibiotarsus & Distal $1 / 4$ & & & 0 & & & \\
\hline 2 & $0-10$ & Mammal & 51 & 29.15 & & & & & 0 & & & \\
\hline 2 & $0-10$ & Marninal & 5 & 3.91 & & & & & 2 & & & \\
\hline 2 & $0-10$ & Mamrnal-1arge & 3 & 10.68 & & & & & 0 & & & \\
\hline 2 & $0-10$ & Mamrnal-medium & 3 & 1.27 & & & & & 0 & & & \\
\hline 2 & $0-10$ & Mamunal wowery large & 7 & 53.17 & & & & & 0 & & & \\
\hline 2 & $0-10$ & Ovis aries & 1 & 9 & Radius & Proximal $1 / 4$ & $\mathbf{R}$ & & 0 & 3 & 2 & Does not go withulna bleow \\
\hline 2 & $0-10$ & Ovis aries & 1 & 4.08 & Ulna & Sernilunar notch & $L$ & & 0 & & & chewed on distal end \\
\hline 2 & $0-10$ & Terrepene sp. & 2 & 1.97 & Carapace & Fragment & & & 0 & & & \\
\hline 2 & $10-20$ & Artiodactyl & 1 & 0.97 & Patclla & Almost complcte & & \begin{tabular}{|l|}
$\mathrm{Y}$ \\
\end{tabular} & 0 & & & Size \& lcxlure suggests young \\
\hline 2 & $10-20$ & Ariodactyl & 1 & 0.99 & Patclla & Complete & & $\mathrm{Y}$ & 0 & & & Size \& lexiurc suggests young \\
\hline 2 & $10-20$ & Artiodactyl & 1 & 0.7 & Thoracic vertebra & Spincous process & & $Y$ & 0 & & & \\
\hline 2 & $10-20$ & Artiodactyl & 1 & 1.05 & Thoracic vertebra & $\begin{array}{l}\text { Spincous process \& part of } \\
\text { nerual arch }\end{array}$ & & $Y$ & 0 & & & Noi sealed to centrum \\
\hline 2 & $10-20$ & Artiodactyl & 1 & 0.54 & Thoracic vertebra & Centrum & & $Y$ & 0 & & & Not scaled to neural arch \\
\hline 2 & $10-20$ & Ariodactyl & 1 & 0.19 & Cervical ventebru & Epiphysis of centrum & & $Y$ & 0 & & & Not sealed \\
\hline 2 & $10-20$ & Arliodaclyl & 1 & 2.22 & Scapula & Fragment & & $Y$ & 0 & & & Sirc \& texture suggest young \\
\hline 2 & $10-20$ & Artiodnciyl & 1 & 1.3 & Caudal vertebra & Almost complete & & & 0 & & & \\
\hline 2 & $10-20$ & Artiodactyl & 1 & 1.01 & Femur & Proximal epiphysis & & $\mathrm{Y}$ & 0 & & & Unsealed \\
\hline 2 & $10-20$ & Artiodactyl & 1 & 1.76 & Rib & Fragment & & & 0 & 3 & 1 & 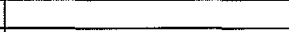 \\
\hline 2 & $10-20$ & Artiodnetyl & 1 & 0.55 & Rib & Fragment & & & 0 & & & \\
\hline 2 & $10-20$ & Ariodnctyl & 1 & 0.58 & Rib & Fragment & & & 0 & 3 & 1 & \\
\hline 2 & $10-20$ & Artiodactyl & 1 & 0.61 & Rib & Fragment & & & 0 & 3 & 2 & \\
\hline 2 & $10-20$ & Artiodactyl & 1 & 1.22 & Rib & Fragment & & & 0 & & & \\
\hline 2 & $10-20$ & Ariodactyl & 1 & 0.82 & Rib & Fragment & & & 0 & 3 & 1 & \\
\hline 2 & $10-20$ & Artiodactyl & 1 & 0.63 & Rib & Fragment & & & 0 & & & \\
\hline 2 & $10-20$ & Artiodactyl & 1 & 1.21 & Rib & Fragmeni & & & 0 & & & \\
\hline 2 & $10-20$ & Artiodactyl & 1) & 0.42 & Rib & Fragmenl & & & 0 & & & \\
\hline 2 & $10-20$ & Ariodactyl & 1) & 0.43 & Rib & Fragment & & & 0 & & & \\
\hline 2 & $10-20$ & Ariodaclyl & 1 & 0.45 & Rib & Fragment & & & 0 & 3 & 1 & \\
\hline 2 & $10-20$ & Ariodactyl & 1 & 0.29 & Rib & Fragment & & & 0 & 3 & 1 & 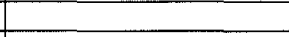 \\
\hline 2 & $10-20$ & Artiodactyl & 1 & 1.87 & Rib & Fragment & & & 0 & 3 & 1 & 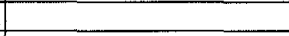 \\
\hline 2 & $10-20$ & Ariodactyl & 1 & 0.26 & 1si phalange & Fragment & & & 2 & & & \\
\hline 2 & $10-20$ & Bos taurus & 1 & 12.25 & $2+3$ carpal & Complete & $R$ & & 0 & & & \\
\hline 2 & $10-20$ & Bovinac & 1 & 20.03 & Astralagus & Almost completc & & $\mathrm{Y}$ & 0 & & & Very small \& undeveloped \\
\hline 2 & $10-20$ & Gallus domesticus & 1 & 3.25 & Tibiolarsus & Proximal 3/4 & & & 0 & & & \\
\hline 2 & $10-20$ & Gallus domesticus & 1 & 0.12 & Fibuli & Proximal 1/4 & & & 0 & & & \\
\hline 2 & $10-20$ & Gallus domesticus & 1 & 0.34 & Cervical vertebra & Almost completc & & & 0 & & & \\
\hline 2 & $10-20$ & Icjaiurus sp. & 1 & 0.44 & Vertebra & Centrum & & & 0 & & & \\
\hline 2 & $10-20$ & Maminal & 45 & 16.16 & & & & & 0 & & & \\
\hline 2 & $10-20$ & Mammal & 3 & 1.43 & & & & & 3 & & & \\
\hline 2 & $10-20$ & Mammal--large & 1 & 12.75 & & & & & 0 & & & \\
\hline 2 & $10-20$ & Mammal--very large & 9 & 35.22 & & & & & 0 & & & \\
\hline 2 & $10-20$ & Mammal--very large & 2 & 5.99 & & & & & 2 & & & \\
\hline 2 & $10-20$ & Meleagris gallopavo & 1 & 5.24 & Tibiotarsus & Proximal 1/2 & $\mathrm{L}$ & & 0 & & & \\
\hline 2 & $10-20$ & Meleagris gallopavo & 3 & 0.77 & Ossified tendons & Fragment & & & 0 & & & \\
\hline 2 & $10-20$ & Meleagris gallopavo & 1 & 0.46 & Fibula & Proximal $1 / 2$ & & & 0 & & & \\
\hline
\end{tabular}




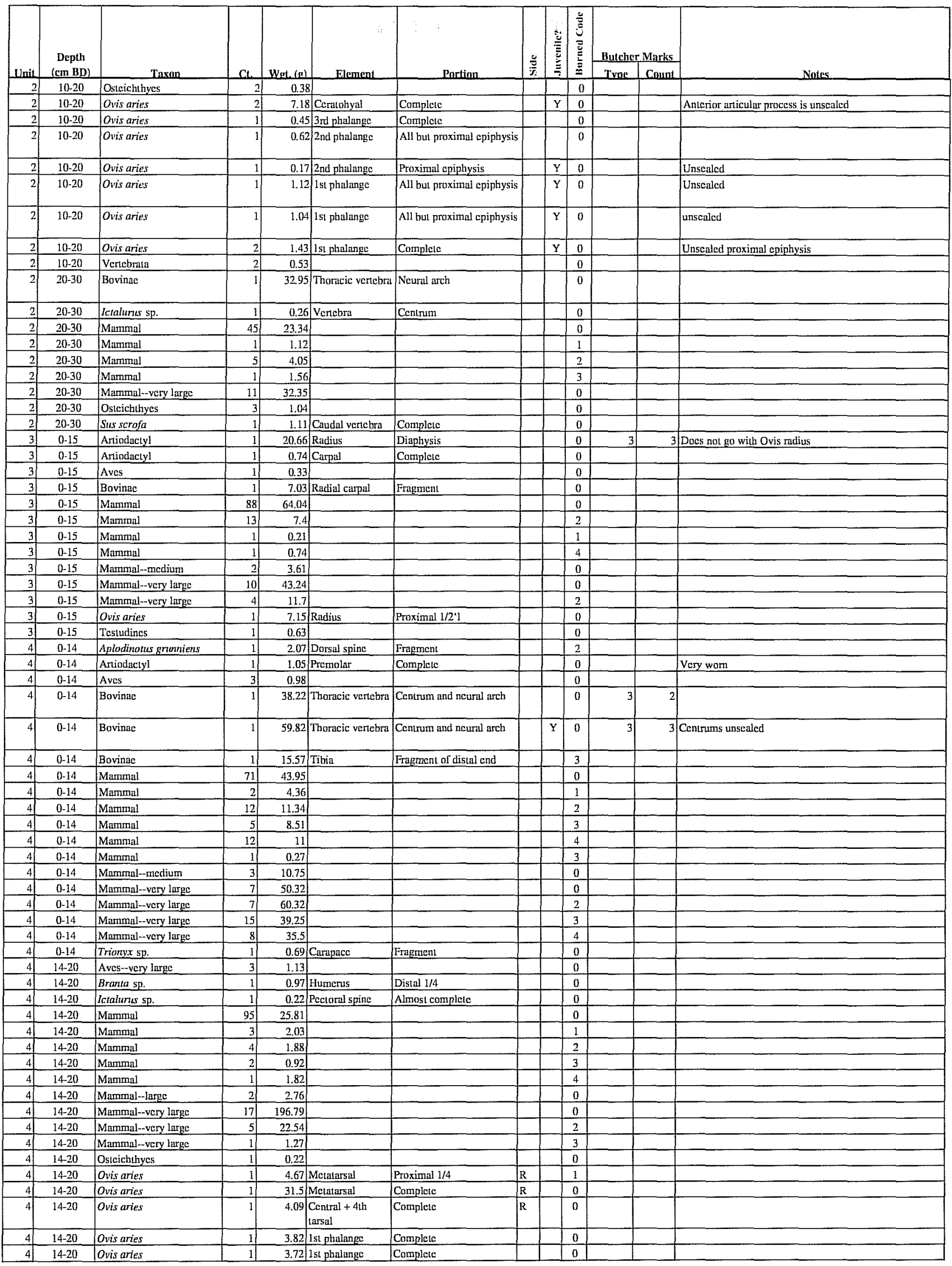




\begin{tabular}{|c|c|c|c|c|c|c|c|c|c|c|c|c|}
\hline \multirow[b]{2}{*}{ Unit } & \multirow{2}{*}{$\begin{array}{c}\text { Depth } \\
\text { (cm BD) }\end{array}$} & \multirow[b]{2}{*}{ Taxon } & \multirow[b]{2}{*}{ C. } & \multirow[b]{2}{*}{$w_{\text {of }}(g)$} & \multirow[b]{2}{*}{ ElemenL } & \multirow[b]{2}{*}{ Partion } & $\cong$ & 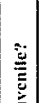 & 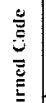 & Butcher & Marks & \\
\hline & & & & & & & $\bar{z}$ & & & Trne & Conme & Notes \\
\hline 4 & $14-20$ & Ovis aries & 1 & 1.76 & 2nd phalenge & Compleic & & & 0 & & & \\
\hline 4. & 1420 & Ovis aries & 1 & 1.43 & 3rd phalange & Complese & & & 0 & & & \\
\hline 4 & $14-20$ & Ovis aries & 1 & 0.26 & Sesmoid & & & & 0 & & & \\
\hline 4 & 14-20 & Vertebrait & 1 & 0.1 & & & & & 0 & & & \\
\hline 5 & $0-16$ & Artiodaclyl & 2 & 14.34 & Radius & Diaphysis & & & 0 & 3 & 1 & \\
\hline 5 & $0-16$ & Aves & 1 & 1.22 & & & & & 0 & & & \\
\hline 5 & $0-16$ & Bos tuunus & 2 & 102.45 & Rib & All bul proximal end & & & 0 & 3 & 1 & \\
\hline 5 & 0.16 & Bovinac & 1 & 16.59 & Rib & Fragment & & & 0 & & & \\
\hline 5 & $0-16$ & Bovinac & 1 & 10.04 & 15t phalange & Diaphysis & & $\mathrm{Y}$ & 0 & & & Both ends unsealed \\
\hline 5 & $0-16$ & Gallus domestictus & 1. & 1.28 & Scapula & Proximal 1/2 & & & 0 & & & \\
\hline 5 & $0-16$ & Gallus domesticus & 1 & 0.98 & $\begin{array}{l}1 \text { st phalinge } \\
\text { (foot) }\end{array}$ & Complete & & & 0 & & & \\
\hline 5 & $0-16$ & Manmal & 52 & 19.22 & & & & & 0 & & & \\
\hline 5 & $0-16$ & Mammal & 2 & 1.82 & & & & & 3 & & & \\
\hline 5 & $0-16$ & Maminal--very large & 22 & 105.02 & & & & & 0 & & & \\
\hline 5 & $0-16$ & Mammal--very large & 2 & 3.85 & & & & & 2 & & & \\
\hline 5 & $0-16$ & Microptertis sp. & 1 & 0.47 & Premaxillary & All but dorsal end & & & 0 & & & \\
\hline 5 & $0-16$ & Vertcbrala & 1 & 0.89 & & & & & 0 & & & \\
\hline 6 & $0-15$ & Aves & 1 & 0.98 & & & & & 0 & & & \\
\hline 6 & $0-15$ & Gallus domesticus & 1 & 2.26 & Humerus & Complete & & & 0 & & & \\
\hline 6 & $0-15$ & Gallus domesticus & 1 & 0.77 & Ulna & Distal $1 / 2$ & & & 0 & & & \\
\hline 6 & 0.15 & Gallus domesticus & 1 & 0.84 & Radius & Distal $1 / 2$ & & & 0 & & & \\
\hline 6 & $0-15$ & Mammal & \begin{tabular}{l|l}
52 & \\
\end{tabular} & 38.16 & & & & & 0 & & & \\
\hline 6 & $0-15$ & Mammal & 2 & 2.27 & & & & & 2 & & & \\
\hline 6 & $0-15$ & Mammal-medium & 3 & 4.27 & & & & & 0 & & & \\
\hline 6 & $0-15$ & Mammal--very large & 14 & 51.91 & & & & & 0 & & & \\
\hline 6 & $0-15$ & Mammal--very large & 1 & 3.34 & & & & & 2 & & & \\
\hline 6 & $0-15$ & Pseudomys 5p. & 1 & 2.62 & Carapace & Fragment & & & 0 & & & \\
\hline 6 & $0-15$ & Pylodictus olivaris & 1 & 0.97 & Dentary & Antcrior $1 / 2$ & & & 0 & & & \\
\hline 6 & $0-15$ & Tesutudines & 1 & 0.29 & & & & & 0 & & & \\
\hline 7 & $0-10$ & Artiodacty] & 1 & 5.57 & Molar & Fragment & & & 0 & & & \\
\hline 7 & $0-10$ & Artiodactyl & 1 & 0.71 & Incisor & Completc & & & 0 & & & \\
\hline 7 & $0-10$ & Bos laurus & 1 & 4.81 & Lateral malcolus & Aimost completc & & & 0 & & & \\
\hline 7 & $0-10$ & Didelphis virginiana & 1 & 2.15 & Cervical vertebra & Almost completc & & $Y$ & 1 & & & Unsealed centrums \\
\hline 7 & $0-10$ & Mammal & 48 & 24.51 & & & & & 0 & & & \\
\hline 7 & $0-10$ & Mammal & 1 & 0.45 & & & & & 1 & & & \\
\hline 7. & $0-10$ & Mammal & 3 & 2.25 & & & & & 2 & & & \\
\hline 7 & $0-10$ & Mammal--very largc & 2 & 15.46 & & & & & 0 & & & \\
\hline 7 & $0-10$ & Vertebrata & 1. & 0.14 & & & & & 0 & & & \\
\hline 7 & $10-20$ & Bovinae & I & 5.72 & Calcaneus & Distal epiphysis & & $Y$ & 0 & & & Unsealed \\
\hline 7 & $10-20$ & Gallus domesticus & 1. & 0.86 & Radius & Distal 1/3 & & & 0 & & & \\
\hline 7. & 10.20 & Mammal & 170 & 71.8 & & & & & 0 & & & \\
\hline 7 & $10-20$ & Mammal & $\mathrm{I}$ & 0.42 & & & & & 2 & & & \\
\hline 7 & $10-20$ & Mammal-nlarge & 1 & 2.29 & & & & & 0 & & & \\
\hline 7. & $10-20$ & Mammal--very large & 1 & 3.08 & & & & & 1 & & & \\
\hline 7. & $10-20$ & Mammal-very large & 9 & 123.72 & & & & & 0 & & & \\
\hline 7 & $10-20$ & Ostcicithyes & 1 & 0.09 & & & & & 0 & & & \\
\hline 7 & $10-20$ & Ostcichthyes & 1 & 0.09 & & & & & 0 & & & \\
\hline 7 & $20-30$ & Mammal & 1 & 0.18 & & & & & 0 & & & \\
\hline 7 & $30-40$ & Mammal & 19 & 10.44 & & & & & 0 & & & \\
\hline 7 & $30-40$ & Mammal--very large & 2 & 17.71 & & & & & 0 & & & \\
\hline 7 & $30-40$ & Ostcichthyes & 1 & 0.04 & & & & & 0 & & & \\
\hline 7 & $40-50$ & Mammal & 2 & 0.23 & & & & & 0 & & & \\
\hline 7 & $50-60$ & Mammal & 1 & 0.11 & & & & & 0 & & & \\
\hline 7 & $50-60$ & Mammal & 1 & 0.52 & & & & & 2 & & & \\
\hline 8 & $0-10$ & Aplodinotus grumniens & 1 & 0.16 & Operculum & Fragment & & & 0 & & & \\
\hline 8 & $0-10$ & Aves & 1 & 0.36 & & & & & 0 & & & \\
\hline 8 & $0-10$ & Bos taurus & I. & 151.74 & Metatarsal & Proximal $1 / 2$ & $R$ & & 0 & 7 & 1 & \\
\hline 8 & $0-10$ & Bos taunus & 1 & 83.47 & Lumbar vertebra & $\begin{array}{l}\text { Part of centrim \& neural } \\
\text { arch }\end{array}$ & & & 0 & 3 & 3 & \\
\hline 8 & 0.10 & Bovinac & 1 & 27.42 & Hom core & Fragment & & & 0 & & & \\
\hline 8 & $0-10$ & Bovinne & 1 & 3.42 & 2nd phalange & Fragment & & & 0 & & & \\
\hline 8 & $0-10$ & Bovinac & 1 & 21.38 & Tibia & Disial epiphysis & & $\mathrm{Y}$ & 0 & & & Unsealed \\
\hline 8 & $0-10$ & Gallus domesticus & 1 & 3.61 & Tibiotarsus & Poxoximal $1 / 2$ & & & 0 & & & \\
\hline 8 & $0-10$ & Mammal & 143 & 67.8 & & & & & 0 & & & \\
\hline 8 & $0-10$ & Mammal & 19 & 9.45 & & & & & 2 & & & \\
\hline 8 & $0-10$ & Mammnl & 8 & 7.13 & & & & & 3 & & & \\
\hline 8 & $0-10$ & Mammal & 5 & 4.27 & & & & & 4 & & & \\
\hline 8 & $0-10$ & Mammal-large & 3 & 16.19 & & & & & 0 & & & \\
\hline 8 & $0-10$ & Murnmal-very large & 20 & 112.17 & & & & & 0 & & & \\
\hline 8 & $0-10$ & Mammal--very large & 6 & 15.92 & & & & & 2 & & & \\
\hline 8 & $0-10$ & Mammal-very large & 2 & 8.61 & & & & & 3 & & & \\
\hline
\end{tabular}




\begin{tabular}{|c|c|c|c|c|c|c|c|c|c|c|c|c|}
\hline \multirow[b]{2}{*}{ Init } & \multirow{2}{*}{$\begin{array}{c}\text { Depth } \\
\text { (cm BD) }\end{array}$} & \multirow[b]{2}{*}{ Taxon } & \multirow[b]{2}{*}{$\mathrm{Ch}$} & \multirow[b]{2}{*}{ Wat. (a) } & \multirow[b]{2}{*}{ Element } & & 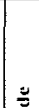 & $\stackrel{3}{\bar{z}}$ & 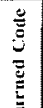 & Butcher & Marks & \\
\hline & & & & & & Portinn & $\overrightarrow{0}$ & & & Trne & Count & Notes \\
\hline 8 & $0-10$ & Osicichthyes & 1 & 0.33 & & & & & 0 & & & \\
\hline 8 & $10-20$ & Mammal & 10 & 4.81 & & & & & 0 & & & \\
\hline 8 & $10-20$ & Mammil & 3 & 0.72 & & & & & 2 & & & \\
\hline 8 & $10-20$ & Marnmal-large & 2 & 9.39 & & & & & 0 & & & Monar adhering to bone \\
\hline 8 & $10-20$ & Mammal--medium & 1 & 0.29 & & & & & 0 & & & \\
\hline 8 & $10-20$ & Mammanl--very large & 1 & 11.58 & & & & & 0 & & & \\
\hline 9 & $0-10$ & Aves & 2 & 0.71 & & & & & 0 & & & \\
\hline 9 & $0-10$ & Bovinac & 1 & 23.67 & Ulna & Fragment & & & 0 & 3 & 1 & 1 \\
\hline 9 & $0-10$ & Capra hircus & 1. & 2.02 & 2nd phalange & Complete & & & 0 & & & \\
\hline 9 & $0-10$ & Equas sp. & 2 & 7.59 & Femur & & & & 0 & 3 & 2 & 2 \\
\hline 9 & $0-10$ & Equas sp. & 1 & 2.85 & Fenus & & & & 0 & 3 & 1 & \\
\hline 9 & $0-10$ & Equiss sp. & 1 & 4.85 & Femur & & & & 0 & & & \\
\hline 9 & $0-10$ & Gallus domesticus & 2 & 0.39 & Radius & Distal $1 / 2$ & & & 0 & & & \\
\hline 9 & $0-10$ & Ictalurus sp. & 1 & 0.23 & Ceratohyal & Almost complete & & & 0 & & & \\
\hline 9 & $0-10$ & Ictalmons sp. & 1 & 0.13 & Ceralobyal & Almost completc & & & 0 & & & \\
\hline 9 & $0-10$ & Mammal & 1 & 3.9 & & & & & 2 & & & \\
\hline 9 & $0-10$ & Marmmal & 5 & 3.58 & & & & & 3 & & & \\
\hline 9 & $0-10$ & Mammal & 2 & 2.09 & & & & & 4 & & & \\
\hline 9) & $0-10$ & Mammal & 69 & 39.15 & & & & & 0 & & & \\
\hline 9 & $0-10$ & Mamrnal--large & 2) & 3.33 & & & & & 0 & & & \\
\hline 9 & 0.10 & Mammal-very large & 24 & 108.33 & & & & & 0 & & & \\
\hline 10 & $0-19$ & Marnmal & 33 & 16.93 & & & & & 0 & & & \\
\hline 10 & $0-19$ & Marnmal & 1 & 0.57 & & & & & 4 & & & \\
\hline 10 & $0-19$ & Mammal--large & 1 & 2.72 & & & & & 0 & & & \\
\hline 10 & $0-19$ & Mummal--very large & 3 & 6.02 & & & & & 0 & & & \\
\hline 11 & $0-10$ & Mammnt--large & 2 & 6.61 & & & & & 0 & & & \\
\hline 12 & $0-20$ & Aves & 2 & 0.64 & & & & & 0 & & & \\
\hline 12 & $0-20$ & Mammal & 9 & 9.05 & & & & & 0 & & & \\
\hline 13 & $0-10$ & Alligator mississippiensis & 1 & 0.41 & Scutc & Fragment & & & 0 & & & \\
\hline 13 & $0-10$ & Mannmal & 5 & 1.96 & & & & & 0 & & & \\
\hline 13 & $10-20$ & Mammal & 3 & 5.07 & & & & & 0 & & & \\
\hline 13 & 20-33 & Equas caballos & 1 & 74.63 & 1si phalange & Complete & & & 0 & 2 & 3 & \\
\hline 13 & $20-33$ & Mammal & 1 & 4.25 & & & & & 2 & & & \\
\hline 13 & $20-33$ & Mannal & 19 & 11.6 & & & & & 0 & & & \\
\hline 13 & $20-33$ & Maminal--small & 2 & 0.6 & & & & & 0 & & & \\
\hline 13 & $20-33$ & Mantmal--very large & 1) & 3.64 & & & & & 0 & & & \\
\hline 13 & $20-33$ & Sylvilagus sp. & 1 & 0.32 & Femur & Distal epiphysis & & $Y$ & 0 & & & Unscalcd \\
\hline 15 & $0-28$ & Mammal & 2 & 1.2 & & & & & 0 & & & \\
\hline 16 & $0-17$ & Mammal & 3 & 0.64 & & & & & 3 & & & \\
\hline 16 & $0-17$ & Mammal & 1 & 0.75 & & & & & 4 & & & \\
\hline 16 & $17-36$ & Mammal & 4 & 2.52 & & & & & 0 & & & \\
\hline 17 & $0-29$ & Manimal & 1 & 1.72 & & & & & 0 & & & \\
\hline 18 & $0-30$ & Aves & 1 & 0.37 & & & & & 0 & & & \\
\hline 18. & $0-30$ & Mammal & 4 & 1.79 & & & & & 0 & & & \\
\hline 18 & 0.30 & Mammnl & 1 & 0.17 & & & & & 2 & & & \\
\hline 18 & $0-30$ & Mammal-very large & 2 & 9.11 & & & & & 0 & & & \\
\hline 19 & $26-66$ & Mammal & 9 & 2.68 & & & & & 0 & & & \\
\hline 19 & $26-66$ & Mammal & 1 & 0.33 & & & & & 2 & & & \\
\hline 20 & $50-60$ & Mammal & 1 & 0.36 & & & & & 0 & & & \\
\hline 20 & $50-60$ & Manmal-very large & 1 & 1.77 & & & & & 0 & & & \\
\hline 21 & $20-30$ & Mammal & 2 & 1.47 & & & & & 0 & & & \\
\hline 21 & $30-40$ & Mammal & 1 & 0.22 & & & & & 0 & & & \\
\hline 22 & $0-10$ & Mammal & 1 & 2.1 & & & & & 0 & & & \\
\hline 22 & $10-26$ & Mnmmal & 1 & 0.34 & & & & & 2 & & & \\
\hline 23. & $0-10$ & Mammal & 1 & 0.57 & & & & & 0 & & & \\
\hline 25 & $0-10$ & Ovis aries & 1 & 2.07 & 2nd phalange & Complete & & & 0 & & & \\
\hline 25 & $10-20$ & Canis sp. & 1 & 3.91 & Mclapodial & All but distal end & & & 0 & & & Le. dog or wolf, heavily pitıed \\
\hline 25 & $10-20$ & Canis sp. & 1 & 3.66 & Melapodial & All but distal end & & & 0 & & & Lg. dog or woll, beavily pilled \\
\hline 25 & $10-20$ & Canis sp. & 1 & 2.9 & Metapodial & Diaphysis & & & 0 & & & Lg. dog or wolf, heavily pitted \\
\hline 25 & $10-20$ & Canis sp. & 1 & 3.29 & Metupodial & Completc & & & 0 & & & Le. dog or woll, heavily pitted \\
\hline 25 & $10-20$ & Marmmal & 17 & 1.98 & & & & & 0 & & & \\
\hline 25 & $10-20$ & Mammal & 1 & 0.57 & & & & & 3 & & & \\
\hline 26 & $0-6$ & Mammal & 1 & 0.88 & & & & & 0 & & & \\
\hline 26 & $0-6$ & Mammal & 1 & 0.79 & & & & & 2 & & & \\
\hline 25 & $0-6$ & Rodentia & 1 & 0.27 & Mandible & Fragment & & & 0 & & & \\
\hline 26 & $0-6$ & Sylvilagus sp. & 1 & 0.93 & Innominalc & All but pubis & & & 0 & & & \\
\hline 26 & 6-16 & Ariodactyl & 1 & 11.49 & Metatarsal & Fragment of diaphysis & & & 0 & & & \\
\hline 26 & 6-16 & Ictalurus sp. & 1 & 0.66 & Vcrtebra & Centrum & & & 0 & & & \\
\hline 26 & 6-16 & Mammal & 15 & 10.84 & & & & & 0 & & & \\
\hline 27 & $0-10$ & Manmal & 6 & 3.59 & & & & & 0 & & & \\
\hline 27 & $10-20$ & Artiodactyl & 1 & 1.12 & $\begin{array}{l}\text { Deciduous } \\
\text { premolar }\end{array}$ & Complete & & $\mathrm{Y}$ & 0 & & & \\
\hline 27 & 10-20 & Mammal & 6 & 1.53 & & & & & 0 & & & \\
\hline
\end{tabular}




\begin{tabular}{|c|c|c|c|c|c|c|c|c|c|c|c|c|}
\hline \multirow[b]{2}{*}{ Unit } & \multirow{2}{*}{$\begin{array}{c}\text { Depth } \\
\text { (cm BD) }\end{array}$} & \multirow[b]{2}{*}{ Taxan } & \multirow[b]{2}{*}{$\mathrm{Cl}$} & \multirow[b]{2}{*}{$W_{\text {gl. }(a)}$} & \multirow[b]{2}{*}{ Elament } & \multirow[b]{2}{*}{ Partinn } & $\doteq$ & 苍 & 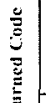 & Butcher & Marks & \\
\hline & & & & & & & 2 & $\Xi$ & $\underline{\Xi}$ & Trne & Count & Notas \\
\hline 27 & $20-30$ & Mamrnal & 1 & 0.31 & & & & & 0 & & & \\
\hline 27. & $20-30$ & Mannmal-very large & 1 & 3.2 & & & & & 0 & & & \\
\hline 27 & $20-30$ & Ostcichthyes & 2 & 0.57 & & & & & 0 & & & \\
\hline 28 & $0-10$ & Aves & 7 & 1.18 & & & & & 0 & & & \\
\hline 28 & 0.10 & Bovinac & 1 & 5.2 & $2+3$ carpal & Fragment & & & 0 & & & \\
\hline 28 & $0-10$ & Manmal & 68 & 23.47 & & & & & 0 & & & \\
\hline 28 & 0.10 & Manmal & 2 & 0.84 & & & & & 2 & & & \\
\hline 28 & $0-10$ & Mammal--very large & 10 & 49.05 & & & & & 0 & & & \\
\hline 28 & $0-19$ & Sylvilagus sp. & 1 & 0.12 & Metatpodinl & Complatc & & & 0 & & & \\
\hline 29 & 0.54 & Mammal & 9 & 1.43 & & & & & 0 & & & \\
\hline 30 & $0-36$ & Mammal & 19 & 9.13 & & & & & 0 & & & \\
\hline 30 & $0-36$ & Munnual--large & 1 & 3.8 & & & & & 0 & & & \\
\hline 30 & $0-36$ & Mammal-very large & 7 & 18.75 & & & & & 0 & & & \\
\hline 31 & $28-36$ & Mammal & 3 & 0.36 & & & & & 0 & & & \\
\hline 33 & $0-18$ & Mammal & 2 & 0.93 & & & & & 0 & & & \\
\hline 34 & $0-30$ & Aves & 2 & 1.53 & & & & & 0 & & & \\
\hline 34 & 0.30 & Mammal & 10 & 3.49 & & & & & 0 & & & \\
\hline 34 & $0-30$ & Mammal-very large & 1 & 2.1 & & & & & 0 & & & \\
\hline 35 & $0-10$ & Marmmal & 3. & 1.37 & & & & & 0 & & & \\
\hline 36 & 0.28 & Marmmal & 1 & 0.53 & & & & & 0 & & & \\
\hline 37 & $0-10$ & Mammal & 1 & 0.64 & & & & & 0 & & & \\
\hline 41 & $0-30$ & Mamıal & 2 & 0.23 & & & & & 0 & & & \\
\hline 41 & $0-30$ & Mammal--very large & 2 & 13.02 & & & & & 0 & & & \\
\hline 41 & $0-30$ & Ventebrata & 4 & 2.59 & & & & & 0 & & & \\
\hline 44 & $0-23$ & Mammal-very large & 2 & 23.15 & & & & & 0 & & & \\
\hline 46 & $0-30$ & Aves--iarge & 1 & 0.4 & & & & & 0 & & & \\
\hline 46 & $0-30$ & Marnmal & 1 & 1.85 & & & & & 0 & & & \\
\hline 46 & $30-40$ & Bos taurus & 1 & 28.19 & 2nd phalange & Complelc & & & 0 & & & \\
\hline 46 & $30-40$ & Mammal & 1 & 0.07 & & & & & 0 & & & \\
\hline 47 & $0-20$ & Aplodinotus grunniens & 1 & 0.37 & Vencbra & Centrim & & & 0 & & & \\
\hline 47 & $0-20$ & Aves & 1 & 0.14 & & & & & 0 & & & \\
\hline 47 & $0-20$ & Mammal & 26 & 13.12 & & & & & 0 & & & \\
\hline 47. & 0.20 & Mammal--large & 2 & 5.7 & & & & & 0 & & & \\
\hline 47. & $0-20$ & Manmal--large & 1) & 4.5 & & & & & 1 & & & \\
\hline 47 & $0-20$ & Mammal-wvery large & 6 & 25.03 & & & & & 0 & & & \\
\hline 48 & $0-48$ & Aves & 1 & 0.45 & & & & & 0 & & & \\
\hline 48 & $0-48$ & Mammal & 14 & 7.37 & & & & & 0 & & & \\
\hline 48 & $0-48$ & Mamnal--large & 2 & 7.21 & & & & & 0 & & & \\
\hline 48 & $0-48$ & Marnmal--very large & 2 & 5.33 & & & & & 0 & & & \\
\hline 48 & 45.60 & Ariodactyl & 1 & 3.39 & $\mathrm{Rib}$ & Fragment & & & 1 & 3 & 4 & \\
\hline 48 & $45-60$ & Aves--large & 1 & 1.65 & & & & & 0 & & & \\
\hline 48 & $45-60$ & Marnmal & 18 & 13.85 & & & & & 0 & & & \\
\hline 48 & $45-60$ & Marmmal & 1 & 0.48 & & & & & 3 & & & \\
\hline 48 & $45-60$ & Mammul--very large & 5. & 24.25 & & & & & 0 & & & \\
\hline 48 & $45-60$ & Testudines & 1 & 0.16 & & & & & 0 & & & \\
\hline 49 & $0-36$ & Mammal & 26 & 12.95 & & & & & 0 & & & \\
\hline 49 & $0-36$ & Mannal--very large & 7 & 21.85 & & & & & 0 & & & \\
\hline 50 & $0-4$ & Mammal & 2 & 2.08 & & & & & 0 & & & \\
\hline 50 & $4-7.5$ & Mammal & 12 & 6.55 & & & & & 0 & & & \\
\hline 51 & $0-30$ & Artiodnciyl & 1 & 6.79 & Lumbar vertebra & Fragment & & & 0 & & & \\
\hline 51 & $0-30$ & Attiodnctyl & 1 & $5.5 . \mathrm{t}$ & Ulna & $\begin{array}{l}\text { Fragment of semi-lunar } \\
\text { notch }\end{array}$ & & & 0 & & & \\
\hline 51 & 0.30 & Lampropelis sp. & 1 & 0.63 & & & & & 0 & & & \\
\hline 51 & $0-30$ & Manmal & 11 & 4.42 & & & & & 0 & & & \\
\hline 51 & $0-30$ & Mammal--large & 2 & 6 & & & & & 0 & & & \\
\hline 51 & $0-30$ & Mammal--very large & 2 & 6 & & & & & 0 & & & \\
\hline 51 & $30-40$ & Marnmal & 2 & 3.62 & & & & & 0 & & & \\
\hline 52 & $0-15$ & Marnmal & 8 & 3.73 & & & & & 0 & & & \\
\hline 53 & $0-22$ & Bos taunis & 1 & 25.542 & $2+3$ carpal & Complete & & & 0 & & & \\
\hline 53 & $0-22$ & Didelphis virginiana & 1 & 4.97 & Maxilla & Left ball & & & 0 & & & $\begin{array}{l}\text { w/ all but } 2 \text { teeth. Carine is } 2 \text { normal size while other teeth } \\
\text { are nomil. Gives maxilla a "sabernooth" look. }\end{array}$ \\
\hline 53 & $0-22$ & Didelphis virginiana & 1 & 6.99 & Mandible & Almost complele & $\mathrm{L}$ & & 0 & & & No leeth \\
\hline 53 & 0.22 & Gallus domesticus & 1 & 0.8 & Corocoid & Almost complete & $\mathrm{R}$ & & 0 & & & \\
\hline 53 & $0-22$ & Lampropeltis sp. & 1 & 0.11 & Vertebra & Complect & & & 0 & & & \\
\hline 53 & $0-22$ & Lampropeltis sp. & 1 & 0.19 & Vertebra & Almost completc & & & 0 & & & \\
\hline 53 & $0-22$ & Mammal & 19 & 18.14 & & & & & 0 & & & \\
\hline 53 & 0.22 & Mammal-medium & 1 & 0.44 & & & & & 0 & & & \\
\hline 53 & $0-22$ & Neotonta sp. & 1 & 0.41 I & Innominale & All bul pubis & $R$ & & 0 & & & \\
\hline 53 & $0-22$ & Neotonia sp. & 1 & 0.73 & Femu & All but distal cpiphysis & $\mathrm{R}$ & $Y$ & 0 & & & Unscaled \\
\hline 53 & $0-22$ & Rodentia & 1 & 0.3 & Maxilla & Fragıent & & & 0 & & & \\
\hline 53 & $0-22$ & Rodentia & 1 & 0.15 & Cranium & Fragment & & & 0 & & & \\
\hline 53 & 0.22 & Sylvilagus sp. & 11 & \begin{tabular}{ll|l}
2.33 & $\mathrm{~F}$ \\
\end{tabular} & Femur & Complete & $\mathrm{R}$ & & 0 & & & \\
\hline
\end{tabular}




\begin{tabular}{|c|c|c|c|c|c|c|c|c|c|c|c|}
\hline \multirow[b]{2}{*}{ Inii } & \multirow{2}{*}{$\begin{array}{c}\text { Depth } \\
\text { (cm BD) }\end{array}$} & \multirow[b]{2}{*}{ Taxan } & \multirow[b]{2}{*}{$\mathrm{Cl}$. } & \multirow[b]{2}{*}{$w a f$ (a) } & \multirow[b]{2}{*}{ Eloment } & \multirow[b]{2}{*}{ Partion } & \multirow{2}{*}{ 䓂 } & \multirow{2}{*}{ 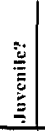 } & Butcher & Marks & \\
\hline & & & & & & & & & Troe & Count & Nintes. \\
\hline 53 & 0.22 & Sylvilagiss sp. & 1 & 2.54 & Tibia & All bus finula & $L$ & 0 & & & \\
\hline 53 & $0-22$ & Sylvilagus sp. & 1 & 0.82 & Tibia & Distal 1/2 & $R$ & 0 & & & \\
\hline 53 & $0-22$ & Sylvilagus sp. & 1 & 0.62 & Lumbar vertebra & Complete & & 0 & & & \\
\hline 53 & $0-22$ & Sylvilagiss sp. & 1 & 1.11 & Humerus & Complece & $\mathrm{L}$ & 0 & & & \\
\hline 53 & $0-22$ & Sylvilagus sp. & 1 & 0.44 & Calcancus & Complete & L. & 0 & & & \\
\hline 53 & $0-22$ & Sylvilagus sp. & 1 & 1.44 & Innominate & Almosit complete & $\mathrm{L}$ & 0 & & & \\
\hline 53 & $0-22$ & Sylvilagitus sp. & 1 & 0.8 & Maxilla & Fragenen1 & & 0 & & & w/ 1 check tooth \\
\hline 53 & $0-22$ & Veriebrala & 1 & 1.02 & & & & 0 & & & \\
\hline 53. & $22-30$ & Bovinac & 1 & 9.93 & 2nd phalange & Fragment & & 0 & & & \\
\hline 53 & $22-30$ & Mammal & 10 & 5.33 & & & & 0 & & & \\
\hline 53 & $22-30$ & Mammal & 1 & 0.39 & & & & 3 & & & \\
\hline 53 & $22-30$ & Mammal--very large & 2 & 10.23 & & & & 0 & & & \\
\hline 54 & $0-35$ & Mammal & 5 & 3.04 & & & & 0 & & & \\
\hline 54. & $0-35$ & Mammal-..very large & 1 & 2.34 & & & & 0 & & & \\
\hline 54 & 0.35 & Vertebrata & 1 & 0.2 & & & & 0 & & & \\
\hline 55 & $0-26$ & Marmmal & 3 & 3.85 & & & & 0 & & & \\
\hline 56 & $0-20$ & Ariodactyl & 1 & 10.86 & Lumber vertebra & Centrum and neural arch & & 0 & & & Heavily pitued \\
\hline 56 & $0-20$ & Mammal & 7 & 0.83 & & & & 0 & & & \\
\hline 56 & 0.20 & Mammal & 1 & 0.74 & & & & 1 & & & \\
\hline 56 & $0-20$ & Marnunal--very large & 2 & 6.13 & & & & 0 & & & \\
\hline 56 & $0-20$ & Mummal--very large & 1 & 1.64 & & & & 4 & & & \\
\hline 56 & $0-20$ & Testudines & 1 & 0.93 & & & & 0 & & & \\
\hline 57 & $0-36$ & Mannmal & 1 & 0.24 & & & & 0 & & & \\
\hline 58 & $0-25$ & Mammal & 1 & 1.04 & & & & 0 & & & \\
\hline 58 & $25-40$ & Murnmal & 2 & 3.15 & & & & 0 & & & \\
\hline 59 & $0-32$ & Manmal & 1 & 0.16 & & & & 0 & & & \\
\hline 59 & $0-32$ & Mummul--larpe & 1 & 6.91 & & & & 0 & & & \\
\hline 59 & $0-32$ & Neotomla sp. & 3 & 0.21 & Mandible & Fragment & & 0 & & & w/ 2 check tecth \\
\hline 59 & $0-32$ & Rodentia & 1 & 0.22 & Innominate & $\begin{array}{l}\text { Ischium \& part of } \\
\text { acctabulum }\end{array}$ & & 0 & & & Heavily pitted-appears partially digested \\
\hline 59 & $32-40$ & Mammal & 1 & 0.67 & & & & 3 & & & \\
\hline 59 & $32-40$ & Mummal--small & 2 & 0.1 & & & & 0 & & & \\
\hline 59 & $32-40$ & Manmal--very harge & 1 & 2.37 & & & & 0 & & & \\
\hline 59 & $32-40$ & Osteichuhyes & 1) & 0.02 & & & . & 0 & & & \\
\hline 59 & $32-40$ & Sylvilaguss sp. & 1 & 0.66 & Tibia & Diaphysis & $\mathrm{L}$ & 0 & & & Very heavily pitted--looks partially digested \\
\hline 59 & $32-40$ & Sylvilagus sp. & 1 & 0.13 & Calcaneus & Almost complete & & 0 & & & Very heavily pitted-looks partially digesied \\
\hline 59 & $32-40$ & Sylvilagus sp. & 1 & 0.1 & Metapodial & Almost complele & & 0 & & & \\
\hline 60 & $0-9$ & Artiodactyl & 1 & 4.83 & Thoracic venebra & $\begin{array}{l}\text { Neural areh \& fragment of } \\
\text { spinc process }\end{array}$ & & 0 & 3 & 2 & \\
\hline 60 & $0-9$ & Mammal & 22 & 4.79 & & & & 0 & & & \\
\hline 60 & $0-9$ & Munmal & 1 & 0.53 & & & & 2 & & & \\
\hline 60 & $0-9$ & Mammal-very large & 3 & 10.14 & & & & 0 & & & \\
\hline 60. & $0-9$ & Odocoileus virginianus & 1 & 19.63 & Femur & Proximal $1 / 3$ & & 0 & 7 & 1 & \\
\hline 61 & $0-11$ & Bovinnc & 1 & 3.7 & Distal sesmoid & Complete & & 0 & & & \\
\hline 61 & $0-11$ & Mammal & 14 & 8.8 & & & & 0 & & & \\
\hline 61 & $0-11$ & Marmmal--large & 2 & 12.35 & & & & 0 & & & \\
\hline 61 & $0-11$ & Mammal--very large & 1 & 10.9 & & & & 0 & & & \\
\hline 61 & $0-11$ & Terrepene sp. & 1 & 0.17 & Carapace & Fragrment & & 0 & & & \\
\hline 62 & $0-10$ & Manmmal & 10 & 6.63 & & & & 0 & & & \\
\hline 62 & $10-20$ & Mammal & 1 & 0.48 & & & & 0 & & & \\
\hline 63 & $0-10$ & Manmal & 6 & 1.85 & & & & 0 & & & \\
\hline 63 & $0-10$ & Mammal--very large & 2 & 11.13 & & & & 0 & & & Extremely pilted \\
\hline 63 & $10-26$ & Mammal & 4 & 4.95 & & & & 0 & & & \\
\hline 64 & $0-10$ & Aves & 1 & 1.56 & & & & 0 & & & \\
\hline 64 & $0-10$ & Capra/Ovis & 1 & 0.39 & $\begin{array}{l}\text { Deciduous } \\
\text { premolar }\end{array}$ & Almost complctc & & 0 & & & \\
\hline 64 & $0-10$ & Capra/Ovis & 1 & 1.18 & $\begin{array}{l}\text { Deciduous } \\
\text { premolar }\end{array}$ & Almost complets & & 0 & & & \\
\hline 64 & $0-10$ & Gallus domesticus & 1 & 0.51 & Corocoid & Proximal 1.2 & & 0 & & & \\
\hline 64 & $0-10$ & Mammal & 157 & 67.38 & & & & 0 & & & \\
\hline 64 & $0-10$ & Manmal & 1 & 0.52 & & & & 1 & & & \\
\hline 64 & $0-10$ & Mammal & 3 & 1.21 & & & & 2 & & & \\
\hline 64 & $0-10$ & Mammal & 7 & 2.44 & & & & 3 & & & \\
\hline 64 & 0.10 & Mamminl--large & 4 & 8.08 & & & & 0 & & & \\
\hline 64 & $0-10$ & Mammal--very large & 16 & 136.95 & & & & 0 & & & \\
\hline 64 & $0-10$ & Mammal--very large & 6 & 31.27 & & & & 2 & & & \\
\hline 64 & $0-10$ & Mammial-very large & 3 & 9.44 & & & & 3 & & & \\
\hline 64 & $0-10$ & Mnmmal--very large & 1 & 1.06 & & & & 4 & & & \\
\hline 64 & $0-10$ & Osteichthyes & 3 & 1.18 & & & & 0 & & & \\
\hline 64 & $0-10$ & Vericbrata & 2 & 0.14 & & & & 0 & & & \\
\hline 64 & $10-20$ & Aves & 1 & 0.53 & & & & 0 & & & \\
\hline
\end{tabular}




\begin{tabular}{|c|c|c|c|c|c|c|c|c|c|c|c|c|}
\hline Unit - & $\begin{array}{c}\text { Depth } \\
\text { (cm BD) }\end{array}$ & Taxon & $\mathrm{Cl}$ & $w_{\text {grt (p) }}$ & Flament & Partion & ב⿱艹 & 葛 & 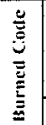 & Butcher 1 & Marks & Notes \\
\hline 64 & $10-20$ & Bovinac & 1 & 1.1 & Deciduous incisor & Almost complete & & $\mathrm{Y}$ & 0 & & & \\
\hline 64 & $10-20$ & Bovinae & 1 & 1.43 & Deciduous incisor & Almost complete & & $\mathrm{Y}$ & 0 & & & \\
\hline 64 & $10-20$ & Bovintue & 1 & 0.52 & Deciduous incisor & Almost completc & & $\mathrm{Y}$ & 0 & & & \\
\hline 64 & $10-20$ & Gallus domesticus & 1 & 2.41 & Carpometacarpus & Almost completc & & & 0 & & & Very large \\
\hline 64 & $10-20$ & Mammal & 143 & 63.3 & & & & & 0 & & & \\
\hline 64 & $10-20$ & Mamingl & 11 & 5.32 & & & & & 3 & & & \\
\hline 64 & $10-20$ & Marnmal & 8 & 3.55 & & & & & 3 & & & \\
\hline 64 & $10-20$ & Marnmal & 5 & 3.66 & & & & & 4. & & & \\
\hline 64 & $10-20$ & Mammal-large & 1 & 0.51 & & & & & 0 & & & \\
\hline 64 & $10-20$ & Mammal-very large & 31 & 239.14 & & & & & 0 & & & \\
\hline 64 & $10-20$ & Mammal--very large & 1 & 4.82 & & & & & 1 & & & \\
\hline 64 & $10-20$ & Manmal--very large & 2 & 31.1 & & & & & 2 & & & \\
\hline 64 & $10-20$ & Preudomys sp. & 1 & 0.88 & Carapace & Eragment & & & 0 & & & \\
\hline 64 & $10-20$ & Sciurts c[. niger & 1 & 0.04 & & & & & 0 & & & \\
\hline 64 & $10-20$ & Testudines & 2 & 1.22 & & & & & 0 & & & \\
\hline 64 & $20-30$ & Artiodactyl & 1 & 17.72 & Cervical vertebra & Neural arch & & $\mathrm{Y}$ & 0 & & & Centrum unsealed \\
\hline 64 & $20 \cdot 30$ & Artiodactyl & 1 & 2.12 & Rib & Fragment & & & 0 & 3 & 2 & \\
\hline 64 & $20-30$ & Artiodactyl & 1 & 5.34 & Rib & Fragmenl & & & 0 & & & \\
\hline 64 & $20-30$ & Artiodactyl & 1) & 1.58 & Rib & Fragment & & & 0 & & & \\
\hline 64 & $20-30$ & Ariodactyl & 1 & 1.61 & Cuudal verebra & Almost complete & & $Y$ & 0 & & & Unscaled \\
\hline 64 & $20-30$ & Artiodactyl & I & 3.37 & Lumbar vertebra & Frugrnent & & $\mathrm{Y}$ & 0 & & & Not sealed to centrum \\
\hline 64 & $20-30$ & Aves-large & 4 & 1.96 & & & & & 0 & & & \\
\hline 64 & 20-30 & Bos taurtus & 1 & 79.38 & Metalarsal & Proximal 1/2 & & $Y$ & 0 & & & Size \& development suggests young \\
\hline 64 & $20-30$ & Bos tamonis & 1 & 29.62 & 1st phalange & Complete & & & 0 & & & \\
\hline 64 & $20-30$ & Bos taurtis & 1 & 24.03 & Ist phalange & Completc & & & 0 & & & \\
\hline 64 & $20-30$ & Falconiformes & 1 & 7.51 & Ulna & Diaphysis & & & 0 & & & Big hawk or cagle \\
\hline 64 & $20-30$ & Ictalurus sp. & 1 & 0.23 & Ceralohyal & Almost complete & & & 0 & & & \\
\hline 64 & $20-30$ & Ictalurus $\mathrm{sp}$. & 1 & 0.23 & Vertebra & Centrum & & & 0 & & & \\
\hline 64 & $20-30$ & Ictalurus sp. & 1 & 0.55 & Vertebra & Centrum & & & 0 & & & \\
\hline 64 & $20-30$ & Manunal & 107 & 40.91 & & & & & 0 & & & \\
\hline 64 & $20-30$ & Marnmal & 1 & 0.23 & & & & & 2 & & & \\
\hline 64 & $20-30$ & Mammal & 1 & 0.52 & & & & & 3 & & & \\
\hline 64 & $20-30$ & Mammnal & 1 & 0.29 & & & & & 4 & & & \\
\hline 64 & $20-30$ & Marnmal-very large & 2. & 3.08 & & & & & 3 & & & \\
\hline 64 & $20-30$ & Mammal--very large & 20 & 185.22 & & & & & 0 & & & \\
\hline 64 & $20-30$ & Pylodicnus olivaris & 1 & 0.45 & Vertebra & Fragment & & & 0 & & & \\
\hline 64 & $20-30$ & Terrepene sp. & 1 & 0.25 & Innorninate & Illium & & & 0 & & & \\
\hline 64 & $20-30$ & Testudines & 1 & 0.2 & & & & & 0 & & & \\
\hline 64 & $20-30$ & Trionvx sp. & 1 & 0.08 & Carapace & End ol rib & & & 0 & & & \\
\hline 64 & $20-30$ & Trionpx sp. & 1 & 4,3 & Carapace & Fragment & & & 0 & & & \\
\hline 64 & $20-30$ & Trionux sp. & 1 & 0.22 & Carapace & Fragment & & & 0 & & & \\
\hline 64 & $20-30$ & Vertebrati & 4 & 0.29 & & & & & 0 & & & \\
\hline 64 & $30-40$ & Arliodactyl & 1 & 15.98 & Mandible & Almost completc & & $\mathrm{Y}$ & 0 & & & All tecth gone but 2nd molar, which is not crupted \\
\hline 64 & $30-40$ & Artiodactyl & 1) & 0.51 & \begin{tabular}{|l|} 
Deciduous \\
premolur
\end{tabular} & Almost complete & & $\mathrm{Y}$ & 0 & & & \\
\hline 64 & $30-40$ & Artiodactyl & 1 & 0.34 & Molar & Fragmen! & & $\mathrm{Y}$ & 0 & & & Not enupled \\
\hline 64 & $30-40$ & Ariodactyl & 1 & 14.02 & Cervical vertebra & Almost completc & & $\mathrm{Y}$ & 0 & & & Cenirum not scaled \\
\hline 64 & $30-40$ & Artiodactyl & 1 & 11.29 & Tibia & Fragment of diaphysis & & & 0 & & & \\
\hline 64 & $30-40$ & Artiodactyl & 1 & 1.12 & Rib & Fragment & & & 0 & & & \\
\hline 64 & $30-40$ & Aves & 1 & 0.19 & & & & & 0 & & & \\
\hline 64 & $30-40$ & Bos taunus & 2 & 118.63 & Mctatarsal & Proximal 1/2 & & & 2 & & & Bumed on broken end of bone \\
\hline 64 & $30-40$ & Bovinac & 1 & 60.32 & Melacarpal & Distal diaphysis & & $Y$ & 2 & & & Burned on broken cnd of bone, condyles unsealed \\
\hline 64 & $30-40$ & Bovinae & 1 & 48.4 & Thoracic vertebra & Neural arch & & & 0 & 3 & 1 & \\
\hline 64 & $30-40$ & Bovinac & 1 & 18.31 & Innominalc & Fragnent of acetabulum & & $\mathbf{Y}$ & 0 & & & not sealed to other parts of acetabulum \\
\hline 64 & $30-40$ & Bovinac & 1 & 56.39 & Rib & Fragment & & $Y$ & 0 & $\begin{array}{l}3 \\
7\end{array}$ & \begin{tabular}{l|}
3 \\
1 \\
\end{tabular} & \\
\hline 64 & $30-40$ & Bovinae & 1 & 17.56 & Rib & Fragment & & $Y$ & 0 & & & Proximal end unsealed \\
\hline 64 & $30-40$ & Gallus domesticus & 1 & 1.01 & Ulna & Proximnl $2 / 3$ & & & 0 & & & \\
\hline 64 & $30-40$ & Gallus domesticus & 1 & 0.2 & $\begin{array}{l}\text { 1st phalange } \\
\text { (foot) }\end{array}$ & Complete & & & 0 & & & \\
\hline 64 & $30-40$ & Ictalunis sp. & 1 & 0.44 & Arricular & Fragmenl & & & 0 & & & \\
\hline 64 & $30-40$ & Icralumus sp. & 1 & 0.38 & Dentary & Almost completc & $\mathrm{L}$ & & 0 & & & \\
\hline 64 & $30-40$ & Ictalurus sp. & 1 & 0.41 & Dentary. & Almost complete & $\mathbf{R}$ & & 0 & & & \\
\hline 64 & $30-40$ & Marnmal & 168 & 46.49 & & & & & 0 & & & \\
\hline 64 & $30-40$ & Mammal & 13 & 2.9 & & & & & 1 & & & \\
\hline
\end{tabular}




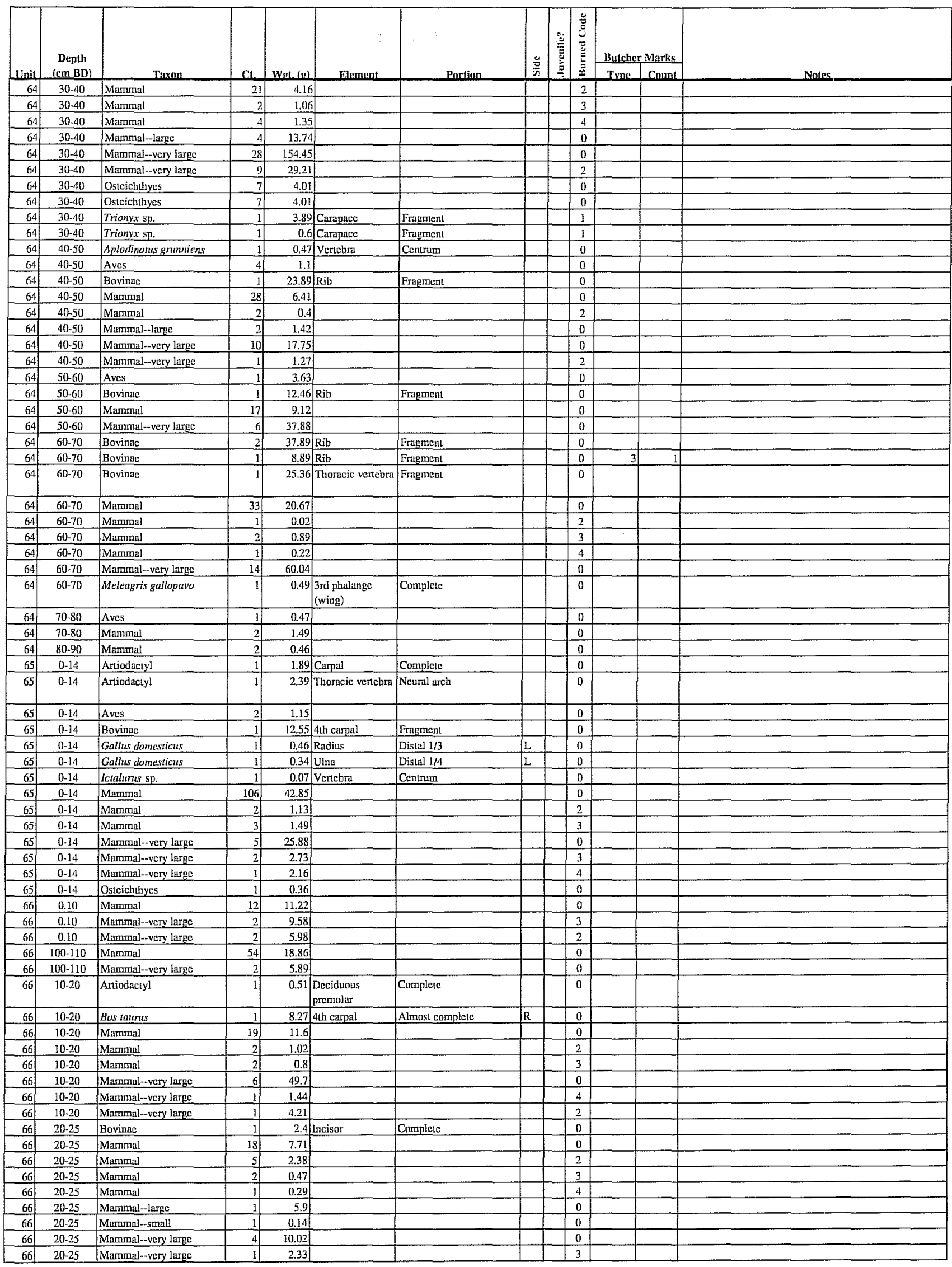




\begin{tabular}{|c|c|c|c|c|c|c|c|c|c|c|c|c|}
\hline \multirow[b]{2}{*}{ Unit } & \multirow{2}{*}{$\begin{array}{l}\text { Depth } \\
\text { (cm BD) }\end{array}$} & \multirow[b]{2}{*}{ Taxion } & \multirow[b]{2}{*}{ C. } & \multirow[b]{2}{*}{ Wot. (n) } & \multirow[b]{2}{*}{ Elament } & \multirow[b]{2}{*}{ Partion } & \multirow{2}{*}{ 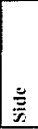 } & \multirow{2}{*}{ 䓂 } & 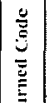 & Butcher & Marks & \\
\hline & & & & & & & & & & \begin{tabular}{|l|} 
True \\
\end{tabular} & Comunt & Notes \\
\hline 66 & $20-25$ & Testudines & 1 & 2.59 & & & & & 0 & & & \\
\hline 66 & $25-30$ & Bovinac & 1 & 18.99 & Premolar & Fragment & & & 0 & & & \\
\hline 66 & $25-30$ & Mammal & 155 & 88.56 & & & & & 0 & & & \\
\hline 66 & $25-30$ & Marnmal & 1 & 0.88 & & & & & 1 & & & \\
\hline 66 & $25-30$ & Marnmal & 20 & 10.41 & & & & & 2 & & & \\
\hline 66 & $25-30$ & Manmal & 15 & 11.52 & & & & & 3 & & & \\
\hline 66 & $25-30$ & Mammal & 8 & 3.42 & & & & & 4 & & & \\
\hline 66 & $25-30$ & Mammal--large & 1 & 2.39 & & & & & 0 & & & \\
\hline 66 & $25-30$ & Mammal--very large & 12 & 66.22 & & & & & 0 & & & \\
\hline 66 & $25-30$ & Mammal-very large & 3 & 9.4 & & & & & 2 & & & \\
\hline 66 & $25-30$ & Mammal--very large & 4 & 8.51 & & & & & 3 & & & \\
\hline 66 & $25-30$ & Mammal--very large & 1 & 1.38 & & & & & 4 & & & \\
\hline 66 & $25-30$ & Pseudomys sp. & 8 & 45.81 & Plastron & Fragment & & & 0 & & & \\
\hline 66 & $25-30$ & Pseudomys sp. & 1 & 7.45 & Calcancus & Fragmen! & & & 0 & & & \\
\hline 66 & $25-30$ & Testudines & 1 & 0.3 & & & & & 2 & & & \\
\hline 66 & $25-30$ & Vertebrata & 3 & 0.52 & & & & & 0 & & & \\
\hline 66 & $30-40$ & Bovinac & 1 & 15.25 & Rib & Fragment & & & 0 & $\begin{array}{l}2 \\
3 \\
\end{array}$ & $\begin{array}{l}2 \\
1 \\
\end{array}$ & \\
\hline 66 & $30-40$ & Ictalurus sp. & 1 & 0.84 & Vertebra & Centrum & & & 0 & & & \\
\hline 66 & $30-40$ & Mamuraal & 84 & 39.14 & & & & & 0 & & & \\
\hline 66 & $30-40$ & Mammal & 3 & 1,01 & & & & & 1 & & & \\
\hline 66 & $30-40$ & Mamrnal & 1 & 1.33 & & & & & 2 & & & \\
\hline 66 & $30-40$ & Mammal & 3 & 3.85 & & & & & 3 & & & \\
\hline 66 & $30-40$ & Murnunal & 4 & 1.39 & & & & & 4 & & & \\
\hline 66 & $30-40$ & Manmal--larec & 3 & 3.18 & & & & & 0 & & & \\
\hline 66 & $30-40$ & Mammal-very large & 12 & 93.83 & & & & & 0 & & & \\
\hline 66 & $40-45$ & Aves-very large & 7 & 4.3 & & & & & 0 & & & \\
\hline 66 & $40-45$ & Equas' sp. & 1 & 20,71 & Rib & Frnement & & & 0 & & & \\
\hline 66 & $40-45$ & Eqtuas sp. & 1 & 4.68 & Rib & Fragment & & & 0 & & & \\
\hline 66 & $40-45$ & Equiss sp. & 1 & 6.08 & Rib & Distal end & & & 0 & & & \\
\hline 66 & $40-45$ & Mummal & 29 & 19,5 & & & & & 0 & & & \\
\hline 66 & $40-45$ & Mammal & 3 & 4.24 & & & & & 1 & & & \\
\hline 66 & $40-45$ & Mammal & 3 & 2.08 & & & & & 2 & & & \\
\hline 66 & $40-45$ & Mamnal--large & 3 & 16.97 & & & & & 0 & & & \\
\hline 66 & $40-45$ & Mammal--very large & 8 & 112.51 & & & & & 0 & & & \\
\hline 66 & $40-45$ & Mammal--very large & 1 & 3.76 & & & & & 3 & & & \\
\hline 66 & $40-45$ & Meleagris gallopavo & 1 & 1.45 & Scapula & Proximal $1 / 4$ & & & 0 & & & \\
\hline 66 & $40-45$ & Meleagris gallopavo & 1 & 0.39 & $\begin{array}{l}\text { 1st phalange } \\
\text { (foot) }\end{array}$ & Completc & & & 0 & & & \\
\hline 66 & $45-50$ & Mammal & 10 & 3.28 & & & & & 0 & & & \\
\hline 66 & $45-50$ & Mammal-very large & 4 & 27,32 & & & & & 0 & & & \\
\hline 66 & $45-50$ & Testudines & 1 & 0.49 & & & & & 0 & & & \\
\hline 66 & $50-60$ & Aves & 1 & 0.35 & & & & & 0 & & & \\
\hline 66 & $50-60$ & Bos tatirns & 13 & 201.86 & Scapula & Fragment & & & 0 & 3 & 2 & Chopped along spinc \\
\hline 66 & $50-60$ & Mammal & 64 & 36.86 & & & & & 0 & & & \\
\hline 66 & $50-60$ & Mammal & 2 & 1.01 & & & & & 0 & & & \\
\hline 66 & $50 \cdot 60$ & Mammal-very large & 14 & 116.11 & & & & & 0 & & & \\
\hline 66 & $60-70$ & Mamraal & 14 & 8.6 & & & & & 0 & & & \\
\hline 66 & $60-70$ & Mammal--very large & 1 & 2.06 & & & & & 2 & & & \\
\hline 66 & $60-70$ & Verebrata & 1 & 0.15 & & & & & 1 & & & \\
\hline 66 & $70-80$ & Artiodactyl & 1 & 4.44 & 1 si phalange & Almost complete & & & 0 & & & \\
\hline 66 & $70-80$ & Bovinae & 1 & 10.43 & $\begin{array}{l}\text { Deciduous } \\
\text { premolar }\end{array}$ & Complete & & $Y$ & 0 & & & \\
\hline 66 & $70-80$ & Marnmal & 10 & 3.7 & & & & & 0 & & & \\
\hline 66 & $70-80$ & Marnmal & 1 & 0.71 & & & & & 4 & & & \\
\hline 66 & $70-80$ & Marnmal-very large & 1 & 8.7 & & & & & 0 & & & \\
\hline 66 & $80-99$ & Mammal & 51 & 16.33 & & & & & 0 & & & \\
\hline 66 & $80-99$ & Mummal & 1 & 0.83 & & & & & 3 & & & \\
\hline 66 & $80-99$ & Marninal--very large & 8 & 21.92 & & & & & 0 & & & \\
\hline 66 & $90-100$ & Artiodactyl & 6) & 3.3 & Molar & Fragment & & & 0 & & & \\
\hline 66 & $90-100$ & Bison bison & 1 & 14.82 & 3rd phalange & Complete & & & 0 & & & \\
\hline 66 & $90-100$ & Bovinac & I & 25.64 & Deciduous moltur & Almost complete & & & 0 & & & \\
\hline 66 & $90-100$ & Bovinac & 1 & 16.47 & Deciduous molar & Almost complete & & & 0 & & & \\
\hline 66 & $90-100$ & Bovinac & I & 9.47 & Deciduous molar & Almost completc & & & 0 & & & \\
\hline 66 & $90-100$ & Bovinae & 1 & 5.66 & Deciduous molar & Frugment of diuphysis & & & 0 & & & \\
\hline 66 & $90-100$ & Bovinac & 1 & 1.78 & Proximal sesmoid & Complete & & & 0 & & & \\
\hline 66 & $90-100$ & Bovinae & 1 & 15.97 & Calcancus & Distal end & L & & 0 & 7 & 1 & 1] \\
\hline 66 & $90-100$ & Bovinae & 1 & 49.89 & Asiralagus & Almost complete & L & & 0 & & & Very heavily pitted \& weathered \\
\hline 66 & $90-100$ & Bovinac & 1 & 12,72 & Astralagus & Lateral $1 / 2$ & $\mathrm{R}$ & & 0 & & & Very hegvily pilted \& weathered \\
\hline
\end{tabular}




\begin{tabular}{|c|c|c|c|c|c|c|c|c|c|c|c|c|}
\hline \multirow[b]{2}{*}{ Unit } & \multirow{2}{*}{$\begin{array}{c}\text { Depth } \\
\text { (cm BD) }\end{array}$} & \multirow[b]{2}{*}{ Taxnn } & \multirow[b]{2}{*}{ Ct. } & \multirow[b]{2}{*}{ Wol. (g) } & \multirow[b]{2}{*}{ Elcment: : } & \multirow[b]{2}{*}{ Partion } & 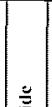 & $\frac{\ddot{E}}{\bar{*}}$ & 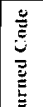 & Butcher & r.Marks & \\
\hline & & & & & & & 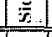 & $\equiv$ & $\underline{E}$ & Tror: & Conunt & Notes \\
\hline 66 & $90-100$ & Bovinac & 1 & 21.98 & Astralagus & Medial $1 / 2$ & $\mathrm{~L}$ & & 0 & & & Very beavily pitted \& weathered \\
\hline 66 & $90-100$ & Bovinac & 1 & 5.51 & Astralagus & Fragment & & & 0 & & & \\
\hline 66 & $90-100$ & Bovinac & 1 & 5.9 & Radial carpal & Fragment & & & 0 & & & \\
\hline 66 & $90-100$ & Bovinae & 1 & 53.03 & Femur & Fragment of proximal end & & & 0 & & & \\
\hline 66 & $90-100$ & Bovinac & 1) & 72.01 & Radius & Fragment of diaphysis & & & 0 & & & \\
\hline 66 & $90-100$ & Mammal & 1123 & 547,02 & & & & & 0 & & & \\
\hline 66 & $90-100$ & Mammal-large & 2 & 3.84 & & & & & 0 & & & \\
\hline 66 & $90-100$ & Mammal-medium & 1 & 0,1 & & & & & 0 & & & \\
\hline 66 & $90-100$ & Mammnl-very large & 68 & 618.26 & & & & & 0 & & & \\
\hline 67 & 0.40 & Bos taurus & 1 & 17.25 & 2nd phalange & Complete & & & 0 & & & \\
\hline 67 & $0-40$ & Ictalurus sp. & 1 & 1.39 & Operculum & Completc & & & 0 & & & \\
\hline 67 & $0-40$ & Mammal & 2 & 2.03 & & & & & 0 & & & \\
\hline 67 & $0-40$ & Mammal & 1 & 0.45 & & & & & 3 & & & \\
\hline 67) & $0-40$ & Mammul & 1 & 0.2 & & & & & 4 & & & \\
\hline 67. & $0-40$ & Mammal--very large & 4 & 11.72 & & & & & 0 & & & \\
\hline 67. & $0-40$ & Marmual--very large & 1 & 1.8 & & & & & 3 & & & \\
\hline 67 & $40-50$ & Aves & 1 & 0.16 & & & & & 0 & & & \\
\hline 67. & $40-50$ & Mummal & 13 & 10.63 & & & & & 0 & & & \\
\hline 67 & $40-50$ & Mammal & 3 & 0.92 & & & & & 3 & & & \\
\hline 67 & $40-50$ & Mammal--larpe & 1 & 1.38 & & & & & 0 & & & \\
\hline 67 & $40-50$ & Mammal--very large & 5 & 19.85 & & & & & 0 & & & \\
\hline 67 & 40.50 & Mammal-very large & 1 & 0.88 & & & & & 2 & & & \\
\hline 67 & $40-50$ & Mammal--very large & 1 & 0.75 & & & & & 4 & & & \\
\hline 68 & $0-30$ & Aves & 1 & 0.25 & & & & & 0 & & & \\
\hline 68 & $0-30$ & Aves & 3 & 0.34 & & & & & 0 & & & \\
\hline 68 & 0.30 & Bos taunis & 1 & 8.92 & Radial carpal & Complcie & $R$ & & 0 & & & \\
\hline 68 & $0-30$ & Bos tantris & 2 & 21.65 & 1st phalange & Complete & & $Y$ & 0 & & & Unscaled \\
\hline 68 & $0-30$ & Bovinas & 2 & 84.5 & Humens & $1 / 2$ of distal end & $R$ & $Y$ & 0 & 3 & 1 & Unscaled \\
\hline 68 & $0-30$ & Bovinac & 1 & 21.92 & Ниmenus & $\begin{array}{l}\text { Fragment of proximal } \\
\text { epiphysis }\end{array}$ & & $\mathrm{Y}$ & 0 & & & Unscaled \\
\hline 68 & $0-30$ & Bovinate & 1 & 34.03 & Cervical ventebra & Neural anch & & & 0 & 3 & 2 & \\
\hline 68 & 0.30 & Bovinae & 1 & 4.13 & 2nd phalange & Proximnl cpipysis & & $Y$ & 0 & & & Unsealed \\
\hline 68 & $0-30$ & Bovinac & 1 & 4.12 & 2nd phalange & Fragment of diaphysis & & $\mathrm{Y}$ & 0 & & & Unsealed \\
\hline 68 & 0.30 & Bovinac & 1 & 5.3 & Metapodial & Fragment of condyle & & & 0 & & & \\
\hline 68 & $0-30$ & Bovinae & 1. & 7.13 & ist phalange & Fragment of diaphysis & & $\mathrm{Y}$ & 0 & & & Unseaied \\
\hline 68 & $0-30$ & Bovinae & 1 & 1.77 & Distal sesmoid & Complete & & & 0 & & & \\
\hline 68 & $0-30$ & Branta sp. & 1 & 2. & Furculum & Medial \& left side & & & 0 & & & \\
\hline 68 & $0-30$ & Lepisostets $\mathrm{sp}$. & 1 & 0.37 & Scalc & Complete & & & 0 & & & \\
\hline 68 & $0-30$ & Mammal & 66 & 42.28 & & & & & 0 & & & \\
\hline 68 & $0-30$ & Mammal & 4 & 2.51 & & & & & 1 & & & \\
\hline 68 & $0-30$ & Mammal & 99 & 57.19 & & & & & 0 & & & \\
\hline 68 & $0-30$ & Mammal & 3 & 1.18 & & & & & 2 & & & \\
\hline 68 & 0.30 & Mammal & 1 & 0.45 & & & & & 3 & & & \\
\hline 68 & 0.30 & Mammal-medium & 3 & 2.8 & & & & & 0 & & & \\
\hline 68 & $0-30$ & Mammal-very large & 23 & 98.3 & & & & & 0 & & & \\
\hline 68 & $0-30$ & Mammal-very large & 8 & 39.44 & & & & & 0 & & & \\
\hline 68 & $0-30$ & Mammal-very large & 4 & 16.14 & & & & & 2 & & & \\
\hline 68 & $0-30$ & Odocoileus virginianus & 1. & 6.52 & Radius & Proximal 1/4 & $L$ & & 0 & 7 & 1 & \\
\hline 68 & $0-30$ & Radentia & 1 & 0.18 & Innominalc & Acctabulum & & & 0 & & & \\
\hline 68 & $0-30$ & Ursus cl americanus & 1 & 1.62 & 2nd phalange & Complete & & & 0 & & & \\
\hline 68 & $0-30$ & Vencbrain & 11 & 0.33 & & & & & 0 & & & \\
\hline 70 & $0-10$ & Artiodacty] & 1 & 0.89 & Molar & Fragment & & & 0 & & & \\
\hline 70 & $0-10$ & Artiodactyl & 1 & 0.39 & Sesmoid & & & & 0 & & & \\
\hline 70 & $0-10$ & Aves & 2 & 1 & & & & & 0 & & & \\
\hline 70 & $0-10$ & Aves-Iarge & 2 & 3.74 & & & & & 0 & & & \\
\hline 70 & $0-10$ & Aves-very large & 2 & 4.13 & & & & & 0 & & & \\
\hline 70 & $0-10$ & Bovinne & 1 & 33.55 & Ist phalange & Almost complete & & & 0 & & & \\
\hline 70 & $0-10$ & Bovinue & 1 & 10.49 & Premolar & Almost completc & & & 0 & & & \\
\hline 70 & $0-10$ & Bovinac & 1 & $6.21 \mathrm{C}$ & Caudal vericbra & Almosi complele & & & 0 & & & \\
\hline 70 & $0-10$ & Iclalurus $\mathrm{sp}$. & 1 & 0.55 & Pectoral spine & Fragment & & & 0 & & & \\
\hline 70 & $0-10$ & Marnmal & 133 & 104.9 & & & & & 0 & & & \\
\hline 70 & $0-10$ & Mammal & 11 & 6.4 & & & & & 2 & & & \\
\hline 70 & $0-10$ & Mammal & 4 & 6.54 & & & & & 1 & & & \\
\hline 70 & 0.10 & Mammin & 4 & 1.56 & & & & & 3 & & & \\
\hline 70 & $0-10$ & Mammal & 1 & 0.8 & & & & & 4 & & & \\
\hline 70 & 0.10 & Mammal & 1 & 0.27 & & & & & 0 & & & \\
\hline 70 & 0.10 & Mamrnal--large & 3 & 13.94 & & & & & 0 & & & \\
\hline 70 & $0-10$ & Mammal--very large & 35 & 123.41 & & & & & 0 & & & \\
\hline 70 & $0-10$ & Mammal--very large & 6 & 12.77 & & & & & 2 & & & \\
\hline 70 & $0-10$ & Mcleagris gallopavo & 1 & 0.58 & $\begin{array}{l}\text { 15t phalange } \\
\text { (Ioot) }\end{array}$ & Almost complete & & & 0 & & & \\
\hline 70 & $0-10$ & Odocoileus virginianus & 1 & 2.65 & 2nd phalange & Completc & & & 0 & & & \\
\hline
\end{tabular}




\begin{tabular}{|c|c|c|c|c|c|c|c|c|c|c|c|c|}
\hline \multirow[b]{2}{*}{ Unit } & \multirow{2}{*}{$\begin{array}{r}\text { Depth } \\
(\mathrm{cm} \text { BD }) \\
\end{array}$} & \multirow[b]{2}{*}{ Taxan } & \multirow[b]{2}{*}{$\mathrm{Ct}}$. & \multirow[b]{2}{*}{ Wot, $(\mathrm{g})$} & \multirow[b]{2}{*}{ Flement. } & \multirow[b]{2}{*}{ Partinn } & \multirow{2}{*}{$\frac{\mathscr{e}}{\tilde{z}}$} & \multirow{2}{*}{ 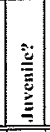 } & 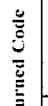 & Butcher & Marks & \\
\hline & & & & & & & & & & Trne & Coune & Notes \\
\hline 70 & $0-10$ & Testudines & 1 & 0.99 & & & & & 0 & & & \\
\hline 70 & $0-10$ & Trionyx sp. & 1) & 1.67 & Carupece & Fragmeni & & & 0 & & & \\
\hline 70 & $0-10$ & Triony. sp. & 1 & 2.57 & Carapace & Fragment & & & 0 & & & \\
\hline 70 & $0-10$ & Vertebraia & 1 & 0.13 & & & & & 0 & & & \\
\hline 71 & $0-10$ & Artiodactyl & 3 & 34.29 & Femur & Diuphysis & & & 0 & & & \\
\hline 71 & $0-10$ & Aves & 5 & 2.85 & & & & & 0 & & & \\
\hline 71 & $0-10$ & Bovinac & 1 & 7.14 & Lumbar vertebra & Epiphysis of centrum & & $\mathrm{Y}$ & 0 & & & Unscaled \\
\hline 71 & $0-10$ & Bovinac & 1 & 3.33 & 2nd phalange & Fragment of proximal end & & & 0 & & & \\
\hline 71 & $0+10$ & Bovinac & 1 & 2.03 & Proximal sestrnoid & Complete & & & 0 & & & \\
\hline 71 & $0-10$ & Colubersp. & 1 & 0.15 & Vertebra & Almost completc & & & 0 & & & \\
\hline 71 & $0-10$ & Didelphis virginiana & 1 . & 1.37 & Sacrum & Onc vertebra & & \begin{tabular}{|l|}
$Y$ \\
\end{tabular} & 0 & & & Nol sealed toother verts of sacrum \\
\hline 71 & $0-10$ & Mammal & 131 & 78.49 & & & & & 0 & & & \\
\hline 71 & $0-10$ & Mammal & 2 & 6.92 & & & & & 1. & & & \\
\hline 71 & $0-10$ & Mammal & 11 & 4.39 & & & & & 2 & & & \\
\hline 71 & $0-10$ & Manmal & 5 & 2.62 & & & & & 3 & & & \\
\hline 71 & $0-10$ & Marnmal & 1 & 0.66 & & & & & 4 & & & \\
\hline 71 & $0-10$ & Mammal--large & 2 & 1.87 & & & & & 0 & & & \\
\hline 71 & $0-10$ & Mammal-very large & 21 & 70.91 & & & & & 0 & & & \\
\hline 71 & $0-10$ & Mammal--very large & 2 & 3.91 & & & & & 2 & & & \\
\hline 71 & $0-10$ & Mammal--very large & 3 & 5.62 & & & & & 3 & & & \\
\hline 71 & $0-10$ & Odocoileus virginianus & 1 & 0.93 & Canine & Completc & & & 0 & & & \\
\hline 71 & $0-10$ & Odocoileus virginiants & 1 & 2.89 & Maxilla & Fragment & & & 0 & & & w/ very worn molar \\
\hline 71 & $0-10$ & Odocoileus virginianus & 1 & 0.79 & Molar & Complete & & & 0 & & & badly worm \\
\hline 71 & $0-10$ & Odocoileus virginianus & 1 & 0.38 & Premolar & Complete & & & 0 & & & Badly wom \\
\hline 71 & $0-10$ & Triony.x sp. & 1 & 1.32 & Carapace & Fragment & & & 0 & & & \\
\hline 71 & $0-10$ & Trionyx sp. & 1 & 1.06 & Carapace & Frapment & & & 0 & & & \\
\hline 72. & $0-10$ & Aves & 3 & 1.18 & & & & & 0 & & & \\
\hline 72 & $0-10$ & Avcs & 1 & 0.19 & & & & & 0 & & & \\
\hline 72 & $0-10$ & Bovinac & 1 & 29.13 & Rib & Fragment & & & 0 & 3 & 2 & \\
\hline 72 & $0-10$ & Bovinac & 1 & 2.79 & 1st phalange & Fragmenl & & & 2 & & & \\
\hline 72 & $0-10$ & Manmal & 173 & 130.78 & & & & & 0 & & & \\
\hline 72 & $0-10$ & Mammal & 40 & 24.46 & & & & & 2 & & & \\
\hline 72 & $0-10$ & Mammal & 7 & 5.5 & & & & & 3 & & & \\
\hline 72 & $0-10$ & Mammal--large & 4 & 9.74 & & & & & 0 & & & \\
\hline 72 & $0-10$ & Manmal-risedium & 2 & 4.71 & & & & & 0 & & & \\
\hline 72 & $0-10$ & Marnmal--very large & 24 & 108.1 & & & & & 0 & & & \\
\hline 72 & $0-10$ & Marnmal-very lurge & 6 & 22.27 & & & & & 2 & & & \\
\hline 72 & $0-10$ & Marnmal--very large & 1 & 5.28 & & & & & 3 & & & \\
\hline 72 & $0-10$ & Odocoileus virginianus & 1 & 4.31 & Radius & Proximal 1/4 & $\mathrm{R}$ & & 0 & 3 & 2 & \\
\hline 72 & $0-10$ & Ostcichthyes & 1 & 0.47 & & & & & 0 & & & \\
\hline 72 & $0-10$ & Ostcichthycs & 1 & 0.28 & & & & & 0 & & & \\
\hline 72 & $10-20$ & Ardeidac & 1 & 3.38 & Tarsomelatarsus & $\begin{array}{l}\text { Diaphysis and frag of } \\
\text { distal end }\end{array}$ & & & 0 & & & \\
\hline 72 & $10-20$ & Artiodactyl & 1 & 7.63 & Lumbar vertebra & Centrum and neural arch & & $\mathrm{Y}$ & 0 & 3 & 1 & Unsealed \\
\hline 72 & $10-20$ & Artiodnctyl & 1 & $3.31 \mathrm{c}$ & Cervical vertebra & Cenirum and neural arch & & $\mathrm{Y}$ & 0 & & & Barely sealed \\
\hline 72 & $10-20$ & Artioductyl & 1 & 4.74 & Thoracic vertebra & Fragment & & $Y$ & 0 & & & Unsealed \\
\hline 72 & $10-20$ & Artiodnctyl & 1 & \begin{tabular}{ll|}
2.49 & 1 \\
\end{tabular} & Lacrimal & Fragment & & $\mathrm{Y}$ & 0 & & & \begin{tabular}{|l} 
Unsealcd \\
\end{tabular} \\
\hline 72 & $10-20$ & Artioductyl & 1 & 9.32 & Calcancus & Almost complete & & & 0 & & & \\
\hline 72 & $10-20$ & Ariodactyl & 1 & 0.581 & Distal sesmoid & Complete & & & 0 & & & \\
\hline 72 & $10 \cdot 20$ & Artioductyl & 1 & 1,05 & Premolar & Complete & & & 0 & & & Very heavily worn \\
\hline 72 & $10-20$ & Artiodnclyl & 1 & 1.43 & Molar & Fragment & & & 0 & & & \\
\hline 72 & $10-20$ & Artiodilctyl & 1 & 3.31 & Metapodial & Condyle & & & 0 & & & \\
\hline 72 & $10-20$ & Artiodactyl & 1 & 0.91 & Incisor & Complcte & & & 0 & & & Very beavily wom w/ grooves \\
\hline 72 & $10-20$ & Aves & 1. & 0.15 & & & & & 1 & & & \\
\hline 72 & $10-20$ & Aves & 9 & 4.68 & & & & & 0 & & & \\
\hline 72 & $10-20$ & Aves & 1 & 0.43 & & & & & 2 & & & \\
\hline 72 & $10-20$ & Aves--very large & 4 & 5.73 & & & & & 0 & & & \\
\hline 72 & $10-20$ & Bos taurus & 1 & 134.41 & Mctalarsal & Proximal 1/3 & & & 0 & \begin{tabular}{l|l}
2 \\
3 \\
\end{tabular} & $\begin{array}{r}7 \\
10 \\
\end{array}$ & \\
\hline 72 & 10.20 & Bos taurns & 1. & 66.43 & Metacarpal & Fragment of distal end & & & 0 & 7 & 1 & \\
\hline 72 & $10-20$ & Bos tatures & 1 & 16.1 & 2nd phalange & Complete & & & 0 & & & \\
\hline 72 & $10-20$ & Bos taums & 1. & 21.87 & 2nd phalange & Compleıc & & & 0 & & & \\
\hline 72 & $10-20$ & Bos taurLs & 1 & 23.44 & 2nd phulange & Complete & & & 0 & & & \\
\hline 72 & $10-20$ & Bos tateris & 1 & 13.56 & 4th carpal & Complete & $L$ & & 0 & & & \\
\hline 72 & $10-20$ & Bos tautus & 1 & 15.75 & $2+3 \mathrm{cuptal}$ & Complelc & $\mathrm{L}$ & & 0 & & & \\
\hline 72 & $10-20$ & Bovinae & 1 & 17.42 & Metapodial & Fragment of distal end & & & 0 & \begin{tabular}{l|l}
2 & \\
3 & \\
\end{tabular} & \begin{tabular}{l|}
15 \\
17 \\
\end{tabular} & \\
\hline 72 & $10-20$ & Bovinae & 11 & 7.16 & Ist phalange & Fragment & & & 0 & & & \\
\hline
\end{tabular}




\begin{tabular}{|c|c|c|c|c|c|c|c|c|c|c|c|c|}
\hline \multirow[b]{2}{*}{ Unit } & \multirow{2}{*}{$\begin{array}{c}\text { Depth } \\
(\mathrm{cm} \text { BD) }\end{array}$} & \multirow[b]{2}{*}{ Taxon } & \multirow[b]{2}{*}{$\mathrm{Cl}$} & \multirow[b]{2}{*}{$W_{0,}(x)$} & \multirow[b]{2}{*}{ Element } & \multirow[b]{2}{*}{ Portion } & 巳 & 焉 & 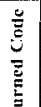 & Butcher & Marks & \\
\hline & & & & & & & $\bar{x}$ & 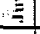 & $\equiv$ & Tran & Comnt & Notes \\
\hline 72 & 10.20 & Bovinac & 1 & 9.71 & Caudil vertebra & Almost complete & & & 0 & & & \\
\hline 72 & 10.20 & Bovinac & 1 & 10.02 & 3 rd phalange & Fragment & & & 0 & & & \\
\hline 72 & $10-20$ & Bovinac & 1 & 1.11 & Distal scsmoid & Almost complele & & & 0 & & & \\
\hline 72 & $10-20$ & Bovinac & 1 & 5.04 & $\begin{array}{l}\text { Deciduous } \\
\text { premolar }\end{array}$ & Almost complete & & $\mathrm{Y}$ & 0 & & & \\
\hline 72 & $10-20$ & Bovinac & 1 & 4.09 & Premolar & Completc & & & 0 & & & \\
\hline 72 & $10-20$ & Canis sp. & 1 & 0.24 & 2nd phalange & Almosi complcic & & & 0 & & & Lg dog or wolf \\
\hline 72 & $10-20$ & Ictalunus sp. & 1 & 2.52 & Pectornil spine & Almosi complele & & & 0 & & & \\
\hline 72 & $10-20$ & Manmail & 364 & 236.91 & & & & & 0 & & & \\
\hline 72 & $10-20$ & Mammal & 3 & 1.65 & & & & & 1 & & & \\
\hline 72 & $10-20$ & Mammal & 37 & 21.14 & & & & & 2 & & & \\
\hline 72 & 10.20 & Mammal & 6 & 4.65 & & & & & 3 & & & \\
\hline 72 & $10-20$ & Marnmal & 1 & 0.7 & & & & & 2 & & & \\
\hline 72 & $10-20$ & Mamnal & 2 & 0.07 & & & & & 0 & & & \\
\hline 72 & $10-20$ & Mummal--large & 4) & 9.12 & & & & & 0 & & & \\
\hline 72 & $10-20$ & Mammal-wery large & 64 & 475.5 & & & & & 0 & & & \\
\hline 72 & $10-20$ & Mammal--very large & 1 & 26.4 & & & & & 1 & & & \\
\hline 72 & $10-20$ & Mammnl--very large & 7 & 34.7 & & & & & 2 & & & \\
\hline 72 & $10-20$ & Mammal-very small & 1 & 0.11 & & & & & 0 & & & \\
\hline 72 & $10 \cdot 20$ & Odocoileus virginiausus & 1 & 1.97 & 2nd phalange & Completc & & & 0 & & & \\
\hline 72 & 1020 & Ostcichthyes & 4 & 1.43 & & & & & 0 & & & \\
\hline 72 & $10-20$ & Rodentia & 1 & 0.06 & Mandible & Fragment & & & 0 & & & \\
\hline 72 & $10-20$ & Terrepene sp. & 1 & 0.6 & Carapace & Fragment & & & 0 & & & \\
\hline 72 & $10-20$ & Testudines & 1 & 6.58 & & & & & 0 & & & \\
\hline 72 & $10-20$ & Trionyx sp. & 1 & 4.18 & Carapace & Fragment & & & 0 & & & \\
\hline 72 & $10-20$ & Trionyx sp. & 1 & 0.39 & Curapacc & Fragment & & & 0 & & & \\
\hline 72 & $10-20$ & Vertebrata & 2 & 0.79 & & & & & 0 & & & \\
\hline 73. & $0-10$ & Artiodaclyl & 1 & 0.85 & Incisor & Almost complete & & & 0 & & & very wom, w/groove \& rool groove \\
\hline 73 & $0-10$ & Artiodactyl & 1. & 2.08 & Melatarsal & Proximal $1 / 2$ & & $Y$ & 0 & & & Very small, undeveloped-probably fetal \\
\hline 73 & 0.10 & Aves & 3 & 0.53 & & & & & 0 & & & \\
\hline 73 & $0-10$ & Bovinae & 1 & 27.67 & 1st phaiange & Almost complete & & & 0 & & & \\
\hline 73 & $0-10$ & Bovinac & 1 & 2.34 & Distal sesmoid & Almost completc & & & 0 & & & \\
\hline 73. & $0-10$ & Bovinac & 1 & 6.03 & $\mathrm{Rib}$ & Proximal end & & & 0 & 3 & 1 & \\
\hline 73 & $0-10$ & Didelphis virginiana & 1 & 1.32 & Cervical vertehra & Alnost complete & & & 0 & & & \\
\hline 73 & $0-10$ & Ictalurts sp. & 1 & 0.87 & Operculum & Fragmenl & & & 2 & & & \\
\hline 73 & $0-10$ & Mammal & 141 & 66.16 & & & & & 0 & & & \\
\hline 73 & $0-10$ & Mammal & 2 & 2.44 & & & & & 4 & & & \\
\hline 73 & $0-10$ & Mammal & 2 & 1.26 & & & & & 3 & & & \\
\hline 73 & $0-10$ & Mammal & 4 & 3.77 & & & & & 2 & & & \\
\hline 73 & $0-10$ & Mammal & 4 & 3.77 & & & & & 1 & & & \\
\hline 73 & $0-10$ & Mammal & 1 & 0.1 & & & & & 0 & & & \\
\hline 73 & $0-10$ & Mammal--very larec & 22 & 119.22 & & & & & 0 & & & \\
\hline 73 & $0-10$ & Mammal--very laree & 3 & 7.33 & & & & & 2 & & & \\
\hline 73 & $0-10$ & Mammal--very large & 1 & 3.22 & & & & & 3 & & & \\
\hline 73 & $0-10$ & $P_{\text {seudomys sp. }}$ & 1 & 3.12 & Carapace & Fragment & & & 2 & & & \\
\hline 73 & $0-10$ & Testudines & 2 & 2.3 & & & & & 0 & & & \\
\hline 73 & $0-10$ & Vertebrata & 2 & 0.58 & & & & & 0 & & & \\
\hline 74 & $0-13$ & Arliodnctyl & 1 & 0.87 & 4th carpal & Complete & & & 0 & & & \\
\hline 74 & $0-13$ & Artiodactyl & 1 & 3.87 & Sacrum & Centrum & & $Y$ & 0 & & & Unscaled \\
\hline 74 & $0-13$ & Artiodactyl & 1 & 1.92 & Sacturn & Coniram & & $Y$ & 0 & & & Unscaled \\
\hline 74 & 0.13 & Artiodactyl & 1 & 17.84 & Lumbar vertebra & Cenirum and neural arch & & $Y$ & 0 & 3 & 1 & Unsenled \\
\hline 74 & $0-13$ & Aves & 10 & 3.37 & & & & & 0 & & & \\
\hline 74 & $0-13$ & Bovinae & 1 & 2.14 & Premolar & Complete & & & 0 & & & \\
\hline 74 & 0.13 & Bovinac & 1 & 2.58 & 2nd phalange & Fragmenl & & & 0 & & & \\
\hline 74 & $0-13$ & Bovinac & 1 & 2.12 & 2nd phalange & Frugment & & & 0 & & & \\
\hline 74 & $0-13$ & Canis sp. & 1 & 0.46 & Deciduous incisor & Complete & & $Y$ & 0 & & & Very large dog or wolf \\
\hline 74 & $0-13$ & Ictalunus sp. & 1 & 0.09 & Veriebra & Cenirum & & & 0 & & & \\
\hline 74 & $0-13$ & Mammal & 397 & 185.85 & & & & & 0 & & & \\
\hline 74 & $0-13$ & Mummal & 7 & 5.37 & & & & & 1 & & & \\
\hline 74 & $0-13$ & Mammal & 26 & 13.69 & & & & & 2 & & & \\
\hline 74 & 0.13 & Manmal & 24 & 12.01 & & & & & 3 & & & \\
\hline 74 & $0-13$ & Mummal & 8 & 3.55 & & & & & 4 & & & \\
\hline 74 & $0-13$ & Manmal--medium & 4 & 2.67 & & & & & 0 & & & \\
\hline 74 & $0-13$ & Manmal--very large & 37 & 159.87 & & & & & 0 & & & \\
\hline 74 & $0-13$ & Mammal--very large & 1 & 3.5 & & & & & 4 & & & \\
\hline 74 & $0-13$ & Mammal-very large & 5 & 8.97 & & & & & 2 & & & \\
\hline 74 & $0-13$ & Thannophis sp. & 1 & 0.08 & Vertcbra & Complete & & & 0 & & & \\
\hline 74 & $0-13$ & Thamnophis sp. & 1 & 0.05 & Vertebra & Fragmen1 & & & 0 & & & \\
\hline 74 & $0-13$ & Trionyx sp. & 1 & 1.87 & Carapace & Fragment & & & 0 & & & \\
\hline 74 & $0-13$ & Trionyx sp. & 1 & 0.31 & Carapace & Fragment & & & 0 & & & \\
\hline 74 & $13-20$ & Bos taurte.s & 1 & 17.03 & $2+3$ carpal & Complete & $L$ & & 0 & & & A litlle arthritic lipping \\
\hline
\end{tabular}




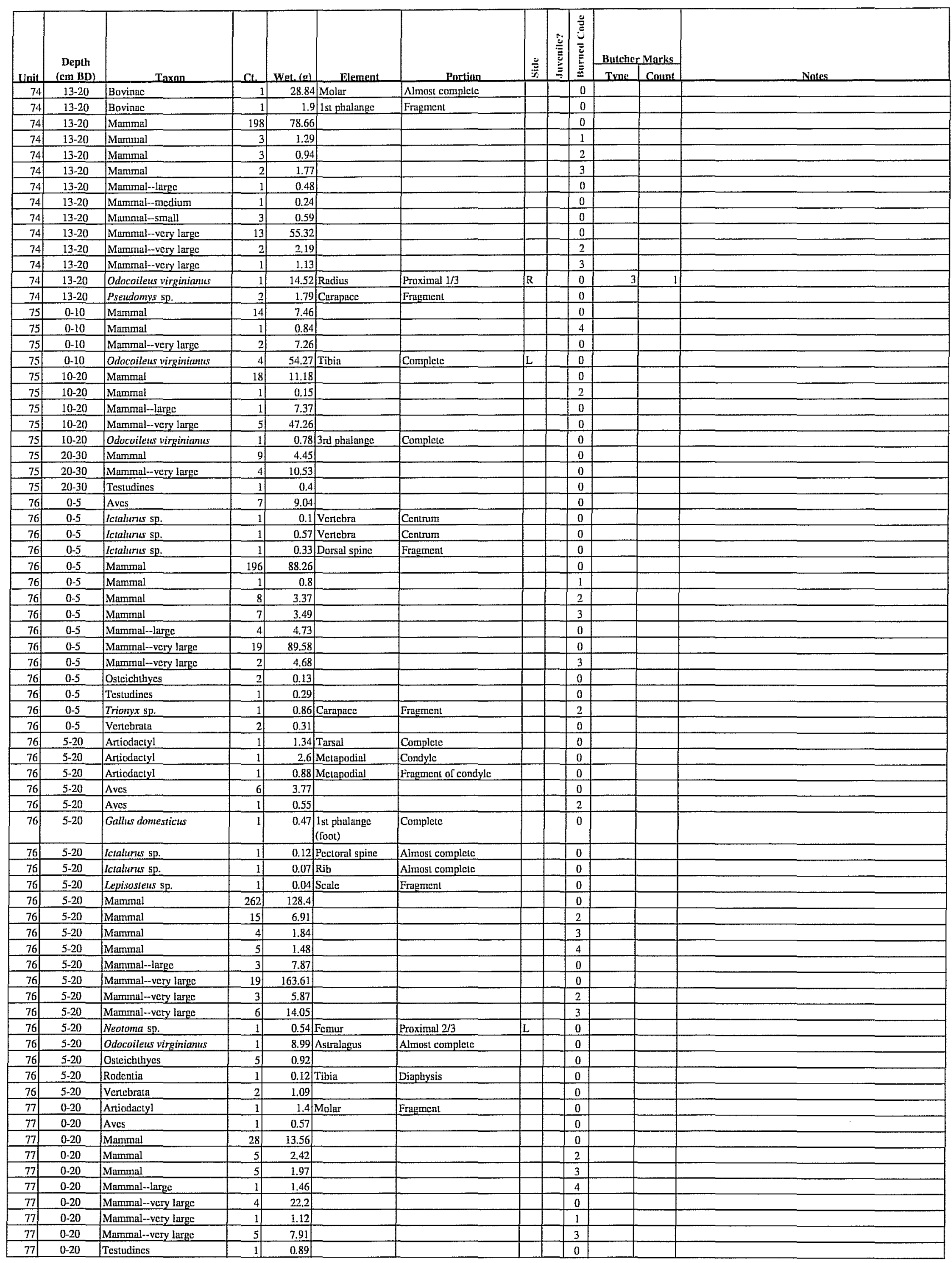




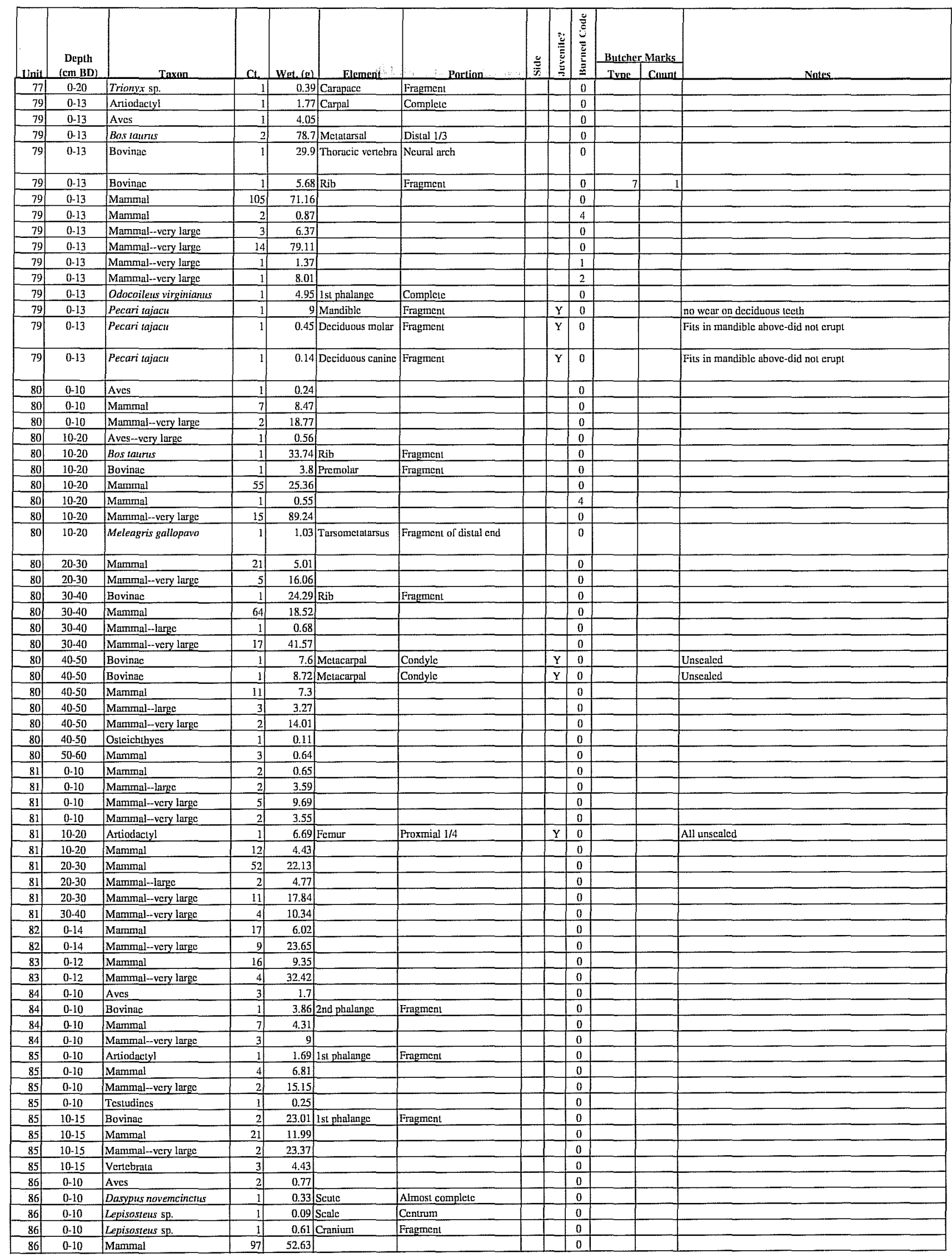




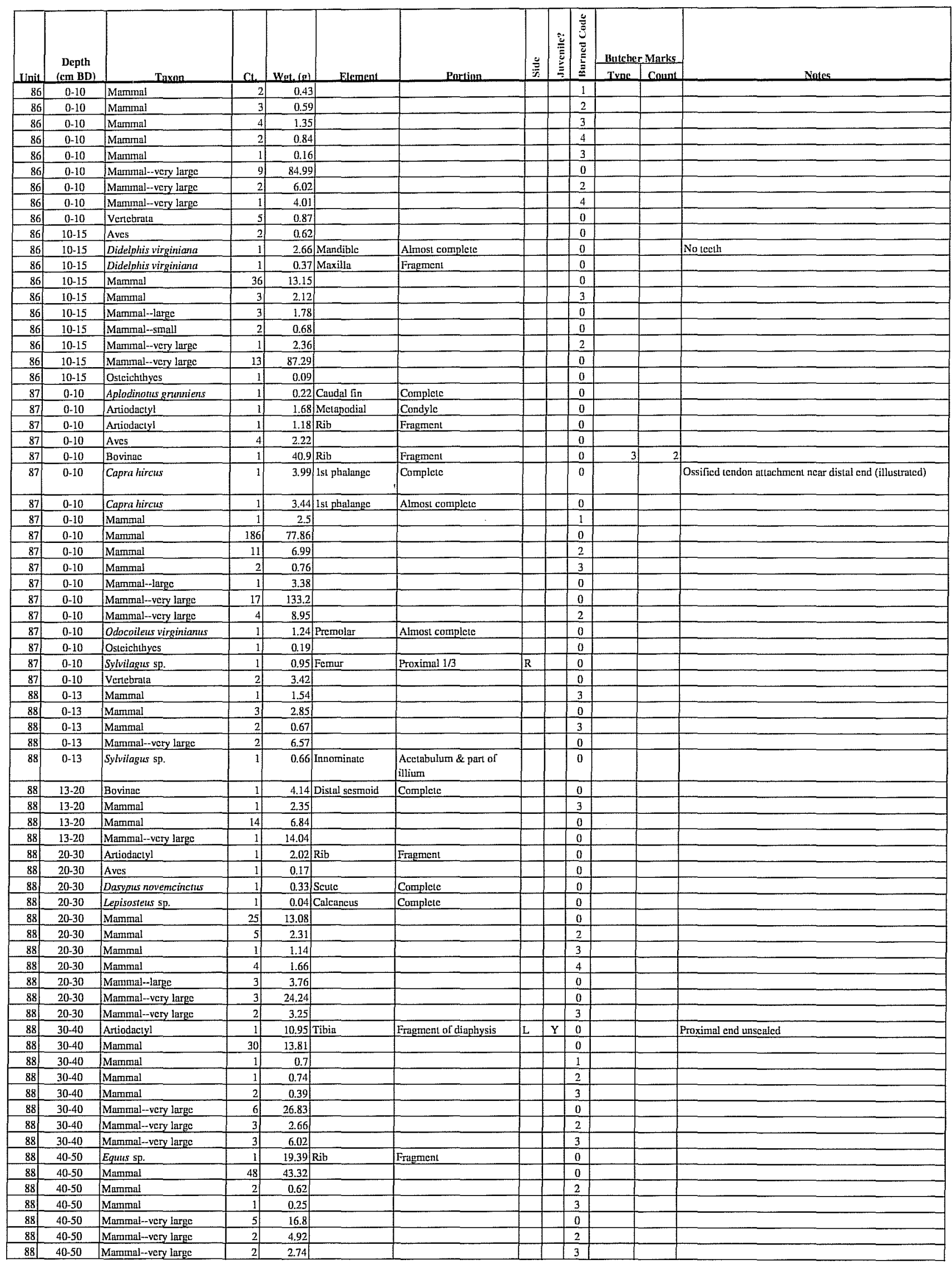




\begin{tabular}{|c|c|c|c|c|c|c|c|c|c|c|c|c|}
\hline \multirow[b]{2}{*}{ Unit } & \multirow{2}{*}{$\begin{array}{c}\text { Depth } \\
\text { (cm BD) }\end{array}$} & \multirow[b]{2}{*}{ Taxon } & \multirow[b]{2}{*}{$\mathrm{Cl}$} & \multirow[b]{2}{*}{ Wat. (v) } & \multirow[b]{2}{*}{ Eloment: } & & y & 荡 & 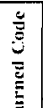 & Butcher & Marks & \\
\hline & & & & & & Portinn & $\frac{2}{2}$ & & 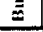 & Trne & Count & Nottus. \\
\hline 89 & $0-21$ & Aves & 5 & 1,59 & & & & & () & & & \\
\hline 89 & $0-21$ & Bovinae & 1 & 12.22 & 2nd phalange & All bul proximnl cpiphysis & & $\mathrm{Y}$ & 0 & & & Unsealed \\
\hline 89 & $0-21$ & Dasypus novemcinctus & 1 & 0.26 & Dermal scute & Fragment & & & 0 & & & \\
\hline 89 & $0-21$ & Mammal & 80 & 42.59 & & & & & 0 & & & \\
\hline 89 & $0-21$ & Mammal & 2 & 0.75 & & & & & 2 & & & \\
\hline 89 & $0-21$ & Mammal & 1 & 0.53 & & & & & 1 & & & \\
\hline 89 & $0-21$ & Mammal & 1 & 0.25 & & & & & 3 & & & \\
\hline 89 & $0-21$ & Marmmal & 1 & 0.4 & & & & & 4 & & & \\
\hline 89 & $0-21$ & Mammal--large & 2 & 0.99 & & & & & 0 & & & \\
\hline 89 & $0-21$ & Mammal-very large & 16 & 74,94 & & & & & 0 & & & \\
\hline 89 & $0-21$ & Mammal-very large & 3 & 5.58 & & & & & 2 & & & \\
\hline 89 & $0-21$ & Meleagris gallopavo & 1 & 1.9 & Scapula & Proximal 1/2 & & & 0 & & & \\
\hline 89 & $0-21$ & Osleichthyes & 2 & 0.55 & & & & & 0 & & & \\
\hline 89 & $0-21$ & Pseudomys sp. & 1 & 0.62 & Curapace & Fragment & & & 0 & & & \\
\hline 89 & $0-21$ & Terrepene sp. & 1 & 1.62 & Carapace & Fragment & & & 0 & & & \\
\hline 89 & $0-21$ & Verebrala & 1 & 0.44 & & & & & 0 & & & \\
\hline 90 & 0.10 & Manmal & 1 & 0.79 & & & & & 0 & & & \\
\hline 90 & $10-45$ & Artiodactyl & 1 & 14.71 & Fenur & Diaphysis & & & 0 & & & Very heavily pitted \\
\hline 90 & $10-45$ & Manmal & 16 & 5.23 & & & & & 0 & & & \\
\hline 90 & $10-45$ & Sylvilagus sp. & 1 & 1.36 & Innominale & Illium \& acclabulum & $\mathrm{R}$ & & 0 & & & \\
\hline 92 & $0-10$ & Marmmul & 1 & 0.21 & & & & & 0 & & & \\
\hline 92 & $10-16$ & Mamnal & 1) & 0.3 & & & & & 0 & & & \\
\hline 93 & $10-20$ & Manmmal & 1 & 0.29 & & & & & 0 & & & \\
\hline 94 & $0-10$ & Aves & 1 & 0.08 & & & & & 0 & & & \\
\hline 94 & $0-10$ & Mammal & 8 & 3.47 & & & & & 0 & & & \\
\hline 94 & $0-10$ & Pylodictus olivaris & 1 & 0.33 & Vertebra & Frapment & & & 0 & & & \\
\hline 94 & $10-18$ & Mammal & 5 & 1.66 & & & & & 0 & & & \\
\hline 95 & $0-10$ & Mammal & 2 & 3.62 & & & & & 0 & & & \\
\hline 97 & $0-25$ & Ictalurts sp. & 1 & 0.12 & Vertcbra & Centrum & & & 0 & & & \\
\hline 97 & $0-25$ & Mammal & 3 & 6.01 & & & & & 2 & & & \\
\hline 97 & $0-25$ & Mummal & 67 & 35.33 & & & & & 0 & & & \\
\hline 97 & $0-25$ & Manmal & 3 & 0.7 & & & & & 2 & & & \\
\hline 97 & $0-25$ & Mammal & 1 & 0.26 & & & & & 3 & & & \\
\hline 97 & $0-25$ & Mammal-very large & 11 & 6.41 & & & & & 0 & & & \\
\hline 97 & $0-25$ & Pecari tajach & 1 & 1.67 & Carpa! & Completc & & & 0 & & & \\
\hline 97 & $0-25$ & Pecari tajacu & 1 & 1.23 & Carpal & Complete & & & 0 & & & \\
\hline 97 & 0.25 & Testudines & 2 & 0.39 & & & & & 0 & & & \\
\hline 97 & $0-25$ & Vertchrata & 1 & 0.13 & & & & & 0 & & & \\
\hline 97 & $25-35$ & Artiodactyl & 1 & 0.49 & Incisor & Almost complete & & & 0 & & & \\
\hline 97. & $25-35$ & Aves & 1 & 0.58 & & & & & 0 & & & \\
\hline 97 & $25-35$ & Bovinate & 1 & 1.89 & Incisor & Almost completc & & $Y$ & 0 & & & Nol erupled \\
\hline 97 & $25-35$ & Equus sp. & 1 & 22.42 & Molar & Fragment & & & 0 & & & \\
\hline 97 & $25-35$ & Marnmal & 103 & 35.19 & & & & & 0 & & & \\
\hline 97. & $25-35$ & Mammal & 1) & 0.1 & & & & & 2 & & & \\
\hline 97 & $25-35$ & Mammal & 1 & $0.6]$ & & & & & 4 & & & \\
\hline 97) & $25-35$ & Mammal-very large & 11 & 31.92 & & & & & 0 & & & \\
\hline 97 & $25-35$ & Osteichthycs & 1 & 0.26 & & & & & 0 & & & \\
\hline 97. & $25-35$ & Sylvilagus sp. & 1) & 0.11 & Melapodial & Proximal 3/4 & & & 0 & & & \\
\hline 97 & $35-45$ & Crotalus sp. & 1 & 0.3 & Vertebra & Almost completc & & & 0 & & & \\
\hline 97 & $35-45$ & Mammal & 34 & 11.82 & & & & & 0 & & & \\
\hline 97 & $35-45$ & Mammal--very large & 4 & 36.23 & & & & & 0 & & & \\
\hline 98 & $0-33$ & Aves & 1 & 0.44 & & & & & 0 & & & \\
\hline 98 & 0.33 & Bovinac & 1 & 1.59 & Incisor & Compleie & & & 0 & & & \\
\hline \begin{tabular}{l|l}
98 \\
\end{tabular} & $0-33$ & Gallus domesticus & 1 & 1.5 & Femur & Proximal 3/4 & & & 0 & & & \\
\hline 98 & $0-33$ & Mammal & 138 & 81.73 & & & & & 0 & & & \\
\hline 98 & $0-33$ & Marmmal & I & 0.82 & & & & & 2 & & & \\
\hline 98 & $0-33$ & Mammal & 2 & 1.11 & & & & & 3 & & & \\
\hline 98 & $0-3.3$ & Mammal-large & 2 & 4.02 & & & & & 0 & & & \\
\hline 98 & $0-33$ & Manmal-very large & 12 & 45.67 & & & & & 0 & & & \\
\hline 98 & $0-33$ & Marnmal-very large & 1 & 1.52 & & & & & 1 & & & \\
\hline 98 & $0-33$ & Munnal-very large & 2 & 2.8 & & & & & 2 & & & \\
\hline 98 & $0-33$ & Mummal--very large & 3 & 8.55 & & & & & 3 & & & \\
\hline 98 & $0-33$ & Odocoileus virginianus & 1) & 5.92 & Metalirsal & Fragment of diaphysis & & & 0 & & & \\
\hline 98 & 0.33 & Sylvilagus sp. & 1 & 0.17 & Calcancus & Almosl completc & & & 0 & & & \\
\hline 98 & $0-33$ & Trionyx sp. & 2 & 1.89 & Carapace & Fragment & & & 0 & & & \\
\hline 98 & $0-33$ & Veriebrata & 1 & 0.22 & & & & & 0 & & & \\
\hline 98 & $33-43$ & Aves & 2 & 0,57 & & & & & 0 & & & \\
\hline 98 & $33-43$ & Bovinac & 1 & 11.51 & Lumbar vertebra & Fragment of neural arch & & & 0 & & & \\
\hline 98 & $33-43$ & Bovinac & 1 & 5.66 & Molar & Frapment & & & 0 & & & \\
\hline 98 & $33-43$ & Mammal & 124 & 57.05 & & & & & 0 & & & \\
\hline 98 & $33-43$ & Mammi1 & 1 & 0.56 & & & & & 3 & & & \\
\hline 98 & $33-43$ & Mammal-very large & 12 & 40.62 & & & & & 0 & & & \\
\hline
\end{tabular}




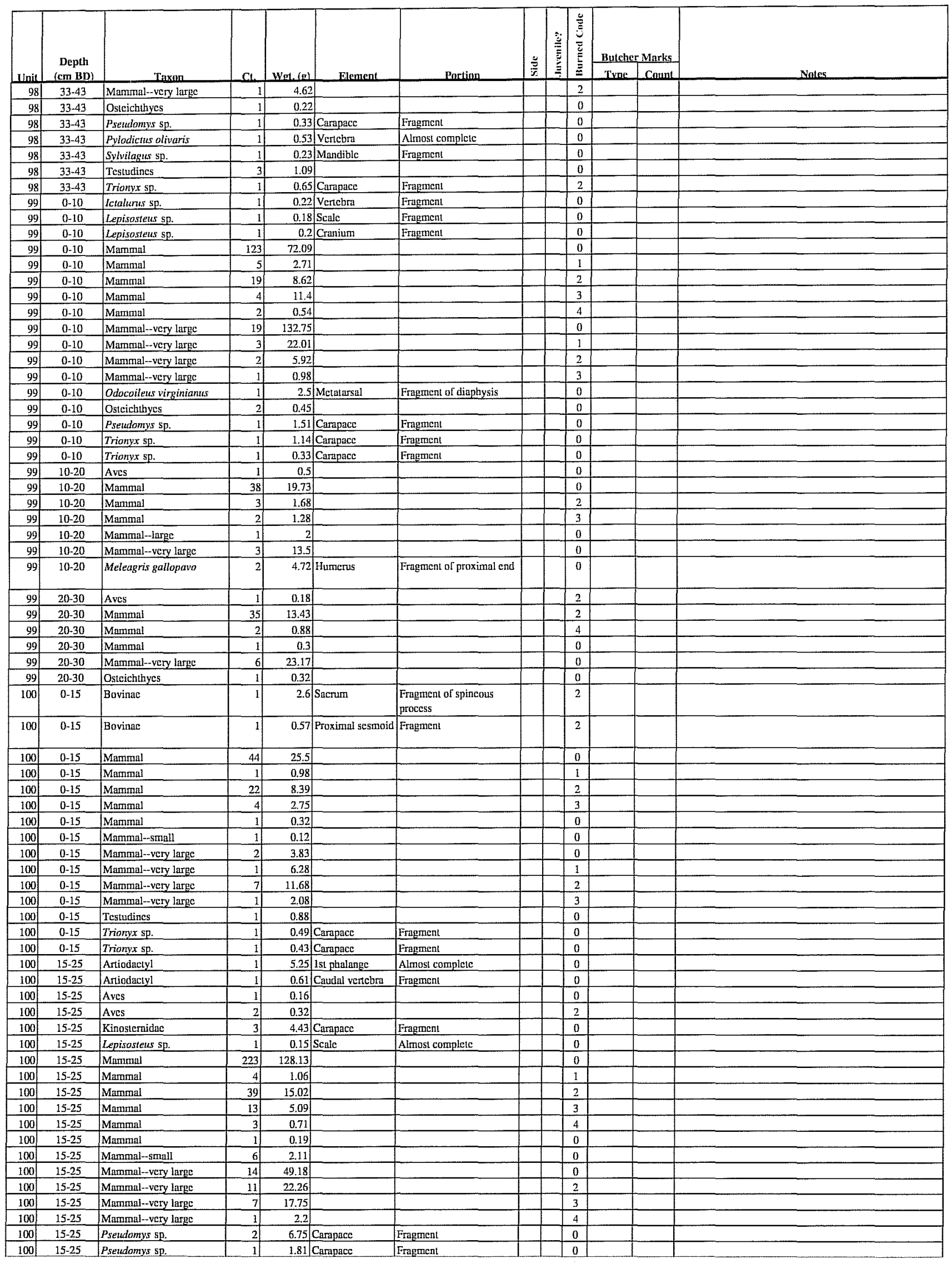




\begin{tabular}{|c|c|c|c|c|c|c|c|c|c|c|c|c|}
\hline & Depth & & & & & & 들 & $\frac{v}{0}$ & 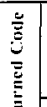 & Bulcher & Marks & \\
\hline Init & $(\mathrm{cm} \mathrm{BD})$ & Taxan & $\mathrm{Cl}$ & Wont (r) & Elemen: & Porting & 云 & & & Tras: & Count & Notes. \\
\hline 100 & $15-25$ & Pseudomys sp. & 1 & 0.62 & Carapace & Fragmenl & & & 0 & & & \\
\hline 100 & $15-25$ & Triony $x$ sp. & 2 & 1.04 & Carapace & Frapment & & & 0 & & & \\
\hline 100 & $15-25$ & Trionyx sp. & 1 & 0.61 & Carapnce & Fragmenl & & & 0 & & & \\
\hline 100 & $25-35$ & Avcs--very large & 1 & 1.08 & & & & & 0 & & & \\
\hline 100 & $25-35$ & Bovinne & 1 & 1.07 & Incisor & Completc & & & 0 & & & \\
\hline 100 & $25-35$ & Kinostemidue & 1 & 1.56 & Carapace & Fragmenl & & & 0 & & & \\
\hline 100 & $25-35$ & Lepisostens sp. & 1 & 0.11 & Scale & Complate & & & 0 & & & \\
\hline 100 & 25-35 & Mammal & 139 & 83.43 & & & & & 0 & & & \\
\hline 100 & $25-35$ & Mammal & 3 & 2.13 & & & & & 1 & & & \\
\hline 100 & 25.35 & Mammal & 25 & 11.89 & & & & & 2 & & & \\
\hline 100 & $25-35$ & Marmmal & 9 & 5.77 & & & & & 3 & & & \\
\hline 100 & $25-35$ & Mammal & 2 & 0.55 & & & & & 4 & & & \\
\hline 100 & $25-35$ & Mammal--small & 2 & 0.62 & & & & & 0 & & & \\
\hline 100 & 25.35 & Mammal-very large & 10 & 81.1 & & & & & 0 & & & \\
\hline 100 & $25-35$ & Mammal--vcry largc & 1 & 1.08 & & & & & 1 & & & \\
\hline 100 & $25-35$ & Mammal--very large & 10 & 37.13 & & & & & 2 & & & \\
\hline 100 & $25-35$ & Marnmal--very large & 3 & 6.43 & & & & & 3 & & & \\
\hline 100 & $25-35$ & Manmial-very large & 1 & 1.48 & & & & & 4 & & & \\
\hline 100 & $25-35$ & Ostcichthyes & 11 & 0.23 & & & & & 0 & & & \\
\hline 100 & $25-35$ & Sylvilagus sp. & 1 & 1.01 & Humerus & All but proximal epiphysis & $R$ & $\mathrm{Y}$ & 0 & & & Unsealed \\
\hline 100 & $25-35$ & Sylvilagus sp. & 1 & 0.39 & Lumbar vertebra & Almost completc & & & 0 & & & \\
\hline 100 & $25-35$ & Testudines & 1 & 0.66 & & & & & 0 & & & \\
\hline 100 & $35-45$ & Aves & 6 & 2.49 & & & & & 0 & & & \\
\hline 100 & $35-45$ & Aves--very large & 3 & 6.32 & & & & & 0 & & & \\
\hline 100 & $35-45$ & Ictaluries sp. & 1 & 0.45 & Vericbra & Centrum & & & 0 & & & \\
\hline 100 & $35-45$ & Ictalurus sp. & 1 & 0.16 & Pecloral spine & Proximal 1/2 & & & 0 & & & \\
\hline 100 & $35-45$ & Lepisosteus sp. & 1 & 0.2 & Cranium & Fragment & & & 0 & & & \\
\hline 100 & $35-45$ & Lepisosteius sp. & 1. & 0.15 & Scalc & Completc & & & 0 & & & \\
\hline 100 & $35-45$ & Lepisostetus sp. & 1 & 0.13 & Scale & Complete & & & 0 & & & \\
\hline 100 & $35-45$ & Mammal & 225 & 119.1 & & & & & 0 & & & \\
\hline 100 & $35-45$ & Mammal & 13 & 5.9 & & & & & 1 & & & \\
\hline 100 & $35-45$ & Mammal & 72 & 37.55 & & & & & 2 & & & \\
\hline 100 & $35-45$ & Mammal & 31 & 12.01 & & & & & 3 & & & \\
\hline 100 & $35-45$ & Mamma! & 8 & 2.22 & & & & & 4 & & & \\
\hline 100 & $35-45$ & Mammal-very large & 21 & 128.79 & & & & & 0 & & & \\
\hline 100 & $35-45$ & Mammal--very large & 2 & 3.36 & & & & & 4 & & & \\
\hline 100 & $35-45$ & Mammal--very large & 13 & 31.39 & & & & & 3 & & & \\
\hline 100 & $35-45$ & Mammal--very large & 14 & 40.71 & & & & & 2 & & & \\
\hline 100 & $35-45$ & Osteichthyes & 5 & 1.57 & & & & & 0 & & & \\
\hline 100 & $35-45$ & Pecari lajacu & 1 & 2.88 & Astralagus & Completc & $\mathrm{L}$ & & 0 & & & \\
\hline 100 & $35-45$ & Rodentia & 1 & 0.29 & Tibia & Diaphysis & & $Y$ & 0 & & & \\
\hline 100 & $35-45$ & Sylvilagus sp. & 1 & 0.42 & Mandible & Fragment & & & 0 & & & \\
\hline 100 & $35-45$ & Sylvilagus sp. & 1) & 0.44 & Calcancus & Almost completc & L & & 2 & & & \\
\hline 100 & $35-45$ & Veriebrain & 21 & 2.14 & & & & & 0 & & & \\
\hline 100 & $45-55$ & Artiodiactyl & 1 & 6.07 & Innominale & Fragment of acetabulum & & & 0 & & & \\
\hline 100 & $45-55$ & Artiodactyl & 1 & 1.68 & Innominatc & Fragment of acetabulum & & & 0 & & & \\
\hline 100 & $45-55$ & Aves & 1 & 0.34 & & & & & 0 & & & \\
\hline-100 & 45.55 & Aves & 1 & 1.05 & & & & & 0 & & & \\
\hline 100 & 45.55 & Bos taunis & 1 & 17.08 & $2+3$ carpal & Complelc & & & 0 & & & \\
\hline 100 & $45-55$ & Bos taurus & 1 & 23.29 & Ist phalange & Proximal 1/2 & & & 2 & 3 & 1 & \\
\hline 100 & $45-55$ & Bovinac & 1 & 2.77 & Distal sesmoid & Complete & & & 0 & & & \\
\hline 100 & $45-55$ & Bovinac & 1 & 10.29 & \begin{tabular}{|l} 
Deciduous \\
premolar
\end{tabular} & Almost complete & $\mathrm{L}$ & $\bar{Y}$ & 0 & & & Did not enupl \\
\hline 100 & $45-55$ & Bovinae & 1 & 4.55 & Molar & Fragment & & & 2 & & & \\
\hline 100 & 45.55 & Ictalurus sp. & 1 & 0.520 & Cranium & Eragment & & & 0 & & & \\
\hline 100 & $45-55$ & Ictalurzes sp. & 1 & 0.41 & Pectornal spine & Almosi complele & & & 0 & & & \\
\hline 100 & $45-55$ & Ictalunts sp. & 1 & 0.29 & Dorsal spine & Fragment of proximal end & & & 0 & & & \\
\hline 100 & $45-55$ & Mammal & 364 & 195.19 & & & & & 0 & & & \\
\hline 100 & $45-55$ & Mammn] & 13 & 10.24 & & & & & 1 & & & \\
\hline 100 & $45-55$ & Manmal & 154 & 97.19 & & & & & 2 & & & \\
\hline 100 & $45-55$ & Mammal & 31 & 29.63 & & & & & 3 & & & \\
\hline 100 & $45-55$ & Mammal & 14 & 10.37 & & & & & 4 & & & \\
\hline 100 & $45-55$ & Manmal-very large & 22 & 105.75 & & & & & 0 & & & \\
\hline 100 & $45-55$ & Mammal-very large & 5 & 25.66 & & & & & 2 & & & \\
\hline 100 & $45-55$ & Mammal--very large & 9 & 35.65 & & & & & 3 & & & \\
\hline 100 & $45-55$ & Odocoileas virginianus & 1. & 6.1 & 1 st pholange & Compleic & & & 0 & & & \\
\hline 100 & $45-55$ & Osteichthyes & 2 & 0.82 & & & & & 0 & & & \\
\hline 100 & $45-55$ & Procyon lotor & 1 & 0.69 & Cervical vertebra & Complete & & $\mathrm{Y}$ & 0 & & & Centrum unscaled \\
\hline
\end{tabular}




\begin{tabular}{|c|c|c|c|c|c|c|c|c|c|c|c|c|}
\hline \multirow[b]{2}{*}{ Unit } & \multirow{2}{*}{$\begin{array}{c}\text { Depth } \\
\text { (cm BD) }\end{array}$} & \multirow[b]{2}{*}{ Taxnn } & \multirow[b]{2}{*}{ Ct. } & \multirow[b]{2}{*}{ Wot. (g) } & \multirow[b]{2}{*}{ Element } & & $\because$ & 晜 & 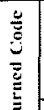 & Butcher & Marks & \\
\hline & & & & & & Partime & $\tilde{z}_{i}$ & & & Trne & Count & Notes \\
\hline 100 & $45-55$ & Tesludines & 1 & 0.62 & & & & & 0 & & & \\
\hline 100 & $45-55$ & Trionyx sp. & 1 & 0.35 & Carapace & Eragmena & & & 0 & & & \\
\hline 100 & $45-55$ & Trionyx sp. & 2 & 0.35 & Carapace & Fragment & & & 2 & & & \\
\hline 100 & $45-55$ & Vertebrita & 5 & 1.42 & & & & & 0 & & & \\
\hline 100 & $55-65$ & Aghistrodon sp. & 1 & 0.12 & Vencbra & Complate & & & 0 & & & \\
\hline 100 & $55-65$ & Aves & 2 & 0.32 & & & & & $\underline{2}$ & & & \\
\hline 100 & $55+65$ & Aves-medium & I & 0,09 & & & & & 0 & & & \\
\hline 100 & $55-65$ & Avesw-very large & 11 & 0.31 & & & & & 0 & & & \\
\hline 100 & $55-65$ & Bos taunis & I & 104,24 & Calcancus & Almost completc & $\mathrm{R}$ & & 0 & & & \\
\hline 100 & $55-65$ & Bovinac & 1 & 22.88 & Thoracic vertebra & Spineous process & & & 0 & $\begin{array}{l}2 \\
3 \\
\end{array}$ & 2 & \\
\hline 100 & $55-65$ & Buvinac & 1 & 13.97 & $\mathrm{Rib}$ & Fragment & & & 0 & $\begin{array}{l}2 \\
7 \\
\end{array}$ & $\begin{array}{l}2 \\
1 \\
\end{array}$ & \\
\hline 100 & 55.65 & Bovinae & 1 & 9.02 & Rib & Fragment & & & 0 & 3 & 4 & \\
\hline 100 & $55-65$ & Marmmal & 224 & 117.04 & & & & & 0 & & & \\
\hline 100 & $55-65$ & Mamminl & 18 & 7.45 & & & & & 4 & & & \\
\hline 100 & $55-65$ & Mammal & 15 & 17.02 & & & & & 3 & & & \\
\hline 100 & $55-65$ & Mammal & 173 & 112.1 & & & & & 2 & & & \\
\hline 100 & $55-65$ & Mammal & 39 & 26.21 & & & & & 1 & & & \\
\hline 100 & $55-65$ & Mammal-large & 5 & 4.1 & & & & & 0 & & & \\
\hline 100 & $55-65$ & Marnmal-medium & 1 & 1.51 & & & & & 2 & & & \\
\hline 100 & $55-65$ & Mammal--very large & 23 & 119.34 & & & & & 0 & & & \\
\hline 100 & $55-65$ & Mammal--very larpe & 1 & 0.64 & & & & & 1. & & & \\
\hline 100 & 55.65 & Mummal--very large & 32 & 123.47 & & & & & 2 & & & \\
\hline 100 & $55-65$ & Marmmal--very large & 7 & $\underline{24.71}$ & & & & & 3 & & & \\
\hline 100 & 55.65 & Mammal--very small & 2 & 0.13 & & & & & 0 & & & \\
\hline 100 & $55-65$ & Meleagris gallopavo & 1 & 2.13 & Innominate & Acctabulum & & & 0 & & & \\
\hline 100 & $55-65$ & Odocoileus virginianus & 1 & 5.91 & 1st phalange & Alnnost completc & & & 0 & & & \\
\hline 100 & $55-65$ & Ouis aries & 1 & 7.24 & Radius & Disial $1 / 3$ & & & 0 & & & \\
\hline 100 & $55-65$ & Sylvilagus sp. & 1. & 0.38 & Calcancus & Complate & $R$ & & 1 & & & \\
\hline 100 & $55-65$ & Sylvilagus sp. & 1 & 0.56 & Innominate & Acctabulum & & & 0 & & & \\
\hline 100 & $55-65$ & Sylvilagus sp. & 1 & 0.11 & Metapodial & Completc & & & 0 & & & \\
\hline 100 & 55.65 & Testudines & 3 & 2.65 & & & & & 0 & & & \\
\hline 100 & 55.65 & Trioryx sp. & 1 & 1.5 & Carapace & Fragment & & & 1 & & & \\
\hline 100 & $55-65$ & Trionyx sp. & 1 & 1.77 & Carapace & Fragment & & & 0 & & & \\
\hline 100 & $55-65$ & Trionyx sp. & 1 & 0.39 & Carapace & Fragment & & & 0 & & & \\
\hline 100 & 55-65 & Trionyx sp. & 1 & 0.33 & Rib end & Fragment & & & 0 & & & \\
\hline 100 & $55-65$ & Trionyx sp. & 1 & 0.77 & Carapace & Fragrnent & & & 0 & & & \\
\hline 100 & $55-65$ & Trionyx sp. & 1 & 0.38 & Caratpace & Fragmant & & & 0 & & & \\
\hline 100 & $55-65$ & Trianyx sp. & 1 & 0.33 & Carapace & Fragment & & & 0 & & & \\
\hline 100 & $55-65$ & Vertebratia & 1 & 0.47 & & & & & 2 & & & \\
\hline 100 & $55-65$ & Vertebrata & 2 & 1.44 & & & & & 0 & & & \\
\hline 100 & $65-75$ & Arliodactyl & 1 & 8.76 & Melapodial & Distal $1 / 4$ & & $Y$ & 0 & & & Condyle unsedled \\
\hline 100 & $65-75$ & Aves & 6. & 2.36 & & & & & 0 & & & \\
\hline 100 & $65-75$ & Aves & 2 & 0.39 & & & & & 2 & & & \\
\hline 100 & $65-75$ & Bos taurus & 2 & 15.88 & 3rd phalange & Almost complelc & & & 0 & & & \\
\hline 100 & $65-75$ & Bos taunes & 1 & 14.09 & 2nd phalange & Completc & & & 0 & & & \\
\hline 100 & $65-75$ & Bovinac & 1 & 12.92 & Molar & Fragment & & & 0 & & & \\
\hline 100 & 65.75 & Bovinac & 1 & 16.44 & Molar & Fragment & & & 2 & & & \\
\hline 100 & $65-75$ & Bovinac & 1. & 12.31 & 1st phalange & Proximal $1 / 2$ & & & 2 & & & \\
\hline 100 & $65-75$ & Bovinac & 1 & 4.23 & 2ni phalange & Proximal end & & & 1 & & & \\
\hline 100 & $65-75$ & Bovinac & 1 & 7.78 & MelapodiaI & Fragment of condyle & & & 3 & & & \\
\hline 100 & 65.75 & Ictalurtes sp, & 1 & 0.33 & Vertebre & Centrum & & & 0 & & & \\
\hline 100 & $65-75$ & Ictalurtus sp. & 1 & 1.13 & Operculum & Fragment & & & 0 & & & \\
\hline 100 & $65-75$ & Lepisostetus $\mathrm{sp}$. & 1 & 0.19 & Sente & Complete & & & 0 & & & \\
\hline 100 & $65-75$ & Manmal & 159 & 94.58 & & & & & 0 & & & \\
\hline 100 & $65-75$ & Manmal & 27 & 14.65 & & & & & 4 & & & \\
\hline 100 & $65-75$ & Mammal & 71 & 39.7 & & & & & 3 & & & \\
\hline 100 & $65-75$ & Mammal & 102 & 82.41 & & & & & 2 & & & \\
\hline 100 & 65.75 & Manmal & 12 & 8.92 & & & & & 1 & & & \\
\hline 100 & 65.75 & Manmal--large & 4 & 8.05 & & & & & 0 & & & \\
\hline 100 & $65-75$ & Marmmal--large & 1 & 3.59 & & & & & 2 & & & \\
\hline 100 & $65-75$ & Mammal--large & 1 & 1 & & & & & 4 & & & \\
\hline 100 & $65-75$ & Mammal-very large & 30 & 165.01 & & & & & 0 & & & \\
\hline 100 & 65.75 & Mammal-very large & 4 & 13.4 & & & & & 4 & & & \\
\hline 100 & $65-75$ & Marnmal--very large & 7 & 24.64 & & & & & 3 & & & \\
\hline 100 & $65-75$ & Mammal--very large & 21 & 99.81 & & & & & 2 & & & \\
\hline 100 & $65-75$ & Mammal-very large & 2 & 9.13 & & & & & 1 & & & \\
\hline 100 & $65-75$ & Meleagris gallopavo & 1. & 0.85 & Dentury & Anterior 2/3 & & & 0 & & & \\
\hline 100 & $65-75$ & Meleagris gallopavo & 1. & 5.54 & Tibiotarsus & Distal $1 / 4$ & $\mathrm{~L}$ & & 0 & 7 & 1 & \\
\hline 100 & $65-75$ & Meleagris gallopavo & 1. & 4.64 & Fermur & Proximal 1/4 & $\mathrm{L}$ & & 0 & 7 & 1 & \\
\hline 100 & $65-75$ & Odocoileus virginianus & 1 & 1.67 & 3 rd phalange & Compleis & & & 0 & & & \\
\hline 100 & $65-75$ & Psendomys sp. & 1 & 2.77 & Carapace & Fragment & & & 1 & & & \\
\hline
\end{tabular}




\begin{tabular}{|c|c|c|c|c|c|c|c|c|c|c|c|c|}
\hline Unit & $\begin{array}{c}\text { Depth } \\
\text { (cm BD) }\end{array}$ & Taxon & $\mathrm{Cl}$ & $W_{0}(g)$ & Elemenit & Portion. & 泀 & | & 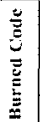 & Butcher & Marks & Notes \\
\hline 100 & $65-75$ & Psetudomys sp. & 1 & 1.74 & Carapace & Fragment & & & 0 & & & \\
\hline 100 & $65-75$ & Pseudomys sp. & 1 & 1.84 & Carupace & Fragment & & & 1 & & & \\
\hline 100 & $65-75$ & Terrepene sp. & 1 & 1.72 & Carapace & Fragment & & & 0 & & & \\
\hline 100 & $65-75$ & Testudincs & 2 & 2.52 & & & & & 0 & & & \\
\hline 100 & $65-75$ & Tesudincs & 1 & 0.52. & & & & & 0 & & & \\
\hline 100 & $65-75$ & Trionyx sp. & 1 & 0.19 & Carapace & Fragment & & & 1 & & & \\
\hline 100 & $65-75$ & Vertcbrala & 4 & 1.75 & & & & & 0 & & & \\
\hline 102 & $0-10$ & Alligator mississippiensis & 1 & 1.14 & Scute & Almost complete & & & 0 & & & \\
\hline 102 & $0-10$ & Alligator mississippiensis & 1 & 1.51 & Scute & Centrum & & & 0 & & & \\
\hline 102 & $0-10$ & Alligator mississippiensis & 1 & 1.02 & Scule & Centum & & & 0 & & & \\
\hline 102 & $0-10$ & Alligator mississippiersis & 1 & 1.24 & Scule & Centrum & & & 0 & & & \\
\hline 102 & $0-10$ & Bovinac & 1 & 7.56 & Premolar & Fragmen! & & & 0 & & & \\
\hline 102 & $0-10$ & Mammal & 154 & 68.05 & & & & & 0 & & & \\
\hline 102 & $0-10$ & Mummal & 2 & 1.26 & & & & & 1 & & & \\
\hline 102 & $0-10$ & Manmal & 6) & 259 & & & & & 2 & & & \\
\hline 102 & $0-10$ & Mammal & 7 & 3.77 & & & & & 3 & & & \\
\hline 102 & $0-10$ & Mammal & 9 & 4,74 & & & & & 4 & & & \\
\hline 102 & $0-10$ & Mammal--very large & 6 & 42.75 & & & & & 0 & & & \\
\hline 102 & $0-10$ & Mammal--very large & 5 & 18.32 & & & & & 2 & & & \\
\hline 102 & $0-10$ & Mammal--very large & 1 & 18.82 & & & & & 1 & & & \\
\hline 102 & $0-10$ & Mummal--very large & 1 & 5.1 & & & & & 3 & & & \\
\hline 102 & $0-10$ & Mammal--very large & 1 & 1.14 & & & & & 4. & & & \\
\hline 102 & $0-10$ & Pyladictus olivaris & 2 & 1.53 & Dentary & Framen & & & 0 & & & \\
\hline 102 & $0-10$ & Venebrata & 9) & 15.87 & & & & & 0 & & & \\
\hline 103 & $25-43$ & Aves-large & 1 & 2.19 & & & & & 0 & & & \\
\hline 103 & $25-43$ & Bovinat & 1] & 12.55 & Molar & Aimosi completc & & $Y$ & 0 & & & Did not crupl \\
\hline 103 & $25-43$ & Mammal & 26 & 20.27 & & & & & 0 & & & \\
\hline 103 & $25-43$ & Mammal & 1) & 1.7 & & & & & 2 & & & \\
\hline 103 & $25-43$ & Mammal-very large & 6) & 38.55 & & & & & 0 & & & \\
\hline 104 & $0-23$ & Mammal & 10 & 3.29 & & & & & 0 & & & \\
\hline 104 & 23-38 & Mammal & 12 & 10.41 & & & & & 0 & & & \\
\hline 104 & $38-49$ & Mammal & 5 & 1.47 & & & & & 0 & & & \\
\hline 104 & $38-49$ & Mammal--very large & 2. & 3.01 & & & & & 0 & & & \\
\hline \multicolumn{2}{|c|}{$\begin{array}{l}\text { Unit between } \\
\text { churches }\end{array}$} & Marimal & 13 & 4.23 & & & & & 0 & & & \\
\hline \multicolumn{2}{|c|}{$\begin{array}{l}\text { Unil between } \\
\text { churches }\end{array}$} & Mammal & 1 & 0.92 & & & & & 4 & & & \\
\hline \multicolumn{2}{|c|}{$\begin{array}{l}\text { Unit between } \\
\text { eturehes }\end{array}$} & Mammal--very large & 4 & 9.39 & & & & & 0 & & & \\
\hline \multicolumn{2}{|c|}{$\begin{array}{l}\text { Unit between } \\
\text { churcbes }\end{array}$} & Mammal--very large & 1 & 6.86 & & & & & 4 & & & \\
\hline
\end{tabular}



Appendix C

Geophysical Survey 
Figure C-1. Mission Rosario geophysical survey of previous excavations.

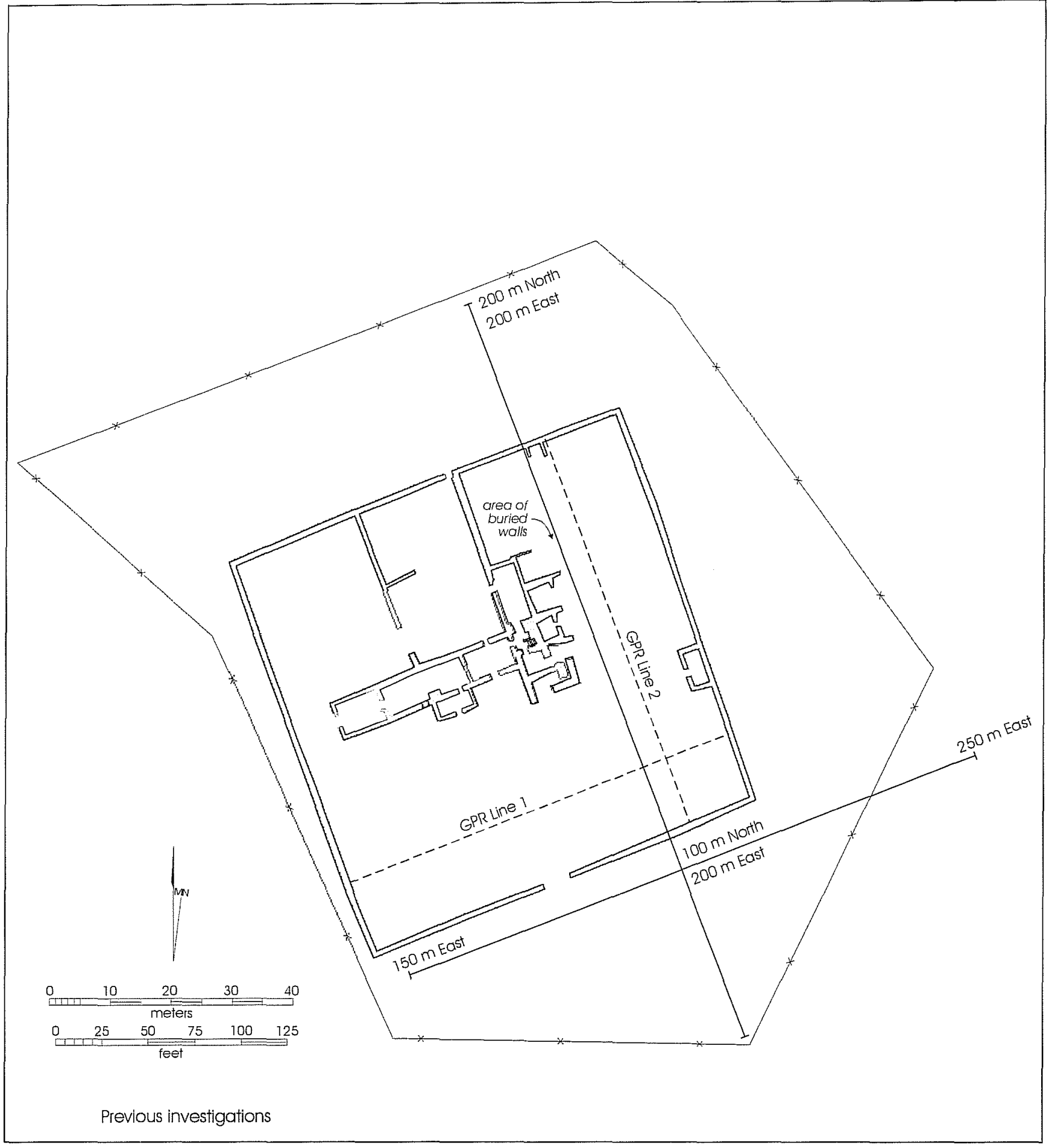

The outer line marks the chain-link fence that surrounds the site. Standing walls are shown and areas excavated in 1973, 1974, 1997, and 1998 and sections of buried wall found during that work are shown in gray. The local coordinate system established for the purpose of the geophysical survey is oriented parallel and perpendicular to the north fence line. The East-West $(x)$ axis is parallel to the north fence line. The North-South $(y)$ axis passes through the southern-most fence post. 


\section{Geophysical Survey of Mission Rosario}

\author{
John Dunbar and Michael Cagle
}

\section{Introduction}

The following is a report on a geophysical survey conducted at the Nuestra Señora del Rosario Mission site near Goliad, Texas between July 27 and July 30, 1999. The survey was conducted by John Dunbar of Baylor University, Department of Geology with the assistance of student Michael Cagle.

The geophysical survey was conducted in support of excavations being carried out by personnel from the Center for Archaeological Research (CAR) at The University of Texas at San Antonio (UTSA) at the Rosario site. These excavations began the week of July 25, 1999 and extended to the end of August, 1999. Four previous excavations of the Mission Rosario site occurred between 1940-1941, 1972-1973, 19731974, and 1997-1998. Several buried walls were found, but not completely excavated, in work done in 1970s (Figure C-1). The goal of the geophysical survey was to define the extent and shape of buried structures within the compound walls, and areas immediately outside the walls. An additional goal was to locate trenches and test units from past excavations as an aid to compiling a comprehensive map of previous work completed at the site.

\section{Procedures}

Two different geophysical tools were used. First, an electromagnetic conductivity meter (EM), was used to map ground electrical conductivity throughout the fenced area of the site. This was done using an EM31 instrument from Geonics Limited, Mississauga, Ontario, Canada. The EM data provide an overview map of the entire site that indicates the horizontal position and shape of buried structures. The instrument package consists of a $4 \mathrm{~m}$ long antenna, electronics model, and a separate data logger. Measurements are made and logged for later processing by a button push as the user walks along measured profiles. The instrument measures ground conductivity in units of $\mathrm{mS} / \mathrm{m}$ (milliSiemens per meter) which decreases sensitively with depth. In the normal mode of operation, with the instrument held $1 \mathrm{~m}$ above the ground, the response to conductive material at a depth of $2.75 \mathrm{~m}(9 \mathrm{ft})$ is $50 \%$ of that of the same material at ground surface.

To provide the maximum horizontal resolution obtainable with the EM 31 , measurements were made on a 1 $\mathrm{m}$ by $1 \mathrm{~m}$ grid throughout the site (Figure $\mathrm{C}-2$ ). Only areas within the remaining walls of the central (Church) building were not sampled. The fenced area of the site is approximately 1.2 hectares, hence, the EM survey required approximately 12,000 measurements. For efficiency, the measurements were made along grid lines oriented parallel to the north fence, which is approximately parallel to the north and south walls of the compound (Figure C-1). A central reference line was defined which extends at an angle of $90^{\circ}$ ( $\sim$ south) from the trend of the north fence and ends at the southern-most fence post. For the purposes of the geophysical survey, we defined the north end of this reference line as $200 \mathrm{~m}$ North, $200 \mathrm{~m}$ East. Survey profiles were spaced at $1 \mathrm{~m}$ intervals along this reference line and extended east-west, to the irregular east and west fence lines. Additional short profiles, offset from the main lines, were required to infill around interior walls. Approximately 150 profile lines were collected. A map was then constructed showing variations in ground electrical conductivity in shades of gray throughout the fenced site (Figure C-3). The EM map required 3-1/2 days of field work to complete.

The second geophysical tool used was ground penetrating radar (GPR). The EM map shows the horizontal position and shape of buried structures, but not their depth or vertical shape. GPR produces a vertical cross-section, which can provide this information and can help identify the features. Our main objective was to discriminate between conductivity anomalies produced by buried walls and those produced by old exploration trenches. The GPR system includes a set of antennas, which are connected to a control module, which is connected to a laptop computer. The data are collected by moving the antennas along a profile, collecting vertical GPR soundings at even distance increments. After acquisition the data are digitally 
Figure C-2. Locations of ground conductivity measurements. Approximately 12,000 measurements were made.

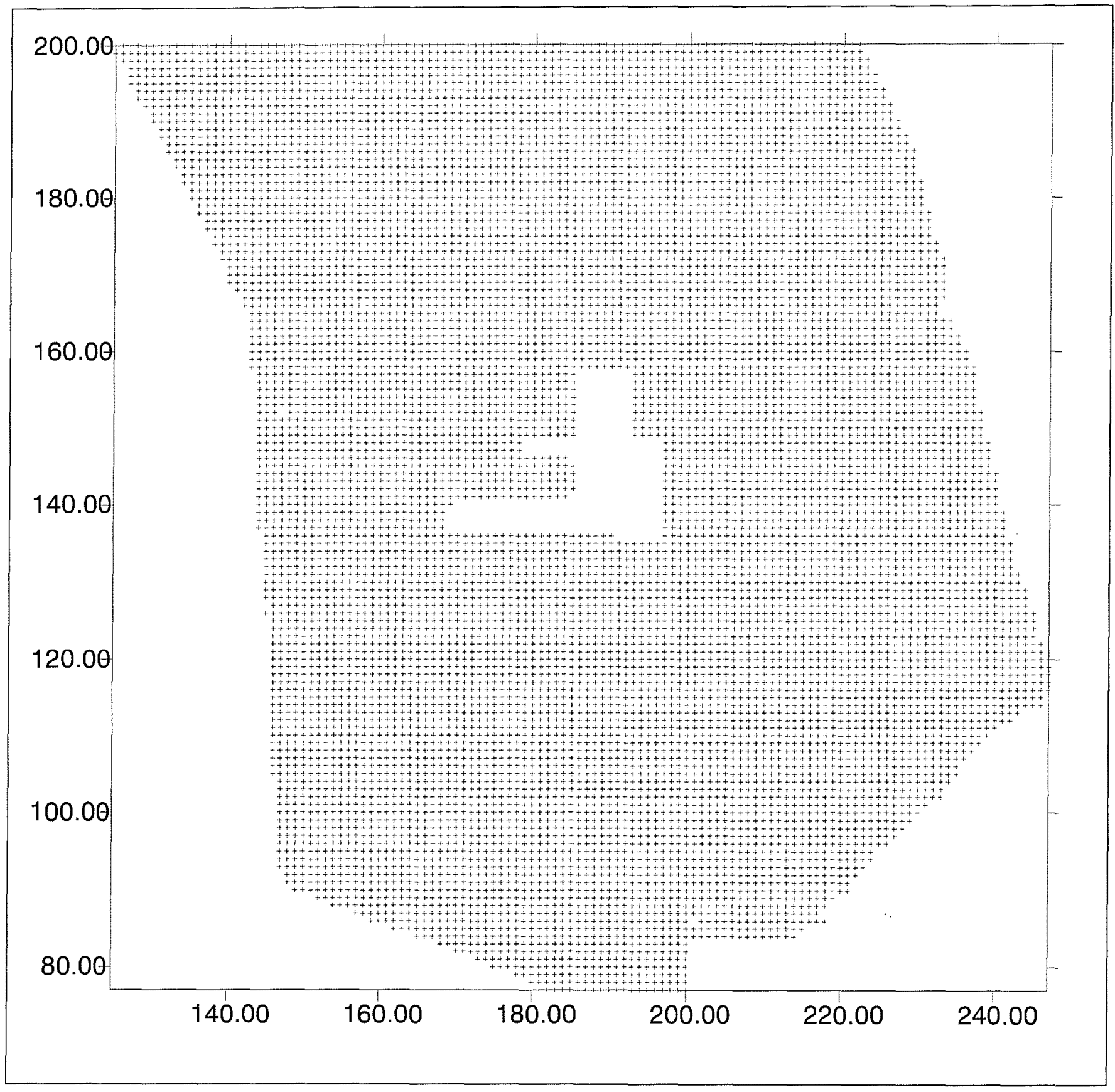

Local Geophysical coordinates (meters) 
Figure C-3. Ground conductivity map of the Rosario site.

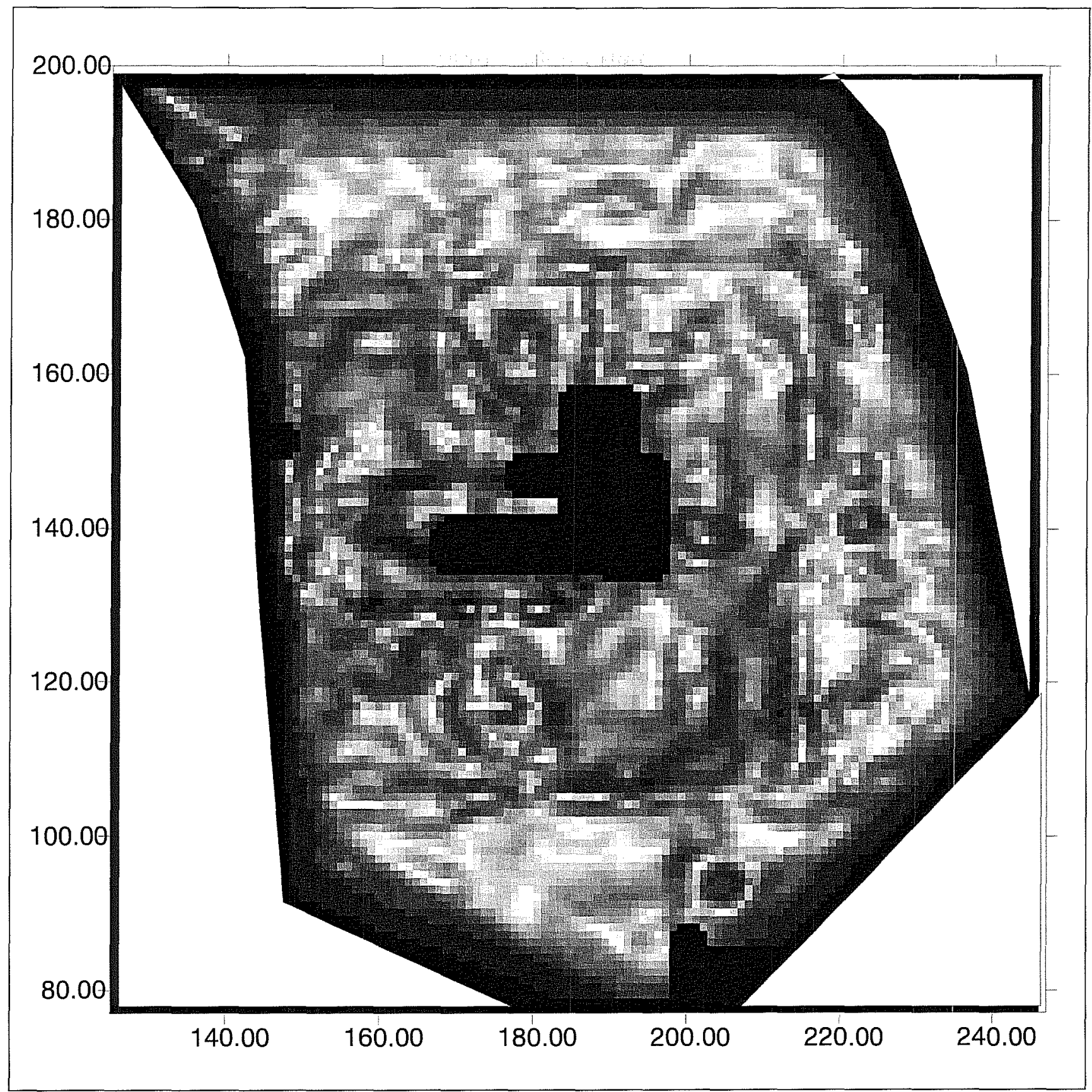

Local geophysical coordinates (meters)

Measurements were made with the EM31 ground conductivity meter. Over the site ground conductivity varies from $20 \mathrm{mS} / \mathrm{m}$ (white) to $40 \mathrm{mS} / \mathrm{m}$ (dark gray). A chain-link fence around the site produces false conductivity readings in the 60 to $120 \mathrm{mS} / \mathrm{m}$ range that mask the true ground conductivity to a distance of $7 \mathrm{~m}$ from the fence. The central black region corresponds to the area of no data coverage shown in Figure $C-2$. 
processed and the traces plotted side-by-side to produce cross sections. Source frequency is the main operational variable. For the Rosario site, we used a source frequency of $200 \mathrm{MHz}$, which is the highest frequency our system (the PulseEKKO IV, from Sensors \& Software Inc., Canada) will produce. The 200 MHz source produces radar waves that are approximately $50 \mathrm{~cm}$ long in the ground and can generally resolve layers and objects on the scale of $12 \mathrm{~cm}$.

The depth of penetration of GPR is primarily controlled by ground conductivity and is approximately given by the expression...

$$
\mathrm{Z}_{\max }=35 / \mathrm{C} \text {, }
$$

... where $\mathbf{Z}_{\max }$ is the expected maximum penetration in meters and $C$ is the ground conductivity in units of $\mathrm{mS} / \mathrm{m}$. At the Rosario site ground conductivity varies from 20 to $40 \mathrm{mS} / \mathrm{m}$. Hence, it was expected that the GPR penetration would range between $90 \mathrm{~cm}$ and 175 $\mathrm{cm}$. The shallowest depth that can be imaged with a given source frequency is limited by the duration of the direct wave between source and receiver antenna. In the case of $200 \mathrm{MHz}$ source, the shallowest depth is $50 \mathrm{~cm}$. Therefore, we expected to image targets in the relatively narrow depth window between $50 \mathrm{~cm}$ and $90-175 \mathrm{~cm}$.

With a required $10 \mathrm{~cm}$ trace spacing to achieve adequate spatial sampling of the $200 \mathrm{MHz}$ data, the GPR data was approximately ten times more labor intensive to collect than the EM data. We collected only two profiles across the interior courtyard area (Figure $\mathrm{C}-1$ ). Line 1 crosses the courtyard in an east-west orientation, south of the central (Church) building, along the $120 \mathrm{~m}$ North line. Line 2 crosses the courtyard in a north-south orientation east of the central building, along the $203 \mathrm{~m}$ East line. After acquisition the lines were digitally processed to remove low frequency source-related noise (WOW), and scattering from surface obstructions such as the fence and trees.

\section{EM Results}

The ground conductivity map produced in this survey contains a complex set of overlapping anomalies (Figure $\mathrm{C}-3$ ). The chain-link fence surrounding the site masks the more subtle ground conductivity variations out to a distance of $7 \mathrm{~m}$ in all directions. Most of the variation in ground conductivity over the site likely results from a combination of colonial-age construction and twentieth century excavation. For clarification, we have numbered 20 of the most obvious features on the ground conductivity map (Figure $\mathrm{C}-4$ ). In Figure C-5, we superimpose the conductivity map with known surface and subsurface structures and excavation sites. The following is a description of those features, together with possible causes:

(1) The outer wall of the mission compound is defined by a linear conductivity low (white) with relative conductivity highs to either side in most places. Most of this anomaly probably stems from the contrast between the stone foundation of the wall and the surrounding soil. There are two apparent breaks in the wall. The break in the anomaly in the middle of the south wall corresponds to an actual break in the surface expression of the wall. The second is in the middle of the east wall. There is no break in the surface wall at this location. One possible explanation is that there is something different about the wall foundation at this location. Perhaps this was an early entrance that was later closed. The west wall is obscured by its close proximity to the west chain-link fence.

(2) This is a series of three circular conductivity highs with central conductivity lows, located outside the compound walls along a northsouth line. Each is approximately $5 \mathrm{~m}(16 \mathrm{ft})$ in diameter. There is a similar feature (Anomaly 15) adjacent to the north-east corner of the outer wall. These may be the sites of native houses, with central hearths. 
(3) Rectangular conductivity low, ringed by an offset conductivity low belt. This could be a buried structure, but is more likely a large excavation pit with remaining spoil from the pit forming the ringing conductivity low. This pattern of a central conductivity anomaly ringed by another is also seen in anomalies 7 , 16 , and 19.

(4) Apparent excavation pit without a spoil pile.

(5) This is a $6 \mathrm{~m}$ diameter circular conductivity high. There is a large bush located at the center of this anomaly which may be its source. However, trees and bushes tend to produce conductivity lows caused by water withdraw from the surrounding soil and there are no significant anomalies associated with the several large trees on the site. We suspect that this may be a trash pit or large native structure and that the location of the bush within it is a coincidence.

(6) Possible trench and pit excavations and associated spoil piles.

(7) Circular excavation pit with central trenches cut east-west and north-south. The surrounding spoil piles form a ring $13 \mathrm{~m}$ in diameter. The spoil pile is broken in the north by the north-south trench line. A small square test unit appears to have been dug north of the trench. There is a noticeable surface depression at this site.

(8) Possible excavation pit or buried structure.

(9) Rectangular anomalies with no surface expression are possible buried structures. The central feature forms a north-south line with Anomaly 12 to the north.

(10) Elongate and curved conductivity high that winds around and between the features in Anomaly 9, from the gap in the south wall, towards the apparent gap in the east wall. The trend appears to continue as a conductivity low outside the east wall and end at the north-most Anomaly 2 feature, previously identified as a native house. This may be the remnants of a foot trail. A similar feature is seen on the opposite side of the compound, in Anomaly 18 .

(11) Oval conductivity high with a long axis of 10 $m$ and a central conductivity low. We have no idea what this could be, but it is one of the highest amplitude anomalies at the site.

(12) Possible buried structures. The northern parts of these buried structures were found in the excavations of the $1970 \mathrm{~s}$.

(13) Apparent excavation pit and adjacent spoil piles.

(14) Three rectangular anomalies forming an eastwest line, roughly centered in the three interior walled partitions of the compound. These are possibly buried structures. The western member of the series appears to coincide with an uncovered section of stone floor.

(15) Possible native house site.

(16) Possible excavation trenches and associated spoil piles.

(17) Anomalies associate with north-south partition walls at the surface.

(18) Possible foot path that crosses (pre-dates?) the western-most partition wall, passes to the north of the western feature of Anomaly 14 and then turns south.

(19) Possible excavation pit and associated spoil piles.

(20) This is a faint ring-anomaly, approximately $22 \mathrm{~m}$ in diameter, that wraps around the west end of the central church building and extends another $16 \mathrm{~m}$ east, parallel to the south wall of the church. The cause of this anomaly is not clear. It could be a long excavation trench, a walkway around the church, or a buried wall of some earlier structure. 
Figure C-4. Numbered ground conductivity anomalies described in Appendix C.

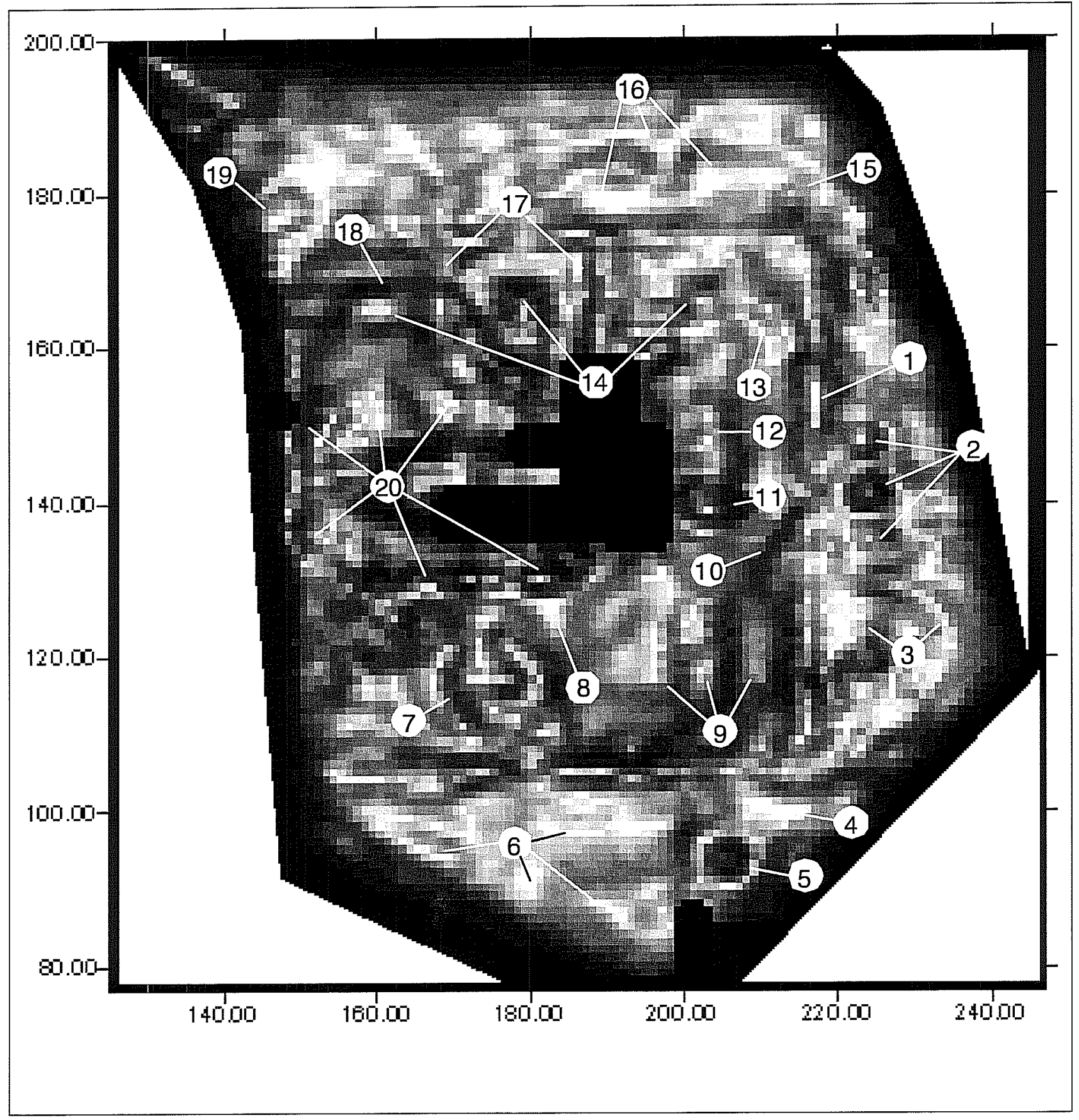


Figure C-5. Superimposed EM conductivity and Rosario site maps.

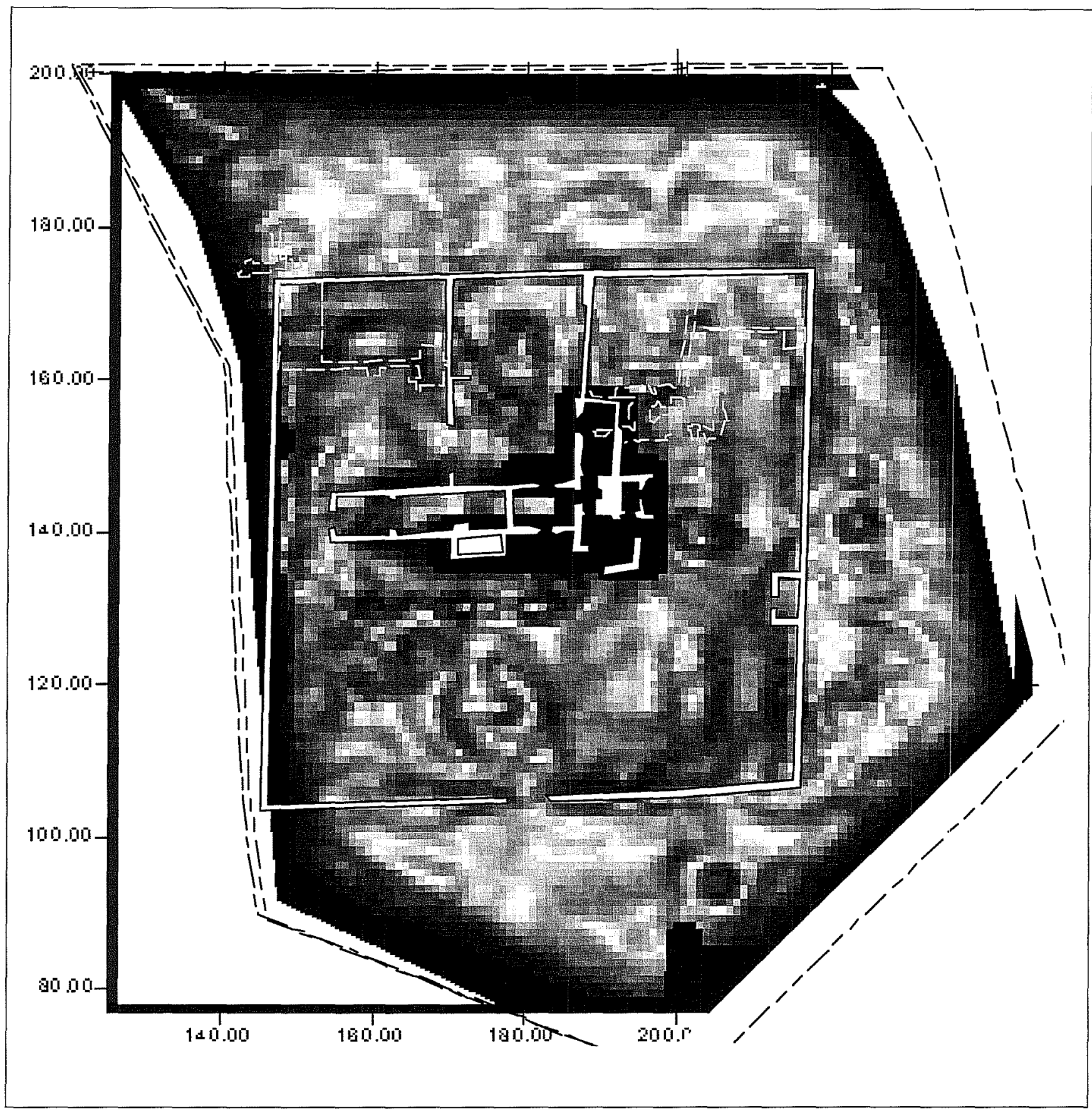




\section{GPR Results}

The limited GPR data we collected were not as revealing as the EM data, but do indicate that GPR could be useful for discriminating between excavations and buried structures (Figure $\mathrm{C}-6$ ). The nearly flat band at the top of each section is the direct signal arrival between the source to receiver antenna. Immediately below the direct arrival is a reflection from a soil horizon, which is perhaps the top of the Pleistocene clay that underlies the Colonial surface over the site. Along the profiles, two-way travel times to this surface range from $<10 \mathrm{~ns}$ ( $50 \mathrm{~cm}$ depth) to $15 \mathrm{~ns}$ (75 cm depth). Where Line 1 crosses Anomaly 7 (Figure C-4), identified as an excavation pit, the reflection becomes disrupted, missing, or occurs later in time (Figure $\mathrm{C}-6 \mathrm{a}$ ). This is likely an indication that the reflector has been disturbed. The GPR pattern over proposed buried structures is different. Where Lines 2 cross Anomalies 9 and 12, a series of hyperbolic-shaped defractions emanate from a rough surface approximately $30 \mathrm{~cm}$ below the surface (Figure $\mathrm{C}-6 \mathrm{~b}$ ). These defractions could be produced by the uppermost stones in buried structures. Most of the bands on the GPR data following the first reflection are likely due to energy trapped between the surface and the highly conductive Pleistocene clay layer. These "ringing" returns give the impression of more subsurface layers, but contain no information.

\section{Discussion}

The purpose of this geophysical survey was general reconnaissance of the entire site. Therefore, the geophysical instruments used have less horizontal resolution than needed to sharply define the shape of buried features. Given the success of the EM approach using the EM31, it may be desirable to generate a higher resolution EM map in the future. The logical tool for this work would be the EM38, also by Geonics Inc. The EM38 works on the same principle as the EM31, but at one-fourth the scale, providing four times greater horizontal resolution. The disadvantage of the EM38 is that it must be placed directly on the ground when measurements are made. This would limit its application to the unobstructed areas of the site. Continuous measurements across the standing walls and piles of debris would not be possible. If further GPR work is done, it would be advantageous to use a higher frequency system, such as the Sensors \& Software PulseEKKO 1000 with the $450 \mathrm{MHz}$ set of antennas. This would provide better images of the shallow $(<50 \mathrm{~cm})$ soil horizons.

\section{Preliminary Conclusions}

Although somewhat grainy, the ground conductivity map produced from the EM31 data defines at least 20 features at the Rosario site. Several of these features are known from their surface expression. Others are known, at least partially, from records of past excavations. However, there are some features that were not known, such as the proposed native home sites (Anomaly 2), the rectangular features in the southeast corner of the compound (Anomaly 9) and the large ring around the west end of the central church building (Anomaly 20). GPR is useful for discriminating between buried walls and excavation trenches. Determining the cause of ground conductivity anomalies will require excavation, however, with the conductivity map, the excavation can be targeted on specified features. 
Figure C-6. Ground penetrating radar (GPR) profiles across Rosario.

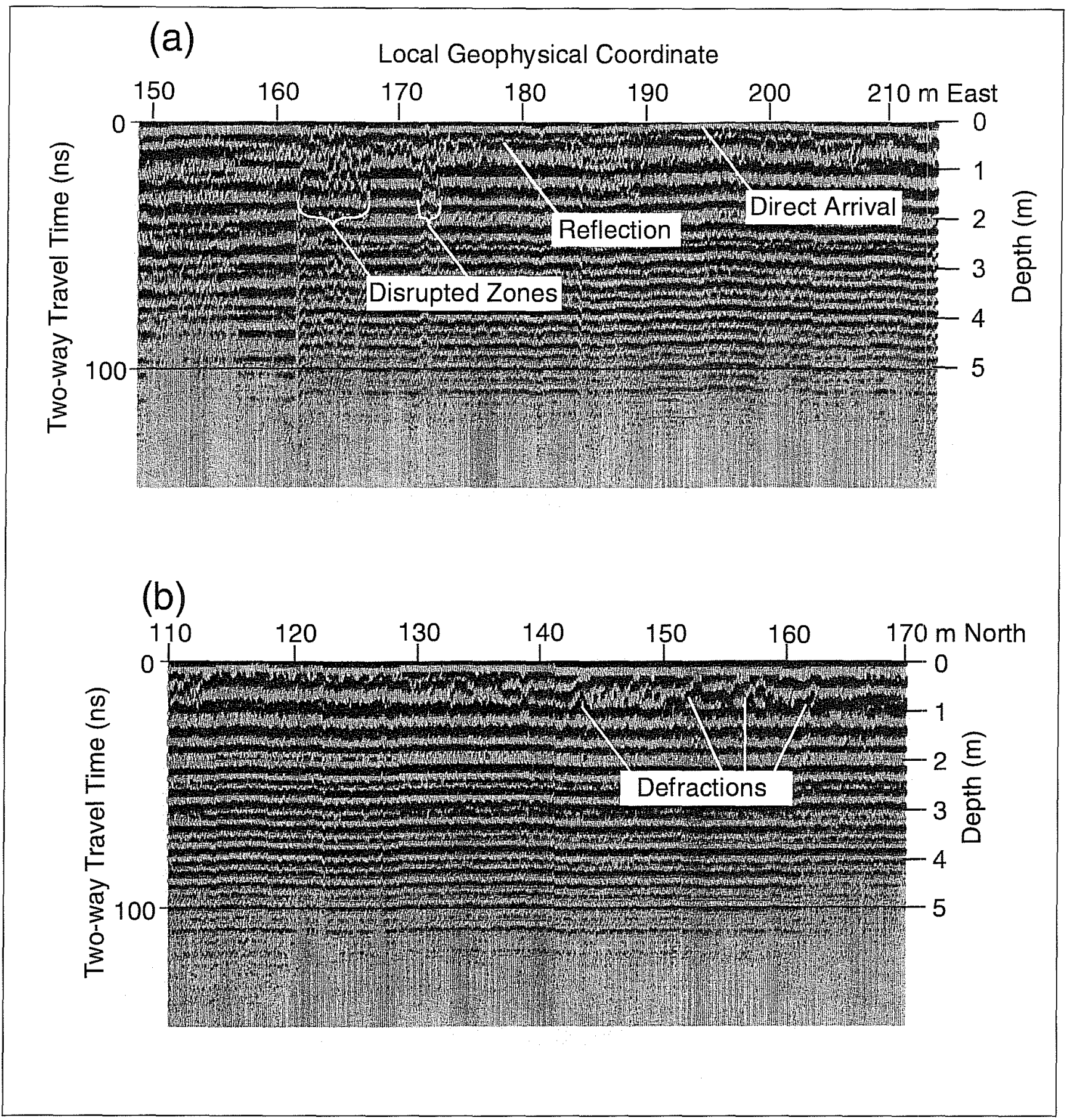

Ground penetrating radar (GPR) profiles across Rosario site.

(a) Line 1 is an east-west profile parallel to local geophysical coordinate $120 \mathrm{~m} \mathrm{North}$.

(b) Line 2 is oriented north-south parallel to $203 \mathrm{~m}$ East. 



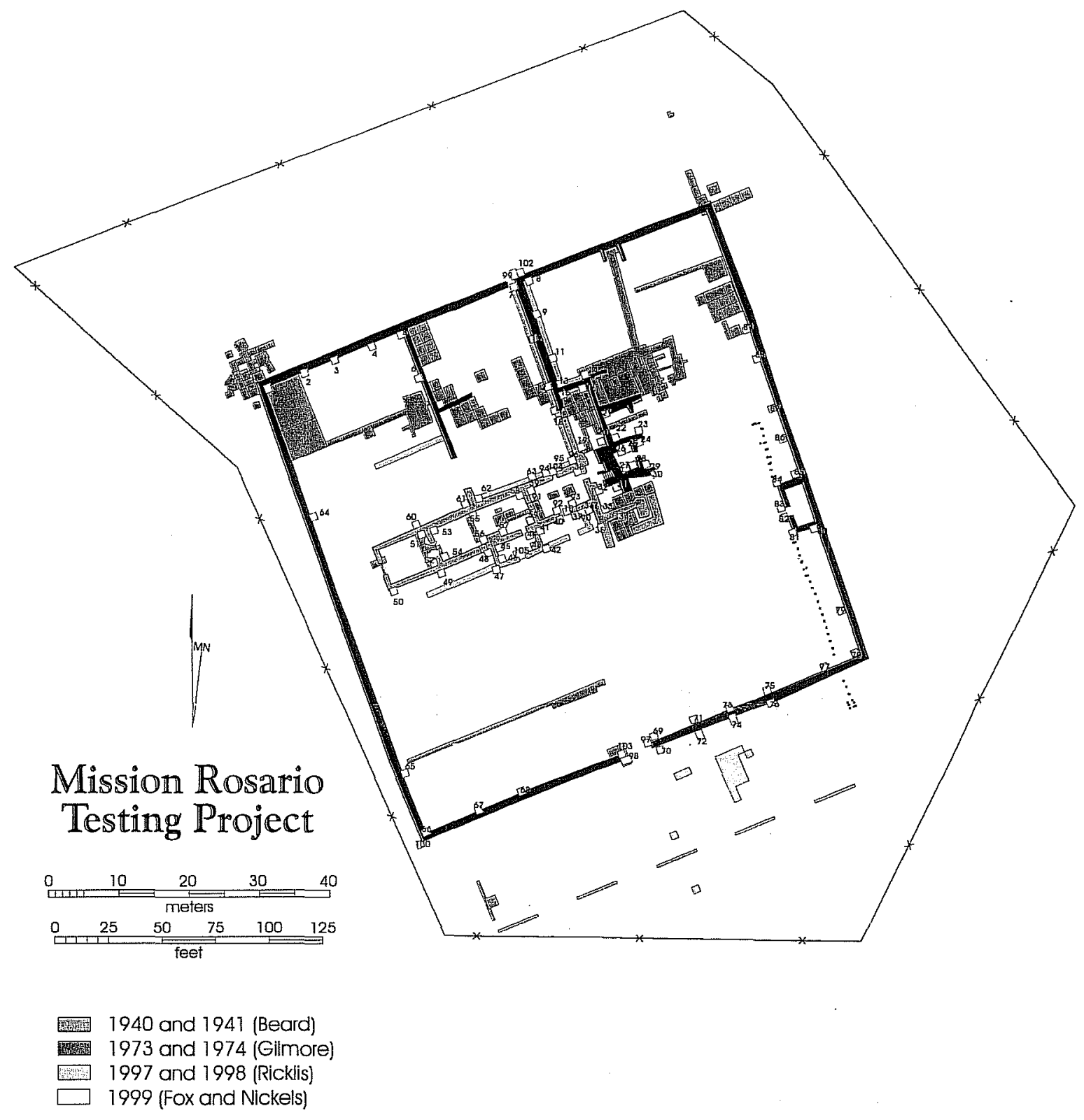

Figure 3-1. 1999 Excavations at Mission Rosario.

Center for Archaeological Research

The University of Texas at San Antonio

Archaeological Survey Report, No. 298 



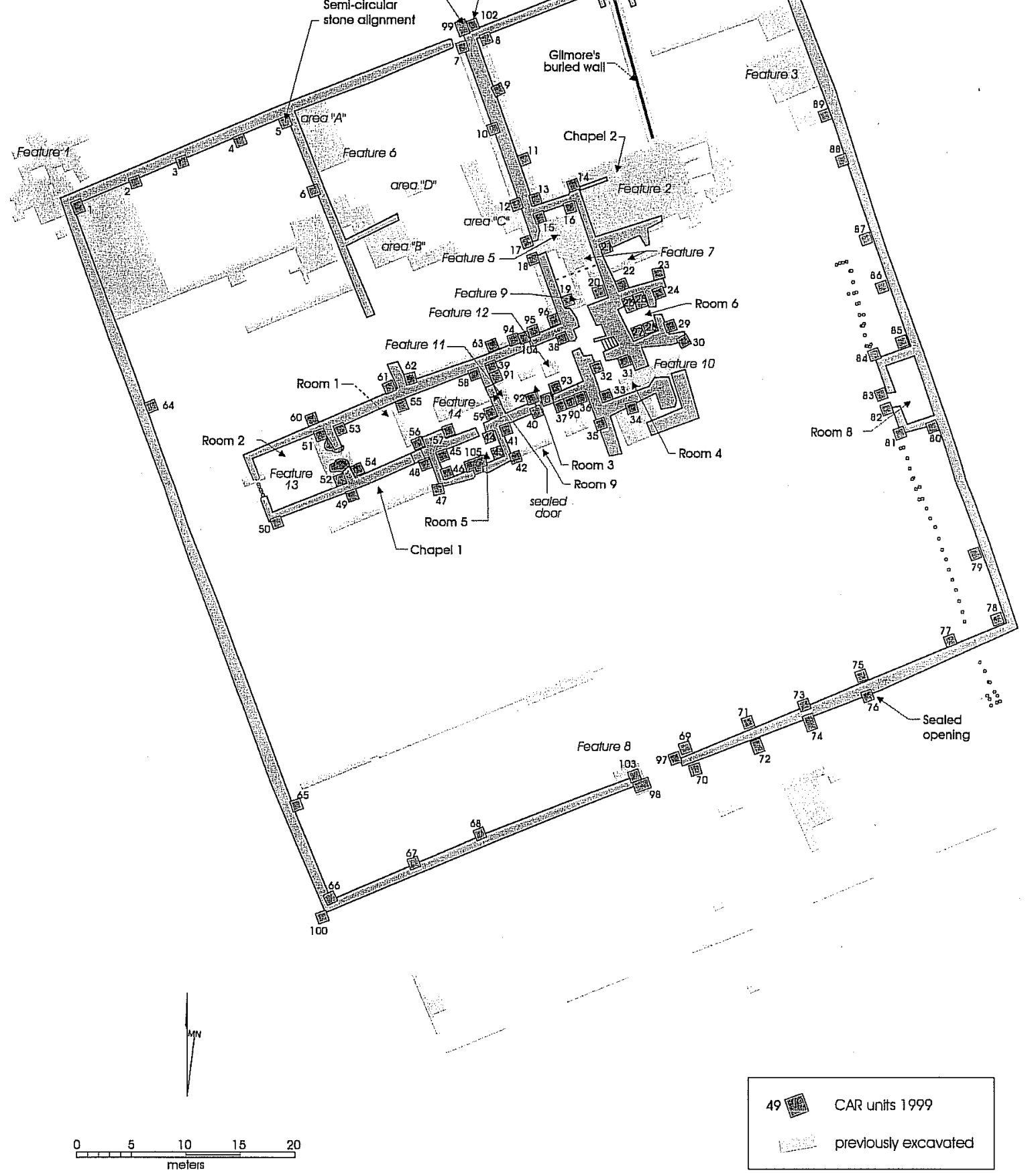

Figure 5-1. 1999 Excavations at Mission Rosario. Center for Archaeological Research The University of Texas at San Antonio Archaeological Survey Report, No. 298 
